UNIVERSIDADE DE SÃO PAULO

INSTITUTO DE GEOCIÊNCIAS

\title{
PETROGÊNESE E EVOLUÇÃO TECTÔNICA DE ROCHAS GRANÍTICAS DA REGIÃO DE GARZÓN, CORDILHEIRA ORIENTAL DA COLÔMBIA
}

\author{
Daniel Alejandro García Chinchilla
}

Orientador: Prof. Dr. Silvio Roberto Farias Vlach

\section{TESE DE DOUTORAMENTO}

Programa de Pós-Graduação em Mineralogia e Petrologia

SÃO PAULO

2018 

UNIVERSIDADE DE SÃO PAULO

INSTITUTO DE GEOCIÊNCIAS

\title{
PETROGÊNESE E EVOLUÇÃO TECTÔNICA DE ROCHAS GRANÍTICAS DA REGIÃO DE GARZÓN, CORDILHEIRA ORIENTAL DA COLÔMBIA
}

\author{
Daniel Alejandro García Chinchilla
}

Orientador: Prof. Dr. Silvio Roberto Farias Vlach

\section{TESE DE DOUTORAMENTO}

Programa de Pós-Graduação em Mineralogia e Petrologia

SÃO PAULO

2018 
Autorizo a reprodução e divulgação total ou parcial deste trabalho, por qualquer meio convencional ou eletrônico, para fins de estudo e pesquisa, desde que citada a fonte.

Serviço de Biblioteca e Documentação do IGc/USP. Ficha catalográfica gerada automaticamente com dados fornecidos pelo(a) autor(a) via programa desenvolvido pela Seção Técnica de Informática do ICMC/USP

Bibliotecários responsáveis pela estrutura de catalogação da publicação: Sonia Regina Yole Guerra - CRB-8/4208 | Anderson de Santana - CRB-8/6658

García-Chinchilla, Daniel Alejandro

Petrogênese e evolução tectônica de rochas graníticas da região de Garzón, Cordilheira Oriental da Colômbia / Daniel Alejandro García-Chinchilla ; orientador Silvio Roberto Farias Vlach. São Paulo, 2018.

274 p.: il.

Tese (Doutorado - Programa de Pós-Graduação em Mineralogia e Petrologia) -- Instituto de Geociências, Universidade de São Paulo, 2018.

1. Rochas graníticas. 2. Petrologia ígnea. 3. Tectônica do Jurássico. 5. Cordilheira Oriental dos Andes. 5. Colômbia. I. Vlach, Silvio Roberto Farias, orient. II. Título. 


\section{AGRADECIMENTOS}

Depois desta maravilhosa experiência no Brasil, e por maravilhosa não falo que tenha sido fácil, quero agradecer ao Silvio por acreditar em mim, por me brindar todo seu conhecimento e experiência, uma pessoa que admiro e respeito. Ao povo brasileiro e em especial o pessoal da USP, que me fizeram sentir na minha casa, saudades de vocês.

A Paula meu amor, minha parceira, por sua incondicionalidade, compreensão, inteligência, seu conselho e por me acompanhar nesta aventura chamada de Brasil, sem pensar, sem perguntar, sem reparar. Tomara que a vida seja longa e cheia de aventuras a seu lado. A meus pais Nubia e Edilberto, por sempre me apoiar em tudo, por sua incondicionalidade, seu infinito amor e sua loucura. O que eu sou, agradeço a vocês. Ao Juan K, meu irmãozinho, porque me faz sentir que não estou sozinho no mundo, um ser com único.

À Maria, minha amiga e parceira de aventuras, porque a vida junto a gente e espero que nunca afaste. À Astrid, por sua alegria e incondicionalidade, por compartir esse amor pela vida, a geologia e pelo futebol comigo. Ao Sebas, meu parceiro, por sua amizade, um cara com muito talento e amor pela geologia e por suas divertidas conversações no bar do Armando. À Santi e Andresito, os bebes, uns seres maravilhosos, inteligentes e com muito talento. À Marta, o Davi e a Lady, "los caleños", por sua amizade, por ser nossa família em Sampa, por esses domingos de pelis e frango assado, e as melhores festinhas da minha vida, porque a aventura sem vocês não tivesse sido o mesmo. 
A Nati, a Ivonne, o "niño" Milton, Carlitos, Pablo, Claudia, Wilner, Juan Felipe, Valentina, Vero, Ana M, Maria P, Lina, Anny, Sebas, Diego, Mauro, Santiago L., Cristian, Carlos S, Mili e Erika, a galera talentosa da Colômbia, que foi procurar um melhor futuro, a esperança, tomara que todos voltem e ajudem a melhorar nossa Colômbia. Ao Adrian, Andrey, Omitar, Charly, Prieto, Juan C, Juan F., Nando, Pati, Cata, "el ripio", por sua amizade, e por suas divertidas conversações que melhoram o estrese do trabalho.

Ao Pedro (porra), o Claudio (kabongi), o Caio (fofona) e o Jader, meus parceiros brasileirinhos, por me ensinar o Brasil e o português de verdade e por me abrir as portas das suas casas. À Melina, Vinicius, Alex, Cassandra, Dory, Eliana, Natasha, Cleber, Giovanna, Jhon, Alice, Mariana, Vanessa, Rafaela, Mauricio, Brenda, Caue, a talentosa galera da pós-graduação, por compartilhar sua amizade, conhecimentos, o cafezinho e a breja. Ao Julio, Viniciuos, Lucas, Leandro, Marcão, André, Milani, Tigrão, Igor, Adriano e a Pinga, a galera do Jiu da Poli, por compartilhar o tatame, o açaí, e o rodizio de sushi, oss.

A os professores do IGc, Adriana Alves, Renato de Morais, Gergely Szabó, Wilson Texeira, Miguel Basei, Claudia Passarelli, Excelso, Gaston Enrich, Johann Schorsher, Patrício Montecinos, Carlos Archanjo, Rogério Azzone, Valdecir Janasi, Horstpeter Ulbrich, por contribuir com seus conhecimentos a minha formação. Ao Leandro, Marcos, Vasco, Vinicius, Samuca, Zé Paulo, Angélica, Katherine, Artur, Solange, Walter, Sandra, os funcionários da Geo., por sua ajuda técnica e administrativa imprescindível para a consecução desta tese. 
Finalmente, ao Governo Brasileiro e ao Conselho Nacional de Desenvolvimento Científico e Tecnológico (CNPq), que me concedeu a bolsa de doutorado.

Na memória do Saenz

Um coração e uma mente gigantes 


\section{RESUMO}

Granitos e rochas associadas aos Maciços Plutônicos de Algeciras, Altamira e Sombrerillo, na cordilheira Oriental da Colômbia, fazem parte de um dos maiores eventos magmáticos dos Andes do Norte, acontecido durante o Jurássico. Estes maciços formados principalmente por hornblenda, biotita hornblenda e biotita monzogranitos, hornblenda biotita granodioritos, quartzo monzodioritos e quartzo monzonitos com dois piroxênios, leuco granitos e uma serie de rochas subvulcânicas como pórfiros dacíticos e riolíticos e diques máficos-intermediários, que atravessam as facies intrusivas. Estas rochas têm afinidades geoquímicas cálcio-alcalinas com concentrações relativamente altas em potássio $\left(3,3<\mathrm{K}_{2} \mathrm{O}\right.$ wt. $\left.\%<6,2\right)$, principalmente metaluminosas e magnesianas; as rochas mais félsicas apresentam tendências levemente peraluminosas e ferroanas $(0,67 \leq \mathrm{ASI} \leq 1,01$ e $0,66 \leq \mathrm{fe \#} \leq 0,94)$. Os padrões das REE mostram um enriquecimento das LREE sobre as HREE $(7,7-8,7 \leq$ $\mathrm{LaN}_{N} / \mathrm{Yb}_{\mathrm{N}} \leq 18,8-22,4 ; 5,5-7,0 \leq \mathrm{LaN}_{N} / \mathrm{Sm}_{N} \leq 3,4-5,8$ and $0,2-1,6 \leq \mathrm{GdN}_{N} / \mathrm{Yb}_{\mathrm{N}} \leq 1,3-$ 2,6), com anomalias negativas do $\mathrm{Eu}\left(\mathrm{Eu} \mathrm{Eu}^{*} \leq 0,6\right)$, que comparado com outros maciços Jurássicos dos Andes do Norte, sugerem uma contribuição do componente crustal maior na Cordilheira Oriental, ao leste. Anfibólio e biotita são os minerais máficos principais. Magnesiohornblenda é a variedade mais comum nas facies intrusivas e os pórfiros riolíticos; enquanto magnésiohastingsita a edenita dominam nos dacitos e diques máficosintermediários. Flogopita é variedade de mica comum em todas as rochas, exceção das rochas félsicas que apresentam um enriquecimento em alumínio (siderofilita). Por sua vez, o Sombrerillo é o único dos três complexos estudados que apresenta facies graníticas com augita e/ou enstatita, esta 
última característica de cristalização a temperaturas elevadas, sob condições crustais relativamente anidras, similares as de rochas graníticas que afloram na Cordilheira Central. Datações U-Pb em zircão por LA-ICP-MS revelam que o intervalo de geração dos principais produtos magmáticos dos Maciços Plutônicos de Algeciras e Altamira ficam entre 176 e 170 Ma, posteriores aos gerados na parte oeste na Cordilheira Central e no Complexo Plutônico de Sombrerillo (189 a $183 \mathrm{Ma}$ ). Estes dados sugerem migração da frente do arco 30 a $50 \mathrm{~km}$ ao leste, relacionada com processos de erosão por subduç̧ão. Dados isotópicos em zircão $\left(-6,3>\varepsilon \mathrm{Hf}_{(\mathrm{t})}>-1,3, \mathrm{~T}_{\mathrm{DM}}=870\right.$ a $\left.1300 \mathrm{Ma}\right)$, indicam contribuições crustais significativas, de fontes similares ao embasamento cristalino regional. Os produtos magmáticos finais, subvulcânicos, se colocaram por volta de 165 Ma e foram gerados possivelmente em ambientes de relaxamento tectônico, associado a um retrocesso da frente do arco da Cordilheira Oriental para a Central. Apresentam características isotópicas $(+5,0$ $>\varepsilon \mathrm{Hf}(\mathrm{t})>+14,6 ; \mathrm{T}_{\mathrm{DM}}=221$ a $\left.830 \mathrm{Ma}\right)$ indicativas de contribuições de fontes mantélicas juvenis. Estimativas geotermobarométricas apontam temperaturas de cristalização magmática entre 700 e $930^{\circ} \mathrm{C}$, sob condições de baixa pressão, ca. $1.5 \pm 0.5 \mathrm{kbar}$, em ambientes relativamente oxidantes $(+1 \leq \Delta \mathrm{QFM}$ $\leq+3)$ para as rochas graníticas, representativas de níveis superiores da crosta (3 a $5 \mathrm{~km}$ ). Núcleos de fenocristais de rochas subvulcânicas apresentam composições compatíveis com condições mais elevadas de temperatura entre 800 e $1050^{\circ} \mathrm{C}$ e pressões até $5,1 \mathrm{kbar}$, evidenciando cristalização em maiores profundidades (ca. 12 a $23 \mathrm{~km}$ ), enquanto que as composições de borda sugerem condições compatíveis com as rochas graníticas hospedeiras (ca. 0,81,7 kbar e $\left.760^{\circ} \mathrm{C}\right)$. 


\section{ABSTRACT}

Granites and associated rocks from the Algeciras, Altamira and Sombrerillo Plutonic Massifs, Eastern Cordillera of Colombia, represent one of the main magmatic events in the Northern Andes at Jurassic times. They are mainly made up by mainly hornblende, biotite hornblende and biotite monzogranites, hornblende biotite granodiorites, two pyroxene-bearing quartz monzodiorites and quartz monzonites, leuco granites, cross cut by subvolcanic rocks as felsic porphyries and intermediate-mafic dikes. They are high $\mathrm{K}$ calc-alkaline $(3.3<$ $\mathrm{K}_{2} \mathrm{O}$ wt. $\%$ < 6.2), mainly metaluminous and magnesian rocks; some felsic varieties present slightly peraluminous and ferroan signatures $(0.66 \leq$ fe\# $\leq 0.94$ e $0.67 \leq \mathrm{ASI} \leq 1.01)$. REE patterns show LREE enrichment over HREE (7.7-8.7 $\leq \mathrm{LaN} / \mathrm{YbN}_{\mathrm{N}} \leq 18.8-22.4 ; 5.5-7.0 \leq \mathrm{LaN} / \mathrm{SmN}_{\mathrm{N}} \leq 3.4-5.8$ and $0.2-1.6 \leq \mathrm{GdN} / \mathrm{YbN} \leq$ 1.3-2.6) with negative $\mathrm{Eu}$ anomalies $\left(\mathrm{Eu} / \mathrm{Eu}^{*} \leq 0.6\right)$. As a whole, Jurassic magmatism in northern Andes is characterized by increasing crustal contributions eastwards, becoming higher in Eastern Cordillera. Amphibole and biotite are the main mafic minerals. Magnesiohornblende is the most common variety in intrusive facies and rhyolite porphyries, while magnesiohastingsite and edenite predominate in dacite and intermediate-mafic dikes. Phlogopite is the main mica variety except for the more felsic rocks, which present a relatively Al-rich biotite (syderophillite). Some petrographic facies from the Sombrerillo Plutonic Massif present augite and/or enstatite. The later suggests high crystallization temperatures, under anhydrous conditions, which maybe related to similar rocks in Central Colombian Cordillera. U-Pb zircon ages by LA-ICPMS analysis indicate that the main magmatic products of Altamira and Algeciras

Plutonic Massifs had emplaced between 176 and $170 \mathrm{Ma}$, after the 
emplacement of the main granites in Central Cordillera and in the Sombrerillo Plutonic Massif (189 to $183 \mathrm{Ma}$ ). This suggests a front arc migration to the east (ca. 30 to $50 \mathrm{~km}$ ), associated with subduction erosion phenomena. $\varepsilon \mathrm{Hf}(\mathrm{t})$-inzircon $\left(-6,3>\varepsilon \mathrm{Ef}_{(t)}>-1,3, \mathrm{~T}_{\mathrm{DM}}=870\right.$ a $\left.1300 \mathrm{Ma}\right)$ point to significant crustal contributions, similar to the enclosed crystalline basement, to the studied granites. The last magmatic, subvolcanic, products were emplaced at ca. 165 $\mathrm{Ma}$ in a possible tectonic extensive environment, created by retreat of the front arc from Eastern Cordillera to Central Cordillera. $\varepsilon \mathrm{Hf}(\mathrm{t})$-in-zircon reveal contrasted young mantle sources $\left(+5,0>\varepsilon \mathrm{Hf}_{(\mathrm{t})}>+14,6 ; \mathrm{T}_{\mathrm{DM}}=221\right.$ a $\left.830 \mathrm{Ma}\right)$. Geothermobarometric estimative points to crystallization temperatures from 700 to $930^{\circ} \mathrm{C}$, under low pressures (ca. $\left.1.5 \pm 0.5 \mathrm{kbar}\right)$ under relatively oxidized $(+1 \leq$ $\Delta \mathrm{QFM} \leq+3)$ conditions in the case of the main granitic rocks. Amphibole phenocryst cores present compositions compatible with higher temperatures (800 to $1050^{\circ} \mathrm{C}$ ) and pressures (up to $5.1 \mathrm{kbar}$ ), suggesting crystallization at deep crustal levels (ca.12 to $23 \mathrm{~km}$ ) while crystal rims are equilibrated at shallow crustal levels, comparable with those obtained for the granite hosts (ca. 0.8 a 1.7 kbar e $\left.760^{\circ} \mathrm{C}\right)$. 


\section{SUMÁRIO}

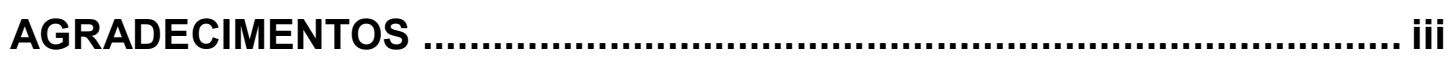

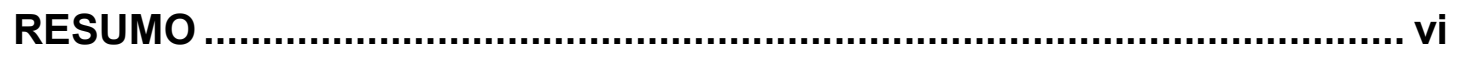

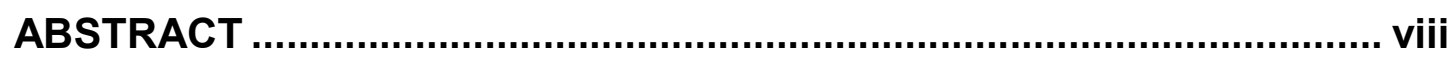

CAPÍTULO I - INTRODUÇÃO ............................................................. 1

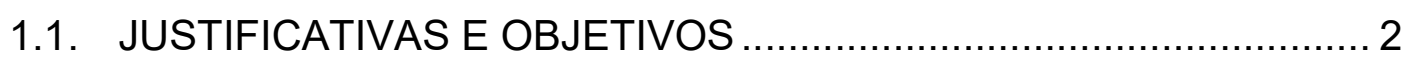

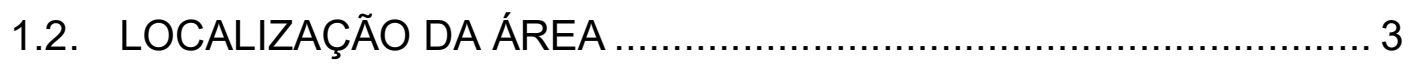

1.3. SITUAÇÃO GEOLÓGICA DA ÁREA ………............................ 4

1.4. APRESENTAÇÃO E ESTRUTURA DA TESE .............................. 7

CAPÍTULO II-MATERIAIS E MÉTODOS ….............................................. 11

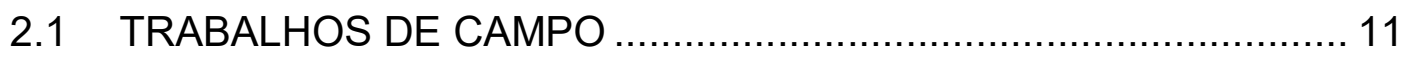

2.2 ANÁLISES PETROGRÁFICAS .................................................. 13

2.3 ANÁLISES GEOQUÍMICAS ELEMENTAIS ................................ 13

2.3.1 Geoquímica de rocha total .............................................. 13

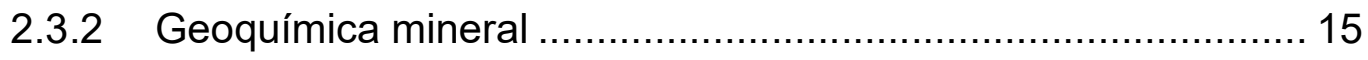

2.4 ANÁLISES ISOTOPICAS ....................................................... 17

2.4.1 Datações U/Pb em zircão...................................................... 19

2.4.2 Análises Isotópicas Lu-Hf................................................. 19

CAPÍTULO III - Mapeamento geológico de rochas intrusivas: Um estudo de caso na região de Garzón, Cordilheira Oriental dos Andes Colombianos. 
CAPÍTULO IV - Introspeções nas idades e fontes do magmatismo Jurássico nos Andes do Noroeste: Geoquímica em rocha total e geoquímica isotópica $\mathrm{U}-\mathrm{Pb}$ e $\mathrm{Hf}$ in situ em zircão de granitos e rochas associadas da região de Garzón, Cordilheira Oriental da Colômbia. 24

CAPÍTULO V - Química mineral de granitos Jurássicos e rochas associadas do Cordilheira Oriental Da Colômbia, Andes do Norte: variações composicionais dos minerais formadores de rocha e parâmetros intensivos de cristalização .................................................... 27

CAPÍTULO VI - SUMÁRIO E COMENTARIOS FINAIS ............................. 30

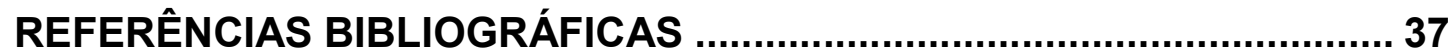

APÊNDICES E ANEXOS 



\title{
CAPÍTULO I
}

\author{
INTRODUÇÃO
}

Rochas graníticas (sensu lato) são as rochas mais abundantes na crosta continental do planeta e o magmatismo granítico é um dos principais responsáveis pelos fenômenos de transferência de massa e calor na crosta desde tempos arqueanos (e.g. Albarède, 1998; Carswell, 1983; Wilson, 1989). Apesar da simplicidade mineralógica geral das rochas graníticas, elas são complexas, uma vez que podem ser originadas a partir de reservatórios-fonte distintos em ambientes geológicos contrastados, associados a mecanismos tectônicos quer convergentes, quer divergentes. Adicionalmente, a estas rochas podem estar associados bens minerais de interesse econômico. Neste contexto, não é por acaso que o estudo deste grupo de rochas continua ativo e relevante na literatura científica moderna.

O magmatismo granítico Jurássico na Colômbia representa um dos principais eventos magmáticos nos Andes do Norte e responde pela ocorrência de rochas plutônicas e vulcânicas associadas por ca. $32.500 \mathrm{~km}^{2}$. Este extenso magmatismo está associado a ambientes de margens continentais ativas, associados processos de subducção da placa proto-Pacífica sob a margem continental oeste de América do Sul (e.g., Noble et al., 1997; Pindell and Dewey, 1982; Pindell and Kennan, 2009; Ross and Scotese, 1988). Apesar da literatura que aborda o tema ser numerosa, diversas das características deste magmatismo e do seu ambiente ainda carecem de aprofundamento científico.

Os corpos intrusivos, agrupados em batólitos e/ou maciços e/ou complexos

plutônicos Jurássicos, afloram principalmente nas Cordilheiras Central e 
Oriental e na Serra Nevada de Santa Marta. A presente tese foca o estudo dos maciços localizados na parte sul da Cordilheira Oriental Colombiana, na região denominada na literatura local como "Maciço de Garzón". Nesta área afloram três maciços plutônicos principais: Algeciras, Altamira e Sombrerillo, objetos deste trabalho. Os principais trabalhos prévios que abordam rochas destes maciços tratam de mapeamentos básicos, caracterizações petrográficas gerais, alguma lito-geoquímica, datações radiométricas de algumas variedades, bem como interpretações geotectônicas preliminares à luz dos modelos atualmente aceitos (e.g., Rodríguez et al., 2003; Velandia et al., 1999, 2001; Bustamante et al., 2010; Rodríguez et al., 2018). Entretanto, tais dados são ainda relativamente escassos e de pouco detalhe; por outro lado inexistem dados mineralógicos e informações geotermobarométricas para estas rochas, que permitam analisar a evolução do magmatismo, seja específica a cada um dos maciços, seja de forma integrada no contexto de todo o magmatismo Jurássico Andino.

\subsection{JUSTIFICATIVAS E OBJETIVOS}

No panorama atual de carência de dados de mais detalhe na região de Garzón, os objetivos gerais da presente Tese incluem principalmente a caracterização mais específica e em maior detalhe da tipologia das rochas geradas durante o magmatismo Jurássico nesta área, dos pontos de vistas geológico, petrográfico, mineralógico e geoquímico, visando estabelecer fundamentos mais sólidos para interpretações sobre a gênese e evolução magmática dos maciços Algeciras, Altamira e Sombrerillo, bem como o seu significado no contexto geral da evolução tectono-magmática desta região dos Andes. Os objetivos específicos podem ser sumarizados como segue: 
- Mapear as principais variedades petrográficas e caracterizar as relações geológicas das unidades que afloram na região;

- Caracterizar petrográficamente as principais variedades mapeadas, enfatizando a distribuição dos minerais máficos e acessórios, bem como as texturas associadas aos minerais formadores de rocha e acessórios, como suporte para interpretações sobre a evolução magmática;

- Caracterizar as assinaturas geoquímicas elementais (elementos maiores, menores e traços) das rochas graníticas e associadas;

- Determinar idades (U-Pb) precisas de cristalização/colocação dos magmas progenitores e, paralelamente, das assinaturas isotópicas de $\mathrm{Hf}$, através de métodos analíticos de alta resolução espacial de cristais de zircão;

- Caracterizar as composições e variações composicionais (elementos maiores e menores) de fases minerais, enfatizando minerais formadores de rocha, e avaliar os principais parâmetros intensivos de cristalização magmática (pressão, temperaturas, fugacidade de oxigênio).

Finalmente, integrar os dados obtidos com os já disponíveis em literatura para examinar criticamente a evolução do magmatismo granítico nesta área e implicações para o magmatismo Jurássico geral da região norte dos Andes.

\subsection{LOCALIZAÇÃO DA ÁREA}

A Colômbia se localiza na borda noroeste da América do Sul, limitando-se ao norte com a América Central e para oeste com o Oceano Pacífico e o Mar Caribe. Do ponto de vista geomorfológico, o país se caracteriza por apresentar regiões planas (Orinoquia e Amazonia), ao leste, e regiões elevadas para oeste, representadas pelos Andes colombianos. Neste intervalo de latitudes, os 
Andes estão constituídos por três cordilheiras principais, denominadas Cordilheira Ocidental, Central e Oriental e separadas entre si pelos vales interAndinos dos rios Cauca e Magdalena, respectivamente (Fig. 1).

A área selecionada para estudo localiza-se na parte sul da Cordilheira Oriental, região em que as altitudes variam entre 1200 e 3000 m, com profundos vales em forma de " $\mathrm{v}$ ". Esta área tem sido tradicionalmente denominada "Maciço de Garzón" (e.g., Alvarez, 1981; Priem et al., 1989) e abrange principalmente o Departamento de Huila e parte dos departamentos de Cauca, Putumayo e Caquetá (¡Error! No se encuentra el origen de la referencia.).

Como principais cidades capitais de departamento encontram-se: Neiva capital do Huila (a $315 \mathrm{~km}$ de Bogotá D.C.), que se comunica por rodovia com Mocoa capital do Putumayo (320 km de Neiva) e Florencia do Caquetá (236 km de Neiva). Adicionalmente, Garzón, Pitalito, Algeciras e San Agustín são os municípios mais importantes estabelecidos. Duas rodovias principais (NeivaMocoa e Pitalito-Florencia) cortam a área; estradas menores em geral ocorrem em pouco quantidade e eventualmente apresentam tráfego bem dificultado, especialmente nas partes sul e leste da área.

\subsection{SITUAÇÃO GEOLÓGICA DA ÁREA}

A região ("Maciço") de Garzón corresponde a um bloco topograficamente elevado da parte sul da Cordilheira Oriental. Geologicamente está constituído, além das intrusivas que constituem os maciços plutônicos jurássicos, por um núcleo de rochas metamórficas (gnaisses diversos, granulitos e charnoquitos) e migmatitos com idade Meso- a Neoproterozoica (Altenberger et al., 2012; Ibanez-Mejia et al., 2011; Jiménez Mejía et al., 2006), que constituem o 
embasamento cristalino regional. Os limites entre estas rochas e as intrusivas jurássicas são principalmente tectônicos e se dão pelo Sistema de Falhamentos de Algeciras, do lado oeste (Velandia et al., 2005). Sequências paleozoicas sedimentares, variavelmente deformadas fazem contato com as rochas intrusivas em algumas áreas, apresentando algumas evidências de metamorfismo de contato (Núñez, 2003). Sequências vulcano-sedimentares mais jovens, do Cretáceo ao Cenozoico, encontram-se em contato discordante e falhado com as rochas mais antigas (e.g., Morales et al., 2001; Velandia et al., 2001). 


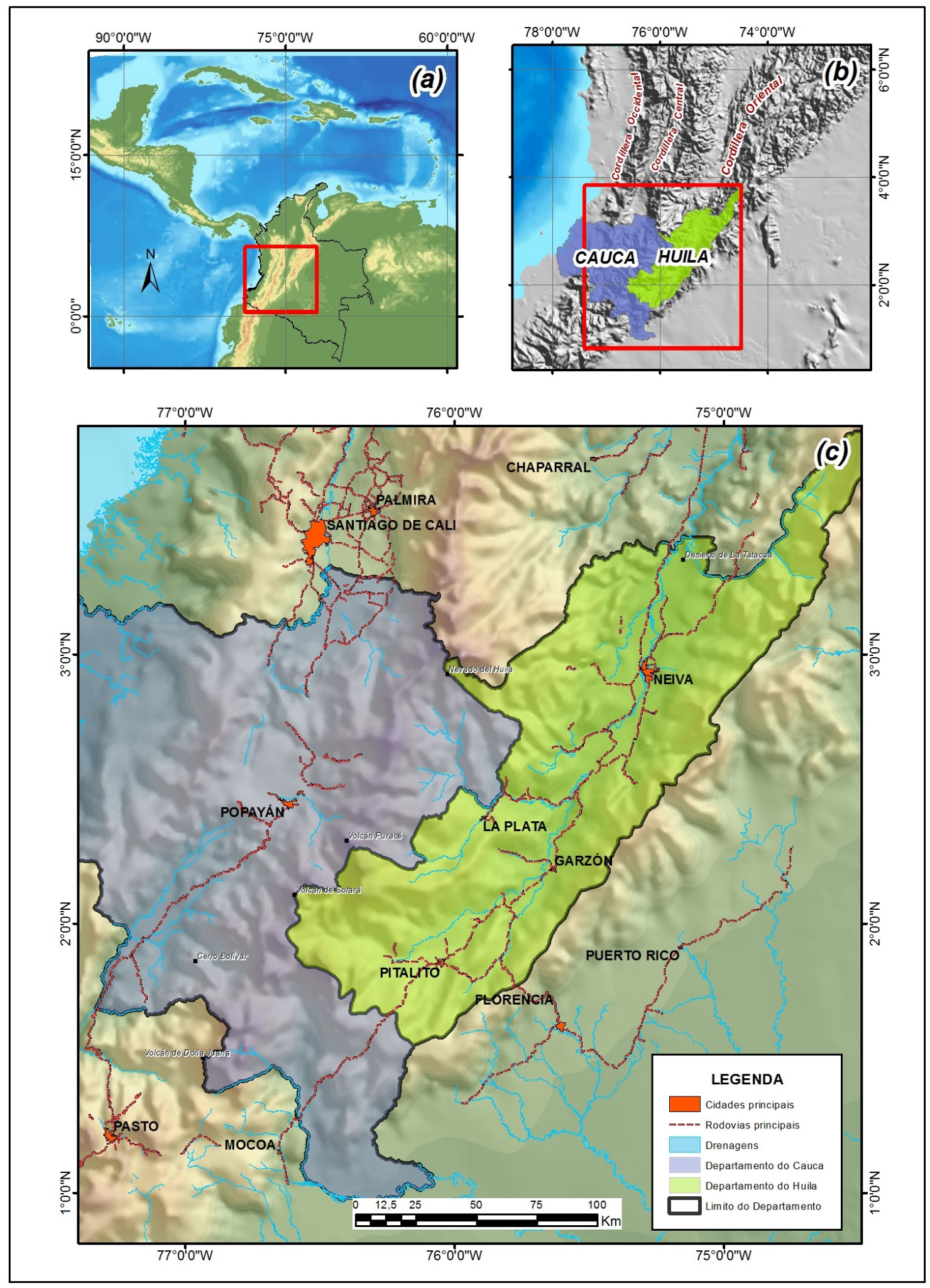

Fig. 1. Mapa de localização da área de estudo no denominado Maciço de Garzón, (a) Localização da Colômbia na esquina noroeste da América do Sul. (b) Modelo da elevação do terreno onde se amostra a Cordilheira dos Andes, que na Colômbia de divide nas Cordilheiras Ocidental, Central e Oriental. (c) Detalhe do Maciço de Garzón na parte sul da Cordilheira Oriental. Com as principais cidades e rodovias. 


\subsection{APRESENTAÇÃO E ESTRUTURA DA TESE}

A Tese está organizada principalmente na forma de textos que se encontram em fase de revisão final para submissão a periódicos especializados. 0 Capítulo I contém esta introdução, o Capítulo || apresenta e discute os materiais e métodos de pesquisa; os três seguintes apresentam textos específicos como segue:

- Capitulo III: "Mapeamento geológico de rochas intrusivas: Um estudo de caso na região de Garzón, Cordilheira Oriental dos Andes Colombianos", apresenta mapas faciológicos para os maciços plutônicos Algeciras e Altamira, bem como suas caracterizações geológica, petrográfica e mineralógica geral e classificação das variedades que neles afloram;

- Capítulo IV: "Introspeções nas idades e fontes do magmatismo Jurássico nos Andes do Noroeste: Geoquímica em rocha total e geoquímica isotópica U-Pb e Hf in situ em zircão de granitos e rochas associadas da região de Garzón, Cordilheira Oriental da Colômbia", o texto enfatiza os resultados dos estudos de geoquímica em rocha total, geocronologia e geoquímica isotópica de alta resolução espacial (datação U-Pb e análises isotópicas Lu-Hf em zircão) obtidos para amostras selecionadas dos três maciços enfocados (Algeciras, Altamira e Sombrerillo), bem como apresenta uma interpretação geral, a luz do conhecimento atual, dos processos tectono-magmáticos associados, integrando os dados obtidos com os já disponíveis em literatura;

- Capítulo V: "Química mineral de granitos Jurássicos e rochas associadas do Cordilheira Oriental Da Colômbia, Andes do Norte: 
variações composicionais dos minerais formadores de rocha $e$ parâmetros intensivos de cristalização.", apresenta e discute as composições e principais variações composicionais dos minerais formadores de rocha e de óxidos de Fe-Ti e aplica os dados quantitativos obtidos para estimar as condições de cristalização (pressão, temperatura e fugacidade de espécies voláteis) de amostras selecionadas dos três maciços plutônicos estudados e discute as potenciais implicações para o magmatismo da Cordilheira Oriental.

Por fim, o Capítulo VI apresenta um sumário e uma discussão geral integrada, que considera um modelo de evolução tectonomagmática para o Jurássico na região de Garzón e algumas considerações sobre os processos de subducção dos Andes do Norte. 
Comentários do Autor: páginas 9 e 10 em branco 


\section{CAPÍTULO II}

\section{MATERIAIS E MÉTODOS}

O desenvolvimento desta pesquisa envolveu etapas extensivas de trabalhos de campo, preparação de amostras, análises petrográficas, análises químicas em rocha total e análises químicas e isotópicas de alta resolução espacial em fases minerais selecionadas.

As etapas analíticas foram efetuadas em laboratórios do Núcleo de Apoio à Pesquisa - NAP - GeoAnalitica-USP e do Centro de Pesquisas Geocronológicas (CPGeo-USP), ambos sediados no Instituto de Geociências da USP (IGc-USP). Os procedimentos e métodos empregados em cada etapa são detalhados a seguir.

\subsection{TRABALHOS DE CAMPO}

Os trabalhos de reconhecimento geológico das rochas graníticas (lato sensu) e relacionadas na região de Garzón, na Cordilheira Oriental da Colômbia, começaram a ser desenvolvidos por volta de 2010 pela Subdirección de Recursos del Subsuelo del Instituto Colombiano de Geologia y MineríaINGEOMINAS (atualmente o Servicio Geológico Colombiano-SGC), no qual o autor da presente Tese atuava como geólogo. Nestas etapas foram examinados cerca de 255 afloramentos, constituídos principalmente por rochas ígneas plutônicas, mas também pelas rochas encaixantes metamórficas. Os objetivos desta etapa foram estabelecer um reconhecimento petrográfico e geoquímico das rochas mais típicas aflorantes na área.

A ideia original desta pesquisa era avançar no conhecimento e pesquisar em detalhe aspectos geocronológicos, geoquímicos e petrogenéticos da região 
utilizando-se da base amostral já disponível a partir dos trabalhos acima mencionados. Entretanto, face à impossibilidade de concretizar convênio com o INGEOMINAS, decidiu-se realizar trabalhos de campo e amostragem específicos, os quais foram conduzidos em Fevereiro de 2014.

Estes trabalhos foram efetuados com o apoio das folhas cartográficas em escala 1:100.000 do SGC e das correspondentes Memórias: 324-Tello (Acosta and Osorno, 1999), 345-Campoalegre (Morales et al., 2001; Velandia et al., 1999), 366-Garzón (Rodríguez et al., 1998; Velandia et al., 2001), 388-Pitalito (Cárdenas et al., 2003, 2002), 389-Timaná (Rodríguez et al., 2003a, 2003b), 412-San Juan de Villalobos (Núñez, 2003; Núñez e Gómez, 2002). Nas etapas de campo, foram revisitados diversos afloramentos já conhecidos, bem como visitados novos, e coletadas cerca de 25 amostras frescas de rochas ígneas correspondentes às principais variedades petrográficas dos Maciços Plutônicos e outras 20 de amostras das rochas encaixantes. Entre as primeiras, 14, 6 e 5 amostras são representativas das intrusões dos maciços Algeciras, Altamira e Sombrerillo, respectivamente. Esta é a base amostral da presente pesquisa.

A partir das informações de campo disponíveis, das novas obtidas e de análise petrográfica convencional, as rochas plutônicas foram mapeadas preliminarmente de acordo com os conceitos de mapeamento faciológico que envolvem conceitos "facies petrográfica plutônica" (Ulbrich et al., 2001) e de “associações de facies” (Vlach, 1993, 1985). Neste panorama, o mapa obtido discrimina facies e associações de facies, de acordo com as características estruturais, texturais, mineralógicas e de distribuição das rochas graníticas. 


\subsection{ANÁLISES PETROGRÁFICAS}

As análises petrográficas e imageamentos digitais foram realizados no Laboratório de Microscopia Petrográfica do NAP. Mais de duzentas de seções delgadas convencionais e/ou delgado-polidas foram examinadas sob luzes transmitida e refletida em microscópios Axioplan-pol da Zeiss e BXP-50 da Olympus, utilizando-se de técnicas clássicas (e.g., MacKenzie et al., 1995; Williams et al., 1982), destacando-se sempre as amostras específicas coletadas. Nestes trabalhos enfatizam-se a identificação e documentação digital das fases minerais essenciais e acessórias, destacando micro-estruturas (e.g. Vernon, 2004), relações texturais de equilíbrio e/ou desequilíbrio e sequência de cristalização, considerando também a mineralogia associada às alterações hidrotermais. Determinações modais quantitativas em amostras selecionadas foram efetuadas com charriot e contador de pontos seguindo as recomendações de Vlach (1985) e bibliografia referida.

\subsection{ANÁLISES GEOQUÍMICAS ELEMENTAIS}

Análises geoquímicas elementais em rocha total e em minerais formadores de rocha foram obtidas para as amostras mais representativas coletadas.

\subsubsection{Geoquímica de rocha total}

Análises químicas para elementos maiores, menores e traços em rocha-total foram realizadas nos laboratórios de Fluorescência de raios $X(F R X)$ e de Química e ICP. Foram analisadas 23 amostras das rochas graníticas e associadas dos complexos de Algeciras (14), Altamira (6) e Sombrerillo (3).

A preparação das amostras foi efetuada no Laboratório de Tratamento de Amostras do NAP e incluiu etapas de fragmentação com marreta e/ou martelo e eliminação de superfícies alteradas, seguidas de britagem com britador de 
mandíbulas de aço e/ou prensa hidráulica e de quarteamento para separação de alíquotas representativas. Uma alíquota foi moída em moinho com elementos de ágata do tipo planetário até a granulometria de pó (200 meshes, $75 \mu \mathrm{m})$.

Do material em pó foi separada uma fração com $7,000 \pm 0,005 \mathrm{~g}$ a qual foi pulverizada a $5 \mu \mathrm{m}$ com micronizador constituído de elementos de ágata e utilizada para a preparação de pastilhas prensadas para análise de elementos traços com FRX. Outra parte do material em pó foi utilizada para a preparação de pastilhas fundidas, para análise de elementos maiores e menores. Uma terceira alíquota foi encaminhada ao Laboratório de Química e ICP para análises complementares de elementos traços por espectrometria de massa com plasma de indução acoplado (ICP-MS).

A quantificação de elementos maiores, menores e alguns traços com FRX, foi realizada com o espectrômetro AXIOS MAX Advance da PANalytica, seguindo os protocolos analíticos do laboratório (Mori et al., 1999). Os resultados para diversos elementos traços aproximam-se dos respectivos limites de detecção com esta técnica, entretanto. Assim, a maioria de elementos traço, incluindo os elementos terras raras (ETRs) foi determinada por ICP-MS, utilizando-se do espectrômetro de massas quadrupolo iCAP Q da Thermo Fisher Scientific. Neste caso, as amostras foram abertas com ácidos nítrico e fluorídrico em bombas tipo Par. Os procedimentos analíticos e padrões utilizados são detalhados em Navarro (2004) e Navarro et al. (2008).

O tratamento dos dados obtidos para rocha total foi efetuado com programas específicos de acesso público, como o GCDkit (Janoušek et al., 2006). 


\subsubsection{Geoquímica mineral}

Análises pontuais qualitativas e quantitativas foram efetuadas no Laboratório de Microssonda Eletrônica, que conta com o equipamento (FE-EPMA) JEOL JXA-8530, provido de um espectrômetro de dispersão de energia (EDS) e cinco espectrômetros de dispersão de comprimentos de onda (WDS), cada qual provido com dois cristais analisadores: TAP/LDE II, PET(L)/LIF(L), TAP/PET(J), PET(L)/LIF(L) e TAP(H)/PET(H), estes últimos de grande área $(H)$, montados em espectrômetro com raio do Círculo de Rowland inferior (100 mm ao invés dos $140 \mathrm{~mm}$ convencionas dos demais), que resultam em significativo aumento da intensidade dos sinais analíticos.

As seções delgado-polidas de rocha para análise foram preparadas com 30 $\mu \mathrm{m}$ de espessura em politriz automática P4 da Logitech, utilizando-se de pasta de alumina para polimento. A necessária metalização das seções com $C$ foi efetuada com o evaporador Auto 306 da Edwards.

Imagens de elétrons retro-espalhados foram utilizadas para examinar aspectos texturais e de zoneamento das fases minerais, como suporte para as análises pontuais quantitativas (WDS). Análises pontuais qualitativas foram empregadas para identificar algumas fases acessórias mais diminutas de difícil reconhecimento ao microscópio petrográfico.

Análises quantitativas, em um total de mais de cinco centenas, foram obtidas essencialmente para os minerais formadores de rocha (feldspato alcalino, plagioclásio, piroxênios, anfibólios e micas) e para os óxidos de $\mathrm{Fe}-\mathrm{Ti}$. $\mathrm{Na}$ maioria dos casos, as condições analíticas empregadas foram $15 \mathrm{kV}, 20 \mathrm{nA}$ e 1-5 um para a voltagem de aceleração da coluna, corrente e diâmetro do feixe de elétrons, respectivamente. No caso dos feldspatos alcalinos, o feixe utilizado 
foi aumentado para $10 \mu \mathrm{m}$, procurando-se obter composições mais representativas do feldspato primário original, pela integração de intensidades do hospedeiro potássico e das lamelas albíticas de exsolução. No caso dos óxidos de Fe-Ti, particularmente magnetita, as lamelas de exsolução, em geral ilmeníticas, foram quantificadas com diâmetro mínimo do feixe $(<1 \mu \mathrm{m})$ devido às suas dimensões diminutas.

As rotinas analíticas correspondem as convencionais do laboratório (e.g., Gualda and Vlach, 2007); os padrões utilizados correspondem aos referidos na documentação do laboratório, em parte doados pelo Smithsonian Institute e, em parte adquiridos da Geller ${ }^{\mathrm{TM}}$. As correções para os efeitos de matriz e as conversões de dados foram efetuadas automaticamente com o programa PRZ/Amstrong fornecido com o equipamento.

A conversão dos dados de química mineral para proporções catiônicas e/ou fórmulas estruturais dos minerais essenciais, bem como a computação de parâmetros químicos pertinentes foram efetuadas com o programa MinCal (G. Gualda e S. Vlach: https://my.vanderbilt.edu/ggualda/mincal). As estimativas de $\mathrm{Fe}^{+2}$ e $\mathrm{Fe}^{+3}$ nos silicatos máficos são, neste programa, baseadas no formalismo de Droop (1987). No caso específico dos anfibólios, o programa utiliza o método estequiométrico de Schumacher (c.f. Leake et al., 1997). No entanto, ao invés de se considerar o valor médio obtido, como indicado, optou-se por se considerar o valor máximo de $\mathrm{Fe}^{+3}$, conforme sugerido por Gualda and Vlach (2005). A nomenclatura seguida para piroxênios, anfibólios e micas segue as recomendações de Morimoto (1988, ver também Deer et al., 1992), Leake et al., (1997b) e Rieder et al. (1999), respectivamente. Deve ser ressaltado que uma nova proposta de classificação para o supergrupo dos anfibólios foi 
recentemente proposta por Hawthorne et al. (2012), mas prefere-se ainda utilizar a anterior para facilidade de comparação com a literatura. No caso dos óxidos de Fe-Ti, as conversões e cálculos foram realizados com programa desenvolvido por Lepage (2003).

A diagramação de resultados, bem como os cálculos efetuados para fins de determinação de parâmetros intensivos de cristalização a partir da química mineral foram efetuados com programas específicos de acesso público.

\subsection{ANÁLISES ISOTOPICAS}

Análises isotópicas pontuais, de alta resolução espacial, por espectrometria de massa multicanal por plasma de indução acoplada com amostragem por ablação laser (LA-MC-ICP-MS), foram obtidas para cristais de zircão de amostras selecionadas com objetivos de datação U/Pb e de análise isotópica pertinente à sistemática Lu-Hf. As preparações específicas ao método e as análises foram efetuadas nos Laboratórios do CPGeo e SHRIMP II do IGcUSP.

A partir dos resultados petrográficos e litogeoquímicos, foram selecionadas para estas análises, 6 amostras de rochas graníticas e 5 de amostras de dacitos, riolitos e diques intermediários a máficos, representativas dos três Complexos estudados e uma representativa de um charnoquito das encaixantes metamórficas adjacente ao Maciço Plutônico Algeciras.

A preparação dos concentrados de cristais de zircão, a partir do material britado disponível das etapas de preparação para geoquímica elemental de rocha total, seguiu os procedimentos indicados no CPGeo-USP e detalhados, entre outros, por Basei et al. (2013) e referências lá citadas. A brita original foi 
cominuida em moinho disco e, em seguida, o material resultante foi peneirado em torre de peneiras de nylon descartáveis com malhas de 60, 80, 100, 250 e <250 ("fundo", ou pó) meshes. A partir da fração 100-250 meshes (0,150 a 0,075 mm), um concentrado de minerais pesados foi obtido em mesa vibratória de tipo Wilfley. A seguir, os minerais magnéticos foram extraídos deste concentrado com imã de mão e, após, com separador magnético Frantz - sob condições variadas de inclinação e de campo magnético - foi obtida uma fração final idealmente não-magnética. Desta, a separação das fases minerais mais densas foi feita por decantação natural em meio dos líquidos pesados Bromoformio $\left(\mathrm{d}=2,85 \mathrm{~g} / \mathrm{cm}^{3}\right.$ ) e, em seguida, lodeto de Metileno $(\mathrm{d}=3,2$ $\left.\mathrm{g} / \mathrm{cm}^{3}\right)$.

A separação e seleção final dos cristais de zircão a partir do concentrado final obtido foi feita manualmente, por catação sob lupa binocular. Cerca de 80100 cristais de cada amostra foram montados em resina, com eixo cristalográfico $\underline{\underline{c}}$ disposto preferencialmente de forma horizontal. Estas montagens foram polidas com pasta de diamante até que as zonas centrais da maioria dos cristais ficassem expostas em superfície. Após, as montagens foram imageadas sob luz transmitida em microscópio petrográfico, metalizadas com C em evaporador e levadas ao microscópio eletrônico de varredura (SEM) para obtenção de imagens de catodo-luminescência $(C L)$. O imageamento $C L$, de alta resolução, foi efetuado no SEM Quanta 250 da FEI, sediado no Laboratóro SHRIMP II do IGc-USP, sob condições instrumentais de rotina.

As imagens obtidas foram analisadas em detalhe para se examinar a estrutura interna dos cristais de zircão (e.g., zoneamentos, inclusões e fraturas) 
e selecionar os pontos mais apropriados para datação U-Pb e análises isotópicas Lu-Hf.

\subsubsection{Datações U/Pb em zircão}

As análises pontuais LA-MC-ICPMS U-Pb foram realizadas com um sistema Laser ArF Excimer $(\lambda=193 \mathrm{~nm})$, acoplado a um espectrômetro Neptune da Thermo-Finnigan, de acordo com os procedimentos e as rotinas analíticas e de tratamento de resultados estabelecidos por Sato et al. (2012).

A ablação foi efetuada com um diâmetro do feixe de laser de $32 \mu \mathrm{m}$, a uma frequência de $6 \mathrm{~Hz}$, tempo de ablação de $40 \mathrm{~s}$ (um segundo por ciclo) e fluxo de energia de $6 \mathrm{~mJ}$. Os isótopos ${ }^{202} \mathrm{Hg},{ }^{204}(\mathrm{Hg}+\mathrm{Pb}),{ }^{206} \mathrm{~Pb},{ }^{207} \mathrm{~Pb},{ }^{208} \mathrm{~Pb},{ }^{232} \mathrm{Th}$ and ${ }^{238} \mathrm{U}$ foram quantificados simultaneamente. $\mathrm{O}$ sinal de ${ }^{204} \mathrm{Hg}$ foi monitorado com brancos para estabelecer a interferência do sinal sobre o isótopo ${ }^{204} \mathrm{~Pb}$ e cada interferência foi corrigida com o valor medido de ${ }^{202} \mathrm{Hg}$, adotando-se a razão ${ }^{204} \mathrm{Hg} /{ }^{202} \mathrm{Hg}=4,2$. A variação instrumental das massas dos isótopos de $\mathrm{Pb}$ foi monitorada com o material de referência NIST610 - utilizando-se a razão ${ }^{207} \mathrm{~Pb} /{ }^{206} \mathrm{~Pb}=0,90986 \pm 5$ indicada por Baker et al. (2004) - e com o padrão internacional GJ-1, com idade $600 \pm 3 \mathrm{Ma}$ (Elhlou et al., 2006). O Pb comum residual foi corrigido com o ${ }^{204} \mathrm{~Pb}$ medido, usando o modelo terrestre de Stacey e Kramers (1975).

A computação das idades pontuais $\mathrm{U} / \mathrm{Pb}$ e a diagramação dos resultados foram efetuadas com o programa Isoplot 4.1 (Ludwig, 2008).

\subsubsection{Análises Isotópicas Lu-Hf}

As determinações pontuais dos isótopos de Lu e Hf foram realizadas para as mesmas amostras datadas, mas somente em zonas de cristais de zircão que 
resultaram em idades concordantes. Os procedimentos analíticos e de tratamento de dados seguiram as propostas de Sato et al. (2009) e Basei et al. (2013).

As análises foram conduzidas com feixe com diâmetro de $47 \mu \mathrm{m}$, sob frequência de $7 \mathrm{~Hz}$, energia nominal de $90 \%\left(7,70 \mathrm{~J} / \mathrm{cm}^{2}\right)$, com 50 ciclos de ablação (um segundo por ablação) e fluxo energético de $60 \mathrm{~mJ}$. Na rotina implantada, os isótopos ${ }^{171} \mathrm{Yb},{ }^{173} \mathrm{Yb},{ }^{174} \mathrm{Yb},{ }^{175} \mathrm{Lu},{ }^{176}(\mathrm{Hf}+\mathrm{Yb}+\mathrm{Lu}),{ }^{177} \mathrm{Hf},{ }^{179} \mathrm{Hf}$ são medidos simultaneamente. A razão ${ }^{176} \mathrm{Lu} /{ }^{177} \mathrm{Hf}$ foi calculada considerandose uma razão ${ }^{176} \mathrm{Lu} /{ }^{175} \mathrm{Lu}=0,02669$. Os padrões utilizados foram o GJ-1e Mud Tank, para os quais as razões ${ }^{176} \mathrm{Hf} /{ }^{177} \mathrm{Hf}$ medidas durante o período das análises foram 0,2820151 $\pm 0,0000023(2 \sigma ; n=334)$ e 0,2824699 $\pm 0,0000080$ $(2 \sigma ; n=85)$, respectivamente. As razões ${ }^{176} \mathrm{Hf} /{ }^{177} \mathrm{Hf}$ obtidas para estes padrões foram similares aos valores obtidos de referência de 0,282015 $\pm 0,0000025$ $(2 \sigma ; n=24)$ e $0,282504 \pm 0,000044(2 \sigma, n=158)$ reportados, entre outros, por Liu et al. (2010) e Woodhead and Hergt (2005), respectivamente, com variações somente na quinta casa decimal.

O parâmetro $\varepsilon \mathrm{Hf}$ - uma forma mais apropriada de representar as razões ${ }^{176} \mathrm{Hf} /{ }^{177} \mathrm{Hf}$, dadas as ordens de grandeza envolvidas foi calculado considerando-se o valor as composições isotópicas de Lu e Hf do reservatório condrítico. As nomenclaturas $\varepsilon H f(0)$ e $\varepsilon H f(t)$ se referem aos valores $\varepsilon_{H f}$ calculados para o momento atual e para a idade de cristalização ${ }^{206} \mathrm{~Pb} / 238 \mathrm{U}$ obtida para o cristal de zircão. As constantes utilizadas nos cálculos foram: $\lambda\left({ }^{176} \mathrm{Lu}\right)=1,867 \mathrm{x}$ $10^{11} \mathrm{ano}^{-1}$ (Söderlund et al., 2004), ${ }^{176} \mathrm{Lu} /{ }^{177} \mathrm{Hf}=0,0332 \mathrm{e}{ }^{176} \mathrm{Hf} /{ }^{177} \mathrm{Hf}=0,282772$ para as razões condríticas atuais (Blichert-Toft and Albarède, 1997). As idades modelo foram calculadas em relação ao manto empobrecido (TDM), 
considerando-se um modelo de evolução de dois estágios e utilizando um fator de enriquecimento de ${ }^{176} \mathrm{Lu} /{ }^{177} \mathrm{Hf}$ de 0,015 - correspondente ao valor da Bulk Earth (Goodge e Vervoort, 2006) - e as razões ${ }^{176} \mathrm{Lu} /{ }^{177} \mathrm{Hf}=0.038512 \mathrm{e}$ ${ }^{176} \mathrm{Hf} /{ }^{177} \mathrm{Hf}=0.283225($ Vervoort e Blichert-Toft, 1999). 


\section{CAPÍTULO III}

\section{Mapeamento geológico de rochas intrusivas: Um estudo de caso na região de Garzón, Cordilheira Oriental dos Andes Colombianos}

Neste capítulo são reunidos e discutidos os resultados dos trabalhos de campo e laboratório que permitiram mapear, com critérios faciológicos as rochas graníticas e associadas que afloram nos Maciços Plutônicos Algeciras e Altamira, na região de Garzón, Cordilheira Oriental dos Andes Colombianos. O texto completo é apresentado no Apêndice A.

Granitos (senso latu) e rochas associadas do Jurássico são as rochas mais abundantes que afloram na Cordilheira Oriental nos Andes do Norte. Apresentase neste capítulo uma primeira tentativa de mapear e caracterizar em detalhe a diversidade petrográfica dos granitos Jurássico e das rochas subvulcânicas associadas colocadas na região de Garzón, no extremo sudeste da Cordilheira Oriental. São oferecidos novos mapas para os maciços plutônicos Algeciras e Altamira, embasados nos conceitos descritivos de facies petrográfica plutônica e associações de facies, e em caracterizações petrográfica e mineralógica de maior detalhe para os tipos de granitos observados. Oito facies e/ou associações de facies plutônicas e três subvulcânicas no Maciço Algeciras e outras cinco no Maciço Altamira foram diferenciadas e mapeadas. Hornblenda biotita granitos (sieno- e monzogranitos) e biotita hornblenda, hornblenda e biotita monzogranitos são os tipos plutônicos principais que constituem o primeiro maciço, enquanto leuco-granitos são as variedades mais abundantes 
no último; um padrão zonado de distribuição de rochas graníticas foi mapeado no Maciço Plutônico Algeciras. Pórfiros félsicos (dacito, riolito), formando corpos menores irregulares, e diques sin-plutônicos máfico-intermediários (principalmente micro-dioritos) cortam as rochas plutônicas em ambos os maciços. Evidências geológicas e petrográficas indicam níveis relativamente rasos de colocação para as rochas plutônicas e sugerem taxas de soerguimento orogênico e erosão algo maior para a porção norte da área estudada. Dados estruturais locais (estruturas planares penetrativas de estado sólido, orientações de diques) se coadunam com movimentos transcorrentes dextrais ao longo do Sistema de Falhas Algeciras, de orientação SWW-NNE, em um regime transpressional associado com um evento maior de compressão durante o Jurássico. 


\section{CAPÍTULO IV}

Introspeções nas idades e fontes do magmatismo Jurássico nos Andes do Noroeste: Geoquímica em rocha total e geoquímica isotópica U-Pb e Hf in situ em zircão de granitos e rochas associadas da região de Garzón,

\section{Cordilheira Oriental da Colômbia}

Neste capítulo são apresentados, integrados e discutidos dados obtidos para geoquímica de rocha total (elementos maiores, menores e traços) e dados geocronológicos U-Pb e isotópicos ( $\mathrm{Lu}-\mathrm{Hf})$ de alta resolução obtidos para cristais de zircão. Os resultados são integrados com informações disponíveis para ocorrências Jurássicas similares dos Andes e interpretados à luz dos modelos existentes relativos à gênese e evolução do magmatismo e do seu ambiente tectônico. O texto completo consta do Apêndice B.

Volumoso magmatismo granítico (sensu lato) ocorre na região noroeste da América do Sul, iniciando-se no Triássico tardio e estendendo-se até o Jurássico. Os Maciços plutônicos Algeciras, Altamira e Sombrerillo são os representantes principais deste magmatismo no Cordilheira Oriental Colombiana e o foco deste estudo. O Maciço Algeciras é constituído principalmente de hornblenda, biotita hornblenda e biotita monzogranitos, hornblenda biotita granodioritos e leucogranitos subordinados, enquanto leucogranitos (sieno- e monzogranitos com biotita) são amplamente predominantes no Maciço Altamira; biotita hornblenda monzogranitos são as rochas principais do Maciço Sombrerillo, e são acompanhados por monzodioritos e monzogranitos muitos 
particulares, contendo dois piroxênios. Intrusões menores são constituídas por pórfiros félsicos (dacito, riolito), bem como diques máfico-intermediários sinplutônicos que ocorrem em todos os maciços. As intrusões graníticas principais se colocaram em torno de ca. $189 \pm 7$ Ma (Maciço Plutônico Sombrerillo) e entre 176 e 170 Ma (maciços plutônicos Algeciras e Altamira); as rochas subvulcânicas, por sua vez, apresentam idades entre 160 e 175 Ma. As rochas intrusivas apresentam assinaturas geoquímicas comuns às series cálcio-alcalina a álcali-cálcica, magnesianas e metaluminosas; variedades mais restritas apresentam assinaturas mais alcalinas, ferroanas e levemente peraluminosas. São caracterizadas típico enriquecimento relativo dos elementos litófilos de raio grande (LIL) sobre os elementos de alto campo de força (HFS) e dos elementos terras raras leves (ETRL) sobre as pesadas (ETRP), com $7.7 \leq \mathrm{LaN} / \mathrm{YbN}_{\mathrm{N}} \leq 22.2$, e anomalias negativas de Eu. Valores de Th relativamente altos e razões $\mathrm{Sm} / \mathrm{Yb}$ baixas $(\leq 4)$ sugerem contribuições crustais, sejam de sedimentos carreados em subducção, sejam da crosta continental sobrejacente ou ainda de ambos. Padrões composicionais e características geoquímicas como estas são típicas de ambientes de arco continental, relacionado a zonas de subducção de crosta oceânica. As rochas plutónicas apresentam valores $\varepsilon \mathrm{Hf}_{(\mathrm{t})}$-em-zircão negativos (7.7 to -1.2 ) e idades modelo de dois estágios (TDM) entre 900 e $1660 \mathrm{Ma}$, sugerindo também contribuições significativas de fontes crustais, relativamente evoluídas do ponto de vista isotópico. Valores $\varepsilon \mathrm{Hf}_{(\mathrm{t})}-\mathrm{em}$-zircão positivos (até 14.6), idades TDM de 220 até 830 Ma e a presença de xenocristais e/ou antecristais de zircão com idades de 404 a 1365 Ma nas rochas subvulcânicas, 
indicam contribuições de manto jovem e de materiais crustais mais antigos. A distribuição das idades de cristalização e a distribuição do magmatismo granítico nas Cordilheiras Central e Oriental sugerem migração para leste da frente do arco magmático Jurássico por volta de $180 \mathrm{Ma}$, associada a fenômenos de subducção-erosão, seguida por uma nova migração desta frente para oeste por volta de $170 \mathrm{Ma}$, esta última associada com mudança de regime de subducção. 


\title{
CAPÍTULO V
}

\author{
Química mineral de granitos Jurássicos e rochas associadas do \\ Cordilheira Oriental Da Colômbia, Andes do Norte: variações \\ composicionais dos minerais formadores de rocha e parâmetros \\ intensivos de cristalização
}

Este capítulo apresenta e discute as variações composicionais das fases minerais principais das rochas graníticas e subvulcânicas dos maciços plutônicos Algeciras, Altamira e Sombrerillo, que afloram na Cordilheira Oriental dos Andes Colombianos, e, juntamente com alguns dados geoquímicos em rocha total, suas implicações para as condições de colocação e cristalização dos respectivos magmas. O texto completo consta do Apêndice C.

Dados texturais e químicos quantitativos, obtidos com Microssonda Eletrônica (EPMA), dos principais minerais formadores de rocha, até então não disponíveis para granitos (sensu lato) e rochas associadas da Andes Colombianos Jurássicos, são apresentados e empregados, juntamente com alguns dados de litogeoquímica, para estimar parâmetros de cristalização/colocação e suas implicações para a evolução do magmatismo granítico. O trabalho enfatiza os maciços plutônicos Algeciras, Altamira e Sombrerillo, os maciços Jurássicos mais importantes da Cordilheira Oriental Colombiana, na região de Garzón. O Maciço Plutônico Algeciras é formado por variedades de hornblenda, biotita hornblenda e biotita monzogranitos e, subordinadamente, por hornblenda biotita granodioritos e leucogranitos; o Maciço Altamira, por sua vez, é constituído essencialmente por leuco sieno- e monzogranitos com biotita. Biotita e biotita 
hornblenda monzogranitos predominam amplamente no Maciço Plutônico Sombrerillo, em que afloram também variedades muito particulares de monzogranitos e monzodioritos com dois piroxênios. Corpos de dimensões reduzidas de biotita hornblenda pórfiros félsicos e diques máfico-intermediários (microdioritos e andesitos) cortam as rochas intrusivas em todos os maciços. As rochas intermediárias e félsicas apresentam amfibólio cálcico variavelmente zonado (magnésiohornblenda, magnésiohastingsita e edenita, com $0.54 \leq \mathrm{mg \#}$ 0.92, mais elevado nas rochas subvulcânicas), biotita relativamente homagenea (principalmente flogopita, siderofilita em alguns leucogranitos peraluminosos, com $0.47 \leq \mathrm{mg \#} \leq 0.65$ ) e piroxênios (enstatita, augita subcálcica, augita e diopsídio, com $0.49 \leq \mathrm{mg} \# \leq 0.71)$. Titanita \pm allanita + magnetita \pm ilmenite + apatita + zircão são as fases acessórias primárias na maioria das amostras estudadas; a magnetite apresenta frequentemente exsolução de ilmenita de tipo treliça. Geotermobarometria baseada em Al-em-hornblenda e no equilíbrio quasi-solidus plagioclásio-hornblenda e termometria de saturação de fases (apatita, zircão) indicam que as rochas plutônicas se colocaram em profundidades crustais semelhantes e relativamente rasas (profundidades de ca. $4.5 \mathrm{~km}$, sob $\mathrm{P} \approx 1.5 \pm 0.5 \mathrm{kbar}$ or $\approx 150 \pm 50 \mathrm{MPa})$. Os intervalos de cristalização estimados situam-se principalmente entre temperaturas de ca. $930^{\circ} \mathrm{C}$ (próximo ao liquidus) a ca. $700^{\circ}$ (próximo ao solidus) e as etapas principais de cristalização ocorreram sob condições insaturadas em água. Os pórfiros riolíticos se colocaram sob pressões similares, mas temperaturas algo mais elevadas. Por outro lado, as composições de fenocristais de anfibólio, 
particularmente dos pórfiros dacíticos, registram uma história de cristalização complexa, em que os núcleos dos cristais se formaram sob pressões mais altas (até $510 \mathrm{MPa}$ ), temperaturas em torno de $1050^{\circ} \mathrm{C}$ e conteúdos de água entre 4.3-5.7 \% em peso, enquanto as bordas dos mesmos foram cristalizadas sob pressões tão baixas quanto $80 \mathrm{MPa}$, a $800^{\circ} \mathrm{C}$ e conteúdos de água entre 4.9-6.7 \% em peso. Estes valores para as bordas são compatíveis com a colocação final dos magmas nas rochas graníticas hospedeiras. Tanto as rochas plutônicas quanto as subvulcânicas foram formadas sob condições francamente oxidantes, com $+1 \leq \Delta \mathrm{QFM} \leq+3$, como esperado em arcos magmáticos continentais. Nos estágios evolutivos pós-magmáticos, as condições foram ainda mais oxidantes, conforme registrado nas fases de óxidos de Fe-Ti exsolvidas, e descrevem uma tendência oxidante com a diminuição de temperatura. 


\section{CAPÍTULO VI}

\section{SUMÁRIO E COMENTÁRIOS FINAIS}

No presente trabalho foram apresentados dados geológicos, petrográficos, mineralógicos, geoquímicos para rocha total e minerais e isotópicos para zircão que contribuem significativamente para fundamentar melhor os modelos existentes para a evolução tectono-magmática do magmatismo granítico andino colombiano, parte NW dos Andes, em tempos Jurássicos.

Na região de Garzón, estudada neste trabalho, a exemplo da maioria das outras áreas colombianas, as informações previamente existentes eram em geral fragmentadas, alguns aspectos conhecidos em maior detalhe, outras praticamente sem informações, fato que dificulta interpretações e correlações mais efetivas para este magmatismo. Para cobrir em parte estas deficiências, foi efetuado um trabalho inicial de mapeamento, fundamentado nos conceitos de fácies e associações de facies petrográficas nos ora denominados Maciços Plutônicos Algeciras e Altamira (cf. Capítulo III), que juntamente com o Maciço Plutônico Sombrerillo, constituem os principais maciços plutônicos que afloram na Cordilheira Oriental dos Andes Colombianos e foram os objetivos principais do trabalho apresentado. Estes maciços são representativos do período principal de magmatismo, que se inicia ao final do Triássico e abrange todo o Jurássico. Merece ser destacado que dados geocronológicos ainda eram muito escassos.

$\mathrm{Na}$ literatura regional, duas hipóteses principais foram levantadas para explicar este magmatismo: uma primeira, o associa a um ambiente de extensão, de rifte 
intra-continental, a segunda, propõe um ambiente compressivo de arco continental, associado à subducção de crosta oceânica proto-Pacífica na área NW do Gondwana.

O primeiro modelo, de extensão, é mencionado nos trabalhos que estudaram as rochas vulcano-sedimentares do Vale Superior do Rio Magdalena (e.g., Formações Luisa, Payandé e Saldaña), localizadas entre as Cordilheiras Central e Oriental da Colômbia (e.g., Cediel et al., 1981, 2003; Mojica, 1984; Mojica \& Dorado, 1987; Mojica \& Franco, 1990; Mojica \& Kammer, 1995; Kammer \& Mojica, 1996). De forma geral, o modelo propõe uma distensão tectônica acontecendo desde o Triássico e continuando sem interrupção durante o Jurássico, gerando grabens ou riftes supra-continentais, que separariam transversalmente as bacias dos altos estruturais, facilitando a sedimentação e a atividade magmática responsável pela origem dos maciços plutônicos. Assume, assim, que todo o magmatismo deste período (Triássico-Jurássico) é gerado em ambiente extensional. Entretanto, modelos envolvendo extensão prolongada, sem interrupções, apresentam inconsistências e não conseguem, por exemplo, explicar hiatos de deposição sedimentar ou eventos metamórficos de caráter regional.

O outro modelo, mais consistente e de reconhecimento mais amplo, advoga que após a desagregação do continente Pangea e até o final do Triássico, existem períodos de compressão, subducção, fusão crustal e magmatismo, processos amplamente registrados em diversas regiões da América do Sul, América Central e América do Norte (Noble et al., 1997; Pindell and Dewey, 1982; Ross and Scotese, 1988). Com apoio, entre outros, de dados geoquímicos (elementais e 
isotópicos) e geocronológicos para as rochas intrusivas e vulcânicas associadas, o modelo propõe a formação de arcos vulcânicos continentais relacionado ao estabelecimento de zonas de subducção por toda a borda noroeste da América do Sul, desde o final do Triássico e início Jurássico (Aspden et al., 1987; Aspden and McCourt, 1986; Jaillard et al., 1990; McCourt et al., 1984).

Assim, os primeiros registros do magmatismo granítico Jurássico na Colômbia são reportados na região de Santander, parte norte da Cordilheira Oriental, entre ca. 195 e 201 Ma, e algumas rochas mais antigas no Distrito de Vetas-Califórnia com idades entre 197 e 211 Ma (Mantilla Figueroa et al., 2013; van der Lelij et al., 2016). Spikings et al. (2015) propuseram uma migração da frente deste arco magmático para oeste em ca. $194 \mathrm{Ma}$, com base nos contrastes observados nas assinaturas geoquímicas e idades das rochas de Santander e as rochas localizadas ao oeste, nas regiões de Segovia e Ibagué, ao norte e sul da Cordilheira Central, respectivamente, que junto com rochas de na região de San Lucas (também ao norte desta Cordilheira) e com rochas mais antigas do Maciço Plutônico de Sombrerillo, foram formadas no intervalo entre 178 e 194 Ma (cf. Capítulo IV).

Os resultados obtidos neste trabalho permitem sugerir uma segunda migração da frente e relocação do arco magmático para leste por volta de ca. 180 Ma (Cap. IV). Esta migração ê tentativamente associada com processos de "erosão por subducção", que ocorrem comumente em margens convergentes, através da combinação de erosão e colapso estrutural da cunha do ante arco para dentro da fossa, gerando abrasão na base da crosta continental, entrada de material jovem 
no canal de subducção e consequente migração da frente do arco para a posição do retro-arco (Stern, 2011). Se esta interpretação for correta, é a primeira referência deste tipo de fenômeno na parte norte dos Andes neste período, de forma similar ao que tem sido interpretado, entre outras áreas, para o Complexo Plutlônico de Chaltén na Patagonia durante o Cenozoico (De Arellano et al., 2012), para a Zona Vulcânica dos Andes do Sul e Centrais (Kay and Mpodozis, 2002; Kay et al., 2014, 2005) também no Cenozoico, e para a região oeste dos Estados Unidos durante o Cretáceo, relacionado com a Orogenia Laramide (e.g., Saleeby, 2003; Ducea et al., 2015).

Os produtos magmáticos gerados nos maciços Algeciras, Altamira e Sombrerillo apresentam assinatura cálcio-alcalina a álcali-cálcica e magnesiana, com teores de $\mathrm{K}_{2} \mathrm{O}$ (> $4 \% \mathrm{wt}$ ) relativamente mais elevados, quando comparados com outras rochas Jurássicas do norte dos Andes (e.g. região de Santander, Distrito de Mineração de Vetas-California , Batólito Mocoa; Mantilla Figueroa et al., 2013; van der Lelij et al., 2016; Zapata et al., 2016); adicionalmente, os dados isotópicos disponíveis também indicam contribuições mais efetivas de fontes isotopicamente mais evoluídas, com valores negativos para ambos os parâmetros $\varepsilon \mathrm{Nd}(\mathrm{t})$ em rocha total e $\varepsilon \mathrm{Hf}(\mathrm{t})$ em zircão (Cap. IV). Estes contrastes podem ser explicados em parte por uma contribuição mais efetiva da crosta continental e, em parte menor, pelas características distintas das rochas que constituem o embasamento cristalino regional. De fato, o embasamento da região da Cordilheira Central está constituído principalmente por orto-gnaisses e anfibolitos de idades Permo-Triássicas (ca. 278-234 Ma; Bustamante et al., 2017; Cochrane et al., 2014a), enquanto o 
embasamento da Cordilheira Oriental na região de Garzón está constituído por, gnaisses, granulitos, anfibolitos e migmatitos de idades Meso- a Neoproterozoica (Altenberger et al., 2012; Jiménez Mejía et al., 2006). A presença de xenocristais de zircão nos riolitos de Algeciras e Altamira com idades entre 982 a 1365 Ma e os valores principalmente negativos do $\varepsilon_{\mathrm{Hf}}(\mathrm{t})(-1,2$ e $-7,7)$, com idades modelo de 890 a 1360 Ma encontrados nas rochas graníticas, sugerem que este embasamento, assim como o manto subjacente e a placa em subdução, devem ter contribuído para os magmas que originaram estas rochas (Capítulo IV).

Estes maciços plutônicos se colocaram em crosta continental relativamente rasa, sob pressões da ordem de $150 \mathrm{MPa}(1,5 \mathrm{kbar}$, ca. 4,5 km de profundidade) e os magmas que os constituíram foram relativamente anidros (caso mais marcante registrado em monzodiotiros e monzogranitos com orto- e clinopiroxênios do Maciço Sombrerrillo) a subsaturados em $\mathrm{H}_{2} \mathrm{O}$ (demais variedades) e cristalizaram sob condições relativamente oxidantes, compatíveis com $+1 \leq \Delta \mathrm{QFM} \leq+3$ (cf. Cap. V).

A partir de ca. 170 Ma o magmatismo na região de Garzón arrefece, estando representado essencialmente pela colocação de diques máficos-intermediários e pórfiros félsicos (dacitos e riolitos), com características geoquímicas e isotópicas mais tipicamente juvenis. Estas variações podem refletir uma variação do regime de subducção, que envolve fusão parcial de crosta oceânica, da cunha do manto, como também materiais crustais, processos bem sustentados por uma base de dados experimental e geoquímica de arcos vulcânicos (Castro et al., 2010; Defant and Drummond, 1990; Stern and Kilian, 1996). De fato, a fusão parcial da placa 
em subducção, composta por basaltos hidratados e sedimentos pelágicos/ terrígenos, e interação dos produtos com o manto suprajacente, geram magmas com características particulares, que incluem valores tipicamente positivos para $\varepsilon \mathrm{Hf}_{(\mathrm{t})}$ em zircão (até $\left.+14,6\right)$ relacionado a fontes mantélicas e o enriquecimento relativo em Th, que sugere contribuição dos mencionados sedimentos. Estas características o magmatismo granítico gerado entre 129 a 165 Ma na região da Cordilheira Central (Bustamante et al., 2016) e também se relacionam os fenômenos de erosão por subducção, os quais contribuem para a entrada destes materiais juvenis.

Merece ser destacado que cristais de anfibólio dos diques máfico-intermediários e, em especial, fenocristrais de anfibólio em dacitos pórfiros registram estágio prolongado de cristalização, sob diferentes pressões e temperaturas. De fato, as zonas de núcleo destes anfibólios são gerados em níveis crustais profundos (13 e $23 \mathrm{~km}$ ), sob altas pressões (até 5,6 kbar) e temperaturas (entre $898^{\circ}$ e $1050^{\circ} \mathrm{C}$ ), e as bordas são estabilizadas em níveis crustais superiores (3-5 km), em condições de pressão e temperatura menores $\left(0,8\right.$ a $1,7 \mathrm{kbar}$ e $806^{\circ}$ a $\left.912^{\circ} \mathrm{C}\right)$, similares às condições regitradas nos granitos encaixantes (cf. Capítulo V).

Estes úlitmos dados permitem admitir uma migração mais jovem, novamente para oeste, do arco magmático ao final do Jurassico, com base no término da atividade magmática nas regiões de Algeciras e Atamira e desenvolvimento de intensa atividade magmática na Cordilheira Central, por volta de $165 \mathrm{Ma}$ (Bustamante et al., 2016). Neste panorama, os diques e pórfiros tardios poderiam ter sido gerados em um ambiente de relaxamento tectônico, associado a um retro- 
arco. Estas idéias são compatíveis com as interpretações de que bacias de retroarco são formadas a partir no final do Jurássico e inicio do Cretáceo na Cordilheira Oriental e no Vale Superior do Rio Magdalema (Cooper et al., 1995; SarmientoRojas et al., 2006). Adicionalmente, estes fenômenos de migração do arco poderiam estar relacionados a uma maior inclinação no mergulho da placa, que dificultaria a subducção, causando um retrocesso e migração da frente do arco para a Cordilheira Central. Estas ideias também são compatíveis com os modelos de slab roll-back propostos na Cordilheira Central, baseados nas idades mais jovens no sentido oeste da Cordilheira (Cochrane et al., 2014b). 


\section{REFERÊNCIAS BIBLIOGRÁFICAS}

Acosta, J., Osorno, J.F., 1999. Geologia de la Plancha 324 Tello. Mapa Geológico. Escala 1:100.000. INGEOMINAS. Bogotá D. C.

Albarède, F., 1998. The growth of continental crust. Tectonophysics 296, 1-14. doi:10.1016/S0040-1951(98)00133-4

Altenberger, U., Mejia Jimenez, D.M., Gunter, C., Sierra Rodriguez, G.I., Scheffler, F., Oberhansli, R., 2012. The Garzón Massif, Colombia-a new ultrahightemperature metamorphic complex in the Early Neoproterozoic of northern South America. Mineral. Petrol. 105, 171-185. doi:10.1007/s00710-012-02021

Alvarez, J.A., 1981. Determinación de la edad $\mathrm{Rb} / \mathrm{Sr}$ en Rocas del Macizo de Garzón, Cordillera Oriental de Colombia. Geol. Norandina 4, 31-38.

Aspden, J.A., McCourt, W.J., 1986. Mesozoic oceanic terrane in the central Andes of Colombia. Geology 14, 415-418.

Aspden, J.A., McCourt, W.J., Brook, M., 1987. Geometrical control of subductionrelated magmatism: the Mesozoic and Cenozoic plutonic history of Western Colombia. J. Geol. Soc. London. 144, 893-905.

Baker, J., Peate, D., Waight, T., Meyzen, C., 2004. Pb isotopic analysis of standards and samples using a 207Pb-204Pb double spike and thallium to correct for mass bias with a double-focusing MC-ICP-MS. Chem. Geol. 211, 275-303. doi:10.1016/j.chemgeo.2004.06.030

Basei, M.A.S., Campos Neto, M.D.C., Lopes, A.P., Nutman, A.P., Liu, D., Sato, K., 2013. Polycyclic evolution of Camboriú Complex migmatites, Santa Catarina, Southern Brazil: integrated $\mathrm{Hf}$ isotopic and $\mathrm{U}-\mathrm{Pb}$ age zircon evidence of episodic reworking of a Mesoarchean juvenile crust. Brazilian J. Geol. 43, 427-443. doi:10.5327/Z2317-48892013000300002

Best, M.G., 2003. Igneous and Metamorphic Petrology, Second Edi. ed. Blackwell Science Ltd, Turin, Italy. doi:10.1180/minmag.1983.047.344.33

Blichert-Toft, J., Albarède, F., 1997. The Lu-Hf isotope geochemistry of chondrites and the evolution of the mantle-crust system. Earth Planet. Sci. Lett. 148, 243-258.

Bustamante, C., Archanjo, C.J., Cardona, A., Bustamante, A., Valencia, V.A., 2017. U-Pb Ages and Hf Isotopes in Zircons from Parautochthonous Mesozoic Terranes in the Western Margin of Pangea: Implications for the Terrane Configurations in the Northern Andes. J. Geol. 125, 487-500. doi:10.1086/693014

Bustamante, C., Archanjo, C.J., Cardona, A., Valencia, V., 2016. Geochronology and geochemistry of Late Jurassic to Early Cretaceous plutonism in the Central Cordillera and Upper Magdalena valley of the Colombian Andes: a 
record of long-term arc maturity and oblique subduction. Geol. Soc. Am. Bull.

Bustamante, C., Cardona, A., Bayona, G., Mora, A., Valencia, V., Gehrels, G., Vervoort, J., 2010. U-Pb LA-ICP-MS Geochronology and regional correlation of Middle Jurassic intrusive rocks from the Garzon Massif, Upper Magdalena Valley and Central Cordillera, Southern Colombia. Boletín Geol. 32, 93-109.

Cárdenas, J.I., Fuquen, J.A., Núñez, A., 2002. Geología de la Plancha 388 Pitalito. Mapa Geológico. Escala 1:100.000. INGEOMINAS. Bogotá D. C.

Cárdenas, J.I., Núñez, A., Fuquen, J.A., 2003. Geología de la plancha 388 Pitalito. Escala 1:100.000. Memoria Explicativa. Bogotá D. C.

Castro, A., Gerya, T., García-Casco, A., Fernández, C., Díaz-Alvarado, J., MorenoVentas, I., Löw, I., 2010. Melting relations of MORB-sediment Mélanges in Underplated Mantle Wedge Plumes; Implications for the origin of Cordillerantype Batholiths. J. Petrol. 51, 1267-1295. doi:10.1093/petrology/egq019

Cediel, F., Mojica, J., Macía, C., 1981. Las formaciones Luisa, Payandé, Saldaña. Sus columnas estratigráficas características. Geol. Norandina 3, 11-19.

Cediel, F., Shaw, R.P., Cáceres, C., 2003. Tectonic Assembly of the Northern Andean Block. AAPG Mem. 79, 815-848.

Cochrane, R., Spikings, R., Gerdes, A., Ulianov, A., Mora, A., Villagómez, D., Putlitz, B., Chiaradia, M., 2014a. Permo-Triassic anatexis, continental rifting and the disassembly of western Pangaea. Lithos 190-191, 383-402. doi:10.1016/j.lithos.2013.12.020

Cochrane, R., Spikings, R., Gerdes, A., Winkler, W., Ulianov, A., Mora, A., Chiaradia, M., 2014b. Distinguishing between in-situ and accretionary growth of continents along active margins. Lithos 202-203, 382-394. doi:10.1016/j.lithos.2014.05.031

Cooper, M.A., Addison, F.T., Alvarez, R., Coral, M., Graham, R.H., Hayward, A.B., Howe, S., Martinez, J., Naar, J., Peñas, R., Pulham, A.J., Taborda, A., 1995. Basin Development and Tectonic History of the Llanos Basin, Eastern Cordillera, and Middle Magdalena Valley, Colombia. Am. Assoc. Pet. Geol. Bull. 79, 1421-1443.

De Arellano, C.R., Putlitz, B., Müntener, O., Ovtcharova, M., 2012. High precision $\mathrm{U} / \mathrm{Pb}$ zircon dating of the Chaltén Plutonic Complex (Cerro Fitz Roy, Patagonia) and its relationship to arc migration in the southernmost Andes. Tectonics 31. doi:10.1029/2011TC003048

Deer, W.A., Howie, R.A., Zussman, J., 1992. An Introduction to Rock Forming Minerals.

Defant, M.J., Drummond, M.S., 1990. Derivation of some moder arc magmas by melting young subducted lithosphere. Nature 347, 662-665.

Ducea, M.N., Paterson, S.R., DeCelles, P.G., 2015. High-volume magmatic events 
in subduction systems. Elements 11, 99-104. doi:10.2113/gselements.11.2.99

Elhlou, S., Belousova, E.A., Griffin, W.L., Pearson, N.J., O'Reilly, S.Y., 2006. Trace element and isotopic composition of GJ-red zircon standard by laser ablation. Geochim. Cosmochim. Acta 70, A158. doi:10.1016/j.gca.2006.06.1383

Goodge, J.W., Vervoort, J.D., 2006. Origin of Mesoproterozoic A-type granites in Laurentia: Hf isotope evidence. Earth Planet. Sci. Lett. 243, 711-731. doi:10.1016/j.epsl.2006.01.040

Gualda, G.A.R., Vlach, S.R.F., 2007. The Serra da Graciosa A-type Granites and Syenites, southern Brazil. Part 2: Petrographic and mineralogical evolution of the alkaline and aluminous associations. Lithos 93, 310-327. doi:10.1016/j.lithos.2006.06.002

Gualda, G.A.R., Vlach, S.R.F., 2005. Stoichiometry-based estimates of ferric iron in calcic, sodic-calcic and sodic amphiboles: A comparison of various methods. An. Acad. Bras. Cienc. 77, 521-534. doi:10.1590/S000137652005000300012

Hawthorne, F.C., Oberti, R., Harlow, G.E., Maresch, W. V., Martin, R.F., Schumacher, J.C., Welch, M.D., 2012. Nomenclature of the amphibole supergroup. Am. Mineral. 97, 2031-2048.

Ibanez-Mejia, M., Ruiz, J., Valencia, V. a., Cardona, A., Gehrels, G.E., Mora, A.R., 2011. The Putumayo Orogen of Amazonia and its implications for Rodinia reconstructions: New $\mathrm{U}-\mathrm{Pb}$ geochronological insights into the Proterozoic tectonic evolution of northwestern South America. Precambrian Res. 191, 5877. doi:10.1016/j.precamres.2011.09.005

Jaillard, E., Solerl, P., Carlier, G., Mourier, T., 1990. Geodynamic evolution of the northern and central Andes during early to. J. Geol. Soc. London. 147, 10091022.

Janoušek, V., Farrow, C.M., Erban, V., 2006. Interpretation of whole-rock geochemical data in igneous geochemistry: Introducing Geochemical Data Toolkit (GCDkit). J. Petrol. 47, 1255-1259. doi:10.1093/petrology/egl013

Jiménez Mejía, D.M., Juliani, C., Cordani, U.G., 2006. P-T-t conditions of highgrade metamorphic rocks of the Garzon Massif, Andean basement, SE Colombia. J. South Am. Earth Sci. 21, 322-336. doi:10.1016/j.jsames.2006.07.001

Kammer, A., Mojica, J., 1996. Una Comparación de la Tectónica de Basamento de las Cordilleras Central y Oriental. Geol. Colomb. 20, 93-106.

Kay, M.S., Mpodozis, C., 2002. Magmatism as a probe to the Neogene shallowing of the Nazca plate beneath the modern Chilean flat-slabs. J. South Am. Earth Sci. 15, 39-57. doi:10.1016/S0895-9811(02)00005-6

Kay, S.M., Godoy, E., Kurtz, A., 2005. Episodic arc migration, crustal thickening, subduction erosion, and magmatism in the south-central Andes. Bull. Geol. 
Soc. Am. 117, 67-88. doi:10.1130/B25431.1

Kay, S.M., Mpodozis, C., Gardeweg, M., 2014. Magma sources and tectonic setting of Central Andean andesites $\left(25.5-28^{\circ} \mathrm{S}\right)$ related to crustal thickening, forearc subduction erosion and delamination. Geol. Soc. London, Spec. Publ. 385, 303-334. doi:10.1144/SP385.11

Leake, B.E., Woolley, A.R., Arps, C.E.S., Birch, W.D., Gilbert, C.M., Grice, J.D., Hawthorne, F.C., Kato, A., Kisch, H.J., Krivovichev, V.G., Linthout, K., Laird, J., Mandarino, J. a., Maresch, W. V., Nickel, E.H., Rock, N.M.S., Schumacher, J.C., Smith, D.C., Stephenson, N.C.N., Ungaretti, L., Whittaker, E.J.W., Youzhi, G., 1997. Nomenclature of Amphiboles: Report of the Subcommittee of the International Commission on New Minerals Names and Mineral. Can. Mineral. 35, 219-246.

Leake, B.E., Woolley, A.R., Arps, C.E.S., Birch, W.D., Gilbert, M.C., Grice, J.D., Hawthorne, F.C., Kisch, H.J., Krivovichev, V.G., Linthout, K., Laird, J., Mandarino, J.A., Maresch, W. V., Schumacher, J.C., Smith, D.C., Stephenson, N.C.N., Whittaker, E.J.W., Youzhi, G., 1997. NOMENCLATURE OF AMPHIBOLES: REPORT OF THE SUBCOMMITTEE ON AMPHIBOLES OF THE INTERNATIONAL MINERALOGICAL ASSOCIATION, COMMISSION ON NEW MINERALS AND MINERAL NAMES WILLIAM D. BIRCH * ( Australia; from January 1995 ) This report was produced in response t. Can. Mineral. 35, 219-246.

Lepage, L.D., 2003. ILMAT: An Excel worksheet for ilmenite-magnetite geothermometry and geobarometry. Comput. Geosci. 29, 673-678. doi:10.1016/S0098-3004(03)00042-6

Liu, Y.S., Hu, Z.C., Zong, K.Q., Gao, C.G., Gao, S., Xu, J., Chen, H.H., 2010. Reappraisement and refinement of zircon $\mathrm{U}-\mathrm{Pb}$ isotope and trace element analyses by LA-ICP-MS. Chinese Sci. Bull. 55, 1535-1546. doi:10.1007/s11434-010-3052-4

Ludwig, K.R., 2008. User 's Manual for Isoplot 3.70. Isoplot 3.70: A Geochronological Toolkit for Microsoft Excel. Berkeley Geochronol. Cent. Spec. Publ. 76.

MacKenzie, W.S., Donaldson, C.H., Guildford, C., 1995. Atlas of igneous rocks and their textures.

Mantilla Figueroa, L.C., Bissig, T., Valencia, V., Hart, C.J.R., 2013. The magmatic history of the Vetas-California mining district, Santander Massif, Eastern Cordillera, Colombia. J. South Am. Earth Sci. 45, 235-249. doi:10.1016/j.jsames.2013.03.006

McCourt, W.J., Aspden, J.A., Brook, M., 1984. New geological and geochronological data from the Colombian Andes: continental growth by multiple accretion. J. Geol. Soc. London. 141, 831-845.

Mojica, J., 1984. AN OUTLINE ON THE JURASSIC IN COLOMBIA. Geol. Colomb. 
13, 129-136.

Mojica, J., Dorado, J., 1987. El Jurásico anterior a los movimientos Intermálmicos en los Andes Colombianos, in: Volkheimer, W. (Ed.), Bioestratigrafía de Los Sistemas Regionales Del Jurásico Y Cretácico de América Del Sur. Comite Sudamericano del Jurásico y Cretácico, Mendoza, Argentina, pp. 49-110.

Mojica, J., Franco, R., 1990. Estructura y Evolucion Tectonlca del Valle Medio y Superior del Magdalena, Colombia. Geol. Colomb. 17, 41-64.

Mojica, J., Kammer, A., 1995. Eventos Jurásicos en Colombia. Geol. Colomb. 19, 165-172.

Morales, C.J., Caicedo, J.C., Velandia, F.A., Núñez, A., 2001. Geología de la Plancha 345 Campoalegre. Escala 1:100.000. Memoria Explicativa. INGEOMINAS. Bogotá D. C.

Mori, P.E., Reeves, S., Correia, C.T., Haukka, M., 1999. Development of a fused glass disc XFR facility and comparision with the pressed powder pellet technique at Instituto de Geociências, São Paulo University. Rev. Bras. Geociências 29, 441-446.

Navarro, M.S., 2004. A implantação de rotina, e seu refinamento, para a determinação de elementos terras raras em materiais geológicos por ICPOES e ICP-MS. Aplicação ao caso dos granitóides de Piedade-Ibiúna (SP) e Cunhaporanga (PR). Universidade de São Paulo. Instituto de Geociências.

Navarro, M.S., Andrade, S., Ulbrich, H., Gomes, C.B., Girardi, V. a V, 2008. The direct determination of rare earth elements in basaltic and related rocks using ICP-MS: Testing the efficiency of microwave oven sample decomposition procedures. Geostand. Geoanalytical Res. 32, 167-180. doi:10.1111/j.1751908X.2008.00840.x

Noble, S.R., Aspden, J.A., Jemielita, R., 1997. Northern Andean crustal evolution: New U-Pb geochronological constraints from Ecuador. Geol. Soc. Am. Bull. 109, 789-798.

Núñez, A., 2003. Reconocimiento geológico regional de las planchas 411 La Cruz, 412 San Juan de Villalobos, 430 Mocoa, 431 Piamonte, 448 Monopamba, 449 Orito y 465 Churuyaco. Departamentos de Caquetá, Cauca, Huila, Nariño y Putumayo. Escala 1:100.000. INGEOMINAS. Memoria . Bogotá D. C. doi:10.1024/0301-1526.32.1.54

Núñez, A., Gómez, J., 2002. Gelogía de la Plancha 412 San Juan de Villalobos. Mapa Geológico. Escala 1:100.000. INGEOMINAS. Bogotá D. C.

Pindell, J., Dewey, J.F., 1982. Permo-Triassic reconstruction of Western Pangea and the Evolution of the Gulf of Mexico/Caribbean Region. Tectonics 1, 179211.

Pindell, J.L., Kennan, L., 2009. Tectonic evolution of the Gulf of Mexico, Caribbean and northern South America in the mantle reference frame: an update. Geol. 
Soc. London, Spec. Publ. 328, 1-55. doi:10.1144/SP328.1

Priem, H.N.A., Kroonenberg, S.B., Boelrijk, N.A.I.M., Hebeda, E.H., 1989. Rb-Sr AND K-Ar EVIDENCE FOR THE PRESENCE OF A $1.6 \mathrm{Ga}$ BASEMENT UNDERLYING THE 1.2 Ga GARZON-SANTA MARTA GRANULITE BELT IN THE COLOMBIAN ANDES. Precambrian Res. 42, 315-324.

Rieder, M., Cavazzini, G., D’Yakonov, Y.S., Frank-Kamenetskii, V., Gottardi, G., Guggenheim, S., Koval, P. V., Muller, G., Neiva, A.M.R., Radoslovich, E., Robert, J.-L., Sassi, F.P., Takeda, H., Weiss, Z., Wones, D.R., 1999. Nomenclature of the micas. Mineral. Mag. 63, 267-279.

Rodríguez, G., Arango, M.I., Zapata, G., Bermúdez, J.G., 2018. Petrotectonic characteristics, geochemistry, and U-Pb geochronology of Jurassic plutons in the Upper Magdalena Valley-Colombia: Implications on the evolution of magmatic arcs in the NW Andes. J. South Am. Earth Sci. 81, 10-30. doi:10.1016/j.jsames.2017.10.012

Rodríguez, G., Ferreira, P., Velandia, F., Núñez, A., 1998. Geología de la Plancha 366 Garzón. Mapa Geológico. Escala 1:100.000. INGEOMINAS. Bogotá D. C.

Rodríguez, G., Zapata, G., Velásquez, M.E., Cossio, U., Londoño, A.C., 2003a. Geología de las planchas 367 Gigante, 368 San Vicente del Caguán, 389 Timaná, 390 Puerto Rico, 391 Lusitania (parte noroccidental) y $414 \mathrm{El}$ Doncello. Departamentos de Caquetá e Huila. INGEOMINAS. Medellín, Colombia.

Rodríguez, G., Zapata, G., Velazquez, M., 2003b. Geología de la Plancha 389 Timaná. Mapa Geológico. Escala 1:100.000. INGEOMINAS. Medellín, Colombia.

Ross, M.I., Scotese, C.R., 1988. A hierarchical tectonic model of the Gulf of Mexico and Caribbean region. Tectonophysics 155, 139-168.

Saleeby, J., 2003. Production and loss of high-density batholithic root, southern Sierra Nevada, California. Tectonics 22, 89-92. doi:10.1029/2002TC001374

Sarmiento-Rojas, L.F., Van Wess, J.D., Cloetingh, S., 2006. Mesozoic transtensional basin history of the Eastern Cordillera, Colombian Andes: Inferences from tectonic models. J. South Am. Earth Sci. 21, 383-411. doi:10.1016/j.jsames.2006.07.003

Sato, K., Basei, M.A.S., Sproesser, W.M., Siga, O.J., 2012. The application of U$\mathrm{Pb}$ Geochronology to zircon and titanite by Laser Ablation-ICP-MS. 8th Int. Conf. Anal. Geol. Environ. Mater.

Sato, K., Siga, O., Da Silva, J.A., Mcreath, I., Dunyi, L., lizuka, T., Rino, S., Hirata, T., Sproesser, W., Basei, M.A., 2009. In Situ Isotopic Analyses of U and Pb in Zircon by Remotely Operated SHRIMP II , and Hf by LA-ICP-MS : an Example of Dating and Genetic Evolution of Zircon by $176 \mathrm{Hf} / 177 \mathrm{Hf}$ from the Ita Quarry in the Atuba Complex, SE Brazil. Geol. USP 9, 61-69. 
Söderlund, U., Patchett, P.J., Vervoort, J.D., Isachsen, C.E., 2004. The 176Lu decay constant determined by $\mathrm{Lu}-\mathrm{Hf}$ and $\mathrm{U}-\mathrm{Pb}$ isotope systematics of Precambrian mafic intrusions. Earth Planet. Sci. Lett. 219, 311-324. doi:10.1016/S0012-821X(04)00012-3

Spikings, R., Cochrane, R., Villagomez, D., Van der Lelij, R., Vallejo, C., Winkler, W., Beate, B., 2015. The geological history of northwestern South America: From Pangaea to the early collision of the Caribbean Large Igneous Province (290-75Ma). Gondwana Res. 27, 95-139. doi:10.1016/j.gr.2014.06.004

Stacey, J.S., Kramers, J.D., 1975. Approximation of terrestrial lead isotope evolution by a two-stage model. Earth Planet. Sci. Lett. 26, 207-221. doi:10.1016/0012-821X(75)90088-6

Stern, C.R., 2011. Subduction erosion: Rates, mechanisms, and its role in arc magmatism and the evolution of the continental crust and mantle. Gondwana Res. 20, 284-308. doi:10.1016/j.gr.2011.03.006

Stern, C.R., Kilian, R., 1996. Role of the subducted slab, mantle wedge and continental crust in the generation of adakites from the Andean Austral Volcanic Zone. Contrib. to Mineral. Petrol. 123, 263-281. doi:10.1007/s004100050155

Ulbrich, H., Vlach, S.R.F., Janasi, V.A., 2001. O mapeamento faciológico em rochas ígneas plutônicas. Rev. Bras. Geociências 31, 163-172.

van der Lelij, R., Spikings, R., Ulianov, A., Chiaradia, M., Mora, A., 2016. Palaeozoic to Early Jurassic history of the northwestern corner of Gondwana, and implications for the evolution of the lapetus, Rheic and Pacific Oceans. Gondwana Res. 31, 271-294. doi:10.1016/j.gr.2015.01.011

Velandia, F., Acosta, J., Terraza, R., Villegas, H., 2005. The current tectonic motion of the Northern Andes along the Algeciras Fault System in SW Colombia. Tectonophysics 399, 313-329. doi:10.1016/j.tecto.2004.12.028

Velandia, F., Morales A., C.J., Caicedo A., J.C., Núñez, A., 1999. Geología de la Plancha 345 Campoalegre. Mapa Geológico. Escala 1:100.000. INGEOMINAS. Bogotá D. C.

Velandia, F.P., Ferreira, P. V., Rodríguez, G., Núñez, A., 2001. Leavantamiento geológico de la Plancha 366 Garzón. Escala 1:100.000. INGEOMINAS. Bogotá D. C.

Vernon, R.H., 2004. A Practical Guide to Rock Microstructure. Cambridge University Press, New York. doi:10.1017/CBO9780511807206

Vervoort, J.D., Blichert-Toft, J., 1999. Evolution of the depleted mantle: Hf isotope evidence from juvenile rocks through time. Geochim. Cosmochim. Acta 63, 533-556. doi:10.1016/S0016-7037(98)00274-9

Vlach, S., 1993. Geologia e Petrologia dos Granitóides de Merongaba, SP. Tese de Doutoramento. Universidade de São Paulo. 
Vlach, S., 1985. Geologia, Petrografia e Geocronologia das Regiões Meridional e Oriental do Complexo de Morungaba, SP. Dissertação de Mestrado. Universidade de São Paulo.

Williams, H., Turner, F.J., Gilbert, C.M., 1982. Petrography. An Introdution to the Study of Rocks in thin sections, Second Edi. ed. W. H. Freeman and Company, Inc., Berkeley, California.

Wilson, M., 1989. Igneous Petrogenesis, 10th ed. Springer, Dordrecht, The Netherlands.

Woodhead, J.D., Hergt, J.M., 2005. A preliminary appraisal of seven natural zircon reference materials for in situ $\mathrm{Hf}$ isotope determination. Geostand. Geoanalytical Res. 29, 183-195. doi:10.1111/j.1751-908X.2005.tb00891.x

Zapata, S., Cardona, A., Jaramillo, C., Valencia, V., Vervoort, J., 2016. U-Pb LAICP-MS geochronology and geochemistry of jurassic volcanic and plutonic rocks from the Putumayo region (southern Colombia): Tectonic setting and regional correlations. Bol. Geol. 38, 21-38. doi:10.18273/revbol.v38n22016001 
Comentários do Autor: páginas 45 a 50 em branco 


\section{APÊNDICES E ANEXOS}

APÊNDICE A (p. 53): "Geological Mapping of Intrusive Rocks: A Study Case in the Garzón region, Eastern Cordillera of Colombian Andes"

(García-Chinchilla D.A.; Vlach, S.R.; Giraldo-Arroyave M.I.)

APÊNDICE B (p. 93): "Insights on timing and source of the Jurassic magmatism in Northwestern Andes: Whole-rock geochemistry and in situ zircon $\mathrm{U}-\mathrm{Pb}$ and $\mathrm{Hf}$ isotope geochemistry in granites and related rocks from the Garzón region, Eastern Cordillera of Colombia"

(García-Chinchilla D.A. \& Vlach, S.R.)

APÊNDICE C (p. 159) "Mineral chemistry of Jurassic granites and related rocks from Eastern Colombian Cordillera, Northern Andes: compositional variations of rockforming minerals and intensive parameters of crystallization"

ANEXO (p. 215) "Supplementary Material" 


\section{Apêndice A}

Manuscrito: "Geological Mapping of Intrusive Rocks: A Study Case in the Garzón region, Eastern Cordillera of Colombian Andes"

García-Chinchilla, D.A.; Vlach, S.R.F.; Giraldo-Arroyave, M.I. 


\title{
Geological Mapping of Intrusive Rocks: A Study Case in the Garzón region, Eastern Cordillera of Colombian Andes
}

\author{
Daniel Alejandro García Chinchilla[1]; Silvio Roberto Farias Vlach[1]; Maria Isabel
} Giraldo Arroyave[1]

[1] Departamento de Mineralogia e Geotectônica, Instituto de Geociências, Universidade de São Paulo, Rua do Lago, 562, Cidade Universitária, 05508-080, São Paulo, SP, Brasil

\begin{abstract}
Jurassic granite (senso latu) and related rocks are the most abundant rocks cropping out in the Eastern Colombian Cordillera in northern Andes. We present herein a first attempt to map and characterize in detail the petrographic diversity of Jurassic granites and related subvolcanic rocks emplaced in the Garzón region, southernmost Eastern Cordillera. We provide new maps for the Algeciras and Altamira plutonic massifs based on the petrographic plutonic facies and facies associations descriptive concepts, and detailed petrographic and mineralogical characterization of the observed granite types. Eight plutonic and three subvolcanic petrographic facies or facies associations were recognized and mapped in the Algeciras and other five in the Altamira plutonic massif. Hornblende biotite granites (syeno- and monzogranites) and biotite hornblende, hornblende and biotite monzogranites are the main plutonic types constituting the former massif, while leuco granites are the most abundant variety on it; a zoned granite distribution pattern was mapped in the Algeciras Plutonic Massif. Felsic porphyries (dacite, rhyolite) as minor irregular bodies or dikes and mafic-intermediate syn-plutonic dikes (mostly microdiorites) cross cut the main plutonic rocks in both massifs. Geological and petrographic evidences indicate relatively shallow emplacement levels
\end{abstract}


for the plutonic rocks and suggest somewhat high uplift and erosion rates to the northern of the studied area. Structural data (local penetrative solid-state planar structures, dike orientations) conforms well the right lateral strike-slip movements along the SWW-NNE trending Algeciras Fault System, in a transpressional regimen associated to a major compressive Jurassic event.

Key words: granite mapping, petrographic facies, Algeciras Plutonic Massif, Altamira Plutonic Massif, Eastern Colombian Cordillera

\section{INTRODUCTION}

Geological mapping and the related stratigraphic nomenclature of igneous intrusive rocks are among the most common and controverted issues in geosciences remaining without a common satisfactory solution. In the past decades, several authors have proposed specific nomenclatures trying to unify concepts for the intrusive rocks (e.g. Bateman and Dodge, 1970; Cobbing et al., 1981; Cobbing, 2000; Ulbrich et al., 2001; and references therein). A consensus have never been reached however. For instance, the North American Stratigraphic Code (NACSN, 2005) groups within a Lithodemic Unit all intrusive bodies, highly deformed rocks, and/or highly metamorphosed rocks, and recognizes that they generally do not conform the Superposition Law. On the other hand, the Internal Union of Geological Sciences (IUGS, Murphy and Salvador, 1998) does not discriminate nor include all of them in the recognized Lithostratigraphic Units. Nevertheless, the minor subdivision of a Lithodemic unit is the "Lithodem", which appears to be not appropriate to describe intrusive igneous rocks characteristic details. 
This also happens with the so-called units and super-units (Cobbing et al., 1981; Cobbing and Pitcher, 1972; Cobbing, 2000).

Ulbrich et al. (2001) proposed plutonic facies as a descriptive term to avoid some of the above questions. It is defined as the minor hierarchical level of informal litostratigraphic units that can be recognized and described in hand samples and field outcrops, on the basis of their mineralogical, textural and structural properties, without a priori genetic implications. In the same way, the term facies association was proposed by Vlach $(1993,1985)$ to group similar petrographic facies that should be mapped together, considering their distributions in relation to the mapping scale. In this sense, a petrographic facies or a facies association correspond to a mapping unit (Ulbrich et al., 2001; Vlach, 1993, 1985).

Grouping facies associations or mapping units into major stratigraphic units may be a difficult task when dealing with granitic and related rocks. Conventional mapping studies generally use terms as "pluton", "intrusion”, "occurrence” or even petrographic names such as "granite" or "syenite" together with a geographic term (e.g. Garzón Granite) in order to name an igneous massif or pluton, a set of intrusive rocks located within a specific geographic position and emplaced at a determined time interval (Ulbrich et al., 2001), which represent a structural coherent single- or multi-intrusive unit limited by well established external contacts (Vlach, 1993). These units, by their side, may be grouped within batholiths, plutonic complexes or massifs.

Jurassic granitic (sensu lato) magmatism is widespread in the Central and Eastern Colombian Andean Cordilleras, cropping out by an area of about $32500 \mathrm{~km}^{2}$ and 
including several major occurrences (e.g., Ibagué, Segovia, Pescadero batholiths). Systematic geological mapping of such rocks at an appropriate scale is still scarce however and there are several local nomenclatural issues. In the studied Garzón region (Eastern Cordillera), for instance, the large $\left(>100 \mathrm{~km}^{2}\right)$ Altamira and Algeciras granitic occurrences has been alternatively named as "batholiths", "stocks", "monzogranites" or even "granites" (e.g. Arango et al., 2015; Rodríguez et al., 2015b; Velandia et al., 2001). Of importance, all plutonic occurrences are constituted by several field-recognizable granite varieties, which can be properly mapped in a 1:50.000 scale (or lower), as individualized petrographic facies or grouped as facies associations. In this contribution we present a geological map of the Algeciras and Altamira Plutonic Massif in the Eastern Colombian Cordillera, which represents a first attempt trying to organize and define granitic mapping units in the Garzón area, to be improved with further detailed fieldwork.

\section{METHOD}

The geological mapping of Algeciras and Altamira granitic rocks follows the concepts of petrographic plutonic facies and facies association, as introduced by Ulbrich et al. (2001) and the Vlach $(1993,1985)$, respectively. Each plutonic facies was defined according to field-observable mineralogical, textural and structural properties, as detailed by these authors. Late refinements, concerning particularly on accessory mineralogical contents, distributions and the proper IUGS (International Union of Geological Sciences) petrographic classification was done through thin section 
analyses under a petrographic microscope at the Optical Laboratory of the GeoAnalitica USP core facility.

The fieldwork was done in several campaigns during the $2010-2013$ years by the main author as a geologist from the Colombian Geologic Service (Servicio Gelógico Colombiano-SGC) and late, by 2014 , during his doctoral studies. Topographic $(1: 100.000)$ and previous geologic (1:100.000) maps were used as field references (Acosta and Osorno, 1999; Cárdenas et al., 2003, 2002; Morales et al., 2001; Núñez, 2003; Núñez and Gómez, 2002a; Rodríguez et al., 1998; Velandia et al., 1999, 2001). The final maps are presented in the 1:50.000 scale and based on a data set that includes ca. 300 rock outcrops and ca. 250 petrographic thin sections.

Of course, this data set is limited to variable extent, due to the huge topography, extensive vegetation cover and local intense weathering, which prevent good rock exposures and difficult field access, as well as the relatively low work time available. So, most contacts between differentiated intrusive plutonic and subvolcanic facies and between intrusive rocks and their metamorphic envelopes or sedimentary cover could not be observed and mapped in the desired detail. Such contacts, as well as the main regional faults and/or lineaments, were drawn mainly based on the Global Digital Elevation Model (NASA, 2016). Minor intrusive or subvolcanic igneous occurrences, such as dikes and plugs, representations are just illustrative in the adopted scale. 


\section{GEOLOGICAL BACKGROUND}

\subsection{Regional setting}

Colombia, NW of South America, is divided in two main regions on a geographic basis. At the Orinoco and Amazonian plane regions, to the east, Paleozoic, Mesozoic and Cenozoic sedimentary rocks and sediments cover older Meso- to Neoproteozoic igneous and metamorphic rocks. The Colombian Andes, to the west, is made up by three main mountain ranges, the Western, Central and Eastern Cordilleras, isolated each other by inter-Andean basins, filled in with Paleozoic to Cenozoic volcanosedimentary rocks. The studied Garzón area is located to the south of the Eastern Cordillera. Of note, local geologists use the term "Massif" as a general name for highland areas in the Eastern Cordillera and Sierra Nevada de Santa Marta, constituted both by Andean intrusive massifs and their Meso to Neoproterozoic igneous and metamorphic country rocks (e.g., Santa Marta, Santander, Floresta, Quetame and Garzón Massifs, cf. Fig. 1). The main geological features of the studied area are drawn in the following.

The country rocks include a variety of sedimentary- and igneous-derived medium- to high-grade metamorphic rocks (charnockites, gneisses, amphibolites, granulites) as well as migmatites. The main metamorphic episode took place under ca. 5-9 kbar and $650^{\circ}-850^{\circ} \mathrm{C}$ (Jiménez Mejía et al., 2006). These ancient rocks correlates with those cropping out in the Putumayo basement, Las Minas and Macarena mountain ranges, as well as other metamorphic complexes in Mexico and Central America (e.g. Oaxaca 
and Guichicovi), formed during the Putumayo-Oaxaca orogeny, by 1.0-1.3 Ga (IbanezMejia et al., 2011).

The Paleozoic, Carboniferous to Permian and Ordovician, sedimentary rocks comprise strongly faulted marine sequences that form isolated outcrops (Mojica et al., 1988a, 1988b; Moreno-Sánchez et al., 2008; Villarroel et al., 1997). Mojica et al. (1988b) and Núñez (2003) suggested that the Andean Jurassic granitic rocks had intruded them. These sequences were late covered by volcano-sedimentary sequences of the Saldaña Formation (Mojica et al., 1988b) with $186 \pm 2$ Ma (Zapata et al., 2016), which are in direct contact with the Andean granitic rocks in this area.

Some samples of granitic rocks from the Algeciras and Altamira plutonic massifs were dated from 169 to $179 \mathrm{Ma}$ (U/Pb in zircon, Bustamante et al., 2010; Rodríguez et al., 2018). The plutonic rocks forming these massifs as well as some subvolcanic equivalents have been related to a magmatic arc developed during oceanic crust subduction beneath the northwestern South American plate (Aspden et al., 1987; Aspden and McCourt, 1986; Bayona et al., 2006; Bustamante et al., 2016; Cochrane et al., 2014; McCourt et al., 1984; Spikings et al., 2015).

This extensive orogeny is well known in the west part of North and Central South America (Aspden et al., 1987; Jaillard et al., 1990; Pindell and Dewey, 1982; Ross and Scotese, 1988), albeit some of its characteristics remains unclear. For instance, subduction regimes change from late Jurassic to Early Cretaceous (Burke, 1988; Bustamante et al., 2016; Pindell et al., 2006) and there was a significant decrease in the overall magmatic activity (Bustamante et al., 2016; Villagómez et al., 2011) as a 
marginal Cretaceous basin was developing in the Eastern Cordillera (Cooper et al., 1995; Sarmiento-Rojas et al., 2006).

In the studied area, the first Cretaceous sedimentation is represented by the Yavi and Caballos Formations, with Aptian and Albian ages, respectively, which crops out in the Upper Magdalena River basin, covering the Saldaña Formation (Cooper et al., 1995; Velandia et al., 2001). Sedimentation appears to had remained relatively constant until the Early Cenozoic, when subduction has increased and the previous back-arc basin settings change to a foreland basin one (Cooper et al., 1995). By this time, younger magmatic arcs were developed in Central and Western Cordilleras (Aspden et al., 1987; Bustamante et al., 2016; Cochrane et al., 2014; McCourt et al., 1984; Spikings et al., 2015) while, in the Eastern Cordillera, the magmatic activity disappeared, perhaps due to a slab roll back process, which moves the subduction front westward (Cochrane et al., 2014). Subduction and related magmatism were most probably related then to the evolution of the Caribbean plate and accretion of oceanic terranes in southwestern South America (Pindell et al., 2005, 2006; Spikings et al., 2015). Foreland basin sedimentation continues, accompanied by deformation and thrust faulting in the Magdalena Valley basin, which unconformable overlays upper Eocene sediments, generating and upper Oligocene angular unconformity (Schamel, 1991). The most significant deformation event in the Eastern Cordillera occurred by the Miocene (Cooper et al., 1995; Schamel, 1991), uplifting it to expose the main Jurassic granitic intrusions and their country rocks. 


\subsection{Previous geological studies}

Grosse (1930) made the first geological studies on the Jurassic granitic rocks in the Garzón region. In the Eastern Cordillera, the author described several elongated granitic bodies with relatively homogenous compositions, varying from granodiorite do diorite, as well as late lamprophyre and aplite dikes, intruding metamorphic country rocks. Based on stratigraphic relations, he attributed a pre-Cretaceous age for them.

The main petrographic characteristics of these plutonic rocks were presented only three decades later however, by Radelli (1962a, 1962b, 1962c). He assigned them into "plutons" and recognized amphibolitic-micaceous syenites in the Suaza and Altamira plutons as well as granite in the Hobo-Algeciras Pluton and porphyritic granite in the Garzón Pluton. He emphasized that amphibole bearing microdiorite, aplite and pegmatite dikes intrude granites in all plutons. According to him, all plutons were formed in the same magmatic event, given their common mineralogical associations and homogeneous structures.

More recent maps from Eastern Cordillera areas, at 1:100.000 and 1:300.000 scales, were presented by several authors (Acosta and Osorno, 1999; Arango et al., 2015; Cárdenas et al., 2003, 2002; Marquínez and Velandia, 2001; Morales et al., 2001; Núñez, 2003; Núñez and Gómez, 2002b, 2002c, Rodríguez et al., 2015b, 2003a, 2003b, 1998, 2015a; Velandia et al., 1999). All of them represent the plutonic rocks undifferentiated, homogeneous "batholiths" or "stocks" however. Also, most rock descriptions are limited to their general composition, without further differentiation or refinements. 


\section{RESULTS}

In general, granite outcrops are relatively continuous, but inherent field difficulties do not allow examine and collect always the best outcrops and samples as pointed out before. Any case, our work reveals significant mineralogical and/or textural and/or structural variations that could be recognized in outcrops and hand samples and certainly better represented in maps. As a general relevant feature, most granitic varieties present light greyish or light to dark pink colors, the most dark colors cropping out in zones with variable evidences of late hydrothermal imprint.

\subsection{The Algeciras Plutonic Massif}

The Algeciras Plutonic Massif is elongated along the SW-NE direction, with ca. 5-10 km width and 50 km length, given an exposition area about 500 km² (Fig. 2).

The contacts between the plutonic and the neighboring rocks are mainly tectonic. Localized fault systems make the western contacts with Cretaceous rocks of the Magdalena Basin while the Algeciras Fault System, a spread deformation zone, limits the intrusive rocks with the high-grade metamorphic country rocks to the east (Fig. 2).

We were able to identify and map eight plutonic and three subvolcanic facies or facies associations (Fig. 2). In the following, a brief geological and petrographic characterization is presented. Representative modal data are given in Table 1 and represented in the QAP modal diagram in Fig. 3. 


\subsubsection{Hornblende biotite granite facies association}

This facies association is predominant all over the granite massif and its best exposures crop out along the Neiva River, close to the Algeciras-Campo Alegre highway and to the north (Fig. 4). Rocks vary from medium- to coarse-grained and the predominant varieties have typical inequigranular hypidiomorphic textures (Fig. 4). In general, the alkali-feldspar modal contents are similar or higher than plagioclase and, according to the IUGS nomenclature (Le Maitre et al., 2002), they classify as monzogranites and syenogranites (Fig. 3). They are leucocratic, with $10<\mathrm{Cl}$ (Color Index) $<15$ Table 1), with similar modal proportions of amphibole and biotite. Under the microscope, the plagioclase is andesine and the alkali-feldspar (orthoclase and/or low microcline) does not present detectable cross hatched twins; some samples have big alkali-feldspar crystals (up to $1 \mathrm{~cm}$ ) with a poiquilitic-like texture, given by significant number of euhedral plagioclase inclusions. The amphibole, with green to yellow greenish pleochroic colors, corresponds to a calcic, hornblende-like, variety. Biotite (brown reddish) occasionally substitutes for hornblende. Titanite, allanite, Fe-Ti oxides, apatite and zircon are the common accessory minerals, which appear as isolated euhedral crystals or forming small mafic clusters with the main mafic silicates (Fig. 4C; D).

A feature most typical of this facies association is the widespread occurrence of mafic microgranular enclaves with rounded, elongate or somewhat more irregular shapes and diameters varying from several millimeters to tens of centimeters. The contacts with the granites are sharp in general; some of them show a thin zone with aphanitic texture at their internal contacts, suggesting they were frozen against the host (Fig. 4B). 


\subsubsection{Leuco-granite facies association}

This is the second most abundant facies association mapped in the massif and crops out towards the middle-eastern and southern areas. Slightly planar orientations, mainly due to solid-state deformation are relatively common. They are hololeucocratic, with $\mathrm{Cl}$ $<5$, and amphibole is typically absent. In thin sections, the plagioclase is oligoclase to andesine to and show some bent lamellae twins; alkali feldspar is a typical microcline, with well-developed cross hatched twining. Quartz crystals have undulatory extinction and sometimes appear as interstitial recrystallized aggregates. Biotite (brown to red greenish by alteration) is mostly interstitial and appears accompanied by titanite, allanite, Fe-Ti oxides, apatite and zircon.

\subsubsection{Hornblende monzogranite facies association}

Rocks from this association dominate the northern massif areas and the best exposures occur along Las Ceibas River. They present pink to pink-grayish colors and are made mostly up massive, medium- (predominant) to coarse-grained inequigranular (alkali-feldspar $>$ plagioclase) varieties with $\mathrm{Cl}<9$. The typical mafic mineral is an amphibole, which appears mainly as isolated euhedral crystals; biotite is absent; quartz is interstitial to feldspars. In most samples, titanite is easily recognized in hand species. Under the petrographic microscope, the plagioclase (andesine) appears compositionally zoned and the alkali-feldspar is Carlbad-twinned. The calcic amphibole shows slight compositional zoning; some crystals may contain minute relicts of earlier colorless pyroxene, identified by its relatively high relief. The accessory phases occur as isolated euhedral crystals, as inclusions within felsic minerals or hornblende, or 
forms mafic aggregates with the late. They include, besides titanite, allanite (occasional), Fe-Ti oxides, apatite and zircon. Epidote-group minerals, chlorite, white micas and some carbonates appear as secondary minerals.

\subsubsection{Hornblende biotite granodiorite facies association}

This facies association crops out mainly in the central-western area of the massif, near the Blanco River area. Typical varieties have similarities with the hornblende monzogranite facies association (see above); plagioclase is largely predominant over the alkali-feldspar, quartz contents are somewhat lower and $\mathrm{Cl}$ is higher, up to 20, however. Of importance, most examined outcrops and collected samples show significant hydrothermal imprint effects. Under the microscope, plagioclase (andesine) is altered to saussuritc aggregates as well as chlorite and the calcic amphibole to chlorite and epidote. Hydrothermal epidote-group minerals, titanite and opaque phases, sometimes forming mineral aggregates filling in rock interstices or fractures, also appear in some thin sections.

In some of the examined exposures, these granodiorites were cross cut by andesite dikes, with flow, oriented structures given by euhedral plagioclase crystals, and rhyolite porphyries.

\subsubsection{Biotite hornblende monzogranite facies association}

These rocks crop out mainly to the northwest of the hornblende monzogranites exposures, along Las Ceibas River and neighboring areas. In hand samples, they are inequigranular, medium- to coarse-grained similar rocks, with $13<\mathrm{Cl}<15$; among the mafic minerals however, hornblende is always joined by biotite. Plagioclase is 
predominant over alkali-feldspar. Both the quartz and biotite modal contents, as well as biotite crystal sizes, increase towards northwestern and eventually biotite becomes the main mafic phase. In thin sections, plagioclase appears zoned (andesine-oligoclase), with sausurritic cores and the alkali-feldspar is slightly cross hatch twinned. Textural relations indicate that the amphibole (zoned hornblende), in general the main accessory mineral, is partially replaced by primary biotite. Typical primary accessory minerals are Fe-Ti oxides, titanite, allanite, apatite and zircon. Among the secondary phases, prehnite appears with chlorite and substitutes for biotite.

\subsubsection{Biotite monzogranite facies association}

Rock varieties constituting this association crop out mainly to the northwestern-most area of the massif. They have $\mathrm{Cl}$ between 5 and 10 and the main contrasts with the biotite hornblende monzogranites are the absence of amphibole and the modal predominance of alkali feldspar over plagioclase; quartz contents are also relatively higher. In thin sections, plagioclase is andesine and the exsolution textures in the perthitic alkali-feldspar are better developed.

\subsubsection{Biotite monzogranite mylonitic facies association}

Mylonitic biotite monzogranites $(5<\mathrm{Cl}<10)$ crop out along most of the western massif external contacts. They present a well-developed foliation striking $\mathrm{N} 18^{\circ} \mathrm{E}$ and dipping $86^{\circ} \mathrm{SE}$. Plagioclase and alkali feldspar porphyroclasts (sometimes slightly rotated) occur in a matrix made up by recrystallized quartz and feldspars and oriented biotite crystals. In general, deformation grade decreases eastwards (Fig. 4E; F). 


\subsubsection{Micrographic leuco-monzogranite facies}

This petrographic facies is of local importance and occurs in the south area of the massif eastern contacts, in the Neiva River and neighboring areas. Under the microscope, it is constituted mainly by medium-grained quartz-alkali feldspar micrographic intergrowths. The alkali feldspar is a typical microcline and plagioclase is an oligoclase-andesine type $\left(\mathrm{An}_{28-30}\right)$; biotite is the main mafic phase and the rocks are hololeucocratic, with low $(<3) \mathrm{Cl}$ values.

\subsubsection{Rhyolite porphyries}

These rocks appear as several minor and irregular bodies in the central and southern areas of the Algeciras Massif, intruding the hornblende monzogranites and leuco granites facies associations. Typical varieties have a porphyritic texture in a finegrained matrix. Phenocrysts population (30-50 \%vol.) is constituted mainly by variable proportions of quartz, plagioclase and alkali feldspar; hornblende, biotite, Fe-Ti oxides and titanite also appear as phenocrysts in some samples. Quartz may appear as embayed or skeletal phenocrysts. In thin sections, a glomeroporphyritic texture given by plagioclase, alkali feldspar and quartz groups of phenocrysts is common; the mesostasis is made up mainly by alkali feldspar + quartz micrographic intergrowths and spherulites (Fig. 4G). Plagioclase and alkali feldspar phenocrysts are partially to fully substituted by saussurite and sericite, respectively.

\subsubsection{Mafic-intermediate dikes}

Andesite and/or microdiorites dikes (5 to $300 \mathrm{~cm}$ thick), often fractured and truncated by minor local faults, intrude the biotite hornblende monzogranites and leuco 
monzogranites in several of the mapped areas. Two main dike swarms, oriented $\mathrm{N} 40^{\circ}$ $60^{\circ} \mathrm{E} / 50^{\circ}-75^{\circ} \mathrm{SW}$ and $\mathrm{N} 40^{\circ}-60^{\circ} \mathrm{W} / 60^{\circ}-80^{\circ} \mathrm{SW}$ were mapped. Other dike set, oriented $\mathrm{N} 8^{\circ}-10^{\circ} \mathrm{W} / 48^{\circ}-68^{\circ} \mathrm{NE}$ occurs close to the Neiva River. The structural relationships between them, specially the microdiorites, and the host granites, as well as their association with mafic microgranular enclaves, point to their syn-plutonic nature.

Andesites and microdiorites are compositionally similar rocks, distinguished solely on the basis of their textures. The andesites are porphyritic and present a very finegrained or aphanitic matrix, while the microdiorites are fine- to medium-grained and more equigranular. In thin sections, the andesites present a trachytic-like texture with zoned plagioclase (andesine to labradorite) and amphibole phenocrysts (up to $0.5 \mathrm{~mm}$ ) in a matrix composed of plagioclase laths, amphibole, biotite, some Fe-Ti oxides, titanite and minor quartz with a flow structure. Microdiorites have equigranular hypidiomorphic textures and strongly zoned plagioclase laths. Biotite content varies to a significant extent in these rocks, from small (ca. $5 \%$ vol.) to relatively high content (up to $20 \%$ vol.). Occasionally, amphibole preserves colorless, corroded, pyroxene crystals.

In thin section, the close associated mafic microgranular enclaves correspond to quartz-diorites and quartz monzodiorites, with an intergranular-like texture, given by strongly zoned plagioclase laths (andesine dominant) evenly distributed and amphibole filling in their interstices. Biotite, minor alkali-feldspar and quartz, accompanied by opaque minerals, titanite and apatite, complete their mineralogy. 


\subsubsection{Felsic dikes}

Rhyolite or microgranite dikes intrude the biotite hornblende monzogranites in some places. They are oriented mainly along a NW trend, similar to the mafic-intermediate dikes. Rocks are hololeucocratic $(\mathrm{Cl}<5)$, fine- to medium-grained, with an inequigranular texture. Under the microscope they show alkali feldspar (microcline) and quartz intergrowths and minor plagioclase (oligoclase). Quartz has undulatory extinction. Mafic mineral includes some amphibole and biotite; Fe-Ti oxides, titanite, apatite and zircon as accessory phases (Fig. $\mathbf{4 H}$ ).

\subsection{The Altamira Plutonic Massif}

The Altamira Plutonic Massif crops out to the south of the Algeciras Plutonic Massif, along a NE-SW trend, exceeding $8 \mathrm{~km}$ in width and $35 \mathrm{~km}$ in length, amounting about $280 \mathrm{~km}^{2}$ (Fig. 5). The massif is covered by Cenozoic deposits of the Magdalena Basin to the west, while, to the east, the contact with high-grade country rocks is tectonic, through the Algecira-Suaza Fault Zone, partially covered by late Quaternary sediments deposited along the Suaza River.

Five facies and facies associations were identified and mapped in this plutonic massif

(Fig. 5). They are briefly characterized in the following; representative modal data are presented in Table 1 and Fig. 3.

\subsubsection{Leuco-monzogranite facies association}

This association groups the most common rock varieties within the massif. It crops out in the southern area, covered by dense vegetation. In general, rock exposures are 
highly weathered and fresh samples are relatively scarce. The typical monzogranites present light greyish or white to pink colors (Fig. 6A; B). They are constituted by hololeucocratic, equigranular to inequigranular, fine- to medium-grained and massive varieties, with biotite as the main mafic mineral (Fig. 6C; D). The texture is hypidiomorphic in thin sections; alkali-feldspar develops a poor microcline twinning and appears in greater amount than plagioclase or quartz; almost poor albite aggregates appear interstitial to it; plagioclase (oligoclase-andesine) have a tabular habit and saussuritic core alteration. Quartz crystals are interstitial, anhedral, and present undulatory extinction. Primary accessories are allanite, Fe-Ti oxides, apatite and zircon. Pyrite appears occasionally.

A mylonite variety, with alkali feldspar and plagioclase porphyroclasts, crops out in small exposure areas close to the eastern tectonic contacts.

\subsubsection{Hornblende biotite granodiorite facies association}

These rock varieties are much subordinated in relation to the main leuco monzogranites and appear as dikes or minor irregular bodies, cropping out for some hundreds of meters. They occur in the core areas and to the northwestern massif borders and exhibit a grayish to whitish color and $10<\mathrm{Cl}<20$. Under the microscope, the texture is hypidiomorphic; plagioclase, zoned from andesine (saussuritic cores in general) to oligoclase, is tabular and often shows corrosion figures. Alkali feldspar is slightly cross hatch twined and contains some albite exsolution lamellae. Quartz is anhedral and interstitial and shows undulatory extinction. The mafic and accessory minerals appear as isolated crystals or crystal aggregates. Amphibole (hornblende) is 
the main mafic mineral; some samples have high biotite contents however, which substitutes for it. The accessories phases are titanite, allanite, Fe-Ti oxides, apatite and zircon. Chlorite usually replaces amphiboles and biotites. Epidote-group minerals, chlorite, carbonate, albite, sericite are secondary minerals.

\subsubsection{Hornblende monzodiorite facies association}

These rocks crop out in the central area of the massif. Most of the examined outcrops are discontinuous and limited, turning difficult to estimate their full extent. Rocks are massive, equigranular, medium- to coarse-grained, with whitish to pinkish colors and have $15<I C<25$. Texture is hypidiomorphic in thin sections, dominated by euhedral, tabular, plagioclase (andesine?) crystals, with minor, mainly interstitial, alkali feldspar (rarely up to $4 \mathrm{~mm}$ ) and quartz. Modal quantification results plot as monzodiorites, close to the monzonite, quartz monzonite and quartz monzodiorite IUGS fields (Fig. 3). Calcic amphibole (hornblende) occurs as isolated euhedral crystals or mafic clots. Saussuritic plagioclase and amphibole strongly altered to chlorite are typical in the pinkish varieties. Fe-Ti oxides (magnetite and ilmenite), apatite, titanite and zircon are the main accessory minerals.

\subsubsection{Mafic-intermediate dikes}

Andesite dikes, often associated with porphyritic rhyolites (see below), are characterized by slightly planar flow structures and a very fine-grained, intergranular, texture, given by amphibole crystals filling in interstices left by plagioclase laths. Plagioclase grains are euhedral and substituted to variable extents to chlorite or/and 
epidote, carbonate and quartz aggregates (Fig. 6E; F). Opaque minerals are altered to Fe-oxides (Fig. 6H).

Microdioritic dikes (20-40 $\mathrm{cm}$ thick) trending $\mathrm{N}-\mathrm{S} / 55^{\circ}-65^{\circ} \mathrm{E}$ present mostly massive structures and cross-cut leuco-monzogranites and hornblende granodiorites. They have a porphyritic texture, with plagioclase phenocrysts (usually zoning) from 0.5 to 1 $\mathrm{mm}$ surrounded by small grains $(0.2$ to $0.5 \mathrm{~mm})$ of alkali feldspar grains, resembling anti-rapakivi textures. Amphibole phenocrysts are occasional, biotite ones are rare. The rock mesostasis has microcrystalline texture and is made up by quartz-feldspar aggregates, with some opaque minerals and epidote. Opaque minerals, apatite and zircon are common primary accessory minerals. Some thin-section areas and fractures are filled in with quartz and alkali feldspar aggregates associated with fine-grained biotite $(<0.2 \mathrm{~mm})$, epidote and titanite, formed in late hydrothermal processes.

\subsubsection{Rhyolite porphyry dikes}

These rocks were mapped in the western areas of the massif. They are strong fractured and weathered, with abundant clay development. These dikes are close related and oriented according the same andesitic dike trends. They are hololeucocratic (IC $\leq 5)$ and present plagioclase, quartz and minor proportion of alkali feldspar phenocrysts surrounded by matrix of quartz-alkali feldspar micrographic intergrowths and very fine-grained chlorite, biotite and sericite aggregates (Fig. 6H). Plagioclase phenocrysts are oligoclase, in general substituted by white mica aggregates. Quartz phenocrysts are clean and rounded, and usually have skeletal textures; they sometimes form aggregates displaying a glomeroporphyritic texture. Perthitic alkali 
feldspar phenocrysts are subordinated. Amphibole, titanite and opaque minerals are the most common mafic minerals.

\section{DISCUSSION}

Geologic mapping of plutonic rocks should be done a priori, on the basis of descriptive, factual and easily observable or measureable rock properties defined in field outcrops and hand samples. Stratigraphic names should be applied with caution, avoiding nomenclatural messes. For instance, in the studied areas, the term "Garzón Massif", even informal, as used to include Jurassic plutonic and volcanic rocks, Paleozoic to Cenozoic meta-sedimentary rocks as well as early Neo- to Mesoproterozoic metamorphic rocks from the crystalline basement, should be avoided.

We show that granites and associated rocks that build the main intrusions in the Algeciras and Altamira massifs may be mapped using just such descriptive criteria to group them into petrographic facies or petrographic facies associations (Ulbrich et al., 2001; Vlach, 1993, 1985) in a 1:50.000 scale. These mapping units are preliminary assigned, given its distribution and extend areas, into big igneous structures named plutonic massif, which eventually could be grouped into a larger Eastern Cordillera Batolith, following, among others, suggestions of Cobbing et al. (1981) as applied in the Peruvian Andes area. Of importance, further work is still needed to assign our mapped units into individualized structural coherent igneous intrusions, or plutons, intrusive units in general with $\leq 80-120 \mathrm{~km}^{2}$ of exposure area (e.g., Cobbing et al., 1981; Cobbing and Pitcher, 1972; Cobbing, 2000). 


\subsection{Distribution and petrographic variations}

Contrasted petrographic facies or facies associations make up the Algeciras and Altamira plutonic massif. In general, albeit for similar structures, textures and even mineralogical contents, they may be easily differentiated on the basis of mafic mineral contents and relative mineral proportions and these differences could be properly mapped at scales 1:50.000 or superior. The extension, distribution and structural relationships among the mapped units are significant and certainly tell us something on the structural behavior and evolutionary history of each massif and so on the whole granite magmatism in the Eastern Colombian Cordillera.

As shown, relatively more mafic rocks, such as hornblende granodiorites, monzodiorites, and biotite hornblende monzogranites are more abundant in Algeciras as compared with the Altamira Plutonic Massif; the latter being made up largely by more felsic rocks as biotite-bearing leuco granites. In addition, our data indicate that the Algeciras massif has a somewhat zoned pattern, to be further detailed, as evidenced nearby Las Ceibas River area, where rocks vary from coarse-grained hornblende monzogranite to medium/fine-grained biotite hornblende monzogranite and then biotite monzogranite towards the western external contacts.

The exposure areas of the Algeciras and Altamira plutonic massif are also contrasted (ca. 500 vs $280 \mathrm{~km}^{2}$, respectively). Of note, the exposure areas of the volcanosedimentary rocks from the Saldaña Formation and the crystalline basement are larger and smaller, respectively, in the southern area, in the neighboring of the Altamira massif. These geologic observations may suggest higher uplift and erosion rates to the 
northern, as compared with the southern area, to expose relatively deep crustal levels. By now, such differential erosional-tectonic process can explain the distribution of volcanic and basement exposures, however it is not enough to justify the observed petrographic variations within the studied massifs.

Mineralogical, geochemical and isotopic detailed data for these massifs are being presented in companion papers (García-Chinchilla and Vlach, submmited). By now, some previous work indicates that the mapped granites have geochemical affinities with rocks from continental magmatic arcs, typical of active plate margins (Bustamante et al., 2010; Rodríguez et al., 2018). This hypothesis is agree with the trend of high-K calc-alkaline showed in the QAP diagram Fig. 3., which is associated to a geodynamic setting of subduction in a continental margin (Nédélec and Bouchez, 2015). At first work hypothesis, the more felsic facies associations may have largest contributions from evolved crustal sources or may be differentiates generated by significant crystal fractionation processes from less evolved precursor magmas, or both. Of importance, our geological (e.g., syn-plutonic mafic-intermediate dikes, mafic microgranular enclaves) and textural (e.g., plagioclase corrosion and reabsorption) evidences point to mingling and partial mixing processes involving basic-intermediate with silicic magmas (e.g. Barbarin, 1990; Vernon, 2004), implying source contributions also from the lithospheric mantle.

\subsection{The subvolcanic associated rocks and micrographic textures}

The closest association between the mapped plutonic with somewhat slightly younger or even coeval subvolcanic rocks and the fact that some of them intrude 
volcano-sedimentary rock sequences, indicates they were emplaced at relatively shallow crustal levels. In addition, some Algeciras leuco granites do contain significant alkali feldspar-quartz micrographic intergrowths, which in such kind of rocks also suggests relatively low pressures on crystallization.

Quartz and alkali feldspar micrographic intergrowths as well as the spherulitic observed textures, suggest fast undercooling of the precursor silicic melts (e.g., Fenn, 1986) under such conditions. Some experimental data and natural examples show that this kind of intergrowth may result from kinetics of crystal growth and elemental diffusion rates rather than representing a simple eutectic or cotectic crystallization (Fenn, 1986; Lentz and Fowler, 1992). For instance, in hydrous granitic compositions, a liquidus undercooling about ca. $75^{\circ} \mathrm{C}$ is enough to induce the development of micrographic textures (London, 1999), while skeletal quartz phenocrysts, as the ones found, may be experimentally produced from melts undercooled over $55^{\circ} \mathrm{C}$ in less than $24 \mathrm{~h}$ (ca. $2^{\circ} \mathrm{C} / \mathrm{h}$, cf. Swanson and Fenn, 1986). If such undercooling-related textures in rhyolite porphyries from the Algeciras and Altamira massifs are related to fast uplift ratios is a matter to be better studied.

\subsection{Deformation, mylonitization, and strain structures}

The main measured orientation patterns in rocks of Algeciras and Altamira massifs, such as mylonite foliation, fracture and dike orientations conforms well the right lateral strike-slip of the Algeciras Fault System, which affected Jurassic intrusive and volcanic rocks as well as the related supracrustal sediments (Velandia et al., 2005). This fault system has been active since earlier Jurassic as an inferred main suture zone, which 
had controlled the emplacement of the Algeciras and Altamira massifs, and was related to a main compressive regime in a continental arc environment (e.g. Rodríguez et al., 2018). The penetrative foliation, given by a NE-trending orientation of the mafic minerals (biotite and, to a lesser extent, amphibole) and rotated feldspar and/or quartz porphyroclasts in the most deformed varieties, suggest that strain was active from synto post-crystallization stages of the main magmatism.

The observed orientation systems of the mafic-intermediate and felsic dikes were also controlled by this main strain pattern. NE-trending dikes are sub parallel to the Algeciras Fault System, while others present a NW trend, more or less orthogonal to it. Thus, they may correspond to synthetic and antithetic structures, respectively, related to the right lateral strike-slip movement of the main fault system (e.g. Velandia et al., 2005). In fact, some authors had suggested that the prevailing tectonic regime in Jurassic times were similar to that observed nowadays, with a transpressional installed fault system being related to the oblique (to orthogonal) convergence of the Nazca plate behind the Andean block (Trenkamp et al., 2002; Velandia et al., 2005; Blanco-Quintero et al., 2014; Bustamante et al., 2016).

\section{CONCLUSIONS}

The herein named Algeciras and Altamira plutonic massifs are made up by several plutonic and subvolcanic petrographic facies or facies associations that could be routinely mapped. Besides some textural and structural properties, the recognized rock varieties were differentiated mainly by their mafic mineral contents, color index, and modal mineral proportions, which are easily contrasted in field outcrops as well as in 
hand samples. Up to eight plutonic and three subvolcanic facies or facies associations were recognized in the Algeciras Plutonic Massif and five others were recognized in the Altamira Plutonic Massif. Hornblende granodiorites, monzodiorites, and biotite hornblende monzogranites are the widely granite types in the former, while the latter is made up mainly of evolved leuco-granite varieties. A zoned pattern, defined by mineralogical and textural properties, had clearly emerged from our data in the case of the Algeciras Plutonic Massif, close to Las Ceibas River and neighboring areas.

Geologic as well as petrographic evidences suggest relatively shallow emplacement levels for granite intrusion. Fast undercooling in some subvolcanic varieties, as deduced from textures observed in felsic porphyries may indicate fast uplift ratios, a theme to be further explored.

Massif forms, elongated along SSW-NNE, mylonite varieties and several local fault/fracture systems are consistent with a syn- to post-magmatic transpressional field strain, probably operating in response to a large scale convergence during the Jurassic period.

\section{ACKNOWLEDGEMENTS}

The authors thank to Conselho Nacional de Desenvolvimento Científico e Tecnológico, CNPq, for the Doctoral scholarship to D.A. García-Chinchilla (Proc. 142098/2013-2). Thanks are due also to Mineral Resources group of Servicio Geológico Colombiano-SGC for the logistic support and for their helpful comments and discussions in the initial field trip works. 


\section{REFERENCES}

Acosta, J., Osorno, J.F., 1999. Geologia de la Plancha 324 Tello. Mapa Geológico. Escala 1:100.000. INGEOMINAS. Bogotá D. C.

Arango, M.I., Gabriel, R., Zapata, G., Bermúdez, J.G., 2015. Monzogranito de Altamira. Cordilleras Oriental y Central. Departamentos Huila y Cauca. Catálogos de Unidadels Litoestratigráficas de Colombia. Servicio Geológico Colombiano. Medellín, Colombia.

Aspden, J.A., McCourt, W.J., 1986. Mesozoic oceanic terrane in the central Andes of Colombia. Geology 14, 415-418.

Aspden, J.A., McCourt, W.J., Brook, M., 1987. Geometrical control of subductionrelated magmatism: the Mesozoic and Cenozoic plutonic history of Western Colombia. J. Geol. Soc. London. 144, 893-905.

Barbarin, B., 1990. Granitoids: Main petrogenetic classifications in relation to origin and tectonic setting. Geol. J. 25, 227-238. doi:10.1002/gj.3350250306

Bateman, P.C., Dodge, F.C., 1970. Variations of major chemical constituents across the central Sierra Nevada batholith. Geol. Soc. Am. Bull. 81, 409-420. doi:10.1130/0016-7606(1970)81[409:VOMCCA]2.0.CO;2

Bayona, G., Rapalini, A., Costanzo-Alvarez, V., 2006. Paleomagnetism in Mesozoic rocks of the Northern Andes and its Implications in Mesozoic Tectonics of Northwestern South America. Earth Planets Sp. 58, 1255-1272.

Blanco-Quintero, I.F., García-Casco, A., Toro, L.M., Moreno, M., Ruiz, E.C., Vinasco, C.J., Cardona, A., Lázaro, C., Morata, D., 2014. Late Jurassic terrane collision in the northwestern margin of Gondwana (Cajamarca Complex, eastern flank of the Central Cordillera, Colombia). Int. Geol. Rev. 56, 1852- 1872. doi:10.1080/00206814.2014.963710

Burke, K., 1988. Tectonic Evolution of The Caribbean. Annu. Rev. Earth Planet. Sci. 16, 201-230.

Bustamante, C., Archanjo, C.J., Cardona, A., Valencia, V., 2016. Geochronology and geochemistry of Late Jurassic to Early Cretaceous plutonism in the Central Cordillera and Upper Magdalena valley of the Colombian Andes: a record of long-term arc maturity and oblique subduction. Geol. Soc. Am. Bull.

Bustamante, C., Cardona, A., Bayona, G., Mora, A., Valencia, V., Gehrels, G., Vervoort, J., 2010. U-Pb LA-ICP-MS Geochronology and regional correlation of Middle Jurassic intrusive rocks from the Garzon Massif, Upper Magdalena Valley and Central Cordillera, Southern Colombia. Boletín Geol. 32, 93-109.

Cárdenas, J.I., Fuquen, J.A., Núñez, A., 2002. Geología de la Plancha 388 Pitalito. Mapa Geológico. Escala 1:100.000. INGEOMINAS. Bogotá D. C.

Cárdenas, J.I., Núñez, A., Fuquen, J.A., 2003. Geología de la plancha 388 Pitalito. Escala 1:100.000. Memoria Explicativa. Bogotá D. C. 
Cobbing, E.J., Pitcher, W.S., 1972. The Coastal Batholith of central Peru. J. Geol. Soc. London. 128, 421-454. doi:10.1144/gsjgs.128.5.0421

Cobbing, E.J., Pitcher, W.S., Wilson, J.J., Baldock, J.W., Taylor, W.P., McCourt, W.J., Snelling, N.J., 1981. The geology of the Western Cordillera of northern Peru. Overseas Memoir 5. Institute of Geological Sciences, London.

Cobbing, J., 2000. The Geology and Mapping of Granite Batholiths. Springer, Berlin.

Cochrane, R., Spikings, R., Gerdes, A., Ulianov, A., Mora, A., Villagómez, D., Putlitz, B., Chiaradia, M., 2014. Permo-Triassic anatexis, continental rifting and the disassembly of western Pangaea. Lithos 190-191, 383-402. doi:10.1016/j.lithos.2013.12.020

Cooper, M.A., Addison, F.T., Alvarez, R., Coral, M., Graham, R.H., Hayward, A.B., Howe, S., Martinez, J., Naar, J., Peñas, R., Pulham, A.J., Taborda, A., 1995. Basin Development and Tectonic History of the Llanos Basin, Eastern Cordillera, and Middle Magdalena Valley, Colombia. Am. Assoc. Pet. Geol. Bull. 79, 14211443.

Fenn, P.M., 1986. On the origin of graphic granite. Am. Mineral. 71, 325-330.

García-Chinchilla, D., Vlach, S.R.F., n.d. Insights on timing and source of Jurassic magmatism on the Northwestern Andes: In situ U-Pb dating, $\mathrm{Hf}$ isotope geochemistry of zircons and whole-rock geochemistry from granites and related rocks of the Garzón region, Eastern Cordillera of Colombia.

García-Chinchilla, D., Vlach, S.R.F., n.d. Mineral chemistry of Jurassic calc-alkaline plutons in the North Andes: Considerations of intensive parameters of granites and related rocks of the Garzón Massif, Eastern Cordillera of Colombia.

Grosse, E., 1930. Informe geológico prelimirar sobre un viaje al Huila y alto Caqueta. Informe No. 133. Bogotá.

Ibanez-Mejia, M., Ruiz, J., Valencia, V. a., Cardona, A., Gehrels, G.E., Mora, A.R., 2011. The Putumayo Orogen of Amazonia and its implications for Rodinia reconstructions: New $\mathrm{U}-\mathrm{Pb}$ geochronological insights into the Proterozoic tectonic evolution of northwestern South America. Precambrian Res. 191, 58-77. doi:10.1016/j.precamres.2011.09.005

Jaillard, E., Solerl, P., Carlier, G., Mourier, T., 1990. Geodynamic evolution of the northern and central Andes during early to. J. Geol. Soc. London. 147, 10091022.

Jiménez Mejía, D.M., Juliani, C., Cordani, U.G., 2006. P-T-t conditions of high-grade metamorphic rocks of the Garzon Massif, Andean basement, SE Colombia. J. South Am. Earth Sci. 21, 322-336. doi:10.1016/j.jsames.2006.07.001

Le Maitre, R.W., Streckeisen, A., Zanettin, B., Le Bas, M.J., Bonin, B., Bateman, P., Bellieni, G., Dudek, A., Efremova, S., Keller, J., Lameyre, J., Sabine, P.A., Schmid, R., Sorensen, H., Woolley, A.R., 2002. IGNEOUS ROCKS: A Classification and Glosary of Terms. recommendations of the International Union 
of Geological Sciences Subcommission on the Systematics of Igneous Rocks, Second Edi. ed. New York.

Lentz, D.R., Fowler, A.D., 1992. A Dynamic Model for Graphic Ouartz-Feldspar Intergrowths in Granitic Pegmatites in the Southwestern Grenville Province. Can. Mineral. 30, 571-585.

London, D., 1999. Melt boundary-layers and the growth of pegamatitic textures. Can. Mineral. 37, 826-826.

Marquínez, G., Velandia, F.P., 2001. Mapa Geológico del Departamento del Huila. Escala 1:300.000. INGEOMINAS. Bogotá D. C.

McCourt, W.J., Aspden, J.A., Brook, M., 1984. New geological and geochronological data from the Colombian Andes: continental growth by multiple accretion. J. Geol. Soc. London. 141, 831-845.

Mojica, J., Villarroel, C., Bayer, K., 1988a. Afloraminetos del Paleozoico Superiror en el Macizo de Garzón (Cordillera Oriental) y Valle Superior del MAgdalena, Colombia. Geol. Colomb. 16, 99-104.

Mojica, J., Villarroel, C., Bayer, K., 1988b. 4. Afloramientos del Paleozoico Superior en el Macizo de Garzón (Cordillera Oriental) y el Valle Superior del Magdalena, Colombia. Geol. Colomb. 16, 99-104.

Morales, C.J., Caicedo, J.C., Velandia, F.A., Núñez, A., 2001. Geología de la Plancha 345 Campoalegre. Escala 1:100.000. Memoria Explicativa. INGEOMINAS. Bogotá D. C.

Moreno-Sánchez, M., Gómez-Cruz, A. de J., Castillo-González, H., 2008. Graptolitos del Ordovícico y Geología de los afloramientos del Río Venado (norte del Departamento del Huila). Bol. Geol. 30, 9-19.

Murphy, M.A., Salvador, A., 1998. Special International Subcommission on Stratigraphic Classification of IUGS International Commission on Stratigraphy International Stratigraphic Guide - An abridged version. Epidodes 22, 255-272.

NACSN, 2005. North American Stratigraphic Code. North American Commission on Stratigraphic Nomenclature. Am. Assoc. Pet. Geol. Bull. 89, 1547-1591. doi:10.1306/07050504129

Nédélec, A., Bouchez, J.-L., 2015. Granites. Petrology, Structure, Geological Setting, and Metallogeny, English Tr. ed. Oxford University Press, New York.

Núñez, A., 2003. Reconocimiento geológico regional de las planchas 411 La Cruz, 412 San Juan de Villalobos, 430 Mocoa, 431 Piamonte, 448 Monopamba, 449 Orito y 465 Churuyaco. Departamentos de Caquetá, Cauca, Huila, Nariño y Putumayo. Escala 1:100.000. INGEOMINAS. Memoria . Bogotá D. C. doi:10.1024/0301-1526.32.1.54

Núñez, A., Gómez, J., 2002a. Gelogía de la Plancha 412 San Juan de Villalobos. Mapa Geológico. Escala 1:100.000. INGEOMINAS. Bogotá D. C.

Núñez, A., Gómez, J., 2002b. Geología de la Plancha 411 La Cruz. Mapa Geológico. 
Escala 1:100.000. INGEOMINAS. Bogotá D. C.

Núñez, A., Gómez, J., 2002c. Geologia de la Plancha 430 Mocoa. Mapa Geológico. Escala 1:100.000. INGEOMINAS, 2002. Bogotá D. C.

Pindell, J., Dewey, J.F., 1982. Permo-Triassic reconstruction of Western Pangea and the Evolution of the Gulf of Mexico/Caribbean Region. Tectonics 1, 179-211.

Pindell, J., Kennan, L., Maresch, W. V., Stanek, K.-P., Draper, G., Higgs, R., 2005. Plate-kinematics and crustal dynamics of circum-Caribbean arc-continent interactions: Tectonic controls on basin development in Proto-Caribbean margins, in: Lallemant, H.G.A., Sisson, V.B. (Eds.), Caribbean-South American Plate Interations, Venezuela. The Geological Society of America. Special Papers 394., Boulder, Colorado, pp. 7-52.

Pindell, J.L., Kennan, L., Stanek, K.P., Maresch, W. V., Draper, G., 2006. Foundations of Gulf of Mexico and Caribbean evolution: eight controversies resolved. Geol. Acta 4, 303-341.

Radelli, L., 1962a. Introducción al estudio de la petrografía del Macizo de Garzón (Huila-Colombia). Geol. Colomb. 3, 17-45.

Radelli, L., 1962b. Un cuadro preliminar de las épocas magmáticas y metalogégicas de los Andes Colombianos. Geol. Colomb. 3, 87-97.

Radelli, L., 1962c. Les formations eruptives Hercyniennes de la Cordillere Orientala de Colombie (Sud Am.). Geol. Colomb. 3, 99-124.

Rodríguez, G., Arango, M.I., Bermúdez, J.G., Zapata, G., 2015a. Granito de Garzón. Coridillera Oriental. Departamento Huila. Catalogos de Unidades Litoestratigráficas de Colombia. Servicio Geológico Colombiano. Medellín, Colombia.

Rodríguez, G., Arango, M.I., Zapata, G., Bermúdez, J.G., 2018. Petrotectonic characteristics, geochemistry, and $\mathrm{U}-\mathrm{Pb}$ geochronology of Jurassic plutons in the Upper Magdalena Valley-Colombia: Implications on the evolution of magmatic arcs in the NW Andes. J. South Am. Earth Sci. 81, 10-30. doi:10.1016/j.jsames.2017.10.012

Rodríguez, G., Ferreira, P., Velandia, F., Núñez, A., 1998. Geología de la Plancha 366 Garzón. Mapa Geológico. Escala 1:100.000. INGEOMINAS. Bogotá D. C.

Rodríguez, G., Zapata, G., Arango, M.I., Bermúdez, J.G., 2015b. Monzogranito de Algeciras. Cordillera Oriental. Departamento Huila. Servicio Geológico Colombiano, Catálogos de Unidades Litoestratigráficas de Colombia. Medellín, Colombia.

Rodríguez, G., Zapata, G., Velásquez, M.E., Cossio, U., Londoño, A.C., 2003a. Geología de las planchas 367 Gigante, 368 San Vicente del Caguán, 389 Timaná, 390 Puerto Rico, 391 Lusitania (parte noroccidental) y 414 El Doncello. Departamentos de Caquetá e Huila. INGEOMINAS. Medellín, Colombia.

Rodríguez, G., Zapata, G., Velazquez, M., 2003b. Geologia de la Plancha 367 
Gigante. Mapa Geológico. Escala 1:100.000. INGEOMINAS. Bogotá D. C.

Ross, M.I., Scotese, C.R., 1988. A hierarchical tectonic model of the Gulf of Mexico and Caribbean region. Tectonophysics 155, 139-168.

Sarmiento-Rojas, L.F., Van Wess, J.D., Cloetingh, S., 2006. Mesozoic transtensional basin history of the Eastern Cordillera, Colombian Andes: Inferences from tectonic models. J. South Am. Earth Sci. 21, 383-411.

doi:10.1016/j.jsames.2006.07.003

Schamel, S., 1991. Middle and Upper Magdalena Basins, Colombia, in: Biddle, K.T.

(Ed.), Active Margins. AAPG Memoir 52. The American Association of Petroleum Geologist, Tulsa, Oklahoma, pp. 283-301.

Spikings, R., Cochrane, R., Villagomez, D., Van der Lelij, R., Vallejo, C., Winkler, W., Beate, B., 2015. The geological history of northwestern South America: From Pangaea to the early collision of the Caribbean Large Igneous Province (29075Ma). Gondwana Res. 27, 95-139. doi:10.1016/j.gr.2014.06.004

Streckeisen, A., 1976. To each plutonic rock its proper name. Earth-Science Rev. 12, 1-33. doi:10.1016/0012-8252(76)90052-0

Swanson, S.E., Fenn, P.M., 1986. Quartz crystallization in igneous rocks. Am. Mineral. 71, 331-342.

Trenkamp, R., Kellogg, J.N., Freymueller, J.T., Mora, H.P., 2002. Wide plate margin deformation, southern Central America and northwestern South America, CASA GPS observations. J. South Am. Earth Sci. 15, 157-171. doi:10.1016/S08959811(02)00018-4

Ulbrich, H., Vlach, S.R.F., Janasi, V.A., 2001. O mapeamento faciológico em rochas ígneas plutônicas. Rev. Bras. Geociências 31, 163-172.

Velandia, F., Acosta, J., Terraza, R., Villegas, H., 2005. The current tectonic motion of the Northern Andes along the Algeciras Fault System in SW Colombia. Tectonophysics 399, 313-329. doi:10.1016/j.tecto.2004.12.028

Velandia, F., Morales A., C.J., Caicedo A., J.C., Núñez, A., 1999. Geología de la Plancha 345 Campoalegre. Mapa Geológico. Escala 1:100.000. INGEOMINAS. Bogotá D. C.

Velandia, F.P., Ferreira, P. V., Rodríguez, G., Núñez, A., 2001. Leavantamiento geológico de la Plancha 366 Garzón. Escala 1:100.000. INGEOMINAS. Bogotá D. C.

Vernon, R.H., 2004. A Practical Guide to Rock Microstructure. Cambridge University Press, New York. doi:10.1017/CBO9780511807206

Villagómez, D., Spikings, R., Magna, T., Kammer, A., Winkler, W., Beltrán, A., 2011. Geochronology, geochemistry and tectonic evolution of the Western and Central cordilleras of Colombia. Lithos 125, 875-896. doi:10.1016/j.lithos.2011.05.003

Villarroel, C., Macia, C., Brieva, J., 1997. Formación Venado, Nueva Unidad Litoestratliqráfica del Ordovícico Colombiano. Geol. Colomb. 22, 41-49. 
Vlach, S., 1993. Geologia e Petrologia dos Granitóides de Merongaba, SP. Tese de Doutoramento. Universidade de São Paulo.

Vlach, S., 1985. Geologia, Petrografia e Geocronologia das Regiões Meridional e Oriental do Complexo de Morungaba, SP. Dissertação de Mestrado. Universidade de São Paulo.

Whitney, D.L., Evans, B.W., 2010. Abbreviations for names of rock-forming minerals. Am. Mineral. 95, 185-187. doi:10.2138/am.2010.3371

Zapata, S., Cardona, A., Jaramillo, C., Valencia, V., Vervoort, J., 2016. U-Pb LA-ICPMS geochronology and geochemistry of jurassic volcanic and plutonic rocks from the Putumayo region (southern Colombia): Tectonic setting and regional correlations. Bol. Geol. 38, 21-38. doi:10.18273/revbol.v38n2-2016001 


\section{FIGURE CAPTIONS}

Fig. 1. Simplified geological map of Garzón region in Eastern Colombia Cordillera showing the Jurassic Plutonic Massif (red), the volcano-sedimentary Saldaña Formation (blue), MesoNeoproterozoic metamorphic basement (white with crosses), Cretaceous and Cenozoic sedimentary rocks (gray) and Quaternary sediments. The main Plutonic Massif as Algeciras, Altamira and Sombrerillo are indicated. In the same way, other Jurassic igneous structures as Ibagué and Mocoa batholith (to the west and to the south, respectively).

Fig. 2. (a) Northwestern of South America, Central America and Caribbean showing Colombia and its internal division in Departments. (b) Detail of southern part of Colombian Andes with the localization of the igneous rocks discriminated Jurassic (red) with Proterozoic to Paleozoic (purple), Cretaceous (green) and Cenozoic (yellow) intrusive rocks. (c) Petrographic facies map of Algeciras Plutonic Massif.

Fig. 3. a) Modal Quartz-Alkali feldspar-Plagioclase (Q-A-P) classification diagram (Streckeisen, 1976). In green: Algeciras. In blue: Altamira. In red: Sombrerillo. Arrow represent typical trend of high-K calc-alkaline rocks, associated to subduction in a continental margin according to (Nédélec and Bouchez, 2015).

Fig. 4. Some geological and petrographic aspects of Algeciras Plutonic Massif. A. Biotite hornblende monzogranite facies association (BHM) and Andesitic dikes facies (AD) B. Mafic microgranular enclaves (ME) in biotite hornblende facies association C. D. Photomicrographs of biotite hornblende monzogranite, under cross and plane polarized light, respectively $\mathbf{E}$. $\mathbf{F}$. Biotite monzogranite milonitic facies. F. Photomicrograph of biotite grain elongated by deformation, and quartz with undulatory extinction, under cross and detail in plane polarized light, respectively. G. Rhyolite with spherulitic intergrowth of quartz and alkali feldspar H. Felsic dikes (FD) of quartz and alkali feldspar. Abbreviations: $\mathrm{Hbl}=$ hornblende; $\mathrm{Qtz}=$ quartz; $\mathrm{Bt}=$ Biotite; $\mathrm{PI}$ = plagioclase; $\mathrm{Kfs}=$ alkali-feldspar Ser = sericite; $\mathrm{Ep}=$ epidote .

Fig. 5. (a) Northwestern of South America, Central America and Caribbean showing Colombia and its internal division in Departments. (b) Detail of southern part of Colombian Andes with the localization of the igneous rocks discriminated Jurassic (red) with Proterozoic to Paleozoic (purple), Cretaceous (green) and Cenozoic (yellow) intrusive rocks. (c) Petrographic facies map of Altamira Plutonic Massif.

Fig. 6. Some geological and petrographic aspects of Altamira Plutonic Massif. A. B. Leucomonzogranite to syenogranite facies association B. Photomicrograph of plagioclase-alkali feldspar-quartz assemblage typical of this facies, under cross polarized light C. D. Biotite hornblende monzogranite facies association, under cross and plane polarized light, respectively E. F. Rhyolite (RL) and Andesitic dikes facies $(A D)$ G. Photomicrograph of rhyolite with micrographic intergrowth of quart and alkali feldspar, and $\mathbf{H}$. Andesitic dikes with intergranular texture, both under cross polarized light. Abbreviations: $\mathrm{Hb}=$ hornblende; $\mathrm{Qtz}=$ quartz; $\mathrm{Bt}=$ Biotite; $\mathrm{PI}$ = plagioclase; $\mathrm{Kfs}=$ alkali feldspar; Ser = sericite; $\mathrm{Ep}=$ epidote; $\mathrm{Mag}$ = magnetite; $\mathrm{Hm}=$ hematite $;$ Sauss = Saussurite; $\mathrm{Chl}=$ Chlorite . 


\section{FIGURES}

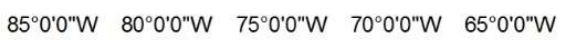

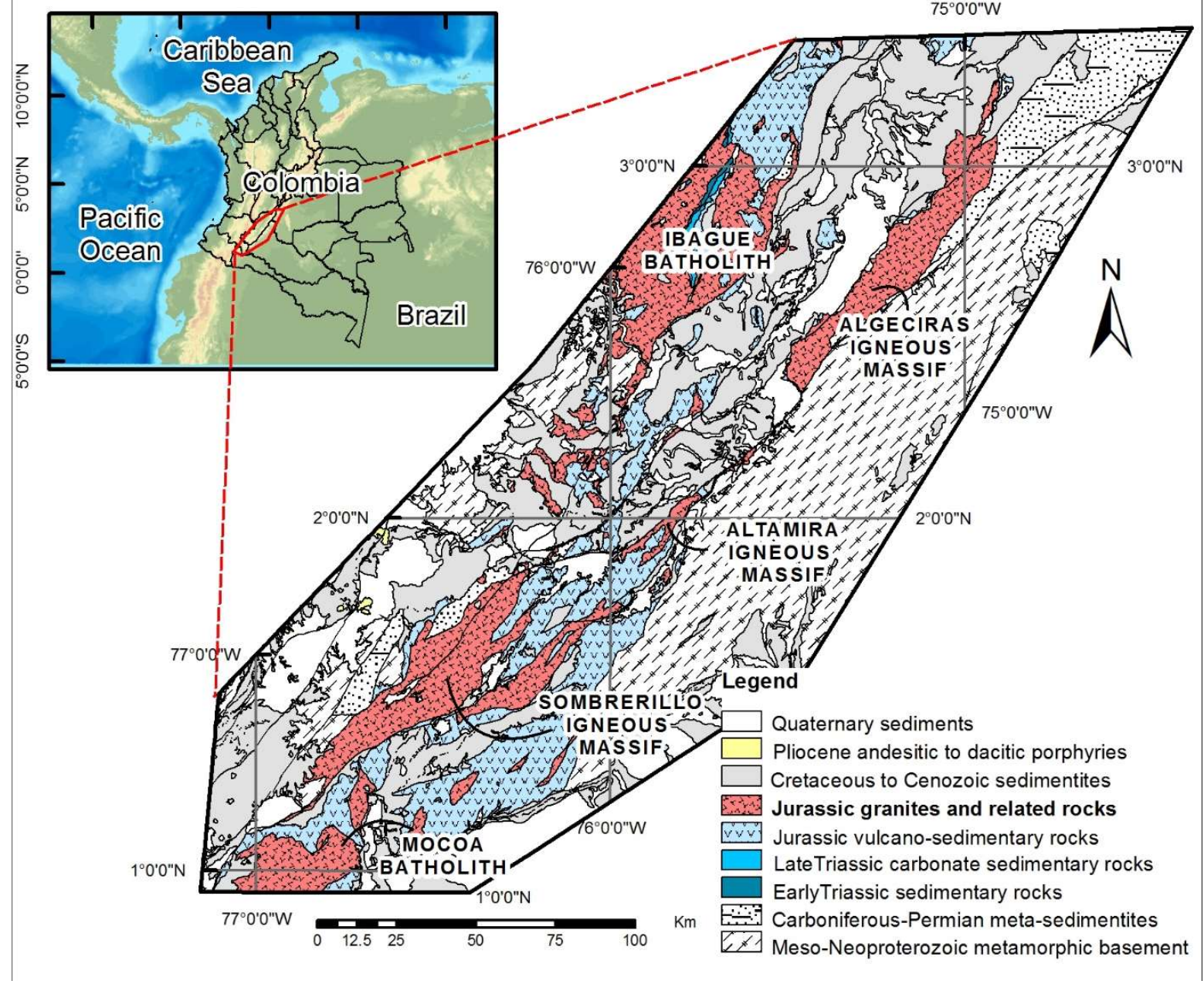

Fig. 1 

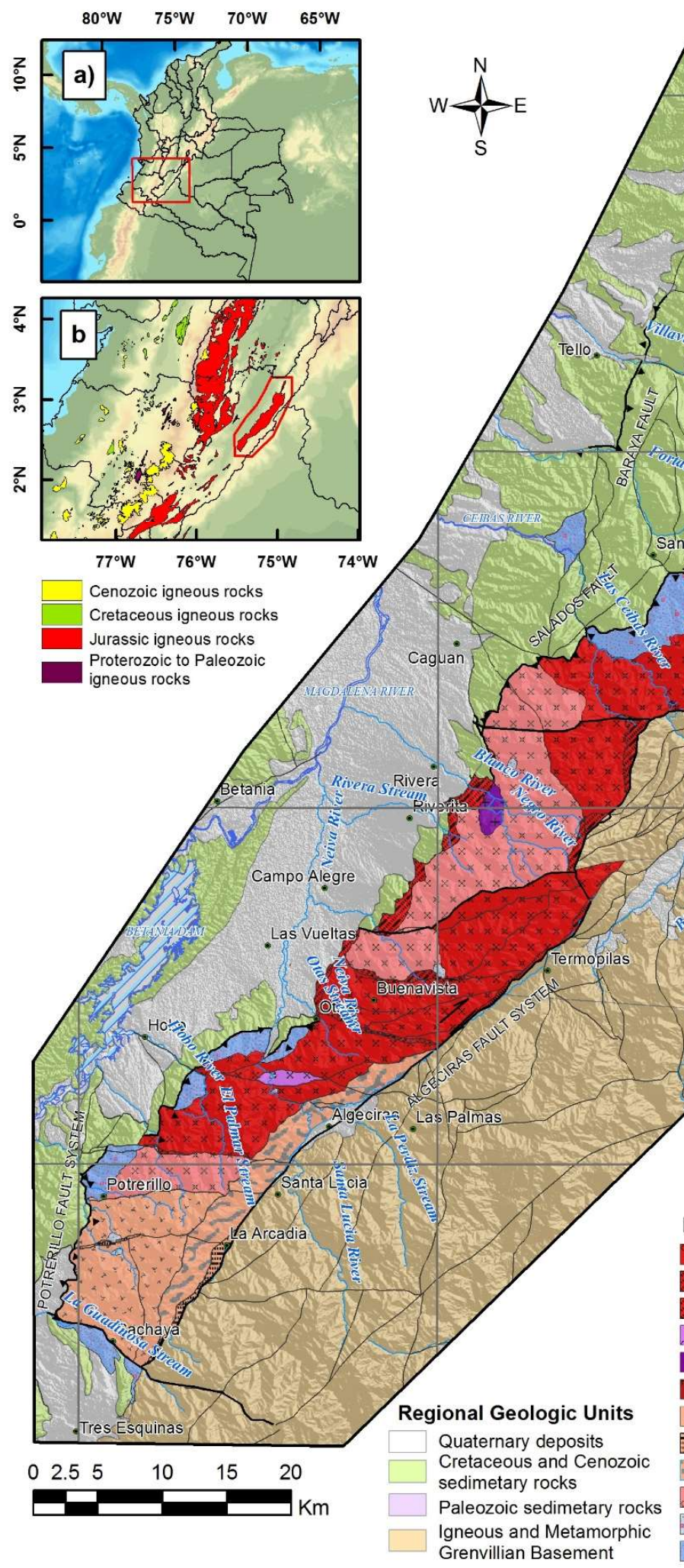

$75^{\circ} 0^{\prime W}$

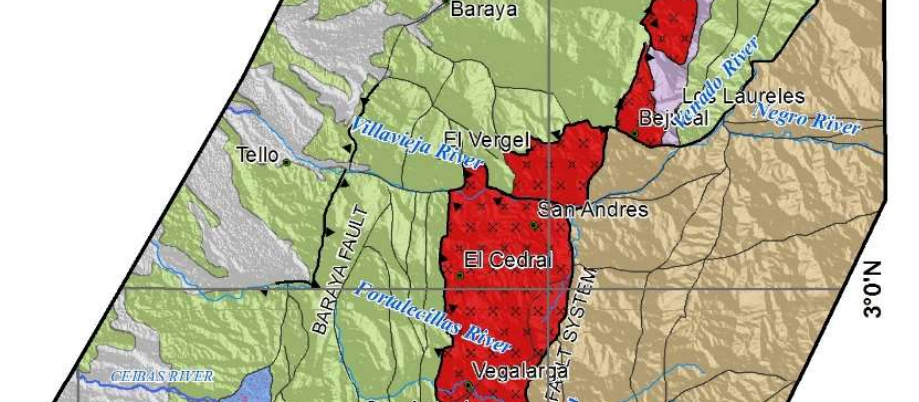




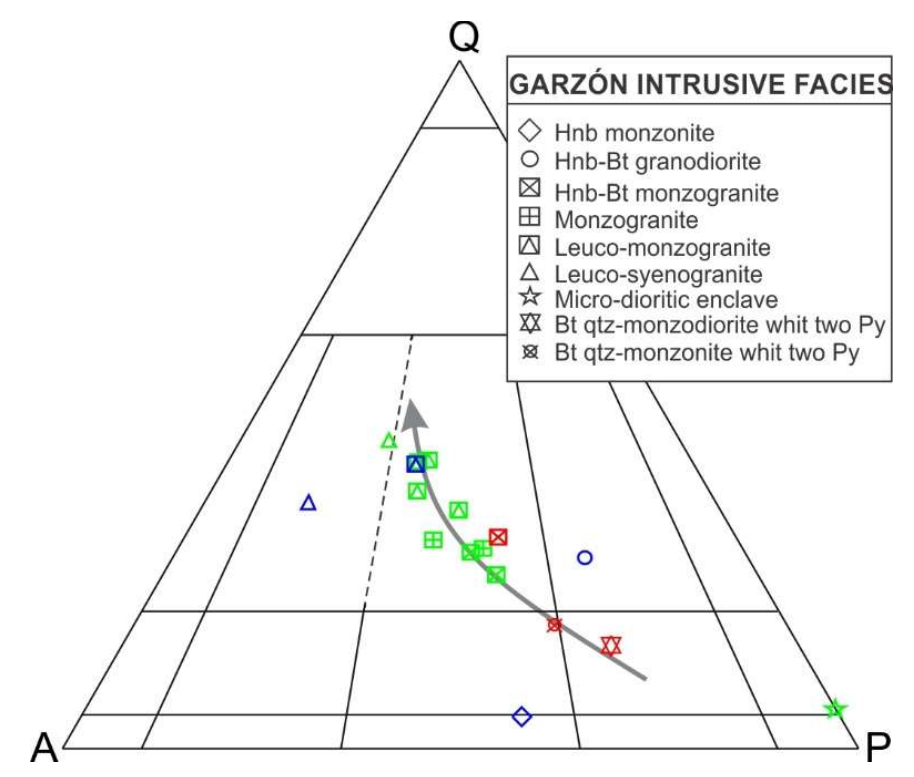

Fig. 3. 

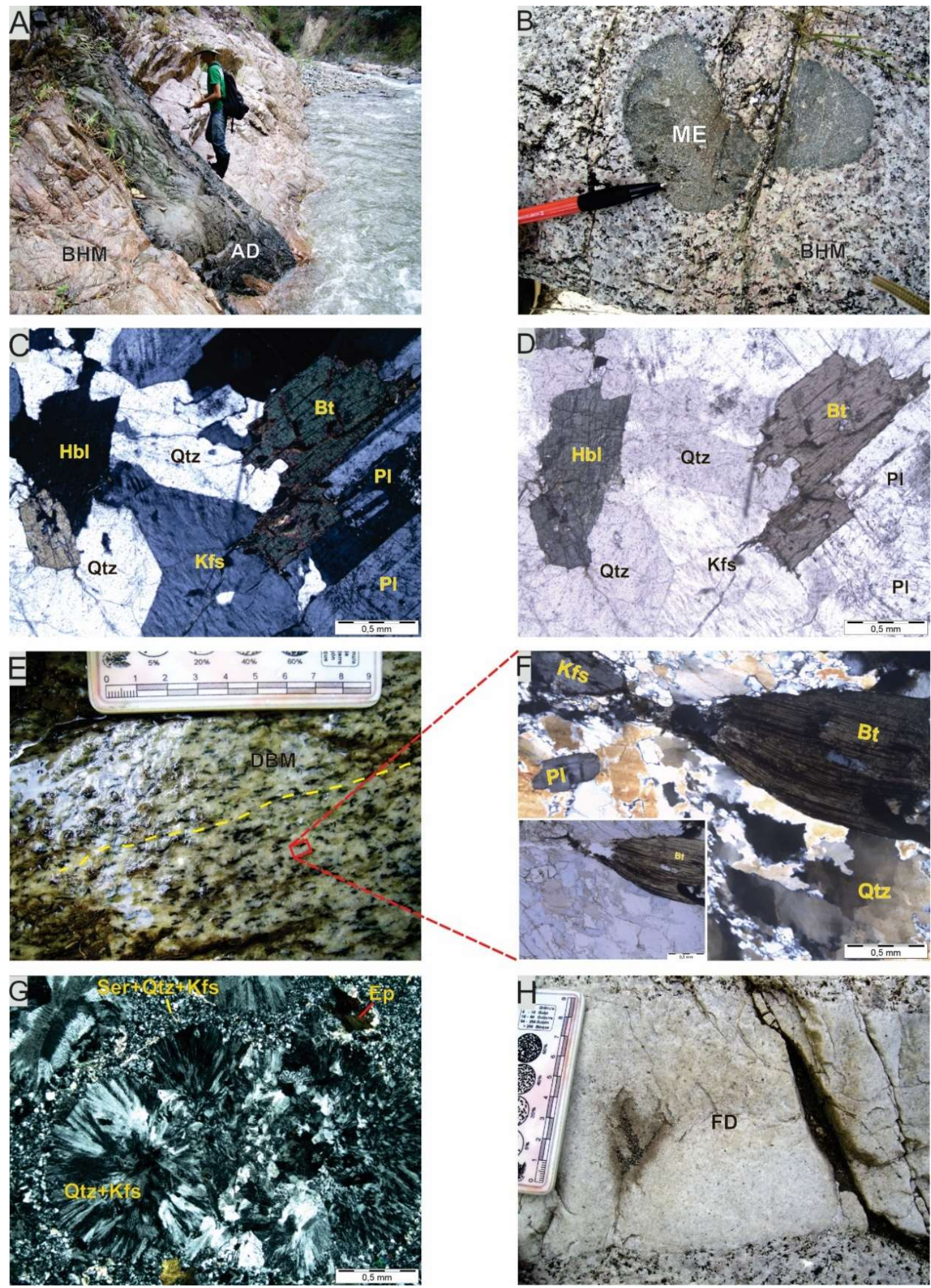

Fig. 4 


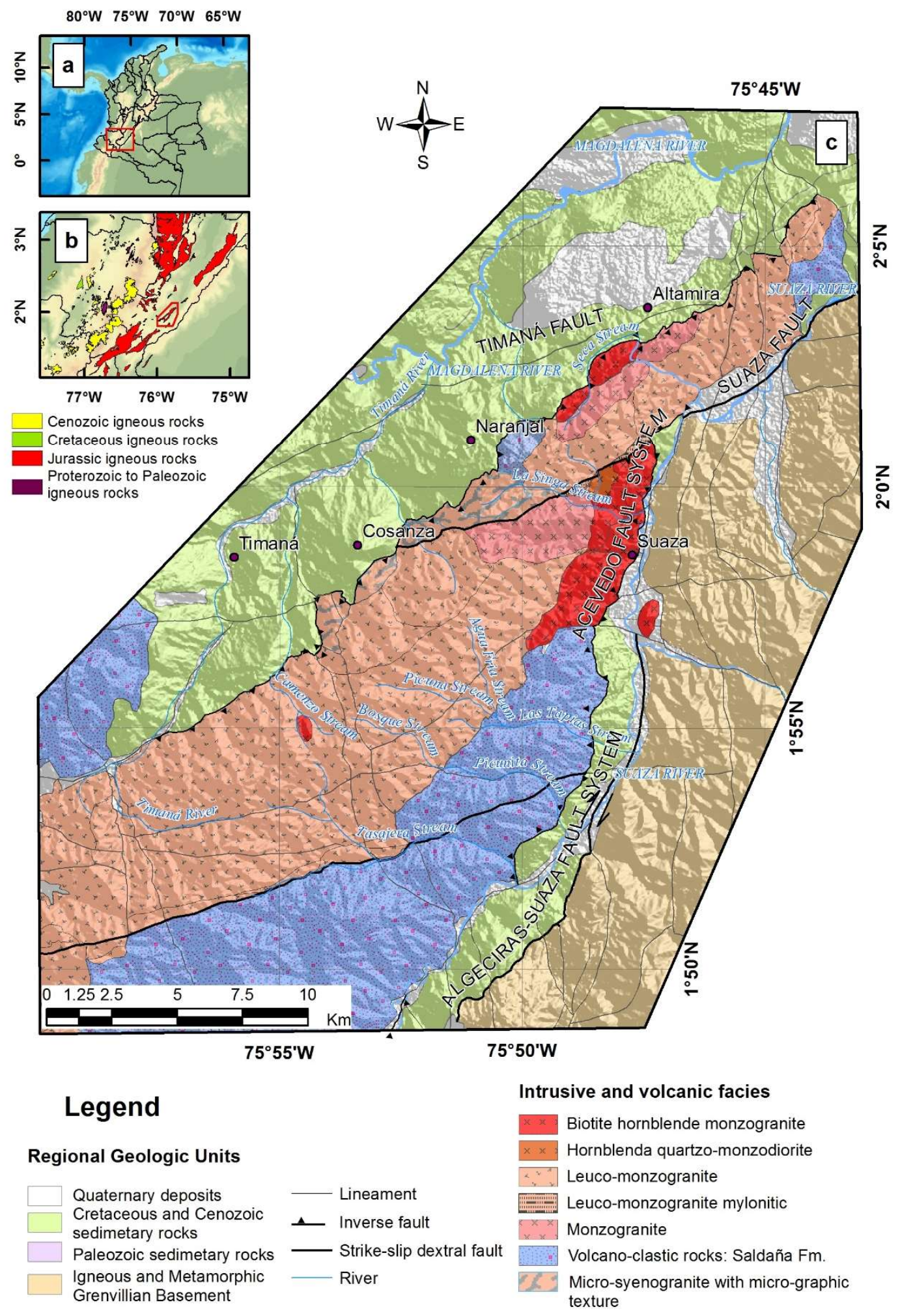

Fig. 5. 

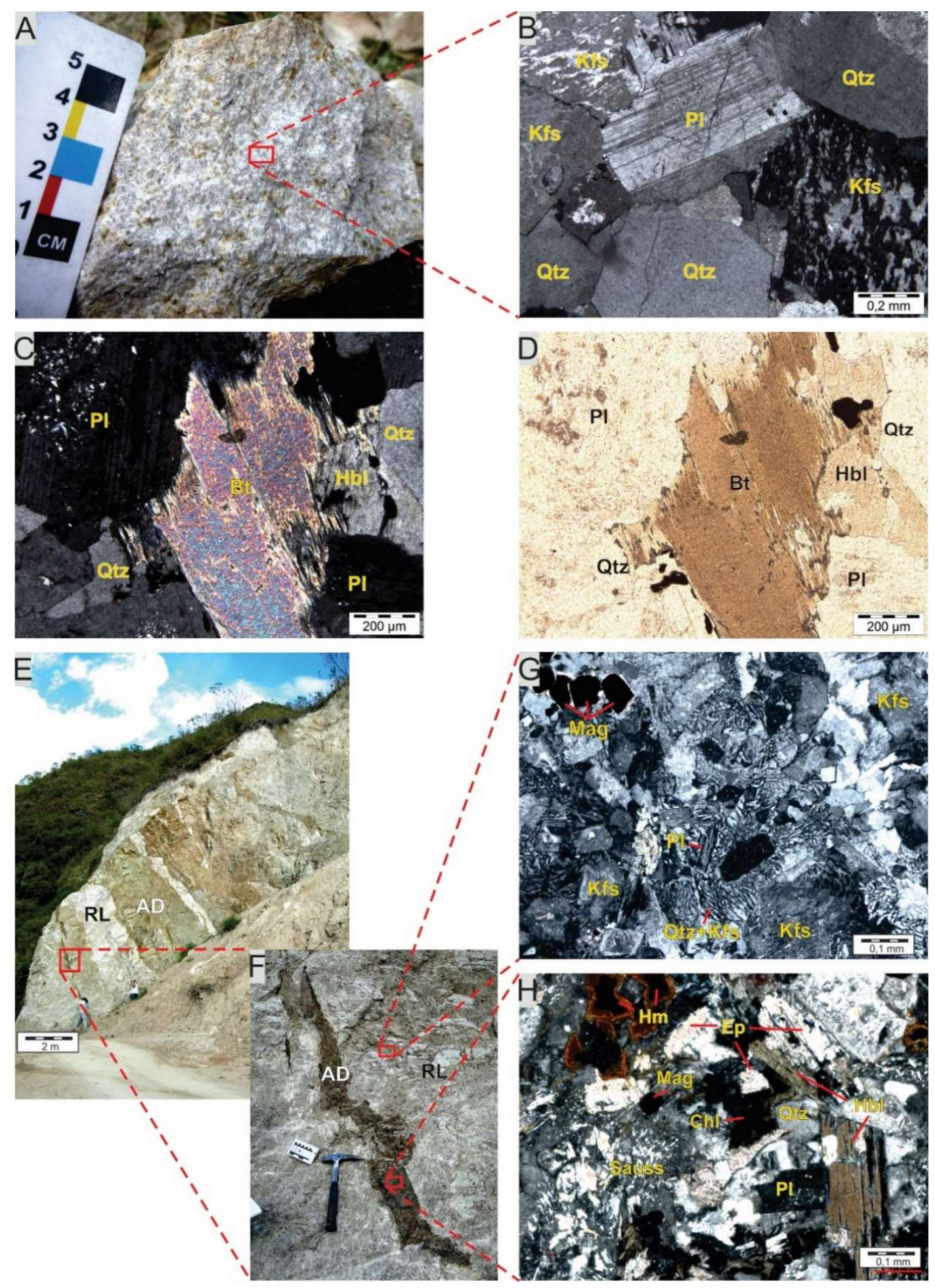

Fig. 6. 


\section{TABLES}

Table 1. Modal compositions of from representative rocks from the Garzón area, Eastern Colombian Cordillera. Mineral abbreviation according to Whitney and Evans (2010)

\begin{tabular}{|c|c|c|c|c|c|c|c|c|c|c|c|c|c|c|c|c|c|c|c|c|}
\hline & & & & Felsic & & & Mafic & & & Acce & ssory & & & & & Othel & & & & \\
\hline $\begin{array}{l}\text { Sampl } \\
\mathrm{e}\end{array}$ & Massif & Facies & $\mathrm{Kfs}$ & Qtz & $\mathrm{PI}$ & $\mathrm{Bt}$ & $\mathrm{Hbl}$ & $\begin{array}{l}\mathrm{Cp} \\
\mathrm{x}\end{array}$ & Ttn & Zrn & $A p$ & Aln & Chl & $\begin{array}{l}\text { Sau } \\
\text { ss }\end{array}$ & Ser & $\begin{array}{l}\mathrm{Mu} \\
\mathrm{s}\end{array}$ & Hem & Ep & Cal & (\%) \\
\hline $\begin{array}{l}\text { GAR- } \\
350\end{array}$ & Algeciras & L-SG & 31 & 38 & 18 & 1.3 & 0.1 & 0 & 0.5 & 0.3 & 0.8 & 0.1 & 1.8 & 3.7 & 0.0 & 0.0 & 0.1 & 1.0 & 0.0 & 5 \\
\hline $\begin{array}{l}\text { GAR- } \\
351\end{array}$ & Algeciras & L-MG & 29 & 31 & 32 & 1.9 & 0.4 & 0 & 0.4 & 0.3 & 0.6 & 0.1 & 1.4 & 0.4 & 0.0 & 0.0 & 0.0 & 0.1 & 0.0 & 5 \\
\hline $\begin{array}{l}\text { GAR- } \\
352\end{array}$ & Algeciras & L-MG & 29 & 35 & 23 & 2.8 & 1.7 & 0 & 1.2 & 0.2 & 0.2 & 0.2 & 2.7 & 0.0 & 0.0 & 0.0 & 0.0 & 0.8 & 0.0 & 9 \\
\hline $\begin{array}{l}\text { GAR- } \\
354\end{array}$ & Algeciras & L-MG & 32 & 41 & 25 & 0.3 & 0.0 & 0 & 0.1 & 0.0 & 0.1 & 0.1 & 0.4 & 0.1 & 0.0 & 0.5 & 0.0 & 0.0 & 0.0 & 1 \\
\hline $\begin{array}{l}\text { GAR- } \\
356\end{array}$ & Algeciras & MG & 27 & 25 & 37 & 3.5 & 3.2 & 0 & 0.8 & 0.2 & 0.5 & 0.0 & 0.5 & 0.6 & 0.1 & 0.0 & 0.0 & 0.0 & 0.0 & 10 \\
\hline $\begin{array}{l}\text { GAR- } \\
357\end{array}$ & Algeciras & $\mathrm{BH}-\mathrm{MG}$ & 27 & 23 & 35 & 2.8 & 6.4 & 0 & 2.0 & 0.2 & 0.4 & 0.0 & 0.0 & 0.4 & 0.0 & 0.0 & 0.0 & 0.2 & 0.0 & 14 \\
\hline $\begin{array}{l}\text { GAR- } \\
357\end{array}$ & Algeciras & E-MD & 0 & 1 & 49 & 20.2 & 20.7 & 0 & 0.5 & 2.5 & 2.0 & 0.0 & 0.0 & 0.0 & 0.0 & 0.0 & 0.0 & 0.0 & 0.0 & 45 \\
\hline $\begin{array}{l}\text { GAR- } \\
360\end{array}$ & Algeciras & BH-MG & 30 & 24 & 30 & 4.0 & 4.8 & 0 & 1.6 & 0.1 & 0.6 & 0.0 & 0.1 & 3.2 & 0.0 & 0.0 & 0.0 & 0.0 & 0.0 & 14 \\
\hline $\begin{array}{l}\text { GAR- } \\
371\end{array}$ & Algeciras & $\mathrm{BH}-\mathrm{MG}$ & 27 & 21 & 40 & 4.5 & 4.9 & 0 & 0.2 & 0.2 & 0.0 & 0.2 & 0.2 & 0.0 & 0.0 & 0.0 & 0.0 & 0.0 & 0.0 & 13 \\
\hline $\begin{array}{l}\text { GAR- } \\
384\end{array}$ & Altamira & L-SG & 50 & 34 & 13 & 0.2 & 0.2 & 0 & 0.5 & 0.2 & 0.2 & 0.0 & 0.8 & 0.2 & 0.0 & 0.0 & 0.0 & 0.2 & 0.0 & 2 \\
\hline $\begin{array}{l}\text { GAR- } \\
385\end{array}$ & Altamira & L-MG & 31 & 32 & 25 & 4.3 & 1.4 & 0 & 1.4 & 0.2 & 0.3 & 0.0 & 0.0 & 1.5 & 0.0 & 0.0 & 0.0 & 0.3 & 0.0 & 9 \\
\hline $\begin{array}{l}\text { GAR- } \\
386\end{array}$ & Altamira & HB-GD & 17 & 23 & 48 & 4.5 & 1.9 & 0 & 0.6 & 0.2 & 0.2 & 0.0 & 0.6 & 1.0 & 0.0 & 0.0 & 0.0 & 0.2 & 0.0 & 10 \\
\hline $\begin{array}{l}\text { GAR- } \\
388\end{array}$ & Altamira & $\mathrm{H}-\mathrm{M}<$ & 24 & 3 & 46 & 0.0 & 10.5 & 0 & 2.5 & 0.8 & 0.7 & 0.1 & 4.3 & 0.0 & 0.0 & 0.0 & 1.8 & 0.4 & 0.1 & 19 \\
\hline $\begin{array}{l}\text { GAR- } \\
394\end{array}$ & $\begin{array}{l}\text { Sombrerill } \\
\text { o }\end{array}$ & HB-MG & 24 & 25 & 37 & 3.8 & 5.8 & 1.5 & 0.6 & 0.6 & 0.3 & 0.0 & 0.0 & 0.0 & 0.0 & 0.0 & 0.0 & 0.2 & 0.0 & 15 \\
\hline
\end{tabular}

Notes: Facies abbreviations BQ-M OC = Biotite quartz-monzodiotire with two pyroxenes; L-SG = Leuco-Syenogranite; BH-MG = Biotite hornblende monzogranite; HB-GD = Hornblende biotite granodiorite; $\mathrm{MG}=$ Monzogranite; $\mathrm{H}-\mathrm{MZ}=$ Hornblende monzodiorite; $\mathrm{E}-\mathrm{MD}=$ Microdiorite enclave; $\mathrm{Kfs}=$ alkali feldspar; $\mathrm{Qtz}=$ quartz; $\mathrm{PI}=\mathrm{plagioclase} ; \mathrm{Bt}=$ biotite; $\mathrm{HbI}=\mathrm{hornblende} ; \mathrm{Cpx}=\mathrm{clino}-$ pyroxene; Ttn = titanite; $\mathrm{Zrn}=$ zircon; $\mathrm{Ap}=$ apatite; $\mathrm{Aln}=$ allanite; Mus = muscovite; $\mathrm{Chl}=$ chlorite; Sauss = saussurite; Ser = sericite; Hem = hematite; $\mathrm{Ep}=$ epidote; cal = calcite; $\mathrm{Cl}=$ color index. 


\section{Apêndice B}

Manuscrito: "Insights on timing and source of the Jurassic magmatism in Northwestern Andes: Whole-rock geochemistry and in situ zircon U-Pb and $\mathrm{Hf}$ isotope geochemistry in granites and related rocks from the Garzón region, Eastern Cordillera of Colombia"

García-Chinchilla, D.A. \& Vlach, S.R.F.; 
Insights on timing and source of the Jurassic magmatism in Northwestern

\author{
Andes: Whole-rock geochemistry and in situ zircon $\mathrm{U}-\mathrm{Pb}$ and $\mathrm{Hf}$ isotope \\ geochemistry in granites and related rocks from the Garzón region, Eastern

\section{Cordillera of Colombia}

\author{
Daniel Alejandro García Chinchilla[1] \& Silvio Roberto Farias Vlach[1] \\ [1] Departamento de Mineralogia e Geotectônica, Instituto de Geociências, Universidade de São Paulo, Rua do \\ Lago, 562, Cidade Universitária, 05508-080, São Paulo, SP, Brasil
}

\begin{abstract}
Voluminous granite (sensu lato) magmatism was recorded in the northwestern region of South America, beginning in late Triassic and extending until the Jurassic. The Algeciras, Altamira and Sombrerillo plutonic massifs are the main representatives of such magmatism in the Eastern Colombian Cordillera and the focus of this study. The Algeciras Massif is made up mainly by hornblende, biotite hornblende and biotite monzogranites, hornblende biotite granodiorites and minor leuco granites, while the last (biotite-bearing syeno- and monzogranites) are largely predominant in the Altamira. Biotite hornblende monzogranites are the main rock types in Sombrerillo and are accompanied by very particular two-pyroxene bearing granites monzodiorites and monzonites. Minor bodies made up by felsic porphyries (dacite and rhyolite), as well as syn-plutonic mafic intermediate dikes occur in all massifs. The main granite intrusions were emplaced ca. $189 \pm 7 \mathrm{Ma}$ (Sombrerillo Plutonic Massif) and between 176 and $170 \mathrm{Ma}$ (Altamira and Algeciras plutonic massifs) while the subvolcanic rocks present ages between 160 and $175 \mathrm{Ma}$. Intrusive rocks present most geochemical fingerprints common to the calc-alkaline to alkali-calcic, magnesian, metaluminous series, with minor alkaline,
\end{abstract}


ferroan and slightly peraluminous varieties. They display typical relative LILE enrichment over HFSE and relative enriched LREE over HREE patterns $(7.7 \leq$ $\left.\mathrm{LaN}_{N} / \mathrm{Yb}_{\mathrm{N}} \leq 22.2\right)$ and negative Eu anomalies. Relatively high Th values and low $\mathrm{Sm} / \mathrm{Yb}$ ratios $(\leq 4)$ suggest crustal contributions, being from subducted sediments, the overlying continental crust or both. Such compositional and geochemical features are typical of continental arc settings, related to oceanic crust subduction zones. The plutonic rocks present negative $\varepsilon \mathrm{Hf}_{(\mathrm{t})}$-in-zircon values $(-7.7$ to -1.2$)$ and two-stage model ages ( $T_{\mathrm{DM}}$ ) between 900 and $1660 \mathrm{Ma}$, suggesting also significant contributions from relatively evolved, crustal sources. High positive $\varepsilon \mathrm{ff}_{(\mathrm{t})}$ values (up to 14.6$), T_{\mathrm{DM}}$ ages from 221 to $830 \mathrm{Ma}$ and xenocryst/antecryst from 404 to 1365 Ma found in subvolcanic rocks, indicate contributions from both young mantle and ancient crustal materials. Emplacement timing and spatial distribution of the whole granite magmatism in Eastern and Central Colombian Cordilleras suggest an eastward migration of the Jurassic arc front at ca. $180 \mathrm{Ma}$, associated to subduction erosion phenomena, followed by a migration towards west by $170 \mathrm{Ma}$, the latter associated with a change in the subduction regime.

\section{INTRODUCTION}

The Jurassic period in the Colombian Andes was characterized by extensive granitic (sensu lato) and related magmatism represented by several large igneous plutonic occurrences and related volcanic rocks in the Central and Eastern Colombian Cordilleras (e.g., Ibagué, Pescadero, Algeciras, Altamira and Sombrerillo massifs or batholiths). The magmatic events were previously related to intracontinental rifting systems operating since the Paleozoic until the late Triassic 
and ending with the Pangea break-up and subsequent sedimentation on the evolving basins (Jaillard et al., 1990; Noble et al., 1997; Pindell and Dewey, 1982; Pindell and Kennan, 2009; Ross and Scotese, 1988). However, the observed island arc geochemical fingerprint of both the intrusive and the volcanic rocks and the occurrence of Jurassic meta-volcano-sedimentary sequences are not satisfactorily explained through a model involving prolonged extensional regimens (e.g. Cediel et al., 2003). To circumvent such questions, the regional models of continental rifting had introduced compressive episodes during the Triassic and the Jurassic along the Andes, with deformation, regional metamorphism over volcanosedimentary sequences, crustal melting and related magmatism triggered by the subduction of the oceanic proto-Pacific plate under the western margin of South American plate (Aspden et al., 1987; Jaillard et al., 1990; Blanco-Quintero et al., 2014; Spikings et al., 2015; van der Lelij et al., 2016).

Literature dealing with detailed petrographic, mineralogical, geochemical and geochronological data is relatively scarce (e.g., Rodríguez et al., 2018) or even absent for most Jurassic magmatic occurrences in Central and, particularly, in the Eastern Cordilleras. This turns it difficult to better evaluate the appropriateness of any geodynamical model applied to the west Gondwana evolution by this time.

After some basic geological and petrographic work (García-Chinchilla et al., submitted), we present in this contribution the main petrographic and geochemical features of Altamira, Algeciras and Sombrerillo plutonic massifs from the Eastern Colombian Cordillera. We also explore the potential of high resolution $\mathrm{U}-\mathrm{Pb}$ dating and ${ }^{176} \mathrm{Hf} /{ }^{177} \mathrm{Hf}$ isotopic analysis through LA-MC-ICP-MS (e.g. Blichert-Toft and 
Albarède, 1997; Gerdes and Zeh, 2009; Hawkesworth and Kemp, 2006; Kemp et al., 2009; Kinny and Maas, 2003; Söderlund et al., 2004; Vervoort and BlichertToft, 1999; Vervoort and Patchett, 1996) in zircon crystals from selected samples to address their timing and isotopic signatures. Results are compared with the available data for the Central and Eastern Cordilleras on the light of the prevailing tectonic models. Detailed mineralogical data and crystallization condition estimates for these occurrences presented in a companion contribution (García-Chinchilla and Vlach, submitted).

\section{GEOLOGICAL SETTING}

\subsection{Regional Geology}

The Andes in the Colombian territory, northwestern border of South American plate, comprise three main SSW-NNE trending mountain ranges: the Western, Central and Eastern Cordilleras, separated each other by inter-Andean basins (Fig. 1). The Western Cordillera, closest to the Pacific Ocean, is constituted mainly by Cretaceous oceanic terranes accreted to the South American margins as a response to the Caribbean plate evolution during the late Cretaceous and Cenozoic (Meschede and Frisch, 1998; Nivia, 1997; Noble et al., 1997; Pindell et al., 2005, 2006; Pindell and Kennan, 2009). Granite and related magmatism in this area is represented by the Mande, Acandí, Anchicaya, Piedrancha batholiths and related plutons with Paleogene and Neogene ages (Aspden et al., 1987; McCourt et al., 1984). The Central Cordillera, to the east, after the Cauca river basin, is built by Paleozoic to Mesozoic metamorphic country rocks late intruded by Permian, Mesozoic and Cenozoic granites and related rocks (Blanco-Quintero et al., 2014; 
Cochrane et al., 2014a; Cordani et al., 2005; Leal-Mejía, 2011; Martens et al., 2014; Molina et al., 2006; Ordóñez-Carmona et al., 2006; Villagómez et al., 2011; Vinasco et al., 2006). To the east, the Eastern Cordillera is limited by the Magdalena river basin to the west and by the Orinoco and Amazonas regions to the east. It is made up of Paleozoic and/or Jurassic granites and related rocks, Paleozoic to Cenozoic uplifted sedimentary basins, as well as windows of Mesoand Neoproterozoic high-grade metamorphic and igneous rocks from the regional crystalline basement (Ibanez-Mejia et al., 2011).

The studied area, also called "Garzón Massif" in the regional nomenclature, locates at the southernmost Eastern Cordillera in Colombia. The crystalline basement is well exposed therein and constituted by earlier sedimentary and igneous rocks metamorphosed under medium- to high-pressure (6.3 kbar) and temperatures up to $680^{\circ} \mathrm{C}$ (Jiménez Mejía et al., 2006). They are correlated with the Putumayo, Las Minas and Macarena Colombian metamorphic complexes, as well as with similar complexes from Central America and Mexico, all of them related to the Putumayo-Oaxaca Orogeny, developed during Rodinia assemblage (ca. 1.0-1.3 Ga), when several pericratonic terranes were accreted to the Amazonia Craton (Ibanez-Mejia et al., 2011).

In the late Permian to early Triassic, during Pangea final assembly, regional metamorphism and granitic intrusion occur in west Central Cordillera and northern Colombia (Bustamante et al., 2017; Cardona et al., 2010; Cochrane et al., 2014a; Martens et al., 2014; Montes et al., 2010; Ordóñez-Carmona et al., 2006; Spikings et al., 2015; van der Lelij et al., 2016; Vinasco et al., 2006). In the Garzón, 
Santander, Quetame and other Colombian areas (Fig. 1), as well as Ecuador and Peru, these events are registered by a well defined unconformity between the Paleozoic sedimentary rocks and the upper Triassic marine sediments (Cediel et al., 1980; Cochrane et al., 2014a; Jaillard et al., 1990; Spikings et al., 2015). In the southern Eastern Cordillera, the Payandé Formation registers Triassic basin generation and sedimentation associated with Pangea break up (Cediel et al., 1981, 1980; Jaillard et al., 1990). Such extensional tectonics had remained until the establishment of subduction regimes and generation or arc magmatism in the Central and Eastern Colombian Cordilleras, from late Triassic to early Jurassic (Aspden et al., 1987; Jaillard et al., 1990; McCourt et al., 1984). The main aspects of this magmatism are presented in the following setion.

\subsection{Jurassic Magmatism in the Northern Andes}

In the Colombian Andes, as compared with Paleozoic, Cretaceous and Cenozoic periods, the Jurassic was characterized by much expressive granite magmatism (Fig. 2). Indeed, Jurassic and correlated intrusive rocks made up large plutonic massifs and/or batholiths trending SW-NE to S-N in several areas of the Central and Eastern Cordilleras (e.g. Segovia, Ibagué, Pescadero, Mogotes, Guamoco and Norosí-San Martin batholiths), as well as in the Sierra Nevada de Santa Marta (e.g. Aracataca, Central, Pueblo Bello, and Patillal batholiths) (Bustamante et al., 2016; Cochrane et al., 2014b; Dorr et al., 1995; Feininger et al., 1972; Goldsmith et al., 1971; Leal-Mejía, 2011; Tschanz et al., 1974; Villagómez et al., 2011). 
Most studies concerning granites and related rocks from the Garzón area deal with petrography and cartography of the main occurrences from a regional perspective (Acosta and Osorno, 1999; Cárdenas et al., 2003, 2002; Grosse, 1930; Marquínez and Velandia, 2001; Morales et al., 2001; Núñez, 2003; Núñez and Gómez, 2002a, 2002b, Radelli, 1962b, 1962c, 1962a, Rodríguez et al., 2003a, 2003b, 1998, Velandia et al., 1999, 2001). Recent data obtained for Algeciras, Altamira, Sombrerillo and Mocoa occurrences, and the so-called "Garzón Granite" rocks point to their continental arc geochemical signatures and emplacement ages between ca. 169 and 189 Ma (Bustamante et al., 2010; Rodríguez et al., 2018; Sillitoe et al., 1982; Zapata et al., 2016). Attempting to provide a better description of these plutonic massifs, García-Chinchilla et al. (submitted) present a more detailed geological map, as well as detailed descriptions of the mapped petrographic facies and facies associations of the Algeciras and Altamira igneous massifs (Fig. 1).

A brief characterization to the Altamira, Algeciras and Sombrerillo plutonic massifs, focused in this contribution, is given in the following section.

\section{GENERAL FEATURES OF THE STUDIED MASSIFS}

\subsection{Algeciras Plutonic Massif}

The Algeciras Plutonic Massif, to the north of the Eastern Colombian Cordillera, crops out over an area with ca. 10 vs. $50 \mathrm{~km}$, trending SSW-NNE (Fig. 1c). It is made of several contrasted petrographic facies or facies associations (GarcíaChinchilla et al., submitted). Hornblende, biotite-hornblende and biotite monzogranites are the main granite varieties. Typical modal compositions of 
intrusive rocks are plotted in IUGS ternary classification diagram in Fig. 3. The most common rocks have grayish to pinkish colors in hand samples and present a massive structure and a slightly inequigranular, medium- to coarse-grained, texture. The Color Index $(\mathrm{Cl})$ ranges from 2 to 15 . Titanite, Fe-Ti oxides, allanite, apatite and zircon are primary accessory phases. Hornblende biotite granodiorites $(10 \leq \mathrm{Cl} \leq 17)$ and leuco granites $(1 \leq \mathrm{Cl} \leq 9)$ with similar structures, textures and mineralogy occur in somewhat restricted areas. Along the eastern external contacts of the massif, mylonitic biotite monzogranites were mapped. Associated subvolcanic rocks are relatively common. Rhyolite porphyries constitute small $(<1$ $\mathrm{km}^{2}$ ) intrusive bodies, made up by quartz, plagioclase, alkali feldspar, as well as biotite, hornblende, Fe-Ti oxides and titanite phenocrysts in a microcrystalline matrix with quartz and alkali feldspar forming micrographic intergrowths and/or spherulites. Syn-plutonic mafic-intermediate dikes cross-cut the granites, particularly the biotite-hornblende monzogranites; they are massive, with an intergranular fine-grained or aphanitic texture composed of plagioclase laths with interstitial hornblende, biotite, accompanied by Fe-Ti oxides, titanite and apatite; the aphanitic varieties are typical andesites, with trachytic-like textures. In some areas, rhyolite dikes join the mafic-intermediate ones. Rounded mafic microgranular enclaves, $\mathrm{mm}$ - to $\mathrm{cm}$-sized, with dioritic compositions are found in the host monzogranites close to the mafic-intermediate dikes.

\subsection{Altamira Plutonic Massif}

The Altamira Plutonic Massif, to the south, is a relatively smaller massif (ca. 8 of vs. $35 \mathrm{~km}$ ) exposed along a similar SSW-NNE trend (Fig. 1). Massive biotite- 
bearing leuco monzogranites $(\mathrm{Cl}<5)$ varieties are largely predominant (Fig. 3). They present whitish to pinkish colors and inequigranular, medium- to coarsegrained textures, with interstitial biotite. Titanite, Fe-Ti oxides, apatite and zircon are typical primary accessories; allanite appears occasionally. Massive hornblende biotite granodiorites $(\mathrm{Cl}=11)$ and hornblende monzonites $(\mathrm{Cl}=17)$, with similar structure, textures and accessory mineralogy, crop out in some small areas. Maficintermediate dikes and some small rhyolite porphyry bodies, as to those described for the Algeciras Plutonic Massif, are found scarcely.

\subsection{Sombrerillo Plutonic Massif}

This is the southernmost granite massif in the Garzón region and the largest one, with ca. 12 vs. $90 \mathrm{~km}$ of exposure area (Fig. 1). To the unstudied south area of this massif, its relation with the so-called Mocoa Batholith is still unclear and both may represent a large continuous plutonic occurrence in the Eastern Cordillera. In the northern part, we recognize seven main facies or facies associations. Biotite hornblende monzogranite varieties (Fig. 3) similar to those from the Algeciras Plutonic Complex are predominant to the north. They are characterized by grayish to pinkish colors $(\mathrm{Cl}=15)$, massive structures and slightly inequigranular, medium-grained textures. Accessory minerals are titanite, Fe-Ti oxides, allanite, apatite and zircon. To the west, close to the contact with the country rocks, two pyroxene-bearing biotite quartz monzonites and monzodiorites

(Fig. 3) constitute a very particular facies association, with both ortho- and clinopyroxene, with $(24 \leq \mathrm{Cl} \leq 26)$. 
Dacite and rhyolite porphyries, with plagioclase, hornblende, biotite, quartz, titanite and Fe-Ti oxides phenocrysts in a matrix made up by plagioclase, opaque minerals, hornblende, biotite, apatite, zircon and micrographic intergrowths of quartz and alkali feldspar, crop out as small intrusive bodies. Occasionally, maficintermediate aphanitic dikes may be found.

\section{MATERIAL AND METHODS}

\subsection{Petrography and whole-rock geochemistry}

Sample preparation and the analytical work were conducted in laboratories from GeoAnalitica-USP and CPGeo-USP core facilities at the University of São Paulo. Conventional petrographic analyses of most collected samples were done on both thin- and polished-thin sections under transmitted and reflected light, emphasizing mineralogical and textural aspects. Quantitative modal data was obtained for selected samples. Whole-rock chemical analysis were obtained for fresh samples, in a total of 23 (14 from Algeciras, 6 from Altamira and 3 from Sombrerillo plutonic massifs), after sample hydraulic fragmentation, quartering and final milling in a ring mill made up by agate elements. Major, minor and some trace elements were quantified by $X$ ray fluorescence spectrometry (XRF), using the PANalytical AXIOS MAX Advanced equipment, following procedures described in Mori et al. (1999), while trace elements were quantified by Inductively Coupled Plasma Mass Spectrometry (ICP-MS), with the quadrupole Thermo-Scientific iCAP Q instrument, according to the methods detailed in Navarro (2004) and Navarro et al. (2008). 


\subsection{U-Pb and Lu-Hf high-resolution isotope analysis}

$\mathrm{U}-\mathrm{Pb}$ dating and $\mathrm{Lu}-\mathrm{Hf}$ high-resolution isotope analysis were made by Multicollector Inductively Coupled Plasma Mass Spectrometry coupled with Laser Ablation (LA-MC-ICPMS), with Thermo-Finnigan Neptune Spectrometer and Laser ArF Excimer $(\lambda=193 \mathrm{~nm})$ instruments from the CPGeo-USP. We select six representative samples of intrusive rocks from the Algeciras, Altamira and Sombrerillo plutonic massifs, as well as one charnockitic sample coming from the metamorphic crystalline basement for detailed analysis.

Samples were prepared following the methods described by Sato et al. (2009) and Basei et al. (2013), which includes the preparation of a 100-250 $\mu \mathrm{m}$ representative grain fraction, obtained by crushing and sieving in nylon dispensable meshes, followed by heavy concentration in a Wiffley Table, magnetic fraction separation, firstly with a hand magnet then with the isodynamic Franz separator, and final heavy mineral fraction concentration with Bromoform and Methilene lodide. More than a hundred of selected zircon crystals from each sample were hand picked under the stereoscope and mount in a thin (ca. $3 \mathrm{~cm}$ of diameter) resin block, lying along the $\underline{c}$ crystallographic axe. High-resolution optical transmitted light $(T L)$ and cathodoluminescence $(C L)$ images were obtained in conventional optical and electronic (SEM) microscopes, the latter after C coating. These images were used to examine internal crystal features and to select the best zones to analyze. A total of 26 crystals were selected for in situ U-Pb dating. Among them, just those with concordant ages were selected for Lu-Hf analysis, in an amount of 10 spots. The spots selected for Lu-Hf quantification were located 
over the dated spots or over immediately contiguous zones with similar TL and CL patterns (e.g., Corfu et al., 2003; Appleby, 2007).

Isotopic measurements for $\mathrm{U}-\mathrm{Pb}$ dating were carried out according to the method established by Sato et al. (2012) in that lab. ${ }^{202} \mathrm{Hg},{ }^{204}(\mathrm{Hg}+\mathrm{Pb}),{ }^{206} \mathrm{~Pb}$, ${ }^{207} \mathrm{~Pb},{ }^{208} \mathrm{~Pb},{ }^{232} \mathrm{Th}$ and ${ }^{238} \mathrm{U}$ masses are simultaneously collected using a laser spot diameter of $32 \mu \mathrm{m}$ during 40 s ( 1 cycle/s) for the ablation time, under a frequency of $6 \mathrm{~Hz}$ and an energy fluency of $6 \mathrm{~mJ}$. A complete analytical run in each analysis includes 4 blanks, 9 external standards and 13 unknowns readings. The ${ }^{204} \mathrm{Hg}$ interference over the ${ }^{204} \mathrm{~Pb}$ signal is estimated monitoring ${ }^{204} \mathrm{Hg}$ blank readings and spot ${ }^{202} \mathrm{Hg}$ measurements, taking ${ }^{204} \mathrm{Hg} /{ }^{202} \mathrm{Hg}=4.2 . \mathrm{Pb}$ isotopes instrumental mass deviations were monitored with the NIST610 reference standard, with ${ }^{207} \mathrm{~Pb} / 206 \mathrm{~Pb}=$ $0.90986 \pm 5$ (Baker et al., 2004) and the zircon standard GJ-1, with a $600 \pm 3 \mathrm{Ma}$ age (Elhlou et al., 2006). Residual, common $\mathrm{Pb}$ contents were corrected with ${ }^{204} \mathrm{~Pb}$ measurements considering the terrestrial $\mathrm{Pb}$ isotope composition (Stacey and Kramers, 1975). Age calculations and related plotting were performed with the Isoplot 4.1 software (Ludwig, 2008). Tera-Wasserburg diagrams were preferred over the conventional Concordia ones as they display better discordant trends (Allègre, 2008). Spot results with ${ }^{206} \mathrm{~Pb} / 238 \mathrm{U}$ and ${ }^{207} \mathrm{~Pb} / 235 \mathrm{U}$ age discordances $\geq$ $10 \%$ and ${ }^{204} \mathrm{~Pb}$ values $\geq 6 \%$ of $\mathrm{Pb}^{\top}$ were cut off in age calculations.

Lu-Hf isotope analysis and related interference correction procedures were performed according to Sato et al. (2009) and Basei et al. (2013), using a laser spot with $47 \mu \mathrm{m}$ diameter and 50 s (1 cycle/s) for the ablation time, under a frequency of $7 \mathrm{~Hz}$ and an energy fluency of $60 \mathrm{~mJ}$ (90\% nominal energy, 7.70 
$\left.\mathrm{J} / \mathrm{cm}^{2}\right)$. In the adopted procedure, ${ }^{171} \mathrm{Yb},{ }^{173} \mathrm{Yb},{ }^{174} \mathrm{Yb},{ }^{175} \mathrm{Lu},{ }^{176}(\mathrm{Hf}+\mathrm{Yb}+\mathrm{Lu}),{ }^{177} \mathrm{Hf}$ and ${ }^{179} \mathrm{Hf}$ masses are simultaneous quantified and a complete measurement run is given by 15 readings: 4 over standards, 1 over blank and 10 over unknowns. ${ }^{176} \mathrm{Lu} / 177 \mathrm{Hf}$ ratio was calculated considering ${ }^{176} \mathrm{Lu} /{ }^{175} \mathrm{Lu}=0.02669$. The zircon standards GJ-1 and Mud Tank gave ${ }^{176} \mathrm{Hf} /{ }^{177} \mathrm{Hf}=0.2820151 \pm 0.0000023(2 \sigma, \mathrm{n}=$ $334)$ and ${ }^{176} \mathrm{Hf} /{ }^{177} \mathrm{Hf}=0.2824699 \pm 0.0000080(2 \sigma, \mathrm{n}=85)$ during our analytical period, values which approach well (to the fifth decimal) those measured by Liu et al. (2010) and Woodhead and Hergt (2005), respectively. $\varepsilon_{\mathrm{Hf}}$ values were computed on the basis of the chondritic reservoir, with present ${ }^{176} \mathrm{Lu} /{ }^{177} \mathrm{Hf}=0.0332$ and ${ }^{176} \mathrm{Hf} /{ }^{177} \mathrm{Hf}=0.282772$ (Blichert-Toft and Albarède, 1997$)$, taking $\lambda_{(176 \mathrm{Lu})}=$ $1.867 \times 10^{-11} \mathrm{y}^{-1}$ (Söderlund et al., 2004). Mantle depleted model ages were estimated on the basis of a two-stage evolutionary model, using a ${ }^{176} \mathrm{Lu} /{ }^{177} \mathrm{Hf}$ enrichment factor value of 0.015 for the bulk earth (Goodge and Vervoort, 2006); ${ }^{176} \mathrm{Hf} /{ }^{177} \mathrm{Hf}=0.283225$ and ${ }^{176} \mathrm{Lu} /{ }^{177} \mathrm{Hf}=0.038512$ (Vervoort and Blichert-Toft, 1999).

\section{RESULTS}

\subsection{General petrography}

A geological map, petrographic descriptions, as well as chemical data for the rock-forming minerals from the Algeciras, Altamira and Sombrerillo plutonic massifs, are given in García-Chinchilla et al. (submitted) and García-Chinchilla and Vlach (submitted), respectively. In this section, we present a brief petrographic description for samples selected for zircon dating and isotope analysis. 


\subsection{Crystalline basement}

\section{Quart mangerite (Sample GAR-364)}

The selected sample is representative of an ancient charnockite magmatism, represented in the area by small massive bodies associated with regional migmatites and granulites developed both over magmatic and sedimentary protoliths. The rock is massive, grayish color, leucocratic with a $\mathrm{Cl}$ about 20 , inequigranular and medium-grained. The main mafic minerals appear as isolated crystals or interstitial crystal aggregates composed by ortho- and clinopyroxenes, calcic amphibole and dark mica (Fig. 4a). Apatite, zircon and rutile are the primary accessories. Alkali feldspar is suhedral, slightly perthitic, with cross-hatched twinning poorly developed or absent; subhedral to euhedral plagioclase (slightly zoned andesine-oligoclase) shows bended polysynthetic (albite) twins and patchy alkali feldspar exsolution; quartz, with undulatory extinction and rutile needle inclusions, is interstitial. Colorless, euhedral to suhedral orthopyroxene crystals $\left(\mathrm{En}_{54-63} \mathrm{Fs}_{35-43} \mathrm{Wo}_{01-2}\right)$ are recognized by their low-order interference, anomalous, colors and straight extinction on (010). Clinopyroxene $\left(\mathrm{En}_{38-39} \mathrm{Fs}_{16-17} \mathrm{Wo}_{44-46}\right)$ is subhedral and usually associated to dark mica. The late is a phlogopite with $0.75 \leq$ $\mathrm{mg \#}\left[=\mathrm{Mg} /\left(\mathrm{Mg}+\mathrm{Fe}^{2+(\mathrm{T})}\right)\right.$, cationic $\left.] \leq 0.77\right)$. Clinopyroxene substitutes for orthopyroxene and both amphibole and phlogopite may replace ortho- and clinopyroxene. The rock present evidence of metamorphic imprints and the zircon crystals present typical recrystallization textures (e.g. Corfu et al., 2003), such as sector, abstract and chaotic zoning patterns combined with stepwise growth 
patterns and some flow-like structures; most crystals present also relatively large homogenous areas.

\subsection{Plutonic rocks}

Two-pyroxene bearing biotite quartz-monzodiorites and quartz-monzonites (Samples L-102 and L-104)

As above mention, these varieties crop out sole in the Sombrerillo Plutonic Massif. The selected samples are massive, grayish, leucocratic $(24 \leq \mathrm{Cl} \leq 26)$, inequigranular, medium- to coarse-grained and their main mineralogical feature is the presence of both ortho- and clinopyroxene. In thin sections, they have hypidiomorphic textures; mafic minerals appear as isolated crystals or forming small mafic clusters. Euhedral to subhedral plagioclase forms tabular zoned crystals with more calcic cores $\left(A n_{31-49} A b_{50-67}\right)$, with Albite-Carlsbad coupled twins sometimes bended; crystal cores are somewhat altered while the rims show occasional corrosion figures. Alkali-feldspar $\left(\operatorname{Or}_{73-83} A b_{17-25}\right)$ forms small anhedral clean crystals with minute albite exsolutions. Quartz is interstitial and clean. Mirmekites appear in plagioclase-alkali-feldspar contacts. Subhedral biotite (phlogopite, $54 \leq \mathrm{mg} \# \leq 56$ ), with dark brown to yellowish green pleochroic colors, is the main mafic mineral. Anhedral, rounded and colorless orthopyroxene $\left(\mathrm{En}_{49-}\right.$ $\left.{ }_{55} \mathrm{Fs}_{42-45} \mathrm{Wo}_{2-3}\right)$ is substituted for biotite, amphibole or clinopyroxene. Subhedral clinopyroxene is an augite [ $\mathrm{En}_{39-44} \mathrm{Fs}_{19-23} \mathrm{Wo}_{34-40}, 69 \leq \mathrm{mg} \#\left(=\mathrm{Mg} /\left(\mathrm{Mg}+\mathrm{Fe}^{2+}\right) \leq 71\right]$; which may appears also as pseudomorphs after orthopyroxene and be rimmed by latter Ca-amphibole [magnesiohornblende, $66 \leq \mathrm{mg} \#\left(=\mathrm{Mg} /\left(\mathrm{Mg}+\mathrm{Fe}^{2+}\right) \leq 69\right.$ ]. Opaque phase exsolution lamellae and minute quartz inclusions is observed in the 
amphibole. The primary accessory minerals are euhedral Fe-Ti oxides (magnetite with ilmenite exsolution dominant, ilmenite), apatite and zircon, which occur in the mafic aggregates or as inclusions in the main mafic minerals.

\section{Hornblende biotite granodiorite (Sample GAR-386)}

The selected GAR-386 sample comes from the Altamira Plutonic Massif. It is massive, light grayish, leucocratic $(\mathrm{Cl}=11)$ and medium-grained. Under the microscope, the hypidiomorphic equigranular texture is dominated by euhedral tabular, Albite-Carlsbad twinned, plagioclase $\left(\mathrm{An}_{19-61} \mathrm{Ab}_{38-78}\right)$ crystals with normal and oscillatory zoning. Alkali feldspar $\left(\operatorname{Or}_{77-94} A_{6} b_{6-22}\right)$, with minute albite exsolution lamellae, is anhedral and clean. Euhedral to subhedral Ca-amphibole (magnesiohornblende, $0.77 \leq \mathrm{mg} \# \leq 0.83$ ) is the main mafic mineral and appears partially substituted by chlorite. Subhedral biotite (phlogopite, $0.55 \leq \mathrm{mg} \# \leq 0.56$ ) appears as individual grains or in aggregates with secondary minerals (epidote, quartz and chlorite). Hydrothermal epidote-group minerals, titanite and opaque phases, sometimes forming mineral aggregates filling in rock interstices or fractures, also appear in some thin sections.

\section{Biotite hornblende monzogranite (Sample GAR-394)}

This sample was collected in the northern area of the Sombrerillo Plutonic Massif (Fig. 4c). It is massive, whitish to pinkish, leucocratic $(I C=14)$ and mediumgrained. In thin sections, plagioclase $\left(\mathrm{An}_{17-46} A b_{53-82}\right)$ is subhedral, tabular and strongly zoned; anti-rapakivi-like textures (plagioclase rimmed by alkali-feldspar) do occur. The alkali-feldspar is a well cross-hatched twinned microcline with some albite exsolution. Quartz, clean and rounded, is usually interstitial. Mafic minerals 
appear as clots including biotite, Ca-amphibole, Fe-Ti oxides and other accessory minerals. Ca-amphibole (magnesiohornblende; $0.50 \leq \mathrm{mg} \# \leq 0.63$ ) is euhedral to subehuedral; some crystal cores preserve colorless augite relicts $\left(\mathrm{En}_{31-35} \mathrm{Fs}_{21} \mathrm{Wo}_{44-}\right.$ 48, $0.65 \leq \mathrm{mg \#} \leq 0.68$ ) relicts; it is partially replaced by late crystallized biotite. Biotite (phlogopite, $\mathrm{mg \#}=0.47$ to 0.49 ) forms subhedral light brown to dark yellow crystals. The primary accessory minerals occur as euhedral crystals associate with the mafic silicates and are Fe-Ti oxides (magnetite with ilmenite lamellae), titanite, allanite, apatite and zircon. Euhedral tourmaline or minute tourmaline crystal veins do occur and sign in for a late hydrothermal imprint.

\section{Hornblende biotite monzogranite (sample GAR-356)}

This sample represents the most widely distributed petrographic facies in the Algeciras Plutonic Massif (Fig. 4d). It is massive, pale reddish, leucocratic $(\mathrm{Cl}=$ 11), inequigranular and coarse-grained. In thin sections, the texture is hypidiomorphic and the mafic minerals appear as isolated euhedral crystals or interstitial crystal aggregates. Plagioclase $\left(A n_{16-35} A b_{62-81}\right)$ occurs as euhedral to subhedral tabular, normal or oscillatory zoned, crystals; corrosion figures due to dissolution-reprecipitation phenomena are relatively common. Anhedral perthitic alkali-feldspar (Or87-94Ab6-12) shows well-developed cross-hatched twining and is relatively late in the crystallization sequence. Quartz is mainly interstitial and always presents undulatory extinction. Ca-amphibole (magnesiohornblende; $0.69 \leq$ $\mathrm{mg \#} \leq 0.74$ ) with slightly compositional zoning and biotite (phlogopite, $0.57 \leq \mathrm{mg \#}$ $\leq 0.63$ ) occur in similar modal proportions; biotite is relatively late in the crystallization sequence and substitutes for amphibole. Titanite, Fe-Ti oxides 
(magnetite and some ilmenite), apatite and zircon complete the rock primary mineralogy.

\subsection{Subvolcanic rocks}

\section{Dacite porphyry (Sample GAR-395)}

GAR-395 sample represents a small irregular body intruding biotite hornblende monzogranite in the Sombrerillo Plutonic Complex (Fig. 4e). The rock is massive and has a porphyritic texture with a very fine-grained matrix. It has plagioclase accompanied by minor hornblende, biotite, quartz and titanite phenocrysts (up to $35 \%$ vol.) in a mesostasis made up mainly by micrographic intergrowths between quartz and alkali-feldspar. Some small plagioclase, amphibole and biotite grains can appear in the matrix. Plagioclase $\left(A n_{28-61} A b_{38-74}\right)$ and Ca-amphibole (magnesiohornblende to tchermakite) phenocrysts have strong oscillatory zoning (Fig. 4e). Both occur as individual crystals or in small groups, defining a glomeroporphyritic texture. Titanite, apatite, zircon, magnetite-ilmenite are the accessory minerals.

\section{Rhyolite porphyries (Samples GAR-383 and GAR-359)}

Samples GAR-383 and GAR-359 represent rhyolite porphyries from the Altamira and Algeciras plutonic massifs, respectively (Fig. 4f). The first comes from a small body intruding the main hornblende biotite monzogranites. It has a porphyritic texture, with alkali feldspar, minor quartz and plagioclase, and rare amphibole phenocrysts (up to $5 \%$ vol.) in a matrix made up mainly by quartz and alkali-feldspar, with some amphibole, opaque minerals, titanite, zircon and 
secondary minerals. Plagioclase phenocrysts $\left(A n_{3-8} A b_{85-93}\right)$ appears isolated or constituting a glomeroporphyritic texture; alkali feldspar phenocrysts ( $\left.\operatorname{Or}_{77-97} A_{2-28}\right)$ are perthitic. Quartz phenocrysts appear rounded and with undulatory extinction.

Sample GAR-359 intrude biotite hornblende monzogranite. It is particularly characterized by the widespread distributions of fine intergrowths of quartz and alkali-feldspar in the mesostasis, constituting a typical spherulitic texture. The spherulites present a radiate form and sometimes a very fine aggregate containing quartz, alkali feldspar, opaque and/or epidote-group minerals in the core. The mesostasis is micro- to cryptocrystalline and contains quartz, sericite, epidote and opaque phases (Fig. 4f).

\section{WHOLE-ROCK GEOCHEMISTRY}

The main geochemical characteristics of the studied massifs are summarized in the next and represented in diagrams together with the available data for the main Jurassic neighboring massifs/batholiths from the Colombian Central and Eastern Cordilleras for comparison. Representative whole-rock compositions are depicted in Table 1. The complete data set is given with the supplementary materials accompanying this paper.

\subsection{Major and minor elements}

As typical for the granite magmatism in the Colombian Eastern Cordillera, the studied rocks are compositionally expanded $\left(51.5<\mathrm{SiO}_{2} \mathrm{wt} . \%<80.4\right)$ and present a dominant high- $\mathrm{K}\left(3.3<\mathrm{K}_{2} \mathrm{O}\right.$ wt. $\left.\%<6.2\right)$ calc-alkaline geochemical trend (Fig. 5), comparable with trend showed in the QAP diagram (Fig. 3.), associated to a subduction in a continental margin (Nédélec and Bouchez, 2015). Most samples 
classify as calc-alkaline or alkali-calcic, magnesian, metaluminous to slightly peraluminous rocks, with $0.66 \leq$ fe\# $\left[\mathrm{Fe}-\right.$ number $=\mathrm{FeO}_{\top} /\left(\mathrm{FeO}_{\top}+\mathrm{MgO}\right)$, wt. \%] $\leq 0.94$ and $0.67 \leq \mathrm{ASI}$ [Alumina Saturation Index $=\mathrm{Al}\left(\mathrm{Ca}-1.67^{*} \mathrm{P}+\mathrm{Na}+\mathrm{K}\right)$ ] $\leq 1.01$, according to Frost et al. (2001) and Frost and Frost (2008). A few samples, corresponding to leuco granites from the Algeciras and Altamira complexes, as well as the hornblende monzonite from Altamira, plot as alkali and ferroan (cf. Fig. 5c). Of interest, the available data for the Ibagué Batolith in the Central Colombian Cordillera (Bustamante et al., 2016; Cochrane et al., 2014b) display a more typical calcic- to alkali-calcic character with a similar metaluminous to slightly peraluminous signature and high $\mathrm{A} / \mathrm{NK}$, a feature reflecting relatively low $\mathrm{K}$ contents, while the Santander plutonic massifs, in the northern area of the Eastern Cordillera are made up just of peraluminous calc-alkaline varieties (Mantilla Figueroa et al., 2013; van der Lelij et al., 2016).

The analyzed subvolcanic rocks show similar general geochemical trends. The mafic and intermediate rocks $\left(69.3 \leq \mathrm{SiO}_{2} \leq 75.7\right)$ plot as basalts and basaltic trachy-andesites in the TAS diagram (not shown), while the felsic porphyries correspond to dacites and rhyolites, as expected, with $65.2 \leq \mathrm{SiO}_{2} \leq 75.7$. Some rhyolite porphyries are slightly peraluminous and ferroan as well (Fig. 5c; d).

\subsection{Trace elements}

Mantle-normalized trace element patterns for the plutonic and subvolcanic associated rocks are presented in Fig. 6. Again, they display trends akin to those observed in magmatic rocks from active continental margins, with well-developed negative anomalies for $\mathrm{Nb}, \mathrm{P}$ and $\mathrm{Ti}$ and a positive one for $\mathrm{Pb}$ (Harris et al., 1986; 
Pearce et al., 1984). Rb, Sr, Y, Zr and Ba contents range from 26-273, 211-990, $14-32,121-394,609-1353 \mathrm{ppm}$, respectively, in the mafic to intermediate to $85-$ 263, 40-439, 9-31, 68-261, 36-1019 ppm in the acid ones (see supplementary material), corresponding to enrichment factors about 100:1, 400:1, 20:1, 200:1, 900:1 respectively, over typical MORB contents (McDonough and Sun, 1995).

REE patterns (Fig. 6) depicts LREE fractionation over HREE, with 7.7-8.7 $\leq$ $\mathrm{LaN}_{N} / \mathrm{Yb}_{\mathrm{N}} \leq 18.8-22.4,5.5-7.0 \leq \mathrm{La}_{N} / \mathrm{Sm}_{N} \leq 3.4-5.8$ and $0.2-1.6 \leq \mathrm{Gd}_{N} / \mathrm{Yb}_{\mathrm{N}} \leq 1.3-2.6$. The leuco-monzogranite sample from Algeciras (GAR-354) has an exceptional high fractionation among the LREE, with $\mathrm{LaN}_{\mathrm{N}} / \mathrm{Sm}_{\mathrm{N}}=29$. As expected, the basic dike from Altamira has the lowest fractionated patterns $\left(\operatorname{LaN}_{\mathrm{N}} / \mathrm{Sm}_{\mathrm{N}}=2.8\right.$ and $\left.\mathrm{Gd}_{N} / \mathrm{Yb}_{N}=2.1\right)$ compatible with a more primitive signature, as indicated also by its higher $\mathrm{Cr}, \mathrm{Cu}, \mathrm{Ni}$ and $\mathrm{Zn}$ abundances (535, 94, 217 and 88 ppm, respectively). Negative Eu anomalies are moderate to absent $\left(\mathrm{Eu} \mathrm{Eu}^{*}=0.5\right.$ to 1.0$)$ in the mafic to intermediate rocks, and better developed in the felsic ones (Eu/Eu* up to 0.6). The REE patterns available for the other occurrences are similar

In general, these trace and REE patterns are similar to other Jurassic granitic rocks from Central and Eastern Cordilleras (Fig. 6). However, the Vetas-California rocks, in Santander region from Eastern Cordillera, are relatively more enriched in all trace elements (cf. Mantilla Figueroa et al., 2013) while the granites from the Ibagué Batholith, in Central Cordillera, depicts relatively low LREE fractionation patterns, with $\mathrm{La}_{\mathrm{N}} / \mathrm{Sm}_{\mathrm{N}}=2.8$ and $\mathrm{Gd}_{\mathrm{N}} / \mathrm{Yb}_{\mathrm{N}}=2.1$ (cf. Cochrane et al., 2014b). 


\section{ZIRCON ISOTOPE ANALYSIS}

In this section, we present and discuss the main zircon morphology and textural features, emphasizing the analyzed crystals, as well as U-Pb dating and Lu-Hf isotope results. The complete analytical data set is presented as supplementary material.

\subsection{Zircon morphology and CL textures}

Zircon crystal populations depict a variety of textural features, as observed in TL and/or CL high-resolution images (Fig. 7).

The quartz mangerite from the crystalline basement (GAR-364) contains rounded pinkness crystals with aspect ratios about 1.5:1 to $1: 1$, in general with complex CL patterns; prismatic habits are rare. Some crystals have concentric zoning with a dark homogeneous core wrapped by lighter homogeneous external rims. Some crystals present sector and others present irregular patchy zoning patterns involving homogeneous areas. Oscillatory zoning, most typical of magmatic crystallization environments is rare or absent (Fig. 7a).

On the other hand, the crystals selected from granite samples present, in general, prismatic habits and are translucent under the binocular stereoscope. The main crystal populations from the Algeciras and Sombrerillo monzogranites (GAR356 and GAR-394, respectively) have similar external morphology with $\{101\}-$ pyramid crystal faces predominating over $\{211\}$-pyramid ones and the $\{100\}$-prism faces over the $\{110\}$-prism ones. The average aspect ratio approaches 2:1. A second zircon population was identified in GAR-356, whit similar characteristics, but developing \{110\}-prism faces and with a relatively high aspect ratio, about 3:1. 
Zircon crystals from the Altamira granodiorite (GAR-386) also present $\{101\}$ pyramid faces dominant over $\{211\}$-pyramid ones, but the $\{110\}$-prism faces are larger than the $\{110\}$-prism ones and the average aspect ratio is lower than $2: 1$. Crystal grains in all samples have well developed oscillatory zoning in CL patterns; sometimes cross-cut by light or dark homogenous zones. A somewhat dark or light spotted pattern, given by minute mineral inclusions (apatite and some unidentified ones) may also be observed. Of note, the original oscillatory CL pattern in some GAR-394 crystals sample appears to be partially homogenized (Fig. 7b).

Zircon crystals in subvolcanic rocks from Algeciras and Sombrerillo (GAR-359 rhyolite and GAR-395 dacite, respectively) have homogenous morphology patterns, characterized by well-developed $\{101\}$-pyramid and $\{110\}$-prism crystal faces. The average aspect ratios are higher in the former (4:1) than in latter $(3: 1)$. Zircon crystals from the GAR-383 rhyolite from Altamira, however, present $\{101\}$ pyramid faces larger than the $\{211\}$-pyramid ones and $\{110\}$ is the sole developed prismatic form and the aspect ratios are close to 2:1. Samples GAR-383 and GAR395 present oscillatory CL and inclusion-derived patterns much like those observed in the plutonic rocks, including partially homogenized zones in sample GAR-395. On the other hand, crystals from GAR-359 are translucent, inclusions are rare or absent and several among them present well-developed hourglass zoning relating CL-lighter and -darker relatively homogenous zones (Fig. 7c). Samples GAR-359, GAR-395 and GAR-383 present more typical zircon xenocrysts characterized by rounded morphologies; some of which homogeneous CL patterns similar to those observed in the quartz mangerite country rock (Fig. 7d). 
7.2. Zircon U-Pb and isotope Lu-Hf systematics

\section{Quartz mangerite country rock}

A total of 26 spots over 25 crystals for the mangerite GAR-364 were measured. Th and $U$ contents range from 208 to 380 and 191 to $313 \mathrm{ppm}$ in the dark CL domains and from 35 to 73 and 47 to 128 ppm in the light ones, respectively. Age concordances are in between $89-103 \%$ (see supplementary material). ${ }^{238} \mathrm{U} / 206 \mathrm{~Pb}$ ages are almost identical for both areas $(1007 \pm 8 \mathrm{Ma}$ and $1009 \pm 8 \mathrm{Ma}$, respectively) and an average age, integrating the two domains gives $1003 \pm 2 \mathrm{Ma}$ (MSWD =5.0, $\mathrm{n}=26$, Fig. 8).

Computed $\varepsilon \mathrm{Hf}(\mathrm{t})$ values for ten analyzed spots gave values between -2.7 and +2.6, most being close to zero or slightly positive (Fig. 9). The conventional twostage model TDM ages are in between 1640 and 2000 Ma.

\section{$\underline{\text { Main plutonic rocks }}$}

Among the plutonic rocks, 27 spots from 25 crystals from the Algeciras hornblende biotite monzogranite GAR-356 were analyzed; eight spots were cut out, as six present ${ }^{204} \mathrm{~Pb}>6 \%$ relative and two result in age discordances $\geq 10 \%$. At a first glance, two main age populations were obtained, with similar values considering analytical errors however: an older one, measured over crystals with aspect ratios $2: 1$, gave ${ }^{238} \mathrm{U} / 206 \mathrm{~Pb}$ ages in between $185 \pm 5 \mathrm{Ma}$ and $179 \pm 3 \mathrm{Ma}$ while the other, measured over crystals with aspect ratios 3:1 gave younger ages, in between $176 \pm 5 \mathrm{Ma}$ and $167 \pm 6 \mathrm{Ma}$. Averaging both populations, a mean ${ }^{238} \mathrm{U} /{ }^{206} \mathrm{~Pb}$ age of $176 \pm 2 \mathrm{Ma}(\mathrm{MSWD}=0.35, \mathrm{n}=19$, Fig. 8) was obtained. 
Results for the Altamira hornblende biotite granodiorite (GAR-386) include 26 spots over 25 crystals; 14 spots were cut out however (see supplementary material), to obtain an average ${ }^{238} \mathrm{U} /{ }^{206} \mathrm{~Pb}$ age about $162 \pm 3 \mathrm{Ma}(\mathrm{MSWD}=0.67, \mathrm{n}$ $=11$, Fig. 8). Of note, an individual ${ }^{238} \mathrm{U} / 206 \mathrm{~Pb}$ age of $192 \pm 6 \mathrm{Ma}(11 \%$ discordance) was obtained in a single crystal. A few (5 out 18) appropriate analytical spots from the Sombrerillo biotite hornblende monzogranite (GAR-394) point to an ${ }^{238} \mathrm{U} /{ }^{206} \mathrm{~Pb}$ age of $189 \pm 7 \mathrm{Ma}(\mathrm{MSWD}=0.0048, \mathrm{n}=5$, Fig. 8), while 13 spots from the two-pyroxene bearing rocks (L-102 and L-104 samples), all of them with low age discordances and ${ }^{204} \mathrm{~Pb}$ values (see supplementary material), gave identical ${ }^{238} \mathrm{U} /{ }^{206} \mathrm{~Pb}$ ages of $187 \pm 1 \mathrm{Ma}(\mathrm{MSWD}=1.3, \mathrm{n}=13)$ and $187 \pm 2 \mathrm{Ma}$ $($ MSWD = 7.1, n = 13, Fig. 8), respectively

Intrusive rocks present predominant negative $\varepsilon \mathrm{Hf}_{(\mathrm{t})}$ values between -1.2 and 6.4 (see supplementary material). Some spots from samples GAR-386, GAR-394 and GAR- 356 result in $\varepsilon \mathrm{Hf}_{(\mathrm{t})}$ values up $+3.8,+3.4$ and +0.9 , respectively (Fig. 9), while the most negative values are depicted by L102 and L104 samples (-1.0 to 7.7). Of note, significant $\varepsilon \mathrm{Hf}_{(\mathrm{t})}$ variations are observed from crystal to crystal in each sample and even in measurements on single crystals; for instance the dark core of a grain from the Algeciras hornblende biotite monzogranite has $\varepsilon \mathrm{Hf}(\mathrm{t})=-1.3$ while the oscillatory zoned rims has $\varepsilon \mathrm{Hf}(\mathrm{t})=5.0$, a variation of $3.7 \varepsilon \mathrm{Hf}$ units, in spite of the similar computed spot ages (179 $\pm 3 \mathrm{Ma}$ and $183 \pm 5 \mathrm{Ma}$, respectively).

The computed model $\mathrm{T}_{\mathrm{DM}}$ ages reflect, as expected, the $\mathrm{Hf}$ isotopic ratios variations range and are in between ca. 900-1100 Ma in the case of positive $\mathrm{\varepsilon Hf}_{(\mathrm{t})}$ values to a 1100-1660 Ma interval in the case of negative ones. 
Importantly, when the available geochronological and Lu-Hf isotope data for granitic and related rocks in the Central and Eastern Colombian Cordilleras are taken together, indicates that old and inner-continent granite emplaced intrusions contain more significant contributions from sources relatively more evolved from the Hf isotopic perspective (Fig. 9).

\section{Subvolcanic rocks}

Among the subvolcanic analyzed rocks, 15 out of 26 analytical spots over 26 zircon crystals from the dacite porphyry (GAR-395, Sombrerillo Plutonic Massif), with individual ${ }^{238 \mathrm{U} / 206} \mathrm{~Pb}$ ages in between 160 and $171 \mathrm{Ma}$ (see supplementary material), result in an average ${ }^{238} \mathrm{U} / 206 \mathrm{~Pb}$ age $167 \pm 2 \mathrm{Ma}(\mathrm{MSWD}=2.6, \mathrm{n}=15$, Fig. 8). The rhyolite porphyries from Algeciras and Altamira averages $172 \pm 1 \mathrm{Ma}$ $(M S W D=0.057, n=22)$ and $175 \pm 3 M a(M S W D=0.16, n=10)$; the individual spot ages being between 171 and $173 \mathrm{Ma}, 162$ and $185 \mathrm{Ma}$ (with errors $\leq 0.008$ Ma at $1 \sigma$ level), respectively. Both rhyolite samples present zircon xenocrysts and perhaps antecrysts. The rounded zircon crystals with homogeneous dark and light CL zones from GAR-359 gave an older, concordant, ${ }^{238} \mathrm{U} /{ }^{206} \mathrm{~Pb}$ age of $1365 \pm 12$ Ma, while two concordant points from GAR-383, with light homogeneous cores and dark rims in $\mathrm{CL}$ patterns, present $1156 \pm 40 \mathrm{Ma}$ and $982 \pm 33 \mathrm{Ma}{ }^{238} \mathrm{U} /{ }^{206} \mathrm{~Pb}$ ages, respectively. Two spots from the first sample gave $185 \pm 2 \mathrm{Ma}$ and $192 \pm 5 \mathrm{Ma}$ ages, with high discordances (32\% and $78 \%$ ) however. Two concordant ${ }^{238} \mathrm{U} /{ }^{206} \mathrm{~Pb}$ ages, $182 \pm 5 \mathrm{Ma}$ and $404 \pm 7 \mathrm{Ma}$, were obtained in two grains with oscillatory CL patterns in this sample, the first considered a potential antecryst, because the 
similar values compare with ages obtain in intrusive facies; while the second is assumed as a xenocryst (Fig. 8).

Subvolcanic rocks present systematically less evolved $\mathrm{Hf}$ isotope compositions as compared with the associated granites and, interestingly, they are similar or even less evolved than the main plutonic rocks from the Central Cordillera to the west (Fig. 9). In fact, dacite GAR-395 and rhyolite GAR-359 present $+7.9 \leq \varepsilon \mathrm{Hf}_{(\mathrm{t})} \leq$ +14.6 and $+5.0 \leq \varepsilon \mathrm{Hf}_{(\mathrm{t})} \leq+12.0$ with corresponding TDM ages within the 221-657 Ma and 392-830 Ma ranges, respectively (see supplementary material). The rhyolite porphyry GAR-383 gave both positive and negative $\varepsilon \mathrm{Hf}_{(\mathrm{t})}$ values, from -3.6 to +4.6 , and model ages from ca. 870 to $1300 \mathrm{Ma}$.

Among the xenocrystic/antecrystic zircon spot populations, the GAR-359 spot with $1365 \pm 12 \mathrm{Ma}$, approaching well U-Pb crystallization ages of crystalline basemen rocks of Garzón (Ibanez-Mejia et al., 2011) and has $\varepsilon \mathrm{Hf}_{(\mathrm{t})}=+8.9$ and $\mathrm{T}_{\mathrm{DM}}$ $=1516 \mathrm{Ma}$, while the $185 \pm 2 \mathrm{Ma}$ spot has $\varepsilon_{\mathrm{Hf}}(\mathrm{t})=-3.9$ and $\mathrm{T}_{\mathrm{DM}}=1421 \mathrm{Ma} . \varepsilon \mathrm{Hf}_{(\mathrm{t})}$ values about -3.5 and +7.4 and $\mathrm{T}_{\mathrm{DM}}=2010$ and $868 \mathrm{Ma}$ were obtained for the 982 \pm 33 and $404 \pm 7$ dated spots from samples GAR-383 and GAR-395, respectively (Fig. 9).

\section{DISCUSSION}

8.1. Charnockite magmatism and the older crystalline basement

The ca. 1000 Ma age obtained for the analyzed quartz mangerite matches well, being ca. $10 \mathrm{Ma}$ younger, the ages obtained in metamorphic overgrowths over zircon from granulites and gneisses from the Garzón and Las Minas basement areas (Ibanez-Mejia et al., 2011). In such high metamorphic terranes, zircon 
overgrowths ages may correspond to partial melting events following the metamorphic peak in a given P-T evolutionary path, when rocks had already been exhumed to low pressure depths, as well-described in ultra-high temperature rocks from the Bohemian Massif of Variscan Central Europe (Roberts and Finger, 1997) and the Socorro-Guaxupé Nappe in Brazil (Mora et al., 2014). In our case however, the time interval is relatively short considering associated errors and the obtained result represents, most probably, an upper age limit for the main metamorphism, an interpretation more akin with the observed zircon morphologies. $\varepsilon \mathrm{Hf}_{(\mathrm{t})}$ values around zero $(-2.7$ to +2.6$)$, and $\mathrm{T}_{\mathrm{DM}}$ between 1640 and $2000 \mathrm{Ma}$ suggest relatively important crustal contributions to ancient magmatic rock.

Our zircon xenocrysts data for volcanic rocks, even reduced in number, indicate that heterogeneous ancient continental materials contributed to a variable extent to the genesis of the Jurassic intermediate-acid magmatism in Eastern Colombian Cordillera. Of importance, the $1365 \pm 12$ Ma (GAR-359) and $982 \pm 33$ Ma (GAR383) ages correlate well with ages observed in zircon xenocrystic cores, in the range between ca. 1010 and $1490 \mathrm{Ma}$, from a variety of gneisses and granulites rocks of the crystalline basement in the area (Ibanez-Mejia et al., 2011). The $\varepsilon \mathrm{Hf}_{(\mathrm{t})}$ values from +8.9 to -3.5 , respectively, suggest contributions from both younger mantle as well as older crustal materials.

No country rocks with ages approaching $400 \mathrm{Ma}$, as obtained in the Sombrerillo rhyolite porphyry, are known in the area. Igneous and ortho-gneissic rocks with similar ages are well known to the North of the Eastern Colombian Cordillera as well as in the Merida Cordillera in Venezuela however, being related to the 
Caparoensis-Farmatian Orogeny, resulting from the interaction among Avalonia, Laurentia and Baltica continents (Cochrane et al., 2014a; Mantilla Figueroa et al., 2012). It may imply similar, unexposed, rocks in the Garzón area. Of note, the typical positive $\varepsilon \mathrm{Hf}_{(t)}$ value (+ 7.4) suggests significant mantle contributions by this time.

\subsection{Geochemical characteristics and some inferences on magmatic sources}

Geochemical signatures as those described for the intrusive rocks from the Garzón are typical associated to continental arc magmatism or "post-collisional" environments under relatively oxidizing conditions, as suggested by their magnesian nature (Frost and Frost, 2008; see also Garcia-Chinchila and Vlach, submitted).

The distinctive high-K calc-alkaline to alkali-calcic signature in such environments is consistent with contributions from both crustal and mantle sources (e.g. Barbarin, 1999) and the relatively higher $\mathrm{K}_{2} \mathrm{O}$ concentration (> 4 wt \%), as compared to other Jurassic igneous rocks of northern Andes (e.g. Santander region, Mocoa batholith, felsic facies of Vetas-California mining district; Mantilla Figueroa et al., 2013; van der Lelij et al., 2016; Zapata et al., 2016; Fig. 10a) suggest that crustal contributions were more important in the inward Eastern Cordillera. Relatively higher contents of the large ion lithophile elements (LILEs) such as $\mathrm{K}, \mathrm{Rb}, \mathrm{Ba}$ and $\mathrm{Pb}$, as compared with the high field strength elements (HFSEs) such as $\mathrm{Nb}$ and $\mathrm{Ta}$, is a major feature of the so-called volcanic arc granites as well as of modern island arc rocks (Pearce et al., 1984) related to subduction zones, the LILEs being mobilized by hydrous fluids from the downgoing 
oceanic slab (Hawkesworth et al., 1997). Th abundances as well as the Ba/Th and $\mathrm{U} / \mathrm{Th}$ ratios cover the range observed for the overall magmatism in the Central and Eastern Cordillera (Fig. 10b; c). Relatively high Th contents, as observed particularly for our more evolved plutonic rocks, may indicate melting of sediments trapped in the subducting slab, as shown by Elliott et al. (1997), Hawkesworth et al. (1997) and Plank and Langmuir (1993) in recent volcanic arcs or significant crustal contamination in a thickened crust (Kay et al., 2014; Trumbull et al., 1999). Similar high-Th granites appear only in the Santander area, specially within the felsic varieties of the Vetas-California mining district (Fig. 10b; c, cf. Mantilla Figueroa et al., 2013).

$\mathrm{Sr} / \mathrm{Y}, \mathrm{La} / \mathrm{Yb}$, and $\mathrm{La} / \mathrm{Sm}$ elemental ratios are sensitive to the retention of mineral phases as plagioclase, garnet and amphibole in magma sources, given the geochemical affinities of the involved elements. The $\mathrm{Sm} / \mathrm{Yb}$ ratio is particularly sensitive to the retention of amphibole and especially garnet $(\mathrm{Sm} / \mathrm{Yb}>4)$ under high pressures melting environments (Kay et al., 2014, 2005; Mamani et al., 2010). Most $\mathrm{Sm} / \mathrm{Yb}$ ratios $(\leq 4)$ of the studied rocks are lower than the typical value usually interpreted as indicative of residual garnet and so relatively high pressures. In general, mafic-intermediate dikes of Algeciras and Altamira present higher ratios $(2.9 \leq \mathrm{Sm} / \mathrm{Yb} \leq 3.6)$ and the highest ratios among the subvolcanics and granites are 4.5 in the Algeciras andesite dike (GAR-353), and 3.5 in the Altamira hornblende monzonite GAR-388, respectively (Fig. 10d). Of importance, increasing $\mathrm{Sm} / \mathrm{Yb}$ ratios may be related to crustal thickening and consequent pressure increase in the source area (e.g. Mamani et al., 2010), while the 
combination of relatively low $\mathrm{Sm} / \mathrm{Yb}$ ratios and high $\mathrm{Th}$ contents are good indications of significant crustal contributions.

\subsection{Lu-Hf isotope composition}

The $\mathrm{Hf}$ isotopic composition in zircon from granitic rocks is a strong indicator of the relative contributions of potential magma sources. Thus, relatively high $\varepsilon \mathrm{Hf}_{(t)}$ positive values indicate mantle contributions, as referred to the CHUR reservoir, while progressively low negative values indicates increasing involvement of crustal reservoirs (Vervoort et al., 2000; Vervoort and Blichert-Toft, 1999; Vervoort and Patchett, 1996).

The plutonic rocks from the Algeciras, Altamira and Sombrerillo massifs show, as stated, negative $\varepsilon \mathrm{Hf}_{(\mathrm{t})}$ values (-1.2 to -7.7), a feature unique among all plutonic rocks from Colombian Cordilleras for which there are Lu-Hf data available. This indicates significant contributions from older crustal materials in their magma precursors, an interpretation well supported by our whole-rock geochemical data; nevertheless, geologic and structural information (e.g. syn-plutonic maficintermediate dikes and associated mafic microgranular enclaves) point also to coeval mantle inputs.

Natural candidates for crustal inputs may well be equivalents to the metamorphic crystalline cropping out in nearby areas. Of importance, the estimated $\mathrm{T}_{\mathrm{DM}}$ values approaches relatively well several available U-Pb ages (from ca. 890 to $1360 \mathrm{Ma}$ ) for the main crystalline basement in the Garzón region. Thus, our interpretation favors important contributions from similar, unexposed, crustal rocks to the main magmatism. In such a perspective, the observed isotope 
composition variations are correlated with basement heterogeneity, as evidenced by some data for zircon xenocrysts found in subvolcanic rocks, and/or variable mantle/continental crust mass ratios contribution.

The origin of two-pyroxene granitic rocks from the Sombrerillo Plutonic Massif imply high-temperature $\left(\geq \mathrm{ca}\right.$. $1000^{\circ} \mathrm{C}$ ) melting of anhydrous lower crustal sources, induced probably by coeval basic magma emplacement, and generation of relatively anhydrous, charnockite-like, hybrid magmas (Kilpatrick and Ellis, 2011; Percival and Mortensen, 2002; Young et al., 1997; Zhao et al., 1997). The predominant negative and variable $\varepsilon \mathrm{Hf}_{(\mathrm{t})}$ values $(-1.0$ to -14.5$)$ are compatible with such an interpretation. Magma fractionation and, arguably, medium- to low-crustal contamination lead to $\mathrm{H}_{2} \mathrm{O}$ increase in progressively evolved magmas, allowing crystallization or hydrous mafic minerals as amphibole and late biotite, replacing for ortho- and clinopyroxene. Clinopyroxene preserved in amphibole crystal cores in biotite hornblende monzogranite from this massif, may also suggest that these rocks evolved from relatively anhydrous, similar magmas.

On the other hand, the subvolcanic rocks present isotope compositions more akin with dominant mantle contributions, particularly samples GAR-359 and GAR395. This may suggest contrasted magma sources or, alternatively, as they intrude the plutonic rocks, magma ascent trough previous open magma conduits and fast crystallization had prevented effective interaction and assimilation of crustal materials. The relatively common occurrence of zircon xenocrysts does not favor the latter interpretation however in the case of the rhyolite porphyries. The dacite GAR-395 present both less positive and negative $\varepsilon \mathrm{Hf}_{(t)}$ values, partially overlapping 
those observed for the main biotite hornblende monzogranite GAR-394 and probably was formed from a very similar magma.

A pre-Jurassic oceanic crust is well document in the Garzón area as indicated by Triassic marine sediments (Payandé Formation, cf. Cediel et al., 1980; Jaillard et al., 1990) as well as the Carboniferous to Permian and Ordovician marine sequences (Mojica et al., 1988b; Moreno-Sánchez et al., 2008; Villarroel et al., 1997), some of them cut across by the Jurassic magmatism (Mojica et al., 1988a; Núñez, 2003). In addition, Triassic basement amphibolites (216-239 Ma) with MORB affinities from the Eastern Cordillera in Ecuador and Central Cordillera in Colombia present high positive $\varepsilon \mathrm{Hf}_{(\mathrm{t})}$ values (ca. +10 to +15 , cf. Cochrane et al., 2014a). Isotopic data for supposal equivalent rocks cropping out in Eastern Colombian Cordillera are absent however; nevertheless, the development of the Paleozoic to Triassic basin suggests that an oceanic crust was involved in subduction processes (Bustamante et al., 2016; Cochrane et al., 2014b), a scenario which could explain the observed $\varepsilon \mathrm{Hf}_{(\mathrm{t})}$ and $\mathrm{T}_{\mathrm{DM}}$ values of our subvolcanic rocks.

\subsection{Jurassic magmatism and geotectonic implications for Colombian Andes}

In this section, we integrate and compare the available geochronological, geochemical and isotope data to discuss the evolving granite and related magmatism through time in Colombian Central and Eastern Cordilleras and neighboring areas. Fig. 11 depicts geochronological and isotope data over a geological map for appropriate comparisons. 
The first known Jurassic arc-related magmatism was emplaced in the Santander region, to the north, mainly between ca. 195 to $201 \mathrm{Ma}$, with some older representatives (197-211 Ma) in the Vetas-California district (Fig. 11a). The emplaced granitic rocks present typically negative zircon $\varepsilon \mathrm{Hf}_{(\mathrm{t})}(-2.5$ to -6.6$)$ coupled with negative whole-rock $\varepsilon N d_{(t)}(-2.2$ to -7.2$)$ values (Mantilla Figueroa et al., 2013; van der Lelij et al., 2016). No younger intrusive rocks are known in this area, thus, a westward migration of the magmatic arc front after ca. $194 \mathrm{Ma}$ was proposed by Spikings et al. (2015). Such inference was drawn taking into account emplacement ages and geochemical trends observed in the Santander and Segovia region (to the west), Ibagué Batholith (in Central Colombian Cordillera, to the south, with 183 to $200 \mathrm{Ma}$ ages), as compared with intrusive and volcanic rocks from Real Cordillera, Ecuador, with an age span between 141 to 189 Ma (see details in Spikings et al., 2015). Such migration established a magmatic arc at the same latitude interval of the Santander region $\left(6^{\circ}-9^{\circ} \mathrm{N}\right)$, but $50 \mathrm{~km}$ to the west, in the so-called San Lucas region. Intrusive units therein (e.g. Norosí-San Martín Batholith), emplaced by 178 to $194 \mathrm{Ma}$ and present dominant negative $\varepsilon \mathrm{Nd}_{(\mathrm{t})}$ values (-0.5 to -6.9 , cf. Fig. 11a; Leal-Mejía, 2011); these rocks, the lbagué Batholith, with $0.7049 \leq\left({ }^{87} \mathrm{Sr} /{ }^{86} \mathrm{Sr}\right) \mathrm{t} \leq 0.7061$ and $-0.9 \leq \varepsilon \mathrm{Nd}_{(\mathrm{t})} \leq+2.3$, cf. Leal-Mejía (2011) and our Sombrerillo two-pyroxene bearing rocks, with more typical negative $\varepsilon \mathrm{Hf}_{(\mathrm{t})}$ values, should represent a largely coeval, correlated, magmatism with somewaht variable crust/mantle source contributions.

On the other hand, the granites from the Algeciras and Altamira plutonic massifs are significantly younger (170 to $176 \mathrm{Ma}$ ) than the equivalent rocks from 
Central Cordillera (30 to $50 \mathrm{~km}$ to the west) and Sombrerillo (50 km to the southwest). This suggests a new migration and relocation of the front arc to the east in the Eastern Cordillera.

Arc migration geodynamic patterns such as the described ones (Fig. 12) are common in modern convergent plate boundaries at accretion margins and has been successful attributed to subduction erosion phenomena (Clift and Vannucchi, 2004; Clift et al., 2009; Kay et al., 2014, 2005; Stern, 2011; von Huene et al., 2004). In this process, the frontal erosion along the top of the fore-arc wedge combined with sub-crustal basal erosion in the wedge underside leads to the collapse of the fore-arc wedge into the trench; as a consequence, there are input of new crustal materials (oceanic crust, pelagic and terrigenous sediments, as well as crystalline fore-arc material) into the subduction channel and magmatic arc migration, from the front-arc to the back-arc region (Stern, 2011). These are important patterns in worldwide distributed active margins, such as the Cenozoic eastward migration recorded by the Chaltén Plutonic Complex in Patagonia (De Arellano et al., 2012), the Andean Southern and Central Volcanic Zones (Kay and Mpodozis, 2002; Kay et al., 2014, 2005) during the Cenozoic, as well as the Cretaceous one related to the Laramide Orogeny in western United States (e.g. Ducea et al., 2015; Saleeby, 2003).

Of importance, significant geochemical and isotopic change are registered in youngest rocks (167 to $173 \mathrm{Ma}$ ), emplaced in the Garzón (rhyolite and dacite porphyries with relatively high positive $\varepsilon \mathrm{Hf}_{(t)}$ values). The observed juvenile geochemical and isotopic characteristics suggest source changes, maybe related 
to subduction regime variation after ca. $170 \mathrm{Ma}$, with partial melting of oceanic crust, of the mantle wedge as well as of the overlaying continental crust, as supported by both experimental and geochemical data from volcanic arcs (e.g. Castro et al., 2010; Defant and Drummond, 1990; Stern and Kilian, 1996). In fact, partial melting of the slab (hydrated basalts, terrigenous and pelagic sediments) and interaction with the overlaying mantle produce magmas with geochemical characteristics very akin with the observed in the 129-165 Ma granitic rocks of Central Cordillera (Bustamante et al., 2016) and in the felsic porphyries and maficintermediate dikes from the Eastern Cordillera. As pointed above, the relative Th enrichment observed in such rocks supports contributions from sedimentgenerated melts. Thus, we interpreted that fore-arc subduction erosion had an effective role in the eastward migration of the front arc from Central to Eastern Cordillera in southern Colombian Andes at about 179 Ma and open up the way for further melting by ca. 173 and late.

A last westward migration is well registered in the Jurassic arc. As the magmatic activity had decreased in the studied Garzón area, the arc front was active mainly in the Central Cordillera by 165 Ma (Fig. 12). Just minor subvolcanic rocks were produced, arguably in a back-arc regime. These ideas agree with the establishment of back-arc basins in Eastern Cordillera and Upper Magdalena Valley through regional extension and subsidence (Cooper et al., 1995; SarmientoRojas et al., 2006). At the west, however, the subduction zone was preserved, the oceanic crust and mantle acting as the main melt sources, with minor crustal 
contribution, as interpreted for the Central Cordillera magmatism (Bustamante et al., 2016; Leal-Mejía, 2011).

\section{FINAL REMARKS AND CONCLUSIONS}

The Algeciras, Altamira and Sombrerillo are the most important plutonic massifs, representative of the voluminous Jurassic granite magmatism in the Eastern Colombian Cordilleras. The elemental geochemical fingerprints of selected granitic samples from these massifs in the studied Garzón region allow establish a continental magmatic arc type signature, related to subduction zones, for the main granite magmatism. Relatively high Th values and low Sm/Yb ratios $(\leq 4)$ suggest significant crustal contributions, from sediments introduced into the subduction channel or from the overlying continental crust, or both. The negative $\varepsilon \mathrm{Hf}_{(t)}$-inzircon values (between -7.7 and -1.2) observed for the granitic rocks suggest also significant contributions of an ancient continental crust.

Compositional differences between the plutonic rocks of Sombrerillo and those of Algeciras and Altamira, suggest that the first is generated from relative more anhydrous and deeper melts, which subsequently are fractionated and contaminated with crustal materials, maybe associated with Jurassic magmatic rocks of the Central Cordillera, to the west. Algeciras and Altamira granite samples appear to have a high crustal contribution of ancient rocks from the regional crystalline basement, as suggested by the relative great abundance of felsic facies with a slightly peraluminous signature, the predominant negative $\varepsilon \mathrm{Hf}_{(t)}$-in-zircon 
values (between -7.7 and -1.2) as well as the presence of zircon xenocrysts in the associated rhyolite porphyries.

The associated subvolcanic rocks (mafic-intermediate syn-plutonic dikes, dacite and rhyolite porphyries), have both, positive and negative $\varepsilon \mathrm{Hf}_{(\mathrm{t})}$-in-zircon values, suggesting mixing of mantle sources and ancient crustal materials, with a possible young source indicate by model ages determinate with $\mathrm{Hf}$ isotopes. In addition, its high $\mathrm{Sm} / \mathrm{Yb}$ ratio (up to 4.5) suggests relative pressure increase in the source area, possibly due to crustal thickening.

Overall, as compared with the younger granite massifs from the Central Cordillera, the granites from studied massifs are relatively enriched in $\mathrm{K}$ and present an alkali-calcic, rather than a typical calc-alkaline, signature; in addition, $\varepsilon \mathrm{Hf}$ values point to a great contribution from relatively evolved, crustal, sources to the respective magmas. In fact, when all available whole-rock geochemistry and isotope data for the Central and Eastern Colombian Cordilleras are taken together, a clear trend of increasing crustal contribution to eastern (inward in relation to the continent) emerges, a pattern most typical of modern active continental margins.

The obtained high-resolution $\mathrm{U}-\mathrm{Pb}$ age results, allied with the available geochemical, isotope and geochronological results for the Colombian Cordilleras, allow suggest two main migrations of the magmatic arc front, arguably associated with subduction erosion phenomena. The first could explain the relative older ages obtained for samples from the Sombrerillo Plutonic Massif $(189 \pm 7 \mathrm{Ma})$ and available similar ages from granites in the Central Cordillera, in respect to the younger ages of the Algeciras and Altamira plutonic massifs (170 and $176 \mathrm{Ma}$ ) 
through an eastward migration of the Jurassic front arc by ca. 180 Ma. A younger westward migration, by $170 \mathrm{Ma}$., is considered to explain the end of significant magmatic activity in the studied region of the Eastern Cordillera and the development of intense granite magmatism in the Central Cordillera, ca. $30-50 \mathrm{~km}$ to the west, with ages about $165 \mathrm{Ma}$ and younger (Bustamante et al., 2016). In the Garzón area, geochemical and Hf-isotope contrasts between the younger subvolcanic and the main granitic rocks suggest a change of the subduction regime.

\section{AKNOWLEDGEMENTS}

Authors thank Conselho Nacional de Desenvolvimento Científico e Tecnológico-CNPq for a Doctoral scholarship (Proc. 142098/2013-2 to D.A. García-Chinchilla). Thanks are also due to GeoAnalitica-USP core facility for lab support. Comments from M.I. Giraldo and J.S. Hernandez help to improve a first manuscript version.

\section{REFERENCES}

Acosta, J., Osorno, J.F., 1999. Geologia de la Plancha 324 Tello. Mapa Geológico. Escala 1:100.000. INGEOMINAS. Bogotá D. C.

Allègre, C.J., 2008. Isotope Geology. Cambridge University Press, Cambridge. doi:10.1017/CBO9780511809323

Aspden, J.A., McCourt, W.J., Brook, M., 1987. Geometrical control of subductionrelated magmatism: the Mesozoic and Cenozoic plutonic history of Western Colombia. J. Geol. Soc. London. 144, 893-905.

Basei, M.A.S., Campos Neto, M.D.C., Lopes, A.P., Nutman, A.P., Liu, D., Sato, K., 2013. Polycyclic evolution of Camboriú Complex migmatites, Santa Catarina, Southern Brazil: integrated $\mathrm{Hf}$ isotopic and $\mathrm{U}-\mathrm{Pb}$ age zircon evidence of 
episodic reworking of a Mesoarchean juvenile crust. Brazilian J. Geol. 43, 427-443. doi:10.5327/Z2317-48892013000300002

Blanco-Quintero, I.F., García-Casco, A., Toro, L.M., Moreno, M., Ruiz, E.C., Vinasco, C.J., Cardona, A., Lázaro, C., Morata, D., 2014. Late Jurassic terrane collision in the northwestern margin of Gondwana (Cajamarca Complex, eastern flank of the Central Cordillera, Colombia). Int. Geol. Rev. 56, 1852- 1872. doi:10.1080/00206814.2014.963710

Blichert-Toft, J., Albarède, F., 1997. The Lu-Hf isotope geochemistry of chondrites and the evolution of the mantle-crust system. Earth Planet. Sci. Lett. 148, 243-258.

Bustamante, C., Archanjo, C.J., Cardona, A., Bustamante, A., Valencia, V.A., 2017. U-Pb Ages and $\mathrm{Hf}$ Isotopes in Zircons from Parautochthonous Mesozoic Terranes in the Western Margin of Pangea: Implications for the Terrane Configurations in the Northern Andes. J. Geol. 125, 487-500. doi:10.1086/693014

Bustamante, C., Archanjo, C.J., Cardona, A., Vervoort, J.D., 2016. Late Jurassic to Early Cretaceous plutonism in the Colombian Andes: A record of long-term arc maturity. Bull. Geol. Soc. Am. 128, 1762-1779. doi:10.1130/B31307.1

Bustamante, C., Cardona, A., Bayona, G., Mora, A., Valencia, V., Gehrels, G., Vervoort, J., 2010. U-Pb LA-ICP-MS Geochronology and regional correlation of Middle Jurassic intrusive rocks from the Garzon Massif, Upper Magdalena Valley and Central Cordillera, Southern Colombia. Boletín Geol. 32, 93-109.

Cárdenas, J.I., Fuquen, J.A., Núñez, A., 2002. Geología de la Plancha 388 Pitalito. Mapa Geológico. Escala 1:100.000. INGEOMINAS. Bogotá D. C.

Cárdenas, J.I., Núñez, A., Fuquen, J.A., 2003. Geología de la plancha 388 Pitalito. Escala 1:100.000. Memoria Explicativa. Bogotá D. C.

Cardona, A., Chew, D., Valencia, V.A., Bayona, G., Mišković, A., Ibañez-Mejía, M., 2010. Grenvillian remnants in the Northern Andes: Rodinian and Phanerozoic paleogeographic perspectives. J. South Am. Earth Sci. 29, 92-104. doi:10.1016/j.jsames.2009.07.011

Castro, A., Gerya, T., García-Casco, A., Fernández, C., Díaz-Alvarado, J., MorenoVentas, I., Löw, I., 2010. Melting relations of MORB-sediment Mélanges in Underplated Mantle Wedge Plumes; Implications for the origin of Cordillerantype Batholiths. J. Petrol. 51, 1267-1295. doi:10.1093/petrology/egq019

Cediel, F., Mojica, J., Macía, C., 1981. Las formaciones Luisa, Payandé, Saldaña. Sus columnas estratigráficas características. Geol. Norandina 3, 11-19.

Cediel, F., Mojica, J., Macía, C., 1980. Definición estratigráfica del Triásico en Colombia, Suramérica. Formaciones Luisa, Payandé y Saldaña. Newsletters Stratigr. 9, 73-104.

Cediel, F., Shaw, R.P., Cáceres, C., 2003. Tectonic Assembly of the Northern Andean Block. AAPG Mem. 79, 815-848.

Clift, P., Vannucchi, P., 2004. Controls on tectonic accretion versus erosion in 
subduction zones: Implications for the origin and recycling of the continental crust. Rev. Geophys. 42, 31. doi:10.1029/2003RG000127

Clift, P.D., Vannucchi, P., Morgan, J.P., 2009. Crustal redistribution, crust-mantle recycling and Phanerozoic evolution of the continental crust. Earth-Science Rev. 97, 80-104. doi:10.1016/j.earscirev.2009.10.003

Cochrane, R., Spikings, R., Gerdes, A., Ulianov, A., Mora, A., Villagómez, D., Putlitz, B., Chiaradia, M., 2014a. Permo-Triassic anatexis, continental rifting and the disassembly of western Pangaea. Lithos 190-191, 383-402. doi:10.1016/j.lithos.2013.12.020

Cochrane, R., Spikings, R., Gerdes, A., Winkler, W., Ulianov, A., Mora, A., Chiaradia, M., 2014b. Distinguishing between in-situ and accretionary growth of continents along active margins. Lithos 202-203, 382-394. doi:10.1016/j.lithos.2014.05.031

Cohen, K.M., Finney, S.C., Gibbard, P.L., Fan, J.-X., 2013. The ICS International Chronostratigraphic Chart. Episodes 36, 199-204.

Cooper, M.A., Addison, F.T., Alvarez, R., Coral, M., Graham, R.H., Hayward, A.B., Howe, S., Martinez, J., Naar, J., Peñas, R., Pulham, A.J., Taborda, A., 1995. Basin Development and Tectonic History of the Llanos Basin, Eastern Cordillera, and Middle Magdalena Valley, Colombia. Am. Assoc. Pet. Geol. Bull. 79, 1421-1443.

Cordani, U., Cardona, A., Jiménez, D.M., Liu, D., Nutman, A., 2005. Geochronology of Proterozoic basement inliers in the Colombian Andes: tectonic history of remnants of a fragmented Grenville belt. Geol. Soc. London, Spec. Publ. 246, 329-346. doi:10.1144/GSL.SP.2005.246.01.13

Corfu, F., Hanchar, J.M., Hoskin, P.W.O., Kinny, P., 2003. Atlas of Zircon Textures. Rev. Mineral. Geochemistry 53, 469-500. doi:10.2113/0530469

De Arellano, C.R., Putlitz, B., Müntener, O., Ovtcharova, M., 2012. High precision $\mathrm{U} / \mathrm{Pb}$ zircon dating of the Chaltén Plutonic Complex (Cerro Fitz Roy, Patagonia) and its relationship to arc migration in the southernmost Andes. Tectonics 31. doi:10.1029/2011TC003048

Defant, M.J., Drummond, M.S., 1990. Derivation of some moder arc magmas by melting young subducted lithosphere. Nature 347, 662-665.

Dorr, W., Grosser, J.R., Rodriguez, G.I., Kramm, U., 1995. Zircon U-Pb age of the Paramo Rico tonalite-granodiorite, Santander Massif (Cordillera Oriental, Colombia) and its geotectonic significance. J. South Am. Earth Sci. 8, 187194.

Ducea, M.N., Paterson, S.R., DeCelles, P.G., 2015. High-volume magmatic events in subduction systems. Elements 11, 99-104. doi:10.2113/gselements.11.2.99

Elhlou, S., Belousova, E.A., Griffin, W.L., Pearson, N.J., O'Reilly, S.Y., 2006. Trace element and isotopic composition of GJ-red zircon standard by laser ablation. Geochim. Cosmochim. Acta 70, A158. doi:10.1016/j.gca.2006.06.1383

Elliott, T., Plank, T., Zindler, A., White, W., Bourdon, B., 1997. Element transport 
from slab to volcanic front at the Mariana arc. J. Geophys. Res. 102, 14991. doi:10.1029/97JB00788

Feininger, T., Barrero, D., Castro, N., 1972. Geologica de parte de los Departamentos de Antioquia y Caldas (Subzona II-B). Boletín Geológico XX, 173.

Frost, B.R., Barnes, C.G., Collins, W.J., Arculus, R.J., Ellis, D.J., Frost, C.D., 2001. A geochemical classification for granitic rocks. J. Petrol. 42, 2033-2048. doi:10.1093/petrology/42.11.2033

Frost, B.R., Frost, C.D., 2008. A Geochemical Classification for Feldspathic Igneous Rocks. J. Petrol. 49, 1955-1969. doi:10.1093/petrology/egn054

García-Chinchilla, D., Vlach, S.R.F., n.d. Mineral chemistry of Jurassic calcalkaline plutons in the North Andes: Considerations of intensive parameters of granites and related rocks of the Garzón Massif, Eastern Cordillera of Colombia.

García-Chinchilla, D., Vlach, S.R.F., Giraldo-Arroyave, M.I., n.d. Geological Mapping of Intrusive Rocks: A Case of Study in the Garzón region, Eastern Cordillera of Colombian Andes.

Gerdes, A., Zeh, A., 2009. Zircon formation versus zircon alteration - New insights from combined $\mathrm{U}-\mathrm{Pb}$ and $\mathrm{Lu}-\mathrm{Hf}$ in-situ LA-ICP-MS analyses, and consequences for the interpretation of Archean zircon from the Central Zone of the Limpopo Belt. Chem. Geol. 261, 230-243. doi:10.1016/j.chemgeo.2008.03.005

Goldsmith, R., Marvin, R.F., Mehert, H.H., 1971. Radiometric ages in the Santander massif, Eastern Cordillera, Colombian Andes, in: Geological Survey Research 1971, Chapter D. United States Government Printing Office, Washington, p. 44.

Grosse, E., 1930. Informe geológico preliminar sobre un viaje al Huila y al Alto Caquetá. INGEOMINAS. Informe 133. Bogotá.

Harris, N.B.W., Pearce, J.A., Tindle, A.G., 1986. Geochemical characteristics of collision-zone magmatism, in: Geological Society, Special Publication No. 19. Collision Tectonics. pp. 67-81.

Hawkesworth, C.J., Kemp, a. I.S., 2006. Using hafnium and oxygen isotopes in zircons to unravel the record of crustal evolution. Chem. Geol. 226, 144-162. doi:10.1016/j.chemgeo.2005.09.018

Hawkesworth, C.J., Turner, S.P., McDermott, F., Peate, D.W., van Calsteren, P., 1997. U-Th Isotopes in Arc Magmas: Implications for Element Transfer from the Subducted Crust. Science (80-. ). 276, 551-555. doi:10.1126/science.276.5312.551

Ibanez-Mejia, M., Ruiz, J., Valencia, V. a., Cardona, A., Gehrels, G.E., Mora, A.R., 2011. The Putumayo Orogen of Amazonia and its implications for Rodinia reconstructions: New $\mathrm{U}-\mathrm{Pb}$ geochronological insights into the Proterozoic tectonic evolution of northwestern South America. Precambrian Res. 191, 58- 
77. doi:10.1016/j.precamres.2011.09.005

Irvine, T.N., Baragar, W.R.A., 1971. A Guide to the Chemical Classification of the Common Volcanic Rocks. Can. J. Earth Sci. 8, 523-548.

Jaillard, E., Solerl, P., Carlier, G., Mourier, T., 1990. Geodynamic evolution of the northern and central Andes during early to. J. Geol. Soc. London. 147, 10091022.

Jiménez Mejía, D.M., Juliani, C., Cordani, U.G., 2006. P-T-t conditions of highgrade metamorphic rocks of the Garzon Massif, Andean basement, SE Colombia. J. South Am. Earth Sci. 21, 322-336. doi:10.1016/j.jsames.2006.07.001

Kay, M.S., Mpodozis, C., 2002. Magmatism as a probe to the Neogene shallowing of the Nazca plate beneath the modern Chilean flat-slabs. J. South Am. Earth Sci. 15, 39-57. doi:10.1016/S0895-9811(02)00005-6

Kay, S.M., Godoy, E., Kurtz, A., 2005. Episodic arc migration, crustal thickening, subduction erosion, and magmatism in the south-central Andes. Bull. Geol. Soc. Am. 117, 67-88. doi:10.1130/B25431.1

Kay, S.M., Mpodozis, C., Gardeweg, M., 2014. Magma sources and tectonic setting of Central Andean andesites $\left(25.5-28^{\circ} \mathrm{S}\right)$ related to crustal thickening, forearc subduction erosion and delamination. Geol. Soc. London, Spec. Publ. 385, 303-334. doi:10.1144/SP385.11

Kemp, A.I.S., Hawkesworth, C.J., Collins, W.J., Gray, C.M., Blevin, P.L., 2009. Isotopic evidence for rapid continental growth in an extensional accretionary orogen: The Tasmanides, eastern Australia. Earth Planet. Sci. Lett. 284, 455-466. doi:10.1016/j.epsl.2009.05.011

Kilpatrick, J. a., Ellis, D.J., 2011. C-type magmas: igneous charnockites and their extrusive equivalents. Trans. R. Soc. Edinb. Earth Sci. 83, 155-164. doi:10.1017/S0263593300007847

Kinny, P.D., Maas, R., 2003. Lu-Hf and Sm-Nd isotope systems in zircon. Rev. Mineral. Geochemistry 53, 327-341. doi:10.2113/0530327

Leal-Mejía, H., 2011. Phanerozoic Gold Metallogeny in the Colombian Andes: A Tectono-Magmatic Approach. Tesis Dr. Universitat de Barcelona.

Liu, Y.S., Hu, Z.C., Zong, K.Q., Gao, C.G., Gao, S., Xu, J., Chen, H.H., 2010. Reappraisement and refinement of zircon $\mathrm{U}-\mathrm{Pb}$ isotope and trace element analyses by LA-ICP-MS. Chinese Sci. Bull. 55, 1535-1546. doi:10.1007/s11434-010-3052-4

Ludwig, K.R., 2008. User 's Manual for Isoplot 3.70. Isoplot 3.70: A Geochronological Toolkit for Microsoft Excel. Berkeley Geochronol. Cent. Spec. Publ. 76.

Mamani, M., Wörner, G., Sempere, T., 2010. Geochemical variations in igneous rocks of the Central Andean orocline $\left(13^{\circ} \mathrm{S}\right.$ to $\left.18^{\circ} \mathrm{S}\right)$ : Tracing crustal thickening and magma generation through time and space. Bull. Geol. Soc. Am. 122, 162-182. doi:10.1130/B26538.1 
Mantilla Figueroa, L.C., Bissig, T., Cottle, J.M., Hart, C.J.R., 2012. Remains of early Ordovician mantle-derived magmatism in the Santander Massif (Colombian Eastern Cordillera). J. South Am. Earth Sci. 38, 1-12. doi:10.1016/j.jsames.2012.03.001

Mantilla Figueroa, L.C., Bissig, T., Valencia, V., Hart, C.J.R., 2013. The magmatic history of the Vetas-California mining district, Santander Massif, Eastern Cordillera, Colombia. J. South Am. Earth Sci. 45, 235-249. doi:10.1016/j.jsames.2013.03.006

Marquínez, G., Velandia, F.P., 2001. Mapa Geológico del Departamento del Huila. Escala 1:300.000. INGEOMINAS. Bogotá D. C.

Martens, U., Restrepo, J.J., Ordóñez-Carmona, O., Correa-Martínez, A.M., 2014. The Tahamí and Anacona Terranes of the Colombian Andes: Missing Links between the South American and Mexican Gondwana Margins. J. Geol. 122, 507-530. doi:10.1086/677177

McCourt, W.J., Aspden, J.A., Brook, M., 1984. New geological and geochronological data from the Colombian Andes: continental growth by multiple accretion. J. Geol. Soc. London. 141, 831-845.

McDonough, W.F., Sun, S. -s., 1995. The composition of the Earth. Chem. Geol. 120, 223-253.

Meschede, M., Frisch, W., 1998. A plate-tectonic model for the Mesozoic and Early Cenozoic history of the Caribbean plate. Tectonophysics 296, 269-291.

Mojica, J., Villarroel, C., Bayer, K., 1988a. 4. Afloramientos del Paleozoico Superior en el Macizo de Garzón (Cordillera Oriental) y el Valle Superior del Magdalena, Colombia. Geol. Colomb. 16, 99-104.

Mojica, J., Villarroel, C., Macia, C., 1988b. 3. Nuevos afloramientos fosilíferos del Ordovícico Medio (Fm. El Hígado) al oeste de Tarqui, Valle Superior del Magdalena (Huila, Colombia). Geol. Colomb. 16, 95-97.

Molina, A.C., Cordani, U.G., MacDonald, W.D., 2006. Tectonic correlations of preMesozoic crust from the northern termination of the Colombian Andes, Caribbean region. J. South Am. Earth Sci. 21, 337-354. doi:10.1016/j.jsames.2006.07.009

Montes, C., Guzman, G., Bayona, G., Cardona, A., Valencia, V., Jaramillo, C., 2010. Clockwise rotation of the Santa Marta massif and simultaneous Paleogene to Neogene deformation of the Plato-San Jorge and CesarRanchería basins. J. South Am. Earth Sci. 29, 832-848. doi:10.1016/j.jsames.2009.07.010

Mora, C.A.S., Campos Neto, M.C., Basei, M.A.S., 2014. Syn-collisional lower continental crust anatexis in the Neoproterozoic Socorro-Guaxupé Nappe System, southern Brasília Orogen, Brazil: Constraints from zircon U-Pb dating, $\mathrm{Sr}-\mathrm{Nd}-\mathrm{Hf}$ signatures and whole-rock geochemistry. Precambrian Res. 255, 847-864. doi:10.1016/j.precamres.2014.10.017

Morales, C.J., Caicedo, J.C., Velandia, F.A., Núñez, A., 2001. Geología de la 
Plancha 345 Campoalegre. Escala 1:100.000. Memoria Explicativa. INGEOMINAS. Bogotá D. C.

Moreno-Sánchez, M., Gómez-Cruz, A. de J., Castillo-González, H., 2008. Graptolitos del Ordovícico y Geología de los afloramientos del Río Venado (norte del Departamento del Huila). Bol. Geol. 30, 9-19.

Mori, P.E., Reeves, S., Correia, C.T., Haukka, M., 1999. Development of a fused glass disc XFR facility and comparision with the pressed powder pellet technique at Instituto de Geociências, São Paulo University. Rev. Bras. Geociências 29, 441-446.

Nakamura, N., 1974. Determination of REE, Ba, $\mathrm{Fe}, \mathrm{Mg}, \mathrm{Na}$ and $\mathrm{K}$ in carbonaceous and ordinary chondrites. Geochim. Cosmochim. Acta 38, 757775.

Navarro, M.S., 2004. A implantação de rotina, e seu refinamento, para a determinação de elementos terras raras em materiais geológicos por ICPOES e ICP-MS. Aplicação ao caso dos granitóides de Piedade-lbiúna (SP) e Cunhaporanga (PR). Universidade de São Paulo. Instituto de Geociências.

Navarro, M.S., Andrade, S., Ulbrich, H., Gomes, C.B., Girardi, V. a V, 2008. The direct determination of rare earth elements in basaltic and related rocks using ICP-MS: Testing the efficiency of microwave oven sample decomposition procedures. Geostand. Geoanalytical Res. 32, 167-180. doi:10.1111/j.1751908X.2008.00840.X

Nédélec, A., Bouchez, J.-L., 2015. Granites. Petrology, Structure, Geological Setting, and Metallogeny, English Tr. ed. Oxford University Press, New York.

Nivia, A., 1997. Una Comparación de la Tectónica de Basamento de las Cordilleras Central y Oriental: Comentario. Geol. Colomb. 22, 199-200.

Noble, S.R., Aspden, J.A., Jemielita, R., 1997. Northern Andean crustal evolution: New U-Pb geochronological constraints from Ecuador. Geol. Soc. Am. Bull. 109, 789-798.

Núñez, A., 2003. Reconocimiento geológico regional de las planchas 411 La Cruz, 412 San Juan de Villalobos, 430 Mocoa, 431 Piamonte, 448 Monopamba, 449 Orito y 465 Churuyaco. Departamentos de Caquetá, Cauca, Huila, Nariño y Putumayo. Escala 1:100.000. INGEOMINAS. Memoria . Bogotá D. C. doi:10.1024/0301-1526.32.1.54

Núñez, A., Gómez, J., 2002a. Geologia de la Plancha 430 Mocoa. Mapa Geológico. Escala 1:100.000. INGEOMINAS, 2002. Bogotá D. C.

Núñez, A., Gómez, J., 2002b. Gelogía de la Plancha 412 San Juan de Villalobos. Mapa Geológico. Escala 1:100.000. INGEOMINAS. Bogotá D. C.

Ordóñez-Carmona, O., Restrepo Álvarez, J.J., Pimentel, M.M., 2006. Geochronological and isotopical review of pre-Devonian crustal basement of the Colombian Andes. J. South Am. Earth Sci. 21, 372-382. doi:10.1016/j.jsames.2006.07.005

Pearce, J.A., Harris, N.B.W., Tindle, A.G., 1984. Trace Element Discrimination 
Diagrams for the Tectonic Interpretation of Granitic Rocks. J. Petrol. 25, 956983.

Peccerillo, A., Taylor, S.R., 1976. Contributions to Mineralogy and Geochemistry of Eocene Calc-Alkaline Volcanic Rocks from the Kastamonu Area, Northern Turkey. Contrib. to Mineral. Petrol. 58, 63-81.

Percival, J.A., Mortensen, J.K., 2002. Water-deficient Calc-alkaline Plutonic Rocks of Northeastern Superior Province, Canada: Significance of Charnockitic Magmatism. J. Petrol. 43, 1617-1650.

Pindell, J., Dewey, J.F., 1982. Permo-Triassic reconstruction of Western Pangea and the Evolution of the Gulf of Mexico/Caribbean Region. Tectonics 1, 179211.

Pindell, J., Kennan, L., Maresch, W. V., Stanek, K.-P., Draper, G., Higgs, R., 2005. Plate-kinematics and crustal dynamics of circum-Caribbean arc-continent interactions: Tectonic controls on basin development in Proto-Caribbean margins, in: Lallemant, H.G.A., Sisson, V.B. (Eds.), Caribbean-South American Plate Interations, Venezuela. The Geological Society of America. Special Papers 394., Boulder, Colorado, pp. 7-52.

Pindell, J.L., Kennan, L., 2009. Tectonic evolution of the Gulf of Mexico, Caribbean and northern South America in the mantle reference frame: an update. Geol. Soc. London, Spec. Publ. 328, 1-55. doi:10.1144/SP328.1

Pindell, J.L., Kennan, L., Stanek, K.P., Maresch, W. V., Draper, G., 2006. Foundations of Gulf of Mexico and Caribbean evolution: eight controversies resolved. Geol. Acta 4, 303-341.

Plank, T., Langmuir, C.H., 1993. Tracing trace elements from sediment input to volcanic output at subduction zones. Nature 362, 739-743.

Radelli, L., 1962b. Les formations eruptives Hercyniennes de la Cordillere Orientala de Colombie (Sud Am.). Geol. Colomb. 3, 99-124.

Radelli, L., 1962c. Introducción al estudio de la petrografía del Macizo de Garzón (Huila-Colombia). Geol. Colomb. 3, 17-45.

Radelli, L., 1962a. Un cuadro preliminar de las épocas magmáticas y metalogégicas de los Andes Colombianos. Geol. Colomb. 3, 87-97.

Roberts, M.P., Finger, F., 1997. Do U-Pb zircon ages from granulites reflect peak metamorphic conditions? Geology 25, 319-322. doi:10.1130/00917613(1997)025<0319:DUPZAF>2.3.CO;2

Rodríguez, G., Arango, M.I., Zapata, G., Bermúdez, J.G., 2018. Petrotectonic characteristics, geochemistry, and U-Pb geochronology of Jurassic plutons in the Upper Magdalena Valley-Colombia: Implications on the evolution of magmatic arcs in the NW Andes. J. South Am. Earth Sci. 81, 10-30. doi:10.1016/j.jsames.2017.10.012

Rodríguez, G., Ferreira, P., Velandia, F., Núñez, A., 1998. Geología de la Plancha 366 Garzón. Mapa Geológico. Escala 1:100.000. INGEOMINAS. Bogotá D. C.

Rodríguez, G., Zapata, G., Velazquez, M., 2003a. Geología de la Plancha 389 
Timaná. Mapa Geológico. Escala 1:100.000. INGEOMINAS. Medellín, Colombia.

Rodríguez, G., Zapata, G., Velazquez, M., 2003b. Geologia de la Plancha 367 Gigante. Mapa Geológico. Escala 1:100.000. INGEOMINAS. Bogotá D. C.

Ross, M.I., Scotese, C.R., 1988. A hierarchical tectonic model of the Gulf of Mexico and Caribbean region. Tectonophysics 155, 139-168.

Saleeby, J., 2003. Production and loss of high-density batholithic root, southern Sierra Nevada, California. Tectonics 22, 89-92. doi:10.1029/2002TC001374

Sarmiento-Rojas, L.F., Van Wess, J.D., Cloetingh, S., 2006. Mesozoic transtensional basin history of the Eastern Cordillera, Colombian Andes: Inferences from tectonic models. J. South Am. Earth Sci. 21, 383-411. doi:10.1016/j.jsames.2006.07.003

Sato, K., Basei, M.A.S., Sproesser, W.M., Siga, O.J., 2012. The application of U$\mathrm{Pb}$ Geochronology to zircon and titanite by Laser Ablation-ICP-MS. 8th Int. Conf. Anal. Geol. Environ. Mater.

Sato, K., Siga, O., Da Silva, J.A., Mcreath, I., Dunyi, L., lizuka, T., Rino, S., Hirata, T., Sproesser, W., Basei, M.A., 2009. In Situ Isotopic Analyses of U and Pb in Zircon by Remotely Operated SHRIMP II , and Hf by LA-ICP-MS : an Example of Dating and Genetic Evolution of Zircon by $176 \mathrm{Hf} / 177 \mathrm{Hf}$ from the Ita Quarry in the Atuba Complex, SE Brazil. Geol. USP 9, 61-69.

Sillitoe, R.H., Jaramillo, L., Damon, P.E., Shafiqullah, M., Escovar, R., 1982. Setting, characteristics, and age of the Andean porphyry copper belt in Colombia. Econ. Geol. 77, 1837-1850.

Söderlund, U., Patchett, P.J., Vervoort, J.D., Isachsen, C.E., 2004. The 176Lu decay constant determined by $\mathrm{Lu}-\mathrm{Hf}$ and $\mathrm{U}-\mathrm{Pb}$ isotope systematics of Precambrian mafic intrusions. Earth Planet. Sci. Lett. 219, 311-324. doi:10.1016/S0012-821X(04)00012-3

Spikings, R., Cochrane, R., Villagomez, D., Van der Lelij, R., Vallejo, C., Winkler, W., Beate, B., 2015. The geological history of northwestern South America: From Pangaea to the early collision of the Caribbean Large Igneous Province (290-75Ma). Gondwana Res. 27, 95-139. doi:10.1016/j.gr.2014.06.004

Stacey, J.S., Kramers, J.D., 1975. Approximation of terrestrial lead isotope evolution by a two-stage model. Earth Planet. Sci. Lett. 26, 207-221. doi:10.1016/0012-821X(75)90088-6

Stern, C.R., 2011. Subduction erosion: Rates, mechanisms, and its role in arc magmatism and the evolution of the continental crust and mantle. Gondwana Res. 20, 284-308. doi:10.1016/j.gr.2011.03.006

Stern, C.R., Kilian, R., 1996. Role of the subducted slab, mantle wedge and continental crust in the generation of adakites from the Andean Austral Volcanic Zone. Contrib. to Mineral. Petrol. 123, 263-281. doi:10.1007/s004100050155

Streckeisen, A., 1976. To each plutonic rock its proper name. Earth-Science Rev. 
12, 1-33. doi:10.1016/0012-8252(76)90052-0

Sun, S. -s., McDonough, W.F., 1989. Chemical and isotopic systematics of oceanic basalts: implications for mantle composition and processes, in: Saunders, A.D., Norry, M.J. (Eds.), Magmatism in the Ocean Basins. pp. 313-345.

Trumbull, R.B., Wittenbrink, R., Hahne, K., Emmermann, R., Büsch, W., Gerstenberger, H., Siebel, W., 1999. Evidence for late Miocene to recent contamination of arc andesites by crustal melts in the Chilean Andes (25$26^{\circ} \mathrm{S}$ ) and its geodynamic implications. J. South Am. Earth Sci. 12, 135-155. doi:10.1016/S0895-9811(99)00011-5

Tschanz, C.M., Marvin, R.F., Cruz B., J., Mehnert, H.H., Cebula, G.T., 1974. Geologic evolution of the Sierra Nevada de Santa Marta, northeastern Colombia. Geol. Soc. Am. Bull. 85, 273-284. doi:10.1130/00167606(1974) $85<273$

van der Lelij, R., Spikings, R., Ulianov, A., Chiaradia, M., Mora, A., 2016. Palaeozoic to Early Jurassic history of the northwestern corner of Gondwana, and implications for the evolution of the lapetus, Rheic and Pacific Oceans. Gondwana Res. 31, 271-294. doi:10.1016/j.gr.2015.01.011

Velandia, F., Morales A., C.J., Caicedo A., J.C., Núñez, A., 1999. Geología de la Plancha 345 Campoalegre. Mapa Geológico. Escala 1:100.000. INGEOMINAS. Bogotá D. C.

Velandia, F.P., Ferreira, P. V., Rodríguez, G., Núñez, A., 2001. Leavantamiento geológico de la Plancha 366 Garzón. Escala 1:100.000. INGEOMINAS. Bogotá D. C.

Vervoort, J.D., Blichert-Toft, J., 1999. Evolution of the depleted mantle: Hf isotope evidence from juvenile rocks through time. Geochim. Cosmochim. Acta 63, 533-556. doi:10.1016/S0016-7037(98)00274-9

Vervoort, J.D., Patchett, P.J., 1996. Behavior of hafnium and neodymium isotopes in the crust: Constraints from Precambrian crustally derived granites. Geochim. Cosmochim. Acta 60, 3717-3733. doi:10.1016/00167037(96)00201-3

Vervoort, J.D., Patchett, P.J., Albarède, F., Blichert-Toft, J., Rudnick, R., Downes, H., 2000. Hf-Nd isotopic evolution of the lower crust. Earth Planet. Sci. Lett. 181, 115-129. doi:10.1016/S0012-821X(00)00170-9

Villagómez, D., Spikings, R., Magna, T., Kammer, A., Winkler, W., Beltrán, A., 2011. Geochronology, geochemistry and tectonic evolution of the Western and Central cordilleras of Colombia. Lithos 125, 875-896. doi:10.1016/j.lithos.2011.05.003

Villarroel, C., Macia, C., Brieva, J., 1997. Formación Venado, Nueva Unidad Litoestratliqráfica del Ordovícico Colombiano. Geol. Colomb. 22, 41-49.

Vinasco, C.J., Cordani, U.G., González, H., Weber, M., Pelaez, C., 2006. Geochronological, isotopic, and geochemical data from Permo-Triassic granitic gneisses and granitoids of the Colombian Central Andes. J. South Am. 
Earth Sci. 21, 355-371. doi:10.1016/j.jsames.2006.07.007

von Huene, R., Ranero, C.R., Vannucchi, P., 2004. Generic model of subduction erosion. Geology 32, 913-916. doi:10.1130/G20563.1

Whitney, D.L., Evans, B.W., 2010. Abbreviations for names of rock-forming minerals. Am. Mineral. 95, 185-187. doi:10.2138/am.2010.3371

Woodhead, J.D., Hergt, J.M., 2005. A preliminary appraisal of seven natural zircon reference materials for in situ $\mathrm{Hf}$ isotope determination. Geostand. Geoanalytical Res. 29, 183-195. doi:10.1111/j.1751-908X.2005.tb00891.x

Young, D.N., Zhao, J., Ellis, D.J., McCulloch, M.T., 1997. Geochemical and Sr-Nd isotopic mapping of source provinces for the Mawson charnockites, east Antarctica: implications for Proterozoic tectonics and Gondwana reconstruction. Precambrian Res. 86, 1-19. doi:10.1016/S03019268(97)00030-2

Zapata, S., Cardona, A., Jaramillo, C., Valencia, V., Vervoort, J., 2016. U-Pb LAICP-MS geochronology and geochemistry of jurassic volcanic and plutonic rocks from the Putumayo region (southern Colombia): Tectonic setting and regional correlations. Bol. Geol. 38, 21-38. doi:10.18273/revbol.v38n22016001

Zhao, J., Ellis, D.J., Kilpatrick, J.A., McCulloch, M.T., 1997. Geochemical and Sr$\mathrm{Nd}$ isotopic study of charnockites and related rocks in the northern Prince Charles Mountains, East Antarctica: implications for charnockite petrogenesis and proterozoic crustal evolution. Precambrian Res. 81, 37-66. doi:http://dx.doi.org/10.1016/S0301-9268(96)00022-8 


\section{FIGURE CAPTIONS}

Fig. 1. (a) Northwestern of South America, Central America and Caribbean showing Colombia and its internal division in Departments. (b) Digital elevation model showing the Colombian Andes (Western, Central and Eastern Cordilleras) and the local of the three igneous massifs studied. (c) Igneous facies map of Algeciras and (d) Altamira. Modified of García-Chinchilla et al. (submitted).

Fig. 2. (a) Digital elevation model of Colombia with intrusive rocks differentiated by age. (b) Simplified geological map of Garzón region shows the sample localization in Algeciras, Altamira and Sombrerillo plutonic massifs.

Fig. 3. (a) Modal Quartz-Alkali feldspar-Plagioclase (Q-A-P) classification diagram (Streckeisen, 1976). In green: Algeciras. In blue: Altamira. In red: Sombrerillo. Arrow represent typical trend of high- $\mathrm{K}$ calc-alkaline rocks, associated to subduction in a continental margin according to (Nédélec and Bouchez, 2015).

Fig. 4. Photomicrographs of Garzón granites and related rocks. (a) Detail of clinopyroxene-orthopyroxene intergrowth from charnockite sample of Grenvillian basement (GAR-364). (b) Biotite quartz-monzodiorite with two pyroxenes (L102). (c) Detail of Augite core on hornblende of Bt-Hrn monzodiorite of Sombrerillo (d) Biotite-Hornblende intergrowth in a monzodiorite from Algeciras (GAR-356). (GAR-394). (e) Amphibole and plagioclase phenocryst on dacite of Sombrerillo (GAR-395). (f) Spherulitic quartz-alkali feldspar intergrowth of rhyolite sample of Algeciras (GAR-359). Mineral abbreviation according to Whitney and Evans (2010).

Fig. 5. Geochemical classification diagrams: (a) AFM diagram showing the more iron-rich chemistry of the quartz (Irvine and Baragar, 1971); (b) Plot of $\mathrm{Na}_{2} \mathrm{O}+\mathrm{K}_{2} \mathrm{O}-\mathrm{CaO}$ against $\mathrm{SiO}_{2}$, and (c) $\mathrm{FeOt} /(\mathrm{FeOt}+\mathrm{MgO})$ vs. $\mathrm{SiO}_{2}$ or $\mathrm{Fe}^{*}$ diagram, and (d) Plot of $\mathrm{A} / \mathrm{NK}$ $\left(\mathrm{Al}_{2} \mathrm{O}_{3} / \mathrm{Na}_{2} \mathrm{O}+\mathrm{K}_{2} \mathrm{O}\right)$ vs. Aluminum Saturation Index (ASI) the molecular ratio $\mathrm{Al} /(\mathrm{Ca}-$ 1.67P+Na+K) (Frost et al., 2001). In shades samples of other Jurassic to early Cretaceous rocks of Colombian Andes.

Fig. 6. Median MORB-normalized extended trace element patterns (Sun and McDonough, 1989) for (a) intrusive, and (b) subvolcanic rocks. Median chondrite-normalized rear-earth elements patterns (Nakamura, 1974) for (c) intrusive, and (d) subvolcanic rocks. Shadow 
samples of another Jurassic granitic and related rocks in Northern Andes. Symbols and shades are listed in Fig. $\mathbf{5}$.

Fig. 7. Zircon Scanning electron microscope Cathodoluminiscence images (CL) from zircon of: (a) charnockite from the basement, (b) Igneous plutonic rocks, (c) volcanic and subvolcanic rocks, and (d) Xenocryst zircons in volcanic rocks. Red circle: represent the spot of U-Pb age analyses. Blue circle: represent the spot of Lu-Hf isotope analyses. Each grain has the sample and point name, the individual $\mathrm{U}-\mathrm{Pb}$ age ( $1 \sigma$ erro), and $\varepsilon \mathrm{Hf}$ calculate for this age.

Fig. 8. Tera-Wasserburg diagrams of analyzed samples. Cyan ellipses: Concordia age calculated with isoplot 4.0; Red ellipses: data considered to the age calculated; Green ellipses: concordant data not consider to the calculated age (xenocrysts); Dark gray ellipses: data with $>10 \%$ discordance. Light gray ellipses: data with common $\mathrm{Pb}$ in excess (>6\%). Data-point error ellipses are $68.3 \%$ confiance.

Fig. 9. $\varepsilon \mathrm{Hf}(\mathrm{t})$ versus ${ }^{206} \mathrm{~Pb} / 208 \mathrm{U}$ age diagram of zircons from: (a) Basement (in purple); (b) Intrusive and volcanic to subvolcanic rocks. Green: Algeciras. Red: Sombrerillo. Blue: Altamira. For this plot $\varepsilon \mathrm{Hf}(\mathrm{t})$ is calculated for a fix ${ }^{206} \mathrm{~Pb} / 208 \mathrm{U}$ age (the average age of each sample). The variation with $\varepsilon \mathrm{Hf}(\mathrm{t})$ calculated for individual zircon ages is ca. \pm 0.05 to 0.5 Hf units.

Fig. 10. (a) Plot of wt $\% \mathrm{~K}_{2} \mathrm{O}$ vs. wt $\% \mathrm{SiO}_{2}$ with boundaries for low- $\mathrm{K}$, medium-K, high-K and Shoshonite Series (Peccerillo and Taylor, 1976). Subduction of crustal component or and melting percentage and differentiation trends are propose by Mamani et al. (2010) and Kay et al. (2014). Plots of (b) Ba/Th and (c) U/Th ratios versus Th abundances. Subduction fluid and sediment component trends suggest by Hawkesworth et al. (1997). (d) $\mathrm{Sm} / \mathrm{Yb}$ ratios versus wt \% $\mathrm{SiO} 2$ and (e) \% wt. Na2O versus La/Yb ratios. Garnet and plagioclase fractionation and differentiation trends are propose by Mamani et al. (2010) and Kay et al. (2014). (f) Sr/Y ratios versus $Y$ abundances whit Adakite and Island Arc Field propose by Defant and Drummond (1990). Symbols and shades are listed in Fig. 5.

Fig. 11. (a) Digital elevation model with intrusive rocks differentiated by age. Green triangles represent sample locations with zircon ${ }^{206} \mathrm{U} /{ }^{238} \mathrm{~Pb}$ ages from references. Blue circles represent locations of samples dated in this study. (b) Geological Map of Garzón. 
Numbers represent ${ }^{206} \mathrm{U} / 238 \mathrm{~Pb}$ ages and $\varepsilon \mathrm{Hf}$ calculated. Background text color match with color code of ICS International Chronostratigraphic Chart (Cohen et al., 2013).

Fig. 12. Synopsis illustrating the subduction evolution of Jurassic arc in Northwestern Andes. 


\section{FIGURES}

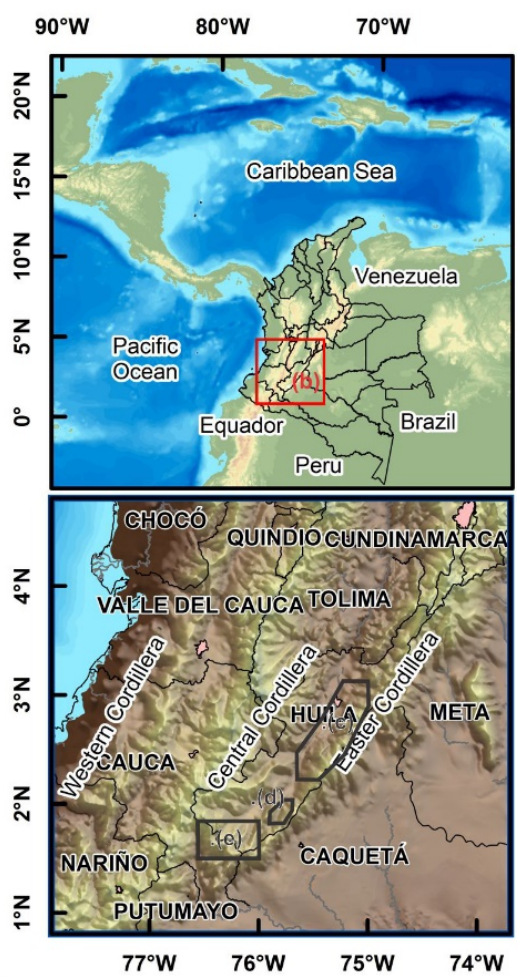

\section{Legend \\ A Geochronology Samples \\ - Lineament \\ $\ldots$ Inverse fault \\ — Strike-slip dextral fault \\ - River \\ Water Reservoir}

Intrusive and volcanic facies

Biotite hornblende monzogranite

Bt-Hrn monzogranite milonitic

Biotite monzogranite milonitic

Hornblende biotite granodiorite

Hornblende granodiorite

Hornblende monzogranite

Leuco-monzogranite

=:": Leuco-monzogranite mylonitic

Leuco-monzogranite with micro-

graphic texture

$\times \times$ Monzogranite

Rhyolitic porphyries

Volcano-clastic rocks: Saldaña Fm

$x \times$ Hornblenda quartzo-monzodiorite

\section{Regional Geologic Units}

Igneous and Metamorphic

Grenvillian Basement

Paleozoic sedimetary rocks

Cretaceous and Cenozoic

sedimetary rocks

Quaternary deposits

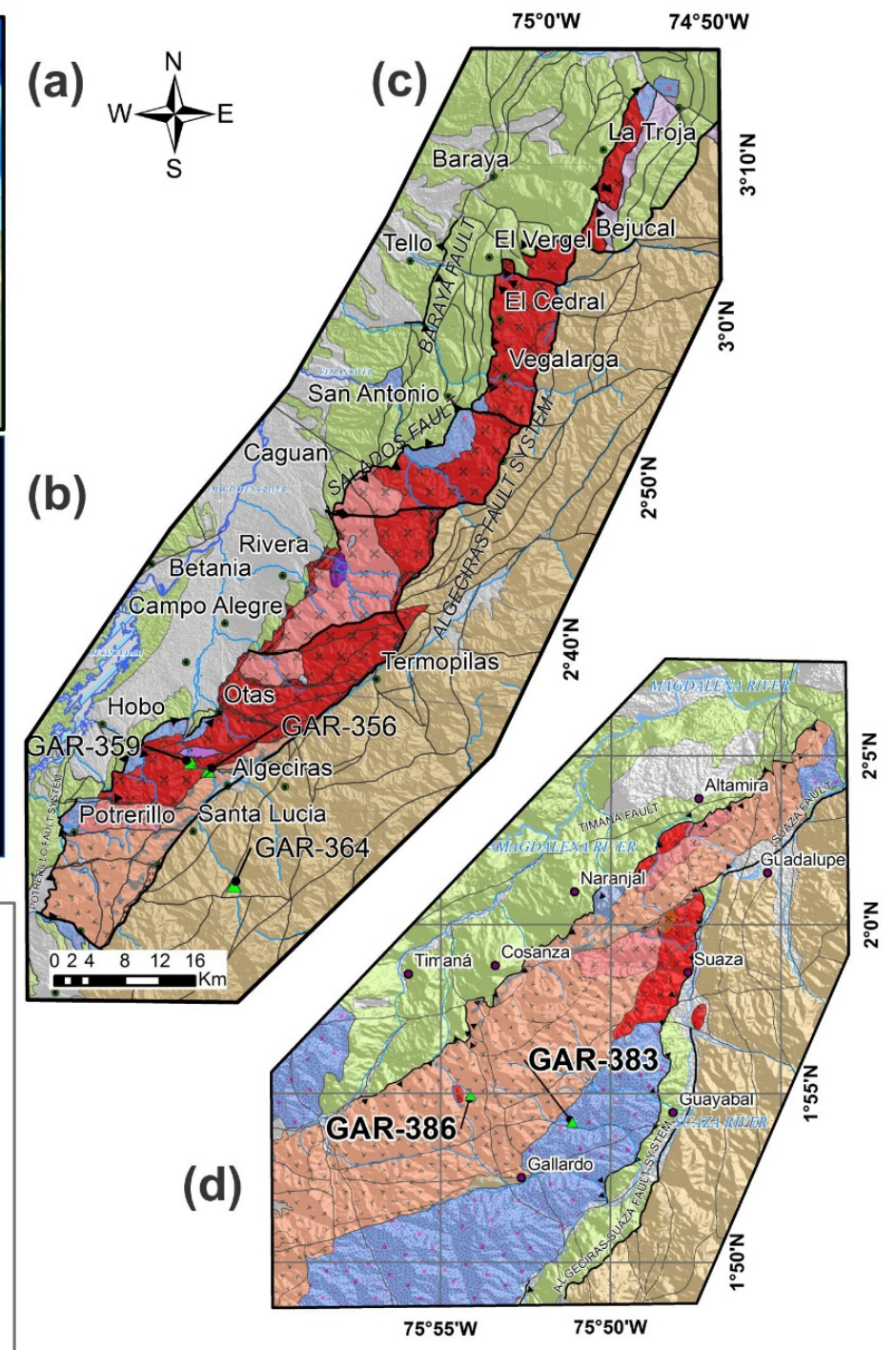

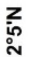

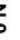

(e)

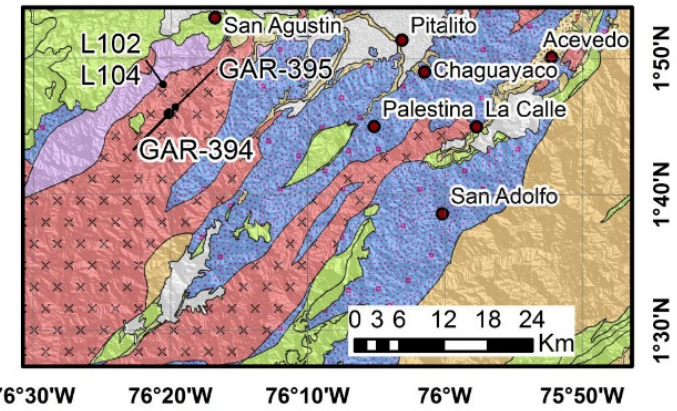

Fig. 1 


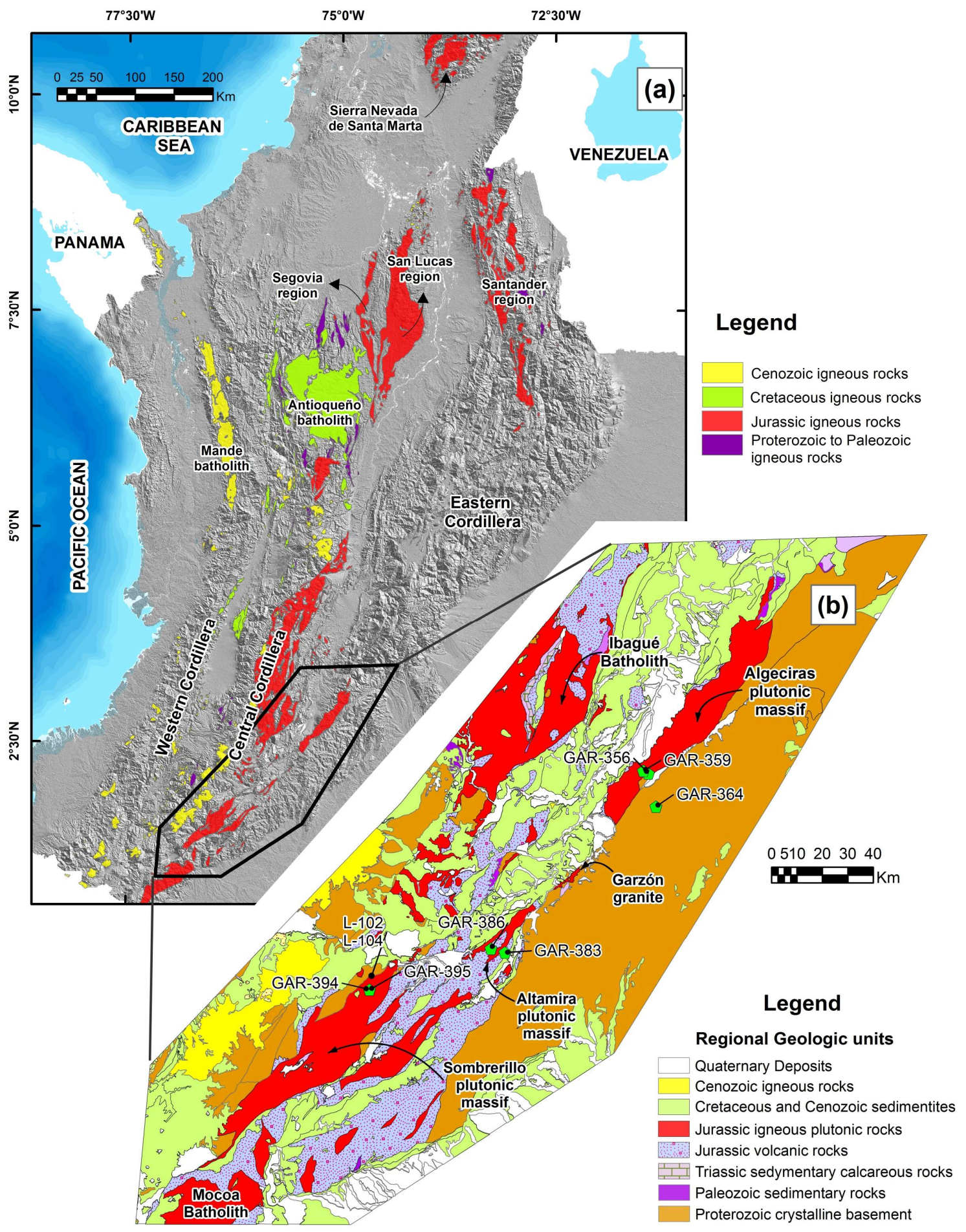

Fig. 2. 


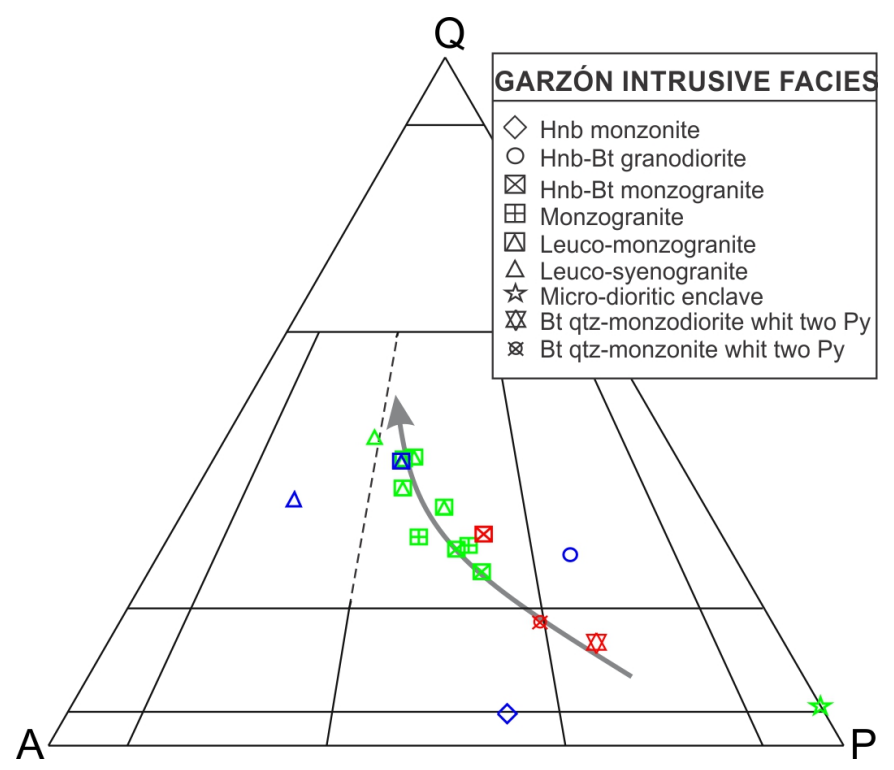

Fig. 3. 

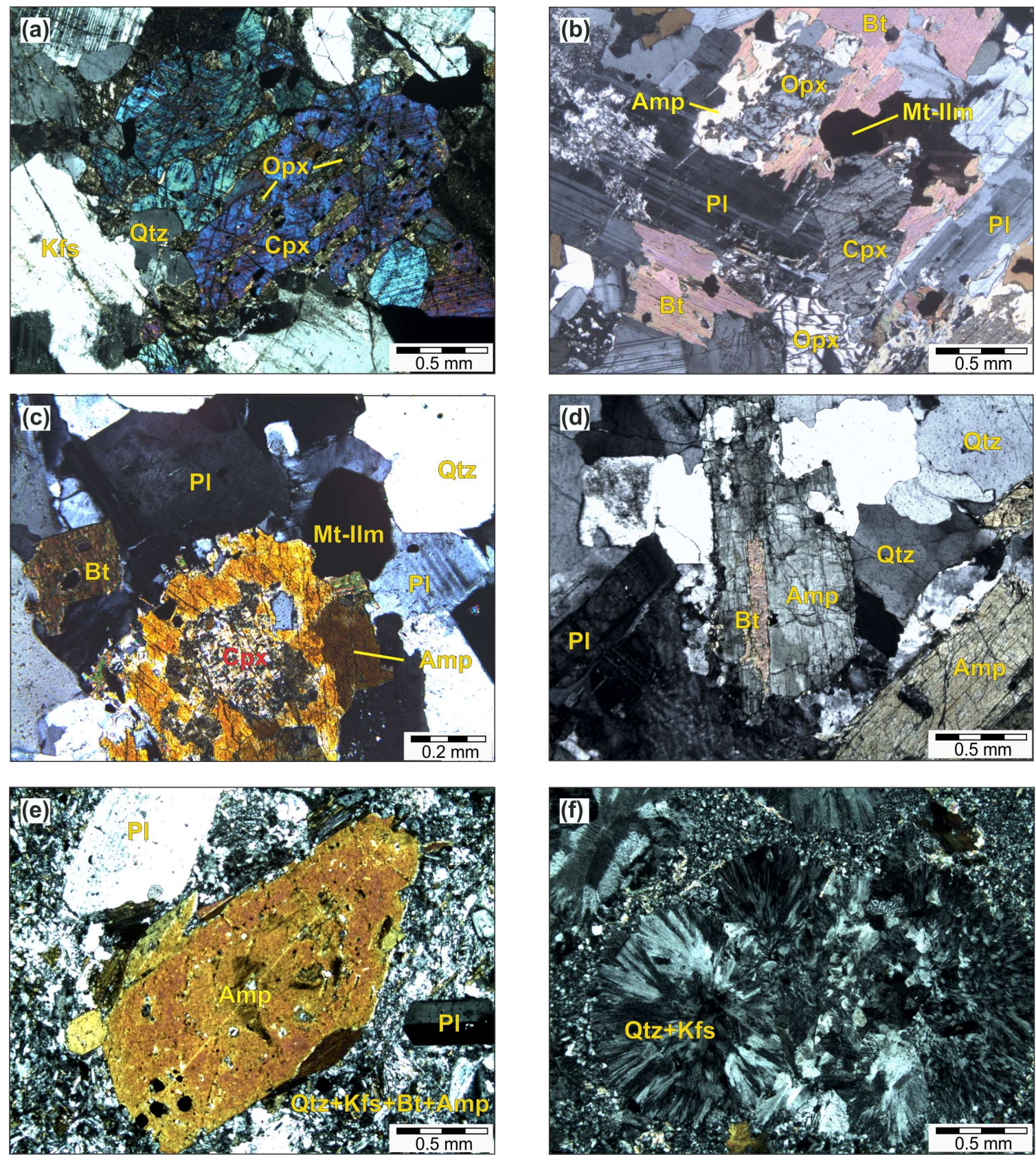

Fig. 4. 


\begin{tabular}{|c|l|l|}
\hline \multicolumn{1}{|c|}{ UNIT } & \multicolumn{1}{|c|}{ AGE } & \multicolumn{1}{c|}{ REFERENCE } \\
\hline $\begin{array}{l}\text { California-Vetas } \\
\text { (Santander region) }\end{array}$ & 211 to $197 \mathrm{Ma}$ & Mantilla Figueroa et al., (2013) \\
\hline$\therefore$ Santander granites & 202 to $196 \mathrm{Ma}$ & van der Leij et al. (2016) \\
\hline Mocoa Batholith & 186 to $181 \mathrm{Ma}$ & Zapata et al. (2016) \\
\hline Ibagué Batholith & 164 to $142 \mathrm{Ma}$ & $\begin{array}{l}\text { Cochrane, et al., (2014b); } \\
\text { Bustamante et al., (2016) }\end{array}$ \\
\hline Payandé Stock & 165 to $164 \mathrm{Ma}$ & Bustamante et al. (2016) \\
\hline Mariquita Stock & 143 to $130 \mathrm{Ma}$ & Bustamante et al. (2016) \\
\hline \\
$\begin{array}{l}\text { Intrusive facies } \\
\text { Volcanic and sub-volcanic facies }\end{array}$ \\
\hline
\end{tabular}

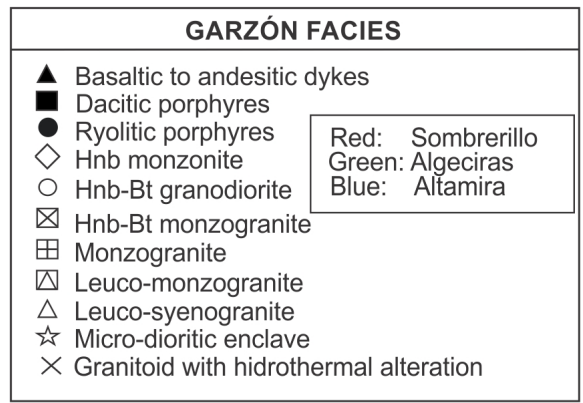
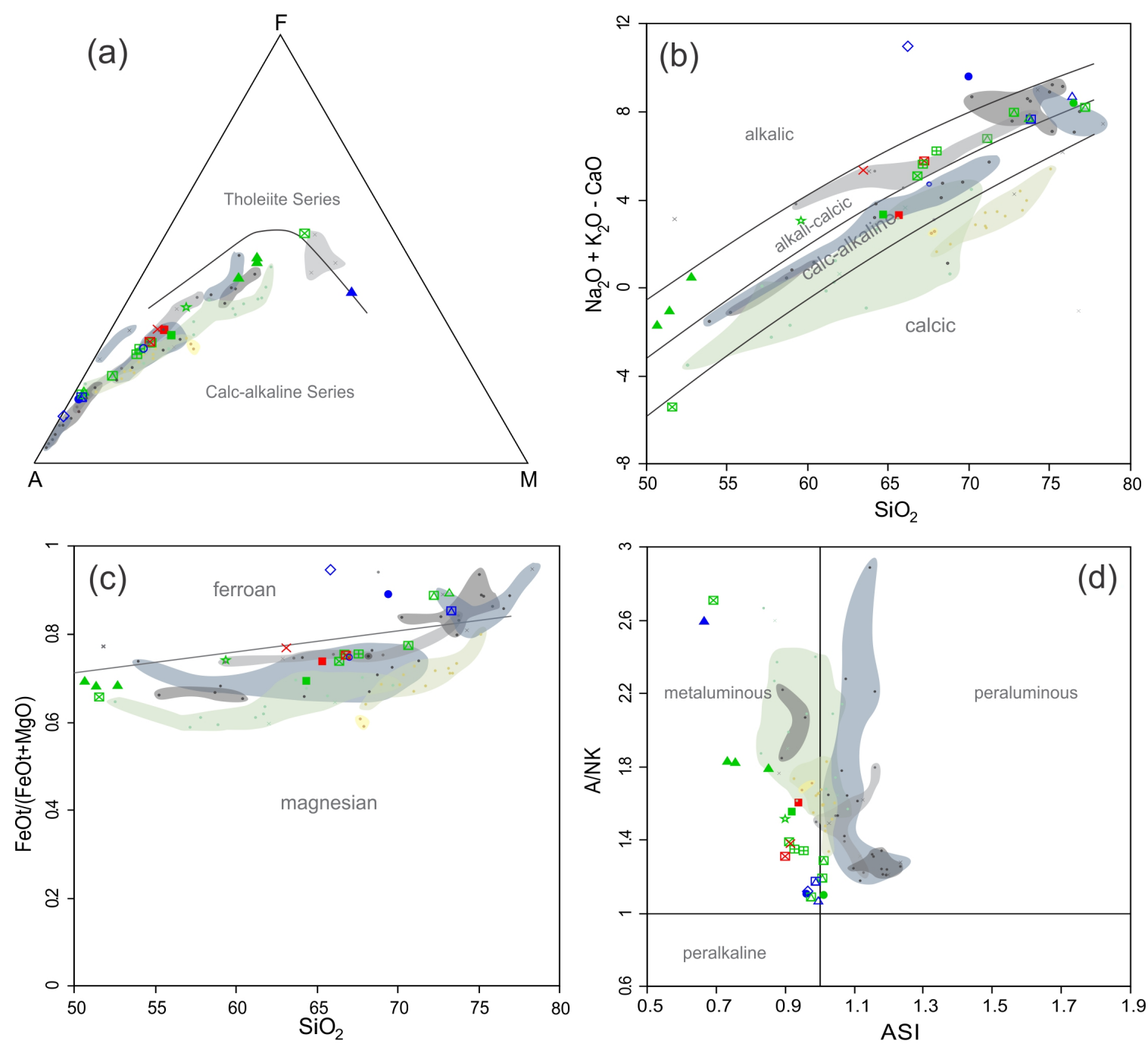

Fig. 5. 

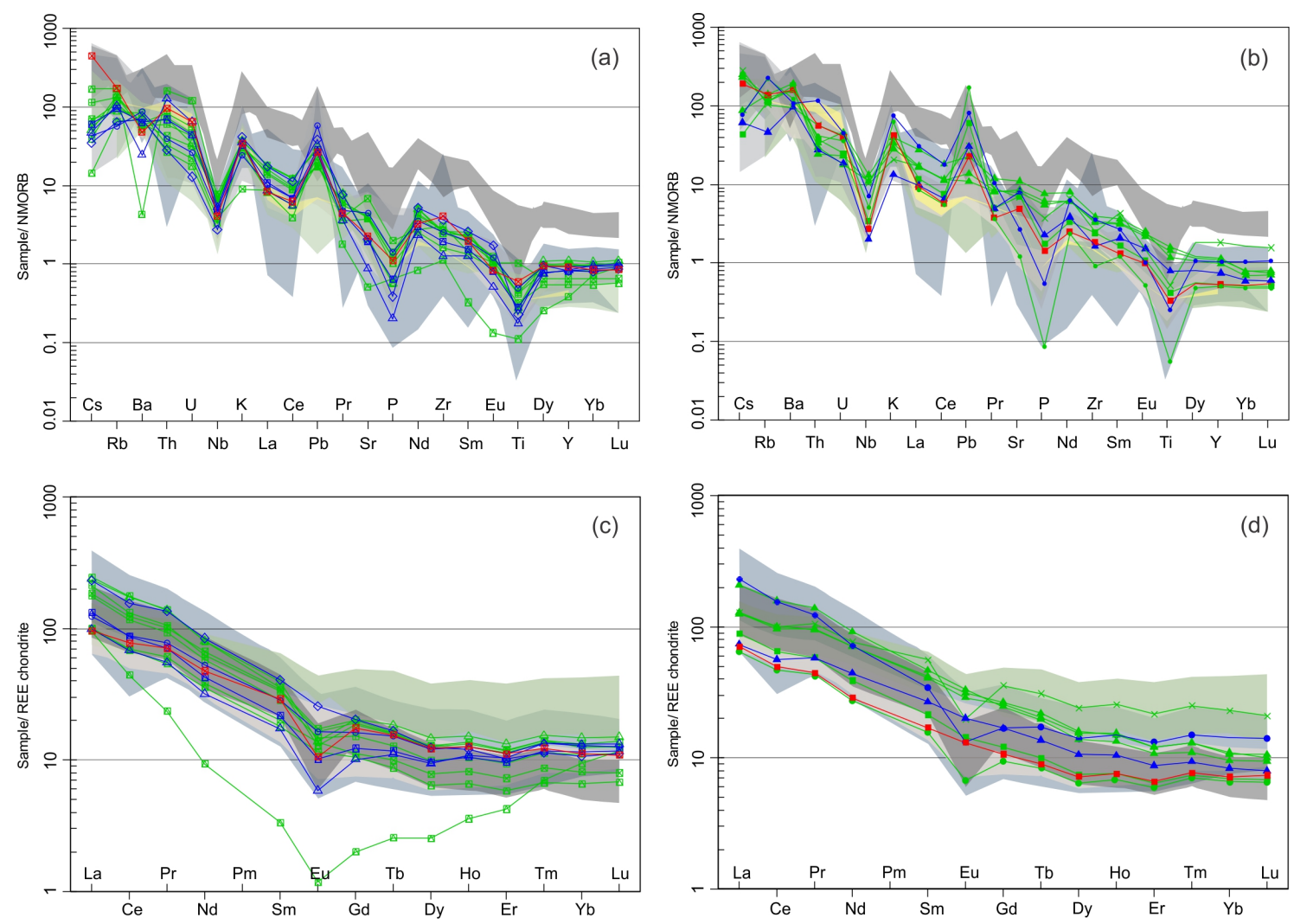

Fig. 6. 
(a) Zircons of charnockite from the basement

(b) Igneous plutonic zircons

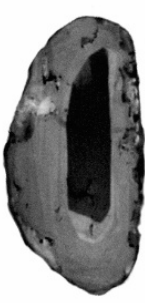

GAR-364 Point 1_ $1037 \pm 10 \mathrm{M}$

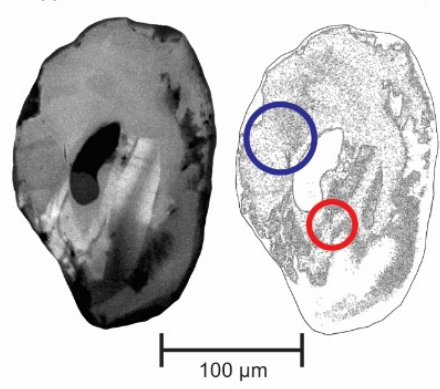

GAR-364 Point 18 $990 \pm 14 \mathrm{Ma}$

(c) Igneous volcanic zircons

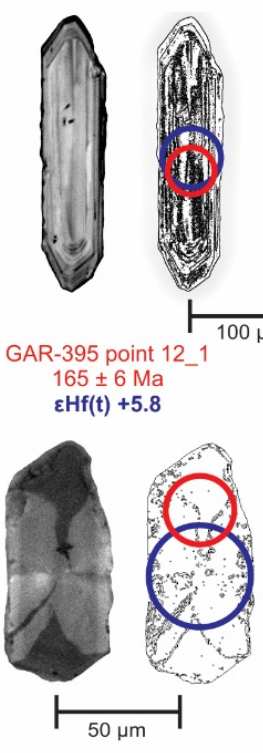

GAR-359 point 10_1 $171 \pm 2 \mathrm{Ma}$

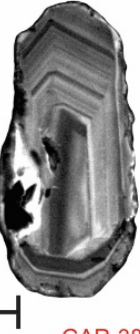

GAR-383 point 7 11
$168 \pm 4 \mathrm{Ma}$

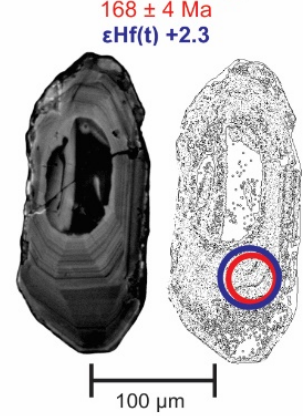

GAR-383 point 2_1 $190 \pm 6 \mathrm{Ma}$

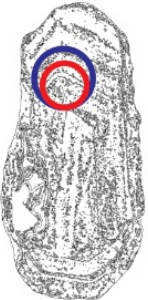

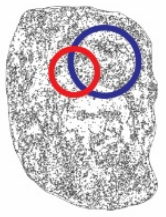

oint 21_1

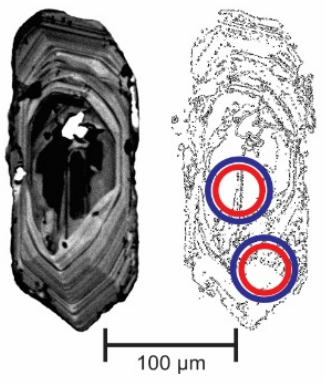

GAR-356 point 1_1

$179 \pm 3 \mathrm{Ma}$

$\varepsilon \mathrm{Hf}(\mathrm{t})-1.3$

GAR-356 point 12

$183 \pm 5 \mathrm{Ma}$

$\varepsilon H f(t)-5.0$
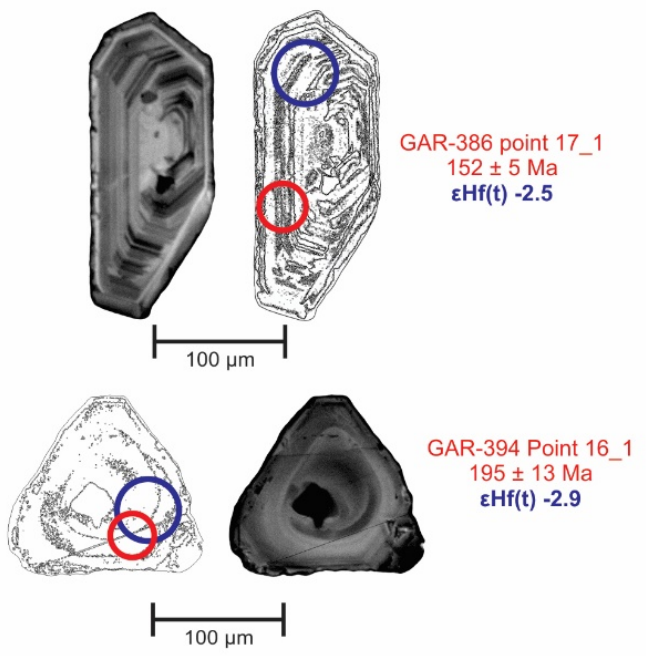

(d) Xenocryst zircons in volcanic rocks
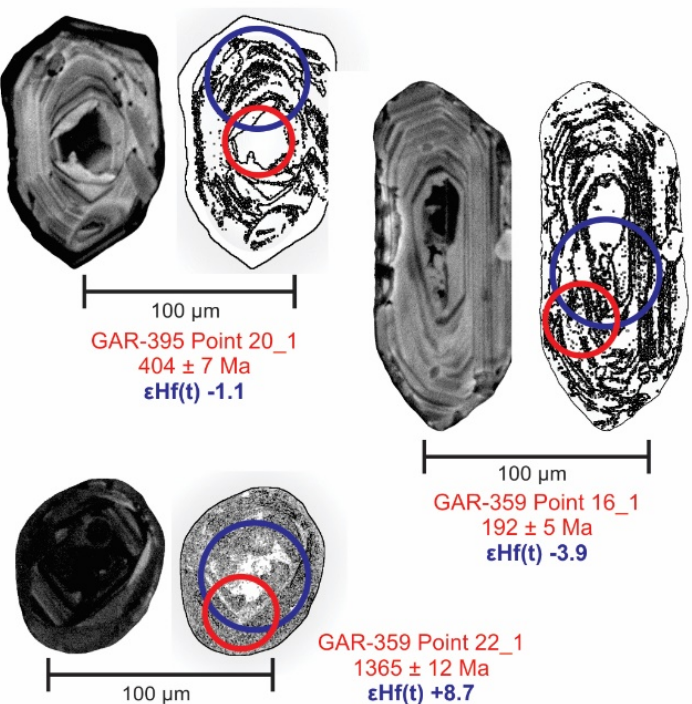

$\pm 5 \mathrm{Ma}$

$f(t)=3.9$

Fig. 7. 

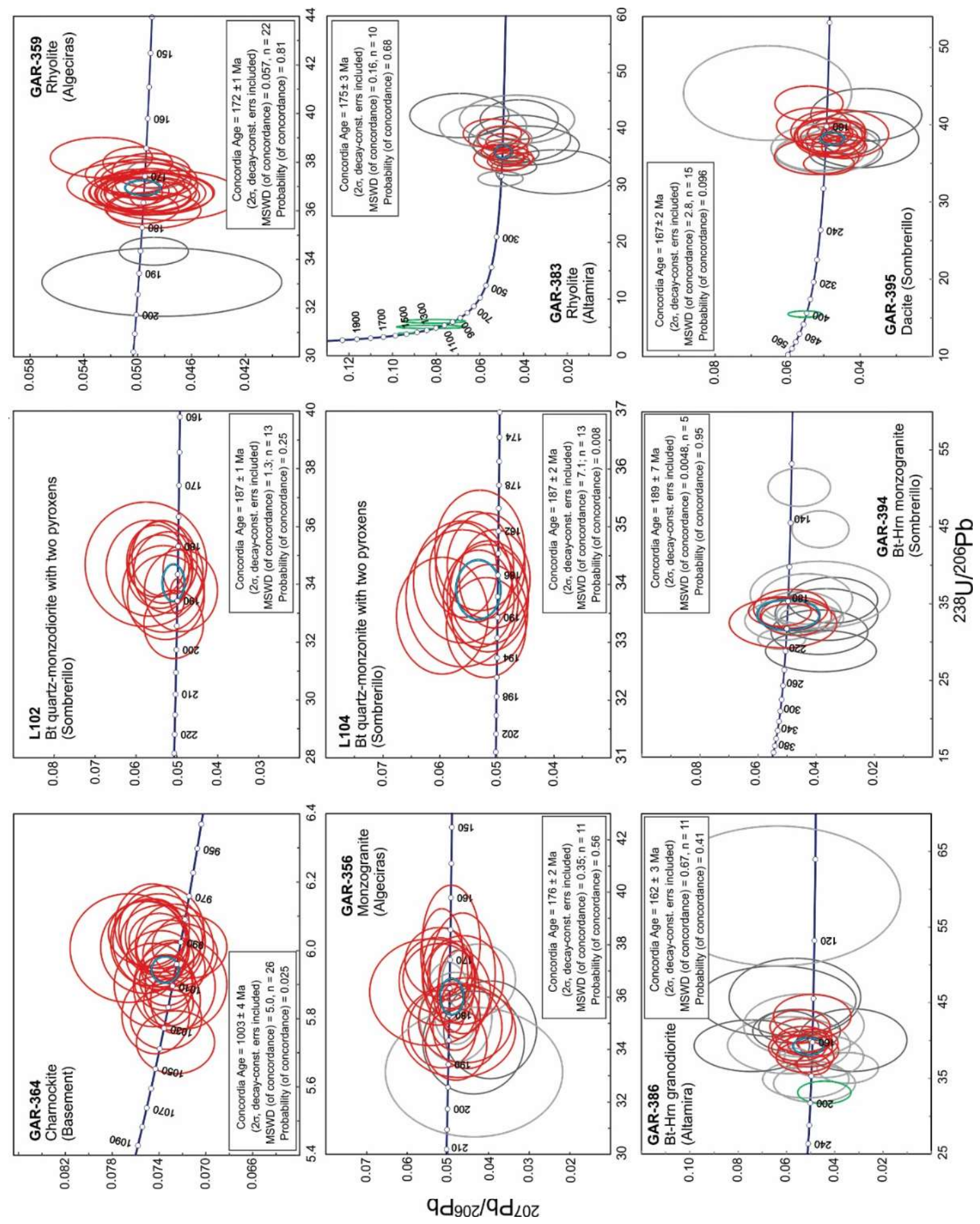

Fig. 8. 


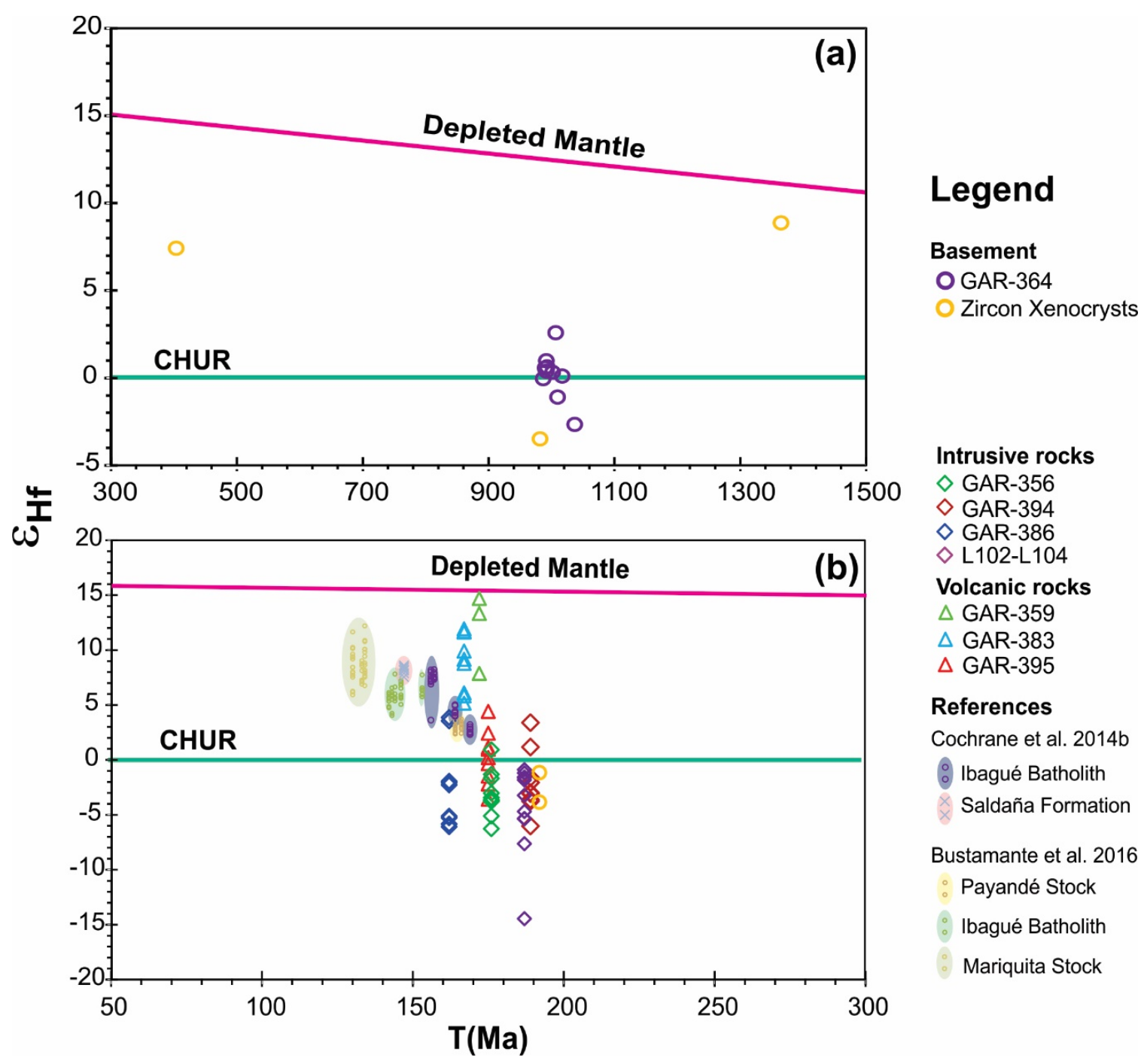

Fig. 9. 


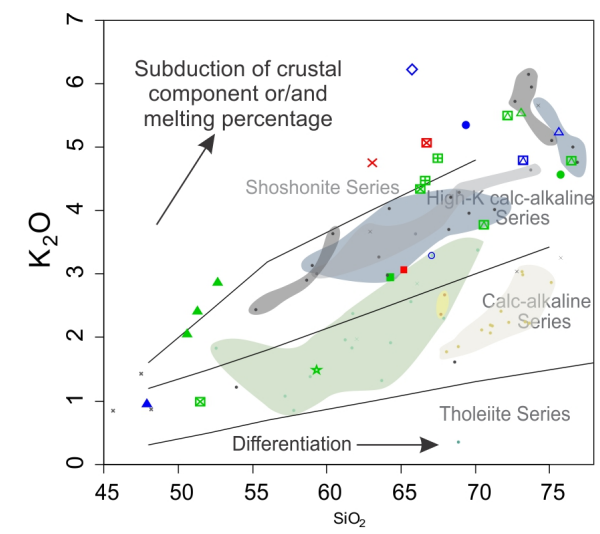

(a)

(b)

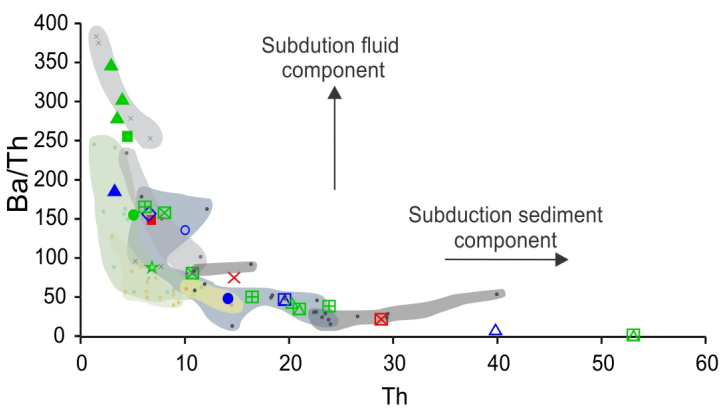

(c)
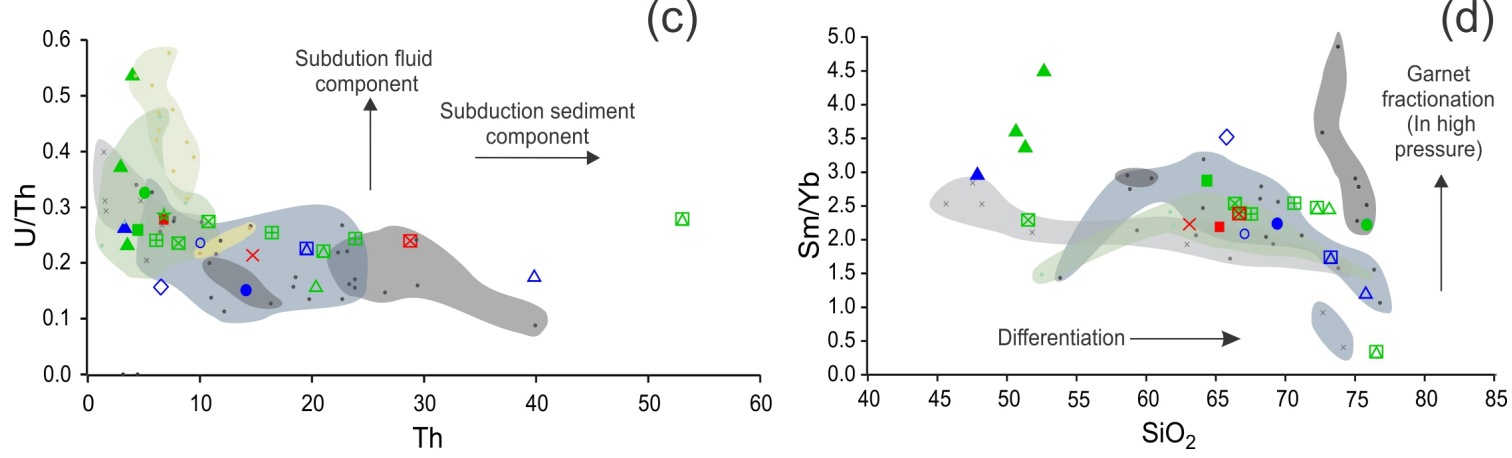

Fig. 10. 


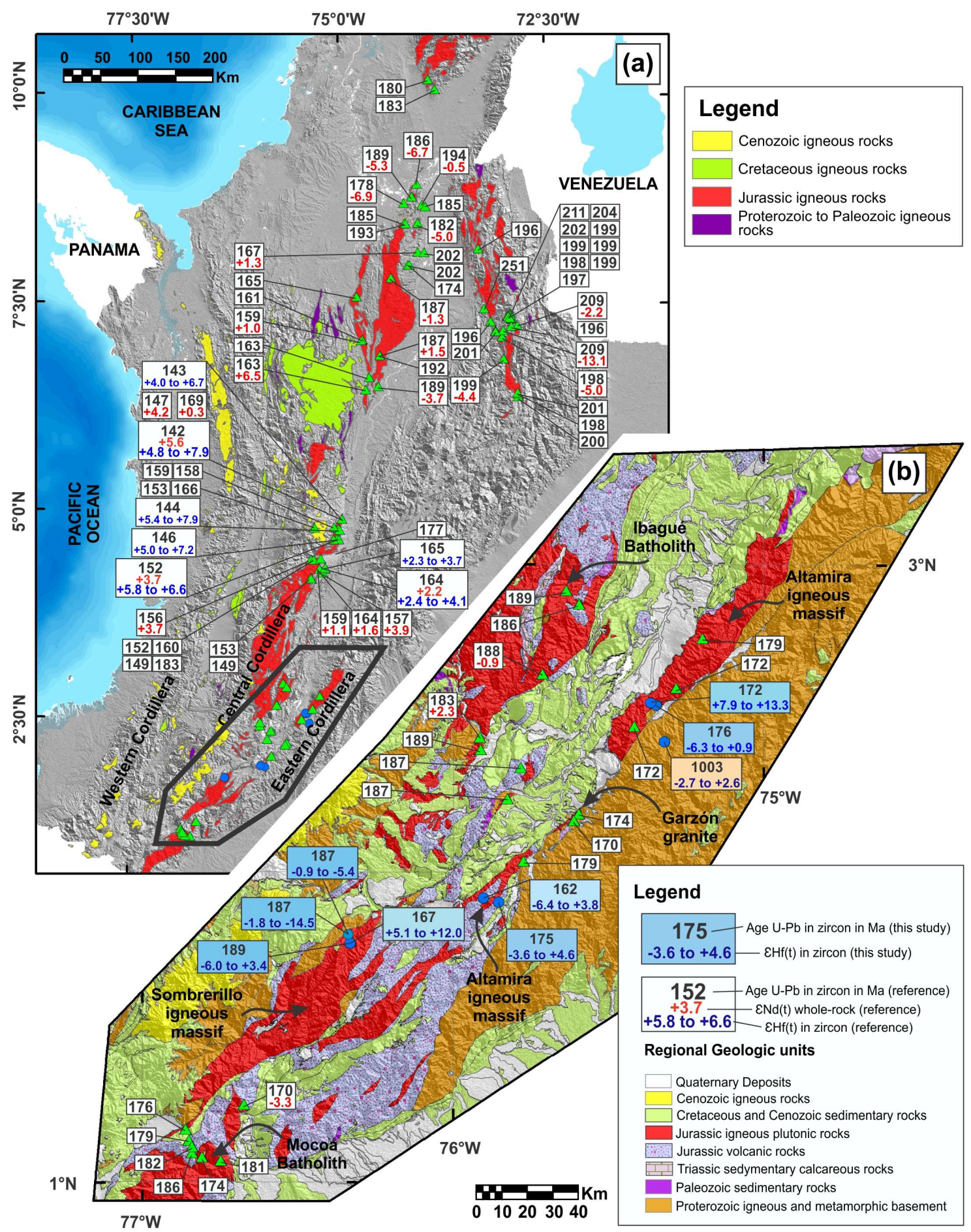

Fig. 11. 
1. The begining of Jurassic magmatism

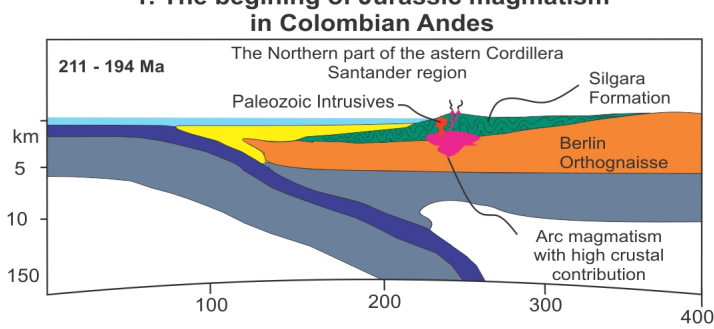

2. Migration to the west and begining of magmatism in

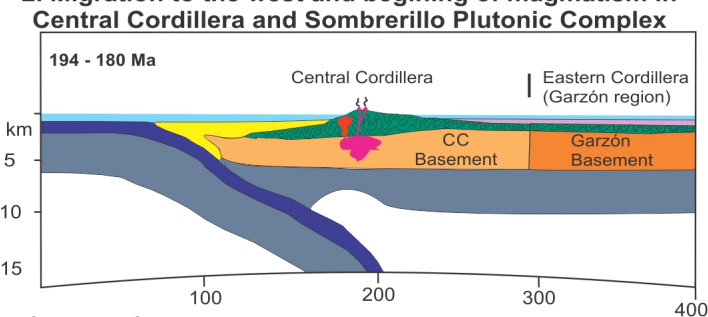

Legend

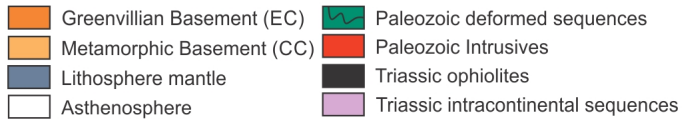

4. Migration to the east and begining of magmatism in Eastern Cordillera

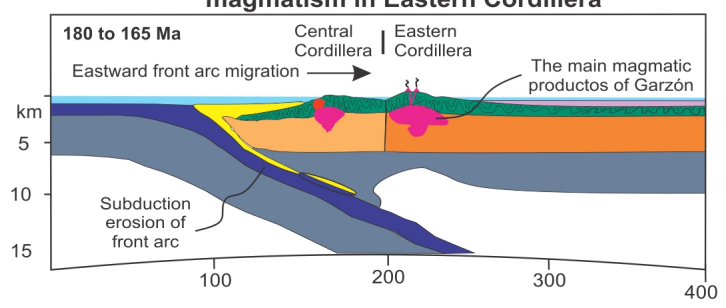

4. The last magmatic producs of Garzón and the front arc comes back to the Central Cordillera

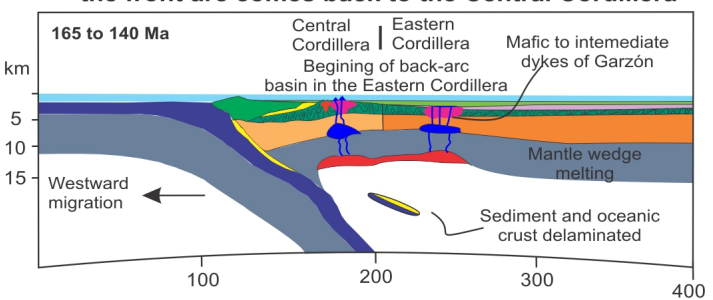

Oceanic crust Fore-arc sediments Jurassic intrusives

Late Jurassic intrusives
Accreted Cretaceous oceanic terranes Molten mantle Sea level
Cretaceous back-arc basin

Fig. 12. 


\section{TABLES}

Table 1. Representative whole-rock geochemical data of granites and related rocks of Garzón Massif.

\begin{tabular}{|c|c|c|c|c|c|c|}
\hline \multirow{2}{*}{$\begin{array}{l}\text { Plutonic Complex } \\
\text { Sample }\end{array}$} & \multicolumn{2}{|c|}{ Algeciras } & \multicolumn{2}{|c|}{ Altamira } & \multicolumn{2}{|c|}{ Sombrerillo } \\
\hline & GAR-356 & GAR-359 & GAR-383 & GAR-386 & GAR-394 & GAR-395 \\
\hline Facies & BH-MG & Rhyolite & Rhyolite & HB-GD & BH-MG & Dacite \\
\hline \multicolumn{7}{|l|}{ Oxides (wt. \%) } \\
\hline $\mathrm{SiO}_{2}$ * & 67.46 & 75.73 & 69.34 & 67.03 & 66.71 & 65.19 \\
\hline $\mathrm{TiO}_{2}$ * & 0.447 & 0.07 & 0.322 & 0.534 & 0.681 & 0.415 \\
\hline $\mathrm{Al}_{2} \mathrm{O}_{3}$ * & 15.27 & 12.85 & 15.76 & 16.12 & 14.31 & 16.27 \\
\hline $\mathrm{Fe}_{2} \mathrm{O}_{3}(\mathrm{~T})$ * & 3.64 & 0.55 & 2.05 & 3.53 & 4.22 & 4.27 \\
\hline $\mathrm{MnO}$ * & 0.060 & 0.03 & 0.054 & 0.063 & 0.066 & 0.086 \\
\hline MgO * & 1.07 & $<0.01$ & 0.23 & 1.07 & 1.26 & 1.38 \\
\hline $\mathrm{CaO}$ * & 2.60 & 0.56 & 1.20 & 3.15 & 2.81 & 4.05 \\
\hline $\mathrm{Na}_{2} \mathrm{O}$ * & 3.78 & 4.10 & 5.15 & 4.40 & 3.31 & 4.14 \\
\hline $\mathrm{K}_{2} \mathrm{O}$ * & 4.83 & 4.58 & 5.37 & 3.30 & 5.07 & 3.08 \\
\hline $\mathrm{P}_{2} \mathrm{O}_{5}$ * & 0.146 & 0.01 & 0.064 & 0.174 & 0.132 & 0.166 \\
\hline LOI & 0.65 & 0.48 & 0.53 & 0.92 & 0.24 & 0.40 \\
\hline Total & 99.95 & 98.94 & 100.07 & 100.29 & 98.81 & 99.45 \\
\hline \multicolumn{7}{|c|}{ Trace elements (ppm) } \\
\hline Sc * & $<14$ & $<14$ & 5 & $<14$ & $<14$ & $<14$ \\
\hline $\mathbf{V}$ * & 56 & $<9$ & 17 & 56 & 75 & 71 \\
\hline Co * & $<6$ & $<6$ & $<6$ & $<6$ & 9 & 11 \\
\hline $\mathrm{Cr}$ * & $<13$ & 12 & $<13$ & $<13$ & $<13$ & 9 \\
\hline $\mathrm{Cu}$ * & 31 & $<5$ & 9 & 13 & 34 & 15 \\
\hline $\mathrm{Ga}$ * & 17 & 13 & 15 & 18 & 15 & 17 \\
\hline $\mathrm{Ni}^{*}$ & $<5$ & $<5$ & $<5$ & 5 & 6 & $<5$ \\
\hline $\mathrm{Zn}$ * & 33 & 48 & 67 & 42 & 48 & 47 \\
\hline $\mathbf{F}^{*}$ & 3600 & 582 & 266 & 606 & 1223 & 237 \\
\hline $\mathrm{Cl}$ * & $<500$ & $<500$ & $<500$ & $<500$ & $<500$ & $<500$ \\
\hline S * & $<550$ & $<550$ & $<550$ & $<550$ & $<550$ & $<550$ \\
\hline $\mathbf{R b}$ * & 198 & 123 & 126 & 71.0 & 273 & 77.0 \\
\hline $\mathrm{Sr}$ * & 468 & 108 & 238 & 545 & 240 & 440 \\
\hline$Y^{* *}$ & 21.8 & 14.1 & 28.9 & 25.7 & 25.4 & 14.8 \\
\hline $\mathrm{Zr}$ * & 218 & 68.0 & 261 & 227 & 394 & 136 \\
\hline Nb ** & 20.6 & 11.8 & 16.3 & 14.1 & 12.4 & 6.33 \\
\hline Cs ** & 2.05 & 0.56 & 0.54 & 0.64 & 10.7 & 1.34 \\
\hline $\mathrm{Ba}^{* *}$ & 910 & 781 & 680 & 1353 & 650 & 1003 \\
\hline La ** & 58.2 & 21.2 & 77.1 & 40.7 & 31.6 & 23.3 \\
\hline$C e^{* *}$ & 101 & 40.6 & 134 & 76.6 & 67.1 & 42.7 \\
\hline $\mathrm{Pr} * *$ & 10.4 & 4.82 & 13.9 & 8.67 & 7.88 & 4.98 \\
\hline $\mathrm{Nd}^{* *}$ & 36.5 & 17.3 & 45.4 & 33.4 & 29.9 & 18.1 \\
\hline $\mathrm{Sm}$ ** & 5.78 & 3.2 & 6.98 & 5.84 & 5.88 & 3.44 \\
\hline $\mathrm{Eu}$ ** & 1.14 & 0.52 & 1.02 & 1.27 & 0.81 & 1.01 \\
\hline $\mathbf{G d}$ ** & 4.17 & 2.62 & 4.68 & 4.49 & 4.81 & 2.94 \\
\hline Tb ** & 0.60 & 0.39 & 0.81 & 0.71 & 0.73 & 0.42 \\
\hline Dy ** & 3.40 & 2.20 & 4.80 & 4.16 & 4.20 & 2.46 \\
\hline Ho ** & 0.73 & 0.48 & 1.04 & 0.89 & 0.89 & 0.53 \\
\hline $\mathrm{Er} * *$ & 2.12 & 1.33 & 2.93 & 2.52 & 2.50 & 1.48 \\
\hline $\mathrm{Tm} * *$ & 0.34 & 0.21 & 0.45 & 0.40 & 0.37 & 0.23 \\
\hline
\end{tabular}




\begin{tabular}{|c|c|c|c|c|c|c|}
\hline Yb ** & 2.43 & 1.45 & 3.12 & 2.81 & 2.47 & 1.57 \\
\hline Lu ** & 0.38 & 0.22 & 0.48 & 0.43 & 0.37 & 0.25 \\
\hline Hf ** & 6.04 & 2.56 & 6.90 & 6.27 & 10.7 & 3.25 \\
\hline $\mathrm{Pb}$ ** & 9.67 & 50.7 & 24.4 & 38.7 & 15.5 & 6.78 \\
\hline Th ** & 23.8 & 5.06 & 14.1 & 10.0 & 28.8 & 6.77 \\
\hline $\mathbf{U} * *$ & 5.81 & 1.66 & 2.14 & 2.36 & 6.96 & 1.90 \\
\hline A/CNK & 0.94 & 1.01 & 0.96 & 0.97 & 0.89 & 0.93 \\
\hline ASI & 0.95 & 1.01 & 0.96 & 0.99 & 0.90 & 0.94 \\
\hline Fe-number & 0.75 & & 0.89 & 0.75 & 0.75 & 0.74 \\
\hline $\mathrm{Eu} / \mathrm{Eu}^{*}$ & 0.7 & 0.6 & 0.5 & 0.8 & 0.5 & 1.0 \\
\hline $\mathrm{Ce} / \mathrm{Ce}^{*}$ & 1.00 & 0.97 & 0.99 & 0.99 & 1.03 & 0.96 \\
\hline$(\mathrm{La} / \mathrm{Yb})_{\mathrm{N}}$ & 16.3 & 10.0 & 16.8 & 9.9 & 8.7 & 10.1 \\
\hline$(\mathrm{La} / \mathrm{Sm})_{\mathrm{N}}$ & 6.31 & 4.13 & 6.92 & 4.37 & 3.36 & 4.24 \\
\hline$(G d / Y b)_{N}$ & 1.39 & 1.47 & 1.22 & 1.29 & 1.58 & 1.52 \\
\hline 176Hf/177Hf (min-max) & $\begin{array}{l}0.282489- \\
0.282632\end{array}$ & $\begin{array}{l}0.282902- \\
0.283097\end{array}$ & $\begin{array}{l}0,282566- \\
0,282797\end{array}$ & $\begin{array}{l}0,282502- \\
0,282788\end{array}$ & $\begin{array}{l}0,282487- \\
0,282754\end{array}$ & $\begin{array}{l}0,282819- \\
0,283015\end{array}$ \\
\hline 176Hf/177Hf (average) & 0.282579 & 0,283020 & 0,282674 & 0,282611 & 0,282598 & 0,282928 \\
\hline 176Lu/177Hf (min-max) & $\begin{array}{l}0.000637- \\
0.001991\end{array}$ & $\begin{array}{l}0,004405- \\
0,005899\end{array}$ & $\begin{array}{l}0,000925- \\
0,002679\end{array}$ & $\begin{array}{l}0,000852- \\
0,002721\end{array}$ & $\begin{array}{l}0,000370- \\
0,000858\end{array}$ & $\begin{array}{l}0,001211- \\
0,003759\end{array}$ \\
\hline 176Lu/177Hf (average) & 0.001189 & 0,005116 & 0,001609 & 0,001604 & 0,000516 & 0,002316 \\
\hline
\end{tabular}

Notes:

* X-ray fluorescence data

** ICP-AES data

$\mathrm{Eu} / \mathrm{Eu}^{*} ; \mathrm{Ce} / \mathrm{Ce} ;(\mathrm{La} / \mathrm{Yb})_{\mathrm{N}} ;(\mathrm{La} / \mathrm{Sm})_{\mathrm{N}} ;(\mathrm{Gd} / \mathrm{Yb})_{\mathrm{N}}$ ratios are mantle-normalized (McDonough and Sun, 1995)

Facies abbreviations BT-MG = Biotite-Hornblende monzogranite; HB-GD = Hornblende-Biotite Granodiorite. 


\section{Apêndice $C$}

Manuscrito: "Mineral chemistry of Jurassic granites and related rocks from Eastern Colombian Cordillera, Northern Andes: compositional variations of rock-forming minerals and intensive parameters of crystallization"

García-Chinchilla, D.A. \& Vlach, S.R.F. 


\title{
Mineral chemistry of Jurassic granites and related rocks from Eastern Colombian Cordillera, Northern Andes: compositional variations of rock-forming minerals and intensive parameters of crystallization \\ Daniel Alejandro García Chinchilla[1] \& Silvio Roberto Farias Vlach[1]
}

[1] Departamento de Mineralogia e Geotectônica, Instituto de Geociências, Universidade de São Paulo, Rua do Lago, 562, Cidade Universitária, 05508-080, São Paulo, SP, Brasil

\begin{abstract}
Textural and quantitative chemical data (EPMA) for the main rock-forming minerals, until unavailable for Colombian Jurassic Andean granitic and related rocks, are presented and used with some whole-rock geochemical data to estimate intensive crystallization/emplacement parameters and their implications to the evolving granite magmatism. The work is focused on representative samples from the Algeciras, Altamira and Sombrerillo plutonic massifs, the most important Jurassic massifs constituting the Eastern Colombian Cordillera in the Garzón region. The Algeciras Plutonic Massif is made up mainly by varieties of hornblende, biotite hornblende and biotite monzogranites, with minor hornblende biotite granodiorites and leuco granites, while the Altamira Plutonic Massif is constituted mainly by biotite-bearing leuco syeno- and monzogranites. In the Sombrerillo Plutonic Massif, besides largely predominant biotite and biotite hornblende monzogranites, very particular two pyroxene-bearing monzodiorites and monzogranites crop out. Biotite hornblende felsic porphyries (dacites and rhyolites) minor bodies and mafic-intermediate (microdiorites and andesites) appear in all massifs. The intermediate and felsic rocks present variable zoned Ca-amphibole (magnesiohornblende, magnesiohastingsite and edenite, with $0.54 \leq \mathrm{mg \#} 0.92$,
\end{abstract}


high in subvolcanic rocks), relatively homogeneous biotite (mainly phlogopite, siderophyllite in some peraluminous leuco granites, with $0.47 \leq \mathrm{mg} \# \leq 0.65$ ) and pyroxenes (enstatite, subcalcic augite, augite and diopside, with $0.49 \leq \mathrm{mg \#} \leq$ 0.71). Titanite \pm allanite + magnetite \pm ilmenite + apatite + zircon are the typical primary accessory phases in most studied samples; magnetite presents common trellis type ilmenite exsolution. Al-in-hornblende and plagioclase-hornblende equilibrium geothermobarometry and phase saturation thermometry indicates the plutonic rocks emplaced in similar, relatively shallow, ca. $4.5 \mathrm{~km}$ depth, crustal levels $(P \approx 1.5 \pm 0.5 \mathrm{kbar}$ or $\approx 150 \pm 50 \mathrm{MPa})$. The estimated crystallization interval ranges mostly from up to $930^{\circ} \mathrm{C}$ close-to-liquidus to ca. $700^{\circ}$ close-to-solidus temperatures, and the main crystallization occurred in under-saturated water conditions. Associated rhyolite porphyries emplaced at similar low pressures but somewhat high temperatures. On the other hand, amphibole phenocryst compositions, particularly from dacite porphyries, register a complex crystallization history, with crystal cores formed at high pressures (up to $5.1 \mathrm{kbar}, 1050^{\circ} \mathrm{C}$ and $\mathrm{H}_{2} \mathrm{O}$ contents in between 4.3-5.7 wt.\%) and crystal rims at pressures and temperatures down to $0.8 \mathrm{kbar}, 800^{\circ} \mathrm{C}$, and water contents between 4.9-6.7 wt.\%, these rim values being compatible with their final emplacement into the granitic hosts. Both the plutonic and subvolcanic rocks were formed under oxidizing conditions, with $+1 \leq \Delta \mathrm{QFM} \leq+3$, as expected in magmatic continental arcs. In the post magmatic evolving stages, conditions were still more oxidizing, as revealed by Fe-Ti oxide exsolution phases, and describe an oxidizing trend with decreasing temperatures. 


\section{INTRODUCTION}

The Northeastern Andes in Colombia is an example of a continental margin arc, built through the interaction of South American plate with Pacific Ocean terrains. In this area, multiple subduction events generated extensive calc-alkalic and alkalicalcic magmatic arcs since the Paleozoic until Cenozoic times (McCourt et al., 1984). One of the most important magmatic period in this area occurred in Jurassic, when the largest intrusive massifs in Central and Eastern Colombian Cordilleras were emplaced (Fig. 1). Several features of this granite (sensu lato) magmatism are still poorly known however. More recent works had tried to establish its distribution within cordilleras, its main geochemical and isotope signatures, its relative timing, and to accommodate these data in the light of worldwide accepted tectonic models (e.g. Cochrane et al., 2014; Bustamante et al., 2016; Rodríguez et al., 2018; Villagómez et al., 2011). The first known Jurassic granitic rocks were emplaced in the northern area of the Eastern Cordillera, Santander region, during a relatively short age interval, 196 to $211 \mathrm{Ma}$ (Cochrane et al., 2014; Mantilla Figueroa et al., 2013). To southwestern, an extensive granite magmatism built important parts of the Ibagué Batholith by 183 to $200 \mathrm{Ma}$ in Central Cordillera (Cochrane et al., 2014; Leal-Mejía, 2011; Villagómez et al., 2011) as well as in the Sombrerillo Plutonic Massif, in the Eastern Cordillera, by $189 \pm 7$ Ma (García-Chinchilla \& Vlach, submitted). As also shown by these authors, the latest granite magmatism 170-176 Ma in this cordillera made up most of the large Algeciras and Altamira plutonic massifs (Fig. 1). 
Current models adopted for the tectonic evolution and related magmatism in the Garzón region consider an eastward migration of the Jurassic magmatic arc front, related to subduction erosion phenomena, by 180 Ma (García-Chinchilla \& Vlach, submitted), take in account that the main magmatism of Algeciras and Altamira are development after those in Central Cordillera, to the west (mentioned above). This kind of process is driven by a frontal erosion along the top of the fore-are wedge combined with sub-crustal basal erosion in the wedge underside leads to the collapse of the fore-arc wedge into the trench, promotes the input of new crustal material into the subduction channel and magmatic arc migration, from the frontarc to the back-arc region (Stern, 2011).

Among the unknown characteristics of this Jurassic granite magmatism, the absence of quantitative mineralogical data is worth to note; in fact, nothing is known about mineral compositions and compositional variations. In this work, we present basic data for selected granitic and associated subvolcanic samples from the Algeciras, Altamira and Sombrerillo plutonic massifs in the Garzón region, Eastern Colombian Cordillera. Basic textural and chemical (major and minor elements by EPMA) mineralogical information are integrated and used as a first attempt to characterize the main compositional variations of the rock-forming minerals as well as to estimate relevant intensive parameters of magma crystallization and/or emplacement. These data, combined with whole-rock geochemical, geochronological and high-resolution zircon isotope analysis presented in a companion contribution (García-Chinchilla \& Vlach, submitted) 
improves the knowledge of these massifs to a significant extent and help to understand their evolutionary history.

\section{GEOLOGICAL BACKGROUND}

Garzón region is located in the southern part of Eastern Cordillera in the Colombian Andes (Fig. 1a), where Jurassic plutonic massif as Algeciras, Altamira and Sombrerillo (focus of this study) have an exposure area of ca. $1860 \mathrm{~km}^{2}$ (Fig. 1b). They are in tectonic contact with medium to high-grade metamorphic basement compose by charnockites, gneisses, amphibolites, granulites as well as migmatites (Altenberger et al., 2012; Jiménez Mejía et al., 2006) of Meso- to Neoproterozoic age (Ibanez-Mejia et al., 2011). Strongly deformed and faulted Paleozoic marine sequences are in contact with plutonic massifs (Mojica et al., 1988a, 1988b; Moreno-Sánchez et al., 2008; Villarroel et al., 1997), some of them with thermal disturb (Mojica et al., 1988b; Núñez, 2003). Vulcano-sedimentary rocks of Jurassic age (e.g. Saldaña Formation; cf. Zapata et al., 2016) are common in this region. Cretaceous marine sequences of Upper Magdalena River (Cooper et al., 1995; Velandia et al., 2001) cover the Jurassic rocks as well as the crystalline basement.

The Algeciras Plutonic Massif is the most northern igneous structure in Garzón region, with elongate SW-NE trending, and exposition area about $500 \mathrm{~km}^{2}$ (Fig. 1c). The Altamira, to the south, is the smallest Plutonic Massif with an area about $280 \mathrm{~km}^{2}$, and similar trending of Algeciras (Fig. 1d). The Sombrerillo is the biggest structure with $1080 \mathrm{~km}^{2}$; it is located in the most southern part, between Central and Eastern Cordilleras (Fig. 1e). 


\section{GENERAL PETROGRAPHY}

Brief petrographic descriptions of the main granites and related subvolcanic rocks from the studied Algeciras, Altamira and Sombrerillo plutonic massifs are presented in the following; some representative modal data are depicted in Fig. 2. Additional geological and petrographic information are given in García-Chinchilla et al. (submmited).

\subsection{Algeciras Plutonic Massif}

The Algeciras Plutonic Massif, to the north, is made up mainly by hornblende, biotite hornblende and biotite monzogranite varieties (Fig. 1c). They are massive, grayish to pinkish, leucocratic $[2<\mathrm{Cl}$ (Color Index) $<15$ ], slightly inequigranular and medium- to coarse-grained (Fig. 3a; b). Titanite, Fe-Ti oxides, allanite, apatite and zircon are the main primary accessory phases. Hornblende biotite granodiorites $(10<\mathrm{Cl}<17)$ and leuco granites $(\mathrm{Cl}<9)$ with similar structure, textures and mineralogy were mapped in somewhat restricted areas within the Massif. Some leuco granites present typical micrographic textures.

Associated subvolcanic rocks are common within the massif. Two main groups were recognized and mapped. The first, a felsic one, is constituted by rhyolite porphyry $(\mathrm{Cl} \leq 5)$ dikes and minor irregular bodies, made up by quartz, alkali feldspar, plagioclase, as well as some biotite, hornblende, Fe-Ti oxides and titanite phenocrysts in a microcrystalline quartz-feldspatic matrix (Fig. 3c). The second correspond to syn-plutonic massive mafic-intermediate dikes $(30 \leq \mathrm{Cl} \leq 40)$ with intergranular fine-grained to aphanitic textures, composed by plagioclase laths with 
interstitial hornblende, biotite, accompanied by Fe-Ti oxides, titanite and apatite (Fig. 3d).

\subsection{Altamira Plutonic Massif}

This massif is smaller, petrographically simple and constituted by relatively evolved granite varieties, as compared with Algeciras. It is made up mainly by massive biotite-bearing leuco monzogranites $(\mathrm{Cl}<5$, Fig. 3d), presenting whitish to pinkish colors and inequigranular medium- to coarse-grained textures. Titanite, Fe-Ti oxides, apatite and zircon are typical accessories; allanite is occasional. Massive hornblende biotite granodiorites $(\mathrm{Cl}=11)$ and hornblende monzonites $(\mathrm{Cl}$ $=17)$ crop out in relatively small exposure areas. They present similar inequigranular, medium- to coarse-grained, textures and mineralogy. Maficintermediate dioritic dikes and some small rhyolite porphyry bodies, similar to those described for the Algeciras Massif, are scarce.

\subsection{Sombrerillo Plutonic Massif}

This is the southernmost studied massif and the largest one, with the greatest petrographic variety (Fig. 1e). Leucocratic biotite hornblende monzogranite varieties $(\mathrm{Cl}=15)$ similar to those described in the Algeciras Massif are predominant to the north. To the western, close to contacts with the country rocks, very particular, two-pyroxene-bearing biotite quartz monzonites and quartz monzodiorites $(24<\mathrm{Cl}<26$, Fig. 3e) crop out (Fig. 3e; f). They are inequigranular and medium-grained. Accessory minerals are titanite, Fe-Ti oxides, allanite, apatite and zircon. 
Dacite $(5 \leq \mathrm{Cl} \leq 10)$ and rhyolite $(5 \leq \mathrm{Cl})$ porphyries, with plagioclase, hornblende, biotite, quartz and some mafic silicate phenocrysts in a matrix made up by plagioclase, opaque minerals, hornblende, biotite and micrographic intergrowths of quartz and alkali feldspar, crop out as small intrusive bodies (Fig. 3g; h; i). Occasionally, syn-plutonic mafic-intermediate aphanitic dikes also appear.

\section{GENERAL GEOCHEMISTRY}

The main geochemical characteristics of intrusive and subvolcanic rocks from the studied massifs are very akin to common high- $\mathrm{K}$ rocks from active continentaltype margins (e.g. Pearce et al., 1984; Barbarin, 1999). The intrusive ones are mainly alkali-calcic, magnesian to slightly ferroan and metaluminous to marginally peraluminous rocks (Fig. 4a; b; c) and depict relative enrichment of the LIL over the HFS elements, as typical. They plot mainly as arc-granites in the discrimination $\mathrm{Rb}$ vs. $\mathrm{Y}+\mathrm{Nb}$ diagram (Fig. 4d) and presents $\mathrm{Eu} / \mathrm{Eu}^{*}$ and $(\mathrm{La} / \mathrm{Yb})_{\mathrm{N}}$ in between 0.4 and 0.6, 7.7 and 22 (Fig. 4e), respectively, with relatively high U/Th (0.2-0.5) and $\mathrm{Ba} / \mathrm{Th}$ (1-346) ratios (Fig. 4f). In the TAS diagram (not shown), the subvolcanic varieties plot as rhyolite, dacite, basaltic trachy-andesite and basalt. Such rocks present $\mathrm{Eu} / \mathrm{Eu}^{*}$ and $(\mathrm{La} / \mathrm{Yb})_{\mathrm{N}}$ in the range 0.9-1.0 and 9-12, respectively (Fig. 4e). $\mathrm{Sm} / \mathrm{Yb}$ ratios are about 2.1-4.5 (mafic-intermediate subvolcanics) and 0.3-2.5 (felsic subvolcanics) (Fig. 4e). Available whole-rock geochemical and Hf-in-zircon isotope data suggest that the intrusive rocks contain significant contributions from relatively evolved, crustal, isotope reservoir, while the subvolcanic ones have more typical primitive compositions (García-Chinchilla \& Vlach, submitted). 


\section{SAMPLING, ANALYTICAL TECHNICS AND DATA TREATMENT}

Fourteen (14) samples were selected for detailed mineralogical work at the GeoAnalitica USP core facility. They are representative of seven (7) samples from Algeciras, four (4) from Altamira and three (3) from Sombrerillo (see Fig. 1 for sample locations). After a previous work with the petrographic microscope under transmitted and reflected light, 14 polished thin-sections were selected for quantitative analysis with a JEOL JXA- 8530 field-emission electron-probe microanalyzer (FE-EPMA). The machine has an energy dispersive (ED) and five wavelength dispersive (WD) spectrometers. Each WD spectrometer has two analyzer crystals and one of them is provided with large area PET and TAP analyzer crystals. Conventional backscattered electronic imaging $(\mathrm{BEI})$ was used routinely to examine mineral zoning patterns and chose appropriate spots for quantitative analysis.

The analytical conditions for quantitative analysis were $15 \mathrm{kV}$ and $20 \mathrm{nA}$ for the column accelerating voltage and beam current, respectively. Most spots were analyzed under a beam diameter of $5 \mu \mathrm{m} ; 1 \mu \mathrm{m}$ - and $10 \mu \mathrm{m}$-sized beams, as needed, were applied to analyze Fe-Ti oxide exsolution lamellae and perthitic alkali-feldspars, respectively. Natural silicate minerals and synthetic compounds, from the Smithsonian Institute and our internal collections, were used as standards. Arenal and Kakanui hornblendes from the Smithsonian were used as Si and Al controlling standards for calcic amphiboles. The applied analytical routines correspond to those described by Gualda and Vlach (2007) and Vilalva et al. (2016) and references cited therein. Raw data were on-line corrected for matrix 
effects using the software PRZ/Armstrong provided with the equipment. Estimated maximum total errors $(2 \sigma)$ are below 1 and $5 \%$ for major and minor elements, respectively, increasing to significant extents as the measured values approaches the respective element detection limits.

More than 500 quantitative WDS spot analyses were obtained for feldspars, pyroxenes, amphiboles, biotite and Fe-Ti oxides from our selected samples.

Silicate mineral atomic proportions and/or structural formulae were computed with the software MinCal (G. Gualda and S. Vlach: https://my.vanderbilt.edu/ggualda/mincal). In this software, the partition of the measured total $\mathrm{Fe}$ between $\mathrm{Fe}^{+2}$ and $\mathrm{Fe}^{+3}$ contents in anhydrous minerals is based on the formalism of Droop (1987). In the case of amphiboles, it uses the method of Schumacher (1997); as discussed in Gualda and Vlach (2005) however, the maximum, rather than the average $\mathrm{Fe}^{3+}$ computed values, approaches better actual values in calcic amphiboles and were herein chosen. Fe-Ti oxides molecular fractions were computed with the ILMAT soltware (Lepage, 2003), which applies the scheme presented by Carmichael (1967).

Pyroxene and biotite nomenclature follows the recommendations of Morimoto (1988) and Rieder et al. (1999), respectively. In the case of amphiboles, in spite of the new IMA recommendations (Hawthorne et al., 2012) we prefer to use the previous one presented by Leake et al. (1997), in order to facilitate comparisons with previous works. 


\section{MINERAL TEXTURES AND CHEMISTRY}

We present and discuss the main textural and chemical features of feldspars, mafic silicates and Fe-Ti oxides in this section. Representative WDS quantitative chemical compositions are presented in Table 1, Table 2 and Table $\mathbf{3}$, respectively. The complete chemical data set is available in the supplementary companion material.

\subsection{Plagioclase}

Plagioclase in the intrusive rocks appears mainly as euhedral to subhedral, tabular, Albite or Albite-Carlsbad twined crystals. In general, they are relatively earlier in the crystallization sequence and present normal or oscillatory compositional zoning. Alteration and substitution by saussurite is common at crystal cores. Some crystal faces in contact with alkali feldspar develop late albite rims and/or mirmekites, especially in more felsic samples. A slightly solid-state deformation is sometimes detectable. Among the subvolcanic rocks, plagioclase phenocrysts in the dacite porphyries present strong oscillatory zoning while in rhyolites they are more homogeneous. In mafic-intermediate rocks, it appears as more pristine and lath-like crystals.

The compositional variations of plagioclase in the intrusive rocks cover the interval from calcic-andesine to sodic-oligoclase (Table 1, Fig. 5a). As expected, the main measured compositional intervals turn more albite-rich in the more felsic rocks, from $A n_{20} A b_{79} \mathrm{Or}_{1}-\mathrm{An}_{61} \mathrm{Ab}_{38} \mathrm{Or}_{1}$ in granodiorites, to $\mathrm{An}_{31} \mathrm{Ab}_{67} \mathrm{O}_{\mathrm{r} 2}$ $\mathrm{An}_{49} \mathrm{Ab}_{50} \mathrm{Or}_{1}$ in the two pyroxene-bearing monzodiorites, to $\mathrm{An}_{14} \mathrm{Ab}_{84} \mathrm{O}_{\mathrm{r} 2}$ - 
$A n_{46} \mathrm{Ab}_{53} \mathrm{Or}_{1}$ in the monzogranites and $\mathrm{An}_{3} \mathrm{Ab}_{92} \mathrm{Or}_{5}-\mathrm{An}_{19} \mathrm{Ab}_{79} \mathrm{Or}_{2}$ in the leuco granites. The molecular Or contents vary from 1 to 7 , being higher in some monzogranites. Fe abundances are in between 0.001 and 0.124 atoms per formula unit (apfu). Sr contents range from 0.001 to 0.043 apfu and correlate with An values; in the more felsic rocks they are close or below detection limits. Other typically measured elements, such as $\mathrm{Ti}, \mathrm{Mn}, \mathrm{Mg}$, and $\mathrm{Ba}$ appear in very low concentrations or are below detection limits.

Among the subvolcanic samples, labradorite-andesine ( $\left.\mathrm{Ab}_{52-31} \mathrm{An}_{65-43} \mathrm{Or}_{7-4}\right)$ compositions characterize the basic-intermediate dikes. The molecular Or content are in between 1 and 15, the highest values occurring in some dacites. $\mathrm{Fe}$ and $\mathrm{Sr}$ abundance are from 0.031 to 0.124 and 0.010 to 0.034 apfu, respectively. The relatively homogeneous plagioclase in the rhyolite porphyry has compositions in the albite range $\left(\mathrm{Ab}_{93-69} \mathrm{An}_{3-8} \mathrm{Or}_{27-2}\right.$ ), with higher values of the molecular Or (from 2 to 27 ) and Fe abundances from 0.003 to 0.032 apfu and Sr lower (<0.010 apfu). In dacite porphyries, the plagioclase is andesine with some labradorite compositions in phenocryst cores, covering the range $A b_{71-38} A n_{61-27} \mathrm{Or}_{1.8-0.4}$ (Fig. 5b).

A typical core-to-rim compositional traverse in the strongly zoned plagioclase phenocryst from a dacite porphyry sample is in Fig. 6. As shown, variations in Al, $\mathrm{Ca}, \mathrm{Si}, \mathrm{Na}$ and $\mathrm{K}$ present well-developed oscillatory patterns. As expected, $\mathrm{Al}$ and Ca abundances show inverse correlations with $\mathrm{Si}$ and $\mathrm{Na}$ decrease and core zones are rich in the anortite component. $\mathrm{K}$ contents increase from core to rim; in the most external rims they decrease strongly. Fe abundances remain almost constant throughout the entire profile. 


\subsection{Alkali-feldspar}

Alkali feldspar in granitic rocks occurs as suhedral to anhedral perthitic crystals, being interstitial in granodiorites and monzodiorites. Exsolved albite appears as thin lamellae, rods or more irregular patches. Most crystals are Carlsbad twined; the microcline chessboard twining in the potassic host is incipient or nonobservable in some relatively mafic samples and better developed in felsic ones, as the leuco granites. In these late rocks, crystal dimensions are usually greater than those of plagioclase or quartz. Micrographic intergrowths between alkali feldspar and quartz are typical in some leuco granite samples, collected close to the intrusive contacts with country rocks. Late albite aggregates occur interstitial to alkali feldspar crystals in somewhat deformed varieties. In the subvolcanic felsic rocks, Carlsbad-twined, euhedral to subhedral phenocrysts are typical in rhyolite and occasional in dacite porphyries. Quartz-alkali-feldspar micrographic- and spherulitic-like intergrowths are common in the mesostasis of these rocks.

The measured alkali feldspars compositions range from $\operatorname{Or}_{73} A b_{25} A n_{2}$ to $\mathrm{Or}_{98} \mathrm{Ab}_{2} \mathrm{An}_{0}$ (Table 1, Fig. 5c). The more significant compositional variations are observed in alkali feldspars from the two pyroxene-bearing and, in general, the alkali-feldspar in monzogranites are relatively Na-rich than in leuco granites. The molecular An content is low (<3), with $\mathrm{Fe}<0.021$; $\mathrm{Sr}<0.018$ and $0.001<\mathrm{Ba}<$ 0.172 apfu. As expected, alkali feldspar crystals in dacite porphyries are, on the average, somewhat rich in An as compared with those in rhyolites; they present Fe $<0.024 ; \mathrm{Sr}<0.011$ and $0.006<\mathrm{Ba}<0.042$ apfu. 


\subsection{Ortho- and clinopyroxenes}

Pyroxenes were observed just in samples from the Sombrerillo Plutonic Massif. Both ortho- and clinopyroxenes occur in the main quartz monzonites and quartz monzodiorites. Clinopyroxene forms subhedral to anhedral, isolated, crystals, some among them partially replaced by calcic amphibole. Orthopyroxene occurs mostly as anhedral, sometimes rounded, crystals partially or fully replaced by clinopyroxene, mineral aggregates containing biotite, Fe-Ti oxides and some quartz, or pseudomorphs constituted by late, hydrothermal, phyllosilicates. In monzogranites, clinopyroxene appears sole as relicts in amphibole crystal cores while orthopyroxene is absent.

The orthopyroxene corresponds to a Fe-rich homogeneous enstatite $\left(E_{55-}\right.$ ${ }_{49} \mathrm{FS}_{42-47} \mathrm{Wo}_{2-3}$ ), with $0.017<\mathrm{Al}<0.024,0.024<\mathrm{Mn}<0.040,0.006<\mathrm{Ti}<0.009$ and $0.001<Z n<0.002$ apfu contents (Table 2, Fig. 5d; Fig. 7). The coexisting clinopyroxene is an augite (Wo $\left.26-42 \mathrm{En}_{39-48} \mathrm{Fs} 19-27\right)$ with similar $\mathrm{mg \#}\left[=\mathrm{Mg} /\left(\mathrm{Mg}+\mathrm{Fe}^{2+}\right)\right]$ numbers, in between 0.65 and 0.71 (Fig. 7). The augite compositions show a significant variation in their wollastonite molecular contents, from 26 to 42 . The observed trend of increasing Wo is interpreted as resulting from some type of kinetic factor influencing the reaction involving these phases and the coexisting melt. Wo increase is accompanied by a slightly $\mathrm{Mg} / \mathrm{Fe}$ ratio decrease.

Augite-diopside compositions (Wo44-48 $\mathrm{En}_{31-35} \mathrm{Fs}_{21}$ ), with similar mg\# numbers (0.63-0.70) characterize pyroxene relicts within amphibole crystal cores in monzogranite varieties (Table 2, Fig. 5e). They present relatively higher $\mathrm{Al}$ and $\mathrm{Na}$ 
contents as compared with the above described clinopyroxenes and present relatively lower $\mathrm{Fe}$ and $\mathrm{Mg}$ contents.

\subsection{Amphiboles}

Amphibole is the unique mafic silicate in some Algeciras monzogranite and granodiorite varieties; in most other petrographic varieties, it is joined by biotite, except the more felsic Altamira leuco granites. It has optical properties of the hornblende group and constitutes euhedral to suhedral prismatic, sometimes compositional zoned, crystals occurring isolated or grouped with biotite and accessory minerals in mafic clusters. In samples from the Sombrerillo Massif, it substitutes for clinopyroxene and/or orthopyroxene, while in most other granitic rocks it is substituted by late primary biotite. Of note, a colorless irregular core, sometimes with small quartz inclusions, appears within the amphibole in some Algeciras granodiorites. In subvolcanic rocks, amphibole is the only mafic silicate in the mafic-intermediate dikes and occurs with biotite in dacite and rhyolite porphyries. Amphibole phenocrysts in dacite porphyries are euhedral and depict a strong oscillatory zoning pattern; some among them are partially replaced by biotite, titanite, Fe-Ti oxides and quartz aggregates.

Amphiboles from plutonic rocks correspond mainly to magnesiohornblende, according the previous IMA recommendations (Leake et al., 1997; 2004; Fig. 8a), or magnesio-ferri-hornblende, according (Hawthorne et al., 2012), given the dominance of $\mathrm{Mg}$ over $\mathrm{Fe}$ in the $\mathrm{C}$ sites (Table 2, Fig. 5f). The colorless cores observed in some granodiorites classify as actinolite, and most probably, their occurrence in magmatic environments is due to kinetic factors affecting a previous 
pyroxene substitution reaction (Vlach, 1993; and references therein). The calcic amphibole from the dacite and rhyolite porphyries from Sombrerillo corresponds also to magnesiohornlende, the former showing also some tchermakite compositions. Amphiboles from the Algeciras dacite porphyry and the Altamira mafic-intermediate dikes present relatively high $(\mathrm{Na}+\mathrm{K})$ contents into $\mathrm{A}$ sites and classify as edenite and magnesiohastingsite (Table 2, Fig. 5g; Fig. 8b).

The analyzed amphiboles present medium to relatively high mg\# values ( 0.54 to 0.92), except for the Altamira rhyolite porphyry with $0.67 \leq \mathrm{mg} \# \leq 0.74$. Of note, mg\# numbers are, on the average, relatively high in subvolcanic $(0.79$ to 0.92$)$ as compared with the plutonic rocks (0.54 to 0.79$)$.

Most among the studied amphiboles display significant compositional zoning; the magnesiohornblende from Sombrerillo quartz monzonites and from the Algeciras rhyolite porphyry represent exceptions (Fig. 5f). In general, compositional core to rim zoning patterns are given by $\mathrm{Si}, \mathrm{Mg}$ and $\mathrm{Ti}$ decrease, accompanied by a proportional $\mathrm{Al}, \mathrm{Fe}^{\top}, \mathrm{Mn}$, and alkalis increase. Amphibole phenocrysts in the Algeciras and Sombrerillo dacite porphyries show strong compositional zoning, as depicted in a core to rim traverse in Fig. 6b. According, three main contrasted stages of phenocryst growth could be deduced: the first one is characterized by the core growth, characterized by relatively high concentrations of $\mathrm{Ti}, \mathrm{Al}, \mathrm{K}, \mathrm{Na}$ and $\mathrm{Fe}$, and low $\mathrm{Mg}$ contents; the intermediary zone depict $\mathrm{Mg}$ increase, accompanied by an abrupt decrease of the first elements; to end, the rim zones show a quick increase in those elements followed by a gradual decrease in most them, with exception Fe and Mn. 
The most relevant cationic correlations observed amphiboles are displayed in Fig. 7. Of importance, almost all Al fill in tetrahedral sites and present excellent positive correlations with total $\mathrm{Fe}, \mathrm{Ti},(\mathrm{Na}+\mathrm{K})^{\mathrm{A}},(\mathrm{Na}+\mathrm{K})^{\mathrm{A}+}{ }^{\mathrm{VI}} \mathrm{Al}+\mathrm{Fe}^{3+}+2 \mathrm{Ti}$, as well as $\mathrm{VI} A \mathrm{I}+\mathrm{Fe}^{3+}+2 \mathrm{Ti}$, indicating that compositional variations were controlled by combinations between tchermackitic-like (Al-, Fe- and Ti-tchermakite) and edenite substitution reactions (Vlach, 1993; and references therein); a slope about 1.2:1 in the linear correlation depicted in the ${ }^{\mathrm{IV}} \mathrm{Al}$ vs. ${ }^{\mathrm{V}} \mathrm{Al}+\mathrm{Fe}^{3+}+2 \mathrm{Ti}$ diagram (Fig. 8g) indicates some tetrahedral cationic deficiency and, thus, the relative dominance of tchermackitic over the edenite reactions (e.g. Robinson et al., 1971). Of note, the dacite porphyries and the mafic-intermediate dikes present relatively high contents of $\mathrm{Al}^{\top}$ (up to 2.347) and $\mathrm{Ti}$ (up to 0.323 ) as compared with plutonic rocks and the rhyolite porphyries.

\subsection{Biotite}

Biotite is the sole mafic silicate in the Altamira leuco monzogranites; in all other studied rocks, it joins calcic amphiboles. It constitutes subhedral to anhedral platy isolated crystals or forming clusters accompanied by the other mafic minerals. In general, crystals depict reddish-brown to brownish pleochroic colors. In the hornblende and biotite bearing rocks, biotite is relatively late in the magmatic crystallization sequence and substitutes for amphibole, as well for orthopyroxene in the two pyroxene-bearing varieties. By its time, it is substituted by chlorite and sometimes by prehnite during the late post-magmatic stages. The Altamira granodiorite present thin interstitial biotite aggregates, associated with epidote- 
group minerals, titanite and opaque phases, which developed in late hydrothermal events.

Biotite compositions, in both the plutonic and subvolcanic analyzed samples, show $2.272 \leq \mathrm{Al}^{\top} \leq 3.550$, relatively low ${ }^{\mathrm{IV}} \mathrm{Al}$ contents ( $\left.\leq 0.3 \mathrm{apfu}\right)$ and $0.47 \leq \mathrm{mg \#}$ $\left[=\mathrm{Mg} /\left(\mathrm{Mg}+\mathrm{Fe}^{\top}\right)\right.$ cationic $] \leq 0.65$. Most analyzes classify as phlogopite (Table 2, Fig. 5); somewhat Mg-rich annite compositions appears in Sombrerillo dacite porphyries and monzogranites. The most contrasted compositions are observed in the Algeciras leuco granite; it has relatively high $\mathrm{Al}$ contents $\left(3.1 \leq \mathrm{Al}^{\top} \leq 3.6\right)$, akin with the slightly peraluminous signature of the host rock (García-Chinchilla \& Vlach, submitted), and classifies as siderophyllite.

In general, our compositions are akin with those typical for calc-alkaline series from Abdel-Fattah \& Abdel-Rahman (1994; see Fig. 9b), and plot between primary and reequilibrate biotites (Nachit et al., 2005; see Fig. 9c). Ti contents are higher in phlogopite from the plutonic rocks (up to 0.586 apfu for instance in the Sombrerillo two-pyroxene bearing monzodiorites and biotite hornblende monzogranite) as compared with the subvolcanic ones and lower in siderophyllite, which by its time is richer in $\mathrm{Mn}$ (up to $0.25 \mathrm{apfu}$ ); $\mathrm{F}$ and $\mathrm{Ba}$ contents are relatively low (0.017 to 0.217 and $<0.056$ apfu, respectively) in all samples. Negative correlations between Si and Ti observed within each sample, except for the Sombrerillo hornblende biotite monzogranite (Fig. 9d), and the poor correlation between octahedral site contents and $\mathrm{Ti}$ (Fig. 9e), suggest that $\mathrm{Ti}$ entries the mica structure mainly through a Titchermakite substitution reaction (e.g. Dimek, 1983). 


\subsection{Fe-Ti oxides}

Magnetite is the main Fe-Ti oxide and opaque phase in all among the studied samples. It occurs as euhedral to subhedral, isolated, crystals or associated with the main mafic silicates and accessories. In the plutonic varieties, it appears with relatively abundant trellis-type exsolution patterns, given by abundant ilmenite lamellae development along (111) crystallographic planes Fig. 5i). Irregular patches of ilmenite is also seeing inside magnetite crystals, associated with fractures, as well as outside, close to magnetite crystal rims. Ilmenite, as typical individualized primary crystals, is scarce or absent in most of our samples.

The measured compositions of magnetite host and ilmenite lamellae are represented in Fig. 10. Magnetite crystal hosting the trellis-type intergrowths has important $\mathrm{Cr}, \mathrm{Zn}, \mathrm{V}$ contents (up to $0.265,0.627,0.788$ wt. $\%$, respectively) and low abundance of $\mathrm{Ti}$ and $\mathrm{Nb}$ and (2.5 and $0.098 \mathrm{wt} \%$, respectively), while the exsolved ilmenite presents low values among the former elements (up to $0.078,0.341$, $0.401 \%$ wt, respectively) and relatively enrichment in $\mathrm{Nb}$ contents (up to 1.13 wt. \%).

\section{CRYSTALLIZATION CONDITION ESTIMATES}

In this section we present and discuss some inferences concerning intensive crystallization parameters as derived from our whole-rock compositions (GarcíaChinchilla \& Vlach, submitted) and the herein presented mineralogical data. 


\subsection{Zircon and apatite saturation temperatures}

In metaluminous granitic rocks, $\mathrm{Zr}$ and $\mathrm{P}$ are typically essential structural constituents in zircon and apatite, respectively, thus the precipitation of these phases from the melt begins when $\mathrm{Zr}$ and $\mathrm{P}$ concentrations attain saturation conditions (e.g. Watson, 1979; Watson and Harrison, 1983; Harrison and Watson, 1984; Dickinson and Hess, 1982; Boehnke et al., 2013). Based on experimental dissolution results, Watson and Harrison $(1983,1984)$ obtained a simple function relating the concentration ratio $Z r_{Z}$ zicon $/ Z r_{\text {Host Rock }}\left(D^{Z r}\right)$, zircon saturation temperature and a compositional parameter $\mathrm{M}$, given by $(\mathrm{Na}+\mathrm{K}+2 \mathrm{Ca}) /\left(\mathrm{Al}{ }^{*} \mathrm{Si}\right)$ expressed in cationic proportions. More recently, Boehnke et al. (2013) revisited such experiments with improved controls for $\mathrm{H}_{2} \mathrm{O}$ and $\mathrm{fO}_{2}$ conditions, as well as applying modern high-resolution SIMS analysis. Their results did best fit the following equation:

$\ln \left(D^{Z r}\right)=\left(10108 \pm 32 / T_{K}\right)-[(1.16 \pm 0.15) \cdot(M-1)]-1.48 \pm 0.09$

, where (K) stands for Kelvin.

In a similar approach, Harrison and Watson (1984) were able to define a relation involving $\mathrm{D}_{\mathrm{P}}$, apatite saturation temperature and $\mathrm{SiO}_{2}$ (wt.\%) content, valid for metaluminous and peralkaline melts. Late, Pichavant et al. (1992) introduce a compositional factor considering Al saturation, expressed by the A/CNK parameter, and expanded it for typical peraluminous crystallization environments. According to the former authors, we have:

$\ln \left(D^{P}\right)=\left(\left(8400+2.64^{*}\left(\mathrm{SiO}_{2}-0.5\right)^{*} 10^{4} / \mathrm{T}_{\mathrm{K}}\right)-\left(3.1+\left(12.4^{*}\left(\mathrm{SiO}_{2}-0.5\right)\right)\right.\right.$ 
, valid for $45<\mathrm{SiO}_{2}$ (wt. \%) $\leq 75$ and $850^{\circ} \leq \mathrm{T}_{\mathrm{C}} \leq 1500^{\circ}$, and $0 \leq \mathrm{H}_{2} \mathrm{O}$ (wt. $\%$ ) $\leq 10$.

Accordingly, zircon and apatite saturation temperature estimates ( $T_{z r}$ and $T_{A p}$, respectively) for the studied samples are compared in Fig. 11a. Most among the intermediate to felsic plutonic rocks present $627^{\circ} \leq \mathrm{T}_{\mathrm{Zr}} \leq 790^{\circ}$ and $766^{\circ} \leq \mathrm{T}_{\mathrm{Ap}} \leq$ $932^{\circ}$; an exception is the Algeciras biotite hornblende monzogranite, with lower values $\left(627^{\circ}\right.$ and $779^{\circ} \mathrm{C}$, respectively). The dacite and rhyolite porphyries present $\mathrm{T}_{\mathrm{Ap}}$ varying in the ranges $907^{\circ}-920^{\circ} \mathrm{C}$ and $765^{\circ}-854^{\circ} \mathrm{C}$ and $\mathrm{Tzr}$ in the ranges $684^{\circ}-$ $705^{\circ} \mathrm{C}$ and $661^{\circ}-762^{\circ} \mathrm{C}$, respectively. As a whole and according to the applied formalism, apatite saturation occurs at higher temperatures than zircon, an expected feature, as minute apatite crystals occur as common zircon inclusions and the contrary was never observed (García-Chinchilla \& Vlach, submitted). Both these accessory phases are relatively earlier in the crystallization sequence of rocks with granitic (sensu estricto) compositions and thus, the obtained results may be considered good close-to-liquidus temperature estimates. Of importance, with the exception of the rhyolite porphyries, most studied rocks do not contain xenocrystic zircon crystals (García-Chinchilla \& Vlach, submitted) and, in the case of the Sombrerillo rocks, the initial crystallization of orthopyroxene among the mafic silicates indicates also relatively hot and anhydrous melts.

In the case of the mafic-intermediate dikes, $T_{A p}$ value (up to $907^{\circ} \mathrm{C}$ ) appears to approach the expected close-to-liquidus temperatures, as textural evidences indicate that apatite appears relatively early in the crystallization sequence. The $\mathrm{T} z \mathrm{r}$ value for this rocks are unrealistic lower $\left(534^{\circ}<\mathrm{T}_{Z \mathrm{r}}<631^{\circ}\right)$, as expected, given 
that $\mathrm{Zr}$ saturation conditions in such rocks is attained only after significant melt crystallization.

\subsection{Al-in-hornblende barometry and plagioclase-hornblende thermometry}

In granitic rocks with the appropriate primary mafic mineral assemblages (Caamphibole + biotite + magnetite + titanite \pm ilmenite \pm epidote $)$, in which the edenite substitution reaction is in general subordinate as compared with the tschermakite ones, the total $\mathrm{Al}$ content in amphibole is controlled mainly by the lithostatic pressure $(P)$. These findings were first announced by Hammarstrom and Zen (1986), based on empirical observations on contact metamorphic aureoles and the available barometric and mineral data. Using these data, authors drawn linear, polinomial and exponential regressions of $\mathrm{P}$ in dependence of $\mathrm{Al}^{\mathrm{T}}$; the linear model was the one with the best data fit. New empirical and experimental data by Hollister et al. (1987); Johnson \& Rutherford (1989); Schmidt (1992); Ridolfi et al. (2010); Mutch et al. (2016), among others, give way to new similar calibrations. The most recent, based on the previous available and new experimental data carried out by later authors, is given by the polimonial:

$\mathrm{P}( \pm 0.5, \mathrm{kbar})=0.5+0.331(8)+\mathrm{Al} \mathrm{I}^{\mathrm{T}}+0.995(4)^{\star}\left(\mathrm{Al}^{\mathrm{T}}\right)^{2}$

as remarked by the authors, this calibration is valid for amphibole in equilibrium with plagioclase $\left(A n_{15-80}\right)$ close to the haplogranite solidus $\left(725 \pm 75^{\circ} \mathrm{C}\right.$, as determined by the amphibole-plagioclase thermometry, e.g., Holland \& Blundy, 1994). 
We compare most among the availlable calibrations for our samples and, in general, linear models give higher pressure values, as compared with exponential or polinomial ones (see Table 4, and Suplementary Materials). For instance, the linear model of Hammarstrom \& Zen (1986) gives ca. $0.8 \leq \mathrm{P} \leq 3.5 \mathrm{kbar}$, while the exponential model of the same authors $\left(\mathrm{P}_{\mathrm{HZ}}\right)$ and the polinomial $\left(\mathrm{P}_{\mathrm{M}}\right)$ by Mutch et al. (2016) give similar lower values, between ca. $0.7 \leq \mathrm{P} \leq 2.2$ kbar. Considering our data, pressure estimated with lineal model $(P)$ is sistematically somewhat higher (up to $10-20 \%$ relative) than polinomial pressure calculated (both, $\mathrm{P}_{\mathrm{Hz}}$ and $\mathrm{P}_{\mathrm{M}}$ ) in the 1-4 kbar range and the latter is negative in the case of our lowest $\mathrm{Al}^{\top}$ contents in amphibole. Thus, $\mathrm{P}_{\mathrm{HZ}}$ values will be considered in this work. Given the expected errors in such estimates, the results show a good linear correlation $\left(r^{2}=\right.$ 0.99); however the exponetial pressure of Hammarstrom \& Zen (1986) fits better our data set $\left[P_{H Z}=0.172^{*}\left(P_{M}\right)^{2}+0.157^{*} P_{M}+0.615\left(r^{2}=1\right)\right]$. Accordingly, the closeto-solidus pressure average estimates for our plutonic rocks approaches $1.5 \pm 0.5$ kbar, from a total variation range of $1.0 \leq \mathrm{P}_{\mathrm{HZ}} \leq 2.2 \mathrm{kbar}$. There are no significant differences among the computed pressures for samples from the Algeciras, Altamira or Sombrerillo plutonic massifs. Of note, the calibration of Ridolfi et al. (2010) gives significant low estimates, between 0.7 and 1.6 kbar. Comparing Al-inhornblende pressure estimates with whole-rock normative compositions ploted in the Q-Ab-Or ternary system, the latter gives somewhat higher values, most samples ploting between 2 and 3 kbar cotectic lines (Fig. 11b).

This relatively low average pressure value (corresponding to ca. $4.5 \mathrm{~km}$ depth) estimated for the plutonic rocks agrees well with both the geological (e.g., close 
association with volcano-sedimentary rocks and felsic porphyries, and intrusive character in the former) and petrographic (micrographic and/or granophyric intergrowths in felsic porphyries and some leuco granites) evidences (cf. GarcíaChinchilla et al., submitted).

Close-to-solidus temperature estimates (Holland and Blundy, 1994) based on plagioclase-horblende equilibrium in the plutonic rocks are in between $720^{\circ}$ and $760^{\circ} \mathrm{C}$ (Fig. 11c).

Among the subvolcanic rocks, the rhyolite porphyries present relatively constant pressures, about $1.1 \mathrm{kbar}$. On the other hand, pressure estimates for the mafic-intermediate synplutonic dikes as well as the dacite porphyries are variable to a great extent, with pressure values up to $7.9 \mathrm{kbar}$ and, in the case of dacites, from $6.9 \mathrm{kbar}$ (crystal cores) to $1.1 \mathrm{kbar}$ (crystal rims), respectively (see Suplementary Materials). The average value for the rhyolite porphyry is compatible with the estimates for the plutonic rocks and should represent mineral assemblage equilibration at the final emplacement levels. Interpreting the results for the other subvolcanic rocks is not so straightforward however as equilibrium among the phenocryst assemblages in dacites for instance cannot be warranted and the used formulations do not apply properly. The systematics developed by Ridolfi et al. (2010) for calc-alkaline rocks allows avoid such questions, as the derived pressures and temperatures depend just on amphibole compositions. Using this approach, an average value about $5.6 \mathrm{kbar}$ is obtained for the mafic-intermediate dikes while values up to $5.1 \mathrm{kbar}$ (crystal cores) and dwon to $0.8 \mathrm{kbar}$ (crystal rims) were computed for dacite porphyries. According (see also Ridolfi and Rensulli, 
20120), an average temperature of $1020^{\circ} \mathrm{C}$ was computed for the maficintermediate dikes, while the phenocryst from dacite porphyries gives values from $898^{\circ}$ to $1050^{\circ} \mathrm{C}$ (crystal cores) and $806^{\circ}$ to $912^{\circ} \mathrm{C}$ (crystal rims). These temperatures comparate well with ternary feldspar solvus temperatures suggested for the Algeciras mafic-intermediate dike and dacite porphyre, in between $750^{\circ}$ and $900^{\circ} \mathrm{C}$ and close to $900^{\circ} \mathrm{C}$ isotherms (Fig. 11c; d), respectively.

The high pressure and temperature values registered in amphibole crystal cores and plagioclase compositions in these subvolcanic rocks suggest these phases begin to crystallize at relatively depth crustal levels, under high P-T conditions. The rims representative values in dacite porphyries, from 0.8 to $1.7 \mathrm{kbar}$, approaches very well those obtained for the host granites and associated rhyolite porphyries and, so, may be taken as representative of late amphibole crystallization stages at emplacement levels.

\subsection{Oxi-red and water saturation conditions}

The primary mafic mineral assemblages observed in most intermediate and felsic rocks ( \pm Ca-amphibole \pm biotite + magnetite + titanite $)$ indicate crystallization under relatively oxidizing environments, close to the titanite- magnetite-quartzamphibole-ilmenite buffer (TMQAI, cf. Noyes et al., 1983; Wones, 1989) and similar to the oxi-red conditions typical of the so-called magnetite series granites (Ishihara, 1977) from a qualitative perspective. As well, relatively oxidizing conditions are also inferred from the predominant magnesian whole-rock geochemical signatures as well as their connection with oceanic plate subduction in an active margin geodynamic scenario. 
In magnetite-bearing granitic rocks, the mg\# values of the coexisting mafic silicates, as biotite (Wones \& Eugster, 1965, see also Anderson et al., 2008) and amphibole (Anderson and Smith, 1995) are also diagnostic, increasing with the oxygen fugacity, $\mathrm{fO}_{2}$ Fig. 11. Diagrams illustrating the complementary parameter (fe\# = 1-mg\#) behavior of our amphibole and biotite compositions are presented in Fig. 11. In both cases, relatively high $f_{\mathrm{O} 2}$ conditions are evidenced and the biotite compositions indicate $a+1 \leq \Delta \mathrm{QFM} \leq+3$ range, where $\Delta \mathrm{QFM}$ stands for relative values in relation to the Quartz-Fayalite-Magnetite buffer at a given temperature. Of note, Sombrerrillo monzogranite and two-pyroxene monzodiorites are relatively less while the more felsic facies are more oxidized (cf. Fig. 12). Estimates based on fugacity-amphibole as propose by Ridolfi et al., (2010), by their time, give similar oxidized conditions and general trends, except for the two pyroxene-bearing granites (cf. supplementary materials).

Most among the studied granite and subvolcanic samples do not present ilmenite as a primary mineral phase in textural equilibrium with magnetite, preventing to determine independent $\mathrm{T}$ and $f_{\mathrm{O} 2}$ (e.g., Budington \& Lindsley, 1964; Anderson et al., 2008). On the other side, magnetite crystals from several samples, as previously described, commonly contains abundant ilmenite exsolution and, assuming that the exsolution process did occur in equilibrium, close-to-solidus to post-magmatic $\mathrm{T}$ and $f_{\mathrm{O} 2}$ figures may be obtained at first principles. Of importance, our compositions plot in accordance with the expected magnetite and ilmenite compositions found in deuteric, post-magmatic environments (see Fig. 10 and Ondrejka et al., 2011). Thus, we compute these parameters with the ILMAT 
software (Lepage, 2003), which is based in Fe-Ti oxides data set of Carmichael (1967) and Ghiorso and Evans (2008), respectively. Fig. 11f depicts the obtained results for the Sombrerillo monzogranites, two pyroxene-bearing monzodiorite and Altamira felsic porphyries. Temperature and $\log \left(f_{\mathrm{O}}\right)$ estimates range from $518^{\circ}$ to $683^{\circ} \mathrm{C}$ and -20 to -14 (monzogranites), $521^{\circ}$ to $595^{\circ} \mathrm{C}$ and -21 to -17 (two pyroxene granites), $674^{\circ}$ to $688^{\circ} \mathrm{C}$ and -13 to -16 (rhyolite porphyries).

Two estimates $\left(632^{\circ}\right.$ to $683^{\circ}$ for the biotite hornblende monzogranite and $674^{\circ}$ to $688^{\circ}$ for the rhyolite porphyry) approaches well the previous close-to-solidus temperature estimates, $\log \left(f_{\mathrm{O}}\right)$ values $(-14$ to -16 and -13 to -16 , corresponding to $\Delta \mathrm{NNO}$ ca. +4.12 to +0.65 and +2.91 to +0.53 , respectively) however they are significant higher than our estimates based on biotite, interpreted as representative of truly magmatic conditions. Thus, if the considered assumptions prove to be correct, our Fe-Ti oxide results reflect successive re-equilibrations events, under progressive temperature decrease during solidus, post-magmatic evolutionary stages. Of interest, the data from Algeciras and Sombrerillo monzogranites and Algeciras felsic porphyry samples describe an oxidizing trend with decreasing temperature, a behavior relatively common in the evolution path of granitic rocks.

Calc-alkaline magmas are typically water under-saturated (e.g. Blundy \& Holland, 1990; Holland \& Blundy, 1994; Ridolfi et al., 2010) and the mafic silicate observed in normal crystallization sequence (biotite initiates precipitation after amphibole and this after pyroxenes) indicates that water contents increase during magmatic evolution, as observed for instance in the rocks from the Sombrerillo Plutonic Massif, in which the earlier crystallization of orthopyroxene suggests low 
initial water contents. However, magmatic evolution in these environments do not occur within closed-like systems and potential very complex processes, as magmatic recharge, magma mixing and crustal assimilation, among others, were active as evidenced by geologic and geochemical data (cf. García-Chinchilla et al., submitted). These introduce external inputs to the evolving magmas and may turn water contents in melt estimates difficult and even meaningless in some granitic rocks. Any case, according to Ridolfi et al. (2010), hygrometric formulations considering amphibole-melt equilibria (cf. Table 2, Supplementary Material), estimates for water contents vary from 1.9 to $5.1 \mathrm{wt} \%$ in granites and in between 4.0 and 8.8 wt.\% in subvolcanic rocks. Of importance, amphibole phenocryst compositions in dacite porphyries point to relatively low water contents in crystal cores (in between 4.3 and 5.7 wt.\%) as compared with rims (4.9 to 6.7 wt.\%), which conforms the idea of an initial crystallization at deep and dry conditions and final equilibration at shallow emplacement levels under high water partial pressures.

\section{CONCLUSIONS AND FINAL REMARKS}

Granitic and related felsic subvolcanic rocks from the Altamira, Algeciras and Sombrerillo plutonic massifs present primary mafic mineral assemblages given by \pm Ca-amphibole+biotite+titanite \pm allanite+magnetite \pm ilmenite+apatite+zircon. Orthoand clinopyroxene also occur in somewhat particular monzodiorites and monzogranites from the Sombrerillo Plutonic Massif.

As a whole, the main mafic silicates (pyroxenes, amphibole and biotite) crystallized according the normal Bowen reaction series. Evidences for incomplete 
reactions due to armoring and kinetic effects were occasionally preserved, as clinopyroxene corroded relicts in Ca-amphibole, low-Ca clinopyroxene substituting for orthopyroxene and actinolite cores in Ca-amphibole. In the Sombrerillo Plutonic Massif, ortho- and clinopyroxene from the two pyroxene-bearing monzodiorites and monzogranites correspond to enstatite $(0.49 \leq \mathrm{mg \#} \leq 0.55)$ and subcalcic augite/augite $(0.65 \leq \mathrm{mg} \# \leq 0.71)$, respectively, while clinopyroxene relics from monzogranites are diopsidic, with $(0.63 \leq \mathrm{mg} \# \leq 0.70)$. Ca-amphiboles classify as magnesiohornblende in the plutonic rocks, with $0.54 \leq \mathrm{mg} \# \leq 0.79$, and magnesiohastingsite-edenite in the subvolcanic ones, presenting high mg\# values, between 0.79 and 0.92 . They are zoned to a variable extent, with increasing $\mathrm{Al}$, $\mathrm{Fe}^{\top}, \mathrm{Mn}$ and alkalis contents towards crystal rims. Amphibole phenocrysts from dacite porphyries show strong zoning patterns, associated with a protracted and complex crystallization history. Biotite compositions in the studied rocks correspond mainly do phlogopite; somewhat Mg-rich annite compositions appear in dacite porphyries and some monzogranites. The most contrasted compositions are observed in leuco granites from Algeciras, which present relatively high Al contents, up to 3.6 apfu, akin with the slightly peraluminous signature of the host rock (García-Chinchilla \& Vlach, submitted), and classify as siderophyllite.

Geothermobarometric estimates based on whole rock geochemistry, mineral compositions and hornblende-plagioclase equilibrium indicates that the main plutonic massifs emplaced at equivalent relatively shallow crustal levels (ca. $1.5 \pm$ $0.5 \mathrm{kbar}=150 \pm 50 \mathrm{MPa} \approx 4.5 \pm 1.5 \mathrm{~km}$ depth$),$ comparable with depths $(3-5 \mathrm{~km})$ estimated for some present day magmatic chambers as the ones associated with 
the Sofriére Hills volcano in West Indies and El Reventador volcano in Ecuador (Ridolfi et al., 2010; Fig. 13.). Granitic rocks were formed by magmas with close-toliquidus temperatures as high as ca. $900^{\circ} \mathrm{C}$, as deduced from apatite saturation in melts and also from the presence of orthopyroxene as the first mafic silicate in the crystallization sequence of monzodiorites and monzogranites from the Sombrerillo Plutonic Massif and crystallization ends by ca. $720^{\circ}-760^{\circ} \mathrm{C}$, our close-to-solidus temperature estimates. The mafic mineral assemblage and mafic silicate compositions indicate relatively oxidizing conditions during the main stages of magma crystallization $(+1 \leq \Delta \mathrm{QFM} \leq+3)$, under water under saturated conditions (ca. 2-5 wt.\% $\mathrm{H}_{2} \mathrm{O}$ ); ilmenite exsolution and magnetite host compositions point to a general $f_{\mathrm{O} 2}$ increase in post-magmatic crystallization stages and relatively oxidizing trends with decreasing sub-solidus temperatures. The results obtained for rhyolite porphyries are similar (ca. 1.1. kbar, and oxidizing conditions).

On the other hand, geothermobarometric, based sole on amphibole compositions, suggest that amphibole from mafic-intermediate syn-plutonic dikes preserves pressure and temperature values up to $5.6 \mathrm{kbar}$ and $1020^{\circ}$, pointing to its crystallization in high depths, while amphibole phenocrysts in dacite porphyries register a protracted crystallization history, given by crystal cores precipitation under relatively high pressures and temperatures (up to $5.1 \mathrm{kbar}, 1050^{\circ} \mathrm{C}$ and $\mathrm{H}_{2} \mathrm{O}$ contents in between 4.3-5.7 wt.\%) and crystal rims equilibration pressure and temperature down to $0.8 \mathrm{kbar}, 800^{\circ} \mathrm{C}, 4.9-6.7$ wt. $\% \mathrm{H}_{2} \mathrm{O}$. These values suggest at least two main crystallization stages, one initial at great depth crustal levels with 
less water, and other at final shallower emplacement levels, under high water contents, compatible with the granite host crystallization conditions.

\section{ACKNOWLEDGEMENTS}

Authors thank to Conselho Nacional de Desenvolvimento Científico e Tecnológico-CNPq for a Doctoral scholarship (Proc. 142098/2013-2 to D.A. García-Chinchilla) and to GeoAnalitica-USP core facility for lab support. L. Moraes and M. Mansueto give support during EPMA work.

\section{REFERENCES}

Abdel-rahman, A.M., 1994. Nature of Biotites from Alkaline , Calc-alkaline , and Peraluminous Magmas. J. Petrol. 35, 525-541.

Altenberger, U., Mejia Jimenez, D.M., Gunter, C., Sierra Rodriguez, G.I., Scheffler, F., Oberhansli, R., 2012. The Garzón Massif, Colombia-a new ultrahightemperature metamorphic complex in the Early Neoproterozoic of northern South America. Mineral. Petrol. 105, 171-185. doi:10.1007/s00710-012-02021

Andersen, D.J., Lindsley, D.H., 1988. Internally consistent solution models for FeMg-Mn-Ti oxides: Fe-Ti oxides: Fe-Ti oxides. Am. Mineral. 73, 714-726.

Anderson, A.T., 1968. Oxidation of the La Blanche Lake titaniferous magnetite deposit, Québec. J. Geol. 76, 528-547.

Anderson, J.L., Barth, a. P., Wooden, J.L., Mazdab, F., 2008. Thermometers and Thermobarometers in Granitic Systems. Rev. Mineral. Geochemistry 69, 121142. doi:10.2138/rmg.2008.69.4

Anderson, J.L., Smith, D.R., 1995. The effects of temperature fO2 on the Al-inhornblende barometer. Am. Mineral. 80, 549-559.

Barbarin, B., 1999. A review of the relationships between granitoid types, their origins and their geodynamic environments. Lithos 46, 605-626. doi:10.1016/S0024-4937(98)00085-1

Blundy, J., Cashman, K., 2001. Ascent-driven crystallisation of dacite magmas at Mount St Helens, 1980-1986. Contrib. to Mineral. Petrol. 140, 631-650. doi:10.1007/s004100000219

Blundy, J.D., Holland, T.J.B., 1990. Mineralogy and Calcic amphibole equilibria and a new amphibole- plagioclase geothermometer. Contrib. to Mineral. Petrol. 104, 208-224. 
Boehnke, P., Watson, E.B., Trail, D., Harrison, T.M., Schmitt, A.K., 2013. Zircon saturation re-revisited. Chem. Geol. 351, 324-334. doi:10.1016/j.chemgeo.2013.05.028

Budington, A.F., Lindsley, D.H., 1964. Iron-Titanium Oxide Minerals and Synthetic Equivalents. J. Petrol. 5, 310-357.

Bustamante, C., Archanjo, C.J., Cardona, A., Vervoort, J.D., 2016. Late Jurassic to Early Cretaceous plutonism in the Colombian Andes: A record of long-term arc maturity. Bull. Geol. Soc. Am. 128, 1762-1779. doi:10.1130/B31307.1

Carmichael, I.S.E., 1967. The Fe-Ti oxides of salic volcanic rocks and their associated ferromagnesian silicates. Contrib. Mineral. Petrol. 14,36-64, 36-64.

Cochrane, R., Spikings, R., Gerdes, A., Winkler, W., Ulianov, A., Mora, A., Chiaradia, M., 2014. Distinguishing between in-situ and accretionary growth of continents along active margins. Lithos 202-203, 382-394. doi:10.1016/j.lithos.2014.05.031

Dimek, R.F., 1983. Titanium, aluminum and interlayer cátion substitutions in biotite from high-grade gneisses, West Greenland. Am. Mineral. 68, 880-899.

Droop, G.T.R., 1987. A General Equation for Estimating Fe3+ Concentrations in Ferromagnesian Silicates and Oxides from Microprobe Analyses, Using Stoichiometric Criteria. Mineral. Mag. 51, 431-435. doi:10.1180/minmag.1987.051.361.10

Elkins, L.T., Grove, T.L., 1990. Ternary feldspar experiments ans thermodynamic models. Am. Mineral. 75, 544-559. doi:scopus/2-s2.0-0025658265

Foster, M.D., 1960. Interpretation of the composition of trioctahedral micas. Geol. Surv. Prof. Pap. 354, 1-49.

Frost, B.R., Barnes, C.G., Collins, W.J., Arculus, R.J., Ellis, D.J., Frost, C.D., 2001. A geochemical classification for granitic rocks. J. Petrol. 42, 2033-2048. doi:10.1093/petrology/42.11.2033

Garcia-Chinchilla, D., Vlach, S.R.F., n.d. Insights on timing and source of Jurassic magmatism on the Northwestern Andes: In situ U-Pb dating, $\mathrm{Hf}$ isotope geochemistry of zircons and whole-rock geochemistry from granites and related rocks of the Garzón region, Eastern Cordillera of Colombia.

García-Chinchilla, D., Vlach, S.R.F., Giraldo-Arroyave, M.I., n.d. Geological Mapping of Intrusive Rocks: A Case of Study in the Garzón region, Eastern Cordillera of Colombian Andes.

Gómez, J., Nohora, E., Ramírez, M., 2015. Mapa Geológico de Colombia, Servicio Geologico Colombiano.

Gualda, G.A.R., Vlach, S.R.F., 2007a. The Serra da Graciosa A-type Granites and Syenites, southern Brazil. Part 2: Petrographic and mineralogical evolution of the alkaline and aluminous associations. Lithos 93, 310-327. doi:10.1016/j.lithos.2006.06.002

Gualda, G.A.R., Vlach, S.R.F., 2007b. The Serra da Graciosa A-type Granites and Syenites, southern Brazil. Part 3: Magmatic evolution and post-magmatic 
breakdown of amphiboles of the alkaline association. Lithos 93, 328-339. doi:10.1016/j.lithos.2006.03.070

Gualda, G.A.R., Vlach, S.R.F., 2005. Stoichiometry-based estimates of ferric iron in calcic, sodic-calcic and sodic amphiboles: A comparison of various methods. An. Acad. Bras. Cienc. 77, 521-534. doi:10.1590/S000137652005000300012

Hammarstrom, J.M., Zen, E., 1986. Aluminum in hornblende: An empirical igneous geobarometer. Am. Mineral. 71, 1297-1313.

Harrison, T.M., Watson, E.B., 1984. The behavior of apatite during crustal anatexis: Equilibrium and kinetic considerations. Geochim. Cosmochim. Acta 48, 1467-1477.

Hawthorne, F.C., Oberti, R., Harlow, G.E., Maresch, W. V., Martin, R.F., Schumacher, J.C., Welch, M.D., 2012. Nomenclature of the amphibole supergroup. Am. Mineral. 97, 2031-2048.

Holland, T., Blundy, J., 1994. Non-ideal interactions in calcic amphiboles and their bearing on amphibole-plagioclase thermometry. Contrib. to Mineral. Petrol. 116, 433-447.

Hollister, L.S., Grissom, G.C., Peters, E.K., Stowell, H.H., Sisson, V.B., 1987. Confirmation of the empirical correlation of $\mathrm{Al}$ in hornblende with pressure of solidification of calc-alkaline plutons. Am. Mineral. 72, 231-239.

Ibanez-Mejia, M., Ruiz, J., Valencia, V. a., Cardona, A., Gehrels, G.E., Mora, A.R., 2011. The Putumayo Orogen of Amazonia and its implications for Rodinia reconstructions: New $\mathrm{U}-\mathrm{Pb}$ geochronological insights into the Proterozoic tectonic evolution of northwestern South America. Precambrian Res. 191, 5877. doi:10.1016/j.precamres.2011.09.005

Ishihara, S., 1977. The magnetite-series and ilmenite-series granitic rocks. Min. Geol. 27, 293-305.

Jiménez Mejía, D.M., Juliani, C., Cordani, U.G., 2006. P-T-t conditions of highgrade metamorphic rocks of the Garzon Massif, Andean basement, SE Colombia. J. South Am. Earth Sci. 21, 322-336. doi:10.1016/j.jsames.2006.07.001

Johnson, M.C., Rutherford, M.J., 1989. Experimental calibration of the aluminumin-hornblende geobarometer with application to Long Valley caldera (California) volcanic rocks. Geology 17, 837-841.

Leake, B.E., Woolley, A.R., Arps, C.E.S., Birch, W.D., Gilbert, C.M., Grice, J.D., Hawthorne, F.C., Kato, A., Kisch, H.J., Krivovichev, V.G., Linthout, K., Laird, J., Mandarino, J. a., Maresch, W. V., Nickel, E.H., Rock, N.M.S., Schumacher, J.C., Smith, D.C., Stephenson, N.C.N., Ungaretti, L., Whittaker, E.J.W., Youzhi, G., 1997. Nomenclature of Amphiboles: Report of the Subcommittee of the International Commission on New Minerals Names and Mineral. Can. Mineral. 35, 219-246.

Leal-Mejía, H., 2011. Phanerozoic Gold Metallogeny in the Colombian Andes: A 
Tectono-Magmatic Approach. Tesis Dr. Universitat de Barcelona.

Lepage, L.D., 2003. ILMAT: An Excel worksheet for ilmenite-magnetite geothermometry and geobarometry. Comput. Geosci. 29, 673-678. doi:10.1016/S0098-3004(03)00042-6

Lindsley, D.H., Spencer, K.J., 1982. Fe-Ti oxide geothermometry: Reducing analyses of coexisting Ti-magnetite (Mt) and ilmenite (Ilm) abstract AGU 1982 Spring Meeting Eos Transactions. Am. Geophys. Union 63, 471.

Mantilla Figueroa, L.C., Bissig, T., Valencia, V., Hart, C.J.R., 2013. The magmatic history of the Vetas-California mining district, Santander Massif, Eastern Cordillera, Colombia. J. South Am. Earth Sci. 45, 235-249. doi:10.1016/j.jsames.2013.03.006

McCourt, W.J., Aspden, J.A., Brook, M., 1984. New geological and geochronological data from the Colombian Andes: continental growth by multiple accretion. J. Geol. Soc. London. 141, 831-845.

McDonough, W.F., Sun, S. -s., 1995. The composition of the Earth. Chem. Geol. 120, 223-253.

Mojica, J., Villarroel, C., Bayer, K., 1988a. Afloraminetos del Paleozoico Superiror en el Macizo de Garzón (Cordillera Oriental) y Valle Superior del MAgdalena, Colombia. Geol. Colomb. 16, 99-104.

Mojica, J., Villarroel, C., Bayer, K., 1988b. 4. Afloramientos del Paleozoico Superior en el Macizo de Garzón (Cordillera Oriental) y el Valle Superior del Magdalena, Colombia. Geol. Colomb. 16, 99-104.

Moreno-Sánchez, M., Gómez-Cruz, A. de J., Castillo-González, H., 2008. Graptolitos del Ordovícico y Geología de los afloramientos del Río Venado (norte del Departamento del Huila). Bol. Geol. 30, 9-19.

Morimoto, N., 1988. Nomenclature of Pyroxenes. Mineral. Petrol. 39, 55-76. doi:10.1007/BF01226262

Mutch, E.J.F., Blundy, J.D., Tattitch, B.C., Cooper, F.J., Brooker, R.A., 2016. An experimental study of amphibole stability in low-pressure granitic magmas and a revised Al-in-hornblende geobarometer. Contrib. to Mineral. Petrol. 171, 127. doi:10.1007/s00410-016-1298-9

Nachit, H., Ibhi, A., Abia, E.H., Ohoud, M. Ben, 2005. Discrimination between primary magmatic biotites, reequilibrated biotites and neoformed biotites 337 , 1415-1420. doi:10.1016/j.crte.2005.09.002

Nakamura, N., 1974. Determination of REE, Ba, $\mathrm{Fe}, \mathrm{Mg}, \mathrm{Na}$ and $\mathrm{K}$ in carbonaceous and ordinary chondrites. Geochim. Cosmochim. Acta 38, 757775.

Noyes, H.J., Wones, D.R., Frey, F.A., 1983. A tale of two plutons: Petrographic and mineralogic constraints on the petrogenesis of the Red Lake and Eagle Peak plutons, central Sierra Nevada, California. J. Geol. 91, 353-379.

Núñez, A., 2003. Reconocimiento geológico regional de las planchas 411 La Cruz, 412 San Juan de Villalobos, 430 Mocoa, 431 Piamonte, 448 Monopamba, 449 
Orito y 465 Churuyaco. Departamentos de Caquetá, Cauca, Huila, Nariño y Putumayo. Escala 1:100.000. INGEOMINAS. Memoria . Bogotá D. C. doi:10.1024/0301-1526.32.1.54

Ondrejka, M., Broska, I., Uher, P., 2011. The late magmatic to subsolidus T-fO2 evolution of the Lower Triassic A- type rhyolites (Silicic Superunit, Western Carpathians, Slovakia ): Fe-Ti oxythermo- metry and petrological implications. Acta Geol. Slovaca 7, 51-61.

Pearce, J.A., Harris, N.B.W., Tindle, A.G., 1984. Trace Element Discrimination Diagrams for the Tectonic Interpretation of Granitic Rocks. J. Petrol. 25, 956983.

Pichavant, M., Montel, J.-M., Richard, L.R., 1992. Apatite solubility in peraluminous liquids: Experimental data and an extension of the Harrison-Watson model. Geochim. Cosmochim. Acta 56, 3855-3861.

Ridolfi, F., Renzulli, A., Puerini, M., 2010. Stability and chemical equilibrium of amphibole in calc-alkaline magmas: an overview, new thermobarometric formulations and application to subduction-related volcanoes. Contrib. to Mineral. Petrol. 160, 45-66. doi:10.1007/s00410-009-0465-7

Rieder, M., Cavazzini, G., D’Yakonov, Y.S., Frank-Kamenetskii, V., Gottardi, G., Guggenheim, S., Koval, P. V., Muller, G., Neiva, A.M.R., Radoslovich, E., Robert, J.-L., Sassi, F.P., Takeda, H., Weiss, Z., Wones, D.R., 1999. Nomenclature of the micas. Mineral. Mag. 63, 267-279.

Robinson, P., Ross, M., Jaffe, H.W., 1971. Composition of the anthophyllite-gedrite series, comparison of gedrite-hornblende, and the anthophyllite-gedrite solvus. Am. Mineral. 56, 1005-1041.

Rodríguez, G., Arango, M.I., Zapata, G., Bermúdez, J.G., 2018. Petrotectonic characteristics, geochemistry, and $\mathrm{U}-\mathrm{Pb}$ geochronology of Jurassic plutons in the Upper Magdalena Valley-Colombia: Implications on the evolution of magmatic arcs in the NW Andes. J. South Am. Earth Sci. 81, 10-30. doi:10.1016/j.jsames.2017.10.012

Salazar, F.A., 2016. Experimento de fusão-desidratação $\left(400 \mathrm{MPa}, 950^{\circ} \mathrm{C}\right)$ de granitos cálcio-alcalinos de alto K (Bragança Paulista, SP( e implicações para a geração de granitos ferroanos peraluminosos. Universidade de São Paulo.

Schmidt, M.W., 1992. Amphibole composition in tonalite as a function of pressure: an experimental calibration of the Al-in-hornblende barometer. Contrib. to Mineral. Petrol. 110, 304-310.

Stern, C.R., 2011. Subduction erosion: Rates, mechanisms, and its role in arc magmatism and the evolution of the continental crust and mantle. Gondwana Res. 20, 284-308. doi:10.1016/j.gr.2011.03.006

Stormer, J.C.J., 1983. The effects of recalculation on estimates of temperature and oxygen fugacity from analyses of multi-component iron-titanium oxides. Am. Mineral. 68, 586-594.

Streckeisen, A., 1976. To each plutonic rock its proper name. Earth-Science Rev. 
12, 1-33. doi:10.1016/0012-8252(76)90052-0

Velandia, F.P., Ferreira, P. V., Rodríguez, G., Núñez, A., 2001. Leavantamiento geológico de la Plancha 366 Garzón. Escala 1:100.000. INGEOMINAS. Bogotá D. C.

Vilalva, F.C.J., Vlach, S.R.F., Simonetti, A., 2016. Chemical and O-isotope compositions of amphiboles and clinopyroxenes from A-type granites of the Papanduva Pluton, South Brazil: Insights into late- to post-magmatic evolution of peralkaline systems. Chem. Geol. 420, 186-199. doi:10.1016/j.chemgeo.2015.11.019

Villagómez, D., Spikings, R., Magna, T., Kammer, A., Winkler, W., Beltrán, A., 2011. Geochronology, geochemistry and tectonic evolution of the Western and Central cordilleras of Colombia. Lithos 125, 875-896. doi:10.1016/j.lithos.2011.05.003

Villarroel, C., Macia, C., Brieva, J., 1997. Formación Venado, Nueva Unidad Litoestratliqráfica del Ordovícico Colombiano. Geol. Colomb. 22, 41-49.

Vlach, S.R.F., 1993. Geologia e Petrologia dos granotóides de Morungaba, SP. Tese de Doutoramento. Universidade de São Paulo.

Watson, E.B., Harrison, T.M., 1983. Zircon saturation revisited: temperature and composition effects in a variety of crustal magma types. Earth Planet. Sci. Lett. 64, 295-304. doi:10.1016/0012-821X(83)90211-X

Whitney, D.L., Evans, B.W., 2010. Abbreviations for names of rock-forming minerals. Am. Mineral. 95, 185-187. doi:10.2138/am.2010.3371

Wones, D.R., 1989. Significance of the assemblage titanite + magnetite + quartz in granitic rocks. Am. Mineral. 74, 744-749.

Wones, D.R., Eugster, H.P., 1965. Stability of biotite: experiment theory, and application. Am. Mineral. 50, 1228-1272.

Zapata, S., Cardona, A., Jaramillo, C., Valencia, V., Vervoort, J., 2016. U-Pb LAICP-MS geochronology and geochemistry of jurassic volcanic and plutonic rocks from the Putumayo region (southern Colombia): Tectonic setting and regional correlations. Bol. Geol. 38, 21-38. doi:10.18273/revbol.v38n22016001 


\section{FIGURE CAPTIONS}

Fig. 1. Geological localization and settings of Garzón granites and related rocks (a) Northwestern of South America, Central America, Caribbean, and Colombia internal division (b) Digital elevation model showing the Colombian Andes (Central and Eastern Cordilleras); Jurassic plutonic massifs in red. (c) Mapped petrographic facies of Algeciras, and (d) Altamira plutonic massif, modified of García-Chinchilla et al. (submitted). Regional geologic map of Sombrerillo igneous massifs modified from Gómez et al. (2015). Sample location in green.

Fig. 2. Modal Quartz-Alkali feldspar-Plagioclase (Q-A-P) classification diagram (Streckeisen, 1976). Samples from Algeciras: green; Altamira: blue and Sombrerillo: red. Arrow represent typical trend of high-K calc-alkaline rocks, associated to subduction in a continental margin according to (Nédélec and Bouchez, 2015). Modified from GarcíaChinchilla et al. (submitted).

Fig. 3. Some textural features of the Garzón granites and related rocks. Optical photomicrographs obtain under cross polarizers (a) (c) (d) (e) (g) (h) and (b) (f) (i), plane polarized light. (a), (b) Biotite hornblende monzogranites of Algeciras. (c) Spherulitic quartz-alkali feldspar intergrowth in rhyolite sample from Algeciras. (d) Mafic-intermediate dikes with intergranular texture given by laths of plagioclase with interstitial Ca-amphibole and chlorite aggregates. (e), (f) Biotite quartz-monzodiorite with clino- and orthopyroxenes. (g) Plagioclase phenocryst with oscillatory zoning in dacitic porphyry from Sombrerillo. (h) (i) Magnesiohornblende, biotite, plagioclase and titanite phenocrysts in a micro-crystalline mesostasis of quartz, orthoclase and opaque minerals. Mineral abbreviations according to Whitney \& Evans (2010): Ab = albite; Amp = amphibole; Ann = annite; $\mathrm{Aug}=$ augite; $\mathrm{Chl}=$ Chlorite; $\mathrm{En}$ = enstatite; Ilm = ilmenite; Mag = magnetite; $\mathrm{Mhb}=$ magnesiohornblende; $\mathrm{Or}=$ orthoclase; $\mathrm{Phl}=$ phlogopite; $\mathrm{Pl}=$ plagioclase; $\mathrm{Qtz}=$ quartz; Ttn $=$ titanite.

Fig. 4. Geochemical classification diagrams of Garzón granites and related rocks. (a) $\mathrm{Na}_{2} \mathrm{O}+\mathrm{K}_{2} \mathrm{O}-\mathrm{CaO}$ vs. $\mathrm{SiO}_{2}$, (b) $\mathrm{FeOt} /(\mathrm{FeOt}+\mathrm{MgO})$ vs. $\mathrm{SiO}_{2}$ diagram, all in oxide wt.\%, and (c) Plot of $\mathrm{A} / \mathrm{NK}\left(\mathrm{Al}_{2} \mathrm{O}_{3} / \mathrm{Na}_{2} \mathrm{O}+\mathrm{K}_{2} \mathrm{O}\right)$ vs. $\mathrm{ASI}$, the molecular ratio $\mathrm{Al} /(\mathrm{Ca}-1.67 \mathrm{P}+\mathrm{Na}+\mathrm{K})$ (Frost et al., 2001). (d) Plot $\mathrm{Rb}$ vs. $(\mathrm{Y}+\mathrm{Nb})$ discriminant diagram for syn-collision (syn$\mathrm{COL}$ ), volcanic ar (VA), within plate (WP) and normal and anomalous ocean ridge (OR) granites (Pearce et al., 1984). (e) Median chondrite-normalized rear-earth elements 
patterns for intrusive (dark gray) and subvolcanic (light gray) rocks (Nakamura, 1974). (f) MORB-normalized extended trace element patterns for intrusive rocks (dark gray) and subvolcanic (light gray) rocks (McDonough and Sun, 1995). Geochemical data from García-Chinchilla \& Vlach, (submitted).

Fig. 5. Back-scattered images in compositional mode (BSE-Compo) of mineral phases of Garzón granites and related rocks. (a) Oligoclase $\left(A n_{14}\right)$ of Algeciras leuco monzogranite. (b) Andesine $\left(A n_{58-33}\right)$ phenocryst of Sombrerillo dacite porphyry. (c) Orthoclase of Algeciras biotite hornblende monzogranite. (d) Enstatite grain substituted by augite of Sombrerillo two-pyroxenes-bearing monzodiorite. (e) Augite relict in magnesiohornblende crystal core from Sombrerillo biotite monzogranite. (f) Magnesiohornblende of Algeciras Bt-Hrn monzogranite (g) Magnesiohastingsite of Altamira intermediate-mafic dikes. (I) Plagioclase from basaltic andesite dyke from Algeciras. (h) Phlogopite and, (i) Magnetite (white or light gray) with lamellae of ilmenite (dark gray) of Sombrerillo biotite hornblende monzogranite. Red points identify analyzed spots.

Fig. 6. Core to rim (A-B) compositional profiles in plagioclase (a) and amphibole (b) phenocrysts from dacite porphyry facies of Sombrerillo. Note strong oscillatory zoning in BSE images. See discussion in text.

Fig. 7. Ca-Mg-(Fe $\left.{ }^{2+}+\mathrm{Mn}\right)$ cationic plots showing the compositions of (a) clinopyroxene and (b) orthopyroxene from the Sombrerillo two-pyroxene bearing monzodiorites (red) and biotite hornblende monzogranites (blue).

Fig. 8. $\mathrm{Mg} / \mathrm{Mg}+\mathrm{Fe}^{2+}$ vs. Si amphibole classification diagram after Leake et al. (1997), $\mathrm{Fe}^{2+} / \mathrm{Fe}^{3+}$ as suggested by Gualda and Vlach (2005). (a) $\mathrm{Ca}_{\mathrm{B}} \geq 1.50 ;(\mathrm{Na}+\mathrm{K})_{\mathrm{A}}<0.50 ; \mathrm{Ca}_{\mathrm{A}}$ $<0.50$; (b) $\mathrm{Ca}_{B} \geq 1.50 ;(\mathrm{Na}+\mathrm{K})_{A} \geq 0.50 ; \mathrm{Ti}<0.50$. Note Si content decrease from crystal cores to rims. Cationic correlations of (c) $\mathrm{Al}^{\mathrm{IV}}$ vs. $\mathrm{Fe}^{\mathrm{T}}$, (d) $\mathrm{Al}^{\mathrm{IV}}$ vs. $\mathrm{Ti}^{\mathrm{v}}$, (e) $\mathrm{Al}^{\mathrm{IV}}$ vs. $(\mathrm{Na}+\mathrm{K})^{\mathrm{A}}$, (f) $A I^{I V}$ vs. $(\mathrm{Na}+\mathrm{K})^{\mathrm{A}}+\mathrm{Al}^{\mathrm{V}+}+\mathrm{Fe}^{+3}+2 \mathrm{Ti}^{\mathrm{VI}}$, (g) $\mathrm{Al}^{\mathrm{IV}}$ vs. $\mathrm{Al}^{\mathrm{V} l}+\mathrm{Fe}^{+3}+2 \mathrm{Ti}^{\mathrm{V} l}$. See discussion in text.

Fig. 9. Cationic plots depicting micas from the Garzón granites and related rocks compositional variations. (a) Alv vs. Fe/Fe+Mg classification diagram after Rieder et al.

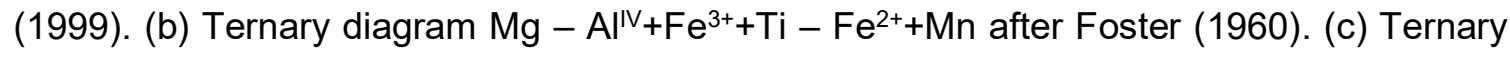
diagram $\mathrm{MgO}-\mathrm{FeO}_{\mathrm{T}}-\mathrm{Al}_{2} \mathrm{O}_{3}$. (d) Correlation of total occupation in the octahedral sheets $\left(\Sigma \mathrm{O}=\mathrm{Al}^{\mathrm{V} I}+\mathrm{Ti}^{\mathrm{Vl}}+\mathrm{Fe}^{3+}+\mathrm{Fe}^{2+}+\mathrm{Mn}^{2+}+\mathrm{Mg}\right)$ and $\mathrm{Ti}^{\mathrm{Vl}}$. (e) Correlation between cationic fractions of $\mathrm{Mg}$ in octahedral sheets $(\mathrm{XMg}=\Sigma \mathrm{O} / \mathrm{Mg})$ and cationic fraction $\mathrm{F} /(\mathrm{F}+\mathrm{OH}+\mathrm{Cl})$, where 
$(\mathrm{F}+\mathrm{OH}+\mathrm{Cl}=4) . \mathrm{Fe} 2+$ and $\mathrm{Fe} 3+$ are discriminate by Droop (1987) equation. Symbols as in Fig. 6.

Fig. 10. Composition of Fe-Ti oxides plotted in $\mathrm{Ti}-\mathrm{Fe}-0.5 \mathrm{Fe} 2 \mathrm{O} 3$ ternary diagram (atomic proportions) as modified after Budington \& Lindsley, 1964; Ondrejka et al., 2011). Thick lines denote high temperature solid solutions (ulvöspinel-magnetite, hematite-ilmenite, pseudobrookite-ferropseudobrookite); the dashed line shows the heterostructural tie line ilmenite-magnetite, resulting from deuteric oxidation and breakdown of primary Ti-rich magnetite. Minor components are allocated as follows: $\mathrm{FeO}=\Sigma \mathrm{R}^{2+}=\mathrm{Fe}^{2+}+\mathrm{Mg}+\mathrm{Mn}$; $\mathrm{Fe}_{2} \mathrm{O}_{3}=0.5 \Sigma \mathrm{R}^{3+}=0.5\left(\mathrm{Fe}^{3+}+\mathrm{Al}+\mathrm{Cr}\right)$. Note that $\left(\mathrm{Fe}_{2} \mathrm{O}_{3} / 2\right)$, instead of $\mathrm{Fe}_{2} \mathrm{O}_{3}$, is plotted; this normalizes all diagram components to one cation.

Fig. 11. Plots involving intensive crystallization parameters for the Garzón granites and related rocks (a) apatite and zircon saturation temperatures ( $T_{A p}$ and $T_{Z r}$, respectively). (b) Normative compositions of Garzón granitic samples (García-Chinchilla \& Vlach, submitted) in the haplogranitic Or-Ab-Qz ternary system, with cotectic lines from Blundy and Cashman (2001). Average compositions of of alkali feldspar and plagioclase compositions in the Anorthite (An) - Albite (Ab) - Orthoclase (Or) molecular ternary plot for (c) intrusive, and (d) volcanic to subvolcanic and facies. Solvus lines at $\mathrm{P}=100 \mathrm{MPa}$, after Elkins and Grove (1990), and Andersen and Lindsley, (1988). (e) Al-in-hornblende barometric estimates (exponential model of Hammarstrom and Zen (1986) vs. Plagioclase-amphibole thermometry of Holland and Blundy (1994) and amphibole temperature after RIdolfi et al. (2010). (f) $\log \mathrm{fO}_{2}$ vs. T estimates from Fe-Ti oxide compositions. Buffers are IW = ironwüstite; $\mathrm{MW}=$ magnetite-wüstite; $\mathrm{Ml}=$ magnetite-iron; $\mathrm{FMQ}$ = fayalite-magnetite-quartz; $\mathrm{NNO}=$ nickel-nickel oxide; $\mathrm{MNO}=6 \mathrm{MnO}+\mathrm{O}_{2} \leftrightarrow 2 \mathrm{Mn}_{3} \mathrm{O}_{4} ; \mathrm{MH}=$ magnetite-hematite; $\mathrm{MMO}=$ $4 \mathrm{Mn}_{3} \mathrm{O}_{4}+\mathrm{O}_{2} \leftrightarrow 6 \mathrm{Mn}_{2} \mathrm{O}_{3}$.

Fig. 12. (a) $\mathrm{Fe} /(\mathrm{Fe}+\mathrm{Mg})$ vs. Alv plot of amphibole compositions with Low oxygen fugacity (fO2), Intermediate fO2 and High fO2 fields according Anderson \& Smith (1995). (b) $\mathrm{Al}^{\top} v s$. $\mathrm{Fe} / \mathrm{Fe}+\mathrm{Mg}$ diagram showing biotite compositions and approximate $\mathrm{fO}_{2}$ values relative to the quartz-fayalite-magnetite (QFM) buffer (assuming $\mathrm{PH}_{2} \mathrm{O}=$ Ptotal), as suggested by Anderson et al. (2008b).

Fig. 13. Schematic illustration showing the two different stages of magma generation. The first stage: in shallow cameras, where are generated most of intrusive products. The second stage: in a depth magma source, involve the lithospheric mantle, which provide 
intermediate- mafic dikes and dacite porphyries. Magmatic products ages intervals from García-Chinchilla \& Vlach (submitted) 


\section{FIGURES}
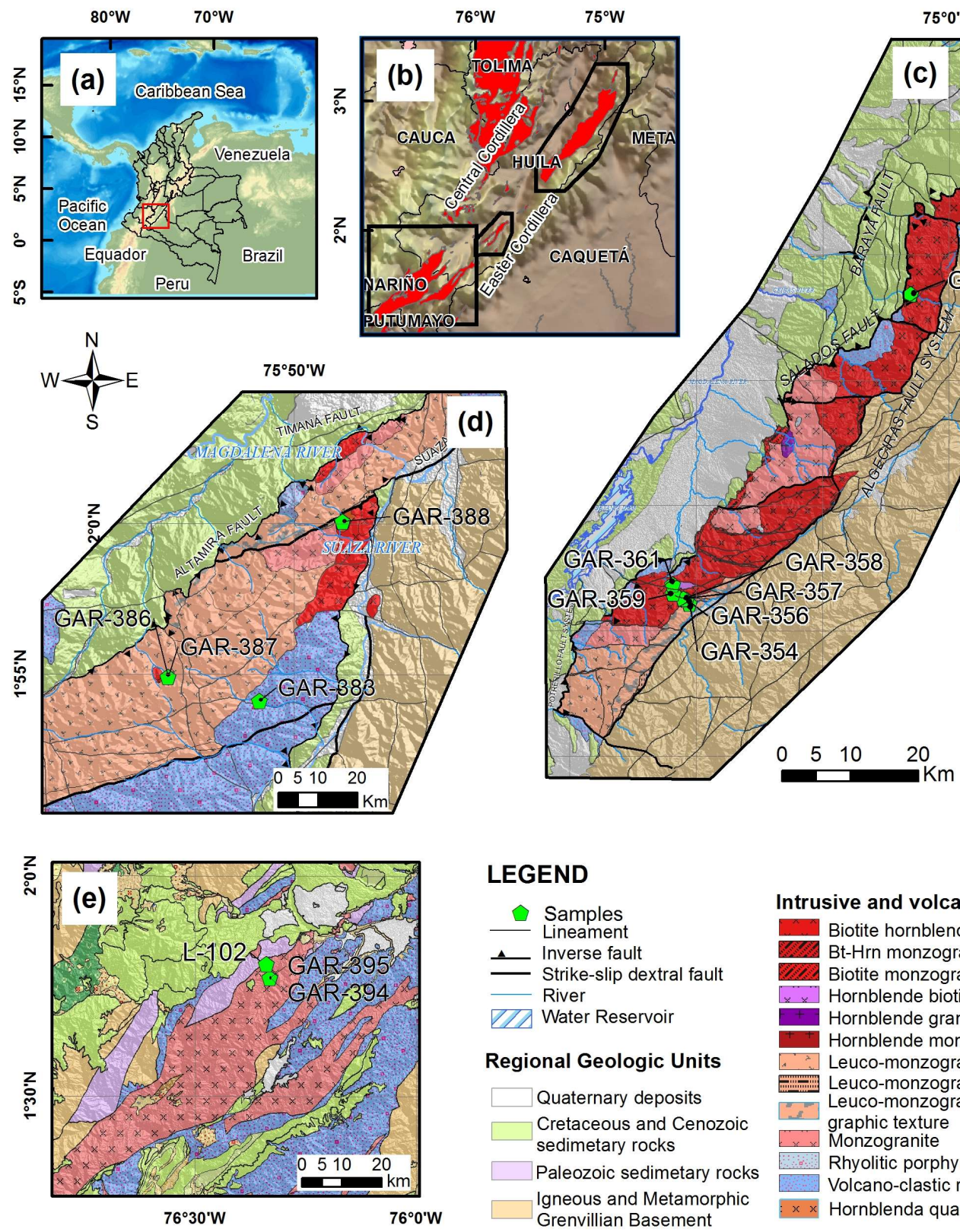

\section{LEGEND}

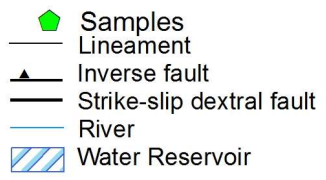

Regional Geologic Units

Quaternary deposits

Cretaceous and Cenozoic sedimetary rocks

Paleozoic sedimetary rocks Igneous and Metamorphic Grenvillian Basement

\section{Intrusive and volcanic facies}

E. Biotite hornblende monzogranite Bt-Hrn monzogranite milonitic Biotite monzogranite milonitic

$\times \times$ Hornblende biotite granodiorite

Hornblende granodiorite

Hornblende monzogranite $\therefore$ Leuco-monzogranite

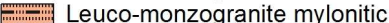
Leuco-monzogranite with micrographic texture Monzogranite

Rhyolitic porphyries Volcano-clastic rocks: Saldaña Fm $\times$ Hornblenda quartzo-monzodiorite

Fig. 1. 


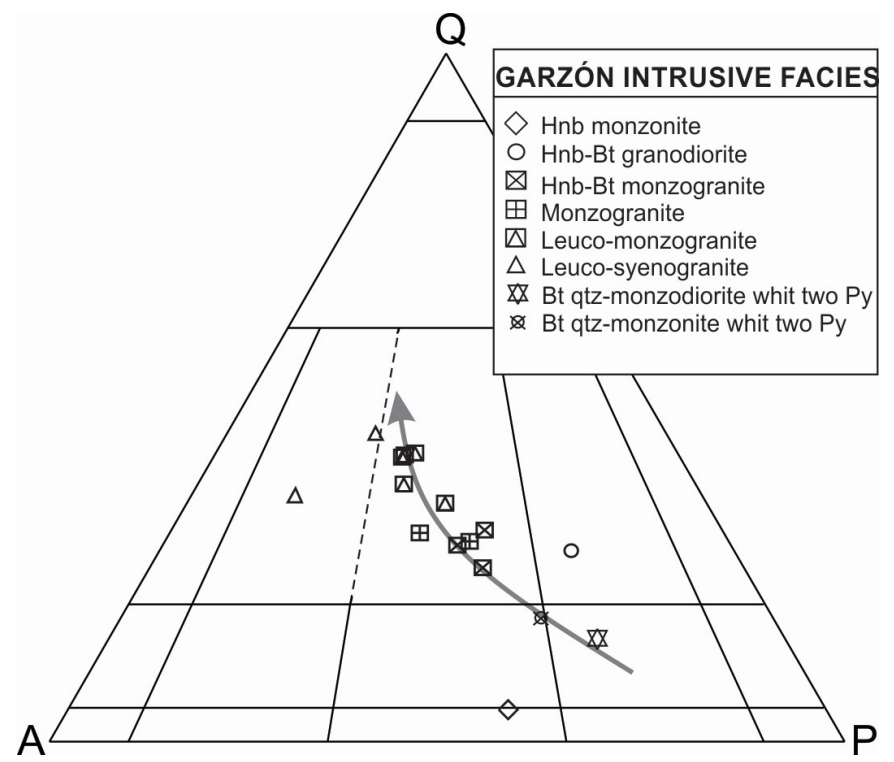

Fig. 2.
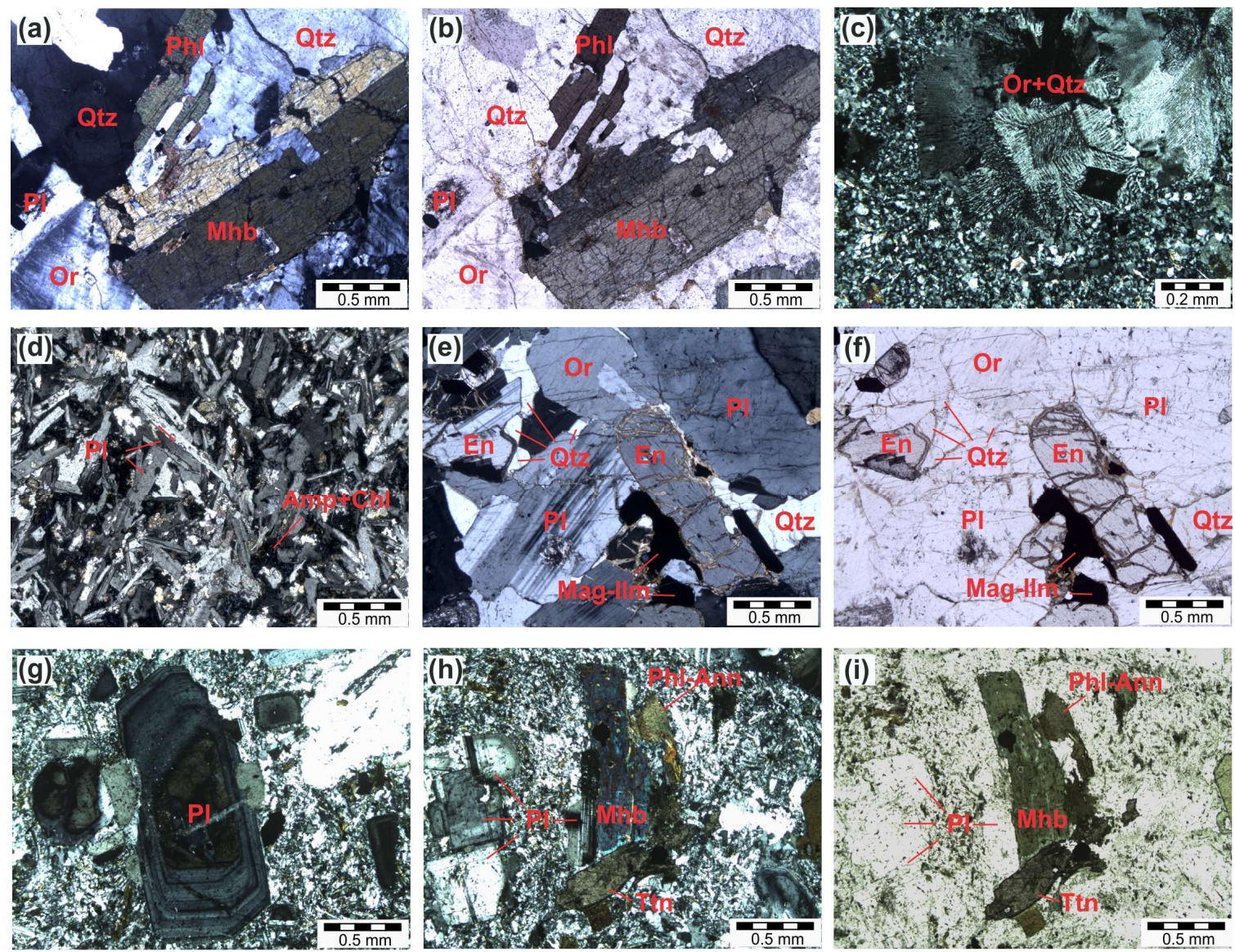

Fig. 3. 

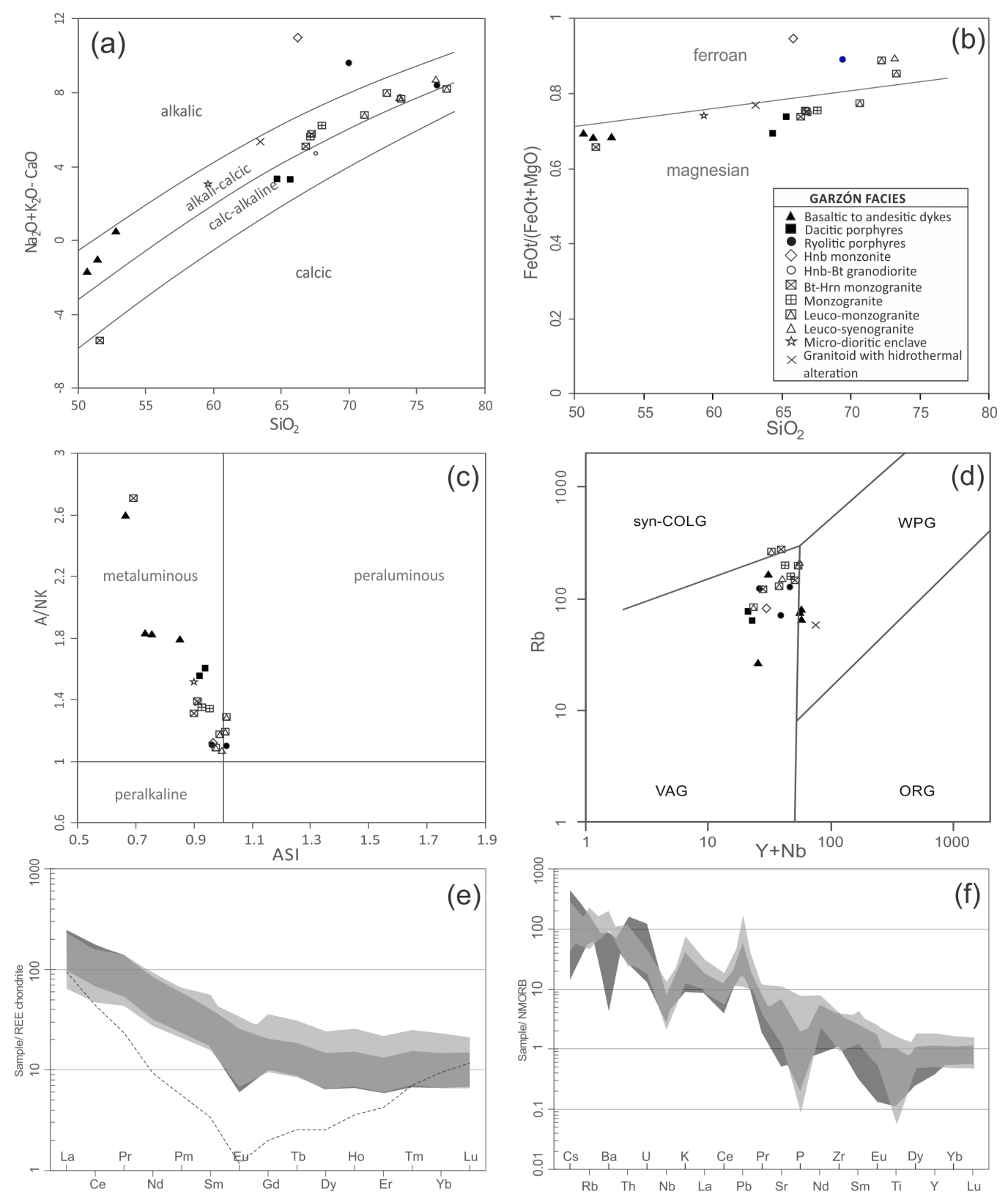

Fig. 4. 

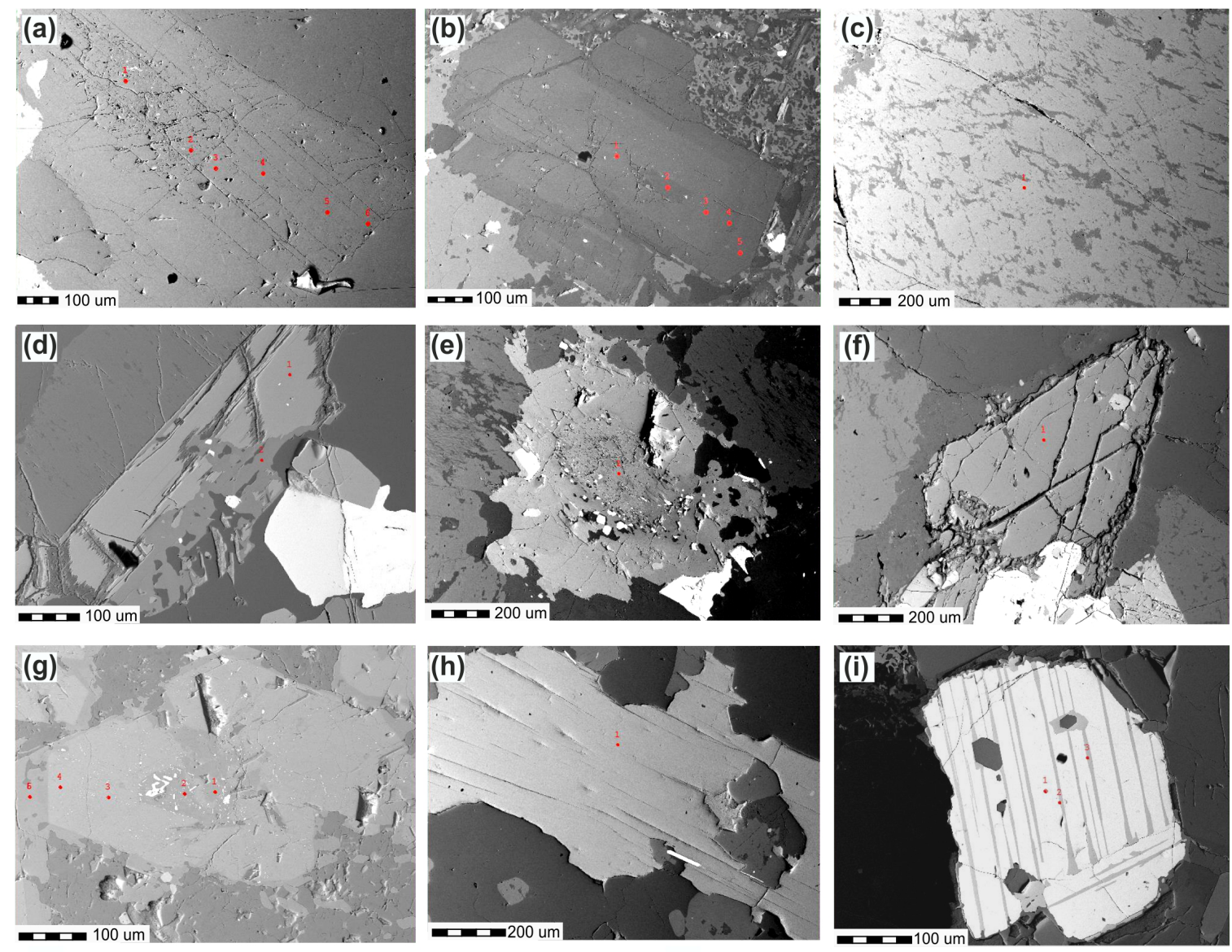

Fig. 5. 

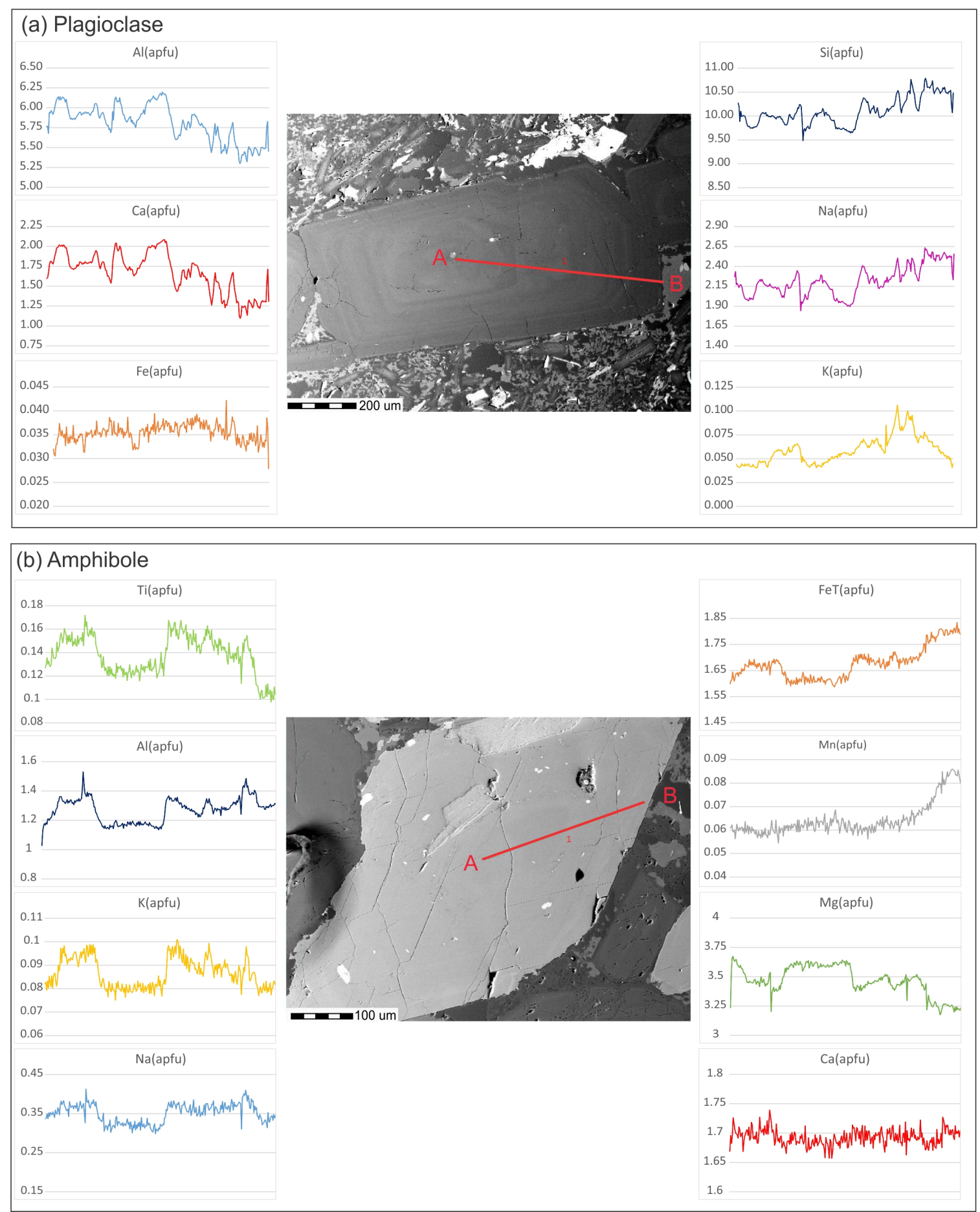

Fig. 6. 
(a)

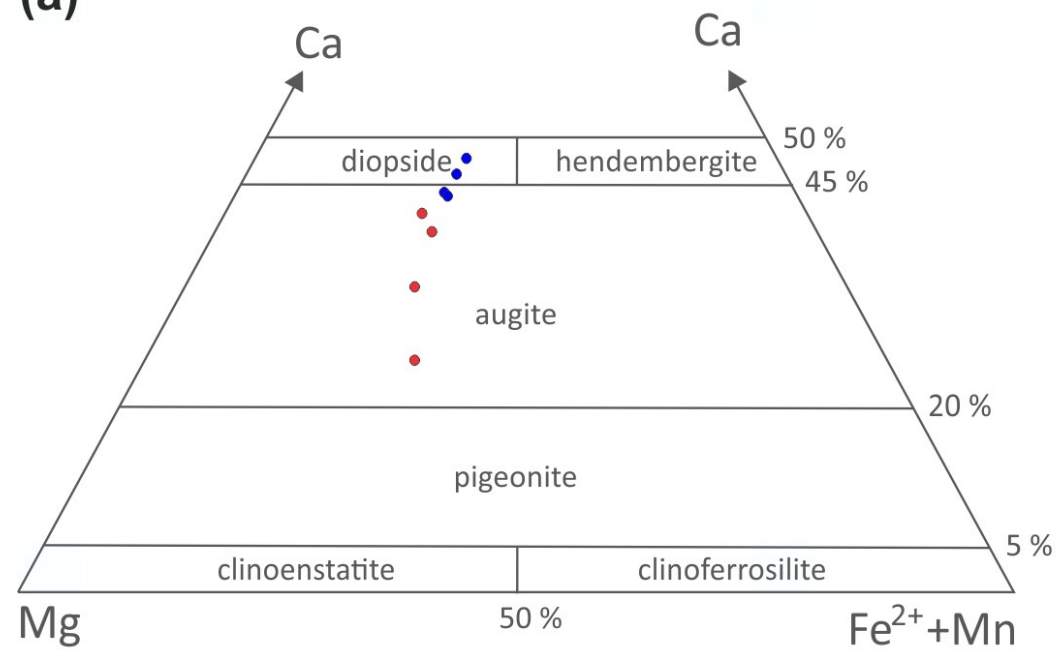

(b)

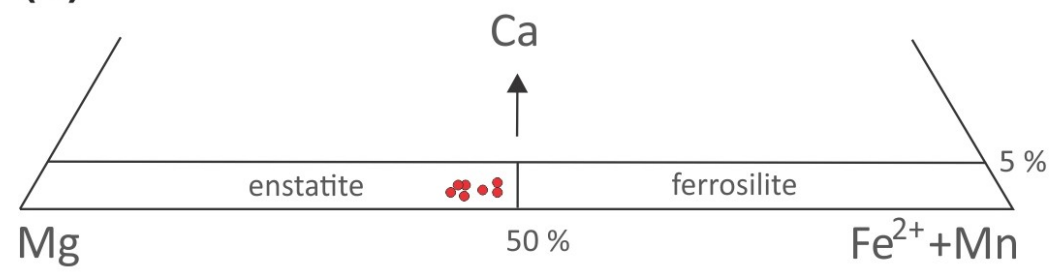

Fig. 7. 
(a) calcic amphiboles

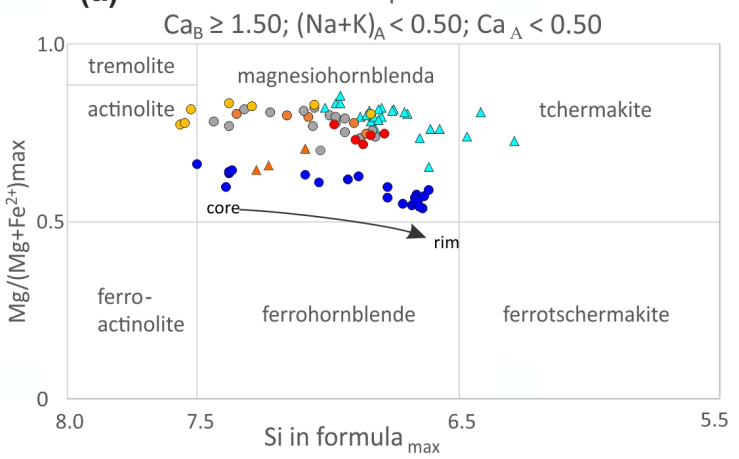

(b) calcic amphiboles

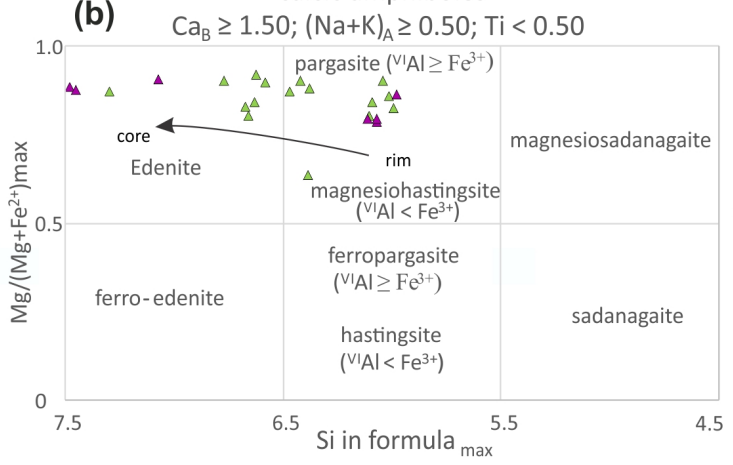

(d)
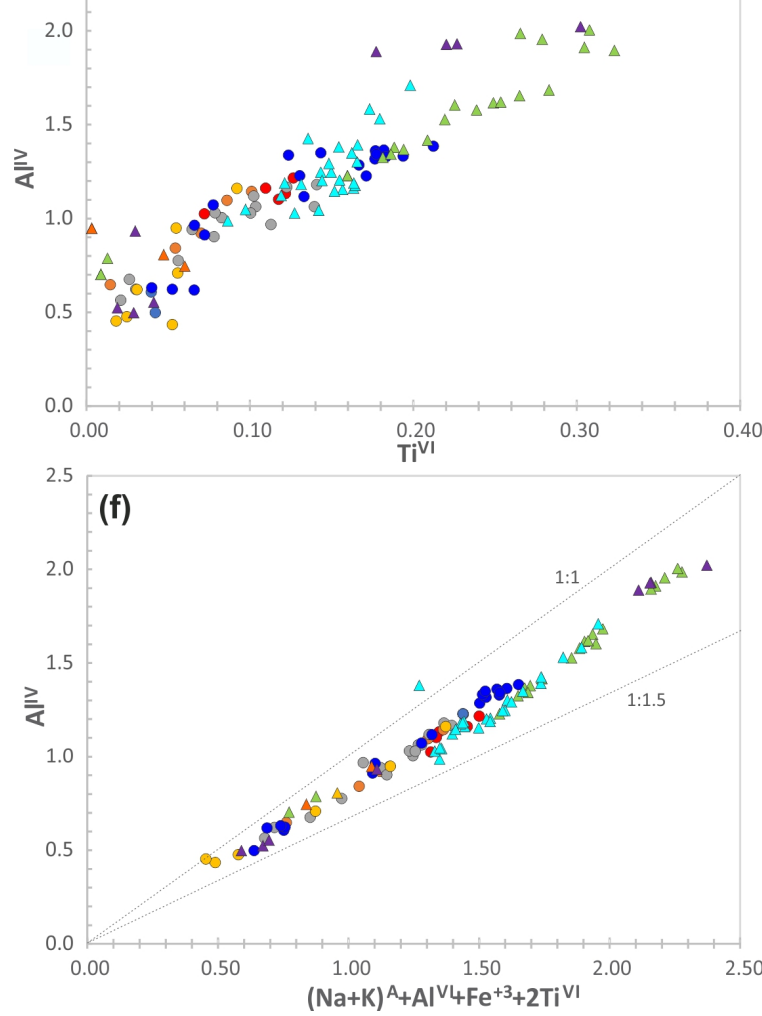

\section{Garzón Facies}

- L-102 Bt quartz-monzonite with two Px

- GAR-354 Leuco-monzogranite

- GAR-356 Monzogranite

- GAR-394

- GAR-357\}Hrn-Bt monzogranites

- GAR-386 Hrn-Bt granodioite

$\triangle$ GAR-383 Rhyolitic porphyry

$\triangle$ GAR-395 $\}$ Dacitic porphyries

^ GAR-358 Basaltic andesite dyke

- GAR-387 Diabase dyke

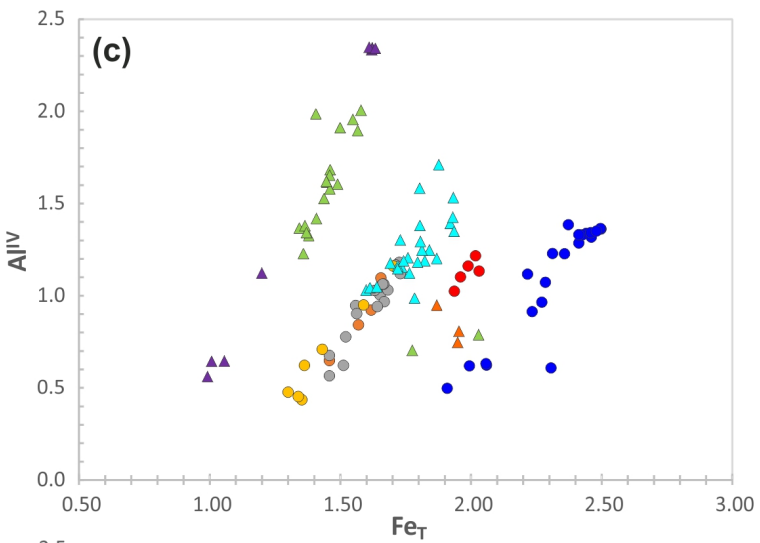

(e)
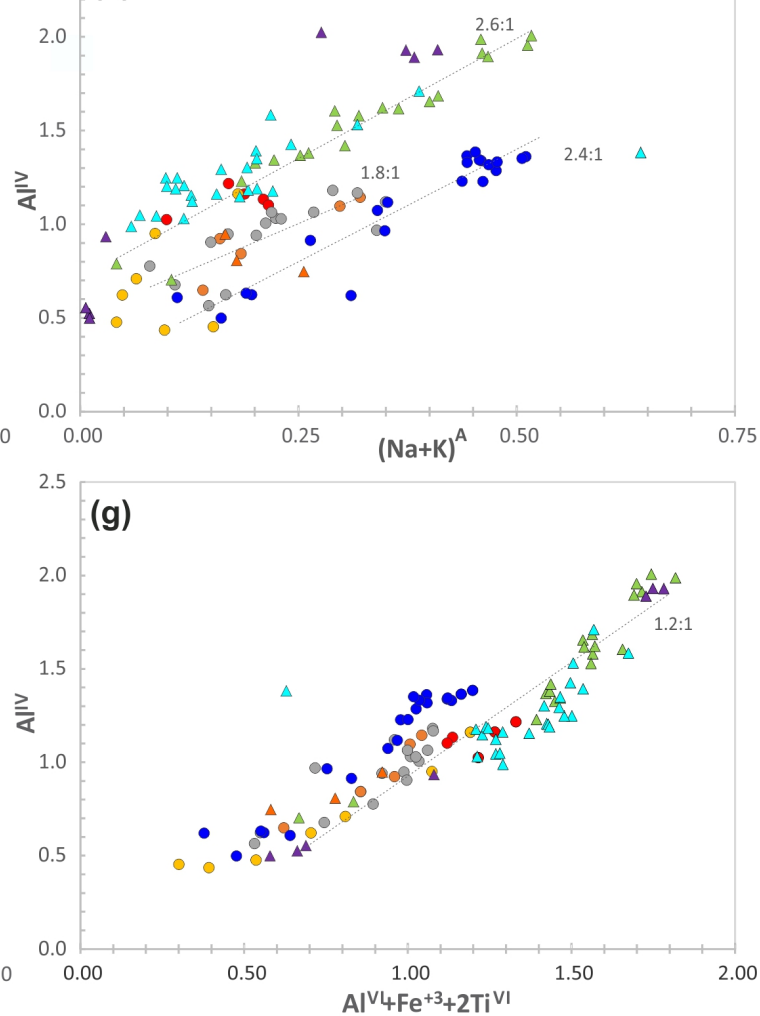

Fig. 8. 

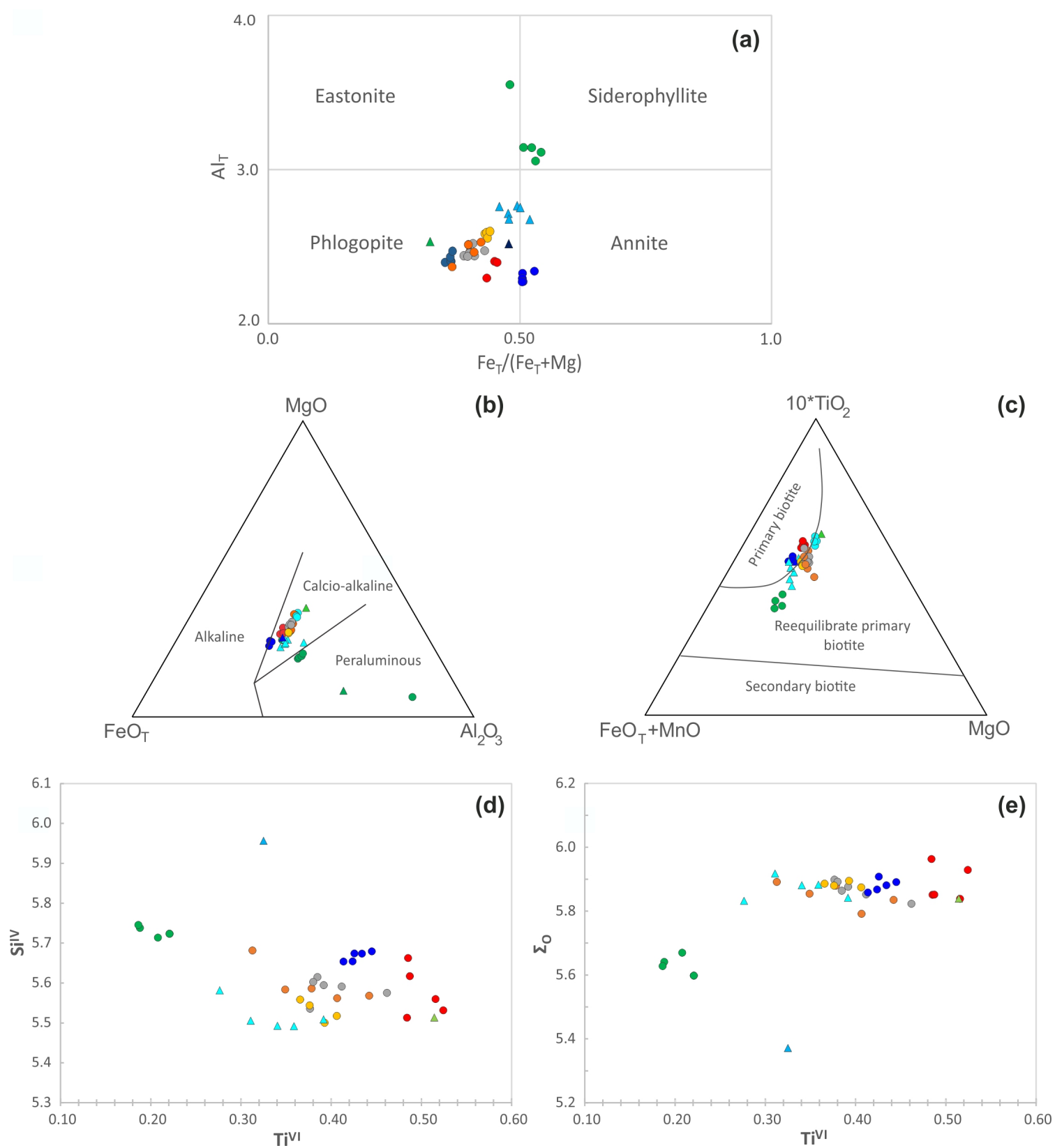

Fig. 9. 


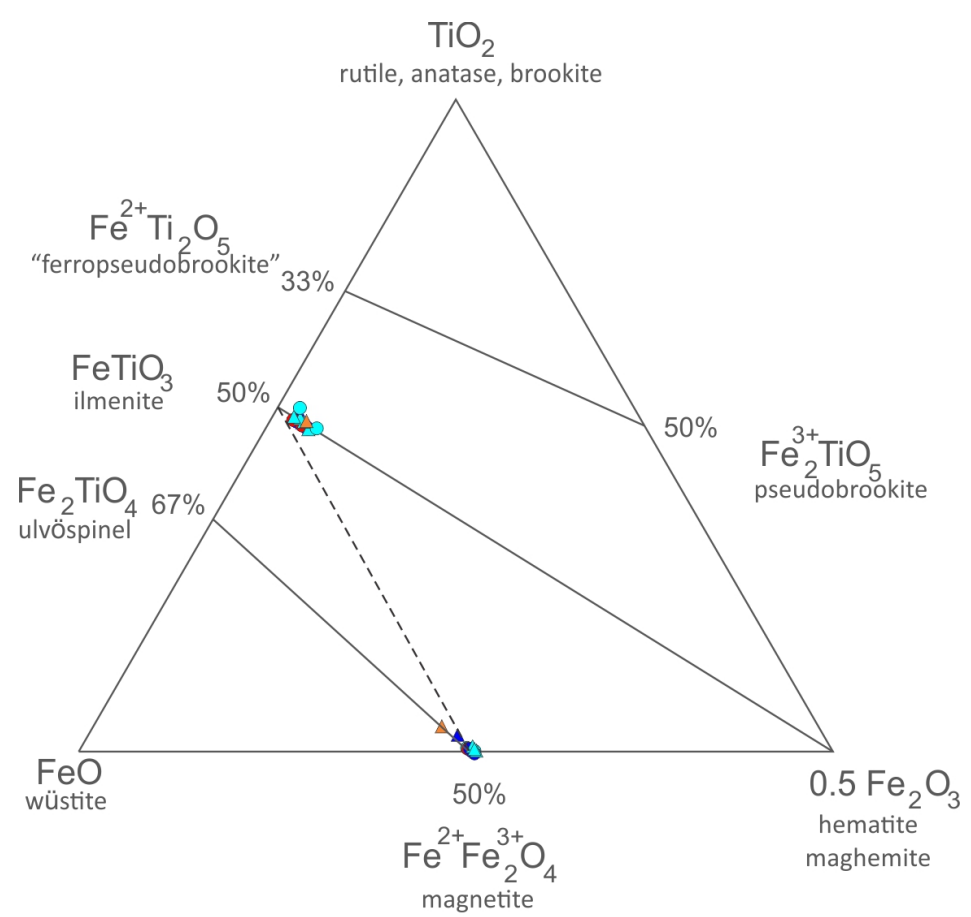

Fig. 10 
(a)

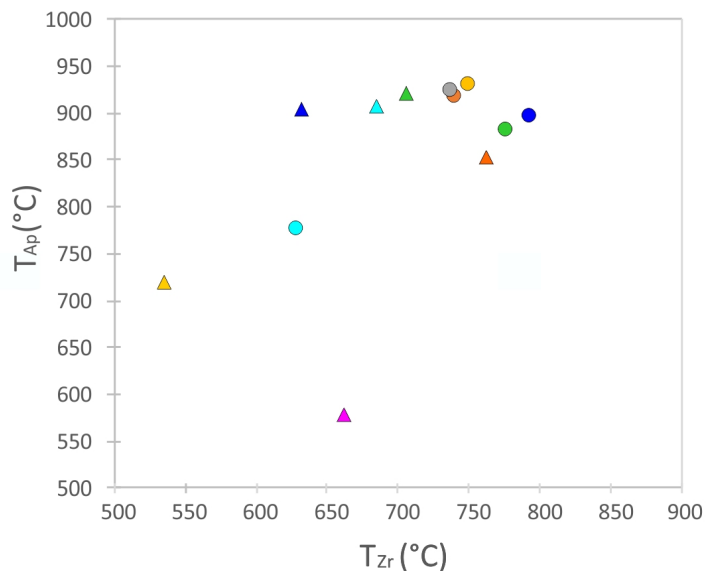

(c)

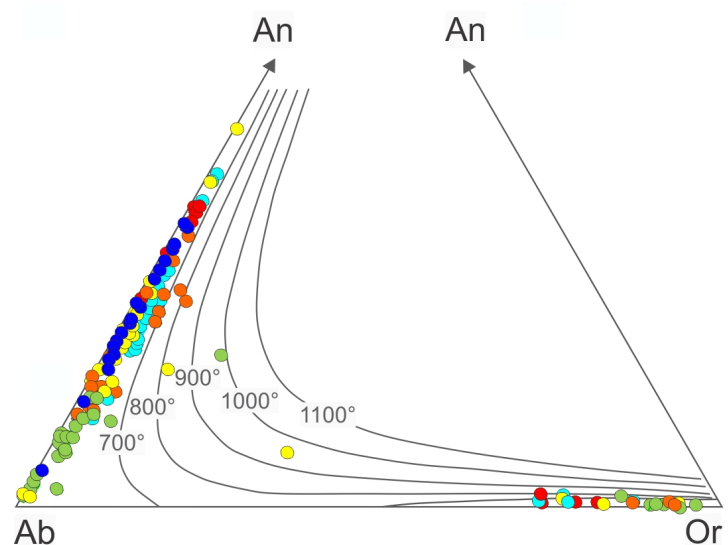

(e)

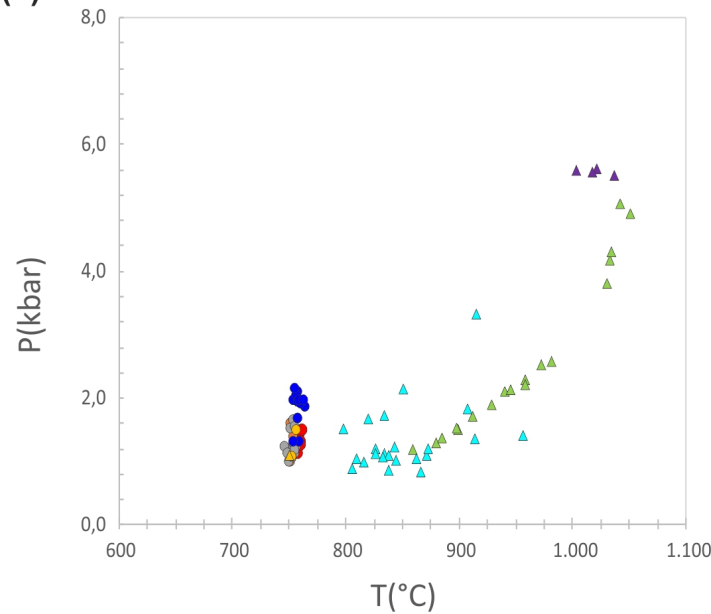

(b)

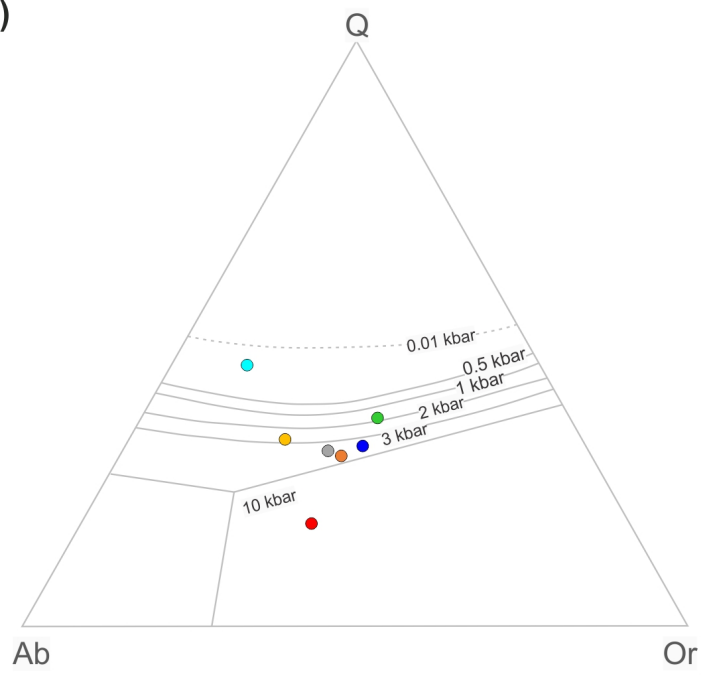

(d)

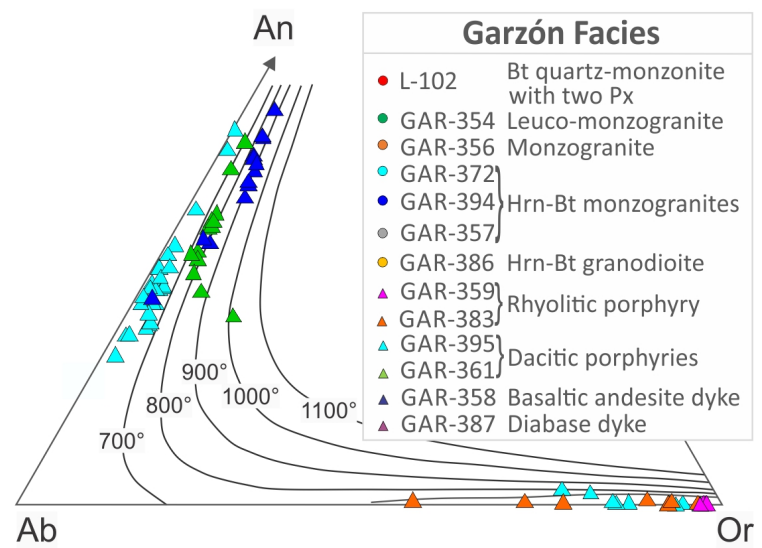

(f)

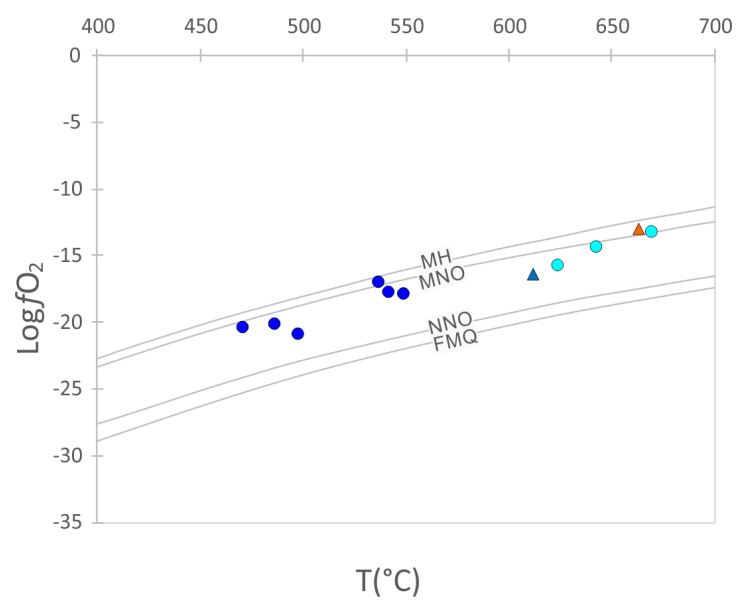

Fig. 11. 

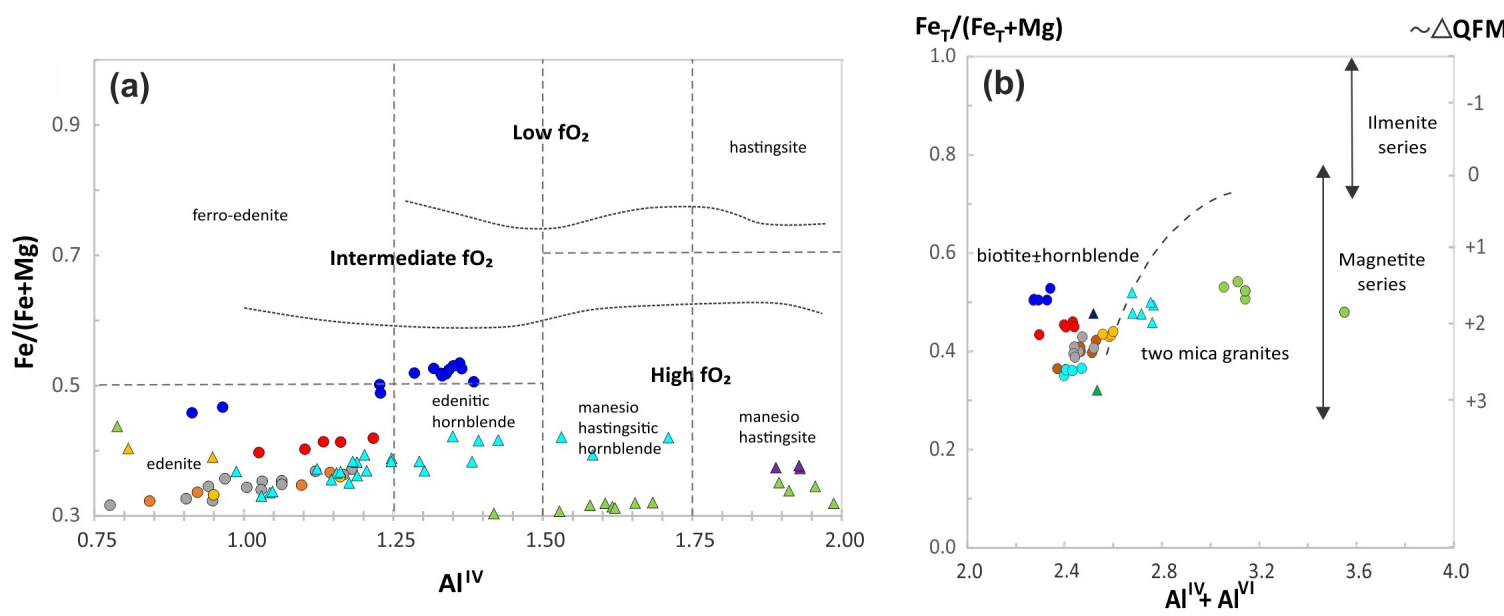

Fig. 12.
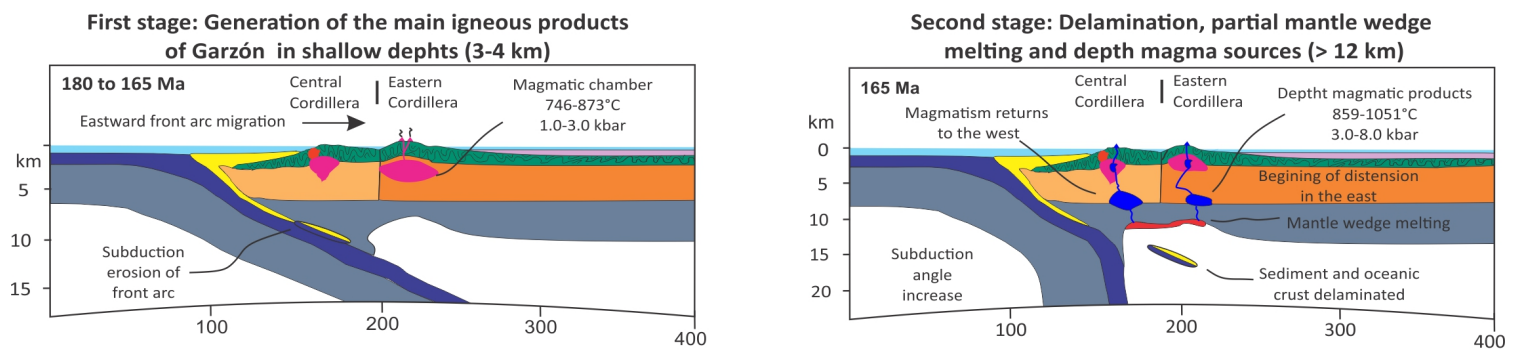

Legend

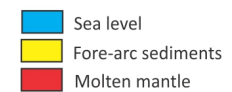

(n)

Molten mantle

Triassic intracontinental sequences

Fig. 13. 


\section{TABLES}

Table 1. Representative electron microprobe analyses of alkali feldspar and plagioclase in granites and related rocks of Garzón region.

\begin{tabular}{|c|c|c|c|c|c|c|c|c|c|c|c|c|c|c|c|c|}
\hline \multirow{3}{*}{$\begin{array}{l}\text { Mineral } \\
\text { Massif } \\
\text { Sample }\end{array}$} & \multicolumn{7}{|c|}{ Alkali feldspar } & \multicolumn{9}{|c|}{ Plagioclase } \\
\hline & \multicolumn{2}{|c|}{ Sombrerillo } & \multicolumn{3}{|c|}{ Algeciras } & \multicolumn{2}{|c|}{ Altamira } & \multicolumn{3}{|c|}{ Sombrerillo } & \multicolumn{4}{|c|}{ Algeciras } & \multicolumn{2}{|c|}{ Altamira } \\
\hline & L-102 & $\begin{array}{c}\text { GAR- } \\
395\end{array}$ & $\begin{array}{c}\text { GAR- } \\
354\end{array}$ & $\begin{array}{c}\text { GAR- } \\
356\end{array}$ & $\begin{array}{c}\text { GAR- } \\
359\end{array}$ & $\begin{array}{c}\text { GAR- } \\
383\end{array}$ & $\begin{array}{c}\text { GAR- } \\
386\end{array}$ & L-102 & $\begin{array}{c}\text { GAR- } \\
394\end{array}$ & $\begin{array}{c}\text { GAR- } \\
395\end{array}$ & $\begin{array}{c}\text { GAR- } \\
354\end{array}$ & $\begin{array}{l}\text { GAR- } \\
357\end{array}$ & $\begin{array}{c}\text { GAR- } \\
358\end{array}$ & $\begin{array}{c}\text { GAR- } \\
361\end{array}$ & $\begin{array}{c}\text { GAR- } \\
383\end{array}$ & $\begin{array}{c}\text { GAR- } \\
386\end{array}$ \\
\hline Facies & $\begin{array}{c}\text { BQ-M } \\
\text { OC }\end{array}$ & Dac & L-MG & $\begin{array}{l}\mathrm{BH} \\
\mathrm{MG}\end{array}$ & Rhy & Rhy & $\begin{array}{l}\mathrm{HB} \\
\mathrm{GD}\end{array}$ & $\begin{array}{c}\text { BQ-M } \\
\text { OC }\end{array}$ & MG & Dac & L-MG & $\begin{array}{l}\mathrm{BH} \\
\mathrm{MG}\end{array}$ & IM-D & Dac & Rhy & $\begin{array}{l}\text { HB- } \\
\text { GD }\end{array}$ \\
\hline $\begin{array}{l}\text { Grain/ } \\
\text { Point } \\
\end{array}$ & $\begin{array}{c}\text { Fk_03 } \\
-2\end{array}$ & $\begin{array}{c}\text { Fk_05 } \\
-1\end{array}$ & $\mathrm{Fk}_{1}$ 05- & $\begin{array}{c}\mathrm{Fk} \text {-101 } \\
\end{array}$ & $\begin{array}{c}\mathrm{Fk}-1 \\
-1\end{array}$ & $\begin{array}{c}\mathrm{Fk}-103 \\
-1\end{array}$ & $\begin{array}{c}\text { Fk_02 } \\
-1\end{array}$ & $\begin{array}{c}\text { pl_03- } \\
1\end{array}$ & pl_03-1 & $\begin{array}{c}\text { pl_02- } \\
1\end{array}$ & $\begin{array}{c}\text { pl_02- } \\
2\end{array}$ & $\begin{array}{c}\text { pl_06- } \\
1\end{array}$ & $\begin{array}{c}\text { pl_01- } \\
1\end{array}$ & $\begin{array}{c}\text { pl_07- } \\
1\end{array}$ & $\begin{array}{c}\text { pl_01- } \\
1\end{array}$ & $\begin{array}{c}\text { pl_06- } \\
1\end{array}$ \\
\hline $\mathrm{SiO} 2$ & 65.25 & 65.00 & 65.04 & 63.57 & 63.06 & 63.45 & 64.24 & 55.89 & 56.34 & 51.95 & 63.59 & 56.33 & 52.56 & 56.30 & 65.49 & 51.62 \\
\hline $\mathrm{TiO} 2$ & 0.07 & 0.00 & 0.00 & 0.00 & 0.00 & 0.04 & 0.00 & 0.03 & 0.04 & 0.00 & 0.00 & 0.00 & 0.07 & 0.00 & 0.00 & 0.06 \\
\hline Al2O3 & 19.49 & 18.97 & 18.94 & 18.86 & 18.55 & 18.71 & 19.05 & 28.75 & 28.52 & 31.07 & 22.96 & 27.77 & 30.01 & 27.73 & 21.34 & 30.93 \\
\hline $\mathrm{FeO}$ & 0.11 & 0.10 & 0.06 & 0.10 & 0.06 & 0.03 & 0.08 & 0.15 & 0.16 & 0.24 & 0.17 & 0.39 & 0.74 & 0.44 & 0.21 & 0.31 \\
\hline $\mathrm{MnO}$ & 0.00 & 0.00 & 0.00 & 0.00 & 0.00 & 0.00 & 0.00 & 0.00 & 0.00 & 0.00 & 0.00 & 0.04 & 0.00 & 0.02 & 0.00 & 0.00 \\
\hline $\mathrm{MgO}$ & 0.04 & 0.00 & 0.02 & 0.02 & 0.00 & 0.02 & 0.03 & 0.00 & 0.00 & 0.00 & 0.00 & 0.00 & 0.02 & 0.00 & 0.07 & 0.00 \\
\hline $\mathrm{SrO}$ & 0.14 & 0.11 & 0.00 & 0.10 & 0.05 & 0.07 & 0.05 & 0.13 & 0.07 & 0.17 & 0.00 & 0.18 & 0.24 & 0.24 & 0.05 & 0.23 \\
\hline $\mathrm{BaO}$ & 0.61 & 0.15 & 0.00 & 0.41 & 0.47 & 0.16 & 0.38 & 0.05 & 0.00 & 0.00 & 0.00 & 0.06 & 0.04 & 0.04 & 0.00 & 0.00 \\
\hline $\mathrm{PbO}$ & 0.00 & 0.00 & 0.00 & 0.04 & 0.00 & 0.00 & 0.00 & 0.04 & 0.00 & 0.05 & 0.06 & 0.00 & 0.00 & 0.00 & 0.07 & 0.00 \\
\hline $\mathrm{CaO}$ & 0.14 & 0.04 & 0.05 & 0.00 & 0.03 & 0.06 & 0.04 & 9.96 & 9.66 & 12.67 & 3.59 & 9.01 & 12.05 & 9.19 & 0.62 & 12.52 \\
\hline $\mathrm{Na} 2 \mathrm{O}$ & 2.27 & 0.84 & 1.02 & 0.69 & 0.24 & 0.24 & 0.65 & 5.68 & 6.14 & 4.39 & 9.29 & 5.68 & 3.87 & 5.52 & 10.34 & 4.27 \\
\hline $\mathrm{K} 2 \mathrm{O}$ & 13.17 & 15.62 & 15.40 & 15.34 & 15.84 & 16.02 & 15.70 & 0.17 & 0.16 & 0.07 & 0.46 & 0.23 & 0.82 & 0.84 & 1.03 & 0.11 \\
\hline Total & 101.28 & 100.87 & 100.58 & 99.13 & 98.32 & 98.85 & 100.22 & 100.84 & 101.11 & 100.63 & 100.14 & 99.69 & 100.43 & 100.32 & 99.22 & 100.06 \\
\hline \multicolumn{17}{|c|}{ Structural formulae on the basis of 32 oxygens } \\
\hline $\mathrm{Si}$ & 11.845 & 11.915 & 11.927 & 11.877 & 11.902 & 11.893 & 11.874 & 9.983 & 10.030 & 9.392 & 11.238 & 10.153 & 9.541 & 10.127 & 11.619 & 9.384 \\
\hline ivAl & 4.170 & 4.098 & 4.094 & 4.153 & 4.127 & 4.133 & 4.150 & 6.052 & 5.984 & 6.620 & 4.782 & 5.899 & 6.421 & 5.879 & 4.462 & 6.627 \\
\hline Felll & 0.017 & 0.016 & 0.009 & 0.015 & 0.009 & 0.005 & 0.012 & 0.022 & 0.024 & 0.036 & 0.025 & 0.058 & 0.113 & 0.066 & 0.032 & 0.047 \\
\hline T site & 16.031 & 16.030 & 16.030 & 16.046 & 16.038 & 16.032 & 16.036 & 16.057 & 16.038 & 16.047 & 16.045 & 16.110 & 16.075 & 16.072 & 16.112 & 16.057 \\
\hline $\mathrm{Ti}$ & 0.009 & 0.000 & 0.000 & 0.000 & 0.000 & 0.006 & 0.000 & 0.004 & 0.006 & 0.000 & 0.000 & 0.000 & 0.010 & 0.000 & 0.000 & 0.009 \\
\hline $\mathrm{Mn}$ & 0.000 & 0.000 & 0.000 & 0.000 & 0.000 & 0.000 & 0.000 & 0.000 & 0.000 & 0.000 & 0.000 & 0.006 & 0.000 & 0.004 & 0.000 & 0.000 \\
\hline $\mathrm{Mg}$ & 0.012 & 0.000 & 0.005 & 0.004 & 0.000 & 0.006 & 0.007 & 0.000 & 0.000 & 0.000 & 0.000 & 0.000 & 0.005 & 0.000 & 0.017 & 0.000 \\
\hline $\mathrm{Sr}$ & 0.014 & 0.011 & 0.000 & 0.011 & 0.006 & 0.007 & 0.005 & 0.013 & 0.007 & 0.018 & 0.000 & 0.019 & 0.026 & 0.025 & 0.005 & 0.024 \\
\hline $\mathrm{Ba}$ & 0.044 & 0.011 & 0.000 & 0.030 & 0.034 & 0.012 & 0.028 & 0.003 & 0.000 & 0.000 & 0.000 & 0.004 & 0.003 & 0.003 & 0.000 & 0.000 \\
\hline $\mathrm{Pb}$ & 0.000 & 0.000 & 0.000 & 0.002 & 0.000 & 0.000 & 0.000 & 0.002 & 0.000 & 0.002 & 0.003 & 0.000 & 0.000 & 0.000 & 0.003 & 0.000 \\
\hline $\mathrm{Ca}$ & 0.027 & 0.007 & 0.009 & 0.000 & 0.005 & 0.012 & 0.009 & 1.906 & 1.843 & 2.454 & 0.680 & 1.740 & 2.344 & 1.771 & 0.118 & 2.439 \\
\hline $\mathrm{Na}$ & 0.799 & 0.300 & 0.361 & 0.250 & 0.089 & 0.086 & 0.232 & 1.967 & 2.119 & 1.539 & 3.183 & 1.985 & 1.362 & 1.925 & 3.557 & 1.505 \\
\hline Ka & 3.050 & $\begin{array}{l}3.653 \\
3\end{array}$ & $\begin{array}{l}3.602 \\
3.602\end{array}$ & 3.656 & 3.814 & 3.831 & 3.702 & 0.039 & 0.037 & 0.015 & 0.104 & 0.053 & 0.191 & 0.193 & 0.232 & 0.026 \\
\hline M site & 3.954 & 3.982 & 3.978 & 3.953 & 3.948 & 3.961 & 3.982 & 3.934 & 4.012 & 4.028 & 3.970 & 3.807 & 3.939 & 3.921 & 3.932 & 4.002 \\
\hline Cations & 19.986 & 20.011 & 20.008 & 19.999 & 19.986 & 19.993 & 20.018 & 19.991 & 20.050 & 20.075 & 20.014 & 19.917 & 20.015 & 19.992 & 20.045 & 20.060 \\
\hline An & 0.70 & 0.18 & 0.23 & 0.00 & 0.14 & 0.32 & 0.22 & 48.72 & 46.08 & 61.23 & 17.14 & 46.05 & 60.15 & 45.54 & 3.01 & 61.43 \\
\hline$A b$ & 20.61 & 7.57 & 9.10 & 6.41 & 2.27 & 2.20 & 5.90 & 50.28 & 53.00 & 38.39 & 80.24 & 52.54 & 34.96 & 49.50 & 91.04 & 37.92 \\
\hline Or & 78.69 & 92.25 & 90.67 & 93.59 & 97.59 & 97.48 & 93.88 & 1.00 & 0.93 & 0.38 & 2.62 & 1.41 & $\begin{array}{r}4.89 \\
\end{array}$ & $\begin{array}{r}4.96 \\
4\end{array}$ & 5.94 & 0.65 \\
\hline
\end{tabular}

Notes: Facies abbreviations BQ-M OC = Biotite quartz-monzodiotire with two pyroxenes; Dac = Dacite; L-MG = Leuco monzogranite; BT-MG = Biotite-Hornblende monzogranite; Rhy = Rhyolite; HB-GD = Hornblende-Biotite Granodiorite; MG = Monzogranite; IM-D = Intermediate-mafic dikes; $\mathrm{An}=$ anortite; $\mathrm{Ab}=$ albite; Or = orthoclase. 
Table 2. Representative electron microprobe analyses of amphiboles, pyroxenes and biotites in granites and related rocks of Garzón region.

\begin{tabular}{|c|c|c|c|c|c|c|c|c|c|c|c|c|c|c|c|c|c|}
\hline \multirow{3}{*}{$\begin{array}{l}\text { Mineral } \\
\text { Massif } \\
\text { Sample }\end{array}$} & \multicolumn{7}{|c|}{ Amphibole } & \multirow{2}{*}{\multicolumn{4}{|c|}{$\begin{array}{r}\text { Pyroxene (Cpx/Opx) } \\
\text { Sombrerillo }\end{array}$}} & \multicolumn{6}{|c|}{ Biotite } \\
\hline & \multicolumn{2}{|c|}{ Algeciras } & \multicolumn{2}{|c|}{ Altamira } & \multicolumn{3}{|c|}{ Sombrerillo } & & & & & \multirow{2}{*}{ Sample } & \multicolumn{2}{|c|}{ Algeciras } & \multirow{2}{*}{\begin{tabular}{l}
\multicolumn{1}{c}{ Alt } \\
GAR- \\
386
\end{tabular}} & \multicolumn{2}{|c|}{ Sombrerillo } \\
\hline & $\begin{array}{l}\text { GAR- } \\
356\end{array}$ & $\begin{array}{l}\text { GAR- } \\
383 \\
\end{array}$ & $\begin{array}{l}\text { GAR- } \\
386 \\
\end{array}$ & $\begin{array}{l}\text { GAR- } \\
387 \\
\end{array}$ & L-102 & $\begin{array}{l}\text { GAR- } \\
395\end{array}$ & $\begin{array}{l}\text { GAR- } \\
394 \\
\end{array}$ & $\begin{array}{l}\text { Sampl } \\
\mathrm{e}\end{array}$ & $\begin{array}{l}\text { L- } \\
102\end{array}$ & $\begin{array}{l}\text { GAR } \\
-394 \\
\end{array}$ & L-102 & & $\begin{array}{l}\text { GAR- } \\
354 \\
\end{array}$ & $\begin{array}{l}\text { GAR- } \\
358 \\
\end{array}$ & & $\begin{array}{l}\text { GAR- } \\
394 \\
\end{array}$ & $\begin{array}{l}\text { GAR- } \\
395 \\
\end{array}$ \\
\hline Facies & $\begin{array}{l}\text { BH- } \\
\text { MG }\end{array}$ & Rhy & $\begin{array}{l}\text { HB- } \\
\text { GD }\end{array}$ & IM-D & $\begin{array}{l}\text { BQ-M- } \\
\text { OC }\end{array}$ & Dac & MG & Facies & $\begin{array}{c}\text { BQ- } \\
\text { M- } \\
\text { OC }\end{array}$ & MG & $\begin{array}{l}\text { BQ-M- } \\
\text { OC }\end{array}$ & Facies & L-MG & IM-D & $\begin{array}{l}\text { HB- } \\
\text { GD }\end{array}$ & MG & Dac \\
\hline $\begin{array}{l}\text { Grain/ } \\
\text { Point }\end{array}$ & $\begin{array}{l}\text { anf_0 } \\
3-1\end{array}$ & $\begin{array}{l}\text { anf_0 } \\
2-1\end{array}$ & $\begin{array}{l}\text { anf_03 } \\
-2\end{array}$ & $\begin{array}{l}\text { anf_03 } \\
-1\end{array}$ & $\begin{array}{l}\text { anf_14 } \\
\text { a-1 }\end{array}$ & $\begin{array}{l}\text { anf_01 } \\
-2\end{array}$ & $\begin{array}{l}\text { anf_11 } \\
\text { a-3 }\end{array}$ & $\begin{array}{l}\text { Grain/ } \\
\text { Point }\end{array}$ & $\begin{array}{l}\mathrm{cpx} \\
14-\overline{1}\end{array}$ & $\begin{array}{l}\mathrm{cpx} \\
01-\overline{1}\end{array}$ & $\begin{array}{l}\text { opx_1 } \\
7-1\end{array}$ & $\begin{array}{l}\text { Grain/ } \\
\text { Point }\end{array}$ & $\begin{array}{l}\text { bt_04- } \\
1\end{array}$ & $\begin{array}{l}\text { bt_01- } \\
1\end{array}$ & $\begin{array}{l}\text { bt_05- } \\
1\end{array}$ & $\begin{array}{l}\text { bt_02- } \\
1\end{array}$ & bt_02- \\
\hline $\mathrm{SiO} 2$ & 46.86 & 48.24 & 47.39 & 42.49 & 48.57 & 42.99 & 44.90 & $\mathrm{SiO} 2$ & $\begin{array}{r}52.7 \\
1\end{array}$ & $\begin{array}{r}51.7 \\
6\end{array}$ & 51.64 & $\mathrm{SiO} 2$ & 38.05 & 37.61 & 36.68 & 36.79 & 35.97 \\
\hline $\begin{array}{l}\mathrm{TiO} 2 \\
\mathrm{Al} 2 \mathrm{O} 3\end{array}$ & $\begin{array}{l}0.92 \\
7.32\end{array}$ & $\begin{array}{l}0.03 \\
5.82\end{array}$ & $\begin{array}{l}0.85 \\
7.15\end{array}$ & $\begin{array}{r}2.11 \\
13.94\end{array}$ & $\begin{array}{l}0.67 \\
6.09\end{array}$ & $\begin{array}{r}1.80 \\
11.49\end{array}$ & $\begin{array}{l}1.64 \\
8.00\end{array}$ & $\begin{array}{l}\mathrm{TiO} 2 \\
\mathrm{Al} 2 \mathrm{O} 3\end{array}$ & $\begin{array}{l}0.26 \\
0.79\end{array}$ & $\begin{array}{l}0.31 \\
1.21\end{array}$ & $\begin{array}{l}0.22 \\
0.38\end{array}$ & $\begin{array}{l}\mathrm{TiO} 2 \\
\mathrm{Al} 2 \mathrm{O} 3\end{array}$ & $\begin{array}{r}1.64 \\
17.66\end{array}$ & $\begin{array}{r}3.37 \\
14.21\end{array}$ & $\begin{array}{r}3.59 \\
14.42\end{array}$ & $\begin{array}{r}3.67 \\
12.50\end{array}$ & $\begin{array}{r}2.70 \\
15.33\end{array}$ \\
\hline $\mathrm{Cr} 2 \mathrm{O} 3$ & 0.00 & 0.00 & 0.00 & 0.00 & 0.04 & 0.00 & $\begin{array}{r}0.00 \\
19.53\end{array}$ & $\begin{array}{l}\mathrm{Cr} 2 \mathrm{O} 3 \\
\mathrm{FeO}\end{array}$ & $\begin{array}{l}0.00 \\
13.9\end{array}$ & $\begin{array}{l}0.00 \\
12.2\end{array}$ & $\begin{array}{r}0.00 \\
27.36\end{array}$ & $\begin{array}{l}\mathrm{FeO} \\
\mathrm{MnO}\end{array}$ & $\begin{array}{r}17.55 \\
0.79\end{array}$ & 19.62 & 18.29 & 21.13 & 20.13 \\
\hline $\begin{array}{l}\mathrm{FeO} \\
\mathrm{MnO}\end{array}$ & $\begin{array}{r}14.09 \\
0.59\end{array}$ & $\begin{array}{r}15.29 \\
1.15\end{array}$ & $\begin{array}{r}14.10 \\
1.00\end{array}$ & $\begin{array}{r}13.48 \\
0.25\end{array}$ & $\begin{array}{r}16.12 \\
0.36\end{array}$ & $\begin{array}{r}15.34 \\
0.51\end{array}$ & $\begin{array}{r}0.51 \\
10.16\end{array}$ & $\begin{array}{l}\mathrm{MnO} \\
\mathrm{MgO}\end{array}$ & $\begin{array}{r}5 \\
0.40 \\
15.5\end{array}$ & $\begin{array}{r}2 \\
0.68 \\
12.1\end{array}$ & $\begin{array}{r}0.77 \\
19.28\end{array}$ & $\begin{array}{l}\mathrm{MgO} \\
\mathrm{ZnO}\end{array}$ & $\begin{array}{l}9.58 \\
0.03\end{array}$ & $\begin{array}{r}0.27 \\
12.04\end{array}$ & $\begin{array}{r}0.47 \\
13.31\end{array}$ & $\begin{array}{r}0.25 \\
11.65\end{array}$ & $\begin{array}{r}0.54 \\
11.55\end{array}$ \\
\hline $\begin{array}{l}\mathrm{MgO} \\
\mathrm{ZnO}\end{array}$ & $\begin{array}{r}13.67 \\
0.03\end{array}$ & $\begin{array}{r}13.42 \\
0.06\end{array}$ & $\begin{array}{r}14.05 \\
0.05\end{array}$ & $\begin{array}{r}12.72 \\
0.07\end{array}$ & $\begin{array}{r}13.73 \\
0.03\end{array}$ & $\begin{array}{r}11.88 \\
0.00\end{array}$ & $\begin{array}{r}0.05 \\
11.01\end{array}$ & $\begin{array}{l}\mathrm{ZnO} \\
\mathrm{CaO}\end{array}$ & $\begin{array}{r}0 \\
0.02 \\
16.7\end{array}$ & $\begin{array}{r}6 \\
0.00 \\
20.9\end{array}$ & $\begin{array}{l}0.06 \\
0.88\end{array}$ & $\begin{array}{l}\mathrm{BaO} \\
\mathrm{CaO}\end{array}$ & $\begin{array}{l}0.00 \\
0.00\end{array}$ & $\begin{array}{l}0.05 \\
0.30\end{array}$ & $\begin{array}{l}0.06 \\
0.19\end{array}$ & $\begin{array}{l}0.00 \\
0.04\end{array}$ & $\begin{array}{l}0.06 \\
0.66\end{array}$ \\
\hline $\begin{array}{l}\mathrm{CaO} \\
\mathrm{Na} 2 \mathrm{O}\end{array}$ & $\begin{array}{r}11.36 \\
1.45\end{array}$ & $\begin{array}{r}11.87 \\
0.80\end{array}$ & $\begin{array}{r}11.57 \\
0.98\end{array}$ & $\begin{array}{r}11.58 \\
1.80\end{array}$ & $\begin{array}{r}11.05 \\
1.06\end{array}$ & $\begin{array}{r}11.19 \\
1.74\end{array}$ & 1.75 & $\mathrm{Na} 2 \mathrm{O}$ & $\begin{array}{r}4 \\
0.27\end{array}$ & $\begin{array}{r}5 \\
0.51\end{array}$ & 0.00 & $\mathrm{Na} 2 \mathrm{O}$ & 0.12 & $\begin{array}{l}0.03 \\
0.08\end{array}$ & $\begin{array}{l}0.05 \\
0.18\end{array}$ & $\begin{array}{l}0.00 \\
0.15\end{array}$ & $\begin{array}{l}0.07 \\
0.14\end{array}$ \\
\hline $\mathrm{K} 2 \mathrm{O}$ & 0.69 & 0.43 & 0.64 & 0.76 & 0.54 & 0.75 & 0.98 & $\mathrm{~K} 2 \mathrm{O}$ & 0.00 & 0.03 & 0.00 & $\mathrm{~K} 2 \mathrm{O}$ & 9.64 & 9.42 & 9.60 & 9.47 & 8.79 \\
\hline $\mathrm{F}$ & 0.22 & 0.04 & 0.04 & 0.02 & 0.07 & 0.02 & 0.13 & & & & & $\mathrm{~F}$ & 0.43 & 0.05 & 0.08 & 0.27 & 0.08 \\
\hline $\mathrm{Cl}$ & 0.09 & 0.04 & 0.08 & 0.07 & 0.16 & 0.11 & 0.39 & & & & & $\mathrm{Cl}$ & 0.01 & 0.23 & 0.12 & 0.23 & 0.11 \\
\hline $\begin{array}{l}\text { Total } \\
\mathrm{O}=(\mathrm{Cl} . \mathrm{F}\end{array}$ & 97.29 & 97.19 & 97.91 & 99.30 & 98.49 & 97.82 & $\begin{array}{r}99.06 \\
0.15\end{array}$ & & & & & $\mathrm{O}=(\mathrm{F} . \mathrm{Cl}$ & 0.18 & & & & \\
\hline ) & 0.12 & 0.03 & 0.04 & 0.02 & 0.06 & 0.03 & 98.91 & Total & 100 & 998 & 100.60 & ) & 95,32 & 0.07 & 0.06 & 0.16 & 0.06 \\
\hline Total & 97.19 & 97.16 & 97.87 & 99.29 & 98.42 & 97.80 & & Str & $\begin{array}{r}67 \\
\text { ctural }\end{array}$ & 3 & on the & & & 97.21 & 96.97 & 96.00 & 96.07 \\
\hline Structur & mulae of & the basi & 4 cation & and 6 ox. & & & & & asis of & 4 cation & $\begin{array}{l}\text { s and } 6 \\
\text { xygens }\end{array}$ & Cation pr & pportion & $n$ the ba & f 23 oxys & & \\
\hline $\mathrm{Si}$ & 6.856 & 7.052 & 6.839 & 6.070 & 6.975 & 6.290 & 6.670 & $\mathrm{Si}$ & $\begin{array}{r}1.96 \\
3\end{array}$ & $\begin{array}{r}1.95 \\
7\end{array}$ & 1.958 & ivSi & 5.746 & 5.657 & 5.518 & 5.674 & 5.506 \\
\hline ivAl & 1.144 & 0.948 & 1.161 & 1.930 & 1.025 & 1.710 & 1.330 & $\mathrm{Al}^{+3}$ & $\begin{array}{r}0.03 \\
5\end{array}$ & $\begin{array}{r}0.04 \\
3\end{array}$ & 0.017 & ivAl & 2.254 & 2.343 & 2.482 & 2.272 & 2.494 \\
\hline T site & 8.000 & 8.000 & 8.000 & 8.000 & 8.000 & 8.000 & 8.000 & T site & $\begin{array}{r}1.99 \\
8\end{array}$ & $\begin{array}{r}2.00 \\
0\end{array}$ & 1.975 & ivTi & 0.000 & 0.000 & 0.000 & 0.054 & 0.000 \\
\hline viAl & 0.118 & 0.055 & 0.055 & 0.416 & 0.006 & 0.271 & 0.071 & $\mathrm{Al}^{+3}$ & $\begin{array}{r}0.00 \\
0\end{array}$ & $\begin{array}{r}0.01 \\
1\end{array}$ & 0.000 & $\Sigma T$ & 8.000 & 8.000 & 8.000 & 8.000 & 8.000 \\
\hline $\mathrm{Ti}$ & 0.101 & 0.003 & 0.092 & 0.227 & 0.072 & 0.198 & 0.183 & $\mathrm{Ti}$ & $\begin{array}{r}0.00 \\
7\end{array}$ & $\begin{array}{r}0.00 \\
9\end{array}$ & 0.006 & viAl & 0.888 & 0.176 & 0.074 & 0.000 & 0.271 \\
\hline $\mathrm{Cr}$ & 0.000 & 0.000 & 0.000 & 0.000 & 0.005 & 0.000 & 0.000 & $\mathrm{Cr}$ & $\begin{array}{r}0.00 \\
0\end{array}$ & $\begin{array}{r}0.00 \\
0\end{array}$ & 0.000 & viTi & 0.186 & 0.381 & 0.406 & 0.426 & 0.311 \\
\hline Felll & 0.722 & 0.861 & 0.952 & 0.879 & 1.066 & 0.901 & 0.696 & Felll & $\begin{array}{r}0.04 \\
5\end{array}$ & $\begin{array}{r}0.05 \\
4\end{array}$ & 0.055 & $\mathrm{Fe}$ & 2.216 & 2.468 & 2.301 & 2.725 & 2.577 \\
\hline $\mathrm{Fe}$ & 1.002 & 1.008 & 0.750 & 0.731 & 0.870 & 0.976 & 1.730 & $\mathrm{Fe}$ & $\begin{array}{r}0.38 \\
9\end{array}$ & $\begin{array}{r}0.33 \\
2\end{array}$ & 0.812 & $\mathrm{Mn}$ & 0.100 & 0.035 & 0.060 & 0.033 & 0.070 \\
\hline Mn & 0.073 & 0.142 & 0.123 & 0.030 & 0.044 & 0.063 & 0.064 & $\mathrm{Mn}$ & $\begin{array}{r}0.01 \\
3\end{array}$ & $\begin{array}{r}0.02 \\
2\end{array}$ & 0.025 & $\mathrm{Mg}$ & 2.156 & 2.699 & 2.984 & 2.678 & 2.635 \\
\hline $\mathrm{Mg}$ & 2.981 & 2.924 & 3.022 & 2.708 & 2.939 & 2.591 & 2.250 & $\mathrm{Mg}$ & 0.86 & 0.68 & 1.089 & $\Sigma 0$ & 5.628 & 5.820 & 5.875 & 5.908 & 5.918 \\
\hline
\end{tabular}




\begin{tabular}{|c|c|c|c|c|c|c|c|c|c|c|c|c|c|c|c|c|c|}
\hline \multirow{3}{*}{$\mathrm{Zn}$} & \multirow{3}{*}{0.003} & \multirow{3}{*}{0.006} & \multirow[b]{2}{*}{0.006} & \multirow[b]{2}{*}{0.008} & \multirow{3}{*}{0.003} & \multirow[b]{2}{*}{0.001} & 0.005 & $\mathrm{Zn}$ & $\begin{array}{r}0 \\
0.00\end{array}$ & $\begin{array}{r}5 \\
0.00\end{array}$ & 0.002 & \multirow[t]{2}{*}{$\mathrm{Zn}$} & \multirow[t]{2}{*}{0.003} & \multirow[t]{2}{*}{0.006} & \multirow[t]{2}{*}{0.007} & \multirow[t]{2}{*}{0.000} & \multirow[t]{2}{*}{0.007} \\
\hline & & & & & & & & & 1 & 0 & & & & & & & \\
\hline & & & & & & & 5.000 & $\mathrm{Ca}$ & 0.66 & 0.84 & 0.036 & $\mathrm{Ba}$ & 0.000 & 0.018 & 0.011 & 0.002 & 0.040 \\
\hline C site & 5.000 & 5.000 & 5.000 & 5.000 & 5.005 & 5.000 & & & 8 & 9 & & & & & & & \\
\hline Excess & & & & & & & 0.000 & $\mathrm{Na}$ & 0.02 & 0.03 & 0.000 & $\mathrm{Ca}$ & 0.000 & 0.005 & 0.008 & 0.000 & 0.011 \\
\hline C & 0.000 & 0.000 & 0.000 & 0.000 & 0.005 & 0.000 & & & 0 & 7 & & & & & & & \\
\hline & & & & & & & 1.752 & $\mathrm{~K}$ & $\begin{array}{r}0.00 \\
0\end{array}$ & $\begin{array}{r}0.00 \\
1\end{array}$ & 0.000 & $\mathrm{Na}$ & 0.035 & 0.023 & 0.052 & 0.046 & 0.042 \\
\hline $\mathrm{Ca}$ & $1 . / 81$ & 1.859 & 1.789 & $1 . / / 2$ & 1.700 & 1.154 & 0.248 & & 2.00 & $\begin{array}{r}1 \\
2.00\end{array}$ & 2.025 & K & 1.857 & 1.807 & 1.842 & 1.863 & 1.716 \\
\hline $\begin{array}{l}\mathrm{NaB} \\
\mathrm{B} \text { site }\end{array}$ & $\begin{array}{l}0.219 \\
2.000\end{array}$ & $\begin{array}{l}0.141 \\
2.000\end{array}$ & $\begin{array}{l}0.211 \\
2.000\end{array}$ & $\begin{array}{l}0.228 \\
2.000\end{array}$ & $\begin{array}{l}0.294 \\
2.000\end{array}$ & $\begin{array}{l}0.246 \\
2.000\end{array}$ & 2.000 & sites & 2 & 0 & & & & . & & 1.000 & 1.10 \\
\hline $\mathrm{NaA}$ & 0.192 & 0.086 & 0.063 & 0.271 & 0.000 & 0.248 & 0.257 & & & & & $\Sigma A$ & 1.895 & 1.859 & 1.920 & 1.911 & 1.816 \\
\hline K & 0.129 & 0.080 & 0.118 & 0.139 & 0.099 & 0.140 & 0.187 & mg\# & 0.69 & 0.67 & 0.57 & & & & & & \\
\hline A site & 0.321 & 0.166 & 0.181 & 0.409 & 0.099 & 0.388 & 0.443 & Molecul & ir comp & onents & & Anions & & & & & \\
\hline & 15.32 & 15.16 & & & & 15.38 & 15.443 & wo & 33.81 & 43. & 1.77 & $\mathrm{~F}$ & 0.208 & 0.024 & 0.038 & 0.130 & 0.037 \\
\hline Cations & 1 & 6 & 15.181 & 15.104 & 15.352 & 8 & & & & 70 & & & & & & & \\
\hline & & & & & & & 0.063 & en & 43.55 & 35.2 & 54.00 & $\mathrm{Cl}$ & 0.002 & 0.057 & 0.031 & 0.060 & 0.028 \\
\hline $\mathrm{F}$ & 0.104 & 0.019 & 0.019 & 0.032 & 0.090 & 0.012 & 0.099 & fs & 22.64 & $\begin{array}{r}8 \\
21.0\end{array}$ & 43.00 & & & & & & \\
\hline $\begin{array}{l}\mathrm{Cl} \\
\mathrm{mg \#}\end{array}$ & $\begin{array}{r}0.024 \\
\mathbf{0 . 7 5}\end{array}$ & $\begin{array}{r}0.011 \\
\mathbf{0 . 7 4} \\
\end{array}$ & $\begin{array}{r}0.021 \\
\mathbf{0 . 8 0} \\
\end{array}$ & $\begin{array}{r}0.038 \\
\mathbf{0 . 7 7}\end{array}$ & $\begin{array}{r}0.062 \\
\mathbf{0 . 6 3} \\
\end{array}$ & $\begin{array}{r}0.026 \\
\mathbf{0 . 7 3}\end{array}$ & 0.57 & & & 2 & & mg\# & 0.48 & 0.52 & 0.56 & 0.50 & 0.51 \\
\hline
\end{tabular}

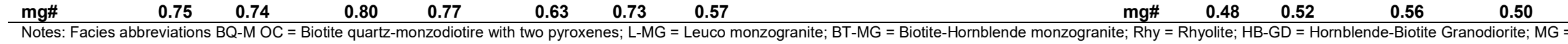
Monzogranite; $\mathrm{H}-\mathrm{MZ}=$ Hornblende monzodiorite; $\mathrm{E}-\mathrm{MD}=$ Micro-diorite enclave; $\mathrm{IM}-\mathrm{D}=$ Intermediate-mafic dikes; Dac = Dacite; wo = wollastonite; en = enstatite; fo = fosterite; $\mathrm{mg} \#=$ magnesium number; $\Sigma \mathrm{T}=$ = sum of tetrahedral cations; $\Sigma O=$ sum of octahedral cations; $\Sigma A=$ sum of interlayer cations. 
Table 3. Representative electron microprobe analyses of magnetites and ilmenites in granites and related rocks of Garzón region.

\begin{tabular}{|c|c|c|c|c|c|c|c|c|c|c|c|c|c|c|}
\hline Mineral & $\mathrm{Mt}$ & $\| \mathrm{m}$ & Mt & $\| \mathrm{m}$ & $\mathrm{Mt}$ & IIm & $\mathrm{Mt}$ & IIm & Mt & $\| \mathrm{m}$ & $\mathrm{Mt}$ & $\| \mathrm{m}$ & Mt & $\| \mathrm{m}$ \\
\hline Massif & \multicolumn{4}{|c|}{ Algeciras } & \multicolumn{4}{|c|}{ Altamira } & \multicolumn{6}{|c|}{ Sombrerillo } \\
\hline Sample & \multirow{2}{*}{\multicolumn{2}{|c|}{$\begin{array}{c}\frac{\text { GAR-372 }}{\text { BH-MG }} \\
\end{array}$}} & \multirow{2}{*}{\multicolumn{2}{|c|}{$\begin{array}{c}\text { GAR-358 } \\
\text { IM-D }\end{array}$}} & \multirow{2}{*}{\multicolumn{2}{|c|}{$\begin{array}{c}\text { GAR-383 } \\
\text { Rhy }\end{array}$}} & \multirow{2}{*}{\multicolumn{2}{|c|}{$\begin{array}{c}\text { GAR-388 } \\
\text { H-MD }\end{array}$}} & \multirow{2}{*}{\multicolumn{2}{|c|}{$\begin{array}{c}\text { L-102 } \\
\text { BQ-M OC }\end{array}$}} & \multirow{2}{*}{\multicolumn{2}{|c|}{$\frac{\text { GAR-394 }}{\text { MG }}$}} & \multirow{2}{*}{\multicolumn{2}{|c|}{$\frac{\text { GAR-395 }}{\text { Dac }}$}} \\
\hline Facies & & & & & & & & & & & & & & \\
\hline $\begin{array}{l}\text { Grain/ } \\
\text { Point }\end{array}$ & $\underset{03-1}{\operatorname{mag} R}$ & $\mathrm{ilm}_{\overline{\mathrm{R}} \mathrm{R}-1}$ & $\underset{-1}{\text { mag_06 }_{-1}}$ & $\mathrm{ilm}_{\overline{1}} 06-$ & mag_02-1 & ilm_02-1 & $\underset{1}{\text { mag_01- }_{1}}$ & $\mathrm{ilm}_{-1} 01$ & $\operatorname{mag}_{1}$ 03- & $\begin{array}{c}\text { Im_03a- } \\
1\end{array}$ & $\operatorname{mag}_{2-1} 0$ & $\mathrm{ilm}_{-1} 02$ & $\operatorname{mag}_{4-1} 0$ & $\mathrm{ilm}_{\overline{1}} 04$ \\
\hline $\mathrm{SiO} 2$ & 0.0652 & 0.03 & 0.08 & 0.06 & 0.71 & 0.02 & 0.00 & 0.01 & 0.0652 & 0.03 & 0.10 & 0.03 & 0.0319 & 0.0047 \\
\hline TiO2 & 0.4997 & 50.49 & 1.66 & 48.75 & 2.55 & 48.45 & 0.07 & 49.56 & 0.4997 & 50.49 & 0.18 & 49.60 & 0.2777 & 49.1 \\
\hline $\mathrm{Al} 2 \mathrm{O} 3$ & 0.4563 & 0.00 & 0.06 & 0.00 & 0.00 & 0.06 & 0.07 & 0.00 & 0.4563 & 0.00 & 0.29 & 0.01 & 0.1562 & c \\
\hline $\mathrm{Fe} 2 \mathrm{O} 3$ & 74.6 & 5.0 & 73.1 & 8.8 & 66.4 & 9.6 & 75.9 & 6.8 & 74.6 & 5.0 & 75.7 & 6.0 & 76.1 & 7.8 \\
\hline $\mathrm{FeO}$ & 35.3 & 42.2 & 36.1 & 36.6 & 35.8 & 36.6 & 34.3 & 23.3 & 35.3 & 42.2 & 35.0 & 40.0 & 34.9 & 21.7 \\
\hline $\mathrm{MnO}$ & 0.0332 & 3.02 & 0.17 & 6.84 & 0.17 & 6.38 & 0.07 & 20.82 & 0.0332 & 3.02 & 0.04 & 4.47 & 0.1182 & 21.91 \\
\hline $\mathrm{MgO}$ & 0 & 0.02 & 0.00 & 0.17 & 0.00 & 0.03 & 0.00 & 0.06 & 0 & 0.02 & 0.01 & 0.03 & 0 & $c$ \\
\hline $\mathrm{CaO}$ & 0.0255 & 0.10 & 0.02 & 0.03 & 0.24 & 0.25 & 0.03 & 0.08 & 0.0255 & 0.10 & 0.03 & 0.01 & 0.031 & 0.1505 \\
\hline $\mathrm{Na} 2 \mathrm{O}$ & 0 & 0.00 & 0.00 & 0.00 & 0.00 & 0.05 & 0.03 & 0.01 & 0 & 0.00 & & 0.02 & 0.0303 & c \\
\hline $\mathrm{K} 2 \mathrm{O}$ & 0.0165 & 0.01 & 0.00 & 0.01 & 0.00 & 0.01 & 0.04 & 0.04 & 0.0165 & 0.01 & 0.02 & 0.02 & 0 & c \\
\hline \multicolumn{15}{|l|}{$\mathrm{BaO}$} \\
\hline $\mathrm{ZnO}$ & 0.0136 & 0.04 & 0.00 & 0.05 & 0.02 & 0.23 & 0.00 & 0.00 & 0.0136 & 0.04 & 0.00 & 0.05 & 0.0309 & 0.0994 \\
\hline V2O3 & 0.7879 & 0.38 & 0.28 & 0.33 & 0.23 & 0.20 & 0.12 & 0.28 & 0.7879 & 0.38 & 0.59 & 0.40 & 0.3056 & 0.2394 \\
\hline $\mathrm{NiO}$ & 0.028 & 0.00 & 0.02 & 0.01 & 0.00 & 0.00 & 0.01 & 0.00 & 0.028 & 0.00 & 0.00 & & 0.0207 & 0 \\
\hline $\mathrm{Nb} 2 \mathrm{O} 3$ & 0.097 & 0.05 & 0.00 & 0.00 & 0.00 & 0.10 & 0.10 & 0.01 & 0.097 & 0.05 & 0.00 & 0.05 & 0.05 & 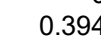 \\
\hline Total & 102.71 & 99.35 & 104.265 & 100.80 & 99.51 & 100.97 & 103.07 & 100.35 & 104.64 & 100.89 & 104.47 & 100.14 & 104.52 & 100.65 \\
\hline \multicolumn{15}{|c|}{ Structural formulae on the basis of 2 oxygen, 2 cations for ilmenite and 3 cations for magnetite } \\
\hline $\mathrm{Si}$ & 0.0013 & 0.0000 & 0.0029 & 0.0015 & 0.0256 & 0.0005 & 0.0000 & 0.0004 & 0.0022 & 0.0008 & 0.0035 & 0.0007 & 0.0011 & 0.0001 \\
\hline $\mathrm{Ti}$ & 0.0320 & 0.8500 & 0.0430 & 0.9125 & 0.0692 & 0.9060 & 0.0019 & 0.9320 & 0.0129 & 0.9475 & 0.0046 & 0.9374 & 0.0072 & 0.9215 \\
\hline Al & 0.0061 & 0.0000 & 0.0022 & 0.0000 & 0.0000 & 0.0018 & 0.0030 & 0.0001 & 0.0184 & 0.0000 & 0.0118 & 0.0003 & 0.0063 & 0.0000 \\
\hline $\mathrm{Fe}+3$ & 1.9191 & 0.2893 & 1.8960 & 0.1649 & 1.8017 & 0.1791 & 1.9872 & 0.1288 & 1.9241 & 0.0944 & 1.9537 & 0.1137 & 1.9662 & 0.1470 \\
\hline $\mathrm{Fe}+2$ & 1.0289 & 0.6788 & 1.0403 & 0.7619 & 1.0797 & 0.7605 & 0.9976 & 0.4870 & 1.0119 & 0.8805 & 1.0052 & 0.8405 & 1.0022 & 0.4528 \\
\hline $\mathrm{Mn}$ & 0.0016 & 0.1622 & 0.0048 & 0.1441 & 0.0052 & 0.1343 & 0.0019 & 0.4408 & 0.0010 & 0.0638 & 0.0011 & 0.0951 & 0.0034 & $0.462 \mathrm{c}$ \\
\hline $\mathrm{Mg}$ & 0.0014 & 0.0023 & 0.0000 & 0.0062 & 0.0002 & 0.0010 & 0.0000 & 0.0023 & 0.0000 & 0.0007 & 0.0004 & 0.0013 & 0.0000 & 0.0000 \\
\hline $\mathrm{Ca}$ & 0.0008 & 0.0059 & 0.0007 & 0.0008 & 0.0093 & 0.0066 & 0.0012 & 0.0022 & 0.0009 & 0.0027 & 0.0012 & 0.0002 & 0.0011 & $0.004 \mathrm{C}$ \\
\hline $\mathrm{Na}$ & 0.0000 & 0.0004 & 0.0000 & 0.0000 & 0.0000 & 0.0026 & 0.0018 & 0.0004 & 0.0000 & 0.0002 & 0.0000 & 0.0012 & 0.0020 & 0.0000 \\
\hline $\mathrm{K}$ & 0.0000 & 0.0001 & 0.0000 & 0.0004 & 0.0000 & 0.0002 & 0.0020 & 0.0011 & 0.0007 & 0.0002 & 0.0007 & 0.0007 & 0.0000 & 0.0000 \\
\hline $\mathrm{Cr}$ & 0.0015 & 0.0000 & 0.0020 & 0.0002 & 0.0019 & 0.0000 & 0.0001 & 0.0000 & 0.0037 & 0.0006 & 0.0019 & 0.0006 & 0.0011 & 0.0000 \\
\hline $\mathrm{Ba}$ & 0.0000 & 0.0000 & 0.0000 & 0.0000 & 0.0000 & 0.0000 & 0.0000 & 0.0000 & 0.0000 & 0.0000 & 0.0000 & 0.0000 & 0.0000 & 0.0000 \\
\hline $\mathrm{Zn}$ & 0.0006 & 0.0008 & 0.0000 & 0.0010 & 0.0005 & 0.0041 & 0.0000 & 0.0001 & 0.0003 & 0.0007 & 0.0000 & 0.0009 & 0.0008 & 0.0018 \\
\hline $\mathrm{V}$ & 0.0067 & 0.0063 & 0.0077 & 0.0066 & 0.0067 & 0.0040 & 0.0034 & 0.0057 & 0.0216 & 0.0075 & 0.0161 & 0.0081 & 0.0084 & 0.0048 \\
\hline $\mathrm{Ni}$ & 0.0000 & 0.0004 & 0.0006 & 0.0001 & 0.0000 & 0.0000 & 0.0002 & 0.0000 & 0.0008 & 0.0000 & 0.0000 & 0.0000 & 0.0006 & 0.0000 \\
\hline $\mathrm{Nb}$ & 0.0000 & 0.0039 & 0.0000 & 0.0000 & 0.0000 & 0.0013 & 0.0017 & 0.0002 & 0.0017 & 0.0006 & 0.0000 & 0.0006 & 0.0009 & 0.0051 \\
\hline Total & 3.0000 & 2.0005 & 3.0001 & 2.0003 & 3.0000 & 2.0018 & 3.0022 & 2.0011 & 3.0004 & 2.0003 & 3.0004 & 2.0012 & 3.0013 & 2.0000 \\
\hline $\mathrm{T}\left({ }^{\circ} \mathrm{C}\right)$ & & \multicolumn{2}{|c|}{653} & \multicolumn{2}{|c|}{688} & \multicolumn{2}{|c|}{500} & \multicolumn{2}{|c|}{541} & \multicolumn{2}{|c|}{518} & \multicolumn{2}{|c|}{574} \\
\hline $\log f 02$ & \multirow{2}{*}{\multicolumn{2}{|c|}{$\begin{array}{c}-14 \\
+2.64\end{array}$}} & \multirow{2}{*}{\multicolumn{2}{|c|}{$\begin{array}{r}-16 \\
+123\end{array}$}} & -1 & & -1 & & & & & & & 16 \\
\hline$\triangle N N O$ & & & & & +2 & & +4 & & & & & 98 & & .89 \\
\hline
\end{tabular}


Table 4. Pressure and temperature estimates with different amphibole and amphibole-plagioclase geothermobarometers for granites and related rocks of Garzón region.

\begin{tabular}{|c|c|c|c|c|c|c|c|c|c|c|c|c|c|c|c|c|}
\hline \multirow{2}{*}{$\begin{array}{l}\text { Sample } \\
\text { Reference }\end{array}$} & \multirow[t]{2}{*}{ Facies } & \multicolumn{6}{|c|}{ Pressure (kbar) Min/Max } & \multicolumn{3}{|c|}{$\begin{array}{c}\text { Average } \\
\text { Pressure (kbar) }\end{array}$} & \multicolumn{3}{|c|}{ Temperature $\left({ }^{\circ} \mathrm{C}\right)$ Min-Max } & \multicolumn{3}{|c|}{$\begin{array}{c}\text { Average } \\
\text { Temperature }\left({ }^{\circ} \mathrm{C}\right)\end{array}$} \\
\hline & & $a$ & $\mathrm{~b}$ & $\mathrm{c}$ & $d$ & $\mathrm{e}$ & $f$ & $a$ & $\mathrm{e}$ & $f$ & $g$ & $\mathrm{~h}$ & $\mathrm{i}$ & $g$ & $\mathrm{~h}$ & $\mathrm{i}$ \\
\hline L-102 & BQ-M OC & $1.3-2.1$ & $1.1-2.2$ & $0.9-1.7$ & $1.9-2.7$ & $1.1-1.5$ & $0.8-1.1$ & 1.8 & 1.3 & 1.0 & $756-761$ & $700-732$ & $776-823$ & 759 & 716 & 807 \\
\hline GAR-356 & BT-MG & $0.9-2.4$ & $0.6-2.4$ & $0.6-1.9$ & $1.5-3.0$ & $1.0-1.6$ & $1.2-0.8$ & 2.2 & 1.5 & 1.1 & $751-753$ & $635-708$ & $781-833$ & 749 & 669 & 811 \\
\hline GAR-357 & BT-MG & $0.8-2.6$ & $0.5-2.5$ & $0.5-2.0$ & $1.4-3.1$ & $1.0-1.7$ & $0.7-1.2$ & 1.6 & 1.3 & 0.9 & $746-756$ & $625-712$ & $778-848$ & 752 & 682 & 804 \\
\hline GAR-361 & Dac & $2.5-7.4$ & $2.4-8.1$ & $2.2-6.2$ & $3.0-7.8$ & $1.6-6.9$ & $1.2-5.1$ & 4.8 & 3.5 & 2.6 & $749-764$ & $540-739$ & $859-1051$ & 758 & 647 & 956 \\
\hline GAR-383 & Rhy & $0.1-1.1$ & 0.9 & $0-0.8$ & $0.8-1.8$ & $0.8-1.1$ & $0.6-0.8$ & 0.4 & 0.9 & 0.7 & $745-750$ & $684-713$ & $746-764$ & 748 & 701 & 752 \\
\hline GAR-386 & HB-GD & $1.0-2.2$ & $0.8-2.1$ & $0.7-1.7$ & $1.7-2.8$ & $1.1-1.5$ & $0.8-1.1$ & 1.6 & 1.3 & 0.9 & $752-756$ & 641-685 & $779-825$ & 754 & 663 & 802 \\
\hline GAR-387 & IM-D & 7.8-7.9 & $8.4-8.5$ & 6.4-6.5 & $8.1-8.2$ & 7.5-7.6 & $5.5-5.6$ & 6.6 & 6.3 & 4.6 & $735-747$ & - & $1017-1037$ & 740 & - & 973 \\
\hline GAR-394 & BT-MG & $1.8-3.5$ & $1.6-3.5$ & $1.3-2.8$ & $2.4-4.0$ & $1.3-2.2$ & $1.0-1.6$ & 2.9 & 1.9 & 1.4 & $753-764$ & $583-667$ & $813-873$ & 758 & 629 & 848 \\
\hline GAR-395 & Dac & $1.3-6.0$ & $1.0-6.4$ & $0.9-4.9$ & $1.9-6.4$ & $1.1-4.5$ & $0.8-3.3$ & 2.8 & 1.9 & 1.4 & $748-761$ & $555-732$ & $798-957$ & 757 & 649 & 851 \\
\hline
\end{tabular}

aHammarstrom and Zen (1986); bHollister et al. (1987); cJohnson and Rutherford (1989); ${ }^{\mathrm{d} S c h m i d t ~(1992) ; ~}{ }^{\mathrm{eHammarstrom}}$ and Zen (1986)

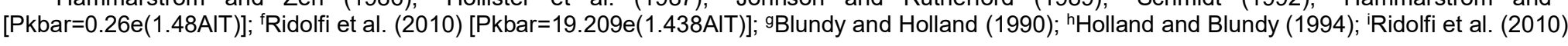




\section{Anexo}

Supplementary Material 
Supplementary Material: Whole rock geochemistry from Garzón granites and related rocks. Eastern Cordillera. Colombia.

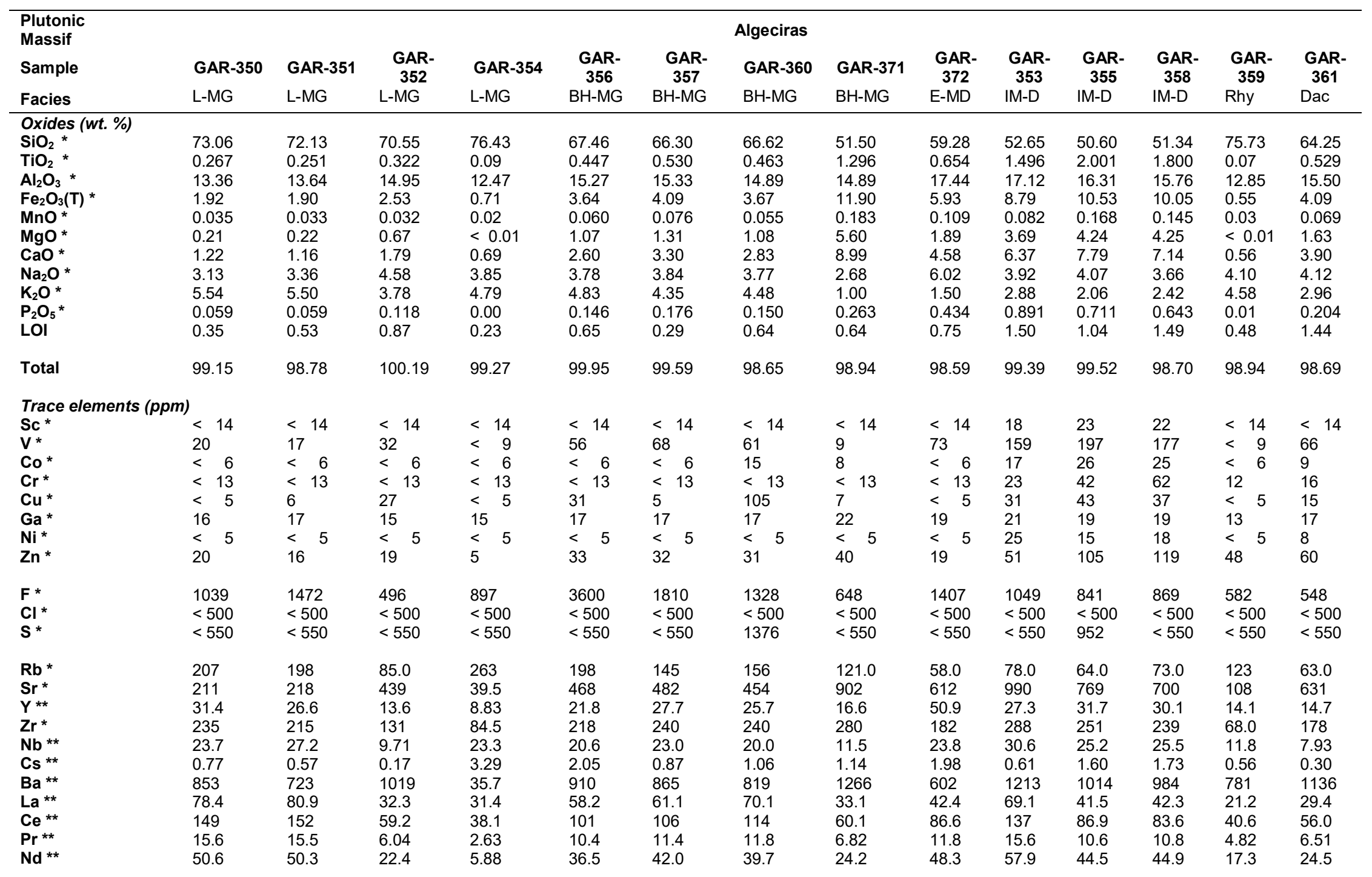




\begin{tabular}{|c|c|c|c|c|c|c|c|c|c|c|c|c|c|c|}
\hline Sm ** & 7.96 & 7.25 & 3.65 & 0.68 & 5.78 & 6.96 & 6.75 & 4.09 & 11.4 & 9.46 & 8.50 & 8.21 & 3.2 & 4.33 \\
\hline Eu ** & 1.07 & 0.98 & 0.89 & 0.09 & 1.14 & 1.33 & 1.26 & 1.05 & 1.52 & 2.55 & 2.40 & 2.21 & 0.52 & 1.10 \\
\hline$G^{* *}$ & 5.60 & 5.11 & 2.89 & 0.55 & 4.17 & 5.53 & 5.31 & 3.10 & 9.85 & 6.81 & 7.34 & 7.12 & 2.62 & 3.35 \\
\hline Tb ** & 0.87 & 0.74 & 0.41 & 0.12 & 0.60 & 0.76 & 0.75 & 0.47 & 1.45 & 0.92 & 1.03 & 0.96 & 0.39 & 0.47 \\
\hline Dy ** & 5.03 & 4.34 & 2.20 & 0.87 & 3.40 & 4.43 & 4.19 & 2.68 & 8.21 & 4.76 & 5.47 & 5.26 & 2.20 & 2.55 \\
\hline Ho ** & 1.06 & 0.92 & 0.46 & 0.25 & 0.73 & 0.95 & 0.89 & 0.57 & 1.79 & 0.93 & 1.05 & 1.08 & 0.48 & 0.53 \\
\hline $\mathrm{Er} * *$ & 2.98 & 2.65 & 1.31 & 0.95 & 2.12 & 2.69 & 2.56 & 1.63 & 4.86 & 2.43 & 2.73 & 2.72 & 1.33 & 1.44 \\
\hline $\mathrm{Tm}^{* *}$ & 0.46 & 0.42 & 0.20 & 0.21 & 0.34 & 0.42 & 0.41 & 0.26 & 0.75 & 0.33 & 0.39 & 0.39 & 0.21 & 0.22 \\
\hline $\mathrm{Yb}^{* *}$ & 3.25 & 2.93 & 1.45 & 2.06 & 2.43 & 2.75 & 2.85 & 1.79 & 5.05 & 2.10 & 2.35 & 2.42 & 1.45 & 1.52 \\
\hline Lu ** & 0.51 & 0.47 & 0.23 & 0.40 & 0.38 & 0.43 & 0.42 & 0.27 & 0.71 & 0.32 & 0.36 & 0.34 & 0.22 & 0.23 \\
\hline$H f * *$ & 6.90 & 7.88 & 4.32 & 4.11 & 6.04 & 5.87 & 7.67 & 5.29 & 4.84 & 5.58 & 5.11 & 5.15 & 2.56 & 4.38 \\
\hline $\mathrm{Pb}^{\text {** }}$ & 18.2 & 17.0 & 10.5 & 15.9 & 9.67 & 9.25 & 9.16 & 13.0 & 9.26 & 6.76 & 3.25 & 4.11 & 50.7 & 18.2 \\
\hline Th ** & 20.3 & 21.0 & 6.18 & 53.0 & 23.8 & 10.8 & 16.4 & 8.05 & 6.83 & 4.01 & 2.93 & 3.54 & 5.06 & 4.46 \\
\hline$U^{* *}$ & 3.21 & 4.67 & 1.48 & 14.8 & 5.81 & 2.95 & 4.19 & 1.91 & 1.95 & 2.16 & 1.09 & 0.83 & 1.66 & 1.16 \\
\hline A/CNK & 1.00 & 1.00 & 1.00 & 0.98 & 0.94 & 0.90 & 0.92 & 0.68 & 0.88 & 0.81 & 0.71 & 0.73 & 1.01 & 0.91 \\
\hline ASI & 1.01 & 1.01 & 1.01 & 0.98 & 0.95 & 0.91 & 0.93 & 0.69 & 0.90 & 0.85 & 0.73 & 0.76 & 1.01 & 0.92 \\
\hline Fe-number & 0.89 & 0.89 & 0.77 & & 0.75 & 0.74 & 0.75 & 0.66 & 0.74 & 0.68 & 0.69 & 0.68 & & 0.69 \\
\hline $\mathrm{Eu} / \mathrm{Eu}^{*}$ & 0.5 & 0.5 & 0.8 & 0.4 & 0.7 & 0.7 & 0.6 & 0.9 & 0.4 & 1.0 & 0.9 & 0.9 & 0.6 & 0.9 \\
\hline $\mathrm{Ce} / \mathrm{Ce}^{*}$ & 1.03 & 1.04 & 1.03 & 1.02 & 1.00 & 0.97 & 0.96 & 0.97 & 0.94 & 1.01 & 1.00 & 0.95 & 0.97 & 0.98 \\
\hline$(\mathrm{La} / \mathrm{Yb})_{\mathrm{N}}$ & 16.4 & 18.8 & 15.2 & 10.4 & 16.3 & 15.1 & 16.8 & 12.6 & 5.7 & 22.4 & 12.0 & 11.9 & 10.0 & 13.2 \\
\hline$(\mathrm{La} / \mathrm{Sm})_{\mathrm{N}}$ & 6.17 & 6.99 & 5.53 & 29.00 & 6.31 & 5.50 & 6.51 & 5.07 & 2.34 & 4.58 & 3.06 & 3.23 & 4.13 & 4.25 \\
\hline$(G d / Y b)_{N}$ & 1.40 & 1.41 & 1.62 & 0.22 & 1.39 & 1.63 & 1.51 & 1.40 & 1.58 & 2.63 & 2.53 & 2.38 & 1.47 & 1.79 \\
\hline$(\mathrm{Sm} / \mathrm{Yb})_{\mathrm{N}}$ & 2.45 & 2.47 & 2.52 & 0.33 & 2.38 & 2.53 & 2.37 & 2.28 & 2.25 & 4.51 & 3.61 & 3.39 & 2.22 & 2.86 \\
\hline Ü/Th & 0.16 & 0.22 & 0.24 & 0.28 & 0.24 & 0.27 & 0.25 & 0.24 & 0.29 & 0.54 & 0.37 & 0.24 & 0.33 & 0.26 \\
\hline $\mathrm{Ba} / \mathrm{Th}$ & 42.06 & 34.46 & 164.95 & 0.67 & 38.20 & 80.09 & 49.80 & 157.35 & 88.27 & 302.52 & 346.10 & 278.20 & 154.18 & 254.75 \\
\hline $\mathrm{T}_{\mathrm{Zr}}\left({ }^{\circ} \mathrm{C}\right)$ (W\&H. 1983) & 817.11 & 808.20 & 760.84 & 731.69 & 792.73 & 792.97 & 798.23 & 723.73 & 750.85 & 759.21 & 716.02 & 723.32 & 717.55 & 766.56 \\
\hline $\mathrm{T}_{\mathrm{Zr}}\left({ }^{\circ} \mathrm{C}\right)_{(\text {Boe. 2013) }}$ & 773.97 & 763.17 & 706.42 & 675.71 & 738.15 & 734.98 & 743.21 & 626.97 & 680.01 & 677.48 & 619.21 & 631.04 & 660.73 & 704.70 \\
\hline $\mathrm{T}_{\mathrm{Ap}}\left({ }^{\circ} \mathrm{C}\right)_{(\mathrm{H} \& W}$ & 883.30 & 874.30 & 926.60 & 0.00 & 917.40 & 925.70 & 911.40 & 779.10 & 956.60 & 976.50 & 906.80 & 902.60 & 765.10 & 919.90 \\
\hline$\left.{ }^{1984)}{ }^{\circ} \mathrm{C}\right)$ & & & & & & & & & & & & & & \\
\hline $\begin{array}{l}\mathrm{T}_{\mathrm{Ap}}\left({ }^{\circ} \mathrm{C}\right)_{(\mathrm{Bea} 1992)} \\
\mathrm{T}_{\mathrm{Ap}}\left({ }^{\circ} \mathrm{C}\right)_{(\mathrm{Pic}, 1992)}\end{array}$ & & $\begin{array}{l}871.8 \\
838\end{array}$ & $\begin{array}{l}923.3 \\
892.7\end{array}$ & $\begin{array}{l}\text { NA } \\
\text { NA }\end{array}$ & $\begin{array}{l}\text { NA } \\
\text { NA }\end{array}$ & $\begin{array}{l}\text { NA } \\
\text { NA }\end{array}$ & $\begin{array}{l}\text { NA } \\
\text { NA }\end{array}$ & $\begin{array}{l}\text { NA } \\
\text { NA }\end{array}$ & $\begin{array}{l}\text { NA } \\
\text { NA }\end{array}$ & NA & $\begin{array}{l}\text { NA } \\
\text { NA }\end{array}$ & $\begin{array}{l}\text { NA } \\
\text { NA }\end{array}$ & $\begin{array}{l}159.00 \\
578.30\end{array}$ & NA \\
\hline * & \multirow{3}{*}{\multicolumn{14}{|c|}{$\begin{array}{l}\text { X-ray fluorescence } \\
\text { data } \\
\text { ICP-AES data }\end{array}$}} \\
\hline & & & & & & & & & & & & & & \\
\hline ** & & & & & & & & & & & & & & \\
\hline
\end{tabular}

Notes: Facies abbreviations BQ-M OC = Biotite quartz-monzodiorite with two pyroxenes; $L$-MG = Leuco-Syenogranite; L-MG = Leuco-Monzogranite; $B H-M G=$ Biotite hornblende

monzogranite; HB-GD = Hornblende-Biotite Granodiorite; MG = Monzogranite; H-MZ = Hornblende monzodiorite; E-MD = Micro-diorite enclave; IM-D = Intermediate-mafic dikes; G-HA $=$ Granite with hydrothermal alteration; Rhy $=$ Rhyolite; $\mathrm{Dac}=$ Dacite. Fe-number $=[\mathrm{FeOT} /(\mathrm{FeOT}+\mathrm{MgO})] \mathrm{Mg}$ and FeT in molecular ratio. ASI $=$ alumina saturation index, defined as the molecular ratio $\left[\mathrm{Al} /(\mathrm{Ca}-1 \cdot 67 \mathrm{P}+\mathrm{Na}+\mathrm{K}]\right.$. A/CNK $=$ Shand index $[\mathrm{Al} 2 \mathrm{O} /(\mathrm{CaO} \mathrm{Na} 2 \mathrm{O} \mathrm{K} 2 \mathrm{O})]$ in molecular ratio. Values of $(\mathrm{La} / \mathrm{Yb})_{\mathrm{N}} \cdot(\mathrm{La} / \mathrm{Sm})_{\mathrm{N}} \cdot(\mathrm{Gd} / \mathrm{Yb})_{\mathrm{N}} .(\mathrm{Sm} / \mathrm{Yb})_{\mathrm{N}}$. are normalized with McDonough \& Sun (1995); $\mathrm{T}_{\mathrm{Zr}}\left({ }^{\circ} \mathrm{C}\right)_{(\mathrm{W} \& \mathrm{H} .1983)}=$ Zircon saturation temperature (Watson \& Harrison, 1983); $\mathrm{T}_{\mathrm{Zr}}\left({ }^{\circ} \mathrm{C}\right)_{(\mathrm{Boe} .2013)}=$ Zircon saturation temperature $\left(\right.$ Boeehnke et al., 2013); $\mathrm{T}_{\mathrm{Ap}}\left({ }^{\circ} \mathrm{C}\right)$

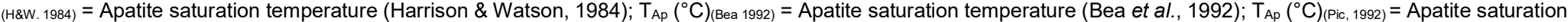
temperature (Pichavant et al., 1992). 
Supplementary Material: Whole rock geochemistry from Garzón granites and related rocks. Eastern Cordillera. Colombia.

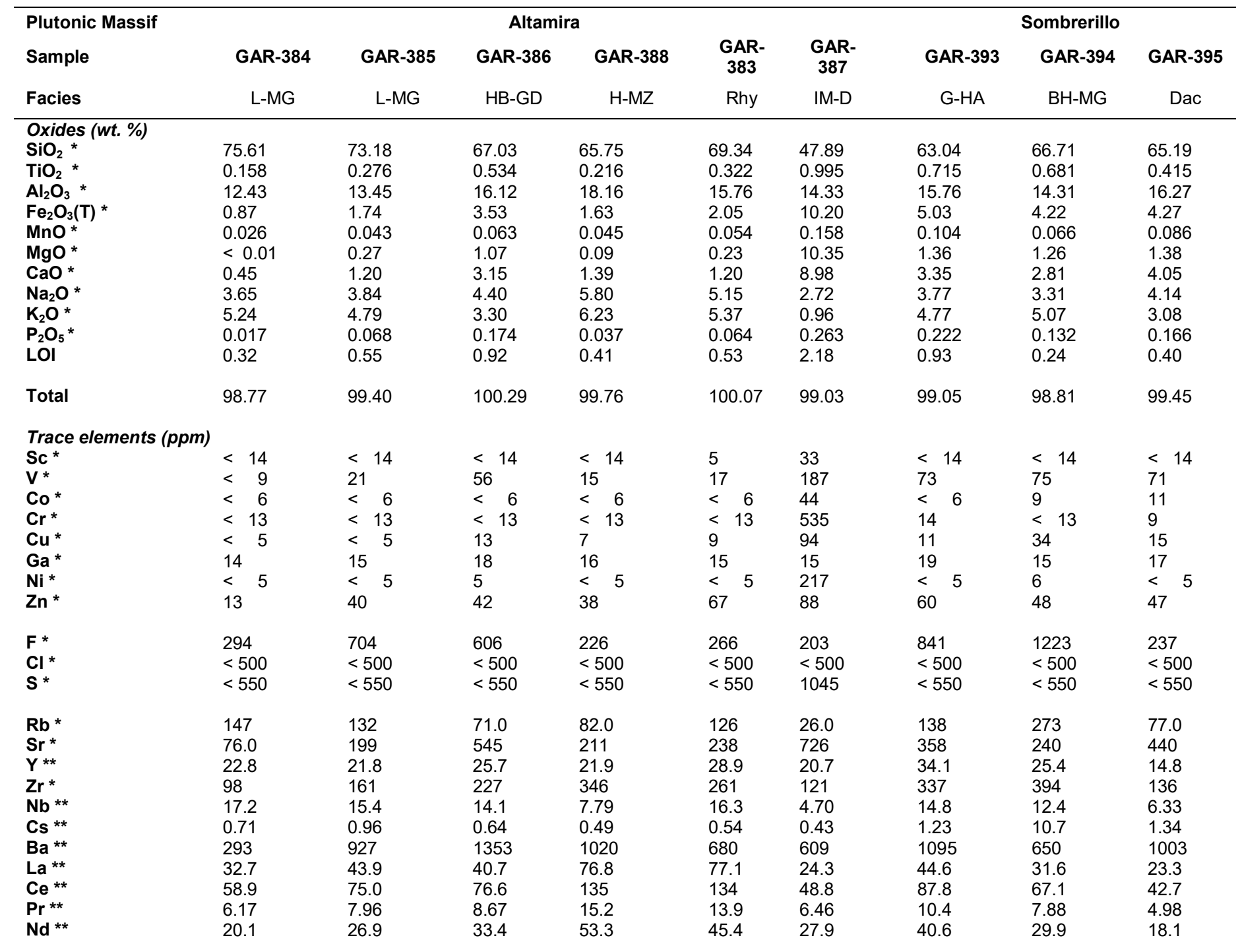




\begin{tabular}{|c|c|c|c|c|c|c|c|c|c|}
\hline$S m$ ** & 3.51 & 4.42 & 5.84 & 8.27 & 6.98 & 5.44 & 7.67 & 5.88 & 3.44 \\
\hline Eu ** & 0.45 & 0.78 & 1.27 & 1.98 & 1.02 & 1.55 & 1.37 & 0.81 & 1.01 \\
\hline $\mathbf{G d}^{* *}$ & 2.78 & 3.38 & 4.49 & 5.59 & 4.68 & 4.64 & 6.49 & 4.81 & 2.94 \\
\hline Tb ** & 0.52 & 0.55 & 0.71 & 0.78 & 0.81 & 0.64 & 0.99 & 0.73 & 0.42 \\
\hline Dy ** & 3.23 & 3.32 & 4.16 & 4.29 & 4.80 & 3.64 & 5.75 & 4.20 & 2.46 \\
\hline Ho ** & 0.76 & 0.74 & 0.89 & 0.84 & 1.04 & 0.73 & 1.20 & 0.89 & 0.53 \\
\hline $\mathrm{Er} * *$ & 2.32 & 2.16 & 2.52 & 2.28 & 2.93 & 1.96 & 3.29 & 2.50 & 1.48 \\
\hline $\mathrm{Tm} * *$ & 0.40 & 0.35 & 0.40 & 0.34 & 0.45 & 0.28 & 0.51 & 0.37 & 0.23 \\
\hline $\mathrm{Yb}^{* *}$ & 2.90 & 2.55 & 2.81 & 2.35 & 3.12 & 1.83 & 3.45 & 2.47 & 1.57 \\
\hline Lu ** & 0.45 & 0.40 & 0.43 & 0.38 & 0.48 & 0.27 & 0.53 & 0.37 & 0.25 \\
\hline $\mathrm{Hf} * *$ & 4.95 & 4.38 & 6.27 & 8.55 & 6.90 & 2.57 & 8.56 & 10.7 & 3.25 \\
\hline $\mathrm{Pb}^{* *}$ & 15.1 & 17.0 & 38.7 & 24.0 & 24.4 & 9.14 & 15.0 & 15.5 & 6.78 \\
\hline Th ** & 39.9 & 19.5 & 10.0 & 6.54 & 14.1 & 3.29 & 14.7 & 28.8 & 6.77 \\
\hline $\mathbf{U}$ ** & 7.03 & 4.43 & 2.36 & 1.01 & 2.14 & 0.87 & 3.15 & 6.96 & 1.90 \\
\hline A/CNK & 0.99 & 0.98 & 0.97 & 0.97 & 0.96 & 0.66 & 0.90 & 0.89 & 0.93 \\
\hline ASI & 1.00 & 0.99 & 0.99 & 0.97 & 0.96 & 0.67 & 0.92 & 0.90 & 0.94 \\
\hline Fe-number & & 0.85 & 0.75 & 0.94 & 0.89 & 0.47 & 0.77 & 0.75 & 0.74 \\
\hline $\mathrm{Eu} / \mathrm{Eu}^{*}$ & 0.4 & 0.6 & 0.8 & 0.9 & 0.5 & 0.9 & 0.6 & 0.5 & 1.0 \\
\hline $\mathrm{Ce} / \mathrm{Ce}^{*}$ & 1.00 & 0.97 & 0.99 & 0.96 & 0.99 & 0.94 & 0.99 & 1.03 & 0.96 \\
\hline$(\mathrm{La} / \mathrm{Yb})_{\mathrm{N}}$ & 7.7 & 11.7 & 9.9 & 22.2 & 16.8 & 9.1 & 8.8 & 8.7 & 10.1 \\
\hline$(\mathrm{La} / \mathrm{Sm})_{\mathrm{N}}$ & 5.83 & 6.23 & 4.37 & 5.82 & 6.92 & 2.81 & 3.65 & 3.36 & 4.24 \\
\hline$(\mathrm{Gd} / \mathrm{Yb})_{\mathrm{N}}$ & 0.78 & 1.07 & 1.29 & 1.93 & 1.22 & 2.06 & 1.53 & 1.58 & 1.52 \\
\hline$(\mathrm{Sm} / \mathrm{Yb})_{\mathrm{N}}$ & 1.21 & 1.73 & 2.08 & 3.51 & 2.24 & 2.98 & 2,23 & 2,39 & 2,19 \\
\hline U/Th & 0.18 & 0.23 & 0.24 & 0.15 & 0.15 & 0.26 & 0,21 & 0,24 & 0,28 \\
\hline $\mathrm{Ba} / \mathrm{Th}$ & 7.36 & 47.47 & 135.10 & 155.93 & 48.15 & 184.85 & 74,50 & 22,55 & 148,06 \\
\hline $\mathrm{T}_{\mathrm{Zr}}\left({ }^{\circ} \mathrm{C}\right)_{(\text {(W\&H. 1983) }}$ & 744.79 & 781.14 & 799.33 & 831.00 & 811.92 & 641.04 & 819.00 & 840.14 & 747.22 \\
\hline $\mathrm{T}_{\mathrm{Zr}}\left({ }^{\circ} \mathrm{C}\right)_{(\text {Boe. 2013) }}$ & 691.23 & 731.01 & 747.01 & 780.74 & 761.59 & 534.14 & 762.86 & 790.00 & 684.07 \\
\hline $\mathrm{T}_{\mathrm{Ap}}\left({ }^{\circ} \mathrm{C}\right)_{\text {(H\&W. 1984) }}$ & 803.00 & 897.80 & 932.30 & 765.80 & 853.80 & 718.20 & 915.90 & 898.50 & 906.90 \\
\hline $\mathrm{T}_{\text {Ap }}\left({ }^{\circ} \mathrm{C}\right)_{\text {(Bea 1992) }}$ & NA & NA & NA & NA & NA & NA & NA & NA & NA \\
\hline $\mathrm{T}_{\text {Ap }}\left({ }^{\circ} \mathrm{C}\right)_{\text {(Pic. 1992) }}$ & NA & NA & NA & NA & NA & NA & NA & NA & NA \\
\hline
\end{tabular}

\section{** X-ray fluorescence data}

ICP-AES

Notes: Facies abbreviations BQ-M OC = Biotite quartz-monzodiorite with two pyroxenes; L-MG = Leuco-Syenogranite; L-MG = Leuco-Monzogranite; $B$ H-MG = Biotite hornblende

monzogranite; HB-GD = Hornblende-Biotite Granodiorite; MG = Monzogranite; H-MZ = Hornblende monzodiorite; E-MD = Micro-diorite enclave; IM-D = Intermediate-mafic dikes; G-HA $=$ Granite with hydrothermal alteration; Rhy $=$ Rhyolite; Dac $=$ Dacite. Fe-number $=[\mathrm{FeOT} /(\mathrm{FeOT}+\mathrm{MgO})] \mathrm{Mg}$ and FeT in molecular ratio. ASI $=$ alumina saturation index, defined as the molecular ratio $\left[\mathrm{Al} /(\mathrm{Ca}-1 \cdot 67 \mathrm{P}+\mathrm{Na}+\mathrm{K}] . \mathrm{A} / \mathrm{CNK}=\right.$ Shand index $[\mathrm{Al} 2 \mathrm{O} 3 /(\mathrm{CaO} \mathrm{Na} 2 \mathrm{O} \mathrm{K} 2 \mathrm{O})]$ in molecular ratio. Values of $(\mathrm{La} / \mathrm{Yb})_{\mathrm{N}}$. $(\mathrm{La} / \mathrm{Sm})_{\mathrm{N}}$. $(\mathrm{Gd} / \mathrm{Yb})_{\mathrm{N}}$. $(\mathrm{Sm} / \mathrm{Yb})_{\mathrm{N}}$. are normalized with McDonough \& Sun (1995); $\mathrm{T}_{\mathrm{Zr}}\left({ }^{\circ} \mathrm{C}\right)_{(\mathrm{W} \& \text { H. } 1983)}=$ Zircon saturation temperature (Watson \& Harrison, 1983); $\mathrm{T}_{\mathrm{Zr}}\left({ }^{\circ} \mathrm{C}\right)_{(\mathrm{Boe} .2013)}=$ Zircon saturation temperature $\left(\right.$ Boehnke et al., 2013); $\mathrm{T}_{\mathrm{Ap}}\left({ }^{\circ} \mathrm{C}\right)$

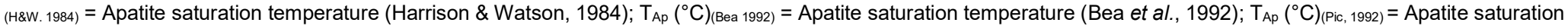
temperature (Pichavant et al., 1992). 
Supplementary Material: U-Pb zircon ages from Garzón granites and related rocks, Eastern Cordillera, Colombia.

\begin{tabular}{|c|c|c|c|c|c|c|c|c|c|c|c|c|c|c|c|c|c|c|c|c|c|c|}
\hline \multicolumn{23}{|c|}{ Algeciras Massif: Sample GAR-356 } \\
\hline $\begin{array}{l}\text { POI } \\
\text { NT }\end{array}$ & $\begin{array}{l}{ }^{207} \mathrm{~Pb} / \\
{ }^{235} \mathrm{U}\end{array}$ & $1 \sigma$ & $\begin{array}{l}{ }^{206} \mathrm{~Pb} / \\
{ }^{238} \mathrm{U}\end{array}$ & $1 \sigma$ & $\begin{array}{l}\text { corr. } \\
\text { coef } \\
f\end{array}$ & $\begin{array}{c}{ }^{238} \mathrm{U} / 20 \\
{ }^{6} \mathrm{~Pb}\end{array}$ & $1 \sigma$ & $\begin{array}{l}{ }^{207} \mathrm{~Pb} / \\
{ }^{206} \mathrm{~Pb}\end{array}$ & $1 \sigma$ & $\begin{array}{l}{ }^{208} \mathrm{~Pb} / \\
{ }^{206} \mathrm{~Pb}\end{array}$ & $1 \sigma$ & $\begin{array}{c}\mathrm{Pb} \\
\text { Total } \\
\text { Com } \\
\text { mon } \\
(\%)\end{array}$ & $\begin{array}{l}\mathrm{Pb} \\
\mathrm{rad} \\
\mathrm{ppm}\end{array}$ & $\begin{array}{c}\text { Th } \\
\text { ppm }\end{array}$ & $\underset{\mathrm{ppm}}{\mathrm{U}}$ & $\begin{array}{l}\text { Th/ } \\
\mathrm{U}\end{array}$ & $\begin{array}{c}\mathrm{Age} \\
{ }^{206} \mathrm{~Pb} / \\
238 \mathrm{U} \\
(\mathrm{Ma})\end{array}$ & $1 \sigma$ & $\begin{array}{c}\mathrm{Age} \\
{ }^{207} \mathrm{~Pb} / \\
{ }^{206} \mathrm{~Pb}\end{array}$ & $1 \sigma$ & $\begin{array}{c}\text { Conc. } \\
{ }^{206} \mathrm{~Pb} / \\
{ }^{238} \mathrm{U} \\
\text { l207 } \mathrm{Pb} /^{{ }^{206} \mathrm{~Pb}}\end{array}$ & \\
\hline $21 \_1$ & 0.1784 & 0.0127 & 0.0263 & 0.0010 & 0.72 & 38.0682 & 1.4520 & 0.0492 & 0.0047 & 0.2509 & 0.0183 & 0.83 & 7 & 33 & 178 & 0.75 & 167 & 0.006 & 159 & 0.197 & 100 & \\
\hline $22 \_1$ & 0.1889 & 0.0095 & 0.0266 & 0.0008 & 0.38 & 37.6206 & 1.1556 & 0.0515 & 0.0034 & 0.3199 & 0.0195 & 1.62 & 11 & 310 & 285 & 1.09 & 169 & 0.005 & 265 & 0.146 & 96 & \\
\hline $17 \_1$ & 0.1929 & 0.0190 & 0.0268 & 0.0006 & 0.32 & 37.3346 & 0.8688 & 0.0522 & 0.0055 & 0.2919 & 0.0217 & 0.74 & 9 & 229 & 239 & 0.96 & 170 & 0.004 & 296 & 0.227 & 95 & \\
\hline 25 & 0.1733 & 0.0147 & 0.0271 & 0.0011 & 0.17 & 36.9068 & 1.5197 & 0.0464 & 0.0053 & 0.1999 & 0.0193 & 1.27 & 7 & 135 & 179 & 0.75 & 172 & 0.007 & 17 & 0.199 & 106 & \\
\hline $12 \_1$ & 0.1854 & 0.0125 & 0.0272 & 0.0006 & 0.30 & 36.8197 & 0.8291 & 0.0495 & 0.0036 & 0.3337 & 0.0291 & 3.54 & 5 & 138 & 125 & 1.10 & 173 & 0.004 & 172 & 0.159 & 100 & \\
\hline $16 \_2$ & 0.1956 & 0.0205 & 0.0272 & 0.0006 & 0.16 & 36.7167 & 0.8725 & 0.0521 & 0.0059 & 0.2790 & 0.0291 & 1.54 & 8 & 166 & 215 & 0.77 & 173 & 0.004 & 289 & 0.242 & 95 & \\
\hline 19_1 & 0.1897 & 0.0103 & 0.0271 & 0.0009 & 0.30 & 36.8483 & 1.1831 & 0.0507 & 0.0037 & 0.3085 & 0.0256 & 0.36 & 14 & 328 & 345 & 0.95 & 173 & 0.005 & 228 & 0.151 & 97 & ס \\
\hline $10 \_1$ & 0.1983 & 0.0205 & 0.0273 & 0.0008 & 0.36 & 36.6011 & 1.1022 & 0.0526 & 0.0062 & 0.3096 & 0.0227 & 0.90 & 8 & 203 & 198 & 1.02 & 174 & 0.005 & 313 & 0.226 & 94 & \\
\hline 11_1 & 0.1739 & 0.0211 & 0.0273 & 0.0008 & 0.11 & 36.6552 & 1.1124 & 0.0462 & 0.0065 & 0.2791 & 0.0183 & 0.89 & 6 & 149 & 170 & 0.87 & 174 & 0.005 & 10 & 0.211 & 106 & \\
\hline 20_1 & 0.1800 & 0.0081 & 0.0273 & 0.0008 & 0.33 & 36.5793 & 1.0253 & 0.0478 & 0.0029 & 0.3485 & 0.0146 & 0.66 & 14 & 368 & 349 & 1.05 & 174 & 0.005 & 87 & 0.129 & 103 & \\
\hline 18_1 & 0.2075 & 0.0346 & 0.0276 & 0.0010 & 0.01 & 36.1847 & 1.3419 & 0.0544 & 0.0098 & 0.2141 & 0.0339 & 1.78 & 5 & 113 & 150 & 0.75 & 176 & 0.006 & 390 & 0.302 & 91 & \\
\hline 24_1 & 0.1812 & 0.0097 & 0.0277 & 0.0009 & 0.01 & 36.1064 & 1.1101 & 0.0474 & 0.0034 & 0.3228 & 0.0315 & 0.88 & 12 & 284 & 278 & 1.02 & 176 & 0.005 & 72 & 0.135 & 104 & एँ \\
\hline 1_1 & 0.1892 & 0.0072 & 0.0281 & 0.0005 & 0.40 & 35.5701 & 0.6014 & 0.0488 & 0.0020 & 0.4556 & 0.0079 & 1.48 & 57 & 2091 & 1295 & 1.61 & 179 & 0.003 & 139 & 0.092 & 101 & \\
\hline 8_1 & 0.1891 & 0.0142 & 0.0284 & 0.0007 & 0.21 & 35.2457 & 0.8398 & 0.0483 & 0.0041 & 0.3098 & 0.0126 & 0.62 & 12 & 298 & 297 & 1.00 & 180 & 0.004 & 115 & 0.146 & 102 & \\
\hline 14_1 & 0.1795 & 0.0282 & 0.0285 & 0.0009 & 0.37 & 35.1155 & 1.0687 & 0.0457 & 0.0076 & 0.2579 & 0.0284 & 1.79 & 6 & 138 & 166 & 0.83 & 181 & 0.005 & 0.000 & 0.182 & 107 & \\
\hline 9_1 & 0.1790 & 0.0200 & 0.0287 & 0.0009 & 0.36 & 34.8515 & 1.0384 & 0.0452 & 0.0056 & 0.2732 & 0.0267 & 0.60 & 17 & 446 & 408 & 1.10 & 182 & 0.005 & 0.000 & 0.132 & 109 & \\
\hline $1 \_2$ & 0.2039 & 0.0192 & 0.0287 & 0.0008 & 0.62 & 34.7859 & 0.9806 & 0.0514 & 0.0055 & 0.2682 & 0.0226 & 0.50 & 9 & 201 & 219 & 0.92 & 183 & 0.005 & 261 & 0.212 & 96 & \\
\hline $13 \_1$ & 0.1877 & 0.0328 & 0.0288 & 0.0010 & 0.71 & 34.7213 & 1.1780 & 0.0473 & 0.0092 & 0.2613 & 0.0472 & 1.68 & 4 & 102 & 106 & 0.96 & 183 & 0.006 & 63 & 0.222 & 104 & \\
\hline 3_1 & 0.1935 & 0.0175 & 0.0292 & 0.0008 & 0.01 & 34.1945 & 0.8997 & 0.0480 & 0.0050 & 0.2444 & 0.0176 & 0.54 & 9 & 199 & 223 & 0.89 & 186 & 0.005 & 99 & 0.139 & 103 & \\
\hline $5 \_1$ & 0.1566 & 0.0260 & 0.0288 & 0.0010 & 0.45 & 34.7480 & 1.2297 & 0.0395 & 0.0076 & 0.2396 & 0.0251 & 1.69 & 6 & 142 & 149 & 0.96 & 183 & 0.006 & 0.000 & 0.119 & 123 & $\#$ \\
\hline $6 \_1$ & 0.1754 & 0.0289 & 0.0292 & 0.0011 & 0.63 & 34.2607 & 1.2948 & 0.0436 & 0.0083 & 0.2401 & 0.0355 & 0.80 & 6 & 108 & 142 & 0.76 & 185 & 0.007 & 0.000 & 0.234 & 113 & $\#$ \\
\hline $16 \_1$ & 0.1591 & 0.0205 & 0.0273 & 0.0007 & 0.53 & 36.6634 & 0.8935 & 0.0423 & 0.0060 & 0.3287 & 0.0321 & 16.92 & 10 & 293 & 265 & 1.10 & 173 & 0.004 & 0.000 & 0.200 & 115 & $\$$ \\
\hline 23_1 & 0.1935 & 0.0095 & 0.0274 & 0.0008 & 0.50 & 36.5354 & 1.1169 & 0.0513 & 0.0033 & 0.2218 & 0.0079 & 6.99 & 13 & 325 & 353 & 0.92 & 174 & 0.005 & 253 & 0.144 & 96 & $\$$ \\
\hline 4_1 & 0.1912 & 0.0118 & 0.0277 & 0.0006 & 0.58 & 36.1573 & 0.7748 & 0.0501 & 0.0034 & 0.3267 & 0.0189 & 25.56 & 15 & 380 & 385 & 0.99 & 176 & 0.004 & 202 & 0.152 & 98 & $\$$ \\
\hline $2 \_1$ & 0.1864 & 0.0129 & 0.0282 & 0.0006 & 0.44 & 35.3996 & 0.7896 & 0.0479 & 0.0036 & 0.2502 & 0.0175 & 71.49 & 10 & 189 & 254 & 0.74 & 180 & 0.004 & 92 & 0.130 & 103 & $\$$ \\
\hline 7_1 & 0.1879 & 0.0221 & 0.0284 & 0.0009 & 0.02 & 35.2304 & 1.1250 & 0.0480 & 0.0059 & 0.3086 & 0.0385 & 9.02 & 10 & 306 & 247 & 1.24 & 180 & 0.006 & 100 & 0.165 & 103 & $\$$ \\
\hline $15 \_1$ & 0.1812 & 0.0544 & 0.0302 & 0.0015 & 0.32 & 33.1334 & 1.6300 & 0.0435 & 0.0145 & 0.4041 & 0.1048 & 8.23 & 2 & 41 & 63 & 0.64 & 192 & 0.009 & 0.000 & 0.348 & 113 & $\$$ \\
\hline
\end{tabular}

\# points not used because the dicordance is higher than $10 \%$

$\$$ point not used because high concentration of $\mathrm{Pb}$ common or analytic problems (high error) 
Supplementary Material: U-Pb zircon ages from Garzón granites and related rocks, Eastern Cordillera, Colombia.

\begin{tabular}{|c|c|c|c|c|c|c|c|c|c|c|c|c|c|c|c|c|c|c|c|c|c|c|}
\hline \multicolumn{23}{|c|}{ Algeciras Massif: Sample GAR-359 } \\
\hline $\begin{array}{c}\text { POIN } \\
T\end{array}$ & $\begin{array}{c}{ }^{207} \mathrm{~Pb} / \\
{ }^{235} \mathrm{U}\end{array}$ & $1 \sigma$ & $\begin{array}{l}{ }^{206} \mathrm{~Pb} / \\
{ }^{238} \mathrm{U}\end{array}$ & $1 \sigma$ & $\begin{array}{l}\text { corr. } \\
\text { coeff }\end{array}$ & $\begin{array}{c}{ }^{238} \mathrm{U} /{ }^{206} \mathrm{P} \\
\mathrm{b}\end{array}$ & $1 \sigma$ & $\begin{array}{c}{ }^{207} \mathrm{~Pb} / \\
{ }^{206} \mathrm{~Pb}\end{array}$ & $1 \sigma$ & $\begin{array}{l}{ }^{208} \mathrm{~Pb} / \\
{ }^{206} \mathrm{~Pb}\end{array}$ & $1 \sigma$ & $\begin{array}{c}\mathrm{Pb} \\
\text { Total } \\
\text { Com } \\
\text { mon } \\
(\%)\end{array}$ & $\begin{array}{c}\mathrm{Pb} \\
\mathrm{rad} \\
\mathrm{ppm}\end{array}$ & $\begin{array}{c}\text { Th } \\
\mathrm{ppm}\end{array}$ & $\begin{array}{c}\mathrm{U} \\
\mathrm{ppm}\end{array}$ & Th/U & $\begin{array}{c}\mathrm{Age}^{20} \\
{ }^{6} \mathrm{~Pb} /{ }^{23} \\
{ }^{8} \mathrm{U} \\
(\mathrm{Ma})\end{array}$ & $1 \sigma$ & $\begin{array}{c}\mathrm{Age} \\
{ }^{207} \mathrm{~Pb} / \\
{ }^{206} \mathrm{~Pb}\end{array}$ & $1 \sigma$ & $\begin{array}{c}\text { Conc. } \\
{ }^{206} \mathrm{~Pb} / \\
{ }^{238} \mathrm{U} \\
\rho^{207} \mathrm{~Pb} \\
/ \\
/ \\
{ }^{206} \mathrm{~Pb}\end{array}$ & \\
\hline 10_1 & 0.1829 & 0.0072 & 0.0268 & 0.0003 & 0.23 & 37.2700 & 0.4786 & 0.0494 & 0.0022 & 0.3540 & 0.0359 & 0.44 & 34 & 1108 & 794 & 1.40 & 171 & 0.002 & 168 & 0.101 & 101 & \\
\hline 14_1 & 0.1827 & 0.0079 & 0.0268 & 0.0004 & 0.18 & 37.3089 & 0.5405 & 0.0494 & 0.0025 & 0.3145 & 0.0102 & 0.15 & 23 & 586 & 554 & 1.06 & 171 & 0.002 & 168 & 0.119 & 101 & \\
\hline 12_1 & 0.1866 & 0.0051 & 0.0272 & 0.0003 & 0.34 & 36.8148 & 0.3827 & 0.0498 & 0.0014 & 0.7035 & 0.0151 & 0.08 & 86 & 3834 & 1723 & 2.23 & 173 & 0.002 & 187 & 0.068 & 92 & \\
\hline 17_1 & 0.1856 & 0.0070 & 0.0273 & 0.0004 & 0.01 & 36.6625 & 0.4854 & 0.0494 & 0.0022 & 0.4338 & 0.0602 & 0.55 & 44 & 1454 & 955 & 1.52 & 173 & 0.002 & 165 & 0.103 & 105 & 옹 \\
\hline 21_1 & 0.1859 & 0.0081 & 0.0272 & 0.0004 & 0.65 & 36.7797 & 0.5427 & 0.0496 & 0.0026 & 0.3867 & 0.0815 & 0.28 & 39 & 1539 & 803 & 1.92 & 173 & 0.003 & 175 & 0.116 & 98 & ๕ \\
\hline 26_1 & 0.1857 & 0.0093 & 0.0272 & 0.0004 & 0.22 & 36.7263 & 0.5957 & 0.0495 & 0.0030 & 0.3577 & 0.0618 & 0.44 & 26 & 921 & 603 & 1.53 & 173 & 0.003 & 170 & 0.131 & 101 & \\
\hline 19_1 & 0.1899 & 0.0057 & 0.0277 & 0.0003 & 0.38 & 36.0950 & 0.4118 & 0.0497 & 0.0018 & 0.3836 & 0.0123 & 5.78 & 45 & 1602 & 1049 & 1.53 & 176 & 0.002 & 181 & 0.084 & 97 & $\#$ \\
\hline 11_1 & 0.1901 & 0.0082 & 0.0262 & 0.0004 & 0.17 & 38.1877 & 0.5464 & 0.0527 & 0.0025 & 0.3435 & 0.0098 & 0.51 & 19 & 480 & 483 & 0.99 & 167 & 0.002 & 314 & 0.113 & 53 & $\#$ \\
\hline 9_1 & 0.1814 & 0.0058 & 0.0263 & 0.0003 & 0.62 & 37.9737 & 0.4306 & 0.0500 & 0.0017 & 0.3690 & 0.0089 & 0.14 & 50 & 1547 & 1217 & 1.27 & 168 & 0.002 & 193 & 0.078 & 86 & $\#$ \\
\hline 3_1 & 0.1794 & 0.0066 & 0.0266 & 0.0003 & 0.01 & 37.6580 & 0.4670 & 0.0490 & 0.0019 & 0.3499 & 0.0064 & 0.94 & 34 & 1122 & 853 & 1.32 & 169 & 0.002 & 148 & 0.088 & 114 & $\#$ \\
\hline 6_1 & 0.1854 & 0.0076 & 0.0267 & 0.0004 & 0.29 & 37.4915 & 0.5046 & 0.0504 & 0.0023 & 0.3620 & 0.0292 & 0.77 & 29 & 951 & 699 & 1.36 & 170 & 0.002 & 214 & 0.104 & 79 & $\#$ \\
\hline 1_1 & 0.1825 & 0.0059 & 0.0270 & 0.0003 & 0.55 & 37.0951 & 0.4248 & 0.0491 & 0.0017 & 0.3686 & 0.0290 & 1.14 & 50 & 1871 & 1179 & 1.59 & 171 & 0.002 & 153 & 0.077 & 112 & $\#$ \\
\hline 7_1 & 0.1863 & 0.0050 & 0.0269 & 0.0003 & 0.50 & 37.1225 & 0.3855 & 0.0502 & 0.0014 & 0.6861 & 0.0626 & 0.20 & 93 & 4385 & 1851 & 2.37 & 171 & 0.002 & 203 & 0.067 & 84 & $\#$ \\
\hline 25_1 & 0.1875 & 0.0100 & 0.0270 & 0.0005 & 0.01 & 37.0591 & 0.6290 & 0.0504 & 0.0032 & 0.3517 & 0.0367 & 0.00 & 17 & 381 & 415 & 0.92 & 172 & 0.003 & 213 & 0.138 & 80 & $\#$ \\
\hline 8_1 & 0.1908 & 0.0064 & 0.0272 & 0.0003 & 0.54 & 36.7549 & 0.4328 & 0.0509 & 0.0018 & 0.5216 & 0.0243 & 0.41 & 36 & 1300 & 828 & 1.57 & 173 & 0.002 & 234 & 0.085 & 73 & $\#$ \\
\hline 18_1 & 0.1835 & 0.0089 & 0.0272 & 0.0004 & 0.01 & 36.7065 & 0.5724 & 0.0488 & 0.0029 & 0.3062 & 0.0217 & 0.91 & 23 & 568 & 561 & 1.01 & 173 & 0.003 & 140 & 0.131 & 123 & $\#$ \\
\hline 23_1 & 0.1817 & 0.0082 & 0.0272 & 0.0004 & 0.01 & 36.7470 & 0.5398 & 0.0484 & 0.0027 & 0.3084 & 0.0234 & 0.29 & 23 & 621 & 580 & 1.07 & 173 & 0.003 & 120 & 0.120 & 144 & $\#$ \\
\hline 24_1 & 0.1883 & 0.0064 & 0.0272 & 0.0003 & 0.39 & 36.6998 & 0.4551 & 0.0501 & 0.0020 & 0.4906 & 0.0206 & 0.17 & 35 & 957 & 779 & 1.23 & 173 & 0.002 & 201 & 0.094 & 86 & $\#$ \\
\hline 2_1 & 0.1842 & 0.0080 & 0.0273 & 0.0004 & 0.40 & 36.6237 & 0.5075 & 0.0489 & 0.0023 & 0.3401 & 0.0549 & 0.76 & 19 & 403 & 491 & 0.82 & 174 & 0.002 & 145 & 0.107 & 120 & \# \\
\hline 5_1 & 0.1818 & 0.0055 & 0.0273 & 0.0003 & 0.03 & 36.5993 & 0.3957 & 0.0483 & 0.0015 & 0.7015 & 0.0155 & 0.16 & 63 & 3051 & 1270 & 2.40 & 174 & 0.002 & 112 & 0.073 & 154 & $\#$ \\
\hline 15_1 & 0.1796 & 0.0109 & 0.0273 & 0.0005 & 0.19 & 36.6344 & 0.6773 & 0.0477 & 0.0035 & 0.3091 & 0.0221 & 0.66 & 24 & 615 & 550 & 1.12 & 174 & 0.003 & 85 & 0.108 & 203 & $\#$ \\
\hline 4_1 & 0.1866 & 0.0079 & 0.0278 & 0.0004 & 0.01 & 36.0311 & 0.4879 & 0.0488 & 0.0023 & 0.3982 & 0.1169 & 2.15 & 21 & 569 & 530 & 1.07 & 176 & 0.002 & 136 & 0.101 & 129 & $\#$ \\
\hline 20_1 & 0.1960 & 0.0058 & 0.0291 & 0.0003 & 0.65 & 34.3457 & 0.3793 & 0.0488 & 0.0017 & 0.6934 & 0.0138 & 2.77 & 70 & 2973 & 1316 & 2.26 & 185 & 0.002 & 139 & 0.083 & 132 & * \\
\hline 22_1 & 2.8346 & 0.0576 & 0.2358 & 0.0022 & 0.99 & 4.2409 & 0.0403 & 0.0872 & 0.0019 & 0.0609 & 0.0119 & 3.04 & 166 & 84 & 583 & 0.14 & 1365 & 0.012 & 365 & 0.042 & 100 & * \\
\hline 16_1 & 0.2008 & 0.0201 & 0.0302 & 0.0009 & 0.62 & 33.0718 & 0.9317 & 0.0482 & 0.0059 & 0.3540 & 0.0557 & 5.34 & 8 & 218 & 163 & 1.34 & 192 & 0.005 & 108 & 0.191 & 178 & * \\
\hline 13_1 & 0.1787 & 0.0052 & 0.0267 & 0.0003 & 0.73 & 37.5229 & 0.4013 & 0.0486 & 0.0015 & 0.6430 & 0.0231 & 6.64 & 59 & 2434 & 1211 & 2.01 & 170 & 0.002 & 130 & 0.071 & 129 & $\$$ \\
\hline
\end{tabular}

* plotted points. but not used to age calcule

\# points not used because the dicordance is higher than $10 \%$

$\$$ point not used because high concentration of $\mathrm{Pb}$ common or analytic problems (high error) 
Supplementary Material: U-Pb zircon ages from Garzón granites and related rocks, Eastern Cordillera, Colombia.

Altamira Massif: Sample GAR-383

\begin{tabular}{|c|c|c|c|c|c|c|c|c|c|c|c|c|c|c|c|c|c|c|c|c|c|c|}
\hline $\begin{array}{c}\text { POIN } \\
T\end{array}$ & $\begin{array}{l}{ }^{207} \mathrm{~Pb} / \\
235 \mathrm{U}\end{array}$ & $1 \sigma$ & $\begin{array}{c}{ }^{206} \mathrm{~Pb} / \\
238 \mathrm{U}\end{array}$ & $1 \sigma$ & $\begin{array}{l}\text { corr. } \\
\text { coeff }\end{array}$ & $\begin{array}{c}{ }^{238} \mathrm{U} /{ }^{206} \mathrm{P} \\
\mathrm{b}\end{array}$ & $1 \sigma$ & $\begin{array}{l}{ }^{207} \mathrm{~Pb} / \\
{ }^{206} \mathrm{~Pb}\end{array}$ & $1 \sigma$ & $\begin{array}{l}{ }^{208} \mathrm{~Pb} / \\
{ }^{206} \mathrm{~Pb}\end{array}$ & $1 \sigma$ & $\begin{array}{c}\mathrm{Pb} \\
\text { Total } \\
\text { Comm } \\
\text { on (\%) }\end{array}$ & $\begin{array}{c}\mathrm{Pb} \\
\mathrm{rad} \\
\mathrm{ppm}\end{array}$ & $\begin{array}{l}\text { Th } \\
\mathrm{pp} \\
\mathrm{m}\end{array}$ & $\begin{array}{c}U \\
\mathrm{ppm}\end{array}$ & Th/U & $\begin{array}{c}\mathrm{Age} \\
206 \mathrm{p} / \mathrm{g} / \\
238 \mathrm{U} \\
(\mathrm{Ma})\end{array}$ & $1 \sigma$ & $\begin{array}{c}\mathrm{Age} \\
207 \mathrm{~Pb} / \\
{ }^{206} \mathrm{~Pb}\end{array}$ & $1 \sigma$ & $\begin{array}{c}\text { Conc. } \\
{ }^{206} \mathrm{~Pb} / \\
28 \mathrm{U} \\
2207 \mathrm{~Pb} / \\
{ }^{206} \mathrm{~Pb} \\
\end{array}$ & \\
\hline 19_1 & 0.1907 & 0.0260 & 0.0255 & 0.0011 & 0.01 & 39.2268 & 1.6920 & 0.0543 & 0.0088 & 0.4681 & 0.0623 & 1.56 & 6 & 217 & 144 & 1.51 & 162 & 0.007 & 382 & 0.326 & 91 & \multirow{10}{*}{ 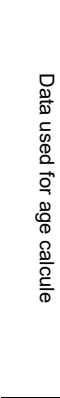 } \\
\hline $16 \_1$ & 0.1772 & 0.0232 & 0.0261 & 0.0010 & 0.17 & 38.2812 & 1.4502 & 0.0492 & 0.0078 & 0.3344 & 0.0291 & 2.76 & 6 & 159 & 152 & 1.05 & 166 & 0.006 & 158 & 0.252 & 100 & \\
\hline 7_1 & 0.1795 & 0.0161 & 0.0264 & 0.0006 & 0.54 & 37.8332 & 0.8868 & 0.0493 & 0.0052 & 0.2389 & 0.0234 & 1.88 & 10 & 216 & 275 & 0.79 & 168 & 0.004 & 160 & 0.185 & 100 & \\
\hline 21_1 & 0.1815 & 0.0151 & 0.0265 & 0.0007 & 0.42 & 37.7329 & 0.9622 & 0.0497 & 0.0050 & 0.3892 & 0.0168 & 1.29 & 10 & 306 & 248 & 1.23 & 169 & 0.004 & 180 & 0.184 & 99 & \\
\hline 8_1 & 0.1832 & 0.0213 & 0.0274 & 0.0008 & 0.18 & 36.5181 & 1.0783 & 0.0485 & 0.0068 & 0.2707 & 0.0302 & 1.01 & 9 & 225 & 235 & 0.95 & 174 & 0.005 & 125 & 0.184 & 101 & \\
\hline 15_1 & 0.1997 & 0.0156 & 0.0278 & 0.0007 & 0.17 & 35.9716 & 0.8893 & 0.0521 & 0.0048 & 0.3592 & 0.0257 & 2.49 & 9 & 257 & 216 & 1.19 & 177 & 0.004 & 290 & 0.158 & 95 & \\
\hline 5_1 & 0.1753 & 0.0170 & 0.0280 & 0.0007 & 0.07 & 35.6617 & 0.8498 & 0.0453 & 0.0050 & 0.2982 & 0.0234 & 2.49 & 10 & 290 & 248 & 1.17 & 178 & 0.004 & 0.000 & 0.166 & 108 & \\
\hline 24_1 & 0.1855 & 0.0155 & 0.0285 & 0.0007 & 0.01 & 35.0327 & 0.8569 & 0.0471 & 0.0047 & 0.3283 & 0.0259 & 0.86 & 9 & 242 & 238 & 1.02 & 181 & 0.004 & 55 & 0.169 & 105 & \\
\hline 13_1 & 0.1944 & 0.0290 & 0.0287 & 0.0012 & 0.33 & 34.8842 & 1.4986 & 0.0492 & 0.0089 & 0.2232 & 0.0426 & 1.45 & 5 & 116 & 136 & 0.86 & 182 & 0.008 & 157 & 0.251 & 101 & \\
\hline 9_1 & 0.1879 & 0.0220 & 0.0291 & 0.0008 & 0.01 & 34.3054 & 0.9883 & 0.0468 & 0.0064 & 0.5038 & 0.0391 & 0.74 & 8 & 328 & 188 & 1.75 & 185 & 0.005 & 37 & 0.168 & 105 & \\
\hline $12 \_2$ & 2.2288 & 0.2155 & 0.1964 & 0.0074 & 0.53 & 5.0916 & 0.1916 & 0.0823 & 0.0105 & 0.2268 & 0.0321 & 0.30 & 5 & 16 & 18 & 0.87 & 1156 & 0.040 & 1253 & 0.256 & 97 & * \\
\hline 12_1 & 1.8403 & 0.1744 & 0.1646 & 0.0059 & 0.67 & 6.0765 & 0.2168 & 0.0811 & 0.0096 & 0.2849 & 0.0410 & 1.74 & 7 & 29 & 26 & 1.12 & 982 & 0.033 & 1224 & 0.232 & 92 & * \\
\hline 18_1 & 0.1390 & 0.0319 & 0.0240 & 0.0013 & 0.65 & 41.6780 & 2.3112 & 0.0420 & 0.0118 & 0.3548 & 0.0698 & 0.00 & 3 & 87 & 82 & 1.07 & 153 & 0.008 & 0.000 & 0.223 & 115 & $\$$ \\
\hline 22_1 & 0.1664 & 0.0211 & 0.0280 & 0.0009 & 0.16 & 35.7337 & 1.1815 & 0.0431 & 0.0067 & 0.3911 & 0.0817 & 1.74 & 8 & 319 & 183 & 1.75 & 178 & 0.006 & 0.000 & 0.122 & 113 & $\$$ \\
\hline 4_1 & 0.1672 & 0.0155 & 0.0288 & 0.0006 & 0.04 & 34.6779 & 0.7586 & 0.0421 & 0.0046 & 0.2584 & 0.0132 & 5.47 & 8 & 225 & 208 & 1.08 & 183 & 0.004 & 0.000 & 0.105 & 116 & $\$$ \\
\hline 2_1 & 0.1831 & 0.0239 & 0.0300 & 0.0009 & 0.01 & 33.3626 & 1.0095 & 0.0443 & 0.0068 & 0.2456 & 0.0291 & 1.14 & 6 & 146 & 152 & 0.97 & 190 & 0.006 & 0.000 & 0.128 & 111 & $\$$ \\
\hline 14_1 & 0.1504 & 0.0452 & 0.0261 & 0.0018 & 0.03 & 38.3415 & 2.7173 & 0.0418 & 0.0154 & 0.5041 & 0.0877 & 3.49 & 3 & 119 & 64 & 1.87 & 166 & 0.012 & 0.000 & 0.303 & 116 & $\$$ \\
\hline 6_1 & 0.1437 & 0.0480 & 0.0269 & 0.0017 & 0.39 & 37.1069 & 2.2741 & 0.0387 & 0.0160 & 0.5657 & 0.0976 & 4.67 & 3 & 130 & 66 & 1.97 & 171 & 0.010 & 0.000 & 0.238 & 125 & $\$$ \\
\hline $11 \_1$ & 0.2256 & 0.0430 & 0.0236 & 0.0014 & 0.30 & 42.4136 & 2.5760 & 0.0694 & 0.0150 & 0.6583 & 0.0784 & 5.50 & 3 & 144 & 62 & 2.33 & 150 & 0.009 & 911 & 0.329 & 72 & $\$$ \\
\hline 3_1 & 0.1084 & 0.0714 & 0.0308 & 0.0024 & 0.48 & 32.4640 & 2.5628 & 0.0255 & 0.0179 & 0.3505 & 0.1096 & 5.10 & 2 & 70 & 43 & 1.61 & 196 & 0.015 & 0.000 & 0.044 & 187 & $\$$ \\
\hline 1_1 & 0.1422 & 0.0483 & 0.0240 & 0.0016 & 0.74 & 41.7199 & 2.8308 & 0.0430 & 0.0174 & 0.4839 & 0.1648 & 98.36 & 2 & 81 & 58 & 1.39 & 153 & 0.010 & 0.000 & 0.278 & 113 & $\$$ \\
\hline 25_1 & 0.1993 & 0.0362 & 0.0247 & 0.0015 & 0.40 & 40.5547 & 2.4104 & 0.0586 & 0.0132 & 0.4482 & 0.1046 & 21.58 & 2 & 47 & 55 & 0.85 & 157 & 0.009 & 553 & 0.263 & 85 & $\$$ \\
\hline 17_1 & 0.1766 & 0.0252 & 0.0261 & 0.0010 & 0.01 & 38.2695 & 1.5290 & 0.0490 & 0.0085 & 0.3585 & 0.0365 & 10.98 & 5 & 156 & 132 & 1.18 & 166 & 0.007 & 149 & 0.257 & 100 & $\$$ \\
\hline 23_1 & 0.1885 & 0.0181 & 0.0287 & 0.0008 & 0.48 & 34.8954 & 0.9775 & 0.0477 & 0.0053 & 0.3354 & 0.0356 & 9.64 & 8 & 316 & 183 & 1.73 & 182 & 0.005 & 85 & 0.169 & 103 & $\$$ \\
\hline 10_1 & 0.2226 & 0.0242 & 0.0320 & 0.0009 & 0.01 & 31.2564 & 0.8735 & 0.0505 & 0.0068 & 0.4226 & 0.0490 & 33.64 & 5 & 213 & 99 & 2.15 & 203 & 0.006 & 216 & 0.161 & 99 & $\$$ \\
\hline 20_1 & 3.2647 & 0.0793 & 0.2526 & 0.0027 & 0.93 & 3.9594 & 0.0420 & 0.0937 & 0.0023 & 0.1572 & 0.1150 & 0.14 & 72 & -31 & 274 & -0.11 & 1452 & 0.014 & 1503 & 0.046 & 98 & $\$$ \\
\hline
\end{tabular}

* plotted points. but not used to age calcule

$\$$ point not used because high concentration of $\mathrm{Pb}$ common or analytic problems (high error) 
Supplementary Material: U-Pb zircon ages from Garzón granites and related rocks, Eastern Cordillera, Colombia.

Altamira Massif: Sample GAR-386

\begin{tabular}{|c|c|c|c|c|c|c|c|c|c|c|c|c|c|c|c|c|c|c|c|c|c|c|}
\hline $\begin{array}{c}\text { POIN } \\
\text { T }\end{array}$ & $\begin{array}{l}207 \mathrm{~Pb} / \\
{ }^{235} \mathrm{U}\end{array}$ & $1 \sigma$ & $\begin{array}{c}206 \mathrm{~Pb} / \\
238 \mathrm{U}\end{array}$ & $1 \sigma$ & $\begin{array}{l}\text { corr. } \\
\text { coeff }\end{array}$ & $\begin{array}{c}{ }^{238} \mathrm{U} / 206 \mathrm{P} \\
\mathrm{b}\end{array}$ & $1 \sigma$ & $\begin{array}{l}{ }^{207} \mathrm{~Pb} / \\
{ }^{206} \mathrm{~Pb}\end{array}$ & $1 \sigma$ & $\begin{array}{l}{ }^{208} \mathrm{~Pb} / /^{2} \\
{ }^{06} \mathrm{~Pb}\end{array}$ & $1 \sigma$ & $\begin{array}{c}\mathrm{Pb} \\
\text { Total } \\
\text { Com } \\
\text { mon } \\
(\%)\end{array}$ & $\begin{array}{c}\mathrm{Pb} \\
\mathrm{rad} \\
\mathrm{ppm}\end{array}$ & $\begin{array}{l}\mathrm{Th} \\
\mathrm{pp} \\
\mathrm{m}\end{array}$ & $\begin{array}{c}\mathrm{U} \\
\mathrm{pp} \\
\mathrm{m}\end{array}$ & Th/U & $\begin{array}{c}\mathrm{Age} \\
{ }^{206} \mathrm{~Pb} / \\
238 \mathrm{U} \\
(\mathrm{Ma})\end{array}$ & $1 \sigma$ & $\begin{array}{c}\mathrm{Age} \\
{ }^{207} \mathrm{~Pb} / \\
{ }^{206} \mathrm{~Pb} \\
(\mathrm{Ma})\end{array}$ & $1 \sigma$ & $\begin{array}{c}\text { Conc. } \\
{ }^{206} \mathrm{~Pb} / \\
238 \mathrm{U} \\
{ }^{207} \mathrm{~Pb} / \\
{ }^{206} \mathrm{~Pb}\end{array}$ & \\
\hline 4 4_2 & 0.1572 & 0.0282 & 0.0231 & 0.0010 & 0.57 & 43.2215 & 1.9026 & 0.0493 & 0.0106 & 0.5257 & 0.0834 & 1.51 & 4 & 185 & 101 & 1.831 & 147 & 0.006 & 160 & 0.325 & 99 & \\
\hline 17_1 & 0.1791 & 0.0222 & 0.0239 & 0.0008 & 0.01 & 41.8648 & 1.4594 & 0.0544 & 0.0082 & 0.4405 & 0.0251 & 1.98 & 6 & 213 & 153 & 1.392 & 152 & 0.005 & 387 & 0.305 & 90 & \multirow{13}{*}{ 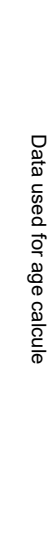 } \\
\hline 12_1 & 0.1950 & 0.0222 & 0.0239 & 0.0008 & 0.20 & 41.7690 & 1.4015 & 0.0591 & 0.0082 & 0.2602 & 0.0330 & 1.18 & 4 & 104 & 119 & 0.869 & 153 & 0.005 & 570 & 0.264 & 84 & \\
\hline 4_1 & 0.1866 & 0.0321 & 0.0242 & 0.0011 & 0.01 & 41.2398 & 1.8832 & 0.0558 & 0.0120 & 0.5210 & 0.0956 & 2.91 & 2 & 58 & 55 & 1.048 & 154 & 0.007 & 445 & 0.377 & 88 & \\
\hline 18_1 & 0.1816 & 0.0241 & 0.0246 & 0.0009 & 0.05 & 40.6346 & 1.4842 & 0.0535 & 0.0081 & 0.7089 & 0.0591 & 2.85 & 6 & 266 & 134 & 1.982 & 157 & 0.006 & 351 & 0.265 & 92 & \\
\hline 6_1 & 0.1832 & 0.0213 & 0.0250 & 0.0008 & 0.31 & 39.9666 & 1.2457 & 0.0531 & 0.0074 & 0.3317 & 0.0749 & 1.78 & 5 & 131 & 132 & 0.991 & 159 & 0.005 & 334 & 0.242 & 93 & \\
\hline 2_1 & 0.1686 & 0.0141 & 0.0251 & 0.0006 & 0.12 & 39.8263 & 0.9131 & 0.0487 & 0.0047 & 0.7911 & 0.0297 & 1.34 & 9 & 463 & 195 & 2.371 & 160 & 0.004 & 133 & 0.182 & 101 & \\
\hline 15_1 & 0.1707 & 0.0202 & 0.0252 & 0.0008 & 0.52 & 39.6637 & 1.2280 & 0.0491 & 0.0069 & 0.3620 & 0.0439 & 2.79 & 7 & 176 & 177 & 0.993 & 161 & 0.005 & 153 & 0.247 & 100 & \\
\hline 5_1 & 0.1912 & 0.0261 & 0.0256 & 0.0010 & 0.01 & 39.0565 & 1.4506 & 0.0542 & 0.0087 & 0.3692 & 0.0441 & 1.68 & 4 & 140 & 101 & 1.387 & 163 & 0.006 & 378 & 0.285 & 91 & \\
\hline 10_1 & 0.1939 & 0.0206 & 0.0256 & 0.0007 & 0.70 & 39.0299 & 1.1379 & 0.0549 & 0.0074 & 0.3616 & 0.0819 & 1.09 & 5 & 102 & 134 & 0.763 & 163 & 0.005 & 407 & 0.199 & 90 & \\
\hline 22_1 & 0.1818 & 0.0256 & 0.0259 & 0.0009 & 0.47 & 38.6353 & 1.3975 & 0.0509 & 0.0083 & 0.4651 & 0.0385 & 1.41 & 5 & 128 & 119 & 1.078 & 165 & 0.006 & 238 & 0.269 & 97 & \\
\hline 7_1 & 0.1907 & 0.0248 & 0.0264 & 0.0009 & 0.01 & 37.8320 & 1.3387 & 0.0523 & 0.0079 & 0.4381 & 0.0525 & 1.27 & 4 & 135 & 99 & 1.361 & 168 & 0.006 & 299 & 0.230 & 94 & \\
\hline 13_1 & 0.2084 & 0.0146 & 0.0266 & 0.0006 & 0.33 & 37.6132 & 0.8788 & 0.0569 & 0.0048 & 0.5939 & 0.0737 & 2.09 & 11 & 372 & 261 & 1.429 & 169 & 0.004 & 486 & 0.191 & 87 & \\
\hline 19_1 & 0.1832 & 0.0148 & 0.0272 & 0.0007 & 0.50 & 36.8154 & 0.8874 & 0.0489 & 0.0045 & 0.6821 & 0.1253 & 0.97 & 12 & 552 & 232 & 2.378 & 173 & 0.004 & 143 & 0.174 & 101 & \\
\hline 1_1 & 0.1849 & 0.0237 & 0.0302 & 0.0009 & 0.03 & 33.0774 & 0.9884 & 0.0443 & 0.0073 & 0.3295 & 0.0988 & 1.36 & 4 & 118 & 93 & 1.273 & 192 & 0.006 & 0.000 & 0.096 & 111 & * \\
\hline 3_1 & 0.2613 & 0.0444 & 0.0255 & 0.0015 & 0.13 & 39.2745 & 2.2585 & 0.0744 & 0.0158 & 0.2131 & 0.0838 & 1.96 & 2 & 46 & 60 & 0.767 & 162 & 0.009 & 1053 & 0.365 & 68 & $\$$ \\
\hline 9_1 & 0.1704 & 0.0485 & 0.0219 & 0.0016 & 0.01 & 45.6944 & 3.4138 & 0.0565 & 0.0180 & 0.3222 & 0.0805 & 4.20 & 2 & 52 & 54 & 0.970 & 140 & 0.010 & 472 & 0.453 & 87 & $\$$ \\
\hline $16 \_1$ & 0.1952 & 0.0477 & 0.0221 & 0.0015 & 0.25 & 45.1702 & 3.0831 & 0.0639 & 0.0216 & 0.5168 & 0.1018 & 1.80 & 3 & 81 & 68 & 1.202 & 141 & 0.010 & 739 & 0.541 & 77 & $\$$ \\
\hline 20_1 & 0.1123 & 0.0491 & 0.0250 & 0.0017 & 0.01 & 40.0151 & 2.7352 & 0.0326 & 0.0149 & 0.5218 & 0.0931 & 5.24 & 15 & 110 & 81 & 1.357 & 159 & 0.011 & 0.000 & 0.105 & 147 & $\$$ \\
\hline 14.1 & 0.1483 & 0.0570 & 0.0169 & 0.0017 & 0.01 & 59.1814 & 6.1185 & 0.0637 & 0.0337 & 0.9273 & 0.3253 & 15.58 & 2 & 115 & 66 & 1.732 & 108 & 0.011 & 730 & 0.800 & 76 & $\$$ \\
\hline 11_1 & 0.1734 & 0.0457 & 0.0238 & 0.0016 & 0.30 & 41.9583 & 2.7541 & 0.0528 & 0.0165 & 0.2944 & 0.0718 & 41.35 & 2 & 50 & 56 & 0.899 & 152 & 0.010 & 318 & 0.382 & 93 & $\$$ \\
\hline 8_1 & 0.2068 & 0.0465 & 0.0254 & 0.0016 & 0.31 & 39.3401 & 2.4850 & 0.0590 & 0.0168 & 0.3806 & 0.1231 & 7.51 & 2 & 52 & 50 & 1.037 & 162 & 0.010 & 568 & 0.501 & 84 & $\$$ \\
\hline 24_1 & 0.1619 & 0.0354 & 0.0264 & 0.0013 & 0.57 & 37.8387 & 1.8378 & 0.0444 & 0.0108 & 0.3161 & 0.0330 & 7.41 & 3 & 79 & 89 & 0.890 & 168 & 0.008 & 0.000 & 0.188 & 110 & $\$$ \\
\hline 21_1 & 0.1312 & 0.0271 & 0.0275 & 0.0010 & 0.03 & 36.3296 & 1.3434 & 0.0346 & 0.0084 & 0.6395 & 0.0691 & 11.01 & 5 & 212 & 103 & 2.063 & 175 & 0.006 & 0.000 & 0.164 & 139 & $\$$ \\
\hline 23_1 & 0.2057 & 0.0392 & 0.0287 & 0.0014 & 0.10 & 34.8441 & 1.6465 & 0.0520 & 0.0118 & 0.3999 & 0.0529 & 12.03 & 3 & 112 & 77 & 1.447 & 182 & 0.009 & 284 & 0.353 & 96 & $\$$ \\
\hline 25_1 & 0.1946 & 0.0396 & 0.0292 & 0.0014 & 0.06 & 34.2704 & 1.6361 & 0.0484 & 0.0112 & 0.4604 & 0.0882 & 7.77 & 4 & 124 & 82 & 1.503 & 185 & 0.009 & 117 & 0.192 & 102 & $\$$ \\
\hline
\end{tabular}

* plotted points. but not used to age calcule

$\$$ point not used because high concentration of $\mathrm{Pb}$ common or analytic problems (high error) 
Supplementary Material: U-Pb zircon ages from Garzón granites and related rocks, Eastern Cordillera, Colombia.

\begin{tabular}{|c|c|c|c|c|c|c|c|c|c|c|c|c|c|c|c|c|c|c|c|c|c|c|}
\hline \multicolumn{23}{|c|}{ Sombrerillo Massif: Sample GAR-394 } \\
\hline $\begin{array}{c}\text { POIN } \\
\text { T }\end{array}$ & $\begin{array}{l}{ }^{207} \mathrm{~Pb} / \\
{ }^{235} \mathrm{U}\end{array}$ & $1 \sigma$ & $\begin{array}{c}206 \mathrm{~Pb} / \\
238 \mathrm{U}\end{array}$ & $1 \sigma$ & $\begin{array}{l}\text { corr. } \\
\text { coeff }\end{array}$ & $\begin{array}{c}{ }^{238} \mathrm{U}^{206} \mathrm{P} \\
\mathrm{b}\end{array}$ & $1 \sigma$ & $\begin{array}{c}{ }^{207} \mathrm{pb} /{ }^{2} \\
{ }^{06} \mathrm{~Pb}\end{array}$ & $1 \sigma$ & $\begin{array}{l}{ }^{208} \mathrm{~Pb} / \\
{ }^{206} \mathrm{~Pb}\end{array}$ & $1 \sigma$ & $\begin{array}{c}\mathrm{Pb} \\
\text { Total } \\
\text { Comn } \\
\text { on (\%) }\end{array}$ & $\begin{array}{c}\mathrm{Pb} \\
\mathrm{rad} \\
\mathrm{ppm}\end{array}$ & $\begin{array}{l}\text { Th } \\
\mathrm{pp} \\
\mathrm{m}\end{array}$ & $\begin{array}{c}\mathrm{U} \\
\mathrm{pp} \\
\mathrm{m}\end{array}$ & Th/U & $\begin{array}{c}\mathrm{Age} \\
206 \mathrm{~Pb} / \\
238 \mathrm{U} \\
(\mathrm{Ma})\end{array}$ & 10 & $\begin{array}{c}\mathrm{Age} \\
207 \mathrm{~Pb} / \\
206 \mathrm{~Pb} \\
(\mathrm{Ma})\end{array}$ & $1 \sigma$ & $\begin{array}{c}\text { Conc. } \\
{ }^{206} \mathrm{~Pb} / \\
238 \mathrm{U} \\
\left.\right|^{207} \mathrm{~Pb} / \\
{ }^{206} \mathrm{~Pb}\end{array}$ & \\
\hline 9_1 & 0.1960 & 0.0294 & 0.0291 & 0.0014 & 0.48 & 34.3162 & 1.6810 & 0.0488 & 0.0084 & 0.2623 & 0.0514 & 4.14 & 3 & 71 & 84 & 0.85 & 185 & 0.009 & 138 & 0.231 & 101 & סूg \\
\hline 6_1 & 0.2129 & 0.0225 & 0.0294 & 0.0011 & 0.30 & 33.9704 & 1.2682 & 0.0525 & 0.0071 & 0.3109 & 0.0307 & 1.12 & 5 & 100 & 107 & 0.94 & 187 & 0.007 & 306 & 0.225 & 95 & \\
\hline 17_1 & 0.1943 & 0.0282 & 0.0300 & 0.0015 & 0.12 & 33.3706 & 1.6554 & 0.0470 & 0.0081 & 0.3583 & 0.0258 & 4.79 & 5 & 112 & 114 & 0.98 & 190 & 0.009 & 50 & 0.224 & 105 & \\
\hline $2 \_1$ & 0.2029 & 0.0215 & 0.0301 & 0.0011 & 0.39 & 33.2314 & 1.1605 & 0.0489 & 0.0066 & 0.3028 & 0.0281 & 1.36 & 5 & 92 & 111 & 0.82 & 191 & 0.007 & 143 & 0.227 & 101 & ६ \\
\hline $16 \_1$ & 0.2182 & 0.0436 & 0.0308 & 0.0020 & 0.08 & 32.5008 & 2.1532 & 0.0514 & 0.0122 & 0.2254 & 0.0580 & 0.73 & 3 & 35 & 62 & 0.56 & 195 & 0.013 & 260 & 0.302 & 97 & \\
\hline 7_1 & 0.1333 & 0.0333 & 0.0282 & 0.0016 & 0.40 & 35.4352 & 1.9672 & 0.0343 & 0.0102 & 0.2348 & 0.0731 & 3.24 & 5 & 118 & 111 & 1.06 & 179 & 0.010 & 0.000 & 0.094 & 141 & \# \\
\hline 8_1 & 0.1499 & 0.0417 & 0.0298 & 0.0020 & 0.01 & 33.5643 & 2.2343 & 0.0365 & 0.0117 & 0.1662 & 0.0579 & 4.36 & 3 & 36 & 81 & 0.44 & 189 & 0.012 & 0.000 & 0.110 & 133 & \# \\
\hline 1_1 & 0.1714 & 0.0408 & 0.0320 & 0.0020 & 0.40 & 31.2605 & 1.9234 & 0.0389 & 0.0110 & 0.1352 & 0.0551 & 3.78 & 5 & 38 & 123 & 0.31 & 203 & 0.012 & 0.000 & 0.065 & 126 & $\#$ \\
\hline $12 \_1$ & 0.1840 & 0.0451 & 0.0347 & 0.0022 & 0.01 & 28.7894 & 1.7834 & 0.0384 & 0.0126 & 0.1704 & 0.0704 & 5.39 & 2 & 32 & 49 & 0.65 & 220 & 0.013 & 0.000 & 0.191 & 128 & \# \\
\hline 4_1 & 0.1476 & 0.0463 & 0.0276 & 0.0022 & 0.27 & 36.1676 & 2.8821 & 0.0387 & 0.0159 & 0.1699 & 0.0884 & 4.08 & 2 & 25 & 50 & 0.50 & 176 & 0.014 & 0.000 & 0.115 & 125 & $\$$ \\
\hline 5_1 & 0.1261 & 0.0133 & 0.0199 & 0.0007 & 0.87 & 50.1852 & 1.6427 & 0.0459 & 0.0071 & 0.4343 & 0.0453 & 42.04 & 5 & 130 & 158 & 0.82 & 127 & 0.004 & 0.000 & 0.160 & 105 & $\$$ \\
\hline $10 \_1$ & 0.1191 & 0.0159 & 0.0224 & 0.0008 & 0.20 & 44.7063 & 1.5913 & 0.0386 & 0.0065 & 0.2579 & 0.0305 & 71.21 & 6 & 117 & 276 & 0.43 & 143 & 0.005 & 0.000 & 0.000 & 124 & $\$$ \\
\hline 15_1 & 0.1675 & 0.0350 & 0.0281 & 0.0017 & 0.39 & 35.6027 & 2.1785 & 0.0433 & 0.0104 & 0.2781 & 0.0461 & 7.79 & 4 & 75 & 99 & 0.76 & 179 & 0.011 & 0.000 & 0.231 & 113 & $\$$ \\
\hline $14 \_1$ & 0.1863 & 0.0326 & 0.0296 & 0.0016 & 0.49 & 33.7313 & 1.8766 & 0.0456 & 0.0094 & 0.2045 & 0.0680 & 18.96 & 5 & 93 & 145 & 0.64 & 188 & 0.010 & 0.000 & 0.205 & 108 & $\$$ \\
\hline 11_1 & 0.1794 & 0.0222 & 0.0299 & 0.0011 & 0.26 & 33.4824 & 1.2337 & 0.0436 & 0.0066 & 0.3262 & 0.0375 & 18.24 & 4 & 132 & 94 & 1.41 & 190 & 0.007 & 0.000 & 0.126 & 113 & $\$$ \\
\hline 3_1 & 0.1734 & 0.0223 & 0.0303 & 0.0011 & 0.50 & 33.0408 & 1.2135 & 0.0415 & 0.0072 & 0.2501 & 0.0374 & 29.86 & 4 & 78 & 100 & 0.78 & 192 & 0.007 & 0.000 & 0.057 & 118 & $\$$ \\
\hline $18 \_1$ & 0.2173 & 0.0310 & 0.0305 & 0.0016 & 0.17 & 32.7660 & 1.6874 & 0.0516 & 0.0086 & 0.2220 & 0.0323 & 13.57 & 5 & 92 & 129 & 0.71 & 194 & 0.010 & 270 & 0.250 & 97 & $\$$ \\
\hline 13_1 & 0.2358 & 0.0195 & 0.0330 & 0.0010 & 0.25 & 30.3333 & 0.8784 & 0.0519 & 0.0054 & 0.2414 & 0.0260 & 16.29 & 6 & 145 & 132 & 1.10 & 209 & 0.006 & 280 & 0.180 & 97 & $\$$ \\
\hline
\end{tabular}

* plotted points. but not used to age calcule

\# points not used because the dicordance is higher than $10 \%$

$\$$ point not used because high concentration of $\mathrm{Pb}$ common or analytic problems (high error) 
Supplementary Material: U-Pb zircon ages from Garzón granites and related rocks, Eastern Cordillera, Colombia.

\begin{tabular}{|c|c|c|c|c|c|c|c|c|c|c|c|c|c|c|c|c|c|c|c|c|c|c|}
\hline \multicolumn{23}{|c|}{ Sombrerillo Massif: Sample GAR-395 } \\
\hline $\begin{array}{c}\text { POIN } \\
\text { T }\end{array}$ & $\begin{array}{l}{ }^{207} \mathrm{~Pb} / \\
{ }^{235} \mathrm{U}\end{array}$ & $1 \sigma$ & $\begin{array}{c}{ }^{206} \mathrm{~Pb} / \\
{ }^{238} \mathrm{U}\end{array}$ & $1 \sigma$ & $\begin{array}{l}\text { corr. } \\
\text { coeff }\end{array}$ & $\begin{array}{l}{ }^{238} \mathrm{U} / \\
{ }^{206} \mathrm{~Pb}\end{array}$ & $1 \sigma$ & $\begin{array}{l}{ }^{207} \mathrm{~Pb} / \\
{ }^{206} \mathrm{~Pb}\end{array}$ & $1 \sigma$ & $\begin{array}{c}{ }^{208} \mathrm{~Pb} / /^{2} \\
{ }^{06} \mathrm{~Pb}\end{array}$ & $1 \sigma$ & $\begin{array}{c}\mathrm{Pb} \\
\text { Total } \\
\text { Comm } \\
\text { on (\%) }\end{array}$ & $\begin{array}{c}\mathrm{Pb} \\
\mathrm{rad} \\
\mathrm{pp} \\
\mathrm{m}\end{array}$ & $\begin{array}{l}\text { Th } \\
\text { ppm }\end{array}$ & $\underset{\mathrm{ppm}}{\mathrm{U}}$ & $\mathrm{Th} / \mathrm{U}$ & $\begin{array}{c}\mathrm{Age} \\
206 \mathrm{gb} / \\
238 \mathrm{U} \\
(\mathrm{Ma})\end{array}$ & $1 \sigma$ & $\begin{array}{c}\mathrm{Age} \\
207 \mathrm{~Pb} / \\
{ }^{206} \mathrm{~Pb}\end{array}$ & $1 \sigma$ & $\begin{array}{c}\text { Conc. } \\
{ }^{206} \mathrm{~Pb}^{23} \\
{ }^{8} \mathrm{U} \\
{ }^{207} \mathrm{~Pb} / 2 \\
{ }^{06} \mathrm{~Pb} \\
\end{array}$ & \\
\hline 24_1 & 0.1745 & 0.0165 & 0.0234 & 0.0008 & 0.46 & 42.7496 & 1.4947 & 0.0541 & 0.0062 & 0.2220 & 0.0343 & 3.34 & 5 & 93 & 149 & 0.62 & 149 & 0.005 & 375 & 0.200 & 91 & \\
\hline $17 \_1$ & 0.1828 & 0.0190 & 0.0251 & 0.0010 & 0.43 & 39.8874 & 1.5167 & 0.0529 & 0.0067 & 0.2776 & 0.0396 & 5.66 & 5 & 119 & 126 & 0.94 & 160 & 0.006 & 324 & 0.248 & 93 & \\
\hline 3_1 & 0.1576 & 0.0115 & 0.0257 & 0.0007 & 0.46 & 38.9643 & 1.0607 & 0.0445 & 0.0039 & 0.2649 & 0.0298 & 5.60 & 6 & 130 & 167 & 0.78 & 163 & 0.004 & 0.000 & 0.104 & 109 & \\
\hline 7_1 & 0.1720 & 0.0190 & 0.0256 & 0.0011 & 0.01 & 39.1321 & 1.7380 & 0.0488 & 0.0068 & 0.2186 & 0.0605 & 4.78 & 4 & 98 & 125 & 0.78 & 163 & 0.007 & 138 & 0.209 & 100 & \\
\hline 4.1 & 0.1632 & 0.0065 & 0.0258 & 0.0004 & 0.24 & 38.8280 & 0.5918 & 0.0460 & 0.0022 & 0.3823 & 0.0272 & 1.85 & 13 & 343 & 335 & 1.02 & 164 & 0.002 & 0.000 & 0.079 & 106 & \\
\hline 21.1 & 0.1713 & 0.0119 & 0.0258 & 0.0006 & 0.16 & 38.8298 & 0.9309 & 0.0482 & 0.0041 & 0.3271 & 0.0580 & 3.58 & 5 & 139 & 149 & 0.94 & 164 & 0.004 & 111 & 0.158 & 102 & \\
\hline 12.1 & 0.1744 & 0.0171 & 0.0259 & 0.0010 & 0.01 & 38.5577 & 1.5259 & 0.0488 & 0.0062 & 0.2161 & 0.0470 & 0.99 & 3 & 36 & 70 & 0.52 & 165 & 0.006 & 136 & 0.178 & 101 & \\
\hline 13.1 & 0.1639 & 0.0096 & 0.0260 & 0.0006 & 0.01 & 38.5318 & 0.8670 & 0.0458 & 0.0034 & 0.6258 & 0.0561 & 1.84 & 10 & 464 & 210 & 2.21 & 165 & 0.004 & 0.000 & 0.102 & 107 & \\
\hline 6.1 & 0.1738 & 0.0178 & 0.0261 & 0.0011 & 0.01 & 38.2741 & 1.6211 & 0.0483 & 0.0064 & 0.1915 & 0.0451 & 1.24 & 4 & 48 & 91 & 0.53 & 166 & 0.007 & 112 & 0.140 & 102 & \\
\hline 22.1 & 0.1829 & 0.0107 & 0.0260 & 0.0006 & 0.17 & 38.4298 & 0.8494 & 0.0510 & 0.0036 & 0.3374 & 0.0470 & 0.47 & 12 & 350 & 290 & 1.21 & 166 & 0.004 & 240 & 0.129 & 97 & ס \\
\hline 19_1 & 0.1856 & 0.0112 & 0.0266 & 0.0006 & 0.22 & 37.5263 & 0.8253 & 0.0505 & 0.0036 & 0.2596 & 0.0506 & 0.00 & 4 & 84 & 99 & 0.84 & 170 & 0.004 & 219 & 0.158 & 98 & \\
\hline 25_1 & 0.1693 & 0.0143 & 0.0267 & 0.0008 & 0.44 & 37.4583 & 1.0624 & 0.0460 & 0.0048 & 0.3242 & 0.0359 & 3.14 & 4 & 94 & 113 & 0.84 & 170 & 0.005 & 0.000 & 0.090 & 106 & \\
\hline 1_1 & 0.1649 & 0.0118 & 0.0269 & 0.0007 & 0.21 & 37.1266 & 0.9932 & 0.0444 & 0.0041 & 0.3950 & 0.0310 & 0.79 & 6 & 182 & 154 & 1.19 & 171 & 0.005 & 0.000 & 0.039 & 110 & \\
\hline 23_1 & 0.1999 & 0.0229 & 0.0279 & 0.0012 & 0.24 & 35.8552 & 1.5013 & 0.0520 & 0.0077 & 0.1854 & 0.0576 & 1.62 & 3 & 54 & 98 & 0.55 & 177 & 0.007 & 285 & 0.268 & 95 & \\
\hline 18_1 & 0.1916 & 0.0144 & 0.0286 & 0.0008 & 0.10 & 34.9475 & 0.9330 & 0.0486 & 0.0046 & 0.4654 & 0.1335 & 4.41 & 5 & 111 & 117 & 0.95 & 182 & 0.005 & 127 & 0.171 & 102 & \\
\hline 15._1 & 0.1547 & 0.0155 & 0.0264 & 0.0008 & 0.31 & 37.9304 & 1.1508 & 0.0426 & 0.0052 & 0.5346 & 0.0632 & 2.85 & 6 & 243 & 131 & 1.86 & 168 & 0.005 & 0.000 & 0.201 & 114 & \\
\hline 26_1 & 0.1669 & 0.0206 & 0.0275 & 0.0010 & 0.44 & 36.3598 & 1.3761 & 0.0440 & 0.0067 & 0.4827 & 0.0617 & 4.03 & 4 & 149 & 97 & 1.54 & 175 & 0.007 & 0.000 & 0.023 & 111 & \\
\hline $16 \_1$ & 0.1283 & 0.0264 & 0.0242 & 0.0013 & 0.52 & 41.2621 & 2.2426 & 0.0384 & 0.0101 & 0.2432 & 0.0635 & 2.51 & 2 & 37 & 64 & 0.58 & 154 & 0.008 & 0.000 & 0.316 & 125 & \\
\hline 10_1 & 0.1590 & 0.0231 & 0.0258 & 0.0014 & 0.33 & 38.7870 & 2.0612 & 0.0447 & 0.0083 & 0.1647 & 0.0690 & 4.96 & 2 & 30 & 54 & 0.55 & 164 & 0.009 & 0.000 & 0.198 & 109 & \\
\hline 5_1 & 0.1431 & 0.0284 & 0.0263 & 0.0017 & 0.15 & 38.0743 & 2.4081 & 0.0395 & 0.0103 & 0.2700 & 0.0721 & 2.56 & 2 & 41 & 55 & 0.76 & 167 & 0.010 & 0.000 & 0.255 & 123 & \\
\hline 8_1 & 0.2053 & 0.0362 & 0.0227 & 0.0021 & 0.04 & 44.0695 & 4.0396 & 0.0656 & 0.0153 & 0.1806 & 0.0917 & 8.70 & 2 & 50 & 58 & 0.86 & 145 & 0.013 & 794 & 0.349 & 76 & \\
\hline 2_1 & 0.1584 & 0.0118 & 0.0258 & 0.0007 & 0.35 & 38.7264 & 1.0591 & 0.0445 & 0.0042 & 0.2638 & 0.0277 & 7.27 & 4 & 91 & 118 & 0.77 & 164 & 0.004 & 0.000 & 0.104 & 110 & \\
\hline 9_1 & 0.1851 & 0.0260 & 0.0271 & 0.0015 & 0.49 & 36.9205 & 2.1001 & 0.0496 & 0.0099 & 0.2391 & 0.0616 & 11.28 & 2 & 29 & 49 & 0.59 & 172 & 0.010 & 174 & 0.300 & 99 & \\
\hline $14 \_1$ & 0.1936 & 0.0234 & 0.0275 & 0.0012 & 0.19 & 36.3579 & 1.5285 & 0.0511 & 0.0081 & 0.2699 & 0.0413 & 8.16 & 4 & 135 & 106 & 1.27 & 175 & 0.007 & 243 & 0.258 & 97 & \\
\hline 11_1 & 0.2006 & 0.0210 & 0.0278 & 0.0012 & 0.63 & 35.9328 & 1.5935 & 0.0523 & 0.0073 & 0.1319 & 0.0551 & 6.18 & 2 & 31 & 66 & 0.46 & 177 & 0.008 & 298 & 0.278 & 95 & \\
\hline 20_1 & 0.4929 & 0.0214 & 0.0646 & 0.0011 & 0.85 & 15.4756 & 0.2714 & 0.0553 & 0.0031 & 0.1946 & 0.0239 & 1.19 & 11 & 75 & 127 & 0.59 & 404 & 0.007 & 425 & 0.124 & 99 & * \\
\hline
\end{tabular}

* plotted points. but not used to age calcule 
Supplementary Material: U-Pb zircon ages from Garzón granites and related rocks, Eastern Cordillera, Colombia.

\begin{tabular}{|c|c|c|c|c|c|c|c|c|c|c|c|c|c|c|c|c|c|c|c|c|c|c|c|c|c|}
\hline \multirow[b]{2}{*}{$\begin{array}{c}\text { PO } \\
\text { IN } \\
T\end{array}$} & \multirow[b]{2}{*}{$\begin{array}{c}{ }^{207} \mathrm{~Pb} / \\
{ }^{235} \mathrm{U}\end{array}$} & \multirow[b]{2}{*}{$1 \sigma$} & \multicolumn{23}{|c|}{ Sombrerillo igneous massif: Sample GAR-102 } \\
\hline & & & $\begin{array}{l}{ }^{206} \mathrm{~Pb} / \\
238 \mathrm{U}\end{array}$ & $1 \sigma$ & $\begin{array}{l}\text { corr. } \\
\text { coeff }\end{array}$ & $\begin{array}{c}{ }^{238} \mathrm{U} /{ }^{206} \\
\mathrm{~Pb}\end{array}$ & $1 \sigma$ & $\begin{array}{l}{ }^{207} \mathrm{~Pb} / \\
{ }^{206} \mathrm{~Pb}\end{array}$ & 10 & $\begin{array}{l}{ }^{208} \mathrm{~Pb} / \\
{ }^{206} \mathrm{~Pb}\end{array}$ & 10 & $\begin{array}{c}\mathrm{Pb} \\
\text { Total } \\
\text { comm } \\
\text { on (\%) }\end{array}$ & $\begin{array}{c}\mathrm{Pb} \\
\mathrm{rad} \\
\mathrm{ppm}\end{array}$ & $\begin{array}{c}\text { Th } \\
\text { ppm }\end{array}$ & $\underset{\mathrm{ppm}}{U}$ & $\mathrm{Th} / \mathrm{U}$ & $\begin{array}{c}\mathrm{Age} \\
206 \mathrm{P} \\
\mathrm{b} / 238 \\
U \\
(\mathrm{Ma})\end{array}$ & $1 \sigma$ & $\begin{array}{c}\mathrm{Age} \\
207 \mathrm{P} \\
\mathrm{b} / 235 \\
U \\
(\mathrm{Ma} \\
)\end{array}$ & $1 \sigma$ & $\begin{array}{c}\text { Age } \\
207 \mathrm{P} \\
\mathrm{b} / \\
206 \mathrm{P} \\
\mathrm{b}\end{array}$ & $1 \sigma$ & $\begin{array}{l}\text { Conc } \\
{ }^{206} \mathrm{~Pb} \\
{ }^{238} \mathrm{U} / \\
{ }^{207} \mathrm{~Pb} \\
{ }^{235} \mathrm{U}\end{array}$ & $\begin{array}{c}\mathrm{Co} \\
\mathrm{nc} . \\
206 \\
\mathrm{~Pb} \\
1 \\
{ }_{238} \\
\mathrm{U} \\
{ }^{207} \\
\mathrm{~Pb} \\
1 \\
206 \\
\mathrm{~Pb}\end{array}$ & \\
\hline 1_1 & 0.2014 & 0.0069 & 0.0294 & 0.0008 & 0.83 & 34.0033 & 0.9712 & 0.0505 & 0.0004 & 0.4582 & 0.1061 & $<0.001$ & 11.5 & 248.4 & 304.8 & $\begin{array}{c}0.814 \\
9\end{array}$ & 187 & 0.005 & 186 & 0.006 & 219 & 0,019 & 100 & 85 & \\
\hline 2_1 & 0.2010 & 0.0069 & 0.0290 & 0.0008 & 0.83 & 34.5179 & 0.9769 & 0.0502 & 0.0003 & 0.2834 & 0.0656 & $<0.001$ & 42.2 & 697.8 & 1206.6 & 0.578 & 184 & 0.005 & 186 & 0.006 & 205 & 0,012 & 99 & 90 & \\
\hline 3_1 & 0.2032 & 0.0072 & 0.0291 & 0.0008 & 0.82 & 34.3312 & 0.9960 & 0.0511 & 0.0005 & 0.3122 & 0.0724 & $<0.001$ & 7.0 & 92.0 & 200.1 & 0.460 & 185 & 0.005 & 188 & 0.006 & 246 & 0,021 & 99 & 75 & \\
\hline 4_1 & 0.2062 & 0.0071 & 0.0294 & 0.0008 & 0.83 & 33.9763 & 0.9763 & 0.0513 & 0.0004 & 0.5518 & 0.1278 & $<0.001$ & 8.0 & 146.2 & 203.0 & 0.720 & 187 & 0.005 & 190 & 0.006 & 254 & 0,017 & 98 & 73 & 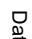 \\
\hline 4_2 & 0.2031 & 0.0071 & 0.0292 & 0.0009 & 0.84 & 34.2403 & 1.0056 & 0.0500 & 0.0006 & 0.5007 & 0.1161 & $<0.001$ & 7.4 & 132.1 & 189.8 & 0.696 & 186 & 0.005 & 188 & 0.006 & 197 & 0,027 & 99 & 94 & \\
\hline 5_1 & 0.1994 & 0.0070 & 0.0288 & 0.0008 & 0.84 & 34.7264 & 1.0184 & 0.0500 & 0.0006 & 0.6044 & 0.1400 & $<0.001$ & 10.0 & 204.5 & 252.6 & 0.810 & 183 & 0.005 & 185 & 0.006 & 198 & 0,027 & 99 & 92 & \\
\hline $5 \_2$ & 0.1986 & 0.0070 & 0.0287 & 0.0008 & 0.83 & 34.8397 & 1.0212 & 0.0513 & 0.0006 & 0.6014 & 0.1394 & $<0.001$ & 9.1 & 196.0 & 231.9 & 0.845 & 182 & 0.005 & 184 & 0.006 & 255 & 0,026 & 99 & 71 & s? \\
\hline $6 \_1$ & 0.2002 & 0.0072 & 0.0286 & 0.0008 & 0.82 & 34.9817 & 1.0244 & 0.0512 & 0.0007 & 0.5755 & 0.1333 & $<0.001$ & 10.7 & 234.3 & 270.2 & 0.867 & 182 & 0.005 & 185 & 0.006 & 249 & 0,030 & 98 & 73 & \\
\hline 7_1 & 0.1983 & 0.0068 & 0.0285 & 0.0008 & 0.83 & 35.0962 & 1.0091 & 0.0512 & 0.0004 & 0.6213 & 0.1438 & $<0.001$ & 11.9 & 264.1 & 300.4 & 0.879 & 181 & 0.005 & 184 & 0.006 & 247 & 0,019 & 99 & 73 & $\overline{\overline{\frac{c}{\bar{T}}}}$ \\
\hline 7_2 & 0.1984 & 0.0069 & 0.0287 & 0.0008 & 0.83 & 34.8528 & 1.0096 & 0.0504 & 0.0005 & 0.4871 & 0.1128 & $<0.001$ & 9.2 & 182.7 & 243.9 & 0.749 & 182 & 0.005 & 184 & 0.006 & 215 & 0,022 & 99 & 85 & \\
\hline 8_1 & 0.1962 & 0.0071 & 0.0285 & 0.0009 & 0.84 & 35.0674 & 1.0689 & 0.0502 & 0.0009 & 0.3483 & 0.0814 & $<0.001$ & 4.7 & 62.9 & 135.3 & 0.465 & 181 & 0.005 & 182 & 0.006 & 207 & 0,040 & 100 & 87 & \\
\hline 9_1 & 0.2022 & 0.0069 & 0.0295 & 0.0008 & 0.83 & 33.9410 & 0.9600 & 0.0498 & 0.0002 & 0.0722 & 0.0167 & $<0.001$ & 239.5 & $\begin{array}{c}1098 . \\
7\end{array}$ & 7565.2 & 0.145 & 187 & 0.005 & 187 & 0.006 & 188 & 0,011 & 100 & 99 & \\
\hline 1_2 & 0.2024 & 0.0070 & 0.0285 & 0.0008 & 0.82 & 35.0317 & 1.0039 & 0.0512 & 0.0004 & 0.3679 & 0.0852 & $<0.001$ & 8.4 & 155.9 & 238.5 & 0.653 & 181 & 0.005 & 187 & 0.006 & 251 & 0,019 & 97 & 72 & \\
\hline
\end{tabular}


Supplementary Material: U-Pb zircon ages from Garzón granites and related rocks, Eastern Cordillera, Colombia.

\begin{tabular}{|c|c|c|c|c|c|c|c|c|c|c|c|c|c|c|c|c|c|c|c|c|c|c|c|}
\hline & & & & & & & & & Son & rerillo igr & us mass & Sample GS & & & & & & & & & & & \\
\hline $\begin{array}{l}\text { POI } \\
\text { NT }\end{array}$ & $\begin{array}{l}{ }^{207} \mathrm{~Pb} / \\
{ }^{235} \mathrm{U}\end{array}$ & $1 \sigma$ & $\begin{array}{l}{ }^{206} \mathrm{pb} / \\
{ }^{238} \mathrm{U}\end{array}$ & $1 \sigma$ & $\begin{array}{l}\text { corr. } \\
\text { coeff }\end{array}$ & $\begin{array}{c}{ }^{238} \mathrm{U}^{206} \\
\mathrm{~Pb}\end{array}$ & $1 \sigma$ & $\begin{array}{l}{ }^{207} \mathrm{~Pb} / \\
{ }^{206} \mathrm{~Pb}\end{array}$ & $1 \sigma$ & $\begin{array}{l}{ }^{208} \mathrm{~Pb} / \\
{ }^{206} \mathrm{~Pb}\end{array}$ & $1 \sigma$ & $\begin{array}{c}\mathrm{Pb} \\
\text { Total } \\
\text { commo } \\
\mathrm{n}(\%)\end{array}$ & $\begin{array}{l}\mathrm{Pb} \\
\mathrm{rad} \\
\mathrm{ppm}\end{array}$ & $\begin{array}{c}\text { Th } \\
\text { ppm }\end{array}$ & $\underset{\mathrm{ppm}}{\mathrm{U}}$ & Th/U & $\begin{array}{c}\mathrm{Age} \\
206 \mathrm{~Pb} / \\
238 \mathrm{U} \\
(\mathrm{Ma})\end{array}$ & $1 \sigma$ & $\begin{array}{c}\mathrm{Age} \\
{ }^{207} \mathrm{~Pb} / \\
{ }^{206} \mathrm{~Pb}\end{array}$ & $1 \sigma$ & $\begin{array}{c}\text { Con } \\
c \\
206 \mathrm{p} \\
\mathrm{b} / \\
{ }^{238} \mathrm{U} / \\
{ }^{207} \mathrm{P} \\
\mathrm{b} / \\
235 \mathrm{U}\end{array}$ & $\begin{array}{c}\text { Conc } \\
{ }^{206} \mathrm{~Pb} \\
/ \\
{ }^{238} \mathrm{U} \\
{ }^{207} \mathrm{P} \\
\mathrm{b} / \\
{ }^{206} \mathrm{~Pb}\end{array}$ & \\
\hline 1_1 & 0.2068 & 0.0030 & 0.0294 & 0.0004 & 0.90 & 33.9891 & 0.4905 & 0.0516 & 0.0004 & 0.4843 & 0.0575 & $<0.001$ & 10.8 & 261.7 & 269.7 & $\begin{array}{l}0.970 \\
4\end{array}$ & 187 & 0.003 & 191 & 0.003 & 0.267 & 0.017 & \\
\hline 1_2 & 0.2023 & 0.0032 & 0.0294 & 0.0004 & 0.90 & 33.9677 & 0.5155 & 0.0503 & 0.0005 & 0.2994 & 0.0362 & 0.15 & 6.2 & 83.9 & 172.4 & 0.487 & 187 & 0.003 & 187 & 0.003 & 0.210 & 0.021 & \\
\hline $2 \_1$ & 0.2075 & 0.0031 & 0.0299 & 0.0004 & 0.90 & 33.4577 & 0.4999 & 0.0509 & 0.0004 & 0.5024 & 0.0596 & $<0.001$ & 11.1 & 238.1 & 270.0 & 0.882 & 190 & 0.003 & 191 & 0.003 & 0.236 & 0.019 & \\
\hline 3_1 & 0.1999 & 0.0029 & 0.0291 & 0.0004 & 0.90 & 34.3409 & 0.4930 & 0.0501 & 0.0003 & 0.4831 & 0.0573 & $<0.001$ & 12.8 & 281.8 & 321.7 & 0.876 & 185 & 0.003 & 185 & 0.002 & 0.200 & 0.014 & 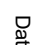 \\
\hline 4_1 & 0.2061 & 0.0030 & 0.0296 & 0.0004 & 0.90 & 33.8180 & 0.4871 & 0.0510 & 0.0003 & 0.2713 & 0.0326 & $<0.001$ & 6.8 & 84.4 & 190.4 & 0.443 & 188 & 0.003 & 190 & 0.002 & 0.239 & 0.014 & w. \\
\hline $5 \_1$ & 0.2065 & 0.0030 & 0.0295 & 0.0004 & 0.90 & 33.8414 & 0.4969 & 0.0508 & 0.0004 & 0.3954 & 0.0471 & $<0.001$ & 8.4 & 162.3 & 221.0 & 0.734 & 188 & 0.003 & 191 & 0.002 & 0.230 & 0.016 & 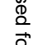 \\
\hline $5 \_2$ & 0.2056 & 0.0031 & 0.0294 & 0.0004 & 0.90 & 34.0302 & 0.4954 & 0.0504 & 0.0005 & 0.5203 & 0.0619 & $<0.001$ & 11.7 & 279.2 & 286.6 & 0.974 & 187 & 0.003 & 190 & 0.003 & 0.214 & 0.020 & bi \\
\hline $6 \_1$ & 0.1944 & 0.0032 & 0.0285 & 0.0004 & 0.88 & 35.0694 & 0.5023 & 0.0496 & 0.0004 & 0.5190 & 0.0616 & $<0.001$ & 12.1 & 318.4 & 300.7 & 1.059 & 181 & 0.003 & 180 & 0.003 & 0.180 & 0.018 & \\
\hline $7 \_1$ & 0.2026 & 0.0029 & 0.0292 & 0.0004 & 0.90 & 34.2695 & 0.5008 & 0.0506 & 0.0003 & 0.4992 & 0.0593 & $<0.001$ & 12.8 & 338.3 & 319.1 & 1.060 & 185 & 0.003 & 187 & 0.002 & 0.225 & 0.014 & $\frac{\bar{c}}{\bar{c}}$ \\
\hline 8_1 & 0.2028 & 0.0029 & 0.0292 & 0.0004 & 0.90 & 34.2222 & 0.5110 & 0.0506 & 0.0004 & 0.5138 & 0.0610 & $<0.001$ & 11.7 & 301.1 & 286.1 & 1.053 & 186 & 0.003 & 187 & 0.002 & 0.221 & 0.015 & \\
\hline 9_1 & 0.1996 & 0.0029 & 0.0287 & 0.0004 & 0.90 & 34.8917 & 0.5196 & 0.0516 & 0.0004 & 0.3504 & 0.0418 & $<0.001$ & 8.6 & 178.1 & 236.9 & 0.752 & 182 & 0.003 & 185 & 0.002 & 0.266 & 0.019 & \\
\hline 10_1 & 0.1960 & 0.0031 & 0.0290 & 0.0004 & 0.90 & 34.4728 & 0.5038 & 0.0495 & 0.0005 & 0.3245 & 0.0388 & $<0.001$ & 7.8 & 131.4 & 219.5 & 0.599 & 184 & 0.003 & 182 & 0.003 & 0.176 & 0.021 & \\
\hline 11_1 & 0.1966 & 0.0029 & 0.0287 & 0.0004 & 0.90 & 34.8566 & 0.5126 & 0.0506 & 0.0004 & 0.3163 & 0.0376 & $<0.001$ & 10.1 & 168.3 & 285.8 & 0.589 & 182 & 0.003 & 182 & 0.002 & 0.224 & 0.016 & \\
\hline
\end{tabular}


Supplementary Material: U-Pb zircon ages from crystalline basement of Garzón region, Eastern Cordillera, Colombia.

\begin{tabular}{|c|c|c|c|c|c|c|c|c|c|c|c|c|c|c|c|c|c|c|c|c|c|}
\hline \multicolumn{22}{|c|}{ Metamorphic basement: Sample GAR-364 } \\
\hline POIN & $\begin{array}{l}{ }^{207} \mathrm{~Pb} / \\
{ }^{235} \mathrm{U}\end{array}$ & $1 \sigma$ & $\begin{array}{l}{ }^{206} \mathrm{~Pb} \\
{ }^{238} \mathrm{U}\end{array}$ & $1 \sigma$ & $\begin{array}{l}\text { corr. } \\
\text { coeff }\end{array}$ & $\begin{array}{c}{ }^{238} \mathrm{U}^{206} \mathrm{P} \\
\mathrm{b}\end{array}$ & $1 \sigma$ & $\begin{array}{l}{ }^{207} \mathrm{pb} / \\
{ }^{206} \mathrm{~Pb}\end{array}$ & $1 \sigma$ & $\begin{array}{l}{ }^{208} \mathrm{~Pb} / \\
{ }^{206} \mathrm{~Pb}\end{array}$ & $1 \sigma$ & $\begin{array}{l}\mathrm{Pb} \\
\text { Total } \\
\text { comm } \\
\text { on (\%) }\end{array}$ & $\begin{array}{c}\mathrm{Pb} \\
\mathrm{rad} \\
\mathrm{ppm}\end{array}$ & $\begin{array}{c}\text { Th } \\
\text { ppm }\end{array}$ & $\underset{\mathrm{ppm}}{\mathrm{U}}$ & $\mathrm{Th} / \mathrm{U}$ & $\begin{array}{c}\mathrm{Age} \\
206 \mathrm{~Pb} / \\
238 \mathrm{U} \\
(\mathrm{Ma})\end{array}$ & $1 \sigma$ & $\begin{array}{c}\mathrm{Age} \\
{ }^{207} \mathrm{~Pb} / 2 \\
06 \mathrm{~Pb} \\
(\mathrm{Ma})\end{array}$ & $1 \sigma$ & $\begin{array}{c}\text { Conc. } \\
{ }^{2066} \mathrm{~Pb} / \\
238 \mathrm{U} \\
{ }^{207} \mathrm{~Pb} / \\
{ }^{206} \mathrm{~Pb}\end{array}$ \\
\hline $15 \_1$ & 1.6944 & 0.0430 & 0.1647 & 0.0022 & 0.30 & 6.0715 & 0.0813 & 0.0746 & 0.0021 & 0.2182 & 0.0216 & 0.47 & 24 & 63 & 108 & 0.59 & 983 & 0.012 & 1058 & 0.056 & 92 \\
\hline $16 \_1$ & 1.6809 & 0.0488 & 0.1651 & 0.0024 & 0.01 & 6.0570 & 0.0872 & 0.0738 & 0.0024 & 0.1805 & 0.0117 & 0.50 & 21 & 53 & 92 & 0.58 & 985 & 0.013 & 1037 & 0.064 & 94 \\
\hline 4_1 & 1.7086 & 0.0457 & 0.1653 & 0.0017 & 0.49 & 6.0497 & 0.0627 & 0.0750 & 0.0022 & 0.1659 & 0.0086 & 0.66 & 17 & 35 & 76 & 0.46 & 986 & 0.009 & 1068 & 0.062 & 92 \\
\hline $17 \_1$ & 1.6960 & 0.0355 & 0.1655 & 0.0020 & 0.32 & 6.0418 & 0.0715 & 0.0743 & 0.0017 & 0.4731 & 0.0047 & 0.28 & 56 & 294 & 202 & 1.46 & 987 & 0.011 & 1050 & 0.046 & 94 \\
\hline 6_1 & 1.6861 & 0.0478 & 0.1657 & 0.0018 & 0.27 & 6.0343 & 0.0647 & 0.0738 & 0.0023 & 0.1594 & 0.0067 & 0.30 & 16 & 33 & 74 & 0.45 & 988 & 0.010 & 1036 & 0.064 & 95 \\
\hline 3_1 & 1.6928 & 0.0365 & 0.1659 & 0.0015 & 0.63 & 6.0276 & 0.0534 & 0.0740 & 0.0017 & 0.3148 & 0.0324 & 0.53 & 49 & 208 & 191 & 1.09 & 989 & 0.008 & 1042 & 0.047 & 94 \\
\hline 18_1 & 1.6938 & 0.0529 & 0.1660 & 0.0025 & 0.20 & 6.0256 & 0.0925 & 0.0740 & 0.0026 & 0.2689 & 0.0101 & 0.38 & 17 & 58 & 72 & 0.81 & 990 & 0.014 & 1042 & 0.070 & 94 \\
\hline 24_1 & 1.7115 & 0.0460 & 0.1660 & 0.0023 & 0.01 & 6.0235 & 0.0839 & 0.0748 & 0.0022 & 0.1729 & 0.0053 & 0.13 & 23 & 56 & 101 & 0.55 & 990 & 0.013 & 1.062 & 0.061 & 93 \\
\hline 9_1 & 1.6370 & 0.0442 & 0.1664 & 0.0017 & 0.56 & 6.0104 & 0.0608 & 0.0714 & 0.0021 & 0.1797 & 0.0087 & 0.28 & 18 & 43 & 82 & 0.52 & 992 & 0.009 & 968 & 0.059 & 102 \\
\hline 20_1 & 1.7251 & 0.0510 & 0.1664 & 0.0025 & 0.44 & 6.0090 & 0.0890 & 0.0752 & 0.0025 & 0.1774 & 0.0073 & 0.50 & 17 & 38 & 78 & 0.49 & 992 & 0.014 & 1073 & 0.067 & 92 \\
\hline 21_1 & 1.6689 & 0.0454 & 0.1664 & 0.0023 & 0.42 & 6.0092 & 0.0833 & 0.0727 & 0.0022 & 0.1918 & 0.0096 & 0.83 & 20 & 46 & 89 & 0.51 & 992 & 0.013 & 1007 & 0.062 & 98 \\
\hline 5_1 & 1.6801 & 0.0388 & 0.1665 & 0.0016 & 0.60 & 6.0044 & 0.0560 & 0.0732 & 0.0018 & 0.1856 & 0.0085 & 0.17 & 29 & 73 & 128 & 0.57 & 993 & 0.009 & 1019 & 0.052 & 97 \\
\hline 25_1 & 1.7584 & 0.0654 & 0.1665 & 0.0029 & 0.36 & 6.0067 & 0.1050 & 0.0766 & 0.0033 & 0.3255 & 0.0107 & 1.09 & 12 & 44 & 47 & 0.94 & 993 & 0.016 & 1111 & 0.089 & 89 \\
\hline 11_1 & 1.6613 & 0.0436 & 0.1670 & 0.0017 & 0.27 & 5.9888 & 0.0600 & 0.0722 & 0.0021 & 0.1716 & 0.0082 & 0.98 & 21 & 55 & 93 & 0.59 & 995 & 0.009 & 990 & 0.059 & 100 \\
\hline 12_1 & 1.7042 & 0.0393 & 0.1674 & 0.0015 & 0.01 & 5.9753 & 0.0546 & 0.0739 & 0.0019 & 0.2256 & 0.0071 & 0.88 & 22 & 57 & 98 & 0.58 & 998 & 0.008 & 1038 & 0.052 & 96 \\
\hline 10_1 & 1.6884 & 0.0388 & 0.1682 & 0.0015 & 0.55 & 5.9470 & 0.0543 & 0.0728 & 0.0018 & 0.2041 & 0.0058 & 0.65 & 28 & 71 & 123 & 0.57 & 1002 & 0.008 & 1009 & 0.050 & 99 \\
\hline 2_1 & 1.7120 & 0.0338 & 0.1691 & 0.0014 & 0.67 & 5.9130 & 0.0493 & 0.0734 & 0.0015 & 0.3320 & 0.0089 & 0.13 & 49 & 225 & 196 & 1.15 & 1007 & 0.008 & 1026 & 0.044 & 98 \\
\hline 2_2 & 1.7159 & 0.0378 & 0.1694 & 0.0015 & 0.01 & 5.9038 & 0.0527 & 0.0735 & 0.0017 & 0.2393 & 0.0081 & 0.06 & 34 & 117 & 141 & 0.83 & 1009 & 0.008 & 1027 & 0.047 & 98 \\
\hline 23_1 & 1.6748 & 0.0482 & 0.1695 & 0.0025 & 0.07 & 5.9000 & 0.0854 & 0.0717 & 0.0023 & 0.1654 & 0.0056 & 0.19 & 18 & 40 & 83 & 0.48 & 1009 & 0.014 & 976 & 0.065 & 103 \\
\hline 13_1 & 1.7004 & 0.0490 & 0.1697 & 0.0024 & 0.73 & 5.8938 & 0.0849 & 0.0727 & 0.0023 & 0.2099 & 0.0093 & 0.37 & 19 & 51 & 84 & 0.61 & 1010 & 0.013 & 1005 & 0.065 & 100 \\
\hline 19_1 & 1.7406 & 0.0457 & 0.1695 & 0.0023 & 0.53 & 5.8985 & 0.0807 & 0.0745 & 0.0022 & 0.3098 & 0.0180 & 1.24 & 20 & 62 & 86 & 0.72 & 1010 & 0.013 & 1054 & 0.061 & 95 \\
\hline 22_1 & 1.7099 & 0.0317 & 0.1708 & 0.0019 & 0.38 & 5.8537 & 0.0643 & 0.0726 & 0.0014 & 0.3387 & 0.0237 & 0.18 & 74 & 380 & 275 & 1.38 & 1017 & 0.010 & 1003 & 0.040 & 101 \\
\hline 7_1 & 1.7267 & 0.0309 & 0.1710 & 0.0013 & 0.70 & 5.8471 & 0.0454 & 0.0732 & 0.0014 & 0.3564 & 0.0044 & 0.03 & 81 & 331 & 313 & 1.06 & 1018 & 0.007 & 1020 & 0.038 & 99 \\
\hline 14_1 & 1.7630 & 0.0416 & 0.1721 & 0.0022 & 0.72 & 5.8101 & 0.0746 & 0.0743 & 0.0019 & 0.2880 & 0.0058 & 0.56 & 32 & 108 & 131 & 0.83 & 1024 & 0.012 & 1049 & 0.053 & 97 \\
\hline 8_1 & 1.7447 & 0.0446 & 0.1725 & 0.0017 & 0.45 & 5.7984 & 0.0582 & 0.0734 & 0.0020 & 0.1989 & 0.0065 & 0.21 & 23 & 66 & 102 & 0.65 & 1026 & 0.010 & 1024 & 0.057 & 100 \\
\hline 1_1 & 1.7468 & 0.0483 & 0.1745 & 0.0019 & 0.01 & 5.7308 & 0.0610 & 0.0726 & 0.0022 & 0.1677 & 0.0116 & 0.31 & 20 & 50 & 86 & 0.59 & 1037 & 0.010 & 1003 & 0.064 & 103 \\
\hline
\end{tabular}


Supplementary Material: Zircon Lu-Hf isotope data from Garzón granites and related rocks, Eastern Cordillera, Colombia.

\begin{tabular}{|c|c|c|c|c|c|c|c|c|c|c|c|c|}
\hline \multicolumn{13}{|c|}{ Algeciras Plutonic Massif: Sample GAR-356 } \\
\hline Grain/spot & ${ }^{176} \mathrm{Hf} /{ }^{177} \mathrm{Hf}$ & $\pm 2 \mathrm{se}$ & ${ }^{176} \mathrm{Lu} /{ }^{177} \mathrm{Hf}$ & $\pm 2 \mathrm{se}$ & $\begin{array}{c}\text { U-Pb Age } \\
\text { (T1) Ma }\end{array}$ & $\varepsilon \mathrm{Hf}(0)$ & $\begin{array}{c}{ }^{176} \mathrm{Hf} /{ }^{177} \mathrm{Hf} \\
(\mathrm{T} 1)\end{array}$ & $\varepsilon \mathrm{Hf}(\mathrm{T} 1)$ & $\begin{array}{c}{ }^{176} \mathrm{Hf} /{ }^{177} \mathrm{Hf} \\
\mathrm{DM}(\mathrm{T})\end{array}$ & $\begin{array}{l}\text { T DM } \\
(\mathrm{Ga}) \\
\end{array}$ & $\begin{array}{c}{ }^{176} \mathrm{Hf} /{ }^{177} \mathrm{Hf} \\
\mathrm{DM}(\mathrm{T})\end{array}$ & $\begin{array}{c}\varepsilon \mathrm{Hf} \\
(\mathrm{TDM})\end{array}$ \\
\hline 1_1 & 0.282632 & 0.000029 & 0.001991 & 0.000050 & 179 & -4.94 & 0.282626 & -1.25 & 0.283096 & 1245 & 0.282319 & +11.64 \\
\hline 1_2 & 0.282522 & 0.000020 & 0.001209 & 0.000012 & 183 & -8.83 & 0.282518 & -4.96 & 0.283093 & 1483 & 0.282144 & +10.79 \\
\hline 3_1 & 0.282563 & 0.000027 & 0.000866 & 0.000007 & 186 & -7.38 & 0.282560 & -3.40 & 0.283091 & 1387 & 0.282215 & +11.14 \\
\hline 6_1 & 0.282561 & 0.000027 & 0.000821 & 0.000005 & 185 & -7.47 & 0.282558 & -3.51 & 0.283092 & 1393 & 0.282211 & +11.12 \\
\hline 5_1 & 0.282568 & 0.000023 & 0.000637 & 0.000005 & 183 & -7.21 & 0.282566 & -3.27 & 0.283093 & 1377 & 0.282223 & +11.17 \\
\hline 16_2 & 0.282694 & 0.000027 & 0.001695 & 0.000019 & 173 & -2.74 & 0.282689 & +0.86 & 0.283100 & 1107 & 0.282421 & +12.14 \\
\hline 14_1 & 0.282559 & 0.000027 & 0.000797 & 0.000004 & 181 & -7.54 & 0.282556 & -3.66 & 0.283095 & 1400 & 0.282206 & +11.09 \\
\hline 11_1 & 0.282489 & 0.000029 & 0.001078 & 0.000009 & 174 & -9.99 & 0.282486 & -6.30 & 0.283100 & 1561 & 0.282087 & +10.51 \\
\hline 25_1 & 0.282581 & 0.000028 & 0.001135 & 0.000028 & 183 & -6.75 & 0.282577 & -2.87 & 0.283093 & 1351 & 0.282242 & +11.27 \\
\hline 221 & 0.282621 & 0.000025 & 0.001656 & 0.000064 & 169 & -5.35 & 0.282616 & -1.82 & 0.283103 & 1274 & 0.282298 & +11.54 \\
\hline
\end{tabular}


Supplementary Material: Zircon Lu-Hf isotope data from Garzón granites and related rocks, Eastern Cordillera, Colombia.

\begin{tabular}{|c|c|c|c|c|c|c|c|c|c|c|c|c|}
\hline \multicolumn{13}{|c|}{ Algeciras Plutonic Massif: Sample GAR-359 } \\
\hline Grain/spot & ${ }^{176} \mathrm{Hf} /{ }^{177} \mathrm{Hf}$ & $\pm 2 \mathrm{se}$ & ${ }^{176} \mathrm{Lu} /{ }^{177} \mathrm{Hf}$ & $\pm 2 \mathrm{se}$ & $\begin{array}{c}\text { U-Pb Age } \\
\text { (T1) Ma }\end{array}$ & $\varepsilon \mathrm{Hf}(0)$ & $\begin{array}{c}{ }^{176} \mathrm{Hf} / /^{177} \mathrm{Hf} \\
(\mathrm{T} 1)\end{array}$ & $\varepsilon \mathrm{Hf}(\mathrm{T} 1)$ & $\begin{array}{c}{ }^{176} \mathrm{Hf} /{ }^{177} \mathrm{Hf} \\
\mathrm{DM}(\mathrm{T})\end{array}$ & $\begin{array}{l}\text { TDM } \\
(\mathrm{Ga})\end{array}$ & $\begin{array}{c}{ }^{176} \mathrm{Hf} /{ }^{177} \mathrm{Hf} \\
\mathrm{DM}(\mathrm{T})\end{array}$ & $\varepsilon \mathrm{Hf}(\mathrm{TDM})$ \\
\hline $10 \_1$ & 0.283061 & 0.000073 & 0.005899 & 0.000074 & 171 & +10.22 & 0.283042 & +13.32 & 0.283102 & 307 & 0.283004 & +14.95 \\
\hline 9_1 & 0.283097 & 0.000069 & 0.005043 & 0.000158 & 168 & +11.48 & 0.283081 & +14.62 & 0.283104 & 221 & 0.283066 & +15.25 \\
\hline $22 \_1$ & 0.282205 & 0.000032 & 0.001559 & 0.000008 & 1365 & -20.05 & 0.282165 & +8.86 & 0.282231 & 1516 & 0.282120 & +10.68 \\
\hline 15_1 & 0.282902 & 0.000050 & 0.004405 & 0.000022 & 174 & +4.59 & 0.282888 & +7.91 & 0.283100 & 657 & 0.282750 & +13.73 \\
\hline $16 \_1$ & 0.282550 & 0.000049 & 0.001731 & 0.000031 & 192 & -7.85 & 0.282544 & -3.86 & 0.283087 & 1421 & 0.282190 & +11.02 \\
\hline
\end{tabular}


Supplementary Material: Zircon Lu-Hf isotope data from Garzón granites and related rocks, Eastern Cordillera, Colombia.

\begin{tabular}{|c|c|c|c|c|c|c|c|c|c|c|c|c|}
\hline \multicolumn{13}{|c|}{ Altamira Plutonic Massif: Sample GAR-383 } \\
\hline Grain/spot & ${ }^{176} \mathrm{Hf} /{ }^{177} \mathrm{Hf}$ & $\pm 2 \mathrm{se}$ & ${ }^{176} \mathrm{Lu} /{ }^{177} \mathrm{Hf}$ & $\pm 2 \mathrm{se}$ & $\begin{array}{c}\text { U-Pb Age } \\
\text { (T1) Ma }\end{array}$ & $\varepsilon \mathrm{Hf}(0)$ & $\begin{array}{c}{ }^{{ }^{176} \mathrm{Hf} /{ }^{177} \mathrm{Hf}} \\
(\mathrm{T} 1)\end{array}$ & $\varepsilon H f(T 1)$ & $\begin{array}{c}{ }^{176} \mathrm{Hf} /{ }^{177} \mathrm{Hf} \\
\mathrm{DM}(\mathrm{T})\end{array}$ & $\begin{array}{l}\text { T DM } \\
(\mathrm{Ma}) \\
\end{array}$ & $\begin{array}{c}{ }^{176} \mathrm{Hf} /{ }^{177} \mathrm{Hf} \\
\mathrm{DM}(\mathrm{T})\end{array}$ & $\varepsilon \mathrm{Hf}(\mathrm{TDM})$ \\
\hline 2_1 & 0.282605 & 0.000023 & 0.001034 & 0.000003 & 190 & -5.92 & 0.282601 & -1.88 & 0.283088 & 1294 & 0.282284 & +11.47 \\
\hline 5_1 & 0.282625 & 0.000033 & 0.000925 & 0.000015 & 178 & -5.20 & 0.282622 & -1.40 & 0.283097 & 1254 & 0.282313 & +11.61 \\
\hline 9_1 & 0.282797 & 0.000039 & 0.002679 & 0.000021 & 185 & +0.87 & 0.282787 & +4.61 & 0.283092 & 877 & 0.282589 & +12.95 \\
\hline 8_1 & 0.282566 & 0.000030 & 0.001133 & 0.000014 & 174 & -7.28 & 0.282562 & -3.59 & 0.283100 & 1390 & 0.282213 & +11.13 \\
\hline 7_1 & 0.282737 & 0.000034 & 0.001582 & 0.000005 & 168 & -1.22 & 0.282733 & +2.29 & 0.283104 & 1012 & 0.282491 & +12.47 \\
\hline $12 \_1$ & 0.282068 & 0.000030 & 0.000499 & 0.000003 & 982 & -24.89 & 0.282059 & -3.50 & 0.282512 & 2010 & 0.281753 & +8.89 \\
\hline 13_1 & 0.282696 & 0.000032 & 0.001666 & 0.000030 & 182 & -2.68 & 0.282690 & +1.11 & 0.283094 & 1098 & 0.282428 & +12.17 \\
\hline 19_1 & 0.282700 & 0.000039 & 0.001301 & 0.000014 & 162 & -2.56 & 0.282696 & +0.86 & 0.283108 & 1098 & 0.282428 & +12.17 \\
\hline $15 \_1$ & 0.282677 & 0.000032 & 0.002483 & 0.000023 & 177 & -3.35 & 0.282669 & +0.24 & 0.283098 & 1149 & 0.282390 & +11.99 \\
\hline $16 \_1$ & 0.282659 & 0.000029 & 0.001675 & 0.000020 & 166 & -3.99 & 0.282654 & -0.53 & 0.283105 & 1190 & 0.282360 & +11.84 \\
\hline
\end{tabular}


Supplementary Material: Zircon Lu-Hf isotope data from Garzón granites and related rocks, Eastern Cordillera, Colombia.

\begin{tabular}{|c|c|c|c|c|c|c|c|c|c|c|c|c|}
\hline \multicolumn{13}{|c|}{ Altamira Plutonic Massif: Sample GAR-386 } \\
\hline Grain/spot & ${ }^{176} \mathrm{Hf} /{ }^{177} \mathrm{Hf}$ & $\pm 2 \mathrm{se}$ & ${ }^{176} \mathrm{Lu} /{ }^{177} \mathrm{Hf}$ & $\pm 2 \mathrm{se}$ & $\begin{array}{c}\text { U-Pb Age } \\
\text { (T1) Ma }\end{array}$ & $\varepsilon \mathrm{Hf}(0)$ & $\begin{array}{c}{ }^{176} \mathrm{Hf} /{ }^{177} \mathrm{Hf} \\
(\mathrm{T} 1)\end{array}$ & $\varepsilon \mathrm{Hf}(\mathrm{T} 1)$ & $\begin{array}{c}{ }^{176} \mathrm{Hf} /{ }^{177} \mathrm{Hf} \\
\mathrm{DM}(\mathrm{T})\end{array}$ & $\begin{array}{l}\text { T DM } \\
(\mathrm{Ma}) \\
\end{array}$ & $\begin{array}{c}{ }^{176} \mathrm{Hf} /{ }^{177} \mathrm{Hf} \\
\mathrm{DM}(\mathrm{T})\end{array}$ & $\varepsilon \mathrm{Hf}(\mathrm{TDM})$ \\
\hline 1_1 & 0.282627 & 0.000049 & 0.001989 & 0.000051 & 192 & -5.12 & 0.282620 & -1.16 & 0.283087 & 1249 & 0.282316 & +11.63 \\
\hline $2 \_1$ & 0.282788 & 0.000047 & 0.002612 & 0.000018 & 160 & +0.58 & 0.282781 & +3.82 & 0.283110 & 908 & 0.282567 & +12.84 \\
\hline 10_1 & 0.282780 & 0.000050 & 0.002721 & 0.000074 & 163 & +0.28 & 0.282772 & +3.57 & 0.283108 & 927 & 0.282553 & +12.78 \\
\hline 4_1 & 0.282616 & 0.000041 & 0.000977 & 0.000001 & 154 & -5.52 & 0.282613 & -2.24 & 0.283114 & 1289 & 0.282287 & +11.49 \\
\hline $4 \_2$ & 0.282502 & 0.000035 & 0.000852 & 0.000003 & 147 & -9.55 & 0.282500 & -6.41 & 0.283119 & 1547 & 0.282097 & +10.56 \\
\hline 6_1 & 0.282620 & 0.000048 & 0.001363 & 0.000025 & 163 & -5.36 & 0.282616 & -1.93 & 0.283108 & 1276 & 0.282297 & +11.53 \\
\hline 5_1 & 0.282530 & 0.000035 & 0.001114 & 0.000031 & 168 & -8.55 & 0.282527 & -4.99 & 0.283104 & 1473 & 0.282151 & +10.83 \\
\hline $17 \_1$ & 0.282613 & 0.000038 & 0.002053 & 0.000044 & 152 & -5.61 & 0.282607 & -2.48 & 0.283116 & 1303 & 0.282277 & +11.44 \\
\hline 18_1 & 0.282527 & 0.000043 & 0.001436 & 0.000014 & 157 & -8.67 & 0.282523 & -5.37 & 0.283112 & 1489 & 0.282140 & +10.77 \\
\hline $15 \_1$ & 0.282509 & 0.000025 & 0.000919 & 0.000009 & 161 & -9.30 & 0.282506 & -5.86 & 0.283109 & 1523 & 0.282114 & +10.65 \\
\hline
\end{tabular}


Supplementary Material: Zircon Lu-Hf isotope data from Garzón granites and related rocks, Eastern Cordillera, Colombia.

\begin{tabular}{|c|c|c|c|c|c|c|c|c|c|c|c|c|}
\hline \multicolumn{13}{|c|}{ Sombrerillo Plutonic Massif: Sample GAR-394 } \\
\hline Grain/spot & ${ }^{176} \mathrm{Hf} /{ }^{177} \mathrm{Hf}$ & $\pm 2 \mathrm{se}$ & ${ }^{176} \mathrm{Lu} /{ }^{177} \mathrm{Hf}$ & $\pm 2 \mathrm{se}$ & $\begin{array}{c}\text { U-Pb Age } \\
\text { (T1) Ma }\end{array}$ & $\varepsilon \mathrm{Hf}(0)$ & $\begin{array}{c}{ }^{176} \mathrm{Hf} /{ }^{177} \mathrm{Hf} \\
(\mathrm{T} 1)\end{array}$ & $\varepsilon \mathrm{Hf}(\mathrm{T} 1)$ & $\begin{array}{c}{ }^{176} \mathrm{Hf} /{ }^{177} \mathrm{Hf} \\
\mathrm{DM}(\mathrm{T})\end{array}$ & $\begin{array}{l}\begin{array}{l}\text { T DM } \\
(\mathrm{Ma})\end{array} \\
\end{array}$ & $\begin{array}{l}{ }^{176} \mathrm{Hf} /{ }^{177} \mathrm{Hf} \\
\mathrm{DM}(\mathrm{T})\end{array}$ & $\varepsilon \mathrm{Hf}(\mathrm{TDM})$ \\
\hline 2_1 & 0.282690 & 0.000063 & 0.000441 & 0.000008 & 191 & -2.92 & 0.282688 & +1.22 & 0.283087 & 1098 & 0.282428 & +12.17 \\
\hline 1_1 & 0.282598 & 0.000032 & 0.000455 & 0.000006 & 203 & -6.15 & 0.282596 & -1.76 & 0.283079 & 1296 & 0.282282 & +11.46 \\
\hline 9_1 & 0.282550 & 0.000028 & 0.000492 & 0.000009 & 185 & -7.86 & 0.282548 & -3.85 & 0.283092 & 1415 & 0.282194 & +11.04 \\
\hline 8_1 & 0.282487 & 0.000039 & 0.000546 & 0.000005 & 189 & -10.09 & 0.282485 & -6.02 & 0.283089 & 1555 & 0.282091 & +10.54 \\
\hline 6_1 & 0.282611 & 0.000037 & 0.000549 & 0.000005 & 187 & -5.68 & 0.282610 & -1.64 & 0.283090 & 1276 & 0.282297 & +11.53 \\
\hline 7_1 & 0.282572 & 0.000027 & 0.000370 & 0.000010 & 179 & -7.08 & 0.282570 & -3.20 & 0.283096 & 1369 & 0.282228 & +11.20 \\
\hline 11_1 & 0.282599 & 0.000037 & 0.000499 & 0.000001 & 190 & -6.13 & 0.282597 & -2.02 & 0.283088 & 1303 & 0.282277 & +11.44 \\
\hline $12 \_1$ & 0.282554 & 0.000038 & 0.000443 & 0.000004 & 120 & -7.71 & 0.282553 & -5.11 & 0.283139 & 1444 & 0.282173 & +10.93 \\
\hline $16 \_1$ & 0.282570 & 0.000026 & 0.000512 & 0.000006 & 195 & -7.16 & 0.282568 & -2.94 & 0.283085 & 1365 & 0.282231 & +11.22 \\
\hline $17 \_1$ & 0.282754 & 0.000044 & 0.000858 & 0.000001 & 190 & -0.65 & 0.282751 & +3.42 & 0.283088 & 957 & 0.282531 & +12.67 \\
\hline
\end{tabular}


Supplementary Material: Zircon Lu-Hf isotope data from Garzón granites and related rocks, Eastern Cordillera, Colombia.

\begin{tabular}{|c|c|c|c|c|c|c|c|c|c|c|c|c|}
\hline \multicolumn{13}{|c|}{ Sombrerillo Plutonic Massif: Sample GAR-395 } \\
\hline Grain/spot & ${ }^{176} \mathrm{Hf} /{ }^{177} \mathrm{Hf}$ & $\pm 2 \mathrm{se}$ & ${ }^{176} \mathrm{Lu} /{ }^{177} \mathrm{Hf}$ & $\pm 2 \mathrm{se}$ & $\begin{array}{c}\text { U-Pb Age } \\
\text { (T1) Ma }\end{array}$ & $\varepsilon \mathrm{Hf}(0)$ & $\begin{array}{c}{ }^{176} \mathrm{Hf} /{ }^{177} \mathrm{Hf} \\
(\mathrm{T} 1)\end{array}$ & $\varepsilon \mathrm{Hf}(\mathrm{T} 1)$ & $\begin{array}{c}{ }^{176} \mathrm{Hf} /{ }^{177} \mathrm{Hf} \\
\mathrm{DM}(\mathrm{T}) \\
\end{array}$ & $\begin{array}{l}\text { T DM } \\
(\mathrm{Ma}) \\
\end{array}$ & $\begin{array}{c}{ }^{176} \mathrm{Hf} / /^{177} \mathrm{Hf} \\
\mathrm{DM}(\mathrm{T}) \\
\end{array}$ & $\varepsilon \mathrm{Hf}(\mathrm{TDM})$ \\
\hline 1_1 & 0.283009 & 0.000049 & 0.003086 & 0.000122 & 171 & +8.37 & 0.282999 & +11.78 & 0.283102 & 406 & 0.282932 & +14.61 \\
\hline 24_1 & 0.282845 & 0.000036 & 0.001211 & 0.000062 & 149 & +2.57 & 0.282841 & +5.73 & 0.283118 & 778 & 0.282662 & +13.30 \\
\hline 25_1 & 0.283015 & 0.000042 & 0.002863 & 0.000089 & 170 & +8.58 & 0.283006 & +12.00 & 0.283103 & 392 & 0.282942 & +14.66 \\
\hline 26_1 & 0.282926 & 0.000052 & 0.002855 & 0.000053 & 175 & +5.44 & 0.282917 & +8.96 & 0.283099 & 591 & 0.282798 & +13.96 \\
\hline 6_1 & 0.282838 & 0.000028 & 0.001431 & 0.000014 & 166 & +2.32 & 0.282833 & +5.81 & 0.283105 & 786 & 0.282656 & +13.27 \\
\hline 7_1 & 0.282819 & 0.000028 & 0.001284 & 0.000004 & 163 & +1.65 & 0.282815 & +5.09 & 0.283108 & 830 & 0.282624 & +13.12 \\
\hline 19_1 & 0.282954 & 0.000041 & 0.001867 & 0.000026 & 161 & +6.45 & 0.282949 & +9.79 & 0.283109 & 527 & 0.282845 & +14.18 \\
\hline $20 \_1$ & 0.282741 & 0.000036 & 0.001446 & 0.000007 & 404 & -1.10 & 0.282730 & +7.41 & 0.282933 & 868 & 0.282596 & +12.98 \\
\hline $15 \_1$ & 0.283009 & 0.000055 & 0.003759 & 0.000068 & 168 & +8.38 & 0.282997 & +11.65 & 0.283104 & 412 & 0.282928 & +14.59 \\
\hline 12_1 & 0.282935 & 0.000047 & 0.002487 & 0.000141 & 165 & +5.77 & 0.282927 & +9.12 & 0.283106 & 573 & 0.282811 & +14.02 \\
\hline
\end{tabular}


Supplementary Material: Zircon Lu-Hf isotope data from Garzón granites and related rocks, Eastern Cordillera, Colombia.

\begin{tabular}{|c|c|c|c|c|c|c|c|c|c|c|c|c|}
\hline \multicolumn{13}{|c|}{ Sombrerillo Plutonic Massif: Samples L102/L104 } \\
\hline Grain/spot & ${ }^{176} \mathrm{Hf} /{ }^{177} \mathrm{Hf}$ & $\pm 2 \mathrm{se}$ & ${ }^{176} \mathrm{Lu} /{ }^{177} \mathrm{Hf}$ & $\pm 2 \mathrm{se}$ & $\begin{array}{l}\text { U-Pb Age } \\
\text { (T1) Ma }\end{array}$ & $\varepsilon \mathrm{Hf}(0)$ & $\begin{array}{c}{ }^{{ }^{176} \mathrm{Hf} /{ }^{177} \mathrm{Hf}} \\
(\mathrm{T} 1)\end{array}$ & $\begin{array}{l}\mathrm{EHf} \\
\text { (T1) }\end{array}$ & $\begin{array}{c}{ }^{176} \mathrm{Hf} /{ }^{177} \mathrm{Hf} \\
\mathrm{DM}(\mathrm{T})\end{array}$ & $\begin{array}{l}\text { T DM } \\
(\mathrm{Ma})\end{array}$ & 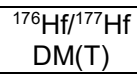 & $\varepsilon \mathrm{Hf}(\mathrm{TDM})$ \\
\hline 8_1 L102 & 0.282509 & 0.000031 & 0.000526 & 0.000005 & 181 & -9.31 & 0.282507 & -5.40 & 0.283095 & 1510 & 0.282124 & +10.70 \\
\hline 7_1 L102 & 0.282628 & 0.000032 & 0.000754 & 0.000004 & 181 & -5.09 & 0.282626 & -1.20 & 0.283095 & 1244 & 0.282320 & +11.65 \\
\hline 7_2 L102 & 0.282615 & 0.000033 & 0.000830 & 0.000002 & 182 & -5.57 & 0.282612 & -1.67 & 0.283094 & 1275 & 0.282298 & +11.54 \\
\hline 6_1 L102 & 0.282634 & 0.000027 & 0.000629 & 0.000002 & 182 & -4.87 & 0.282632 & -0.95 & 0.283094 & 1229 & 0.282332 & +11.70 \\
\hline 5_1 L102 & 0.282524 & 0.000042 & 0.000420 & 0.000019 & 183 & -8.77 & 0.282522 & -4.81 & 0.283093 & 1474 & 0.282151 & +10.83 \\
\hline 5_2 L102 & 0.282617 & 0.000054 & 0.000687 & 0.000012 & 182 & -5.50 & 0.282614 & -1.58 & 0.283094 & 1269 & 0.282302 & +11.56 \\
\hline 5_2 L104 & 0.282248 & 0.000061 & 0.000809 & 0.000001 & 187 & -18.55 & 0.282245 & -14.55 & 0.283090 & 2088 & 0.281694 & +8.61 \\
\hline 9_1 L104 & 0.282566 & 0.000051 & 0.000355 & 0.000002 & 182 & -7.30 & 0.282564 & -3.35 & 0.283094 & 1381 & 0.282220 & +11.16 \\
\hline 8_1 L104 & 0.282608 & 0.000043 & 0.000734 & 0.000010 & 186 & -5.80 & 0.282606 & -1.80 & 0.283091 & 1286 & 0.282290 & +11.50 \\
\hline 7_1 L104 & 0.282507 & 0.000040 & 0.000648 & 0.000007 & 185 & -9.38 & 0.282505 & -5.40 & 0.283092 & 1512 & 0.282122 & +10.69 \\
\hline 6.1 L104 & 0.282444 & 0.000044 & 0.000813 & 0.000001 & 181 & -11.60 & 0.282441 & -7.73 & 0.283095 & 1656 & 0.282016 & +10.17 \\
\hline
\end{tabular}


Supplementary Material: Zircon Lu-Hf isotope data from Garzón granites and related rocks, Eastern Cordillera, Colombia.

\begin{tabular}{|c|c|c|c|c|c|c|c|c|c|c|c|c|}
\hline \multicolumn{13}{|c|}{ Igneous and metamorphic basement: Sample GAR-364 } \\
\hline $\begin{array}{c}\text { Grain/ } \\
\text { spot }\end{array}$ & ${ }^{176} \mathrm{Hf} /{ }^{177} \mathrm{Hf}$ & $\pm 2 \mathrm{se}$ & ${ }^{176} \mathrm{Lu} /{ }^{177} \mathrm{Hf}$ & $\pm 2 \mathrm{se}$ & $\begin{array}{l}\text { U-Pb Age } \\
\text { (T1) Ma }\end{array}$ & $\varepsilon \mathrm{Hf}(0)$ & $\begin{array}{c}{ }^{176} \mathrm{Hf} /{ }^{177} \mathrm{Hf} \\
(\mathrm{T} 1)\end{array}$ & $\begin{array}{l}\varepsilon \mathrm{Hf} \\
(\mathrm{T} 1)\end{array}$ & 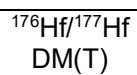 & $\begin{array}{l}\text { T DM } \\
(\mathrm{Ma})\end{array}$ & $\begin{array}{c}{ }^{176} \mathrm{Hf} /{ }^{177} \mathrm{Hf} \\
\mathrm{DM}(\mathrm{T})\end{array}$ & $\begin{array}{c}\varepsilon \mathrm{Hf} \\
(\mathrm{TDM})\end{array}$ \\
\hline 5_1 & 0.282178 & 0.000052 & 0.000532 & 0.000010 & 993 & -20.99 & 0.282168 & +0.63 & 0.282504 & 1756 & 0.281942 & +9.81 \\
\hline 2_1 & 0.282224 & 0.000029 & 0.000480 & 0.000002 & 1007 & -19.38 & 0.282215 & +2.58 & 0.282494 & 1642 & 0.282026 & +10.22 \\
\hline 1_1 & 0.282053 & 0.000032 & 0.000281 & 0.000002 & 1037 & -25.42 & 0.282048 & -2.67 & 0.282472 & 2000 & 0.281760 & +8.93 \\
\hline 9_1 & 0.282186 & 0.000039 & 0.000369 & 0.000003 & 992 & -20.73 & 0.282179 & +0.98 & 0.282505 & 1733 & 0.281959 & +9.89 \\
\hline 10_1 & 0.282159 & 0.000027 & 0.000253 & 0.000001 & 1002 & -21.69 & 0.282154 & +0.32 & 0.282498 & 1783 & 0.281922 & +9.71 \\
\hline $17 \_1$ & 0.282163 & 0.000034 & 0.000551 & 0.000000 & 987 & -21.52 & 0.282153 & -0.05 & 0.282509 & 1795 & 0.281913 & +9.67 \\
\hline 18_1 & 0.282172 & 0.000032 & 0.000202 & 0.000002 & 990 & -21.20 & 0.282169 & +0.57 & 0.282507 & 1758 & 0.281941 & +9.81 \\
\hline 19_1 & 0.282112 & 0.000025 & 0.000173 & 0.000000 & 1010 & -23.33 & 0.282109 & -1.10 & 0.282492 & 1880 & 0.281850 & +9.37 \\
\hline 21_1 & 0.282167 & 0.000031 & 0.000263 & 0.000008 & 992 & -21.40 & 0.282162 & +0.38 & 0.282505 & 1771 & 0.281930 & +9.76 \\
\hline $22 \_1$ & 0.282151 & 0.000032 & 0.000684 & 0.000005 & 1017 & -21.94 & 0.282138 & +0.10 & 0.282487 & 1809 & 0.281903 & +9.62 \\
\hline
\end{tabular}


Supplementary Material: Electron microprobe analyses of alkali feldspar and plagioclase from Garzón granites and related rocks, Eastern Cordillera, Colombia.

\begin{tabular}{|c|c|c|c|c|c|c|c|c|c|c|c|c|c|c|}
\hline \multirow{3}{*}{$\begin{array}{l}\text { Mineral } \\
\text { Massif } \\
\text { Sample }\end{array}$} & \multicolumn{14}{|c|}{ Plagioclase } \\
\hline & & & & & & & Somb & rerillo & & & & & & \\
\hline & 102 & 102 & 102 & 102 & 102 & 102 & 102 & 102 & 102 & 102 & 102 & 102 & 102 & 102 \\
\hline Facies & $\begin{array}{l}\text { BQ-M- } \\
\text { OC }\end{array}$ & $\begin{array}{l}\text { BQ-M- } \\
\text { OC }\end{array}$ & $\begin{array}{l}\text { BQ-M- } \\
\text { OC }\end{array}$ & $\begin{array}{l}\text { BQ-M- } \\
\text { OC }\end{array}$ & $\begin{array}{l}\text { BQ-M- } \\
\text { OC }\end{array}$ & $\begin{array}{l}\text { BQ-M- } \\
\text { OC }\end{array}$ & $\begin{array}{l}\text { BQ-M- } \\
\text { OC }\end{array}$ & $\begin{array}{l}\text { BQ-M- } \\
\text { OC }\end{array}$ & $\begin{array}{l}\text { BQ-M- } \\
\text { OC }\end{array}$ & $\begin{array}{l}\text { BQ-M- } \\
\text { OC }\end{array}$ & $\begin{array}{l}\text { BQ-M- } \\
\text { OC }\end{array}$ & $\begin{array}{l}\text { BQ-M- } \\
\text { OC }\end{array}$ & $\begin{array}{l}\text { BQ-M- } \\
\text { OC }\end{array}$ & $\begin{array}{l}\text { BQ-M- } \\
\text { OC }\end{array}$ \\
\hline $\begin{array}{l}\text { Grain/ } \\
\text { Point }\end{array}$ & pl_01-1 & pl_01-2 & pl_01-3 & pl_01-4 & pl_02-1 & pl_02-2 & pl_02-3 & pl_03-1 & pl_03-2 & pl_03-3 & pl_03-4 & pl_04-1 & pl_04-2 & pl_04-3 \\
\hline $\mathrm{SiO} 2$ & 56.74 & 55.82 & 58.91 & 59.74 & 56.25 & 55.82 & 59.64 & 55.89 & 59.09 & 59.90 & 57.49 & 55.44 & 59.76 & 59.83 \\
\hline TiO2 & 0.08 & 0.06 & 0.00 & 0.00 & 0.06 & 0.12 & 0.00 & 0.03 & 0.00 & 0.04 & 0.09 & 0.08 & 0.03 & 0.03 \\
\hline Al2O3 & 27.88 & 28.32 & 26.21 & 26.06 & 28.28 & 28.39 & 25.91 & 28.75 & 26.49 & 25.82 & 27.28 & 28.36 & 25.86 & 25.57 \\
\hline $\mathrm{FeO}$ & 0.26 & 0.21 & 0.18 & 0.22 & 0.27 & 0.25 & 0.20 & 0.15 & 0.16 & 0.26 & 0.21 & 0.23 & 0.20 & 0.29 \\
\hline $\mathrm{MnO}$ & 0.00 & 0.02 & 0.00 & 0.02 & 0.00 & 0.00 & 0.00 & 0.00 & 0.00 & 0.02 & 0.02 & 0.00 & 0.00 & 0.00 \\
\hline $\mathrm{MgO}$ & 0.00 & 0.00 & 0.00 & 0.00 & 0.00 & 0.00 & 0.00 & 0.00 & 0.00 & 0.00 & 0.00 & 0.00 & 0.00 & 0.00 \\
\hline $\mathrm{SrO}$ & 0.07 & 0.16 & 0.12 & 0.07 & 0.13 & 0.06 & 0.13 & 0.13 & 0.09 & 0.08 & 0.07 & 0.08 & 0.11 & 0.11 \\
\hline $\mathrm{BaO}$ & 0.00 & 0.09 & 0.00 & 0.04 & 0.00 & 0.00 & 0.00 & 0.05 & 0.06 & 0.00 & 0.00 & 0.00 & 0.00 & 0.00 \\
\hline $\mathrm{PbO}$ & 0.00 & 0.00 & 0.00 & 0.10 & 0.00 & 0.09 & 0.07 & 0.04 & 0.00 & 0.00 & 0.00 & 0.00 & 0.00 & 0.00 \\
\hline $\mathrm{CaO}$ & 9.51 & 9.85 & 7.31 & 6.92 & 9.53 & 10.11 & 6.95 & 9.96 & 7.38 & 6.70 & 8.41 & 9.80 & 6.96 & 6.55 \\
\hline $\mathrm{Na} 2 \mathrm{O}$ & 6.04 & 5.75 & 7.11 & 7.49 & 5.88 & 5.65 & 7.39 & 5.68 & 7.29 & 7.35 & 6.59 & 5.73 & 7.30 & 7.74 \\
\hline $\mathrm{K} 2 \mathrm{O}$ & 0.27 & 0.31 & 0.40 & 0.31 & 0.30 & 0.29 & 0.30 & 0.17 & 0.24 & 0.40 & 0.27 & 0.23 & 0.41 & 0.28 \\
\hline Total & 100.86 & 100.59 & 100.25 & 100.96 & 100.74 & 100.78 & 100.63 & 100.84 & 100.82 & 100.61 & 100.44 & 99.96 & 100.64 & 100.42 \\
\hline $\mathrm{Si}$ & 10.123 & 10.011 & 10.510 & 10.579 & 10.057 & 9.992 & 10.594 & 9.983 & 10.484 & 10.629 & 10.269 & 9.990 & 10.606 & 10.641 \\
\hline ivAl & 5.862 & 5.986 & 5.511 & 5.439 & 5.959 & 5.990 & 5.424 & 6.052 & 5.539 & 5.400 & 5.743 & 6.023 & 5.409 & 5.360 \\
\hline Felll & 0.038 & 0.031 & 0.027 & 0.032 & 0.040 & 0.037 & 0.030 & 0.022 & 0.024 & 0.038 & 0.031 & 0.035 & 0.030 & 0.043 \\
\hline T site & 16.024 & 16.028 & 16.048 & 16.050 & 16.056 & 16.019 & 16.048 & 16.057 & 16.048 & 16.066 & 16.043 & 16.049 & 16.045 & 16.044 \\
\hline $\mathrm{Ti}$ & 0.011 & 0.008 & 0.000 & 0.000 & 0.008 & 0.016 & 0.000 & 0.004 & 0.000 & 0.005 & 0.012 & 0.011 & 0.004 & 0.004 \\
\hline $\mathrm{Mn}$ & 0.000 & 0.002 & 0.000 & 0.002 & 0.000 & 0.000 & 0.000 & 0.000 & 0.000 & 0.004 & 0.003 & 0.000 & 0.000 & 0.000 \\
\hline $\mathrm{Mg}$ & 0.000 & 0.000 & 0.000 & 0.000 & 0.000 & 0.000 & 0.000 & 0.000 & 0.000 & 0.000 & 0.000 & 0.000 & 0.000 & 0.000 \\
\hline $\mathrm{Sr}$ & 0.008 & 0.017 & 0.013 & 0.007 & 0.014 & 0.006 & 0.013 & 0.013 & 0.009 & 0.008 & 0.008 & 0.008 & 0.011 & 0.011 \\
\hline $\mathrm{Ba}$ & 0.000 & 0.006 & 0.000 & 0.002 & 0.000 & 0.000 & 0.000 & 0.003 & 0.004 & 0.000 & 0.000 & 0.000 & 0.000 & 0.000 \\
\hline $\mathrm{Pb}$ & 0.000 & 0.000 & 0.000 & 0.005 & 0.000 & 0.004 & 0.003 & 0.002 & 0.000 & 0.000 & 0.000 & 0.000 & 0.000 & 0.000 \\
\hline $\mathrm{Ca}$ & 1.818 & 1.893 & 1.397 & 1.313 & 1.826 & 1.939 & 1.323 & 1.906 & 1.403 & 1.274 & 1.610 & 1.892 & 1.323 & 1.248 \\
\hline $\mathrm{Na}$ & 2.089 & 1.999 & 2.460 & 2.572 & 2.038 & 1.961 & 2.545 & 1.967 & 2.508 & 2.529 & 2.282 & 2.002 & 2.512 & 2.669 \\
\hline K & 0.061 & 0.070 & 0.091 & 0.070 & 0.068 & 0.065 & 0.068 & 0.039 & 0.055 & 0.091 & 0.063 & 0.052 & 0.093 & 0.064 \\
\hline M site & 3.987 & 3.995 & 3.961 & 3.972 & 3.953 & 3.992 & 3.953 & 3.934 & 3.979 & 3.910 & 3.977 & 3.965 & 3.943 & 3.997 \\
\hline Cations & 20.010 & 20.023 & 20.009 & 20.022 & 20.009 & 20.010 & 20.001 & 19.991 & 20.027 & 19.976 & 20.020 & 20.014 & 19.988 & 20.041 \\
\hline An & 45.81 & 47.77 & 35.40 & 33.20 & 46.43 & 48.90 & 33.60 & 48.72 & 35.38 & 32.72 & 40.70 & 47.95 & 33.69 & 31.35 \\
\hline$A b$ & 52.65 & 50.46 & 62.30 & 65.03 & 51.84 & 49.45 & 64.66 & 50.28 & 63.24 & 64.95 & 57.72 & 50.73 & 63.94 & 67.05 \\
\hline Or & 1.54 & 1.77 & 2.30 & 1.78 & 1.73 & 1.65 & 1.73 & 1.00 & 1.38 & 2.34 & 1.58 & 1.32 & 2.37 & 1.60 \\
\hline
\end{tabular}

Notes: Facies abbreviations BQ-M OC = Biotite quartz-monzodiorite with two pyroxenes; Dac = Dacite; L-MG = Leuco monzogranite; BT-MG = Biotite hornblende monzogranite; Rhy = Rhyolite; HB-GD = Hornblende biotite granodiorite; $M G=$ Monzogranite; IM-D = Intermediate-mafic dikes; An = anortite; $A b=$ albite; Or = orthoclase. 
Supplementary Material: Electron microprobe analyses of alkali feldspar and plagioclase from Garzón granites and related rocks, Eastern Cordillera, Colombia.

\begin{tabular}{|c|c|c|c|c|c|c|c|c|c|c|c|c|c|c|c|c|}
\hline \multirow{3}{*}{$\begin{array}{l}\text { Mineral } \\
\text { Massif } \\
\text { Sample }\end{array}$} & \multirow{2}{*}{\multicolumn{6}{|c|}{$\begin{array}{l}\text { Alkali feldspar } \\
\text { Sombrerillo }\end{array}$}} & \multicolumn{10}{|c|}{ Plagioclase } \\
\hline & & & & & & & & & & & Algec & iras & & & & \\
\hline & 102 & 102 & 102 & 102 & 102 & 102 & $\begin{array}{l}\text { GAR- } \\
354\end{array}$ & $\begin{array}{l}\text { GAR- } \\
354\end{array}$ & $\begin{array}{l}\text { GAR- } \\
354\end{array}$ & $\begin{array}{l}\text { GAR- } \\
354\end{array}$ & $\begin{array}{l}\text { GAR- } \\
354\end{array}$ & $\begin{array}{l}\text { GAR- } \\
354\end{array}$ & $\begin{array}{l}\text { GAR- } \\
354\end{array}$ & $\begin{array}{l}\text { GAR- } \\
354\end{array}$ & $\begin{array}{l}\text { GAR- } \\
354\end{array}$ & $\begin{array}{l}\text { GAR- } \\
354\end{array}$ \\
\hline Facies & $\begin{array}{l}\text { BQ-M- } \\
\text { OC }\end{array}$ & $\begin{array}{l}\text { BQ-M- } \\
\text { OC }\end{array}$ & $\begin{array}{l}\text { BQ-M- } \\
\text { OC }\end{array}$ & $\begin{array}{l}\text { BQ-M- } \\
\text { OC }\end{array}$ & $\begin{array}{l}\text { BQ-M- } \\
\text { OC }\end{array}$ & $\begin{array}{l}\text { BQ-M- } \\
\text { OC }\end{array}$ & L-MG & L-MG & L-MG & L-MG & L-MG & L-MG & L-MG & L-MG & L-MG & L-MG \\
\hline $\begin{array}{l}\text { Grain/ } \\
\text { Point }\end{array}$ & Fk_01- & $\mathrm{Fk}_{2} 01-$ & $\mathrm{Fk}_{\frac{1}{02}}$ & $\mathrm{Fk}_{2}$ & Fk_03- & $\mathrm{Fk}_{2} \mathrm{O3-}$ & pl_02-1 & pl_02-2 & pl_02-3 & pl_02-4 & pl_02-5 & pl_02-6 & pl_04-1 & pl_04-2 & pl_04-3 & pl_04-4 \\
\hline $\mathrm{SiO} 2$ & 64.95 & 65.27 & 65.06 & 65.38 & 64.89 & 65.25 & 63.43 & 63.59 & 64.50 & 64.94 & 65.14 & 65.73 & 64.96 & 62.91 & 65.58 & 67.60 \\
\hline TiO2 & 0.00 & 0.00 & 0.06 & 0.03 & 0.06 & 0.07 & 0.00 & 0.00 & 0.00 & 0.00 & 0.00 & 0.06 & 0.00 & 0.00 & 0.05 & 0.05 \\
\hline $\mathrm{Al} 2 \mathrm{O} 3$ & 19.14 & 19.30 & 19.12 & 19.21 & 19.55 & 19.49 & 23.20 & 22.96 & 22.58 & 22.30 & 22.09 & 21.69 & 21.99 & 22.12 & 21.41 & 20.39 \\
\hline $\mathrm{FeO}$ & 0.08 & 0.09 & 0.13 & 0.09 & 0.00 & 0.11 & 0.21 & 0.17 & 0.16 & 0.09 & 0.07 & 0.06 & 0.10 & 0.56 & 0.10 & 0.02 \\
\hline $\mathrm{MnO}$ & 0.00 & 0.00 & 0.02 & 0.00 & 0.00 & 0.00 & 0.00 & 0.00 & 0.00 & 0.00 & 0.00 & 0.02 & 0.00 & 0.03 & 0.00 & 0.00 \\
\hline $\mathrm{MgO}$ & 0.00 & 0.00 & 0.00 & 0.00 & 0.00 & 0.04 & 0.00 & 0.00 & 0.00 & 0.00 & 0.00 & 0.00 & 0.00 & 0.00 & 0.00 & 0.00 \\
\hline $\mathrm{SrO}$ & 0.17 & 0.15 & 0.04 & 0.05 & 0.10 & 0.14 & 0.00 & 0.00 & 0.00 & 0.05 & 0.06 & 0.05 & 0.00 & 0.08 & 0.00 & 0.00 \\
\hline $\mathrm{BaO}$ & 0.32 & 0.38 & 0.44 & 0.34 & 0.43 & 0.61 & 0.00 & 0.00 & 0.00 & 0.00 & 0.00 & 0.00 & 0.00 & 0.00 & 0.00 & 0.00 \\
\hline $\mathrm{PbO}$ & 0.00 & 0.00 & 0.00 & 0.00 & 0.04 & 0.00 & 0.00 & 0.06 & 0.00 & 0.05 & 0.00 & 0.08 & 0.10 & 0.06 & 0.00 & 0.00 \\
\hline $\mathrm{CaO}$ & 0.07 & 0.10 & 0.09 & 0.06 & 0.39 & 0.14 & 3.64 & 3.59 & 2.99 & 2.67 & 2.42 & 2.18 & 2.54 & 4.04 & 1.75 & 0.51 \\
\hline $\mathrm{Na} 2 \mathrm{O}$ & 1.97 & 2.23 & 1.82 & 2.82 & 2.76 & 2.27 & 9.20 & 9.29 & 9.73 & 9.95 & 10.26 & 10.28 & 10.40 & 9.41 & 10.58 & 11.27 \\
\hline $\mathrm{K} 2 \mathrm{O}$ & 14.17 & 13.30 & 13.69 & 12.58 & 12.50 & 13.17 & 0.53 & 0.46 & 0.43 & 0.38 & 0.26 & 0.17 & 0.13 & 0.33 & 0.35 & 0.15 \\
\hline Total & 100.90 & 100.81 & 100.45 & 100.56 & 100.73 & 101.28 & 100.24 & 100.14 & 100.40 & 100.45 & 100.30 & 100.30 & 100.24 & 99.53 & 99.86 & 100.00 \\
\hline $\mathrm{Si}$ & 11.873 & 11.886 & 11.902 & 11.899 & 11.815 & 11.845 & 11.201 & 11.238 & 11.343 & 11.407 & 11.445 & 11.530 & 11.435 & 11.238 & 11.561 & 11.826 \\
\hline ivAl & 4.124 & 4.142 & 4.122 & 4.120 & 4.195 & 4.170 & 4.829 & 4.782 & 4.680 & 4.617 & 4.574 & 4.484 & 4.562 & 4.657 & 4.448 & 4.204 \\
\hline Felll & 0.013 & 0.014 & 0.020 & 0.014 & 0.000 & 0.017 & 0.031 & 0.025 & 0.023 & 0.013 & 0.010 & 0.009 & 0.014 & 0.083 & 0.014 & 0.003 \\
\hline T site & 16.009 & 16.042 & 16.044 & 16.034 & 16.011 & 16.031 & 16.061 & 16.045 & 16.046 & 16.037 & 16.029 & 16.023 & 16.011 & 15.978 & 16.024 & 16.033 \\
\hline $\mathrm{Ti}$ & 0.000 & 0.000 & 0.008 & 0.004 & 0.009 & 0.009 & 0.000 & 0.000 & 0.000 & 0.000 & 0.000 & 0.008 & 0.000 & 0.000 & 0.007 & 0.007 \\
\hline $\mathrm{Mn}$ & 0.000 & 0.000 & 0.003 & 0.000 & 0.000 & 0.000 & 0.000 & 0.000 & 0.000 & 0.001 & 0.000 & 0.003 & 0.000 & 0.004 & 0.000 & 0.000 \\
\hline $\mathrm{Mg}$ & 0.000 & 0.000 & 0.000 & 0.000 & 0.000 & 0.012 & 0.000 & 0.000 & 0.000 & 0.000 & 0.000 & 0.000 & 0.000 & 0.000 & 0.000 & 0.000 \\
\hline $\mathrm{Sr}$ & 0.018 & 0.016 & 0.004 & 0.006 & 0.010 & 0.014 & 0.000 & 0.000 & 0.000 & 0.005 & 0.006 & 0.005 & 0.000 & 0.008 & 0.000 & 0.000 \\
\hline $\mathrm{Ba}$ & 0.023 & 0.027 & 0.031 & 0.024 & 0.031 & 0.044 & 0.000 & 0.000 & 0.000 & 0.000 & 0.000 & 0.000 & 0.000 & 0.000 & 0.000 & 0.000 \\
\hline $\mathrm{Pb}$ & 0.000 & 0.000 & 0.000 & 0.000 & 0.002 & 0.000 & 0.000 & 0.003 & 0.000 & 0.002 & 0.000 & 0.004 & 0.005 & 0.003 & 0.000 & 0.000 \\
\hline $\mathrm{Ca}$ & 0.014 & 0.019 & 0.018 & 0.011 & 0.076 & 0.027 & 0.689 & 0.680 & 0.563 & 0.503 & 0.456 & 0.410 & 0.479 & 0.773 & 0.331 & 0.096 \\
\hline $\mathrm{Na}$ & 0.698 & 0.787 & 0.646 & 0.995 & 0.974 & 0.799 & 3.150 & 3.183 & 3.318 & 3.389 & 3.495 & 3.496 & 3.549 & 3.259 & 3.616 & 3.823 \\
\hline & 3.304 & 3.090 & 3.195 & 2.921 & 2.903 & 3.050 & 0.120 & 0.104 & 0.096 & 0.085 & 0.058 & 0.037 & 0.030 & 0.075 & 0.079 & 0.033 \\
\hline M site & 4.058 & 3.939 & 3.905 & 3.961 & 4.006 & 3.954 & 3.959 & 3.970 & 3.978 & 3.984 & 4.016 & 3.963 & 4.063 & 4.122 & 4.033 & 3.960 \\
\hline Cations & 20.067 & 19.981 & 19.949 & 19.995 & 20.017 & 19.986 & 20.020 & 20.014 & 20.024 & 20.021 & 20.045 & 19.986 & 20.074 & 20.100 & 20.056 & 19.993 \\
\hline An & 0.35 & 0.48 & 0.46 & 0.29 & 1.93 & 0.70 & 17.40 & 17.14 & 14.16 & 12.64 & 11.36 & 10.39 & 11.80 & 18.83 & 8.21 & 2.44 \\
\hline$A b$ & 17.38 & 20.21 & 16.73 & 25.34 & 24.64 & 20.61 & 79.57 & 80.24 & 83.41 & 85.23 & 87.18 & 88.66 & 87.45 & 79.36 & 89.82 & 96.72 \\
\hline Or & 82.27 & 79.31 & 82.81 & 74.37 & 73.43 & 78.69 & 3.03 & 2.62 & 2.43 & 2.13 & 1.46 & 0.95 & 0.74 & 1.81 & 1.97 & 0.84 \\
\hline
\end{tabular}

Notes: Facies abbreviations BQ-M OC = Biotite quartz-monzodiorite with two pyroxenes; Dac = Dacite; L-MG = Leuco monzogranite; BT-MG = Biotite hornblende monzogranite; Rhy = Rhyolite; HB-GD = Hornblende biotite granodiorite; $M G=$ Monzogranite; IM-D = Intermediate-mafic dikes; An = anortite; Ab = albite; Or = orthoclase. 
Supplementary Material: Electron microprobe analyses of alkali feldspar and plagioclase from Garzón granites and related rocks, Eastern Cordillera, Colombia.

\begin{tabular}{|c|c|c|c|c|c|c|c|c|c|c|c|c|c|c|c|}
\hline \multirow{3}{*}{$\begin{array}{l}\text { Mineral } \\
\text { Massif } \\
\text { Sample }\end{array}$} & \multicolumn{12}{|c|}{ Plagioclase } & \multicolumn{3}{|c|}{ Alkali feldspar } \\
\hline & \multicolumn{12}{|c|}{ Algeciras } & & & \\
\hline & $\begin{array}{l}\text { GAR- } \\
354\end{array}$ & $\begin{array}{l}\text { GAR- } \\
354\end{array}$ & $\begin{array}{l}\text { GAR- } \\
354\end{array}$ & $\begin{array}{l}\text { GAR- } \\
354\end{array}$ & $\begin{array}{l}\text { GAR- } \\
354\end{array}$ & $\begin{array}{l}\text { GAR- } \\
354\end{array}$ & $\begin{array}{l}\text { GAR- } \\
354\end{array}$ & $\begin{array}{l}\text { GAR- } \\
354\end{array}$ & $\begin{array}{l}\text { GAR- } \\
354\end{array}$ & $\begin{array}{l}\text { GAR- } \\
354\end{array}$ & $\begin{array}{l}\text { GAR- } \\
354\end{array}$ & $\begin{array}{l}\text { GAR- } \\
354\end{array}$ & $\begin{array}{l}\text { GAR- } \\
354\end{array}$ & $\begin{array}{l}\text { GAR- } \\
354\end{array}$ & $\begin{array}{l}\text { GAR- } \\
354\end{array}$ \\
\hline Facies & L-MG & L-MG & L-MG & L-MG & L-MG & L-MG & L-MG & L-MG & L-MG & L-MG & L-MG & L-MG & L-MG & L-MG & L-MG \\
\hline $\begin{array}{l}\text { Grain/ } \\
\text { Point }\end{array}$ & pl_07-1 & pl_07-2 & pl_07-3 & pl_07-4 & pl_07-5 & pl_07-6 & pl_08-1 & pl_08-2 & pl_08-3 & pl_08-4 & pl_08-5 & pl_08-6 & Fk_01-1 & Fk_01-2 & Fk_02-1 \\
\hline $\mathrm{SiO} 2$ & 63.30 & 64.13 & 64.08 & 64.36 & 65.33 & 64.53 & 65.69 & 65.74 & 65.71 & 67.24 & 67.13 & 68.00 & 64.72 & 64.85 & 65.00 \\
\hline TiO2 & 0.00 & 0.03 & 0.00 & 0.00 & 0.00 & 0.00 & 0.00 & 0.00 & 0.05 & 0.00 & 0.03 & 0.00 & 0.00 & 0.05 & 0.00 \\
\hline $\mathrm{Al} 2 \mathrm{O} 3$ & 23.15 & 22.63 & 22.43 & 22.19 & 21.85 & 20.99 & 21.76 & 21.53 & 21.71 & 20.61 & 20.60 & 20.14 & 18.99 & 19.03 & 18.88 \\
\hline $\mathrm{FeO}$ & 0.07 & 0.17 & 0.17 & 0.12 & 0.09 & 0.27 & 0.12 & 0.07 & 0.06 & 0.06 & 0.01 & 0.05 & 0.11 & 0.11 & 0.08 \\
\hline $\mathrm{MnO}$ & 0.00 & 0.02 & 0.00 & 0.00 & 0.00 & 0.03 & 0.00 & 0.00 & 0.00 & 0.00 & 0.00 & 0.00 & 0.00 & 0.00 & 0.00 \\
\hline $\mathrm{MgO}$ & 0.00 & 0.03 & 0.00 & 0.00 & 0.00 & 0.00 & 0.00 & 0.00 & 0.00 & 0.00 & 0.00 & 0.00 & 0.00 & 0.00 & 0.00 \\
\hline $\mathrm{SrO}$ & 0.00 & 0.00 & 0.00 & 0.00 & 0.00 & 0.05 & 0.00 & 0.06 & 0.04 & 0.00 & 0.00 & 0.00 & 0.05 & 0.04 & 0.00 \\
\hline $\mathrm{BaO}$ & 0.00 & 0.00 & 0.00 & 0.00 & 0.00 & 0.00 & 0.00 & 0.07 & 0.06 & 0.00 & 0.00 & 0.00 & 0.00 & 0.05 & 0.00 \\
\hline $\mathrm{PbO}$ & 0.00 & 0.00 & 0.00 & 0.00 & 0.00 & 0.00 & 0.00 & 0.00 & 0.06 & 0.00 & 0.00 & 0.07 & 0.00 & 0.00 & 0.10 \\
\hline $\mathrm{CaO}$ & 3.64 & 2.96 & 3.04 & 2.91 & 2.48 & 0.49 & 2.10 & 1.86 & 2.00 & 0.75 & 0.82 & 0.27 & 0.08 & 0.27 & 0.02 \\
\hline $\mathrm{Na} 2 \mathrm{O}$ & 9.45 & 9.44 & 9.41 & 9.35 & 10.37 & 10.34 & 10.34 & 10.48 & 10.20 & 11.39 & 11.24 & 11.62 & 0.82 & 1.45 & 1.04 \\
\hline $\mathrm{K} 2 \mathrm{O}$ & 0.28 & 0.57 & 0.66 & 1.21 & 0.11 & 0.81 & 0.37 & 0.52 & 0.29 & 0.15 & 0.11 & 0.11 & 15.13 & 14.22 & 15.24 \\
\hline Total & 99.92 & 99.99 & 99.81 & 100.16 & 100.22 & 97.52 & 100.43 & 100.33 & 100.18 & 100.23 & 99.99 & 100.31 & 99.93 & 100.10 & 100.43 \\
\hline $\mathrm{Si}$ & 11.202 & 11.326 & 11.344 & 11.378 & 11.478 & 11.632 & 11.521 & 11.549 & 11.540 & 11.764 & 11.766 & 11.872 & 11.925 & 11.904 & 11.938 \\
\hline ivAl & 4.828 & 4.710 & 4.680 & 4.624 & 4.524 & 4.459 & 4.498 & 4.458 & 4.494 & 4.250 & 4.255 & 4.144 & 4.124 & 4.117 & 4.087 \\
\hline Felll & 0.010 & 0.025 & 0.025 & 0.018 & 0.013 & 0.041 & 0.018 & 0.011 & 0.009 & 0.009 & 0.001 & 0.007 & 0.017 & 0.017 & 0.013 \\
\hline T site & 16.040 & 16.061 & 16.050 & 16.020 & 16.015 & 16.133 & 16.036 & 16.018 & 16.043 & 16.023 & 16.023 & 16.023 & 16.067 & 16.039 & 16.038 \\
\hline $\mathrm{Ti}$ & 0.000 & 0.004 & 0.000 & 0.000 & 0.000 & 0.000 & 0.000 & 0.000 & 0.007 & 0.000 & 0.003 & 0.000 & 0.000 & 0.007 & 0.000 \\
\hline $\mathrm{Mn}$ & 0.000 & 0.003 & 0.000 & 0.000 & 0.000 & 0.005 & 0.000 & 0.000 & 0.000 & 0.000 & 0.000 & 0.000 & 0.000 & 0.000 & 0.000 \\
\hline $\mathrm{Mg}$ & 0.000 & 0.007 & 0.000 & 0.000 & 0.000 & 0.000 & 0.000 & 0.000 & 0.000 & 0.000 & 0.000 & 0.000 & 0.000 & 0.000 & 0.001 \\
\hline $\mathrm{Sr}$ & 0.000 & 0.000 & 0.000 & 0.000 & 0.000 & 0.005 & 0.000 & 0.006 & 0.004 & 0.000 & 0.000 & 0.000 & 0.006 & 0.005 & 0.000 \\
\hline $\mathrm{Ba}$ & 0.000 & 0.000 & 0.000 & 0.000 & 0.000 & 0.000 & 0.000 & 0.005 & 0.004 & 0.000 & 0.000 & 0.000 & 0.000 & 0.004 & 0.000 \\
\hline $\mathrm{Pb}$ & 0.000 & 0.000 & 0.000 & 0.000 & 0.000 & 0.000 & 0.000 & 0.000 & 0.003 & 0.000 & 0.000 & 0.003 & 0.000 & 0.000 & 0.005 \\
\hline $\mathrm{Ca}$ & 0.690 & 0.560 & 0.577 & 0.551 & 0.467 & 0.095 & 0.395 & 0.350 & 0.376 & 0.140 & 0.154 & 0.051 & 0.015 & 0.053 & 0.003 \\
\hline $\mathrm{Na}$ & 3.242 & 3.232 & 3.230 & 3.205 & 3.532 & 3.614 & 3.516 & 3.570 & 3.473 & 3.864 & 3.820 & 3.933 & 0.293 & 0.516 & 0.372 \\
\hline $\mathrm{K}$ & 0.064 & 0.128 & 0.149 & 0.273 & 0.024 & 0.187 & 0.083 & 0.116 & 0.065 & 0.034 & 0.025 & 0.024 & 3.556 & 3.330 & 3.571 \\
\hline M site & 3.997 & 3.934 & 3.956 & 4.029 & 4.023 & 3.906 & 3.994 & 4.047 & 3.932 & 4.038 & 4.002 & 4.011 & 3.871 & 3.915 & 3.951 \\
\hline Cations & 20.037 & 19.995 & 20.005 & 20.049 & 20.038 & 20.038 & 20.030 & 20.065 & 19.975 & 20.060 & 20.025 & 20.035 & 19.937 & 19.953 & 19.989 \\
\hline An & 17.27 & 14.29 & 14.58 & 13.68 & 11.60 & 2.45 & 9.88 & 8.67 & 9.61 & 3.46 & 3.85 & 1.28 & 0.40 & 1.36 & 0.09 \\
\hline$A b$ & 81.13 & 82.44 & 81.65 & 79.55 & 87.81 & 92.76 & 88.03 & 88.45 & 88.72 & 95.69 & 95.53 & 98.13 & 7.59 & 13.24 & 9.42 \\
\hline Or & 1.60 & 3.27 & 3.77 & 6.77 & 0.59 & 4.79 & 2.09 & 2.88 & 1.67 & 0.85 & 0.62 & 0.59 & 92.01 & 85.41 & 90.49 \\
\hline
\end{tabular}

Notes: Facies abbreviations BQ-M OC = Biotite quartz-monzodiorite with two pyroxenes; Dac = Dacite; L-MG = Leuco monzogranite; BT-MG = Biotite hornblende monzogranite; Rhy = Rhyolite; HB-GD = Hornblende biotite granodiorite; $M G=$ Monzogranite; IM-D = Intermediate-mafic dikes; $A n=$ anortite; $A b=$ albite; Or = orthoclase. 
Supplementary Material: Electron microprobe analyses of alkali feldspar and plagioclase from Garzón granites and related rocks, Eastern Cordillera, Colombia.

\begin{tabular}{|c|c|c|c|c|c|c|c|c|c|c|c|c|c|c|c|}
\hline \multirow{3}{*}{$\begin{array}{l}\text { Mineral } \\
\text { Massif } \\
\text { Sample }\end{array}$} & \multicolumn{6}{|c|}{ Alkali feldspar } & \multicolumn{9}{|c|}{ Plagioclase } \\
\hline & & & & & & & & Algeciras & & & & & & & \\
\hline & $\begin{array}{l}\text { GAR- } \\
354 \\
\end{array}$ & $\begin{array}{l}\text { GAR- } \\
354\end{array}$ & $\begin{array}{l}\text { GAR- } \\
354\end{array}$ & $\begin{array}{l}\text { GAR- } \\
354 \\
\end{array}$ & $\begin{array}{l}\text { GAR- } \\
354 \\
\end{array}$ & $\begin{array}{l}\text { GAR- } \\
354 \\
\end{array}$ & $\begin{array}{l}\text { GAR- } \\
356 \\
\end{array}$ & $\begin{array}{l}\text { GAR- } \\
356\end{array}$ & $\begin{array}{l}\text { GAR- } \\
356 \\
\end{array}$ & $\begin{array}{l}\text { GAR- } \\
356 \\
\end{array}$ & $\begin{array}{l}\text { GAR- } \\
356 \\
\end{array}$ & $\begin{array}{l}\text { GAR- } \\
356 \\
\end{array}$ & $\begin{array}{l}\text { GAR- } \\
356 \\
\end{array}$ & $\begin{array}{l}\text { GAR- } \\
356 \\
\end{array}$ & $\begin{array}{l}\text { GAR- } \\
356 \\
\end{array}$ \\
\hline Facies & L-MG & L-MG & L-MG & L-MG & L-MG & L-MG & BH-MG & BH-MG & BH-MG & BH-MG & BH-MG & BH-MG & BH-MG & BH-MG & BH-MG \\
\hline $\begin{array}{l}\text { Grain/ } \\
\text { Point }\end{array}$ & Fk_02-2 & Fk_05-1 & Fk_05-2 & Fk_07-1 & Fk_07-2 & Fk_07-3 & pl_01-1 & pl_01-2 & pl_01-3 & pl_05-1 & pl_05-2 & pl_05-3 & pl_05-4 & pl_07-1 & pl_07-2 \\
\hline $\mathrm{SiO} 2$ & 64.64 & 65.04 & 65.03 & 65.27 & 64.88 & 64.65 & 58.45 & 57.84 & 62.35 & 60.50 & 59.33 & 58.07 & 61.53 & 57.90 & 62.11 \\
\hline TiO2 & 0.00 & 0.00 & 0.00 & 0.03 & 0.00 & 0.04 & 0.05 & 0.00 & 0.00 & 0.00 & 0.05 & 0.00 & 0.03 & 0.00 & 0.00 \\
\hline Al2O3 & 18.83 & 18.94 & 18.91 & 18.95 & 18.94 & 18.94 & 25.53 & 25.85 & 22.26 & 23.01 & 25.25 & 26.14 & 24.00 & 25.91 & 23.46 \\
\hline $\mathrm{FeO}$ & 0.05 & 0.06 & 0.12 & 0.08 & 0.10 & 0.05 & 0.32 & 0.28 & 0.16 & 0.03 & 0.31 & 0.25 & 0.19 & 0.43 & 0.10 \\
\hline $\mathrm{MnO}$ & 0.00 & 0.00 & 0.00 & 0.00 & 0.00 & 0.00 & 0.00 & 0.00 & 0.00 & 0.00 & 0.00 & 0.00 & 0.00 & 0.00 & 0.00 \\
\hline $\mathrm{MgO}$ & 0.00 & 0.02 & 0.00 & 0.00 & 0.00 & 0.00 & 0.00 & 0.00 & 0.00 & 0.00 & 0.00 & 0.00 & 0.00 & 0.12 & 0.00 \\
\hline $\mathrm{SrO}$ & 0.00 & 0.00 & 0.00 & 0.00 & 0.00 & 0.00 & 0.23 & 0.13 & 0.04 & 0.19 & 0.18 & 0.20 & 0.06 & 0.20 & 0.07 \\
\hline $\mathrm{BaO}$ & 0.05 & 0.00 & 0.00 & 0.04 & 0.04 & 0.00 & 0.05 & 0.09 & 0.00 & 0.00 & 0.07 & 0.00 & 0.00 & 0.00 & 0.00 \\
\hline $\mathrm{PbO}$ & 0.09 & 0.00 & 0.06 & 0.00 & 0.00 & 0.00 & 0.00 & 0.05 & 0.09 & 0.00 & 0.00 & 0.00 & 0.00 & 0.00 & 0.00 \\
\hline $\mathrm{CaO}$ & 0.00 & 0.05 & 0.03 & 0.00 & 0.00 & 0.01 & 7.11 & 7.13 & 3.27 & 3.93 & 6.37 & 7.13 & 4.99 & 6.09 & 4.42 \\
\hline $\mathrm{Na} 2 \mathrm{O}$ & 0.65 & 1.02 & 0.68 & 1.10 & 0.88 & 0.39 & 7.05 & 7.01 & 9.29 & 8.66 & 7.75 & 7.27 & 8.47 & 7.35 & 9.17 \\
\hline $\mathrm{K} 2 \mathrm{O}$ & 15.79 & 15.40 & 15.61 & 15.06 & 15.19 & 15.94 & 0.48 & 0.43 & 0.46 & 0.18 & 0.30 & 0.21 & 0.28 & 0.84 & 0.06 \\
\hline Total & 100.13 & 100.58 & 100.44 & 100.56 & 100.06 & 100.06 & 99.26 & 98.81 & 97.97 & 96.52 & 99.64 & 99.29 & 99.59 & 98.86 & 99.45 \\
\hline $\mathrm{Si}$ & 11.932 & 11.927 & 11.942 & 11.946 & 11.940 & 11.929 & 10.551 & 10.490 & 11.270 & 11.092 & 10.648 & 10.469 & 10.971 & 10.501 & 11.074 \\
\hline ivAl & 4.097 & 4.094 & 4.093 & 4.088 & 4.108 & 4.119 & 5.431 & 5.525 & 4.742 & 4.972 & 5.341 & 5.554 & 5.044 & 5.538 & 4.930 \\
\hline Felll & 0.008 & 0.009 & 0.018 & 0.012 & 0.015 & 0.008 & 0.048 & 0.042 & 0.025 & 0.005 & 0.047 & 0.037 & 0.029 & 0.065 & 0.015 \\
\hline T site & 16.036 & 16.030 & 16.053 & 16.046 & 16.063 & 16.055 & 16.030 & 16.057 & 16.036 & 16.070 & 16.036 & 16.060 & 16.044 & 16.105 & 16.018 \\
\hline $\mathrm{Ti}$ & 0.000 & 0.000 & 0.000 & 0.004 & 0.000 & 0.005 & 0.006 & 0.000 & 0.000 & 0.000 & 0.007 & 0.000 & 0.004 & 0.000 & 0.000 \\
\hline $\mathrm{Mn}$ & 0.000 & 0.000 & 0.000 & 0.000 & 0.000 & 0.000 & 0.000 & 0.000 & 0.000 & 0.000 & 0.000 & 0.000 & 0.000 & 0.001 & 0.000 \\
\hline $\mathrm{Mg}$ & 0.000 & 0.005 & 0.000 & 0.000 & 0.000 & 0.000 & 0.000 & 0.000 & 0.000 & 0.000 & 0.000 & 0.000 & 0.000 & 0.031 & 0.000 \\
\hline $\mathrm{Sr}$ & 0.000 & 0.000 & 0.000 & 0.000 & 0.000 & 0.000 & 0.024 & 0.014 & 0.004 & 0.020 & 0.019 & 0.021 & 0.006 & 0.021 & 0.007 \\
\hline $\mathrm{Ba}$ & 0.004 & 0.000 & 0.000 & 0.003 & 0.003 & 0.000 & 0.004 & 0.006 & 0.000 & 0.000 & 0.005 & 0.000 & 0.000 & 0.000 & 0.000 \\
\hline $\mathrm{Pb}$ & 0.004 & 0.000 & 0.003 & 0.000 & 0.000 & 0.000 & 0.000 & 0.002 & 0.004 & 0.000 & 0.000 & 0.000 & 0.000 & 0.000 & 0.000 \\
\hline $\mathrm{Ca}$ & 0.000 & 0.009 & 0.006 & 0.000 & 0.000 & 0.001 & 1.375 & 1.385 & 0.633 & 0.772 & 1.225 & 1.377 & 0.953 & 1.183 & 0.844 \\
\hline $\mathrm{Na}$ & 0.231 & 0.361 & 0.242 & 0.391 & 0.313 & 0.138 & 2.467 & 2.465 & 3.256 & 3.078 & 2.697 & 2.541 & 2.928 & 2.585 & 3.170 \\
\hline K & 3.718 & 3.602 & 3.657 & 3.516 & 3.566 & 3.752 & 0.110 & 0.098 & 0.107 & 0.042 & 0.069 & 0.049 & 0.065 & 0.194 & 0.014 \\
\hline M site & 3.958 & 3.978 & 3.908 & 3.914 & 3.882 & 3.896 & 3.987 & 3.972 & 4.004 & 3.912 & 4.022 & 3.989 & 3.956 & 4.015 & 4.035 \\
\hline Cations & 19.994 & 20.008 & 19.961 & 19.960 & 19.945 & 19.951 & 20.016 & 20.029 & 20.040 & 19.982 & 20.058 & 20.049 & 19.999 & 20.119 & 20.053 \\
\hline An & 0.00 & 0.23 & 0.16 & 0.00 & 0.00 & 0.03 & 34.79 & 35.09 & 15.85 & 19.83 & 30.69 & 34.72 & 24.16 & 29.87 & 20.96 \\
\hline$A b$ & 5.86 & 9.10 & 6.21 & 10.01 & 8.07 & 3.55 & 62.43 & 62.42 & 81.48 & 79.09 & 67.57 & 64.06 & 74.20 & 65.23 & 78.70 \\
\hline Or & 94.14 & 90.67 & 93.64 & 89.99 & 91.93 & 96.42 & 2.78 & 2.49 & 2.67 & 1.07 & 1.74 & 1.23 & 1.64 & 4.90 & 0.34 \\
\hline
\end{tabular}

Notes: Facies abbreviations BQ-M OC = Biotite quartz-monzodiorite with two pyroxenes; Dac = Dacite; L-MG = Leuco monzogranite; BT-MG = Biotite hornblende monzogranite; Rhy = Rhyolite; HB-GD = Hornblende biotite granodiorite; $M G=$ Monzogranite; IM-D = Intermediate-mafic dikes; An = anortite; $A b=$ albite; Or = orthoclase. 
Supplementary Material: Electron microprobe analyses of alkali feldspar and plagioclase from Garzón granites and related rocks, Eastern Cordillera, Colombia.

\begin{tabular}{|c|c|c|c|c|c|c|c|c|c|c|c|c|c|c|c|}
\hline \multirow{3}{*}{$\begin{array}{l}\text { Mineral } \\
\text { Massif } \\
\text { Sample }\end{array}$} & \multicolumn{4}{|c|}{ Alkali feldspar } & \multicolumn{11}{|c|}{ Plagioclase } \\
\hline & & & & & & & & Igeciras & & & & & & & \\
\hline & $\begin{array}{l}\text { GAR- } \\
356\end{array}$ & $\begin{array}{l}\text { GAR- } \\
356\end{array}$ & $\begin{array}{l}\text { GAR- } \\
356\end{array}$ & $\begin{array}{l}\text { GAR- } \\
356\end{array}$ & $\begin{array}{l}\text { GAR- } \\
357\end{array}$ & $\begin{array}{l}\text { GAR- } \\
357\end{array}$ & $\begin{array}{l}\text { GAR- } \\
357\end{array}$ & $\begin{array}{l}\text { GAR- } \\
357\end{array}$ & $\begin{array}{l}\text { GAR- } \\
357\end{array}$ & $\begin{array}{l}\text { GAR- } \\
357\end{array}$ & $\begin{array}{l}\text { GAR- } \\
357\end{array}$ & $\begin{array}{l}\text { GAR- } \\
357\end{array}$ & $\begin{array}{l}\text { GAR- } \\
357\end{array}$ & $\begin{array}{l}\text { GAR- } \\
357\end{array}$ & $\begin{array}{l}\text { GAR- } \\
357\end{array}$ \\
\hline Facies & BH-MG & BH-MG & BH-MG & BH-MG & BH-MG & BH-MG & BH-MG & BH-MG & BH-MG & BH-MG & BH-MG & BH-MG & BH-MG & BH-MG & BH-MG \\
\hline /Point & Fk_01-1 & Fk_01-2 & Fk_02-1 & Fk_03-1 & pl_01-1 & pl_02-1 & pl_03-1 & pl_05-1 & pl_05-2 & pl_05-3 & pl_05-4 & pl_05-5 & pl_05-6 & pl_05-7 & pl_05-8 \\
\hline $\mathrm{SiO} 2$ & 63.57 & 63.52 & 63.46 & 63.70 & 58.43 & 59.38 & 58.70 & 59.02 & 56.56 & 58.89 & 59.90 & 58.15 & 60.18 & 62.20 & 63.08 \\
\hline TiO2 & 0.00 & 0.04 & 0.00 & 0.00 & 0.05 & 0.06 & 0.00 & 0.00 & 0.00 & 0.00 & 0.10 & 0.00 & 0.00 & 0.00 & 0.03 \\
\hline $\mathrm{Al} 2 \mathrm{O} 3$ & 18.86 & 19.00 & 18.83 & 19.02 & 25.88 & 25.25 & 25.73 & 25.49 & 27.41 & 25.73 & 25.04 & 26.61 & 24.71 & 22.14 & 22.68 \\
\hline $\mathrm{FeO}$ & 0.10 & 0.12 & 0.11 & 0.10 & 0.48 & 0.56 & 0.55 & 0.46 & 0.43 & 0.48 & 0.53 & 0.52 & 0.41 & 0.34 & 0.36 \\
\hline $\mathrm{MnO}$ & 0.00 & 0.02 & 0.00 & 0.00 & 0.05 & 0.08 & 0.07 & 0.06 & 0.02 & 0.04 & 0.06 & 0.05 & 0.06 & 0.03 & 0.06 \\
\hline $\mathrm{MgO}$ & 0.02 & 0.02 & 0.00 & 0.00 & 0.00 & 0.00 & 0.00 & 0.00 & 0.00 & 0.00 & 0.00 & 0.00 & 0.00 & 0.00 & 0.00 \\
\hline $\mathrm{SrO}$ & 0.10 & 0.10 & 0.13 & 0.17 & 0.20 & 0.27 & 0.20 & 0.15 & 0.22 & 0.21 & 0.21 & 0.19 & 0.14 & 0.00 & 0.00 \\
\hline $\mathrm{BaO}$ & 0.41 & 0.78 & 0.72 & 0.79 & 0.00 & 0.07 & 0.00 & 0.00 & 0.00 & 0.07 & 0.05 & 0.00 & 0.00 & 0.00 & 0.00 \\
\hline $\mathrm{PbO}$ & 0.04 & 0.00 & 0.06 & 0.00 & 0.00 & 0.00 & 0.00 & 0.11 & 0.00 & 0.07 & 0.00 & 0.00 & 0.00 & 0.06 & 0.00 \\
\hline $\mathrm{CaO}$ & 0.00 & 0.07 & 0.08 & 0.03 & 7.18 & 6.78 & 7.37 & 6.95 & 8.75 & 7.00 & 6.30 & 7.92 & 6.01 & 3.60 & 3.63 \\
\hline $\mathrm{Na} 2 \mathrm{O}$ & 0.69 & 1.32 & 0.76 & 0.81 & 6.59 & 6.66 & 6.44 & 6.86 & 5.90 & 6.50 & 7.03 & 6.36 & 7.31 & 8.25 & 8.45 \\
\hline $\mathrm{K} 2 \mathrm{O}$ & 15.34 & 14.33 & 15.01 & 15.04 & 0.33 & 1.27 & 0.43 & 0.64 & 0.43 & 0.95 & 0.51 & 0.38 & 0.45 & 0.80 & 0.32 \\
\hline Total & 99.13 & 99.35 & 99.17 & 99.66 & 99.20 & 100.39 & 99.52 & 99.76 & 99.72 & 99.94 & 99.72 & 100.20 & 99.29 & 97.48 & 98.68 \\
\hline $\mathrm{Si}$ & 11.877 & 11.838 & 11.870 & 11.856 & 10.532 & 10.631 & 10.557 & 10.601 & 10.200 & 10.570 & 10.724 & 10.406 & 10.799 & 11.294 & 11.280 \\
\hline ivAl & 4.153 & 4.173 & 4.151 & 4.172 & 5.498 & 5.328 & 5.454 & 5.396 & 5.826 & 5.443 & 5.284 & 5.612 & 5.226 & 4.738 & 4.780 \\
\hline Felll & 0.015 & 0.019 & 0.017 & 0.016 & 0.073 & 0.084 & 0.082 & 0.069 & 0.064 & 0.072 & 0.079 & 0.077 & 0.062 & 0.052 & 0.055 \\
\hline T site & 16.046 & 16.031 & 16.039 & 16.045 & 16.102 & 16.043 & 16.093 & 16.066 & 16.090 & 16.086 & 16.087 & 16.096 & 16.086 & 16.084 & 16.115 \\
\hline $\mathrm{Ti}$ & 0.000 & 0.006 & 0.000 & 0.000 & 0.007 & 0.008 & 0.000 & 0.000 & 0.000 & 0.000 & 0.013 & 0.000 & 0.000 & 0.000 & 0.005 \\
\hline $\mathrm{Mn}$ & 0.000 & 0.003 & 0.000 & 0.000 & 0.008 & 0.011 & 0.011 & 0.009 & 0.003 & 0.006 & 0.009 & 0.007 & 0.009 & 0.005 & 0.009 \\
\hline $\mathrm{Mg}$ & 0.004 & 0.005 & 0.000 & 0.000 & 0.000 & 0.000 & 0.000 & 0.000 & 0.000 & 0.000 & 0.000 & 0.000 & 0.000 & 0.000 & 0.000 \\
\hline $\mathrm{Sr}$ & 0.011 & 0.011 & 0.014 & 0.018 & 0.021 & 0.028 & 0.020 & 0.016 & 0.023 & 0.021 & 0.021 & 0.020 & 0.015 & 0.000 & 0.000 \\
\hline $\mathrm{Ba}$ & 0.030 & 0.057 & 0.053 & 0.057 & 0.000 & 0.005 & 0.000 & 0.000 & 0.000 & 0.005 & 0.004 & 0.000 & 0.000 & 0.000 & 0.000 \\
\hline $\mathrm{Pb}$ & 0.002 & 0.000 & 0.003 & 0.000 & 0.000 & 0.000 & 0.000 & 0.005 & 0.000 & 0.003 & 0.000 & 0.000 & 0.000 & 0.003 & 0.000 \\
\hline $\mathrm{Ca}$ & 0.000 & 0.014 & 0.017 & 0.006 & 1.387 & 1.301 & 1.420 & 1.338 & 1.691 & 1.346 & 1.209 & 1.519 & 1.155 & 0.700 & 0.695 \\
\hline $\mathrm{Na}$ & 0.250 & 0.478 & 0.276 & 0.293 & 2.303 & 2.312 & 2.246 & 2.389 & 2.063 & 2.262 & 2.440 & 2.207 & 2.543 & 2.904 & 2.930 \\
\hline $\mathrm{K}$ & 3.656 & 3.407 & 3.582 & 3.571 & 0.075 & 0.290 & 0.098 & 0.146 & 0.099 & 0.218 & 0.116 & 0.086 & 0.103 & 0.186 & 0.074 \\
\hline M site & 3.953 & 3.981 & 3.945 & 3.945 & 3.800 & 3.955 & 3.796 & 3.902 & 3.879 & 3.862 & 3.812 & 3.838 & 3.826 & 3.798 & 3.712 \\
\hline Cations & 19.999 & 20.011 & 19.983 & 19.989 & 19.902 & 19.998 & 19.888 & 19.968 & 19.969 & 19.948 & 19.899 & 19.934 & 19.912 & 19.882 & 19.827 \\
\hline An & 0.00 & 0.35 & 0.44 & 0.15 & 36.83 & 33.33 & 37.73 & 34.54 & 43.88 & 35.18 & 32.10 & 39.84 & 30.39 & 18.48 & 18.80 \\
\hline$A b$ & 6.41 & 12.27 & 7.14 & 7.56 & 61.17 & 59.24 & 59.66 & 61.69 & 53.54 & 59.12 & 64.82 & 57.89 & 66.90 & 76.62 & 79.21 \\
\hline Or & 93.59 & 87.38 & 92.43 & 92.29 & 2.00 & 7.43 & 2.61 & 3.78 & 2.58 & 5.69 & 3.08 & 2.27 & 2.71 & 4.90 & 1.99 \\
\hline
\end{tabular}

Notes: Facies abbreviations BQ-M OC = Biotite quartz-monzodiorite with two pyroxenes; Dac = Dacite; L-MG = Leuco monzogranite; BT-MG = Biotite hornblende monzogranite; Rhy = Rhyolite; HB-GD = Hornblende biotite granodiorite; $M G=$ Monzogranite; IM-D = Intermediate-mafic dikes; An = anortite; $A b=$ albite; Or = orthoclase. 
Supplementary Material: Electron microprobe analyses of alkali feldspar and plagioclase from Garzón granites and related rocks, Eastern Cordillera, Colombia.

\begin{tabular}{|c|c|c|c|c|c|c|c|c|c|c|c|c|c|c|c|}
\hline \multirow{3}{*}{$\begin{array}{l}\text { Mineral } \\
\text { Massif } \\
\text { Sample }\end{array}$} & \multicolumn{15}{|c|}{ Plagioclase } \\
\hline & \multicolumn{15}{|c|}{ Algeciras } \\
\hline & $\begin{array}{l}\text { GAR- } \\
357 \\
\end{array}$ & $\begin{array}{l}\text { GAR- } \\
357\end{array}$ & $\begin{array}{l}\text { GAR- } \\
357\end{array}$ & $\begin{array}{l}\text { GAR- } \\
357 \\
\end{array}$ & $\begin{array}{l}\text { GAR- } \\
357\end{array}$ & $\begin{array}{l}\text { GAR- } \\
357\end{array}$ & $\begin{array}{l}\text { GAR- } \\
357 \\
\end{array}$ & $\begin{array}{l}\text { GAR- } \\
357\end{array}$ & $\begin{array}{l}\text { GAR- } \\
357 \\
\end{array}$ & $\begin{array}{l}\text { GAR- } \\
357 \\
\end{array}$ & $\begin{array}{l}\text { GAR- } \\
357\end{array}$ & $\begin{array}{l}\text { GAR- } \\
358 \\
\end{array}$ & $\begin{array}{l}\text { GAR- } \\
358 \\
\end{array}$ & $\begin{array}{l}\text { GAR- } \\
358 \\
\end{array}$ & $\begin{array}{l}\text { GAR- } \\
358 \\
\end{array}$ \\
\hline Facies & BH-MG & BH-MG & BH-MG & BH-MG & BH-MG & BH-MG & BH-MG & BH-MG & BH-MG & BH-MG & BH-MG & IM-D & IM-D & IM-D & IM-D \\
\hline $\begin{array}{l}\text { Grain/ } \\
\text { Point }\end{array}$ & pl_05-9 & pl_06-1 & pl_06-2 & pl_06-3 & pl_06-4 & pl_06-5 & pl_11-1 & pl_11-2 & pl_11-3 & pl_11-4 & pl_11-5 & pl_01-1 & pl_01-2 & pl_01-3 & pl_01-4 \\
\hline $\mathrm{SiO} 2$ & 63.86 & 56.33 & 59.08 & 63.65 & 63.36 & 63.36 & 59.39 & 59.79 & 59.82 & 63.33 & 64.21 & 52.56 & 59.33 & 53.40 & 53.95 \\
\hline TiO2 & 0.00 & 0.00 & 0.04 & 0.00 & 0.03 & 0.00 & 0.00 & 0.00 & 0.00 & 0.00 & 0.00 & 0.07 & 0.00 & 0.10 & 0.16 \\
\hline Al2O3 & 22.18 & 27.77 & 25.58 & 22.74 & 23.07 & 22.46 & 25.08 & 25.09 & 25.11 & 22.74 & 22.11 & 30.01 & 23.00 & 29.37 & 29.19 \\
\hline $\mathrm{FeO}$ & 0.19 & 0.39 & 0.47 & 0.41 & 0.29 & 0.28 & 0.46 & 0.50 & 0.52 & 0.44 & 0.38 & 0.74 & 0.24 & 0.76 & 0.67 \\
\hline $\mathrm{MnO}$ & 0.04 & 0.04 & 0.06 & 0.08 & 0.03 & 0.06 & 0.07 & 0.07 & 0.06 & 0.08 & 0.07 & 0.00 & 0.00 & 0.02 & 0.00 \\
\hline $\mathrm{MgO}$ & 0.00 & 0.00 & 0.00 & 0.00 & 0.00 & 0.00 & 0.00 & 0.00 & 0.00 & 0.00 & 0.00 & 0.02 & 0.00 & 0.03 & 0.00 \\
\hline $\mathrm{SrO}$ & 0.07 & 0.18 & 0.18 & 0.00 & 0.00 & 0.08 & 0.12 & 0.11 & 0.17 & 0.05 & 0.08 & 0.24 & 0.13 & 0.25 & 0.24 \\
\hline $\mathrm{BaO}$ & 0.00 & 0.06 & 0.06 & 0.00 & 0.05 & 0.00 & 0.00 & 0.05 & 0.00 & 0.00 & 0.00 & 0.04 & 0.08 & 0.16 & 0.05 \\
\hline $\mathrm{PbO}$ & 0.00 & 0.00 & 0.00 & 0.00 & 0.00 & 0.00 & 0.07 & 0.00 & 0.00 & 0.00 & 0.08 & 0.00 & 0.00 & 0.00 & 0.00 \\
\hline $\mathrm{CaO}$ & 2.92 & 9.01 & 6.81 & 3.75 & 3.71 & 2.95 & 6.31 & 6.26 & 6.30 & 3.70 & 2.68 & 12.05 & 7.27 & 11.35 & 11.11 \\
\hline $\mathrm{Na} 2 \mathrm{O}$ & 9.04 & 5.68 & 6.69 & 8.52 & 8.55 & 8.60 & 7.06 & 6.97 & 7.06 & 8.52 & 9.00 & 3.87 & 7.57 & 4.15 & 4.38 \\
\hline $\mathrm{K} 2 \mathrm{O}$ & 0.23 & 0.23 & 0.35 & 0.39 & 0.20 & 0.56 & 0.54 & 0.80 & 0.67 & 0.44 & 0.27 & 0.82 & 0.43 & 0.85 & 1.10 \\
\hline Total & 98.55 & 99.69 & 99.32 & 99.57 & 99.33 & 98.40 & 99.11 & 99.65 & 99.72 & 99.31 & 98.89 & 100.43 & 98.05 & 100.45 & 100.88 \\
\hline $\mathrm{Si}$ & 11.404 & 10.153 & 10.620 & 11.288 & 11.250 & 11.351 & 10.701 & 10.721 & 10.715 & 11.269 & 11.432 & 9.541 & 10.847 & 9.681 & 9.736 \\
\hline ivAl & 4.668 & 5.899 & 5.419 & 4.753 & 4.828 & 4.742 & 5.326 & 5.302 & 5.301 & 4.769 & 4.640 & 6.421 & 4.956 & 6.276 & 6.209 \\
\hline Felll & 0.029 & 0.058 & 0.070 & 0.061 & 0.043 & 0.043 & 0.069 & 0.075 & 0.079 & 0.066 & 0.056 & 0.113 & 0.036 & 0.116 & 0.102 \\
\hline T site & 16.101 & 16.110 & 16.110 & 16.102 & 16.120 & 16.136 & 16.096 & 16.098 & 16.095 & 16.104 & 16.128 & 16.075 & 15.839 & 16.072 & 16.046 \\
\hline $\mathrm{Ti}$ & 0.000 & 0.000 & 0.006 & 0.000 & 0.004 & 0.000 & 0.000 & 0.000 & 0.000 & 0.000 & 0.001 & 0.010 & 0.000 & 0.013 & 0.021 \\
\hline $\mathrm{Mn}$ & 0.006 & 0.006 & 0.009 & 0.012 & 0.005 & 0.010 & 0.011 & 0.011 & 0.010 & 0.012 & 0.010 & 0.000 & 0.000 & 0.002 & 0.000 \\
\hline $\mathrm{Mg}$ & 0.000 & 0.000 & 0.000 & 0.000 & 0.000 & 0.000 & 0.000 & 0.000 & 0.000 & 0.000 & 0.001 & 0.005 & 0.000 & 0.009 & 0.000 \\
\hline $\mathrm{Sr}$ & 0.007 & 0.019 & 0.019 & 0.000 & 0.000 & 0.009 & 0.013 & 0.011 & 0.017 & 0.005 & 0.008 & 0.026 & 0.014 & 0.027 & 0.025 \\
\hline $\mathrm{Ba}$ & 0.000 & 0.004 & 0.004 & 0.000 & 0.003 & 0.000 & 0.000 & 0.003 & 0.000 & 0.000 & 0.000 & 0.003 & 0.006 & 0.012 & 0.004 \\
\hline $\mathrm{Pb}$ & 0.000 & 0.000 & 0.000 & 0.000 & 0.000 & 0.000 & 0.003 & 0.000 & 0.000 & 0.000 & 0.004 & 0.000 & 0.000 & 0.000 & 0.000 \\
\hline $\mathrm{Ca}$ & 0.559 & 1.740 & 1.312 & 0.713 & 0.706 & 0.566 & 1.218 & 1.203 & 1.209 & 0.705 & 0.511 & 2.344 & 1.424 & 2.205 & 2.148 \\
\hline $\mathrm{Na}$ & 3.130 & 1.985 & 2.332 & 2.930 & 2.943 & 2.987 & 2.466 & 2.423 & 2.452 & 2.939 & 3.107 & 1.362 & 2.683 & 1.459 & 1.533 \\
\hline K & 0.051 & 0.053 & 0.081 & 0.089 & 0.045 & 0.128 & 0.124 & 0.182 & 0.153 & 0.101 & 0.062 & 0.191 & 0.100 & 0.197 & 0.254 \\
\hline M site & 3.753 & 3.807 & 3.761 & 3.743 & 3.707 & 3.699 & 3.836 & 3.833 & 3.841 & 3.762 & 3.704 & 3.939 & 4.227 & 3.923 & 3.985 \\
\hline Cations & 19.853 & 19.917 & 19.871 & 19.845 & 19.827 & 19.835 & 19.931 & 19.931 & 19.936 & 19.867 & 19.832 & 20.015 & 20.066 & 19.995 & 20.031 \\
\hline An & 14.94 & 46.05 & 35.22 & 19.10 & 19.10 & 15.38 & 31.98 & 31.58 & 31.70 & 18.83 & 13.89 & 60.15 & 33.85 & 57.11 & 54.59 \\
\hline$A b$ & 83.69 & 52.54 & 62.61 & 78.53 & 79.68 & 81.15 & 64.76 & 63.64 & 64.30 & 78.47 & 84.43 & 34.96 & 63.78 & 37.79 & 38.95 \\
\hline Or & 1.38 & 1.41 & 2.17 & 2.37 & 1.22 & 3.47 & 3.26 & 4.78 & 4.00 & 2.69 & 1.68 & 4.89 & 2.37 & 5.10 & 6.46 \\
\hline
\end{tabular}

Notes: Facies abbreviations BQ-M OC = Biotite quartz-monzodiorite with two pyroxenes; Dac = Dacite; L-MG = Leuco monzogranite; BT-MG = Biotite hornblende monzogranite; Rhy = Rhyolite; HB-GD = Hornblende biotite granodiorite; $M G=$ Monzogranite; IM-D = Intermediate-mafic dikes; An = anortite; $A b=$ albite; Or = orthoclase. 
Supplementary Material: Electron microprobe analyses of alkali feldspar and plagioclase from Garzón granites and related rocks, Eastern Cordillera, Colombia.

\begin{tabular}{|c|c|c|c|c|c|c|c|c|c|c|c|c|c|c|c|}
\hline \multirow{3}{*}{$\begin{array}{l}\text { Mineral } \\
\text { Massif } \\
\text { Sample }\end{array}$} & \multicolumn{9}{|c|}{ Plagioclase } & \multicolumn{4}{|c|}{ Alkali feldspar } & \multicolumn{2}{|c|}{ Plagioclase } \\
\hline & & & & & & & & Algeci & & & & & & & \\
\hline & $\begin{array}{l}\text { GAR- } \\
358 \\
\end{array}$ & $\begin{array}{l}\text { GAR- } \\
358 \\
\end{array}$ & $\begin{array}{l}\text { GAR- } \\
358 \\
\end{array}$ & $\begin{array}{l}\text { GAR- } \\
358 \\
\end{array}$ & $\begin{array}{l}\text { GAR- } \\
358 \\
\end{array}$ & $\begin{array}{l}\text { GAR- } \\
358 \\
\end{array}$ & $\begin{array}{l}\text { GAR- } \\
358 \\
\end{array}$ & $\begin{array}{l}\text { GAR- } \\
358 \\
\end{array}$ & $\begin{array}{l}\text { GAR- } \\
358 \\
\end{array}$ & $\begin{array}{l}\text { GAR- } \\
359 \\
\end{array}$ & $\begin{array}{l}\text { GAR- } \\
359 \\
\end{array}$ & $\begin{array}{l}\text { GAR- } \\
359 \\
\end{array}$ & $\begin{array}{l}\text { GAR- } \\
359 \\
\end{array}$ & $\begin{array}{l}\text { GAR- } \\
361 \\
\end{array}$ & $\begin{array}{l}\text { GAR- } \\
361 \\
\end{array}$ \\
\hline Facies & IM-D & IM-D & IM-D & IM-D & IM-D & IM-D & IM-D & IM-D & IM-D & Rhy & Rhy & Rhy & Rhy & Dac & Dac \\
\hline $\begin{array}{l}\text { Grain/ } \\
\text { Point }\end{array}$ & pl_01-5 & pl_02-1 & pl_02-2 & pl_02-3 & pl_02-4 & pl_03-1 & pl_03-2 & pl_03-3 & pl_03-4 & Fk_01-1 & Fk_02-1 & Fk_03-1 & Fk_03-2 & pl_02-1 & pl_03-1 \\
\hline $\mathrm{SiO} 2$ & 56.84 & 49.88 & 52.32 & 53.09 & 56.57 & 54.48 & 53.87 & 54.01 & 53.34 & 63.06 & 63.06 & 63.15 & 63.65 & 55.82 & 57.25 \\
\hline TiO2 & 0.76 & 0.09 & 0.07 & 0.10 & 0.04 & 0.11 & 0.13 & 0.04 & 0.07 & 0.00 & 0.00 & 0.00 & 0.00 & 0.08 & 0.00 \\
\hline Al2O3 & 27.28 & 28.55 & 30.04 & 29.27 & 27.28 & 28.33 & 28.58 & 28.85 & 29.27 & 18.29 & 18.55 & 18.69 & 18.61 & 28.10 & 27.17 \\
\hline $\mathrm{FeO}$ & 0.44 & 0.79 & 0.62 & 0.67 & 0.45 & 0.56 & 0.61 & 0.55 & 0.62 & 0.01 & 0.06 & 0.00 & 0.04 & 0.44 & 0.32 \\
\hline $\mathrm{MnO}$ & 0.00 & 0.03 & 0.00 & 0.02 & 0.00 & 0.00 & 0.03 & 0.00 & 0.00 & 0.00 & 0.00 & 0.00 & 0.00 & 0.04 & 0.00 \\
\hline $\mathrm{MgO}$ & 0.00 & 0.02 & 0.04 & 0.07 & 0.00 & 0.00 & 0.05 & 0.00 & 0.02 & 0.00 & 0.00 & 0.00 & 0.00 & 0.00 & 0.00 \\
\hline $\mathrm{SrO}$ & 0.23 & 0.17 & 0.20 & 0.28 & 0.26 & 0.31 & 0.33 & 0.22 & 0.28 & 0.00 & 0.05 & 0.00 & 0.00 & 0.27 & 0.22 \\
\hline $\mathrm{BaO}$ & 0.04 & 0.00 & 0.00 & 0.06 & 0.00 & 0.10 & 0.05 & 0.12 & 0.00 & 0.37 & 0.47 & 0.58 & 0.43 & 0.06 & 0.06 \\
\hline $\mathrm{PbO}$ & 0.00 & 0.00 & 0.00 & 0.00 & 0.00 & 0.04 & 0.00 & 0.00 & 0.00 & 0.00 & 0.00 & 0.00 & 0.00 & 0.00 & 0.06 \\
\hline $\mathrm{CaO}$ & 8.51 & 14.10 & 11.92 & 11.45 & 8.54 & 10.22 & 10.61 & 10.63 & 11.23 & 0.00 & 0.03 & 0.01 & 0.04 & 9.37 & 8.24 \\
\hline $\mathrm{Na} 2 \mathrm{O}$ & 5.60 & 3.76 & 3.83 & 4.24 & 5.61 & 4.78 & 4.58 & 4.51 & 4.23 & 0.34 & 0.24 & 0.30 & 0.27 & 5.21 & 5.89 \\
\hline K2O & 1.00 & 0.80 & 0.78 & 0.89 & 0.79 & 1.23 & 1.14 & 1.09 & 1.02 & 15.74 & 15.84 & 15.94 & 15.93 & 0.75 & 0.85 \\
\hline Total & 100.03 & 98.19 & 99.85 & 100.13 & 99.56 & 100.16 & 99.99 & 100.04 & 100.12 & 97.84 & 98.32 & 98.73 & 99.00 & 100.14 & 100.06 \\
\hline $\mathrm{Si}$ & 10.175 & 9.365 & 9.538 & 9.659 & 10.225 & 9.890 & 9.806 & 9.811 & 9.697 & 11.942 & 11.902 & 11.884 & 11.921 & 10.059 & 10.289 \\
\hline ivAl & 5.756 & 6.318 & 6.454 & 6.277 & 5.811 & 6.061 & 6.131 & 6.176 & 6.271 & 4.082 & 4.127 & 4.145 & 4.108 & 5.968 & 5.755 \\
\hline Felll & 0.066 & 0.124 & 0.095 & 0.103 & 0.068 & 0.085 & 0.093 & 0.084 & 0.094 & 0.002 & 0.009 & 0.000 & 0.006 & 0.067 & 0.048 \\
\hline T site & 15.997 & 15.806 & 16.087 & 16.039 & 16.104 & 16.036 & 16.030 & 16.071 & 16.062 & 16.026 & 16.038 & 16.030 & 16.034 & 16.093 & 16.092 \\
\hline $\mathrm{Ti}$ & 0.103 & 0.012 & 0.009 & 0.013 & 0.005 & 0.014 & 0.017 & 0.005 & 0.009 & 0.000 & 0.000 & 0.000 & 0.000 & 0.011 & 0.000 \\
\hline $\mathrm{Mn}$ & 0.000 & 0.004 & 0.000 & 0.003 & 0.000 & 0.000 & 0.004 & 0.000 & 0.000 & 0.000 & 0.000 & 0.000 & 0.000 & 0.006 & 0.000 \\
\hline $\mathrm{Mg}$ & 0.000 & 0.006 & 0.012 & 0.018 & 0.000 & 0.000 & 0.013 & 0.000 & 0.006 & 0.000 & 0.000 & 0.000 & 0.000 & 0.000 & 0.000 \\
\hline $\mathrm{Sr}$ & 0.024 & 0.019 & 0.021 & 0.029 & 0.028 & 0.033 & 0.034 & 0.023 & 0.030 & 0.000 & 0.006 & 0.000 & 0.000 & 0.028 & 0.023 \\
\hline $\mathrm{Ba}$ & 0.003 & 0.000 & 0.000 & 0.004 & 0.000 & 0.007 & 0.004 & 0.008 & 0.000 & 0.028 & 0.034 & 0.042 & 0.031 & 0.004 & 0.004 \\
\hline $\mathrm{Pb}$ & 0.000 & 0.000 & 0.000 & 0.000 & 0.000 & 0.002 & 0.000 & 0.000 & 0.000 & 0.000 & 0.000 & 0.000 & 0.000 & 0.000 & 0.003 \\
\hline $\mathrm{Ca}$ & 1.632 & 2.836 & 2.328 & 2.232 & 1.654 & 1.988 & 2.069 & 2.069 & 2.187 & 0.001 & 0.005 & 0.002 & 0.007 & 1.809 & 1.587 \\
\hline $\mathrm{Na}$ & 1.944 & 1.369 & 1.354 & 1.496 & 1.966 & 1.682 & 1.616 & 1.588 & 1.491 & 0.124 & 0.089 & 0.110 & 0.099 & 1.820 & 2.052 \\
\hline $\mathrm{K}$ & 0.228 & 0.192 & 0.182 & 0.206 & 0.181 & 0.285 & 0.264 & 0.252 & 0.238 & 3.802 & 3.814 & 3.827 & 3.806 & 0.172 & 0.195 \\
\hline M site & 3.933 & 4.438 & 3.907 & 4.002 & 3.834 & 4.012 & 4.022 & 3.946 & 3.961 & 3.954 & 3.948 & 3.982 & 3.944 & 3.849 & 3.864 \\
\hline Cations & 19.930 & 20.244 & 19.994 & 20.040 & 19.938 & 20.048 & 20.052 & 20.016 & 20.023 & 19.980 & 19.986 & 20.011 & 19.978 & 19.943 & 19.957 \\
\hline An & 42.91 & 64.51 & 60.25 & 56.74 & 43.51 & 50.26 & 52.39 & 52.92 & 55.86 & 0.02 & 0.14 & 0.05 & 0.18 & 47.59 & 41.39 \\
\hline$A b$ & 51.09 & 31.13 & 35.03 & 38.02 & 51.72 & 42.54 & 40.93 & 40.63 & 38.07 & 3.15 & 2.27 & 2.80 & 2.53 & 47.89 & 53.54 \\
\hline Or & 6.00 & 4.36 & 4.72 & 5.24 & 4.77 & 7.20 & 6.68 & 6.45 & 6.07 & 96.84 & 97.59 & 97.16 & 97.29 & 4.52 & 5.07 \\
\hline
\end{tabular}

Notes: Facies abbreviations BQ-M OC = Biotite quartz-monzodiorite with two pyroxenes; Dac = Dacite; L-MG = Leuco monzogran
Hornblende biotite granodiorite; $M G=$ Monzogranite; IM-D = Intermediate-mafic dikes; $A n=$ anortite; $A b=$ albite; Or = orthoclase. 
Supplementary Material: Electron microprobe analyses of alkali feldspar and plagioclase from Garzón granites and related rocks, Eastern Cordillera, Colombia.

\begin{tabular}{|c|c|c|c|c|c|c|c|c|c|c|c|c|}
\hline \multirow{3}{*}{$\begin{array}{l}\text { Mineral } \\
\text { Massif } \\
\text { Sample }\end{array}$} & \multicolumn{12}{|c|}{ Alkali feldspar } \\
\hline & \multicolumn{12}{|c|}{ Algeciras } \\
\hline & $\begin{array}{l}\text { GAR- } \\
361\end{array}$ & $\begin{array}{l}\text { GAR- } \\
361\end{array}$ & $\begin{array}{l}\text { GAR- } \\
361\end{array}$ & $\begin{array}{l}\text { GAR- } \\
361\end{array}$ & $\begin{array}{l}\text { GAR- } \\
361\end{array}$ & $\begin{array}{l}\text { GAR- } \\
361\end{array}$ & $\begin{array}{l}\text { GAR- } \\
361\end{array}$ & $\begin{array}{l}\text { GAR- } \\
361\end{array}$ & $\begin{array}{l}\text { GAR- } \\
361\end{array}$ & $\begin{array}{l}\text { GAR- } \\
361\end{array}$ & $\begin{array}{l}\text { GAR- } \\
361\end{array}$ & $\begin{array}{l}\text { GAR- } \\
361\end{array}$ \\
\hline Facies & Dac & Dac & Dac & Dac & Dac & Dac & Dac & Dac & Dac & Dac & Dac & Dac \\
\hline $\begin{array}{l}\text { Grain/ } \\
\text { Point }\end{array}$ & pl_03-2 & pl_03-3 & pl_05-1 & pl_05-2 & pl_05-3 & pl_05-4 & pl_05-5 & pl_07-1 & pl_07-2 & pl_07-3 & pl_07-4 & pl_03-2 \\
\hline $\mathrm{SiO} 2$ & 56.43 & 57.54 & 53.96 & 52.67 & 56.51 & 57.76 & 58.39 & 56.30 & 55.98 & 57.69 & 57.71 & 56.43 \\
\hline $\mathrm{TiO} 2$ & 0.00 & 0.00 & 0.00 & 0.06 & 0.00 & 0.08 & 0.00 & 0.00 & 0.00 & 0.00 & 0.00 & 0.00 \\
\hline Al2O3 & 27.80 & 26.46 & 28.97 & 29.96 & 27.39 & 26.61 & 26.20 & 27.73 & 27.82 & 26.87 & 26.90 & 27.80 \\
\hline $\mathrm{FeO}$ & 0.40 & 0.46 & 0.33 & 0.41 & 0.37 & 0.36 & 0.39 & 0.44 & 0.53 & 0.37 & 0.24 & 0.40 \\
\hline $\mathrm{MnO}$ & 0.00 & 0.03 & 0.03 & 0.04 & 0.00 & 0.00 & 0.00 & 0.02 & 0.02 & 0.02 & 0.00 & 0.00 \\
\hline $\mathrm{MgO}$ & 0.00 & 0.00 & 0.00 & 0.00 & 0.00 & 0.00 & 0.00 & 0.00 & 0.00 & 0.00 & 0.00 & 0.00 \\
\hline $\mathrm{SrO}$ & 0.26 & 0.17 & 0.28 & 0.17 & 0.27 & 0.18 & 0.24 & 0.24 & 0.23 & 0.22 & 0.24 & 0.26 \\
\hline $\mathrm{BaO}$ & 0.09 & 0.00 & 0.00 & 0.00 & 0.09 & 0.00 & 0.11 & 0.04 & 0.00 & 0.04 & 0.08 & 0.09 \\
\hline $\mathrm{PbO}$ & 0.00 & 0.00 & 0.00 & 0.06 & 0.00 & 0.00 & 0.00 & 0.00 & 0.00 & 0.00 & 0.00 & 0.00 \\
\hline $\mathrm{CaO}$ & 9.16 & 6.43 & 10.89 & 11.69 & 8.95 & 7.97 & 7.50 & 9.19 & 9.40 & 8.20 & 6.91 & 9.16 \\
\hline $\mathrm{Na} 2 \mathrm{O}$ & 5.36 & 6.19 & 4.63 & 4.14 & 5.48 & 5.97 & 6.14 & 5.52 & 5.49 & 6.06 & 6.19 & 5.36 \\
\hline $\mathrm{K} 2 \mathrm{O}$ & 0.75 & 2.67 & 0.49 & 0.46 & 0.76 & 0.94 & 1.03 & 0.84 & 0.80 & 0.73 & 1.45 & 0.75 \\
\hline Total & 100.28 & 99.96 & 99.63 & 99.69 & 99.84 & 99.88 & 100.03 & 100.32 & 100.27 & 100.20 & 99.72 & 100.28 \\
\hline $\mathrm{Si}$ & 10.144 & 10.405 & 9.807 & 9.592 & 10.198 & 10.383 & 10.482 & 10.127 & 10.084 & 10.343 & 10.394 & 10.144 \\
\hline ivAl & 5.890 & 5.639 & 6.205 & 6.431 & 5.825 & 5.638 & 5.543 & 5.879 & 5.907 & 5.678 & 5.710 & 5.890 \\
\hline Felll & 0.060 & 0.069 & 0.051 & 0.062 & 0.056 & 0.054 & 0.059 & 0.066 & 0.080 & 0.056 & 0.037 & 0.060 \\
\hline T site & $\begin{array}{r}16.094 \\
\end{array}$ & 16.114 & 16.063 & 16.085 & $\begin{array}{r}16.079 \\
\end{array}$ & 16.075 & 16.084 & $\begin{array}{r}16.072 \\
\end{array}$ & $\begin{array}{r}16.071 \\
\end{array}$ & 16.077 & 16.140 & 16.094 \\
\hline $\mathrm{Ti}$ & 0.000 & 0.000 & 0.000 & 0.008 & 0.000 & 0.010 & 0.000 & 0.000 & 0.000 & 0.000 & 0.000 & 0.000 \\
\hline $\mathrm{Mn}$ & 0.000 & 0.004 & 0.004 & 0.006 & 0.000 & 0.000 & 0.000 & 0.004 & 0.003 & 0.003 & 0.000 & 0.000 \\
\hline $\mathrm{Mg}$ & 0.000 & 0.000 & 0.000 & 0.000 & 0.000 & 0.000 & 0.000 & 0.000 & 0.000 & 0.000 & 0.000 & 0.000 \\
\hline $\mathrm{Sr}$ & 0.027 & 0.018 & 0.029 & 0.018 & 0.028 & 0.019 & 0.025 & 0.025 & 0.024 & 0.023 & 0.025 & 0.027 \\
\hline $\mathrm{Ba}$ & 0.006 & 0.000 & 0.000 & 0.000 & 0.006 & 0.000 & 0.007 & 0.003 & 0.000 & 0.003 & 0.006 & 0.006 \\
\hline $\mathrm{Pb}$ & 0.000 & 0.000 & 0.000 & 0.003 & 0.000 & 0.000 & 0.000 & 0.000 & 0.000 & 0.000 & 0.000 & 0.000 \\
\hline $\mathrm{Ca}$ & 1.764 & 1.246 & 2.121 & 2.281 & 1.730 & 1.535 & 1.443 & 1.771 & 1.814 & 1.575 & 1.333 & 1.764 \\
\hline $\mathrm{Na}$ & 1.868 & 2.170 & 1.632 & 1.462 & 1.917 & 2.081 & 2.137 & 1.925 & 1.918 & 2.107 & 2.162 & 1.868 \\
\hline K & 0.172 & 0.616 & 0.113 & 0.106 & 0.174 & 0.215 & 0.236 & 0.193 & 0.183 & 0.167 & 0.333 & 0.172 \\
\hline M site & 3.837 & 4.055 & 3.899 & 3.884 & 3.856 & 3.860 & 3.849 & 3.921 & 3.942 & 3.877 & 3.858 & 3.837 \\
\hline Cations & 19.931 & 20.168 & 19.963 & 19.969 & 19.935 & 19.935 & 19.933 & 19.992 & 20.012 & 19.954 & 19.999 & 19.931 \\
\hline An & 46.37 & 30.90 & 54.86 & 59.26 & 45.28 & 40.07 & 37.80 & 45.54 & 46.35 & 40.93 & 34.83 & 46.37 \\
\hline$A b$ & 49.11 & 53.83 & 42.21 & 37.98 & 50.17 & 54.32 & 56.00 & 49.50 & 48.98 & 54.73 & 56.47 & 49.11 \\
\hline Or & 4.52 & 15.28 & 2.93 & 2.76 & 4.55 & 5.61 & 6.19 & 4.96 & 4.67 & 4.34 & 8.70 & 4.52 \\
\hline
\end{tabular}

Notes: Facies abbreviations BQ-M OC = Biotite quartz-monzodiorite with two pyroxenes; Dac = Dacite; L-MG = Leuco monzogranite; BT-MG = Biotite hornblende monzogranite; Rhy = Rhyolite; HB-GD = Hornblende biotite granodiorite; $M G=$ Monzogranite; IM-D = Intermediate-mafic dikes; An = anortite; $A b=$ albite; Or = orthoclase. 
Supplementary Material: Electron microprobe analyses of alkali feldspar and plagioclase from Garzón granites and related rocks, Eastern Cordillera, Colombia.

\begin{tabular}{|c|c|c|c|c|c|c|c|c|c|c|c|c|c|c|}
\hline \multirow{3}{*}{$\begin{array}{l}\text { Mineral } \\
\text { Massif } \\
\text { Sample }\end{array}$} & \multicolumn{2}{|c|}{ Alkali feldspar } & \multicolumn{12}{|c|}{ Plagioclase } \\
\hline & & & & & & & Algecir & & & & & & & \\
\hline & $\begin{array}{l}\text { GAR- } \\
372\end{array}$ & GAR-372 & $\begin{array}{l}\text { GAR- } \\
372\end{array}$ & $\begin{array}{l}\text { GAR- } \\
372\end{array}$ & $\begin{array}{l}\text { GAR- } \\
372\end{array}$ & $\begin{array}{l}\text { GAR- } \\
372\end{array}$ & $\begin{array}{l}\text { GAR- } \\
372\end{array}$ & $\begin{array}{l}\text { GAR- } \\
372\end{array}$ & $\begin{array}{l}\text { GAR- } \\
372\end{array}$ & $\begin{array}{l}\text { GAR- } \\
372\end{array}$ & $\begin{array}{l}\text { GAR- } \\
372\end{array}$ & $\begin{array}{l}\text { GAR- } \\
372\end{array}$ & $\begin{array}{l}\text { GAR- } \\
372\end{array}$ & $\begin{array}{l}\text { GAR- } \\
372\end{array}$ \\
\hline Facies & BH-MG & BH-MG & BH-MG & BH-MG & BH-MG & BH-MG & BH-MG & BH-MG & BH-MG & BH-MG & BH-MG & BH-MG & BH-MG & BH-MG \\
\hline $\begin{array}{l}\text { Grain/ } \\
\text { Point }\end{array}$ & $\begin{array}{l}\text { Fk_02 } \\
\mathrm{R}-1\end{array}$ & $\begin{array}{l}\text { Fk_03_R- } \\
1\end{array}$ & $\begin{array}{l}\text { pl_01_R } \\
-1\end{array}$ & $\begin{array}{l}\text { pl_01_R } \\
-2\end{array}$ & $\begin{array}{l}\text { pl_01_R } \\
-3\end{array}$ & $\begin{array}{l}\text { pl_01_R } \\
-4\end{array}$ & $\begin{array}{l}\text { pl_01_R } \\
-5\end{array}$ & pl_01_R & $\begin{array}{l}\text { pl_02_R } \\
-1\end{array}$ & $\begin{array}{l}\text { pl_02_R } \\
-2\end{array}$ & $\begin{array}{l}\text { pl_02_R } \\
-3\end{array}$ & pl_02_R & $\begin{array}{l}\text { pl_02_R } \\
-5\end{array}$ & $\begin{array}{l}\text { pl_02_R } \\
-6\end{array}$ \\
\hline $\mathrm{SiO} 2$ & 63.96 & 64.00 & 58.66 & 58.79 & 59.96 & 60.45 & 60.67 & 63.80 & 60.33 & 61.00 & 59.01 & 60.36 & 59.97 & 63.13 \\
\hline TiO2 & 0.00 & 0.00 & 0.00 & 0.00 & 0.00 & 0.00 & 0.00 & 0.05 & 0.00 & 0.00 & 0.06 & 0.00 & 0.00 & 0.00 \\
\hline Al2O3 & 18.76 & 19.16 & 25.81 & 25.63 & 24.90 & 24.48 & 24.33 & 22.10 & 24.70 & 24.21 & 25.41 & 24.71 & 24.77 & 22.64 \\
\hline $\mathrm{FeO}$ & 0.10 & 0.10 & 0.13 & 0.09 & 0.08 & 0.19 & 0.23 & 0.20 & 0.19 & 0.12 & 0.19 & 0.20 & 0.30 & 0.22 \\
\hline $\mathrm{MnO}$ & 0.00 & 0.04 & 0.00 & 0.00 & 0.00 & 0.00 & 0.00 & 0.00 & 0.00 & 0.00 & 0.00 & 0.00 & 0.00 & 0.00 \\
\hline $\mathrm{MgO}$ & 0.00 & 0.00 & 0.00 & 0.00 & 0.00 & 0.00 & 0.00 & 0.00 & 0.00 & 0.00 & 0.00 & 0.00 & 0.00 & 0.00 \\
\hline SrO & 0.09 & 0.08 & 0.17 & 0.22 & 0.14 & 0.17 & 0.16 & 0.12 & 0.19 & 0.24 & 0.19 & 0.16 & 0.20 & 0.11 \\
\hline $\mathrm{BaO}$ & 0.24 & 0.70 & 0.05 & 0.00 & 0.06 & 0.00 & 0.11 & 0.11 & 0.00 & 0.06 & 0.00 & 0.10 & 0.05 & 0.04 \\
\hline $\mathrm{PbO}$ & 0.00 & 0.00 & 0.00 & 0.00 & 0.07 & 0.00 & 0.00 & 0.00 & 0.05 & 0.10 & 0.05 & 0.00 & 0.07 & 0.00 \\
\hline $\mathrm{CaO}$ & 0.12 & 0.10 & 7.10 & 6.78 & 5.82 & 5.24 & 5.37 & 2.95 & 5.59 & 5.14 & 6.40 & 5.62 & 5.87 & 3.73 \\
\hline $\mathrm{Na} 2 \mathrm{O}$ & 1.33 & 2.31 & 7.22 & 7.35 & 7.70 & 8.02 & 7.86 & 9.32 & 7.81 & 8.03 & 7.57 & 7.76 & 7.70 & 8.98 \\
\hline $\mathrm{K} 2 \mathrm{O}$ & 14.47 & 12.85 & 0.47 & 0.53 & 0.56 & 0.63 & 0.71 & 0.61 & 0.63 & 0.62 & 0.44 & 0.60 & 0.55 & 0.41 \\
\hline Total & 99.08 & 99.33 & 99.64 & 99.39 & 99.30 & 99.25 & 99.47 & 99.27 & 99.51 & 99.53 & 99.36 & 99.54 & 99.48 & 99.26 \\
\hline $\mathrm{Si}$ & 11.902 & 11.848 & 10.541 & 10.580 & 10.768 & 10.854 & 10.876 & 11.367 & 10.811 & 10.918 & 10.621 & 10.813 & 10.767 & 11.254 \\
\hline ivAl & 4.114 & 4.180 & 5.466 & 5.436 & 5.270 & 5.180 & 5.140 & 4.641 & 5.217 & 5.107 & 5.390 & 5.217 & 5.241 & 4.757 \\
\hline Felll & 0.016 & 0.015 & 0.020 & 0.013 & 0.011 & 0.028 & 0.034 & 0.030 & 0.028 & 0.019 & 0.028 & 0.031 & 0.045 & 0.032 \\
\hline T site & 16.032 & 16.043 & 16.026 & 16.029 & 16.049 & 16.062 & 16.051 & 16.038 & 16.056 & 16.044 & 16.039 & 16.060 & 16.053 & 16.043 \\
\hline $\mathrm{Ti}$ & 0.000 & 0.000 & 0.000 & 0.000 & 0.000 & 0.000 & 0.000 & 0.006 & 0.000 & 0.000 & 0.008 & 0.000 & 0.000 & 0.000 \\
\hline $\mathrm{Mn}$ & 0.000 & 0.006 & 0.000 & 0.000 & 0.000 & 0.000 & 0.000 & 0.000 & 0.000 & 0.000 & 0.000 & 0.000 & 0.000 & 0.000 \\
\hline $\mathrm{Mg}$ & 0.000 & 0.000 & 0.000 & 0.000 & 0.001 & 0.000 & 0.000 & 0.000 & 0.000 & 0.000 & 0.000 & 0.000 & 0.000 & 0.000 \\
\hline $\mathrm{Sr}$ & 0.010 & 0.009 & 0.018 & 0.022 & 0.014 & 0.018 & 0.017 & 0.012 & 0.020 & 0.025 & 0.020 & 0.017 & 0.021 & 0.011 \\
\hline $\mathrm{Ba}$ & 0.018 & 0.051 & 0.003 & 0.000 & 0.004 & 0.000 & 0.008 & 0.008 & 0.000 & 0.004 & 0.000 & 0.007 & 0.003 & 0.003 \\
\hline $\mathrm{Pb}$ & 0.000 & 0.000 & 0.000 & 0.000 & 0.003 & 0.000 & 0.000 & 0.000 & 0.002 & 0.005 & 0.002 & 0.000 & 0.003 & 0.000 \\
\hline $\mathrm{Ca}$ & 0.024 & 0.020 & 1.367 & 1.307 & 1.120 & 1.008 & 1.031 & 0.563 & 1.073 & 0.986 & 1.234 & 1.079 & 1.129 & 0.712 \\
\hline $\mathrm{Na}$ & 0.479 & 0.829 & 2.515 & 2.565 & 2.681 & 2.792 & 2.732 & 3.220 & 2.714 & 2.787 & 2.642 & 2.695 & 2.680 & 3.104 \\
\hline $\mathrm{K}$ & 3.435 & 3.035 & 0.109 & 0.121 & 0.129 & 0.143 & 0.162 & 0.139 & 0.144 & 0.143 & 0.101 & 0.137 & 0.126 & 0.093 \\
\hline M site & 3.965 & 3.950 & 4.012 & 4.016 & 3.953 & 3.961 & 3.950 & 3.948 & 3.953 & 3.949 & 4.008 & 3.935 & 3.963 & 3.924 \\
\hline Cations & 19.997 & 19.993 & 20.038 & 20.045 & 20.002 & 20.023 & 20.001 & 19.986 & 20.009 & 19.993 & 20.047 & 19.995 & 20.016 & 19.966 \\
\hline An & 0.60 & 0.53 & 34.25 & 32.74 & 28.49 & 25.56 & 26.28 & 14.36 & 27.31 & 25.18 & 31.03 & 27.58 & 28.69 & 18.22 \\
\hline $\mathrm{Ab}$ & 12.15 & 21.35 & 63.03 & 64.23 & 68.22 & 70.80 & 69.60 & 82.09 & 69.04 & 71.18 & 66.42 & 68.92 & 68.11 & 79.39 \\
\hline Or & 87.24 & 78.13 & 2.72 & 3.03 & 3.29 & 3.63 & 4.13 & 3.55 & 3.66 & 3.64 & 2.55 & 3.50 & 3.20 & 2.39 \\
\hline
\end{tabular}

Notes: Facies abbreviations BQ-M OC = Biotite quartz-monzodiorite with two pyroxenes; Dac = Dacite; L-MG = Leuco monzogranite; BT-MG = Biotite hornblende monzogranite; Rhy = Rhyolite; HB-GD = Hornblende biotite granodiorite; $M G=$ Monzogranite; IM-D = Intermediate-mafic dikes; An = anortite; $A b=$ albite; Or = orthoclase. 
Supplementary Material: Electron microprobe analyses of alkali feldspar and plagioclase from Garzón granites and related rocks, Eastern Cordillera, Colombia.

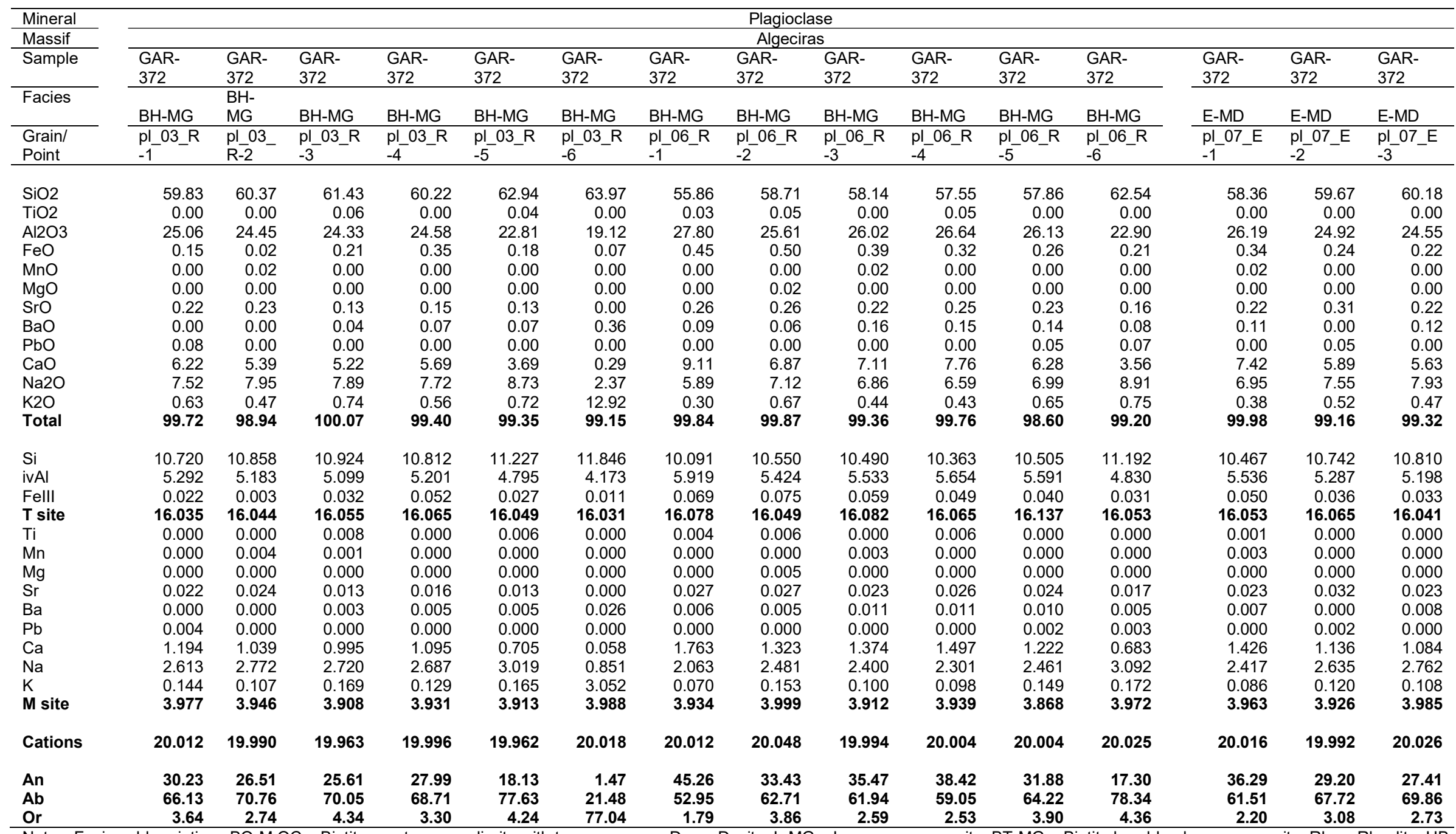

Notes: Facies abbreviations BQ-M OC = Biotite quartz-monzodiorite with two pyroxenes; Dac = Dacite; L-MG = Leuco monzogranite; BT-MG = Biotite hornblende monzogranite; Rhy = Rhyolite; HB-GD = Hornblende biotite granodiorite; $M G=$ Monzogranite; IM-D = Intermediate-mafic dikes; An = anortite; $A b=$ albite; Or = orthoclase. 
Supplementary Material: Electron microprobe analyses of alkali feldspar and plagioclase from Garzón granites and related rocks, Eastern Cordillera, Colombia.

\begin{tabular}{|c|c|c|c|c|c|c|c|c|c|c|c|c|c|c|c|}
\hline \multirow{3}{*}{$\begin{array}{l}\text { Mineral } \\
\text { Massif } \\
\text { Sample }\end{array}$} & \multicolumn{12}{|c|}{ Plagioclase } & \multirow{2}{*}{\multicolumn{3}{|c|}{$\begin{array}{c}\text { Alkali feldspar } \\
\text { Altamira }\end{array}$}} \\
\hline & \multicolumn{12}{|c|}{ Algeciras } & & & \\
\hline & $\begin{array}{l}\text { GAR- } \\
372 \\
\end{array}$ & $\begin{array}{l}\text { GAR- } \\
372 \\
\end{array}$ & $\begin{array}{l}\text { GAR- } \\
372 \\
\end{array}$ & $\begin{array}{l}\text { GAR- } \\
372 \\
\end{array}$ & $\begin{array}{l}\text { GAR- } \\
372 \\
\end{array}$ & $\begin{array}{l}\text { GAR- } \\
372 \\
\end{array}$ & $\begin{array}{l}\text { GAR- } \\
372 \\
\end{array}$ & $\begin{array}{l}\text { GAR- } \\
372 \\
\end{array}$ & $\begin{array}{l}\text { GAR- } \\
372 \\
\end{array}$ & $\begin{array}{l}\text { GAR- } \\
372 \\
\end{array}$ & $\begin{array}{l}\text { GAR- } \\
372 \\
\end{array}$ & $\begin{array}{l}\text { GAR- } \\
372 \\
\end{array}$ & $\begin{array}{l}\text { GAR- } \\
383 \\
\end{array}$ & $\begin{array}{l}\text { GAR- } \\
383 \\
\end{array}$ & $\begin{array}{l}\text { GAR- } \\
383 \\
\end{array}$ \\
\hline Facies & E-MD & E-MD & E-MD & E-MD & E-MD & E-MD & E-MD & E-MD & E-MD & E-MD & E-MD & E-MD & Rhy & Rhy & Rhy \\
\hline $\begin{array}{l}\text { Grain/ } \\
\text { Point }\end{array}$ & $\begin{array}{l}\text { pl_07_E } \\
-4\end{array}$ & $\begin{array}{l}\text { pl_07_- } \\
\text { E-5 }\end{array}$ & pl_09_E & pl_09_E & $\begin{array}{l}\text { pl_09_E } \\
-3\end{array}$ & $\begin{array}{l}\text { pl_09_E } \\
-4\end{array}$ & $\begin{array}{l}\text { pl_09_E } \\
-5\end{array}$ & pl_10_E & ${ }_{-2}$ pl_10_E & $\begin{array}{l}\text { pl_10_E } \\
-3\end{array}$ & $\begin{array}{l}\text { pl_10_E } \\
-4\end{array}$ & $\begin{array}{l}\text { pl_10_E } \\
-5\end{array}$ & Fk_01-1 & Fk_02-1 & Fk_03-1 \\
\hline $\mathrm{SiO} 2$ & 59.62 & 60.47 & 53.78 & 53.60 & 56.96 & 54.67 & 59.28 & 57.29 & 60.03 & 57.52 & 54.75 & 58.90 & 64.38 & 64.51 & 63.45 \\
\hline TiO2 & 0.05 & 0.00 & 0.05 & 0.03 & 0.00 & 0.04 & 0.00 & 0.00 & 0.00 & 0.06 & 0.00 & 0.03 & 0.04 & 0.03 & 0.04 \\
\hline Al2O3 & 25.14 & 24.81 & 29.19 & 29.20 & 26.63 & 28.65 & 25.24 & 26.66 & 24.73 & 26.27 & 28.56 & 25.23 & 18.84 & 18.74 & 18.71 \\
\hline $\mathrm{FeO}$ & 0.27 & 0.55 & 0.28 & 0.45 & 0.32 & 0.30 & 0.37 & 0.25 & 0.26 & 0.32 & 0.40 & 0.38 & 0.17 & 0.00 & 0.03 \\
\hline $\mathrm{MnO}$ & 0.00 & 0.00 & 0.00 & 0.00 & 0.00 & 0.03 & 0.00 & 0.03 & 0.00 & 0.00 & 0.00 & 0.00 & 0.02 & 0.00 & 0.00 \\
\hline $\mathrm{MgO}$ & 0.00 & 0.00 & 0.00 & 0.00 & 0.00 & 0.00 & 0.00 & 0.00 & 0.00 & 0.00 & 0.00 & 0.00 & 0.00 & 0.00 & 0.02 \\
\hline $\mathrm{SrO}$ & 0.19 & 0.10 & 0.36 & 0.40 & 0.32 & 0.29 & 0.21 & 0.25 & 0.21 & 0.30 & 0.26 & 0.16 & 0.07 & 0.09 & 0.07 \\
\hline $\mathrm{BaO}$ & 0.16 & 0.00 & 0.08 & 0.09 & 0.04 & 0.06 & 0.08 & 0.07 & 0.17 & 0.07 & 0.08 & 0.00 & 0.10 & 0.19 & 0.16 \\
\hline $\mathrm{PbO}$ & 0.00 & 0.07 & 0.00 & 0.00 & 0.00 & 0.07 & 0.00 & 0.00 & 0.00 & 0.00 & 0.00 & 0.00 & 0.00 & 0.00 & 0.00 \\
\hline $\mathrm{CaO}$ & 6.08 & 5.67 & 10.87 & 10.65 & 7.75 & 9.78 & 6.47 & 7.86 & 5.70 & 7.63 & 9.68 & 6.43 & 0.15 & 0.02 & 0.06 \\
\hline $\mathrm{Na} 2 \mathrm{O}$ & 7.77 & 8.01 & 4.93 & 5.05 & 6.73 & 5.33 & 7.25 & 6.58 & 7.95 & 6.82 & 5.55 & 7.67 & 1.13 & 0.85 & 0.24 \\
\hline $\mathrm{K} 2 \mathrm{O}$ & 0.45 & 0.35 & 0.23 & 0.24 & 0.41 & 0.26 & 0.50 & 0.29 & 0.58 & 0.40 & 0.23 & 0.37 & 14.86 & 15.47 & 16.02 \\
\hline Total & 99.76 & 100.05 & 99.81 & 99.74 & 99.16 & 99.47 & 99.47 & 99.27 & 99.68 & 99.43 & 99.53 & 99.16 & 99.75 & 99.91 & 98.85 \\
\hline $\mathrm{Si}$ & 10.689 & 10.786 & 9.762 & 9.747 & 10.324 & 9.921 & 10.662 & 10.352 & 10.769 & 10.394 & 9.932 & 10.624 & 11.902 & 11.930 & 11.893 \\
\hline ivAl & 5.312 & 5.216 & 6.245 & 6.258 & 5.689 & 6.128 & 5.350 & 5.678 & 5.229 & 5.595 & 6.106 & 5.363 & 4.105 & 4.084 & 4.133 \\
\hline Felll & 0.040 & 0.081 & 0.043 & 0.068 & 0.048 & 0.045 & 0.055 & 0.037 & 0.039 & 0.049 & 0.061 & 0.057 & 0.026 & 0.001 & 0.005 \\
\hline T site & 16.042 & 16.083 & 16.050 & 16.074 & 16.061 & 16.093 & 16.067 & 16.067 & 16.036 & 16.037 & 16.098 & 16.044 & 16.033 & 16.015 & 16.032 \\
\hline $\mathrm{Ti}$ & 0.006 & 0.000 & 0.006 & 0.004 & 0.000 & 0.005 & 0.000 & 0.000 & 0.000 & 0.009 & 0.000 & 0.004 & 0.005 & 0.004 & 0.006 \\
\hline $\mathrm{Mn}$ & 0.000 & 0.000 & 0.000 & 0.000 & 0.000 & 0.005 & 0.000 & 0.004 & 0.000 & 0.000 & 0.000 & 0.000 & 0.003 & 0.000 & 0.000 \\
\hline $\mathrm{Mg}$ & 0.000 & 0.000 & 0.000 & 0.000 & 0.000 & 0.000 & 0.000 & 0.000 & 0.001 & 0.000 & 0.000 & 0.000 & 0.000 & 0.000 & 0.006 \\
\hline $\mathrm{Sr}$ & 0.020 & 0.010 & 0.038 & 0.043 & 0.033 & 0.031 & 0.022 & 0.026 & 0.022 & 0.032 & 0.027 & 0.016 & 0.008 & 0.010 & 0.007 \\
\hline $\mathrm{Ba}$ & 0.011 & 0.000 & 0.006 & 0.006 & 0.003 & 0.004 & 0.006 & 0.005 & 0.012 & 0.005 & 0.006 & 0.000 & 0.007 & 0.014 & 0.012 \\
\hline $\mathrm{Pb}$ & 0.000 & 0.003 & 0.000 & 0.000 & 0.000 & 0.003 & 0.000 & 0.000 & 0.000 & 0.000 & 0.000 & 0.000 & 0.000 & 0.000 & 0.000 \\
\hline $\mathrm{Ca}$ & 1.168 & 1.084 & 2.114 & 2.075 & 1.505 & 1.902 & 1.247 & 1.522 & 1.096 & 1.477 & 1.881 & 1.243 & 0.030 & 0.004 & 0.012 \\
\hline $\mathrm{Na}$ & 2.701 & 2.770 & 1.735 & 1.781 & 2.365 & 1.875 & 2.528 & 2.305 & 2.765 & 2.389 & 1.952 & 2.682 & 0.403 & 0.306 & 0.086 \\
\hline $\mathrm{K}$ & 0.102 & 0.080 & 0.054 & 0.056 & 0.094 & 0.059 & 0.115 & 0.066 & 0.133 & 0.092 & 0.053 & 0.086 & 3.504 & 3.649 & 3.831 \\
\hline M site & 4.008 & 3.947 & 3.954 & 3.964 & 4.001 & 3.884 & 3.918 & 3.928 & 4.029 & 4.004 & 3.920 & 4.031 & 3.961 & 3.987 & 3.961 \\
\hline Cations & 20.050 & 20.031 & 20.004 & 20.038 & 20.061 & 19.977 & 19.985 & 19.995 & 20.066 & 20.041 & 20.018 & 20.075 & 19.994 & 20.002 & 19.993 \\
\hline An & 29.41 & 27.55 & 54.16 & 53.05 & 37.96 & 49.57 & 32.05 & 39.09 & 27.43 & 37.31 & 48.41 & 30.98 & 0.76 & 0.11 & 0.32 \\
\hline$A b$ & 68.02 & 70.42 & 44.45 & 45.52 & 59.66 & 48.89 & 64.98 & 59.21 & 69.24 & 60.35 & 50.22 & 66.87 & 10.25 & 7.72 & 2.20 \\
\hline Or & 2.57 & 2.03 & 1.39 & 1.43 & 2.38 & 1.55 & 2.97 & 1.70 & 3.33 & 2.34 & 1.37 & 2.15 & 88.99 & 92.16 & 97.48 \\
\hline
\end{tabular}

Notes: Facies abbreviations BQ-M OC = Biotite quartz-monzodiorite with two pyroxenes; Dac = Dacite; L-MG = Leuco monzogranite; BT-MG = Biotite hornblende monzogranite; Rhy = Rhyolite; HB-GD = Hornblende biotite granodiorite; $M G=$ Monzogranite; IM-D = Intermediate-mafic dikes; An = anortite; $A b=$ albite; Or = orthoclase. 
Supplementary Material: Electron microprobe analyses of alkali feldspar and plagioclase from Garzón granites and related rocks, Eastern Cordillera, Colombia.

\begin{tabular}{|c|c|c|c|c|c|c|c|c|c|c|c|c|c|c|c|}
\hline \multirow{3}{*}{$\begin{array}{l}\text { Mineral } \\
\text { Massif } \\
\text { Sample }\end{array}$} & \multicolumn{15}{|c|}{ Alkali feldspar } \\
\hline & \multicolumn{15}{|c|}{ Altamira } \\
\hline & $\begin{array}{l}\text { GAR- } \\
383 \\
\end{array}$ & $\begin{array}{l}\text { GAR- } \\
383 \\
\end{array}$ & $\begin{array}{l}\text { GAR- } \\
383 \\
\end{array}$ & $\begin{array}{l}\text { GAR- } \\
383 \\
\end{array}$ & $\begin{array}{l}\text { GAR- } \\
383 \\
\end{array}$ & $\begin{array}{l}\text { GAR- } \\
383 \\
\end{array}$ & $\begin{array}{l}\text { GAR- } \\
383 \\
\end{array}$ & $\begin{array}{l}\text { GAR- } \\
383 \\
\end{array}$ & $\begin{array}{l}\text { GAR- } \\
383 \\
\end{array}$ & $\begin{array}{l}\text { GAR- } \\
383 \\
\end{array}$ & $\begin{array}{l}\text { GAR- } \\
383 \\
\end{array}$ & $\begin{array}{l}\text { GAR- } \\
383 \\
\end{array}$ & $\begin{array}{l}\text { GAR- } \\
386 \\
\end{array}$ & $\begin{array}{l}\text { GAR- } \\
386 \\
\end{array}$ & $\begin{array}{l}\text { GAR- } \\
386 \\
\end{array}$ \\
\hline Facies & Rhy & Rhy & Rhy & Rhy & Rhy & Rhy & Rhy & Rhy & Rhy & Rhy & Rhy & Rhy & HB-GD & HB-GD & HB-GD \\
\hline $\begin{array}{l}\text { Grain/ } \\
\text { Point }\end{array}$ & Fk_03-2 & $\mathrm{Fk} \_04-1$ & Fk_04-2 & Fk_04-3 & Fk_04-4 & pl_01-1 & pl_01-2 & pl_01-3 & pl_05-1 & pl_05-2 & pl_05-3 & pl_05-4 & Fk_01-1 & Fk_02-1 & Fk_03-1 \\
\hline $\mathrm{SiO} 2$ & 63.97 & 63.86 & 64.79 & 66.61 & 65.71 & 65.49 & 65.46 & 65.56 & 65.75 & 65.73 & 66.17 & 88.04 & 63.34 & 64.24 & 64.48 \\
\hline TiO2 & 0.00 & 0.05 & 0.00 & 0.00 & 0.00 & 0.00 & 0.00 & 0.00 & 0.00 & 0.00 & 0.00 & 0.04 & 0.00 & 0.00 & 0.00 \\
\hline $\mathrm{Al} 2 \mathrm{O} 3$ & 18.97 & 18.91 & 19.09 & 18.87 & 18.69 & 21.34 & 21.45 & 21.47 & 20.72 & 21.16 & 21.06 & 7.74 & 19.40 & 19.05 & 19.24 \\
\hline $\mathrm{FeO}$ & 0.01 & 0.05 & 0.15 & 0.13 & 0.07 & 0.21 & 0.13 & 0.21 & 0.02 & 0.15 & 0.11 & 0.05 & 0.06 & 0.08 & 0.04 \\
\hline $\mathrm{MnO}$ & 0.00 & 0.00 & 0.00 & 0.03 & 0.00 & 0.00 & 0.00 & 0.00 & 0.00 & 0.00 & 0.02 & 0.00 & 0.00 & 0.00 & 0.00 \\
\hline $\mathrm{MgO}$ & 0.00 & 0.04 & 0.00 & 0.00 & 0.00 & 0.07 & 0.00 & 0.05 & 0.00 & 0.00 & 0.04 & 0.00 & 0.00 & 0.03 & 0.00 \\
\hline $\mathrm{SrO}$ & 0.04 & 0.08 & 0.04 & 0.04 & 0.06 & 0.05 & 0.10 & 0.00 & 0.09 & 0.05 & 0.06 & 0.05 & 0.08 & 0.05 & 0.09 \\
\hline $\mathrm{BaO}$ & 0.27 & 0.24 & 0.09 & 0.10 & 0.14 & 0.00 & 0.00 & 0.00 & 0.00 & 0.00 & 0.00 & 0.00 & 1.68 & 0.38 & 0.79 \\
\hline $\mathrm{PbO}$ & 0.00 & 0.00 & 0.00 & 0.00 & 0.06 & 0.07 & 0.00 & 0.00 & 0.07 & 0.11 & 0.00 & 0.00 & 0.00 & 0.00 & 0.00 \\
\hline $\mathrm{CaO}$ & 0.09 & 0.03 & 0.08 & 0.13 & 0.11 & 0.62 & 1.64 & 0.74 & 0.79 & 1.05 & 0.99 & 0.35 & 0.19 & 0.04 & 0.03 \\
\hline $\mathrm{Na} 2 \mathrm{O}$ & 0.77 & 0.37 & 2.51 & 4.87 & 3.00 & 10.34 & 10.47 & 10.58 & 9.84 & 10.88 & 10.76 & 3.08 & 2.34 & 0.65 & 1.79 \\
\hline K2O & 15.57 & 16.09 & 13.14 & 9.51 & 11.83 & 1.03 & 0.27 & 0.75 & 1.99 & 0.32 & 0.48 & 1.85 & 12.49 & 15.70 & 13.79 \\
\hline Total & 99.70 & 99.72 & 99.87 & 100.30 & 99.69 & 99.22 & 99.55 & 99.42 & 99.31 & 99.48 & 99.70 & 101.21 & 99.59 & 100.22 & 100.27 \\
\hline $\mathrm{Si}$ & 11.874 & 11.873 & 11.887 & 11.995 & 12.002 & 11.619 & 11.567 & 11.599 & 11.697 & 11.625 & 11.661 & 14.490 & 11.772 & 11.874 & 11.863 \\
\hline ivAl & 4.150 & 4.144 & 4.128 & 4.005 & 4.023 & 4.462 & 4.467 & 4.477 & 4.344 & 4.411 & 4.374 & 1.501 & 4.250 & 4.150 & 4.172 \\
\hline Felll & 0.002 & 0.008 & 0.023 & 0.019 & 0.010 & 0.032 & 0.019 & 0.031 & 0.003 & 0.022 & 0.017 & 0.007 & 0.010 & 0.012 & 0.006 \\
\hline T site & 16.026 & 16.024 & 16.039 & 16.020 & 16.036 & 16.112 & 16.053 & 16.108 & 16.044 & 16.058 & 16.052 & 15.998 & 16.032 & 16.036 & 16.041 \\
\hline $\mathrm{Ti}$ & 0.000 & 0.007 & 0.000 & 0.000 & 0.000 & 0.000 & 0.000 & 0.000 & 0.000 & 0.000 & 0.001 & 0.004 & 0.000 & 0.000 & 0.000 \\
\hline $\mathrm{Mn}$ & 0.000 & 0.000 & 0.000 & 0.004 & 0.000 & 0.000 & 0.000 & 0.001 & 0.000 & 0.001 & 0.003 & 0.000 & 0.000 & 0.000 & 0.000 \\
\hline $\mathrm{Mg}$ & 0.000 & 0.010 & 0.000 & 0.000 & 0.000 & 0.017 & 0.001 & 0.012 & 0.000 & 0.000 & 0.012 & 0.000 & 0.000 & 0.007 & 0.000 \\
\hline $\mathrm{Sr}$ & 0.005 & 0.008 & 0.004 & 0.004 & 0.006 & 0.005 & 0.010 & 0.000 & 0.009 & 0.005 & 0.006 & 0.005 & 0.009 & 0.005 & 0.009 \\
\hline $\mathrm{Ba}$ & 0.020 & 0.018 & 0.006 & 0.007 & 0.010 & 0.000 & 0.000 & 0.000 & 0.000 & 0.000 & 0.000 & 0.000 & 0.122 & 0.028 & 0.057 \\
\hline $\mathrm{Pb}$ & 0.000 & 0.000 & 0.000 & 0.000 & 0.003 & 0.003 & 0.000 & 0.000 & 0.004 & 0.005 & 0.000 & 0.000 & 0.000 & 0.000 & 0.000 \\
\hline $\mathrm{Ca}$ & 0.019 & 0.007 & 0.016 & 0.025 & 0.021 & 0.118 & 0.310 & 0.141 & 0.151 & 0.199 & 0.187 & 0.062 & 0.038 & 0.009 & 0.007 \\
\hline $\mathrm{Na}$ & 0.278 & 0.135 & 0.893 & 1.700 & 1.062 & 3.557 & 3.587 & 3.629 & 3.394 & 3.731 & 3.677 & 0.983 & 0.843 & 0.232 & 0.639 \\
\hline $\mathrm{K}$ & 3.687 & 3.816 & 3.075 & 2.185 & 2.756 & 0.232 & 0.062 & 0.170 & 0.452 & 0.073 & 0.107 & 0.388 & 2.961 & 3.702 & 3.236 \\
\hline M site & 4.007 & 4.000 & 3.994 & 3.925 & 3.860 & 3.932 & 3.971 & 3.953 & 4.010 & 4.013 & 3.991 & 1.443 & 3.974 & 3.982 & 3.948 \\
\hline Cations & 20.033 & 20.024 & 20.033 & 19.945 & 19.895 & 20.045 & 20.024 & 20.061 & 20.054 & 20.071 & 20.043 & 17.441 & 20.005 & 20.018 & 19.989 \\
\hline An & 0.47 & 0.17 & 0.40 & 0.64 & 0.56 & 3.01 & 7.84 & 3.58 & 3.77 & 4.97 & 4.70 & 4.33 & 1.00 & 0.22 & 0.17 \\
\hline$A b$ & 6.97 & 3.40 & 22.41 & 43.49 & 27.67 & 91.04 & 90.59 & 92.10 & 84.93 & 93.21 & 92.60 & 68.57 & 21.94 & 5.90 & 16.45 \\
\hline Or & 92.57 & 96.43 & 77.19 & 55.87 & 71.78 & 5.94 & 1.56 & 4.31 & 11.30 & 1.82 & 2.71 & 27.10 & 77.06 & 93.88 & 83.38 \\
\hline
\end{tabular}

Notes: Facies abbreviations BQ-M OC = Biotite quartz-monzodiorite with two pyroxenes; Dac = Dacite; L-MG = Leuco monzogranite; BT-MG = Biotite hornblende monzogranite; Rhy = Rhyolite; HB-GD = Hornblende biotite granodiorite; $M G=$ Monzogranite; $I M-D=$ Intermediate-mafic dikes; An = anortite; Ab = albite; Or = orthoclase. 
Supplementary Material: Electron microprobe analyses of alkali feldspar and plagioclase from Garzón granites and related rocks, Eastern Cordillera, Colombia.

\begin{tabular}{|c|c|c|c|c|c|c|c|c|c|c|c|c|c|c|c|}
\hline \multirow{3}{*}{$\begin{array}{l}\text { Mineral } \\
\text { Massif } \\
\text { Sample }\end{array}$} & \multicolumn{15}{|c|}{ Plagioclase } \\
\hline & \multicolumn{15}{|c|}{ Altamira } \\
\hline & $\begin{array}{l}\text { GAR- } \\
386\end{array}$ & GAR-386 & $\begin{array}{l}\text { GAR- } \\
386\end{array}$ & $\begin{array}{l}\text { GAR- } \\
386\end{array}$ & $\begin{array}{l}\text { GAR- } \\
386\end{array}$ & $\begin{array}{l}\text { GAR- } \\
386\end{array}$ & $\begin{array}{l}\text { GAR- } \\
386\end{array}$ & $\begin{array}{l}\text { GAR- } \\
386\end{array}$ & $\begin{array}{l}\text { GAR- } \\
386\end{array}$ & $\begin{array}{l}\text { GAR- } \\
386\end{array}$ & $\begin{array}{l}\text { GAR- } \\
386\end{array}$ & $\begin{array}{l}\text { GAR- } \\
386\end{array}$ & $\begin{array}{l}\text { GAR- } \\
386\end{array}$ & $\begin{array}{l}\text { GAR- } \\
386\end{array}$ & $\begin{array}{l}\text { GAR- } \\
386\end{array}$ \\
\hline Facies & HB-GD & HB-GD & HB-GD & HB-GD & HB-GD & HB-GD & HB-GD & HB-GD & HB-GD & HB-GD & HB-GD & HB-GD & HB-GD & HB-GD & HB-GD \\
\hline $\begin{array}{l}\text { Grain/ } \\
\text { Point }\end{array}$ & pl_02-1 & pl_02-2 & pl_02-3 & pl_02-4 & pl_02-5 & pl_02-6 & pl_02-7 & pl_04-1 & pl_04-2 & pl_04-3 & pl_04-4 & pl_04-5 & pl_04-6 & pl_04-7 & pl_06-1 \\
\hline $\mathrm{SiO} 2$ & 57.11 & 58.38 & 58.79 & 60.18 & 61.18 & 60.53 & 61.51 & 58.47 & 59.52 & 59.96 & 59.80 & 60.52 & 62.74 & 62.48 & 51.62 \\
\hline TiO2 & 0.08 & 0.04 & 0.00 & 0.00 & 0.00 & 0.00 & 0.00 & 0.08 & 0.00 & 0.05 & 0.00 & 0.07 & 0.03 & 0.00 & 0.06 \\
\hline Al2O3 & 27.18 & 25.96 & 26.01 & 25.07 & 24.68 & 24.94 & 23.70 & 26.68 & 25.72 & 25.15 & 25.62 & 25.13 & 23.26 & 23.46 & 30.93 \\
\hline $\mathrm{FeO}$ & 0.36 & 0.82 & 0.29 & 0.27 & 0.21 & 0.15 & 0.07 & 0.18 & 0.17 & 0.18 & 0.15 & 0.18 & 0.08 & 0.19 & 0.31 \\
\hline $\mathrm{MnO}$ & 0.02 & 0.00 & 0.00 & 0.00 & 0.00 & 0.00 & 0.00 & 0.00 & 0.00 & 0.00 & 0.00 & 0.02 & 0.00 & 0.00 & 0.00 \\
\hline $\mathrm{MgO}$ & 0.05 & 0.00 & 0.00 & 0.00 & 0.00 & 0.00 & 0.00 & 0.00 & 0.00 & 0.00 & 0.00 & 0.00 & 0.00 & 0.00 & 0.00 \\
\hline $\mathrm{SrO}$ & 0.13 & 0.15 & 0.14 & 0.15 & 0.13 & 0.18 & 0.10 & 0.19 & 0.13 & 0.10 & 0.10 & 0.11 & 0.09 & 0.08 & 0.23 \\
\hline $\mathrm{BaO}$ & 0.07 & 0.06 & 0.11 & 0.12 & 0.05 & 0.00 & 0.06 & 0.09 & 0.04 & 0.00 & 0.00 & 0.00 & 0.16 & 0.06 & 0.00 \\
\hline $\mathrm{PbO}$ & 0.08 & 0.00 & 0.00 & 0.00 & 0.00 & 0.00 & 0.00 & 0.00 & 0.00 & 0.00 & 0.00 & 0.05 & 0.00 & 0.00 & 0.00 \\
\hline $\mathrm{CaO}$ & 1.57 & 7.05 & 7.05 & 5.82 & 5.71 & 5.93 & 4.52 & 7.45 & 6.62 & 5.90 & 6.47 & 5.95 & 3.89 & 4.24 & 12.52 \\
\hline $\mathrm{Na} 2 \mathrm{O}$ & 5.79 & 7.18 & 7.13 & 7.85 & 7.90 & 8.00 & 7.62 & 7.03 & 7.54 & 7.91 & 7.64 & 8.06 & 9.00 & 8.92 & 4.27 \\
\hline $\mathrm{K} 2 \mathrm{O}$ & 5.22 & 0.38 & 0.37 & 0.37 & 0.53 & 0.38 & 1.79 & 0.16 & 0.21 & 0.35 & 0.21 & 0.18 & 0.54 & 0.65 & 0.11 \\
\hline Total & 97.65 & 100.04 & 99.89 & 99.89 & 100.41 & 100.16 & 99.39 & 100.33 & 99.96 & 99.63 & 100.04 & 100.28 & 99.82 & 100.10 & 100.06 \\
\hline $\mathrm{Si}$ & 10.531 & 10.479 & 10.532 & 10.751 & 10.854 & 10.777 & 11.031 & 10.428 & 10.624 & 10.727 & 10.658 & 10.751 & 11.150 & 11.091 & 9.384 \\
\hline ivAl & 5.907 & 5.492 & 5.492 & 5.278 & 5.160 & 5.233 & 5.009 & 5.608 & 5.411 & 5.303 & 5.382 & 5.262 & 4.872 & 4.908 & 6.627 \\
\hline Felll & 0.056 & 0.124 & 0.044 & 0.040 & 0.032 & 0.023 & 0.011 & 0.027 & 0.025 & 0.027 & 0.022 & 0.027 & 0.012 & 0.028 & 0.047 \\
\hline T site & 16.494 & 16.095 & 16.067 & 16.069 & 16.046 & 16.033 & 16.051 & 16.064 & 16.060 & 16.057 & 16.062 & 16.040 & 16.034 & 16.027 & 16.057 \\
\hline $\mathrm{Ti}$ & 0.011 & 0.006 & 0.000 & 0.000 & 0.000 & 0.000 & 0.000 & 0.010 & 0.000 & 0.006 & 0.000 & 0.010 & 0.003 & 0.000 & 0.009 \\
\hline $\mathrm{Mn}$ & 0.003 & 0.000 & 0.000 & 0.000 & 0.000 & 0.000 & 0.000 & 0.000 & 0.000 & 0.000 & 0.000 & 0.003 & 0.000 & 0.000 & 0.000 \\
\hline $\mathrm{Mg}$ & 0.014 & 0.000 & 0.000 & 0.000 & 0.000 & 0.000 & 0.000 & 0.000 & 0.000 & 0.000 & 0.000 & 0.000 & 0.000 & 0.000 & 0.000 \\
\hline $\mathrm{Sr}$ & 0.013 & 0.016 & 0.014 & 0.016 & 0.013 & 0.018 & 0.011 & 0.019 & 0.013 & 0.010 & 0.010 & 0.011 & 0.010 & 0.008 & 0.024 \\
\hline $\mathrm{Ba}$ & 0.005 & 0.004 & 0.008 & 0.008 & 0.003 & 0.000 & 0.004 & 0.006 & 0.003 & 0.000 & 0.000 & 0.000 & 0.011 & 0.004 & 0.000 \\
\hline $\mathrm{Pb}$ & 0.004 & 0.000 & 0.000 & 0.000 & 0.000 & 0.000 & 0.000 & 0.000 & 0.000 & 0.000 & 0.000 & 0.003 & 0.000 & 0.000 & 0.000 \\
\hline $\mathrm{Ca}$ & 0.310 & 1.356 & 1.353 & 1.114 & 1.085 & 1.131 & 0.868 & 1.424 & 1.266 & 1.131 & 1.235 & 1.133 & 0.741 & 0.806 & 2.439 \\
\hline $\mathrm{Na}$ & 2.070 & 2.499 & 2.476 & 2.719 & 2.717 & 2.762 & 2.650 & 2.431 & 2.609 & 2.744 & 2.640 & 2.776 & 3.101 & 3.070 & 1.505 \\
\hline $\mathrm{K}$ & 1.228 & 0.087 & 0.084 & 0.085 & 0.119 & 0.086 & 0.409 & 0.037 & 0.048 & 0.080 & 0.047 & 0.040 & 0.122 & 0.147 & 0.026 \\
\hline M site & 3.659 & 3.967 & 3.936 & 3.943 & 3.938 & 3.998 & 3.943 & 3.927 & 3.940 & 3.971 & 3.932 & 3.976 & 3.988 & 4.036 & 4.002 \\
\hline Cations & 20.153 & 20.062 & 20.003 & 20.012 & 19.984 & 20.031 & 19.994 & 19.991 & 20.000 & 20.027 & 19.994 & 20.016 & 20.023 & 20.063 & 20.060 \\
\hline An & 8.60 & 34.40 & 34.57 & 28.43 & 27.68 & 28.43 & 22.11 & 36.58 & 32.26 & 28.60 & 31.50 & 28.68 & 18.68 & 20.04 & 61.43 \\
\hline $\mathbf{A b}$ & 57.37 & 63.39 & 63.28 & 69.39 & 69.29 & 69.40 & 67.46 & 62.47 & 66.50 & 69.38 & 67.31 & 70.31 & 78.23 & 76.30 & 37.92 \\
\hline Or & 34.03 & 2.21 & 2.15 & 2.17 & 3.03 & 2.17 & 10.43 & 0.95 & 1.23 & 2.02 & 1.19 & 1.01 & 3.09 & 3.65 & 0.65 \\
\hline
\end{tabular}

Notes: Facies abbreviations BQ-M OC = Biotite quartz-monzodiorite with two pyroxenes; Dac = Dacite; L-MG = Leuco monzogranite; BT-MG = Biotite hornblende monzogranite; Rhy = Rhyolite; HB-GD = Hornblende biotite granodiorite; $M G=$ Monzogranite; IM-D = Intermediate-mafic dikes; An = anortite; $A b=$ albite; Or = orthoclase. 
Supplementary Material: Electron microprobe analyses of alkali feldspar and plagioclase from Garzón granites and related rocks, Eastern Cordillera, Colombia.

\begin{tabular}{|c|c|c|c|c|c|c|c|c|c|c|c|c|c|c|c|}
\hline \multirow{3}{*}{$\begin{array}{l}\text { Mineral } \\
\text { Massif } \\
\text { Sample }\end{array}$} & \multicolumn{15}{|c|}{ Plagioclase } \\
\hline & \multicolumn{13}{|c|}{ Altamira } & \multicolumn{2}{|c|}{ Sombrerillo } \\
\hline & $\begin{array}{l}\text { GAR- } \\
386\end{array}$ & $\begin{array}{l}\text { GAR- } \\
386\end{array}$ & $\begin{array}{l}\text { GAR- } \\
386\end{array}$ & $\begin{array}{l}\text { GAR- } \\
386\end{array}$ & $\begin{array}{l}\text { GAR- } \\
386\end{array}$ & $\begin{array}{l}\text { GAR- } \\
386\end{array}$ & $\begin{array}{l}\text { GAR- } \\
386\end{array}$ & $\begin{array}{l}\text { GAR- } \\
386\end{array}$ & $\begin{array}{l}\text { GAR- } \\
386\end{array}$ & $\begin{array}{l}\text { GAR- } \\
386\end{array}$ & $\begin{array}{l}\text { GAR- } \\
386\end{array}$ & $\begin{array}{l}\text { GAR- } \\
388\end{array}$ & $\begin{array}{l}\text { GAR- } \\
388\end{array}$ & $\begin{array}{l}\text { GAR- } \\
394\end{array}$ & $\begin{array}{l}\text { GAR- } \\
394\end{array}$ \\
\hline Facies & HB-GD & HB-GD & HB-GD & HB-GD & HB-GD & HB-GD & HB-GD & HB-GD & HB-GD & HB-GD & HB-GD & H-MD & $\mathrm{H}-\mathrm{MD}$ & MG & MG \\
\hline $\begin{array}{l}\text { Grain/ } \\
\text { Point }\end{array}$ & pl_06-2 & pl_06-3 & pl_06-4 & pl_06-5 & pl_06-6 & pl_07-1 & pl_07-2 & pl_07-3 & pl_07-4 & pl_07-5 & pl_07-6 & pl_03-2 & pl_05-1 & pl_01-1 & pl_02-1 \\
\hline $\mathrm{SiO} 2$ & 53.52 & 60.28 & 60.13 & 62.86 & 62.40 & 59.51 & 61.34 & 60.63 & 60.76 & 60.02 & 61.38 & 67.22 & 67.10 & 59.27 & 56.45 \\
\hline $\mathrm{TiO} 2$ & 0.05 & 0.00 & 0.03 & 0.00 & 0.00 & 0.00 & 0.00 & 0.00 & 0.00 & 0.00 & 0.00 & 0.00 & 0.00 & 0.00 & 0.12 \\
\hline Al2O3 & 29.72 & 25.22 & 25.74 & 23.41 & 23.57 & 25.52 & 24.72 & 25.15 & 24.50 & 25.53 & 24.34 & 20.33 & 20.44 & 26.05 & 27.64 \\
\hline $\mathrm{FeO}$ & 0.11 & 0.18 & 0.20 & 0.07 & 0.05 & 0.10 & 0.15 & 0.19 & 0.11 & 0.19 & 0.18 & 0.05 & 0.07 & 0.10 & 0.21 \\
\hline $\mathrm{MnO}$ & 0.00 & 0.02 & 0.00 & 0.00 & 0.00 & 0.00 & 0.00 & 0.00 & 0.00 & 0.00 & 0.02 & 0.00 & 0.00 & 0.00 & 0.00 \\
\hline $\mathrm{MgO}$ & 0.00 & 0.00 & 0.00 & 0.00 & 0.00 & 0.00 & 0.00 & 0.00 & 0.00 & 0.00 & 0.00 & 0.00 & 0.00 & 0.00 & 0.00 \\
\hline SrO & 0.19 & 0.16 & 0.14 & 0.05 & 0.09 & 0.14 & 0.18 & 0.16 & 0.18 & 0.12 & 0.15 & 0.04 & 0.05 & 0.09 & 0.09 \\
\hline $\mathrm{BaO}$ & 0.06 & 0.00 & 0.10 & 0.07 & 0.05 & 0.05 & 0.00 & 0.04 & 0.00 & 0.07 & 0.00 & 0.00 & 0.00 & 0.04 & 0.00 \\
\hline $\mathrm{PbO}$ & 0.00 & 0.00 & 0.00 & 0.00 & 0.00 & 0.00 & 0.00 & 0.00 & 0.00 & 0.00 & 0.00 & 0.00 & 0.00 & 0.00 & 0.07 \\
\hline $\mathrm{CaO}$ & 10.87 & 6.11 & 5.57 & 4.41 & 4.25 & 6.55 & 5.51 & 5.88 & 5.31 & 6.51 & 4.90 & 0.41 & 0.27 & 6.71 & 8.87 \\
\hline $\mathrm{Na} 2 \mathrm{O}$ & 5.21 & 7.84 & 8.07 & 8.40 & 9.26 & 7.74 & 8.17 & 7.91 & 8.19 & 7.68 & 8.45 & 11.24 & 11.24 & 7.58 & 6.43 \\
\hline K2O & 0.23 & 0.34 & 0.30 & 0.14 & 0.11 & 0.23 & 0.42 & 0.42 & 0.41 & 0.33 & 0.38 & 0.01 & 0.27 & 0.25 & 0.21 \\
\hline Total & 99.98 & 100.16 & 100.31 & 99.44 & 99.80 & 99.86 & 100.55 & 100.44 & 99.47 & 100.45 & 99.84 & 99.32 & 99.47 & 100.11 & 100.10 \\
\hline $\mathrm{Si}$ & 9.690 & 10.731 & 10.685 & 11.164 & 11.082 & 10.639 & 10.862 & 10.765 & 10.867 & 10.667 & 10.928 & 11.833 & 11.811 & 10.570 & 10.145 \\
\hline ivAl & 6.342 & 5.291 & 5.391 & 4.900 & 4.934 & 5.377 & 5.159 & 5.263 & 5.164 & 5.347 & 5.107 & 4.218 & 4.240 & 5.475 & 5.854 \\
\hline Felll & 0.017 & 0.026 & 0.030 & 0.010 & 0.008 & 0.014 & 0.023 & 0.028 & 0.016 & 0.028 & 0.027 & 0.007 & 0.011 & 0.015 & 0.032 \\
\hline T site & 16.050 & 16.048 & 16.105 & 16.074 & 16.024 & 16.030 & 16.044 & 16.056 & 16.048 & 16.042 & 16.062 & 16.057 & 16.063 & 16.060 & 16.031 \\
\hline $\mathrm{Ti}$ & 0.007 & 0.000 & 0.004 & 0.000 & 0.000 & 0.001 & 0.000 & 0.000 & 0.000 & 0.000 & 0.000 & 0.000 & 0.000 & 0.000 & 0.016 \\
\hline $\mathrm{Mn}$ & 0.000 & 0.003 & 0.000 & 0.000 & 0.000 & 0.000 & 0.000 & 0.000 & 0.000 & 0.000 & 0.003 & 0.001 & 0.000 & 0.000 & 0.000 \\
\hline $\mathrm{Mg}$ & 0.000 & 0.000 & 0.000 & 0.000 & 0.000 & 0.000 & 0.000 & 0.000 & 0.000 & 0.000 & 0.000 & 0.000 & 0.000 & 0.000 & 0.000 \\
\hline $\mathrm{Sr}$ & 0.020 & 0.016 & 0.014 & 0.005 & 0.009 & 0.015 & 0.018 & 0.017 & 0.018 & 0.012 & 0.016 & 0.004 & 0.005 & 0.010 & 0.010 \\
\hline $\mathrm{Ba}$ & 0.004 & 0.000 & 0.007 & 0.005 & 0.004 & 0.004 & 0.000 & 0.003 & 0.000 & 0.005 & 0.000 & 0.000 & 0.000 & 0.002 & 0.000 \\
\hline $\mathrm{Pb}$ & 0.000 & 0.000 & 0.000 & 0.000 & 0.000 & 0.000 & 0.000 & 0.000 & 0.000 & 0.000 & 0.000 & 0.000 & 0.000 & 0.000 & 0.004 \\
\hline $\mathrm{Ca}$ & 2.109 & 1.165 & 1.060 & 0.839 & 0.809 & 1.255 & 1.045 & 1.119 & 1.018 & 1.240 & 0.935 & 0.077 & 0.051 & 1.282 & 1.708 \\
\hline $\mathrm{Na}$ & 1.829 & 2.706 & 2.780 & 2.893 & 3.189 & 2.683 & 2.805 & 2.723 & 2.840 & 2.646 & 2.917 & 3.836 & 3.836 & 2.621 & 2.240 \\
\hline $\mathrm{K}$ & 0.054 & 0.077 & 0.069 & 0.032 & 0.024 & 0.054 & 0.095 & 0.095 & 0.093 & 0.074 & 0.087 & 0.003 & 0.062 & 0.056 & 0.047 \\
\hline M site & 4.023 & 3.967 & 3.936 & 3.774 & 4.034 & 4.010 & 3.964 & 3.957 & 3.969 & 3.978 & 3.958 & 3.921 & 3.955 & 3.971 & 4.025 \\
\hline Cations & 20.073 & 20.015 & 20.040 & 19.848 & 20.057 & 20.040 & 20.008 & 20.012 & 20.017 & 20.020 & 20.020 & 19.978 & 20.017 & 20.031 & 20.056 \\
\hline An & 52.83 & 29.51 & 27.12 & 22.29 & 20.11 & 31.44 & 26.50 & 28.41 & 25.75 & 31.30 & 23.73 & 1.97 & 1.30 & 32.38 & 42.74 \\
\hline$A b$ & 45.82 & 68.53 & 71.11 & 76.85 & 79.29 & 67.22 & 71.10 & 69.17 & 71.88 & 66.82 & 74.05 & 97.96 & 97.14 & 66.20 & 56.07 \\
\hline Or & 1.35 & 1.95 & 1.77 & 0.86 & 0.59 & 1.34 & 2.41 & 2.42 & 2.36 & 1.88 & 2.22 & 0.08 & 1.56 & 1.42 & 1.18 \\
\hline
\end{tabular}

Notes: Facies abbreviations BQ-M OC = Biotite quartz-monzodiorite with two pyroxenes; Dac $=$ Dacite; L-MG = Leuco monzogran
Hornblende biotite granodiorite; $M G=$ Monzogranite; IM-D = Intermediate-mafic dikes; $A n=$ anortite; $A b=$ albite; Or = orthoclase. 
Supplementary Material: Electron microprobe analyses of alkali feldspar and plagioclase from Garzón granites and related rocks, Eastern Cordillera, Colombia.

\begin{tabular}{|c|c|c|c|c|c|c|c|c|c|c|c|c|c|c|c|}
\hline \multirow{3}{*}{$\begin{array}{l}\text { Mineral } \\
\text { Massif } \\
\text { Sample }\end{array}$} & \multicolumn{15}{|c|}{ Plagioclase } \\
\hline & & & & & & & & ombrerillo & & & & & & & \\
\hline & $\begin{array}{l}\text { GAR- } \\
394 \\
\end{array}$ & GAR-394 & $\begin{array}{l}\text { GAR- } \\
394 \\
\end{array}$ & $\begin{array}{l}\text { GAR- } \\
394 \\
\end{array}$ & $\begin{array}{l}\text { GAR- } \\
394\end{array}$ & $\begin{array}{l}\text { GAR- } \\
394 \\
\end{array}$ & $\begin{array}{l}\text { GAR- } \\
394 \\
\end{array}$ & $\begin{array}{l}\text { GAR- } \\
394\end{array}$ & $\begin{array}{l}\text { GAR- } \\
394 \\
\end{array}$ & $\begin{array}{l}\text { GAR- } \\
394 \\
\end{array}$ & $\begin{array}{l}\text { GAR- } \\
394 \\
\end{array}$ & $\begin{array}{l}\text { GAR- } \\
394 \\
\end{array}$ & $\begin{array}{l}\text { GAR- } \\
394\end{array}$ & $\begin{array}{l}\text { GAR- } \\
394 \\
\end{array}$ & $\begin{array}{l}\text { GAR- } \\
394 \\
\end{array}$ \\
\hline Facies & MG & MG & MG & MG & MG & MG & MG & MG & MG & MG & MG & MG & MG & MG & MG \\
\hline $\begin{array}{l}\text { Grain/ } \\
\text { Point } \\
\end{array}$ & pl_02-2 & pl_03-1 & pl_03-2 & pl_04-1 & pl_04-2 & pl_04-3 & pl_04-4 & pl_04-5 & pl_05-1 & pl_05-2 & pl_05-3 & pl_06-1 & pl_06-2 & pl_06-3 & pl_10-1 \\
\hline $\mathrm{SiO} 2$ & 60.77 & 56.34 & 59.55 & 61.58 & 57.21 & 56.27 & 58.53 & 62.79 & 58.06 & 57.99 & 64.22 & 60.22 & 61.98 & 66.71 & 56.17 \\
\hline TiO2 & 0.03 & 0.04 & 0.06 & 0.03 & 0.05 & 0.00 & 0.12 & 0.05 & 0.07 & 0.03 & 0.00 & 0.00 & 0.00 & 0.04 & 0.00 \\
\hline $\mathrm{Al} 2 \mathrm{O} 3$ & 25.08 & 28.52 & 25.92 & 24.37 & 27.49 & 28.15 & 26.50 & 23.96 & 26.91 & 26.95 & 23.14 & 25.47 & 24.34 & 21.00 & 28.20 \\
\hline $\mathrm{FeO}$ & 0.12 & 0.16 & 0.12 & 0.18 & 0.19 & 0.23 & 0.18 & 0.16 & 0.14 & 0.19 & 0.14 & 0.17 & 0.17 & 0.09 & 0.16 \\
\hline $\mathrm{MnO}$ & 0.00 & 0.00 & 0.00 & 0.00 & 0.00 & 0.00 & 0.00 & 0.02 & 0.00 & 0.00 & 0.00 & 0.00 & 0.00 & 0.00 & 0.00 \\
\hline $\mathrm{MgO}$ & 0.00 & 0.00 & 0.00 & 0.00 & 0.00 & 0.00 & 0.00 & 0.00 & 0.00 & 0.00 & 0.00 & 0.00 & 0.00 & 0.00 & 0.00 \\
\hline $\mathrm{SrO}$ & 0.08 & 0.07 & 0.08 & 0.08 & 0.09 & 0.08 & 0.04 & 0.04 & 0.08 & 0.06 & 0.00 & 0.08 & 0.00 & 0.05 & 0.11 \\
\hline $\mathrm{BaO}$ & 0.00 & 0.00 & 0.00 & 0.07 & 0.00 & 0.04 & 0.04 & 0.07 & 0.04 & 0.00 & 0.00 & 0.00 & 0.04 & 0.00 & 0.10 \\
\hline $\mathrm{PbO}$ & 0.06 & 0.00 & 0.00 & 0.06 & 0.00 & 0.00 & 0.00 & 0.00 & 0.00 & 0.00 & 0.00 & 0.00 & 0.00 & 0.00 & 0.00 \\
\hline $\mathrm{CaO}$ & 5.82 & 9.66 & 6.93 & 5.09 & 8.62 & 9.49 & 7.64 & 4.67 & 7.99 & 8.40 & 3.58 & 6.43 & 5.03 & 1.20 & 9.35 \\
\hline $\mathrm{Na} 2 \mathrm{O}$ & 8.13 & 6.14 & 7.71 & 8.49 & 6.46 & 6.09 & 7.09 & 8.86 & 6.91 & 6.84 & 9.59 & 8.04 & 8.70 & 10.96 & 6.00 \\
\hline K2O & 0.16 & 0.16 & 0.13 & 0.31 & 0.28 & 0.22 & 0.21 & 0.37 & 0.23 & 0.21 & 0.21 & 0.21 & 0.23 & 0.15 & 0.30 \\
\hline Total & 100.26 & 101.11 & 100.52 & 100.28 & 100.43 & 100.59 & 100.34 & 100.97 & 100.44 & 100.67 & 100.93 & 100.63 & 100.51 & 100.20 & 100.40 \\
\hline $\mathrm{Si}$ & 10.786 & 10.030 & 10.579 & 10.922 & 10.228 & 10.072 & 10.436 & 11.038 & 10.358 & 10.331 & 11.246 & 10.678 & 10.951 & 11.684 & 10.072 \\
\hline ivAl & 5.246 & 5.984 & 5.427 & 5.094 & 5.793 & 5.939 & 5.569 & 4.964 & 5.658 & 5.658 & 4.776 & 5.323 & 5.068 & 4.335 & 5.960 \\
\hline Felll & 0.018 & 0.024 & 0.017 & 0.027 & 0.028 & 0.034 & 0.027 & 0.023 & 0.021 & 0.028 & 0.020 & 0.025 & 0.025 & 0.013 & 0.024 \\
\hline T site & 16.050 & 16.038 & 16.022 & 16.044 & 16.049 & 16.045 & 16.031 & 16.025 & 16.037 & 16.017 & 16.042 & 16.025 & 16.044 & 16.032 & 16.056 \\
\hline $\mathrm{Ti}$ & 0.003 & 0.006 & 0.008 & 0.004 & 0.007 & 0.000 & 0.017 & 0.007 & 0.009 & 0.004 & 0.000 & 0.000 & 0.000 & 0.005 & 0.000 \\
\hline $\mathrm{Mn}$ & 0.000 & 0.000 & 0.000 & 0.000 & 0.000 & 0.000 & 0.000 & 0.002 & 0.000 & 0.000 & 0.000 & 0.001 & 0.000 & 0.000 & 0.000 \\
\hline $\mathrm{Mg}$ & 0.000 & 0.000 & 0.000 & 0.000 & 0.000 & 0.000 & 0.000 & 0.000 & 0.000 & 0.000 & 0.000 & 0.000 & 0.000 & 0.000 & 0.000 \\
\hline $\mathrm{Sr}$ & 0.008 & 0.007 & 0.009 & 0.009 & 0.009 & 0.008 & 0.004 & 0.004 & 0.008 & 0.006 & 0.000 & 0.008 & 0.000 & 0.005 & 0.012 \\
\hline $\mathrm{Ba}$ & 0.000 & 0.000 & 0.000 & 0.005 & 0.000 & 0.003 & 0.002 & 0.004 & 0.003 & 0.000 & 0.000 & 0.000 & 0.003 & 0.000 & 0.007 \\
\hline $\mathrm{Pb}$ & 0.003 & 0.000 & 0.000 & 0.003 & 0.000 & 0.000 & 0.000 & 0.000 & 0.000 & 0.000 & 0.000 & 0.000 & 0.000 & 0.000 & 0.000 \\
\hline $\mathrm{Ca}$ & 1.107 & 1.843 & 1.319 & 0.967 & 1.651 & 1.820 & 1.459 & 0.880 & 1.527 & 1.603 & 0.672 & 1.222 & 0.952 & 0.225 & 1.796 \\
\hline $\mathrm{Na}$ & 2.798 & 2.119 & 2.656 & 2.920 & 2.239 & 2.114 & 2.451 & 3.020 & 2.390 & 2.363 & 3.256 & 2.764 & 2.980 & 3.722 & 2.086 \\
\hline $\mathrm{K}$ & 0.037 & 0.037 & 0.029 & 0.071 & 0.064 & 0.050 & 0.048 & 0.082 & 0.052 & 0.048 & 0.046 & 0.047 & 0.051 & 0.033 & 0.068 \\
\hline M site & 3.955 & 4.012 & 4.020 & 3.978 & 3.971 & 3.995 & 3.982 & 4.000 & 3.989 & 4.025 & 3.974 & 4.041 & 3.986 & 3.990 & 3.969 \\
\hline Cations & 20.005 & 20.050 & 20.042 & 20.022 & 20.020 & 20.040 & 20.013 & 20.024 & 20.025 & 20.042 & 20.017 & 20.067 & 20.031 & 20.022 & 20.025 \\
\hline An & 28.08 & 46.08 & 32.95 & 24.44 & 41.76 & 45.69 & 36.87 & 22.09 & 38.48 & 39.94 & 16.90 & 30.29 & 23.90 & 5.66 & 45.47 \\
\hline$A b$ & 70.99 & 53.00 & 66.33 & 73.77 & 56.63 & 53.05 & 61.91 & 75.84 & 60.22 & 58.85 & 81.93 & 68.54 & 74.82 & 93.50 & 52.81 \\
\hline Or & 0.93 & 0.93 & 0.73 & 1.79 & 1.61 & 1.26 & 1.22 & 2.07 & 1.30 & 1.21 & 1.17 & 1.17 & 1.28 & 0.84 & 1.72 \\
\hline
\end{tabular}
Notes: Facies abbreviations BQ-M OC = Biotite quartz-monzodiorite with two pyroxenes; Dac = Dacite; L-MG = Leuco monzogranite; BT-MG = Biotite hornblende monzogranite; Rhy = Rhyolite; HB-GD =
Hornblende biotite granodiorite; MG = Monzogranite; IM-D = Intermediate-mafic dikes; An = anortite; Ab = albite; Or = orthoclase. 
Supplementary Material: Electron microprobe analyses of alkali feldspar and plagioclase from Garzón granites and related rocks, Eastern Cordillera, Colombia.

\begin{tabular}{|c|c|c|c|c|c|c|c|c|c|c|c|c|c|c|c|}
\hline \multirow{3}{*}{$\begin{array}{l}\text { Mineral } \\
\text { Massif } \\
\text { Sample }\end{array}$} & \multicolumn{3}{|c|}{ Plagioclase } & \multirow{2}{*}{\multicolumn{9}{|c|}{ Alkali feldspar }} & \multirow{2}{*}{\multicolumn{3}{|c|}{ Plagioclase }} \\
\hline & & & & & & & & & & & & & & & \\
\hline & $\begin{array}{l}\text { GAR- } \\
394\end{array}$ & $\begin{array}{l}\text { GAR- } \\
394\end{array}$ & $\begin{array}{l}\text { GAR- } \\
394\end{array}$ & $\begin{array}{l}\text { GAR- } \\
395\end{array}$ & $\begin{array}{l}\text { GAR- } \\
395\end{array}$ & $\begin{array}{l}\text { GAR- } \\
395\end{array}$ & $\begin{array}{l}\text { GAR- } \\
395\end{array}$ & $\begin{array}{l}\text { GAR- } \\
395\end{array}$ & $\begin{array}{l}\text { GAR- } \\
395\end{array}$ & $\begin{array}{l}\text { GAR- } \\
395\end{array}$ & $\begin{array}{l}\text { GAR- } \\
395\end{array}$ & $\begin{array}{l}\text { GAR- } \\
395\end{array}$ & $\begin{array}{l}\text { GAR- } \\
395\end{array}$ & $\begin{array}{l}\text { GAR- } \\
395\end{array}$ & $\begin{array}{l}\text { GAR- } \\
395\end{array}$ \\
\hline Facies & MG & MG & MG & Dac & Dac & Dac & Dac & Dac & Dac & Dac & Dac & Dac & Dac & Dac & Dac \\
\hline $\begin{array}{l}\text { Grain/ } \\
\text { Point }\end{array}$ & pl_10-2 & pl_15-1 & pl_15-2 & Fk_01-1 & Fk_02-1 & Fk_03-1 & Fk_04-1 & Fk_04-2 & Fk_05-1 & Fk_05-2 & Fk_05-3 & Fk_06-1 & pl_01-1 & pl_01-2 & pl_01-3 \\
\hline $\mathrm{SiO} 2$ & 61.43 & 60.24 & 61.04 & 64.83 & 64.21 & 64.25 & 64.58 & 64.17 & 65.00 & 64.63 & 64.78 & 64.78 & 57.14 & 60.19 & 59.91 \\
\hline TiO2 & 0.00 & 0.00 & 0.00 & 0.06 & 0.06 & 0.00 & 0.05 & 0.08 & 0.00 & 0.00 & 0.00 & 0.06 & 0.00 & 0.03 & 0.03 \\
\hline Al2O3 & 24.42 & 25.24 & 24.88 & 19.37 & 19.65 & 18.76 & 19.15 & 19.00 & 18.97 & 18.96 & 18.94 & 19.16 & 27.03 & 24.77 & 24.71 \\
\hline $\mathrm{FeO}$ & 0.12 & 0.15 & 0.17 & 0.09 & 0.16 & 0.08 & 0.09 & 0.02 & 0.10 & 0.09 & 0.12 & 0.10 & 0.23 & 0.27 & 0.30 \\
\hline $\mathrm{MnO}$ & 0.00 & 0.00 & 0.00 & 0.00 & 0.02 & 0.02 & 0.00 & 0.00 & 0.00 & 0.00 & 0.02 & 0.00 & 0.02 & 0.00 & 0.00 \\
\hline $\mathrm{MgO}$ & 0.00 & 0.00 & 0.00 & 0.00 & 0.03 & 0.00 & 0.00 & 0.02 & 0.00 & 0.00 & 0.00 & 0.00 & 0.00 & 0.00 & 0.00 \\
\hline $\mathrm{SrO}$ & 0.08 & 0.06 & 0.04 & 0.07 & 0.07 & 0.00 & 0.07 & 0.08 & 0.11 & 0.00 & 0.09 & 0.00 & 0.10 & 0.13 & 0.17 \\
\hline $\mathrm{BaO}$ & 0.00 & 0.00 & 0.00 & 0.19 & 0.26 & 0.19 & 0.22 & 0.25 & 0.15 & 0.13 & 0.15 & 0.11 & 0.00 & 0.09 & 0.00 \\
\hline $\mathrm{PbO}$ & 0.00 & 0.00 & 0.00 & 0.00 & 0.00 & 0.00 & 0.00 & 0.00 & 0.00 & 0.00 & 0.00 & 0.00 & 0.00 & 0.00 & 0.00 \\
\hline $\mathrm{CaO}$ & 5.43 & 6.11 & 5.67 & 0.38 & 0.51 & 0.00 & 0.08 & 0.05 & 0.04 & 0.01 & 0.06 & 0.12 & 8.05 & 5.98 & 5.94 \\
\hline $\mathrm{Na} 2 \mathrm{O}$ & 8.41 & 7.87 & 8.37 & 1.99 & 2.46 & 0.35 & 1.45 & 0.62 & 0.84 & 0.74 & 1.68 & 1.71 & 6.95 & 7.43 & 7.59 \\
\hline $\mathrm{K} 2 \mathrm{O}$ & 0.16 & 0.26 & 0.17 & 13.63 & 13.10 & 16.19 & 14.52 & 15.65 & 15.62 & 15.56 & 14.43 & 14.25 & 0.17 & 0.67 & 0.67 \\
\hline Total & 100.07 & 99.96 & 100.36 & 100.63 & 100.56 & 99.92 & 100.20 & 99.97 & 100.87 & 100.12 & 100.28 & 100.31 & 99.73 & 99.61 & 99.35 \\
\hline $\mathrm{Si}$ & 10.905 & 10.733 & 10.820 & 11.840 & 11.750 & 11.919 & 11.874 & 11.878 & 11.915 & 11.917 & 11.902 & 11.877 & 10.284 & 10.785 & 10.768 \\
\hline ivAl & 5.109 & 5.300 & 5.198 & 4.169 & 4.238 & 4.102 & 4.150 & 4.145 & 4.098 & 4.120 & 4.101 & 4.140 & 5.733 & 5.231 & 5.234 \\
\hline Felll & 0.017 & 0.022 & 0.025 & 0.014 & 0.024 & 0.013 & 0.014 & 0.003 & 0.016 & 0.014 & 0.019 & 0.015 & 0.035 & 0.040 & 0.045 \\
\hline T site & 16.032 & 16.055 & 16.043 & 16.023 & 16.012 & 16.034 & 16.038 & 16.027 & 16.030 & 16.050 & 16.022 & 16.033 & 16.052 & 16.055 & 16.047 \\
\hline $\mathrm{Ti}$ & 0.000 & 0.000 & 0.000 & 0.008 & 0.008 & 0.000 & 0.007 & 0.010 & 0.000 & 0.000 & 0.000 & 0.008 & 0.000 & 0.005 & 0.003 \\
\hline $\mathrm{Mn}$ & 0.000 & 0.000 & 0.000 & 0.000 & 0.003 & 0.003 & 0.000 & 0.000 & 0.000 & 0.000 & 0.003 & 0.000 & 0.003 & 0.000 & 0.000 \\
\hline $\mathrm{Mg}$ & 0.000 & 0.000 & 0.000 & 0.000 & 0.008 & 0.000 & 0.000 & 0.005 & 0.000 & 0.000 & 0.001 & 0.001 & 0.000 & 0.000 & 0.000 \\
\hline $\mathrm{Sr}$ & 0.009 & 0.006 & 0.004 & 0.008 & 0.007 & 0.000 & 0.007 & 0.008 & 0.011 & 0.000 & 0.010 & 0.000 & 0.010 & 0.014 & 0.018 \\
\hline $\mathrm{Ba}$ & 0.000 & 0.000 & 0.000 & 0.013 & 0.018 & 0.014 & 0.016 & 0.018 & 0.011 & 0.010 & 0.010 & 0.008 & 0.000 & 0.006 & 0.000 \\
\hline $\mathrm{Pb}$ & 0.000 & 0.000 & 0.000 & 0.000 & 0.000 & 0.000 & 0.000 & 0.000 & 0.000 & 0.000 & 0.000 & 0.000 & 0.000 & 0.000 & 0.000 \\
\hline $\mathrm{Ca}$ & 1.033 & 1.166 & 1.077 & 0.075 & 0.101 & 0.000 & 0.015 & 0.010 & 0.007 & 0.002 & 0.012 & 0.023 & 1.552 & 1.148 & 1.144 \\
\hline $\mathrm{Na}$ & 2.895 & 2.719 & 2.877 & 0.705 & 0.873 & 0.127 & 0.517 & 0.223 & 0.300 & 0.264 & 0.598 & 0.608 & 2.425 & 2.581 & 2.645 \\
\hline $\mathrm{K}$ & 0.037 & 0.059 & 0.038 & 3.175 & 3.058 & 3.831 & 3.406 & 3.695 & 3.653 & 3.660 & 3.382 & 3.333 & 0.039 & 0.153 & 0.154 \\
\hline M site & 3.973 & 3.950 & 3.996 & 3.984 & 4.077 & 3.975 & 3.967 & 3.971 & 3.982 & 3.935 & 4.016 & 3.981 & 4.030 & 3.907 & 3.964 \\
\hline Cations & 20.006 & 20.006 & 20.039 & 20.007 & 20.088 & 20.009 & 20.006 & 19.998 & 20.011 & 19.985 & 20.038 & 20.014 & 20.082 & 19.962 & 20.011 \\
\hline An & 26.05 & 29.57 & 26.98 & 1.89 & 2.50 & 0.00 & 0.38 & 0.25 & 0.18 & 0.04 & 0.30 & 0.59 & 38.65 & 29.57 & 29.01 \\
\hline$A b$ & 73.01 & 68.93 & 72.07 & 17.82 & 21.65 & 3.20 & 13.13 & 5.68 & 7.57 & 6.72 & 14.99 & 15.33 & 60.38 & 66.49 & 67.08 \\
\hline Or & 0.94 & 1.50 & 0.96 & 80.29 & 75.85 & 96.80 & 86.49 & 94.06 & 92.25 & 93.24 & 84.71 & 84.08 & 0.97 & 3.94 & 3.91 \\
\hline
\end{tabular}

Hornblende biotite granodiorite; MG = Monzogranite; IM-D = Intermediate-mafic dikes; $A n=$ anortite; $A b=$ albite; Or = orthoclase. 
Supplementary Material: Electron microprobe analyses of alkali feldspar and plagioclase from Garzón granites and related rocks, Eastern Cordillera, Colombia.

\begin{tabular}{|c|c|c|c|c|c|c|c|c|c|c|c|c|c|c|c|}
\hline \multirow{3}{*}{$\begin{array}{l}\text { Mineral } \\
\text { Massif } \\
\text { Sample }\end{array}$} & \multicolumn{15}{|c|}{ Plagioclase } \\
\hline & \multicolumn{15}{|c|}{ Sombrerillo } \\
\hline & $\begin{array}{l}\text { GAR- } \\
395\end{array}$ & $\begin{array}{l}\text { GAR- } \\
395\end{array}$ & $\begin{array}{l}\text { GAR- } \\
395\end{array}$ & $\begin{array}{l}\text { GAR- } \\
395\end{array}$ & $\begin{array}{l}\text { GAR- } \\
395\end{array}$ & $\begin{array}{l}\text { GAR- } \\
395\end{array}$ & $\begin{array}{l}\text { GAR- } \\
395\end{array}$ & $\begin{array}{l}\text { GAR- } \\
395\end{array}$ & $\begin{array}{l}\text { GAR- } \\
395\end{array}$ & $\begin{array}{l}\text { GAR- } \\
395\end{array}$ & $\begin{array}{l}\text { GAR- } \\
395\end{array}$ & $\begin{array}{l}\text { GAR- } \\
395\end{array}$ & $\begin{array}{l}\text { GAR- } \\
395\end{array}$ & $\begin{array}{l}\text { GAR- } \\
395\end{array}$ & $\begin{array}{l}\text { GAR- } \\
395\end{array}$ \\
\hline Facies & Dac & Dac & Dac & Dac & Dac & Dac & Dac & Dac & Dac & Dac & Dac & Dac & Dac & Dac & Dac \\
\hline $\begin{array}{l}\text { Grain/ } \\
\text { Point }\end{array}$ & pl_01-4 & pl_01-5 & pl_01-6 & pl_01-7 & pl_01-8 & pl_01-9 & pl_01-10 & pl_02-1 & pl_02-2 & pl_02-3 & pl_02-4 & pl_02-5 & pl_03-1 & pl_03-2 & pl_03-3 \\
\hline $\mathrm{SiO} 2$ & 58.47 & 59.03 & 59.87 & 58.51 & 58.83 & 59.16 & 58.45 & 51.95 & 59.82 & 57.01 & 58.83 & 60.75 & 52.96 & 58.55 & 55.23 \\
\hline $\mathrm{TiO} 2$ & 0.04 & 0.00 & 0.00 & 0.00 & 0.00 & 0.00 & 0.00 & 0.00 & 0.06 & 0.05 & 0.03 & 0.00 & 0.07 & 0.00 & 0.00 \\
\hline Al2O3 & 25.87 & 25.66 & 24.85 & 26.22 & 26.13 & 25.87 & 26.12 & 31.07 & 25.29 & 27.31 & 25.94 & 24.86 & 30.08 & 26.19 & 28.47 \\
\hline $\mathrm{FeO}$ & 0.23 & 0.29 & 0.25 & 0.26 & 0.28 & 0.26 & 0.29 & 0.24 & 0.31 & 0.21 & 0.23 & 0.21 & 0.37 & 0.22 & 0.26 \\
\hline $\mathrm{MnO}$ & 0.00 & 0.00 & 0.00 & 0.00 & 0.00 & 0.00 & 0.00 & 0.00 & 0.02 & 0.00 & 0.00 & 0.00 & 0.03 & 0.00 & 0.00 \\
\hline $\mathrm{MgO}$ & 0.00 & 0.00 & 0.00 & 0.00 & 0.00 & 0.00 & 0.00 & 0.00 & 0.00 & 0.00 & 0.00 & 0.00 & 0.00 & 0.00 & 0.00 \\
\hline $\mathrm{SrO}$ & 0.19 & 0.18 & 0.19 & 0.10 & 0.20 & 0.14 & 0.16 & 0.17 & 0.15 & 0.22 & 0.15 & 0.15 & 0.13 & 0.16 & 0.16 \\
\hline $\mathrm{BaO}$ & 0.05 & 0.08 & 0.15 & 0.08 & 0.04 & 0.00 & 0.05 & 0.00 & 0.10 & 0.06 & 0.00 & 0.10 & 0.00 & 0.06 & 0.13 \\
\hline $\mathrm{PbO}$ & 0.00 & 0.00 & 0.00 & 0.09 & 0.00 & 0.00 & 0.05 & 0.05 & 0.00 & 0.05 & 0.00 & 0.00 & 0.00 & 0.00 & 0.00 \\
\hline $\mathrm{CaO}$ & 7.12 & 6.80 & 6.13 & 7.26 & 7.32 & 6.82 & 7.47 & 12.67 & 6.56 & 8.68 & 7.26 & 5.84 & 11.67 & 7.20 & 9.83 \\
\hline $\mathrm{Na} 2 \mathrm{O}$ & 6.94 & 7.31 & 7.48 & 6.98 & 6.93 & 7.33 & 7.14 & 4.39 & 7.62 & 6.36 & 7.15 & 8.24 & 4.57 & 7.14 & 5.68 \\
\hline $\mathrm{K} 2 \mathrm{O}$ & 0.46 & 0.57 & 0.71 & 0.52 & 0.51 & 0.51 & 0.18 & 0.07 & 0.54 & 0.23 & 0.36 & 0.31 & 0.13 & 0.21 & 0.21 \\
\hline Total & 99.38 & 99.93 & 99.67 & 100.03 & 100.26 & 100.14 & 99.90 & 100.63 & 100.46 & 100.18 & 99.99 & 100.50 & 100.03 & 99.74 & 100.00 \\
\hline $\mathrm{Si}$ & 10.528 & 10.580 & 10.744 & 10.484 & 10.510 & 10.571 & 10.479 & 9.392 & 10.659 & 10.230 & 10.530 & 10.788 & 9.594 & 10.498 & 9.967 \\
\hline ivAl & 5.490 & 5.421 & 5.256 & 5.537 & 5.502 & 5.448 & 5.519 & 6.620 & 5.311 & 5.776 & 5.472 & 5.203 & 6.423 & 5.535 & 6.055 \\
\hline Felll & 0.034 & 0.043 & 0.038 & 0.040 & 0.042 & 0.039 & 0.043 & 0.036 & 0.046 & 0.031 & 0.035 & 0.032 & 0.056 & 0.033 & 0.039 \\
\hline T site & 16.053 & 16.044 & 16.037 & 16.061 & 16.055 & 16.058 & 16.042 & 16.047 & 16.016 & 16.037 & 16.037 & 16.023 & 16.073 & 16.065 & 16.061 \\
\hline $\mathrm{Ti}$ & 0.006 & 0.000 & 0.000 & 0.000 & 0.000 & 0.000 & 0.000 & 0.000 & 0.007 & 0.007 & 0.004 & 0.000 & 0.010 & 0.000 & 0.000 \\
\hline $\mathrm{Mn}$ & 0.001 & 0.000 & 0.000 & 0.000 & 0.000 & 0.000 & 0.000 & 0.000 & 0.002 & 0.000 & 0.000 & 0.000 & 0.004 & 0.000 & 0.000 \\
\hline $\mathrm{Mg}$ & 0.000 & 0.000 & 0.000 & 0.000 & 0.000 & 0.000 & 0.000 & 0.000 & 0.000 & 0.000 & 0.000 & 0.000 & 0.000 & 0.000 & 0.000 \\
\hline $\mathrm{Sr}$ & 0.020 & 0.018 & 0.020 & 0.010 & 0.021 & 0.014 & 0.016 & 0.018 & 0.016 & 0.023 & 0.016 & 0.015 & 0.014 & 0.016 & 0.017 \\
\hline $\mathrm{Ba}$ & 0.004 & 0.005 & 0.010 & 0.006 & 0.003 & 0.000 & 0.003 & 0.000 & 0.007 & 0.004 & 0.000 & 0.007 & 0.000 & 0.004 & 0.009 \\
\hline $\mathrm{Pb}$ & 0.000 & 0.000 & 0.000 & 0.004 & 0.000 & 0.000 & 0.002 & 0.002 & 0.000 & 0.003 & 0.000 & 0.000 & 0.000 & 0.000 & 0.000 \\
\hline $\mathrm{Ca}$ & 1.374 & 1.306 & 1.179 & 1.394 & 1.401 & 1.306 & 1.435 & 2.454 & 1.252 & 1.669 & 1.392 & 1.111 & 2.265 & 1.383 & $\begin{array}{l}1.901 \\
\text {. }\end{array}$ \\
\hline $\mathrm{Na}$ & 2.423 & 2.540 & 2.602 & 2.425 & 2.401 & 2.539 & 2.482 & 1.539 & 2.633 & 2.213 & 2.481 & 2.837 & 1.605 & 2.482 & 1.987 \\
\hline $\mathrm{K}$ & 0.105 & 0.131 & 0.162 & 0.119 & 0.117 & 0.116 & 0.041 & 0.015 & 0.124 & 0.052 & 0.083 & 0.071 & 0.031 & 0.048 & 0.048 \\
\hline M site & 3.932 & 4.001 & 3.974 & 3.958 & 3.943 & 3.975 & 3.980 & 4.028 & 4.041 & 3.971 & 3.976 & 4.042 & 3.930 & 3.934 & 3.962 \\
\hline Cations & 19.985 & 20.045 & 20.011 & 20.019 & 19.997 & 20.033 & 20.022 & 20.075 & 20.056 & 20.007 & 20.013 & 20.064 & 20.002 & 20.000 & 20.023 \\
\hline An & 35.20 & 32.83 & 29.89 & 35.39 & 35.75 & 32.96 & 36.26 & 61.23 & 31.24 & 42.42 & 35.19 & 27.65 & 58.06 & 35.35 & 48.29 \\
\hline$A b$ & 62.10 & 63.87 & 66.00 & 61.58 & 61.26 & 64.11 & 62.71 & 38.39 & 65.67 & 56.25 & 62.71 & 70.59 & 41.14 & 63.43 & 50.49 \\
\hline Or & 2.70 & 3.30 & 4.12 & 3.03 & 2.99 & 2.93 & 1.03 & 0.38 & 3.09 & 1.32 & 2.10 & 1.76 & 0.80 & 1.22 & 1.22 \\
\hline
\end{tabular}

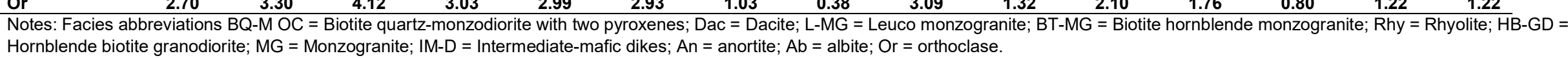


Supplementary Material: Electron microprobe analyses of alkali feldspar and plagioclase from Garzón granites and related rocks, Eastern Cordillera, Colombia.

\begin{tabular}{|c|c|c|c|c|c|c|c|}
\hline \multirow{3}{*}{$\begin{array}{l}\text { Mineral } \\
\text { Massif } \\
\text { Sample }\end{array}$} & \multicolumn{7}{|c|}{ Alkali feldspar } \\
\hline & & & & Sombrerillo & & & \\
\hline & $\begin{array}{l}\text { GAR- } \\
395\end{array}$ & $\begin{array}{l}\text { GAR- } \\
395\end{array}$ & $\begin{array}{l}\text { GAR- } \\
395\end{array}$ & $\begin{array}{l}\text { GAR- } \\
395\end{array}$ & $\begin{array}{l}\text { GAR- } \\
395\end{array}$ & $\begin{array}{l}\text { GAR- } \\
395\end{array}$ & $\begin{array}{l}\text { GAR- } \\
395\end{array}$ \\
\hline Facies & Dac & Dac & Dac & Dac & Dac & Dac & Dac \\
\hline $\begin{array}{l}\text { Grain/ } \\
\text { Point }\end{array}$ & pl_03-4 & pl_03-5 & pl_14-1 & pl_14-2 & pl_14-3 & pl_14-4 & pl_01a-1 \\
\hline $\mathrm{SiO} 2$ & 60.38 & 59.68 & 57.23 & 58.06 & 59.06 & 61.78 & 58.31 \\
\hline TiO2 & 0.00 & 0.00 & 0.00 & 0.00 & 0.03 & 0.04 & 0.00 \\
\hline Al2O3 & 24.91 & 25.88 & 27.25 & 26.80 & 25.99 & 24.13 & 26.82 \\
\hline $\mathrm{FeO}$ & 0.26 & 0.23 & 0.22 & 0.28 & 0.22 & 0.21 & 0.23 \\
\hline $\mathrm{MnO}$ & 0.02 & 0.00 & 0.03 & 0.03 & 0.00 & 0.00 & 0.00 \\
\hline $\mathrm{MgO}$ & 0.00 & 0.00 & 0.00 & 0.00 & 0.00 & 0.00 & 0.00 \\
\hline Sro & 0.11 & 0.16 & 0.12 & 0.09 & 0.15 & 0.14 & 0.10 \\
\hline $\mathrm{BaO}$ & 0.11 & 0.16 & 0.06 & 0.05 & 0.00 & 0.10 & 0.00 \\
\hline $\mathrm{PbO}$ & 0.00 & 0.06 & 0.00 & 0.00 & 0.00 & 0.00 & 0.00 \\
\hline $\mathrm{CaO}$ & 5.80 & 6.79 & 8.31 & 7.62 & 7.12 & 5.05 & 7.96 \\
\hline $\mathrm{Na} 2 \mathrm{O}$ & 8.05 & 7.51 & 6.53 & 6.92 & 7.54 & 8.43 & 6.69 \\
\hline $\mathrm{K} 2 \mathrm{O}$ & 0.37 & 0.21 & 0.19 & 0.31 & 0.20 & 0.33 & 0.40 \\
\hline Total & 100.00 & 100.69 & 99.96 & 100.17 & 100.33 & 100.21 & 100.52 \\
\hline $\mathrm{Si}$ & 10.771 & 10.600 & 10.272 & 10.385 & 10.532 & 10.961 & 10.392 \\
\hline ivAl & 5.237 & 5.418 & 5.764 & 5.650 & 5.462 & 5.046 & 5.633 \\
\hline Felll & 0.038 & 0.034 & 0.032 & 0.042 & 0.033 & 0.031 & 0.034 \\
\hline T site & 16.046 & 16.052 & 16.068 & 16.077 & 16.027 & 16.038 & 16.060 \\
\hline $\mathrm{Ti}$ & 0.000 & 0.000 & 0.000 & 0.000 & 0.004 & 0.005 & 0.000 \\
\hline $\mathrm{Mn}$ & 0.003 & 0.000 & 0.004 & 0.004 & 0.000 & 0.000 & 0.000 \\
\hline $\mathrm{Mg}$ & 0.000 & 0.000 & 0.000 & 0.000 & 0.000 & 0.000 & 0.000 \\
\hline $\mathrm{Sr}$ & 0.011 & 0.016 & 0.013 & 0.010 & 0.015 & 0.015 & 0.011 \\
\hline $\mathrm{Ba}$ & 0.008 & 0.011 & 0.004 & 0.004 & 0.000 & 0.007 & 0.000 \\
\hline $\mathrm{Pb}$ & 0.000 & 0.003 & 0.000 & 0.000 & 0.000 & 0.000 & 0.000 \\
\hline $\mathrm{Ca}$ & 1.109 & 1.292 & 1.598 & 1.460 & 1.360 & 0.960 & 1.520 \\
\hline $\mathrm{Na}$ & 2.784 & 2.586 & 2.272 & 2.400 & 2.607 & 2.900 & 2.312 \\
\hline $\mathrm{K}$ & 0.084 & 0.047 & 0.044 & 0.072 & 0.046 & 0.074 & 0.090 \\
\hline M site & 3.998 & 3.956 & 3.936 & 3.949 & 4.033 & 3.961 & 3.932 \\
\hline Cations & 20.045 & 20.008 & 20.004 & 20.026 & 20.059 & 19.998 & 19.992 \\
\hline An & 27.88 & 32.92 & 40.83 & 37.14 & 33.90 & 24.40 & 38.76 \\
\hline$A b$ & 70.02 & 65.89 & 58.06 & 61.04 & 64.96 & 73.71 & 58.95 \\
\hline
\end{tabular}

Notes: Facies abbreviations BQ-M OC = Biotite quartz-monzodiorite with two pyroxenes; Dac = Dacite; L-MG = Leuco monzogranite; BT-MG = Biotite hornblende monzogranite; Rhy = Rhyolite; HB-GD = Hornblende biotite granodiorite; $M G=$ Monzogranite; IM-D = Intermediate-mafic dikes; An = anortite; $A b=$ albite; Or = orthoclase. 
Supplementary Material: Electron microprobe analyses of amphibole from Garzón granites and related rocks, Eastern Cordillera, Colombia.

\begin{tabular}{|c|c|c|c|c|c|c|c|c|c|c|c|c|c|c|}
\hline \multirow{3}{*}{$\begin{array}{l}\text { Mineral } \\
\text { Massif } \\
\text { Sample }\end{array}$} & \multicolumn{14}{|c|}{ Amphibole } \\
\hline & \multicolumn{5}{|c|}{ Sombrerillo } & \multicolumn{9}{|c|}{ Algeciras } \\
\hline & 102 & 102 & 102 & 102 & 102 & $\begin{array}{l}\text { GAR- } \\
356\end{array}$ & $\begin{array}{l}\text { GAR- } \\
356\end{array}$ & $\begin{array}{l}\text { GAR- } \\
356\end{array}$ & $\begin{array}{l}\text { GAR- } \\
356\end{array}$ & $\begin{array}{l}\text { GAR- } \\
356\end{array}$ & $\begin{array}{l}\text { GAR- } \\
357\end{array}$ & $\begin{array}{l}\text { GAR- } \\
357\end{array}$ & $\begin{array}{l}\text { GAR- } \\
357\end{array}$ & $\begin{array}{l}\text { GAR- } \\
357\end{array}$ \\
\hline Facies & $\begin{array}{l}\text { BQ-M- } \\
\text { OC }\end{array}$ & $\begin{array}{l}\text { BQ-M- } \\
\text { OC }\end{array}$ & $\begin{array}{l}\text { BQ-M- } \\
\text { OC }\end{array}$ & $\begin{array}{l}\text { BQ-M- } \\
\text { OC }\end{array}$ & $\begin{array}{l}\text { BQ-M- } \\
\text { OC }\end{array}$ & BH-MG & BH-MG & BH-MG & BH-MG & BH-MG & BH-MG & BH-MG & BH-MG & BH-MG \\
\hline Grain/ Point & anf_13 & $\begin{array}{l}\text { anf_14a- } \\
1\end{array}$ & anf_15 & $\begin{array}{l}\text { anf_16a- } \\
1\end{array}$ & $\begin{array}{l}\text { anf_17a- } \\
1\end{array}$ & $\begin{array}{l}\text { anf_01- } \\
1\end{array}$ & $\begin{array}{l}\text { anf_02- } \\
1\end{array}$ & $\begin{array}{l}\text { anf_03- } \\
1\end{array}$ & $\begin{array}{l}\text { anf_04- } \\
1\end{array}$ & $\begin{array}{l}\text { anf_04- } \\
2\end{array}$ & $\begin{array}{l}\text { anf_01- } \\
2\end{array}$ & $\begin{array}{l}\text { anf_01- } \\
3\end{array}$ & $\begin{array}{l}\text { anf_02- } \\
1\end{array}$ & anf_02-2 \\
\hline $\mathrm{SiO} 2$ & 47.12 & 48.57 & 47.85 & 47.30 & 47.80 & 51.36 & 49.58 & 46.86 & 47.83 & 48.99 & 51.43 & 47.06 & 49.03 & 48.39 \\
\hline $\mathrm{TiO} 2$ & 1.00 & 0.67 & 1.13 & 1.17 & 1.08 & 0.14 & 0.50 & 0.92 & 0.79 & 0.65 & 0.24 & 1.29 & 0.77 & 0.73 \\
\hline Al2O3 & 6.98 & 6.09 & 6.70 & 7.27 & 6.48 & 3.84 & 4.95 & 7.32 & 6.88 & 5.57 & 4.03 & 7.55 & 6.06 & 6.39 \\
\hline $\mathrm{Cr} 2 \mathrm{O} 3$ & 0.00 & 0.04 & 0.00 & 0.04 & 0.00 & 0.00 & 0.00 & 0.00 & 0.00 & 0.00 & 0.06 & 0.10 & 0.00 & 0.00 \\
\hline $\mathrm{FeO}$ & 16.39 & 16.12 & 16.92 & 16.82 & 16.24 & 12.18 & 13.00 & 14.09 & 13.71 & 13.39 & 12.24 & 14.24 & 13.84 & 13.96 \\
\hline $\mathrm{MnO}$ & 0.34 & 0.36 & 0.39 & 0.36 & 0.41 & 0.74 & 0.71 & 0.59 & 0.59 & 0.72 & 0.78 & 0.80 & 0.83 & 0.81 \\
\hline $\mathrm{MgO}$ & 13.06 & 13.73 & 13.46 & 13.07 & 13.53 & 16.36 & 15.29 & 13.67 & 14.45 & 14.83 & 16.10 & 13.50 & 14.82 & 14.36 \\
\hline $\mathrm{ZnO}$ & 0.01 & 0.03 & 0.07 & 0.02 & 0.02 & 0.01 & 0.01 & 0.03 & 0.04 & 0.04 & 0.02 & 0.00 & 0.00 & 0.03 \\
\hline $\mathrm{CaO}$ & 10.98 & 11.05 & 11.06 & 11.14 & 11.16 & 11.94 & 11.64 & 11.36 & 11.59 & 11.65 & 11.87 & 11.62 & 11.50 & 11.65 \\
\hline $\mathrm{Na} 2 \mathrm{O}$ & 1.24 & 1.06 & 1.14 & 1.19 & 1.20 & 0.74 & 1.05 & 1.45 & 1.36 & 0.97 & 0.85 & 1.19 & 1.22 & 1.13 \\
\hline $\mathrm{K} 2 \mathrm{O}$ & 0.71 & 0.54 & 0.58 & 0.70 & 0.62 & 0.27 & 0.48 & 0.69 & 0.68 & 0.47 & 0.32 & 0.81 & 0.64 & 0.60 \\
\hline $\mathrm{F}$ & 0.05 & 0.07 & 0.05 & 0.05 & 0.05 & 0.11 & 0.17 & 0.22 & 0.15 & 0.15 & 0.08 & 0.14 & 0.11 & 0.12 \\
\hline $\mathrm{Cl}$ & 0.28 & 0.16 & 0.24 & 0.27 & 0.18 & 0.06 & 0.04 & 0.09 & 0.14 & 0.05 & 0.00 & 0.12 & 0.04 & 0.05 \\
\hline Total & 98.18 & 98.49 & 99.58 & 99.40 & 98.78 & 97.75 & 97.42 & 97.29 & 98.21 & 97.47 & 98.04 & 98.43 & 98.87 & 98.23 \\
\hline $\mathrm{O}=(\mathrm{Cl} . \mathrm{F})$ & 0.09 & 0.06 & 0.07 & 0.08 & 0.06 & 0.06 & 0.08 & 0.12 & 0.09 & 0.07 & 0.04 & 0.09 & 0.06 & 0.06 \\
\hline Total & 98.09 & 98.42 & 99.52 & 99.33 & 98.72 & 97.69 & 97.34 & 97.19 & 98.11 & 97.40 & 98.00 & 98.35 & 98.80 & 98.19 \\
\hline \multicolumn{15}{|c|}{ Structural formulae (according mean Fe3+ values. schumacher. after Gualda \& Vlach. 2005) } \\
\hline $\mathrm{Si}$ & 6.906 & 7.045 & 6.916 & 6.850 & 6.953 & 7.380 & 7.206 & 6.907 & 6.952 & 7.125 & 7.369 & 6.864 & 7.052 & 7.017 \\
\hline ivAl & 1.094 & 0.955 & 1.084 & 1.150 & 1.047 & 0.620 & 0.794 & 1.093 & 1.048 & 0.875 & 0.631 & 1.136 & 0.948 & 0.983 \\
\hline T site & 8.000 & 8.000 & 8.000 & 8.000 & 8.000 & 8.000 & 8.000 & 8.000 & 8.000 & 8.000 & 8.000 & 8.000 & 8.000 & 8.000 \\
\hline viAl & 0.112 & 0.086 & 0.058 & 0.091 & 0.063 & 0.031 & 0.053 & 0.178 & 0.131 & 0.079 & 0.050 & 0.162 & 0.080 & 0.109 \\
\hline $\mathrm{Ti}$ & 0.111 & 0.073 & 0.123 & 0.128 & 0.118 & 0.015 & 0.055 & 0.102 & 0.087 & 0.071 & 0.026 & 0.142 & 0.083 & 0.079 \\
\hline $\mathrm{Cr}$ & 0.000 & 0.005 & 0.000 & 0.004 & 0.000 & 0.000 & 0.000 & 0.000 & 0.000 & 0.000 & 0.007 & 0.011 & 0.001 & 0.000 \\
\hline Felll & 0.567 & 0.616 & 0.568 & 0.625 & 0.528 & 0.418 & 0.445 & 0.387 & 0.443 & 0.493 & 0.411 & 0.386 & 0.485 & 0.488 \\
\hline $\mathrm{Fe}$ & 1.442 & 1.340 & 1.477 & 1.412 & 1.448 & 1.045 & 1.135 & 1.350 & 1.223 & 1.136 & 1.056 & 1.351 & 1.180 & 1.205 \\
\hline $\mathrm{Mn}$ & 0.043 & 0.045 & 0.047 & 0.044 & 0.051 & 0.091 & 0.088 & 0.074 & 0.073 & 0.089 & 0.095 & 0.099 & 0.101 & 0.100 \\
\hline $\mathrm{Mg}$ & 2.853 & 2.968 & 2.900 & 2.821 & 2.933 & 3.504 & 3.312 & 3.003 & 3.131 & 3.215 & 3.438 & 2.935 & 3.177 & 3.104 \\
\hline $\mathrm{Zn}$ & 0.001 & 0.004 & 0.008 & 0.002 & 0.002 & 0.001 & 0.001 & 0.003 & 0.004 & 0.004 & 0.002 & 0.000 & 0.000 & 0.004 \\
\hline C site & 5.129 & 5.136 & 5.181 & 5.127 & 5.144 & 5.105 & 5.089 & 5.096 & 5.091 & 5.086 & 5.086 & 5.086 & 5.107 & 5.089 \\
\hline Excess C & 0.129 & 0.136 & 0.181 & 0.127 & 0.144 & 0.105 & 0.089 & 0.096 & 0.091 & 0.086 & 0.086 & 0.086 & 0.107 & 0.089 \\
\hline $\mathrm{Ca}$ & 1.724 & 1.717 & 1.713 & 1.729 & 1.739 & 1.838 & 1.813 & 1.794 & 1.805 & 1.815 & 1.822 & 1.816 & 1.772 & 1.810 \\
\hline $\mathrm{NaB}$ & 0.146 & 0.147 & 0.107 & 0.144 & 0.117 & 0.057 & 0.099 & 0.110 & 0.104 & 0.098 & 0.092 & 0.098 & 0.121 & 0.101 \\
\hline B site & 2.000 & 2.000 & 2.000 & 2.000 & 2.000 & 2.000 & 2.000 & 2.000 & 2.000 & 2.000 & 2.000 & 2.000 & 2.000 & 2.000 \\
\hline $\mathrm{NaA}$ & 0.207 & 0.150 & 0.212 & 0.190 & 0.221 & 0.149 & 0.197 & 0.305 & 0.279 & 0.174 & 0.144 & 0.240 & 0.220 & 0.216 \\
\hline $\mathrm{K}$ & 0.132 & 0.100 & 0.107 & 0.129 & 0.115 & 0.050 & 0.089 & 0.130 & 0.125 & 0.087 & 0.059 & 0.151 & 0.118 & 0.112 \\
\hline A site & 0.339 & 0.250 & 0.319 & 0.319 & 0.336 & 0.198 & 0.286 & 0.434 & 0.405 & 0.261 & 0.202 & 0.390 & 0.337 & 0.328 \\
\hline Cations & 15.339 & 15.250 & 15.319 & 15.319 & 15.336 & 15.198 & 15.286 & 15.434 & 15.405 & 15.261 & 15.202 & 15.390 & 15.337 & 15.328 \\
\hline $\mathrm{F}$ & 0.025 & 0.032 & 0.023 & 0.025 & 0.025 & 0.051 & 0.077 & 0.104 & 0.068 & 0.067 & 0.038 & 0.065 & 0.052 & 0.056 \\
\hline $\mathrm{Cl}$ & 0.070 & 0.039 & 0.058 & 0.066 & 0.045 & 0.014 & 0.011 & 0.024 & 0.034 & 0.012 & 0.000 & 0.031 & 0.009 & 0.013 \\
\hline mg\# & 0.66 & 0.69 & 0.66 & 0.67 & 0.67 & 0.77 & 0.74 & 0.69 & 0.72 & 0.74 & 0.77 & 0.68 & 0.73 & 0.72 \\
\hline \multicolumn{15}{|c|}{ Structural formulae (according max Fe3+ values. schumacher. after Gualda \& Vlach. 2005) } \\
\hline $\mathrm{Si}$ & 6.838 & 6.975 & 6.867 & 6.784 & 6.898 & 7.352 & 7.158 & 6.856 & 6.904 & 7.078 & 7.324 & 6.819 & 6.995 & 6.969 \\
\hline
\end{tabular}




\begin{tabular}{|c|c|c|c|c|c|c|c|c|c|c|c|c|c|c|}
\hline ivAl & 1.162 & 1.025 & 1.133 & 1.216 & 1.102 & 0.648 & 0.842 & 1.144 & 1.096 & 0.922 & 0.676 & 1.181 & 1.005 & 1.031 \\
\hline T site & 8.000 & 8.000 & 8.000 & 8.000 & 8.000 & 8.000 & 8.000 & 8.000 & 8.000 & 8.000 & 8.000 & 8.000 & 8.000 & 8.000 \\
\hline viAl & 0.032 & 0.006 & 0.000 & 0.012 & 0.000 & 0.000 & 0.000 & 0.118 & 0.074 & 0.026 & 0.000 & 0.109 & 0.014 & 0.054 \\
\hline $\mathrm{Ti}$ & 0.110 & 0.072 & 0.122 & 0.127 & 0.118 & 0.015 & 0.054 & 0.101 & 0.086 & 0.070 & 0.026 & 0.141 & 0.083 & 0.079 \\
\hline $\mathrm{Cr}$ & 0.000 & 0.005 & 0.000 & 0.004 & 0.000 & 0.000 & 0.000 & 0.000 & 0.000 & 0.000 & 0.007 & 0.011 & 0.001 & 0.000 \\
\hline Felll & 1.015 & 1.066 & 0.893 & 1.065 & 0.886 & 0.592 & 0.747 & 0.722 & 0.761 & 0.793 & 0.692 & 0.686 & 0.855 & 0.797 \\
\hline $\mathrm{Fe}$ & 0.975 & 0.870 & 1.137 & 0.952 & 1.074 & 0.866 & 0.822 & 1.002 & 0.894 & 0.825 & 0.765 & 1.040 & 0.796 & 0.884 \\
\hline $\mathrm{Mn}$ & 0.042 & 0.044 & 0.047 & 0.043 & 0.050 & 0.090 & 0.087 & 0.073 & 0.072 & 0.088 & 0.094 & 0.098 & 0.100 & 0.099 \\
\hline $\mathrm{Mg}$ & 2.825 & 2.939 & 2.879 & 2.794 & 2.910 & 3.491 & 3.290 & 2.981 & 3.109 & 3.193 & 3.417 & 2.916 & 3.151 & 3.083 \\
\hline $\mathrm{Zn}$ & 0.001 & 0.003 & 0.008 & 0.002 & 0.002 & 0.001 & 0.001 & 0.003 & 0.004 & 0.004 & 0.002 & 0.000 & 0.000 & 0.004 \\
\hline C site & 5.000 & 5.005 & 5.086 & 5.000 & 5.040 & 5.055 & 5.002 & 5.000 & 5.000 & 5.000 & 5.005 & 5.000 & 5.000 & 5.000 \\
\hline Excess $\mathrm{C}$ & 0.000 & 0.005 & 0.086 & 0.000 & 0.040 & 0.055 & 0.002 & 0.000 & 0.000 & 0.000 & 0.005 & 0.000 & 0.000 & 0.000 \\
\hline $\mathrm{Ca}$ & 1.707 & 1.700 & 1.701 & 1.712 & 1.725 & 1.831 & 1.800 & 1.781 & 1.792 & 1.803 & 1.811 & 1.804 & 1.758 & 1.798 \\
\hline $\mathrm{NaB}$ & 0.293 & 0.294 & 0.213 & 0.288 & 0.234 & 0.114 & 0.198 & 0.219 & 0.208 & 0.197 & 0.184 & 0.196 & 0.242 & 0.202 \\
\hline B site & 2.000 & 2.000 & 2.000 & 2.000 & 2.000 & 2.000 & 2.000 & 2.000 & 2.000 & 2.000 & 2.000 & 2.000 & 2.000 & 2.000 \\
\hline $\mathrm{NaA}$ & 0.058 & 0.000 & 0.104 & 0.043 & 0.102 & 0.091 & 0.096 & 0.192 & 0.173 & 0.074 & 0.050 & 0.139 & 0.096 & 0.113 \\
\hline $\mathrm{K}$ & 0.131 & 0.099 & 0.106 & 0.127 & 0.114 & 0.049 & 0.089 & 0.129 & 0.124 & 0.086 & 0.058 & 0.150 & 0.117 & 0.111 \\
\hline A site & 0.188 & 0.099 & 0.210 & 0.170 & 0.216 & 0.140 & 0.184 & 0.321 & 0.297 & 0.160 & 0.109 & 0.289 & 0.212 & 0.224 \\
\hline Cations & 15.188 & 15.104 & 15.296 & 15.170 & 15.256 & 15.195 & 15.186 & 15.321 & 15.297 & 15.160 & 15.113 & 15.289 & 15.212 & 15.224 \\
\hline $\mathrm{F}$ & 0.025 & 0.032 & 0.022 & 0.025 & 0.025 & 0.051 & 0.077 & 0.104 & 0.068 & 0.067 & 0.038 & 0.065 & 0.051 & 0.056 \\
\hline $\mathrm{Cl}$ & 0.069 & 0.038 & 0.058 & 0.065 & 0.045 & 0.014 & 0.011 & 0.024 & 0.034 & 0.012 & 0.000 & 0.030 & 0.009 & 0.013 \\
\hline mg\# & 0.74 & 0.77 & 0.72 & 0.75 & 0.73 & 0.80 & 0.80 & 0.75 & 0.78 & 0.79 & 0.82 & 0.74 & 0.80 & 0.78 \\
\hline $\mathrm{Mg} /\left(\mathrm{Mg}+\mathrm{Fe}^{2+}\right) \mathrm{med}$ & 0.664 & 0.689 & 0.663 & 0.666 & 0.670 & 0.770 & 0.745 & 0.690 & 0.719 & 0.739 & 0.765 & 0.685 & 0.729 & 0.720 \\
\hline $\mathrm{Mg} /\left(\mathrm{Mg}+\mathrm{Fe}^{2+}\right) \mathrm{max}$ & 0.744 & 0.771 & 0.717 & 0.746 & 0.730 & 0.801 & 0.800 & 0.749 & 0.777 & 0.795 & 0.817 & 0.737 & 0.798 & 0.777 \\
\hline $\mathrm{P}(\mathrm{kbar})$ & 2.1 & 1.3 & 1.8 & 2.3 & 1.6 & -0.7 & 0.3 & 2.4 & 2.0 & 0.9 & -0.5 & 2.6 & 1.2 & 1.5 \\
\hline $\mathrm{P}_{\mathrm{HZ}}$ (kbar) & 1.4 & 1.1 & 1.3 & 1.5 & 1.3 & 0.7 & 0.9 & 1.6 & 1.4 & 1.0 & 0.7 & 1.7 & 1.1 & 1.2 \\
\hline $\mathrm{P}_{\mathrm{M}}(\mathrm{kbar})$ & 1.3 & 0.9 & 1.2 & 1.4 & 1.1 & 0.1 & 0.5 & 1.5 & 1.3 & 0.7 & 0.2 & 1.6 & 0.9 & 1.0 \\
\hline$P_{R}(k b a r)$ & 1.1 & 0.8 & 1.0 & 1.1 & 0.9 & 0.5 & 0.6 & 1.2 & 1.0 & 0.8 & 0.5 & 1.2 & 0.8 & 0.9 \\
\hline $\mathrm{T}\left({ }^{\circ} \mathrm{C}\right)_{R}$ & 812 & 776 & 815 & 823 & 809 & 731 & 765 & 833 & 821 & 781 & 731 & 848 & 796 & 803 \\
\hline $\mathrm{T}\left({ }^{\circ} \mathrm{C}\right)_{\mathrm{HB}}$ & 758 & 756 & 760 & 761 & 759 & 739 & 750 & 751 & 753 & 751 & 741 & 753 & 755 & 753 \\
\hline$\triangle \mathrm{NNO}$ & 1.6 & 1.8 & 1.7 & 1.6 & 1.7 & 2.5 & 2.2 & 1.6 & 1.8 & 2.0 & 2.4 & 1.5 & 2.0 & 1.8 \\
\hline $\mathrm{H}_{2}$ Omelt & 2.1 & 1.3 & 1.8 & 2.3 & 1.6 & 3.5 & 3.8 & 4.5 & 4.2 & 4.4 & 3.9 & 4.5 & 4.0 & 4.5 \\
\hline
\end{tabular}


Supplementary Material: Electron microprobe analyses of amphibole from Garzón granites and related rocks, Eastern Cordillera, Colombia.

\begin{tabular}{|c|c|c|c|c|c|c|c|c|c|c|c|c|c|c|}
\hline \multirow{3}{*}{$\begin{array}{l}\text { Mineral } \\
\text { Massif } \\
\text { Sample }\end{array}$} & \multicolumn{14}{|c|}{ Amphibole } \\
\hline & \multicolumn{14}{|c|}{ Algeciras } \\
\hline & $\begin{array}{l}\text { GAR- } \\
357\end{array}$ & $\begin{array}{l}\text { GAR- } \\
357\end{array}$ & $\begin{array}{l}\text { GAR- } \\
357\end{array}$ & $\begin{array}{l}\text { GAR- } \\
357\end{array}$ & $\begin{array}{l}\text { GAR- } \\
357\end{array}$ & $\begin{array}{l}\text { GAR- } \\
357\end{array}$ & $\begin{array}{l}\text { GAR- } \\
357\end{array}$ & $\begin{array}{l}\text { GAR- } \\
357\end{array}$ & $\begin{array}{l}\text { GAR- } \\
357\end{array}$ & $\begin{array}{l}\text { GAR- } \\
357\end{array}$ & $\begin{array}{l}\text { GAR- } \\
357\end{array}$ & $\begin{array}{l}\text { GAR- } \\
357\end{array}$ & $\begin{array}{l}\text { GAR- } \\
361\end{array}$ & $\begin{array}{l}\text { GAR- } \\
361\end{array}$ \\
\hline \multirow{2}{*}{$\begin{array}{l}\text { Facies } \\
\text { Grain/Point }\end{array}$} & BH-MG & BH-MG & BH-MG & BH-MG & BH-MG & BH-MG & BH-MG & BH-MG & BH-MG & BH-MG & BH-MG & BH-MG & Dac & Dac \\
\hline & anf_03-2 & anf_03-3 & anf_03-4 & anf_04-2 & anf_05-1 & anf_05-2 & anf_07-1 & anf_07-2 & anf_08-1 & anf_08-2 & anf_08-3 & anf_08-4 & anf_01-1 & $\begin{array}{l}\text { anf_01- } \\
2\end{array}$ \\
\hline $\mathrm{SiO} 2$ & 48.35 & 48.16 & 49.35 & 48.35 & 47.46 & 47.36 & 49.10 & $\overline{50.78}$ & 49.65 & $\overline{51.67}$ & 48.52 & 52.15 & 44.48 & 49.78 \\
\hline TiO2 & 1.03 & 1.29 & 0.61 & 0.96 & 0.94 & 1.13 & 0.60 & 0.52 & 0.73 & 0.28 & 0.93 & 0.19 & 2.65 & 0.12 \\
\hline $\mathrm{Al} 2 \mathrm{O} 3$ & 6.36 & 6.61 & 5.76 & 6.44 & 7.20 & 7.34 & 6.05 & 4.89 & 5.56 & 3.70 & 6.20 & 3.36 & 10.79 & 6.29 \\
\hline $\mathrm{Cr} 2 \mathrm{O} 3$ & 0.06 & 0.07 & 0.04 & 0.06 & 0.05 & 0.00 & 0.04 & 0.04 & 0.05 & 0.06 & 0.04 & 0.00 & 0.00 & 0.00 \\
\hline $\mathrm{FeO}$ & 13.71 & 13.83 & 13.04 & 13.85 & 14.26 & 14.19 & 13.65 & 12.78 & 13.07 & 12.66 & 13.57 & 12.23 & 12.30 & 16.75 \\
\hline $\mathrm{MnO}$ & 0.72 & 0.68 & 0.72 & 0.76 & 0.69 & 0.67 & 0.75 & 0.79 & 0.76 & 0.86 & 0.65 & 0.85 & 0.30 & 0.68 \\
\hline $\mathrm{MgO}$ & 13.85 & 14.17 & 15.31 & 14.53 & 13.72 & 13.96 & 14.53 & 15.47 & 15.15 & 16.12 & 14.77 & 16.42 & 14.64 & 12.09 \\
\hline $\mathrm{ZnO}$ & 0.00 & 0.03 & 0.00 & 0.03 & 0.03 & 0.00 & 0.00 & 0.00 & 0.01 & 0.00 & 0.01 & 0.05 & 0.00 & 0.03 \\
\hline $\mathrm{CaO}$ & 12.23 & 11.59 & 11.66 & 11.56 & 11.62 & 11.46 & 11.77 & 11.80 & 11.44 & 11.87 & 11.49 & 11.84 & 11.24 & 12.16 \\
\hline $\mathrm{Na} 2 \mathrm{O}$ & 1.11 & 1.24 & 1.02 & 1.18 & 1.47 & 1.47 & 1.02 & 0.78 & 1.07 & 0.77 & 1.28 & 0.77 & 2.12 & 0.31 \\
\hline $\mathrm{K} 2 \mathrm{O}$ & 0.66 & 0.72 & 0.55 & 0.62 & 0.71 & 0.73 & 0.57 & 0.36 & 0.56 & 0.30 & 0.57 & 0.26 & 0.64 & 0.22 \\
\hline $\mathrm{F}$ & 0.10 & 0.16 & 0.13 & 0.11 & 0.15 & 0.13 & 0.14 & 0.11 & 0.11 & 0.15 & 0.14 & 0.13 & 0.06 & 0.02 \\
\hline $\mathrm{Cl}$ & 0.06 & 0.08 & 0.11 & 0.10 & 0.11 & 0.12 & 0.08 & 0.06 & 0.04 & 0.00 & 0.07 & 0.02 & 0.08 & 0.00 \\
\hline Total & 98.23 & 98.62 & 98.31 & 98.55 & 98.41 & 98.56 & 98.29 & 98.39 & 98.20 & 98.44 & 98.24 & 98.28 & 99.30 & 98.46 \\
\hline $\mathrm{O}=(\mathrm{Cl} . \mathrm{F})$ & 0.05 & 0.08 & 0.08 & 0.07 & 0.09 & 0.08 & 0.07 & 0.06 & 0.06 & 0.06 & 0.07 & 0.06 & 0.04 & 0.01 \\
\hline Total & 98.17 & 98.55 & 98.22 & 98.48 & 98.32 & 98.49 & 98.22 & 98.32 & 98.14 & 98.38 & 98.18 & 98.24 & 99.25 & 98.46 \\
\hline \multicolumn{15}{|c|}{ Structural formulae (according mean Fe3+ values. schumacher. after Gualda \& Vlach. 2005) } \\
\hline $\mathrm{Si}$ & 7.054 & 6.986 & 7.104 & 6.989 & 6.926 & 6.886 & 7.104 & 7.273 & 7.156 & 7.402 & 7.026 & 7.464 & 6.377 & 7.233 \\
\hline ivAl & 0.946 & 1.014 & 0.896 & 1.011 & 1.074 & 1.114 & 0.896 & 0.727 & 0.844 & 0.598 & 0.974 & 0.536 & 1.623 & 0.767 \\
\hline T site & 8.000 & 8.000 & 8.000 & 8.000 & 8.000 & 8.000 & 8.000 & 8.000 & 8.000 & 8.000 & 8.000 & 8.000 & 8.000 & 8.000 \\
\hline viAl & 0.148 & 0.116 & 0.081 & 0.086 & 0.164 & 0.144 & 0.135 & 0.098 & 0.101 & 0.027 & 0.084 & 0.031 & 0.201 & 0.310 \\
\hline $\mathrm{Ti}$ & 0.113 & 0.140 & 0.066 & 0.104 & 0.103 & 0.124 & 0.065 & 0.056 & 0.079 & 0.030 & 0.101 & 0.021 & 0.286 & 0.013 \\
\hline $\mathrm{Cr}$ & 0.006 & 0.008 & 0.005 & 0.007 & 0.006 & 0.000 & 0.005 & 0.004 & 0.005 & 0.007 & 0.005 & 0.000 & 0.000 & 0.000 \\
\hline Felll & 0.224 & 0.338 & 0.507 & 0.487 & 0.345 & 0.401 & 0.422 & 0.430 & 0.427 & 0.336 & 0.450 & 0.315 & 0.438 & 0.389 \\
\hline $\mathrm{Fe}$ & 1.448 & 1.340 & 1.063 & 1.187 & 1.395 & 1.324 & 1.230 & 1.101 & 1.148 & 1.181 & 1.194 & 1.149 & 1.037 & 1.646 \\
\hline $\mathrm{Mn}$ & 0.089 & 0.084 & 0.088 & 0.093 & 0.085 & 0.082 & 0.092 & 0.096 & 0.093 & 0.105 & 0.080 & 0.103 & 0.036 & 0.083 \\
\hline $\mathrm{Mg}$ & 3.012 & 3.064 & 3.285 & 3.131 & 2.984 & 3.025 & 3.133 & 3.303 & 3.255 & 3.442 & 3.188 & 3.503 & 3.129 & 2.618 \\
\hline $\mathrm{Zn}$ & 0.000 & 0.003 & 0.000 & 0.003 & 0.004 & 0.000 & 0.000 & 0.000 & 0.001 & 0.000 & 0.001 & 0.005 & 0.000 & 0.004 \\
\hline C site & 5.041 & 5.093 & 5.094 & 5.098 & 5.086 & 5.101 & 5.082 & 5.088 & 5.109 & 5.128 & 5.102 & 5.127 & 5.126 & 5.063 \\
\hline Excess C & 0.041 & 0.093 & 0.094 & 0.098 & 0.086 & 0.101 & 0.082 & 0.088 & 0.109 & 0.128 & 0.102 & 0.127 & 0.126 & 0.063 \\
\hline $\mathrm{Ca}$ & 1.912 & 1.801 & 1.798 & 1.790 & 1.817 & 1.785 & 1.824 & 1.811 & 1.767 & 1.822 & 1.783 & 1.816 & 1.727 & 1.893 \\
\hline $\mathrm{NaB}$ & 0.047 & 0.106 & 0.107 & 0.112 & 0.098 & 0.114 & 0.093 & 0.101 & 0.124 & 0.050 & 0.116 & 0.057 & 0.147 & 0.044 \\
\hline B site & 2.000 & 2.000 & 2.000 & 2.000 & 2.000 & 2.000 & 2.000 & 2.000 & 2.000 & 2.000 & 2.000 & 2.000 & 2.000 & 2.000 \\
\hline $\mathrm{NaA}$ & 0.266 & 0.243 & 0.178 & 0.219 & 0.318 & 0.300 & 0.193 & 0.116 & 0.174 & 0.163 & 0.245 & 0.157 & 0.442 & 0.044 \\
\hline K & 0.122 & 0.134 & 0.101 & 0.115 & 0.132 & 0.136 & 0.105 & 0.067 & 0.103 & 0.054 & 0.105 & 0.048 & 0.117 & 0.042 \\
\hline A site & 0.388 & 0.376 & 0.280 & 0.334 & 0.451 & 0.436 & 0.298 & 0.182 & 0.277 & 0.218 & 0.349 & 0.205 & 0.560 & 0.086 \\
\hline Cations & 15.388 & 15.376 & 15.280 & 15.334 & 15.451 & 15.436 & 15.298 & 15.182 & 15.277 & 15.218 & 15.349 & 15.205 & 15.560 & 15.086 \\
\hline $\mathrm{F}$ & 0.046 & 0.072 & 0.059 & 0.049 & 0.069 & 0.058 & 0.062 & 0.049 & 0.052 & 0.068 & 0.063 & 0.058 & 0.026 & 0.011 \\
\hline $\mathrm{Cl}$ & 0.014 & 0.018 & 0.026 & 0.025 & 0.028 & 0.031 & 0.018 & 0.015 & 0.010 & 0.000 & 0.018 & 0.005 & 0.021 & 0.000 \\
\hline mg\# & 0.68 & 0.70 & 0.76 & 0.73 & 0.68 & 0.70 & 0.72 & 0.75 & 0.74 & 0.74 & 0.73 & 0.75 & 0.75 & 0.61 \\
\hline \multicolumn{15}{|c|}{ Structural formulae (according max Fe3+ values. schumacher. after Gualda \& Vlach. 2005) } \\
\hline $\mathrm{Si}$ & 7.032 & 6.937 & 7.053 & 6.937 & 6.880 & 6.833 & 7.059 & 7.224 & 7.097 & 7.377 & 6.971 & 7.435 & 6.316 & 7.212 \\
\hline ivAl & 0.968 & 1.063 & 0.947 & 1.063 & 1.120 & 1.167 & 0.941 & 0.776 & 0.903 & 0.623 & 1.029 & 0.565 & 1.684 & 0.788 \\
\hline
\end{tabular}




\begin{tabular}{|c|c|c|c|c|c|c|c|c|c|c|c|c|c|c|}
\hline T site & 8.000 & 8.000 & 8.000 & 8.000 & 8.000 & 8.000 & 8.000 & 8.000 & 8.000 & 8.000 & 8.000 & 8.000 & 8.000 & 8.000 \\
\hline viAl & 0.122 & 0.059 & 0.023 & 0.026 & 0.111 & 0.081 & 0.084 & 0.044 & 0.033 & 0.000 & 0.021 & 0.000 & 0.122 & 0.286 \\
\hline $\mathrm{Ti}$ & 0.113 & 0.139 & 0.065 & 0.103 & 0.102 & 0.123 & 0.065 & 0.056 & 0.078 & 0.030 & 0.100 & 0.021 & 0.283 & 0.013 \\
\hline $\mathrm{Cr}$ & 0.006 & 0.008 & 0.005 & 0.007 & 0.006 & 0.000 & 0.005 & 0.004 & 0.005 & 0.007 & 0.005 & 0.000 & 0.000 & 0.000 \\
\hline Felll & 0.369 & 0.662 & 0.835 & 0.828 & 0.644 & 0.751 & 0.708 & 0.738 & 0.807 & 0.489 & 0.803 & 0.490 & 0.876 & 0.522 \\
\hline $\mathrm{Fe}$ & 1.299 & 1.004 & 0.723 & 0.833 & 1.085 & 0.961 & 0.934 & 0.782 & 0.755 & 1.022 & 0.827 & 0.968 & 0.585 & 1.507 \\
\hline $\mathrm{Mn}$ & 0.089 & 0.083 & 0.088 & 0.092 & 0.084 & 0.082 & 0.091 & 0.096 & 0.092 & 0.104 & 0.079 & 0.103 & 0.036 & 0.083 \\
\hline Mg & 3.002 & 3.042 & 3.261 & 3.107 & 2.965 & 3.002 & 3.114 & 3.280 & 3.228 & 3.431 & 3.163 & 3.489 & 3.099 & 2.611 \\
\hline $\mathrm{Zn}$ & 0.000 & 0.003 & 0.000 & 0.003 & 0.003 & 0.000 & 0.000 & 0.000 & 0.001 & 0.000 & 0.001 & 0.005 & 0.000 & 0.004 \\
\hline C site & 5.000 & 5.000 & 5.000 & 5.000 & 5.000 & 5.000 & 5.000 & 5.000 & 5.000 & 5.084 & 5.000 & 5.077 & 5.000 & 5.025 \\
\hline Excess C & 0.000 & 0.000 & 0.000 & 0.000 & 0.000 & 0.000 & 0.000 & 0.000 & 0.000 & 0.084 & 0.000 & 0.077 & 0.000 & 0.025 \\
\hline $\mathrm{Ca}$ & 1.906 & 1.789 & 1.785 & 1.777 & 1.805 & 1.772 & 1.813 & 1.799 & 1.752 & 1.816 & 1.769 & 1.809 & 1.710 & 1.888 \\
\hline $\mathrm{NaB}$ & 0.094 & 0.211 & 0.215 & 0.223 & 0.195 & 0.228 & 0.187 & 0.201 & 0.248 & 0.101 & 0.231 & 0.114 & 0.290 & 0.087 \\
\hline B site & 2.000 & 2.000 & 2.000 & 2.000 & 2.000 & 2.000 & 2.000 & 2.000 & 2.000 & 2.000 & 2.000 & 2.000 & 2.000 & 2.000 \\
\hline $\mathrm{NaA}$ & 0.218 & 0.135 & 0.069 & 0.105 & 0.218 & 0.183 & 0.097 & 0.013 & 0.048 & 0.112 & 0.126 & 0.099 & 0.294 & 0.000 \\
\hline $\mathrm{K}$ & 0.122 & 0.133 & 0.100 & 0.114 & 0.132 & 0.135 & 0.104 & 0.066 & 0.102 & 0.054 & 0.104 & 0.048 & 0.116 & 0.042 \\
\hline A site & 0.340 & 0.267 & 0.169 & 0.219 & 0.350 & 0.317 & 0.202 & 0.080 & 0.149 & 0.167 & 0.230 & 0.147 & 0.410 & 0.042 \\
\hline Cations & 15.340 & 15.267 & 15.169 & 15.219 & 15.350 & 15.317 & 15.202 & 15.080 & 15.149 & 15.250 & 15.230 & 15.224 & 15.410 & 15.067 \\
\hline $\mathrm{F}$ & 0.046 & 0.071 & 0.059 & 0.049 & 0.068 & 0.057 & 0.061 & 0.048 & 0.051 & 0.068 & 0.062 & 0.057 & 0.026 & 0.011 \\
\hline $\mathrm{Cl}$ & 0.014 & 0.018 & 0.026 & 0.025 & 0.028 & 0.030 & 0.018 & 0.015 & 0.010 & 0.000 & 0.018 & 0.005 & 0.020 & 0.000 \\
\hline mg\# & 0.70 & 0.75 & 0.82 & 0.79 & 0.73 & 0.76 & 0.77 & 0.81 & 0.81 & 0.77 & 0.79 & 0.78 & 0.84 & 0.63 \\
\hline $\mathrm{Mg} /\left(\mathrm{Mg}+\mathrm{Fe}^{2+}\right) \mathrm{med}$ & 0.675 & 0.696 & 0.756 & 0.725 & 0.681 & 0.696 & 0.718 & 0.750 & 0.739 & 0.745 & 0.728 & 0.753 & 0.751 & 0.614 \\
\hline $\mathrm{Mg} /\left(\mathrm{Mg}+\mathrm{Fe}^{2+}\right) \max$ & 0.698 & 0.752 & 0.818 & 0.788 & 0.732 & 0.758 & 0.769 & 0.807 & 0.810 & 0.770 & 0.793 & 0.783 & 0.841 & 0.634 \\
\hline $\mathrm{P}$ (kbar) & 1.6 & 1.7 & 1.0 & 1.6 & 2.3 & 2.4 & 1.2 & 0.2 & 0.8 & -0.8 & 1.4 & -1.1 & 1.5 & 5.1 \\
\hline $\mathrm{P}_{\mathrm{HZ}}$ (kbar) & 1.2 & 1.3 & 1.0 & 1.2 & 1.5 & 1.6 & 1.1 & 0.8 & 1.0 & 0.6 & 1.2 & 0.6 & 1.2 & 3.4 \\
\hline $\mathrm{P}_{\mathrm{M}}$ (kbar) & 1.0 & 1.1 & 0.8 & 1.0 & 1.4 & 1.5 & 0.9 & 0.4 & 0.7 & 0.1 & 0.9 & 0.0 & 1.0 & 3.3 \\
\hline$P_{R}(k b a r)$ & 0.9 & 1.0 & 0.8 & 0.9 & 1.1 & 1.2 & 0.8 & 0.6 & 0.7 & 0.5 & 0.9 & 0.4 & 0.9 & 2.5 \\
\hline $\mathrm{T}\left({ }^{\circ} \mathrm{C}\right)_{\mathrm{R}}$ & 816 & 825 & 785 & 812 & 831 & 840 & 787 & 753 & 778 & 731 & 807 & 719 & 742 & 972 \\
\hline $\mathrm{T}\left({ }^{\circ} \mathrm{C}\right)_{\mathrm{HB}}$ & 746 & 754 & 752 & 756 & 751 & 755 & 748 & 744 & 750 & 737 & 755 & 733 & 727 & 758 \\
\hline$\triangle N N O$ & 1.6 & 1.7 & 2.2 & 1.9 & 1.5 & 1.7 & 1.9 & 2.2 & 2.1 & 2.4 & 2.0 & 2.5 & 1.6 & 1.2 \\
\hline $\mathrm{H}_{2}$ Omelt & 4.1 & 4.0 & 4.2 & 4.3 & 4.3 & 4.3 & 4.5 & 4.5 & 4.1 & 3.1 & 4.1 & 3.0 & 5.5 & 6.8 \\
\hline
\end{tabular}

Notes: Facies abbreviations BQ-M OC = Biotite quartz-monzodiorite with two pyroxenes; L-MG = Leuco monzogranite; BT-MG = Biotite hornblende monzogranite; Rhy = Rhyolite; HB-GD = Hornblende biotite granodiorite; $\mathrm{MG}=$ Monzogranite; $\mathrm{H}-\mathrm{MZ}=$ Hornblende monzodiorite; $\mathrm{E}-\mathrm{MD}=$ Micro-diorite enclave; $\mathrm{IM}-\mathrm{D}=$ Intermediate-mafic dikes; $\mathrm{Dac}=\mathrm{Dacite} ; \mathrm{mg} \#=$ magnesium number. $\mathrm{P}=-3.92+5.03 \mathrm{Al} \mathrm{I}^{\top}$ (Hammarstorm and Zen, 1986); $\mathrm{P}=0.26 \mathrm{e}\left(1.48 \mathrm{Al}^{\top}\right)$ (Hammarstrorm \& Zen, 1986); $\mathrm{P}_{\mathrm{M}}=-0.5+0.331(8) \times \mathrm{Al} \mathrm{I}^{\top}+0.995(4) \times\left(\mathrm{Al}^{\top}\right)^{2}$ from Mutch, et al. $(2016) ; \mathrm{T}\left({ }^{\circ} \mathrm{C}\right) \mathrm{R}=\mathrm{Temperature} \mathrm{from} \mathrm{Ridolfi} \mathrm{et} \mathrm{al.}(2010) ; \mathrm{T}\left({ }^{\circ} \mathrm{C}\right)$ Hв $=\left(\right.$ Holland \& Blundy, 1994); $\triangle N N O=$ oxygen fugacity-amphibole relative to NNO buffer from Ridolfi et al. $(2010) ; \mathrm{H}_{2}$ Omelt $=$ The water content in the melt from Ridolfi et al. $(2010)$. 
Supplementary Material: Electron microprobe analyses of amphibole from Garzón granites and related rocks, Eastern Cordillera, Colombia.

\begin{tabular}{|c|c|c|c|c|c|c|c|c|c|c|c|c|c|c|}
\hline \multirow{3}{*}{$\begin{array}{l}\text { Mineral } \\
\text { Massif } \\
\text { Sample }\end{array}$} & \multicolumn{14}{|c|}{ Amphibole } \\
\hline & \multicolumn{14}{|c|}{ Algeciras } \\
\hline & GAR-361 & $\begin{array}{l}\text { GAR- } \\
361\end{array}$ & $\begin{array}{l}\text { GAR- } \\
361\end{array}$ & $\begin{array}{l}\text { GAR- } \\
361\end{array}$ & $\begin{array}{l}\text { GAR- } \\
361\end{array}$ & $\begin{array}{l}\text { GAR- } \\
361\end{array}$ & $\begin{array}{l}\text { GAR- } \\
361\end{array}$ & $\begin{array}{l}\text { GAR- } \\
361\end{array}$ & $\begin{array}{l}\text { GAR- } \\
361\end{array}$ & $\begin{array}{l}\text { GAR- } \\
361\end{array}$ & $\begin{array}{l}\text { GAR- } \\
361\end{array}$ & $\begin{array}{l}\text { GAR- } \\
361\end{array}$ & $\begin{array}{l}\text { GAR- } \\
361\end{array}$ & $\begin{array}{l}\text { GAR- } \\
361\end{array}$ \\
\hline Facies & Dac & Dac & Dac & Dac & Dac & Dac & Dac & Dac & Dac & Dac & Dac & Dac & Dac & Dac \\
\hline Grain/Point & anf_01-4 & anf_02-1 & anf_02-2 & anf_02-3 & anf_02-4 & anf_02-5 & anf_03-1 & anf_03-2 & anf_03-3 & anf_04-1 & anf_04-2 & anf_04-3 & anf_04-4 & anf_04-5 \\
\hline $\mathrm{SiO} 2$ & 45.25 & 47.30 & 45.12 & 42.83 & 42.54 & 45.31 & 42.58 & 41.74 & 47.61 & 45.75 & 45.04 & 42.64 & 47.05 & 46.48 \\
\hline TiO2 & 2.12 & 1.84 & 2.34 & 2.85 & 2.61 & 2.24 & 2.50 & 2.85 & 1.72 & 2.06 & 2.38 & 3.00 & 1.78 & 1.96 \\
\hline $\mathrm{Al} 2 \mathrm{O} 3$ & 10.00 & 8.68 & 10.33 & 12.79 & 12.91 & 10.01 & 13.68 & 13.32 & 8.06 & 9.54 & 10.18 & 12.30 & 8.71 & 9.13 \\
\hline $\mathrm{Cr} 2 \mathrm{O} 3$ & 0.00 & 0.00 & 0.00 & 0.00 & 0.00 & 0.00 & 0.00 & 0.00 & 0.00 & 0.00 & 0.00 & 0.00 & 0.00 & 0.00 \\
\hline $\mathrm{FeO}$ & 12.60 & 11.45 & 12.24 & 12.61 & 13.03 & 12.32 & 11.91 & 13.15 & 11.76 & 12.15 & 12.21 & 13.08 & 11.59 & 11.89 \\
\hline $\mathrm{MnO}$ & 0.39 & 0.27 & 0.30 & 0.31 & 0.25 & 0.37 & 0.28 & 0.38 & 0.43 & 0.28 & 0.30 & 0.30 & 0.36 & 0.40 \\
\hline $\mathrm{MgO}$ & 15.06 & 16.09 & 14.98 & 13.82 & 13.86 & 14.96 & 14.26 & 13.16 & 16.19 & 15.39 & 15.09 & 13.56 & 15.92 & 15.30 \\
\hline $\mathrm{ZnO}$ & 0.04 & 0.02 & 0.02 & 0.01 & 0.02 & 0.04 & 0.02 & 0.01 & 0.01 & 0.01 & 0.00 & 0.00 & 0.02 & 0.00 \\
\hline $\mathrm{CaO}$ & 10.94 & 11.27 & 11.30 & 11.40 & 11.46 & 11.16 & 11.30 & 11.34 & 11.16 & 11.04 & 11.22 & 11.32 & 11.17 & 11.06 \\
\hline $\mathrm{Na} 2 \mathrm{O}$ & 1.93 & 1.68 & 1.95 & 2.17 & 2.38 & 1.90 & 2.44 & 2.26 & 1.59 & 1.88 & 1.91 & 2.19 & 1.73 & 1.82 \\
\hline $\mathrm{K} 2 \mathrm{O}$ & 0.59 & 0.57 & 0.65 & 0.70 & 0.62 & 0.57 & 0.45 & 0.78 & 0.52 & 0.58 & 0.66 & 0.67 & 0.59 & 0.69 \\
\hline $\mathrm{F}$ & 0.06 & 0.07 & 0.05 & 0.05 & 0.06 & 0.08 & 0.08 & 0.03 & 0.08 & 0.06 & 0.05 & 0.05 & 0.06 & 0.04 \\
\hline $\mathrm{Cl}$ & 0.13 & 0.10 & 0.06 & 0.07 & 0.10 & 0.08 & 0.06 & 0.13 & 0.10 & 0.07 & 0.15 & 0.10 & 0.04 & 0.11 \\
\hline Total & 99.12 & 99.34 & 99.33 & 99.60 & 99.83 & 99.04 & 99.57 & 99.15 & 99.23 & 98.82 & 99.19 & 99.21 & 99.01 & 98.88 \\
\hline $\mathrm{O}=(\mathrm{Cl} . \mathrm{F})$ & 0.06 & 0.05 & 0.03 & 0.04 & 0.05 & 0.05 & 0.05 & 0.04 & 0.06 & 0.04 & 0.06 & 0.04 & 0.03 & 0.04 \\
\hline Total & 99.07 & 99.29 & 99.31 & 99.56 & 99.81 & 98.98 & 99.52 & 99.12 & 99.16 & 98.79 & 99.12 & 99.18 & 99.01 & 98.85 \\
\hline \multicolumn{15}{|c|}{ Structural formulae (according mean Fe3+ values. schumacher. after Gualda \& Vlach. 2005) } \\
\hline $\mathrm{Si}$ & 6.471 & 6.702 & 6.446 & 6.142 & 6.096 & 6.488 & 6.072 & 6.046 & 6.748 & 6.544 & 6.444 & 6.159 & 6.692 & 6.649 \\
\hline ivAl & 1.529 & 1.298 & 1.554 & 1.858 & 1.904 & 1.512 & 1.928 & 1.954 & 1.252 & 1.456 & 1.556 & 1.841 & 1.308 & 1.351 \\
\hline T site & 8.000 & 8.000 & 8.000 & 8.000 & 8.000 & 8.000 & 8.000 & 8.000 & 8.000 & 8.000 & 8.000 & 8.000 & 8.000 & 8.000 \\
\hline viAl & 0.156 & 0.151 & 0.185 & 0.304 & 0.277 & 0.177 & 0.372 & 0.320 & 0.094 & 0.153 & 0.161 & 0.254 & 0.152 & 0.188 \\
\hline $\mathrm{Ti}$ & 0.228 & 0.196 & 0.251 & 0.307 & 0.281 & 0.241 & 0.268 & 0.310 & 0.183 & 0.222 & 0.256 & 0.326 & 0.190 & 0.211 \\
\hline $\mathrm{Cr}$ & 0.000 & 0.000 & 0.000 & 0.000 & 0.000 & 0.000 & 0.000 & 0.000 & 0.000 & 0.000 & 0.000 & 0.001 & 0.000 & 0.000 \\
\hline Felll & 0.619 & 0.498 & 0.496 & 0.471 & 0.545 & 0.527 & 0.553 & 0.489 & 0.585 & 0.558 & 0.530 & 0.461 & 0.508 & 0.457 \\
\hline $\mathrm{Fe}$ & 0.888 & 0.859 & 0.967 & 1.041 & 1.017 & 0.948 & 0.867 & 1.104 & 0.808 & 0.895 & 0.930 & 1.119 & 0.870 & 0.965 \\
\hline $\mathrm{Mn}$ & 0.048 & 0.032 & 0.036 & 0.037 & 0.030 & 0.045 & 0.034 & 0.046 & 0.051 & 0.034 & 0.036 & 0.037 & 0.043 & 0.049 \\
\hline $\mathrm{Mg}$ & 3.210 & 3.398 & 3.190 & 2.954 & 2.961 & 3.193 & 3.031 & 2.841 & 3.420 & 3.281 & 3.218 & 2.920 & 3.375 & 3.262 \\
\hline $\mathrm{Zn}$ & 0.004 & 0.002 & 0.002 & 0.001 & 0.002 & 0.004 & 0.002 & 0.001 & 0.001 & 0.001 & 0.000 & 0.000 & 0.002 & 0.000 \\
\hline C site & 5.152 & 5.136 & 5.127 & 5.116 & 5.113 & 5.135 & 5.128 & 5.112 & 5.143 & 5.145 & 5.131 & 5.116 & 5.140 & 5.132 \\
\hline Excess C & 0.152 & 0.136 & 0.127 & 0.116 & 0.113 & 0.135 & 0.128 & 0.112 & 0.143 & 0.145 & 0.131 & 0.116 & 0.140 & 0.132 \\
\hline $\mathrm{Ca}$ & 1.676 & 1.711 & 1.730 & 1.752 & 1.760 & 1.712 & 1.727 & 1.760 & 1.695 & 1.692 & 1.720 & 1.752 & 1.702 & 1.695 \\
\hline $\mathrm{NaB}$ & 0.172 & 0.153 & 0.144 & 0.132 & 0.128 & 0.153 & 0.145 & 0.128 & 0.162 & 0.163 & 0.149 & 0.132 & 0.158 & 0.173 \\
\hline B site & 2.000 & 2.000 & 2.000 & 2.000 & 2.000 & 2.000 & 2.000 & 2.000 & 2.000 & 2.000 & 2.000 & 2.000 & 2.000 & 2.000 \\
\hline $\mathrm{NaA}$ & 0.363 & 0.308 & 0.397 & 0.471 & 0.534 & 0.375 & 0.530 & 0.507 & 0.275 & 0.358 & 0.381 & 0.482 & 0.319 & 0.332 \\
\hline $\mathrm{K}$ & 0.107 & 0.103 & 0.118 & 0.127 & 0.113 & 0.104 & 0.082 & 0.144 & 0.093 & 0.106 & 0.120 & 0.124 & 0.107 & 0.127 \\
\hline A site & 0.471 & 0.411 & 0.514 & 0.599 & 0.647 & 0.478 & 0.611 & 0.651 & 0.368 & 0.464 & 0.502 & 0.605 & 0.426 & 0.458 \\
\hline Cations & 15.471 & 15.411 & 15.514 & 15.599 & 15.647 & 15.478 & 15.611 & 15.651 & 15.368 & 15.464 & 15.502 & 15.605 & 15.426 & 15.458 \\
\hline $\mathrm{F}$ & 0.029 & 0.032 & 0.024 & 0.024 & 0.029 & 0.034 & 0.038 & 0.013 & 0.036 & 0.027 & 0.022 & 0.025 & 0.027 & 0.018 \\
\hline $\mathrm{Cl}$ & 0.032 & 0.023 & 0.013 & 0.017 & 0.023 & 0.020 & 0.014 & 0.033 & 0.025 & 0.018 & 0.037 & 0.023 & 0.010 & 0.026 \\
\hline mg\# & 0.78 & 0.80 & 0.77 & 0.74 & 0.74 & 0.77 & 0.78 & 0.72 & 0.81 & 0.79 & 0.78 & 0.72 & 0.79 & 0.77 \\
\hline \multicolumn{15}{|c|}{ Structural formulae (according max Fe3+ values. schumacher. after Gualda \& Vlach. 2005} \\
\hline $\mathrm{Si}$ & 6.396 & 6.632 & 6.383 & 6.088 & 6.044 & 6.421 & 6.013 & 5.994 & 6.674 & 6.472 & 6.379 & 6.105 & 6.620 & 6.582 \\
\hline ivAl & 1.604 & 1.368 & 1.617 & 1.912 & 1.956 & 1.579 & 1.987 & 2.006 & 1.326 & 1.528 & 1.621 & 1.895 & 1.380 & 1.418 \\
\hline T site & 8.000 & 8.000 & 8.000 & 8.000 & 8.000 & 8.000 & 8.000 & 8.000 & 8.000 & 8.000 & 8.000 & 8.000 & 8.000 & 8.000 \\
\hline
\end{tabular}




\begin{tabular}{|c|c|c|c|c|c|c|c|c|c|c|c|c|c|c|}
\hline viAl & 0.061 & 0.067 & 0.106 & 0.231 & 0.206 & 0.093 & 0.290 & 0.249 & 0.006 & 0.063 & 0.079 & 0.180 & 0.065 & 0.106 \\
\hline $\mathrm{Ti}$ & 0.225 & 0.194 & 0.249 & 0.305 & 0.279 & 0.239 & 0.265 & 0.308 & 0.181 & 0.219 & 0.254 & 0.323 & 0.188 & 0.209 \\
\hline $\mathrm{Cr}$ & 0.000 & 0.000 & 0.000 & 0.000 & 0.000 & 0.000 & 0.000 & 0.000 & 0.000 & 0.000 & 0.000 & 0.001 & 0.000 & 0.000 \\
\hline Felll & 1.144 & 0.968 & 0.935 & 0.875 & 0.935 & 0.995 & 0.997 & 0.879 & 1.081 & 1.059 & 0.986 & 0.865 & 0.993 & 0.914 \\
\hline $\mathrm{Fe}$ & 0.345 & 0.375 & 0.513 & 0.624 & 0.613 & 0.465 & 0.409 & 0.700 & 0.298 & 0.379 & 0.461 & 0.701 & 0.371 & 0.494 \\
\hline $\mathrm{Mn}$ & 0.047 & 0.032 & 0.036 & 0.037 & 0.030 & 0.044 & 0.034 & 0.046 & 0.051 & 0.033 & 0.036 & 0.036 & 0.042 & 0.048 \\
\hline $\mathrm{Zn}$ & 0.004 & 0.002 & 0.002 & 0.001 & 0.002 & 0.004 & 0.002 & 0.001 & 0.001 & 0.001 & 0.000 & 0.000 & 0.002 & 0.000 \\
\hline C site & 5.000 & 5.000 & 5.000 & 5.000 & 5.000 & 5.000 & 5.000 & 5.000 & 5.000 & 5.000 & 5.000 & 5.000 & 5.000 & 5.000 \\
\hline Excess $\mathrm{C}$ & 0.000 & 0.000 & 0.000 & 0.000 & 0.000 & 0.000 & 0.000 & 0.000 & 0.000 & 0.000 & 0.000 & 0.000 & 0.000 & 0.000 \\
\hline $\mathrm{Ca}$ & 1.657 & 1.693 & 1.713 & 1.736 & 1.745 & 1.694 & 1.710 & 1.745 & 1.676 & 1.673 & 1.703 & 1.736 & 1.684 & 1.678 \\
\hline $\mathrm{NaB}$ & 0.343 & 0.307 & 0.287 & 0.264 & 0.255 & 0.306 & 0.290 & 0.255 & 0.324 & 0.327 & 0.297 & 0.264 & 0.316 & 0.322 \\
\hline $\mathrm{NaA}$ & 0.186 & 0.150 & 0.248 & 0.334 & 0.400 & 0.216 & 0.378 & 0.374 & 0.108 & 0.189 & 0.227 & 0.344 & 0.156 & 0.178 \\
\hline $\mathrm{K}$ & 0.106 & 0.102 & 0.117 & 0.126 & 0.112 & 0.103 & 0.081 & 0.143 & 0.092 & 0.105 & 0.119 & 0.123 & 0.106 & 0.125 \\
\hline A site & 0.292 & 0.252 & 0.364 & 0.460 & 0.512 & 0.319 & 0.459 & 0.517 & 0.200 & 0.294 & 0.346 & 0.467 & 0.262 & 0.303 \\
\hline Cations & 15.292 & 15.252 & 15.364 & 15.460 & 15.512 & 15.319 & 15.459 & 15.517 & 15.200 & 15.294 & 15.346 & 15.467 & 15.262 & 15.303 \\
\hline $\mathrm{F}$ & 0.029 & 0.031 & 0.024 & 0.024 & 0.028 & 0.034 & 0.038 & 0.013 & 0.036 & 0.027 & 0.022 & 0.025 & 0.027 & 0.018 \\
\hline $\mathrm{Cl}$ & 0.032 & 0.023 & 0.013 & 0.017 & 0.023 & 0.020 & 0.014 & 0.032 & 0.025 & 0.018 & 0.037 & 0.023 & 0.010 & 0.026 \\
\hline mg\# & 0.90 & 0.90 & 0.86 & 0.82 & 0.83 & 0.87 & 0.88 & 0.80 & 0.92 & 0.90 & 0.87 & 0.80 & 0.90 & 0.87 \\
\hline $\mathrm{Mg} /\left(\mathrm{Mg}+\mathrm{Fe}^{2+}\right) \mathrm{med}$ & 0.783 & 0.798 & 0.767 & 0.739 & 0.744 & 0.771 & 0.778 & 0.720 & 0.809 & 0.786 & 0.776 & 0.723 & 0.795 & 0.772 \\
\hline $\mathrm{Mg} /\left(\mathrm{Mg}+\mathrm{Fe}^{2+}\right) \max$ & 0.902 & 0.900 & 0.860 & 0.824 & 0.827 & 0.872 & 0.880 & 0.801 & 0.919 & 0.895 & 0.874 & 0.805 & 0.900 & 0.867 \\
\hline $\mathrm{P}$ (kbar) & 4.5 & 3.3 & 4.7 & 6.9 & 7.0 & 4.5 & 7.5 & 7.4 & 2.8 & 4.1 & 4.6 & 6.5 & 3.3 & 3.7 \\
\hline $\mathrm{P}_{\mathrm{R}}(\mathrm{kbar})$ & 2.1 & 1.5 & 2.3 & 4.2 & 4.3 & 2.1 & 5.1 & 4.9 & 1.3 & 1.9 & 2.2 & 3.8 & 1.5 & 1.7 \\
\hline $\mathrm{T}\left({ }^{\circ} \mathrm{C}\right)_{\mathrm{R}}$ & 940 & 898 & 959 & 1033 & 1034 & 946 & 1042 & 1051 & 880 & 929 & 958 & 1030 & 898 & 912 \\
\hline $\mathrm{T}\left({ }^{\circ} \mathrm{C}\right)_{\mathrm{HB}}$ & 763 & 760 & 760 & 753 & 755 & 761 & 749 & 752 & 764 & 762 & 762 & 757 & 760 & 758 \\
\hline$\triangle N N O$ & 1.9 & 2.2 & 1.8 & 1.3 & 1.3 & 1.8 & 1.4 & 1.1 & 2.3 & 2.0 & 1.9 & 1.3 & 2.2 & 2.0 \\
\hline $\mathrm{H}_{2}$ Omelt & 5.7 & 5.0 & 5.5 & 6.7 & 6.7 & 5.6 & 7.8 & 6.8 & 4.9 & 5.3 & 5.4 & 6.4 & 5.0 & 4.9 \\
\hline
\end{tabular}

Notes: Facies abbreviations BQ-M OC = Biotite quartz-monzodiorite with two pyroxenes; L-MG = Leuco monzogranite; BT-MG = Biotite hornblende monzogranite; Rhy = Rhyolite; HB-GD = Hornblende biotite granodiorite; $M G=$ Monzogranite; $\mathrm{H}-\mathrm{MZ}=$ Hornblende monzodiorite; $\mathrm{E}-\mathrm{MD}=$ Micro-diorite enclave; $I \mathrm{M}-\mathrm{D}=$ Intermediate-mafic dikes; Dac = Dacite; $\mathrm{mg} \#=$ magnesium number. $\mathrm{P}=-3.92+5.03 \mathrm{~A} \mathrm{I}^{\top}$ (Hammarstorm and Zen, 1986); $\mathrm{P}=0.26 \mathrm{e}\left(1.48 \mathrm{Al} \mathrm{I}^{\top}\right.$ ) (Hammarstrorm \& Zen, 1986); $\mathrm{P}_{\mathrm{M}}=-0.5+0.331(8) \times \mathrm{Al} \mathrm{I}^{\top}+0.995(4) \times\left(\mathrm{Al} \mathrm{I}^{\top}\right)^{2}$ from Mutch, et al. $(2016) ; \mathrm{T}\left({ }^{\circ} \mathrm{C}\right)_{\mathrm{R}}=\mathrm{Temperature} \mathrm{from} \mathrm{Ridolfi} \mathrm{et} \mathrm{al.}(2010) ; \mathrm{T}\left({ }^{\circ} \mathrm{C}\right) \mathrm{HB}$ $=\left(\right.$ Holland \& Blundy, 1994); $\triangle \mathrm{NNO}=$ oxygen fugacity-amphibole relative to NNO buffer from Ridolfi et al. (2010); $\mathrm{H}_{2} \mathrm{Omelt}=$ The water content in the melt from Ridolfi et al. $(2010)$. 
Supplementary Material: Electron microprobe analyses of amphibole from Garzón granites and related rocks, Eastern Cordillera, Colombia.

\begin{tabular}{|c|c|c|c|c|c|c|c|c|c|c|c|c|c|c|}
\hline \multirow{3}{*}{$\begin{array}{l}\text { Mineral } \\
\text { Massif } \\
\text { Sample }\end{array}$} & \multicolumn{14}{|c|}{ Amphibole } \\
\hline & \multicolumn{14}{|c|}{ Altamira } \\
\hline & GAR-361 & $\begin{array}{l}\text { GAR- } \\
361\end{array}$ & $\begin{array}{l}\text { GAR- } \\
383\end{array}$ & $\begin{array}{l}\text { GAR- } \\
383\end{array}$ & $\begin{array}{l}\text { GAR- } \\
383\end{array}$ & $\begin{array}{l}\text { GAR- } \\
386 \\
\end{array}$ & $\begin{array}{l}\text { GAR- } \\
386\end{array}$ & $\begin{array}{l}\text { GAR- } \\
386\end{array}$ & $\begin{array}{l}\text { GAR- } \\
386\end{array}$ & $\begin{array}{l}\text { GAR- } \\
386 \\
\end{array}$ & $\begin{array}{l}\text { GAR- } \\
386 \\
\end{array}$ & $\begin{array}{l}\text { GAR- } \\
386\end{array}$ & $\begin{array}{l}\text { GAR- } \\
387\end{array}$ & $\begin{array}{l}\text { GAR- } \\
387\end{array}$ \\
\hline Facies & Dac & Dac & Rhy & Rhy & Rhy & HB-GD & HB-GD & HB-GD & HB-GD & HB-GD & HB-GD & HB-GD & IM-D & IM-D \\
\hline Grain/Point & anf_07-2 & $\begin{array}{l}\text { anf_07- } \\
3\end{array}$ & $\begin{array}{l}\text { anf_02- } \\
1\end{array}$ & $\begin{array}{l}\text { anf_05a- } \\
1\end{array}$ & $\begin{array}{l}\text { anf_05a- } \\
2\end{array}$ & $\begin{array}{l}\text { anf_02- } \\
1\end{array}$ & $\begin{array}{l}\text { anf_02- } \\
2\end{array}$ & $\begin{array}{l}\text { anf_03- } \\
1\end{array}$ & $\begin{array}{l}\text { anf_03- } \\
2\end{array}$ & $\begin{array}{l}\text { anf_04- } \\
1\end{array}$ & $\begin{array}{l}\text { anf_04- } \\
2\end{array}$ & $\begin{array}{l}\text { anf_06- } \\
1\end{array}$ & $\begin{array}{l}\text { anf_07- } \\
3\end{array}$ & $\begin{array}{l}\text { anf_07- } \\
4\end{array}$ \\
\hline $\mathrm{SiO} 2$ & 47.31 & 48.19 & 48.24 & 49.74 & 49.39 & 53.07 & 49.14 & 52.87 & 47.39 & 51.63 & 51.18 & 53.00 & 41.78 & 42.46 \\
\hline $\mathrm{TiO} 2$ & 1.76 & 1.51 & 0.03 & 0.55 & 0.43 & 0.49 & 0.51 & 0.23 & 0.85 & 0.29 & 0.52 & 0.17 & 2.81 & 1.64 \\
\hline $\mathrm{Al} 2 \mathrm{O} 3$ & 8.22 & 7.66 & 5.82 & 4.34 & 4.70 & 2.59 & 5.82 & 2.84 & 7.15 & 3.69 & 4.27 & 2.70 & 13.84 & 13.82 \\
\hline $\mathrm{Cr} 2 \mathrm{O} 3$ & 0.00 & 0.00 & 0.00 & 0.00 & 0.00 & 0.00 & 0.00 & 0.00 & 0.00 & 0.00 & 0.00 & 0.00 & 0.00 & 0.00 \\
\hline $\mathrm{FeO}$ & 11.64 & 11.56 & 15.29 & 15.98 & 16.04 & 11.35 & 13.24 & 10.92 & 14.10 & 11.40 & 12.01 & 11.24 & 13.54 & 13.48 \\
\hline $\mathrm{MnO}$ & 0.41 & 0.39 & 1.15 & 1.21 & 1.25 & 1.07 & 1.01 & 1.00 & 1.00 & 0.92 & 0.90 & 0.89 & 0.24 & 0.27 \\
\hline $\mathrm{MgO}$ & 16.08 & 16.21 & 13.42 & 13.62 & 13.31 & 17.06 & 14.94 & 17.14 & 14.05 & 16.69 & 16.16 & 17.49 & 12.84 & 12.65 \\
\hline $\mathrm{ZnO}$ & 0.02 & 0.00 & 0.06 & 0.05 & 0.07 & 0.04 & 0.04 & 0.00 & 0.05 & 0.01 & 0.03 & 0.03 & 0.01 & 0.00 \\
\hline $\mathrm{CaO}$ & 10.98 & 10.96 & 11.87 & 11.41 & 11.52 & 11.67 & 11.64 & 11.92 & 11.57 & 11.80 & 11.78 & 11.98 & 10.77 & 11.54 \\
\hline $\mathrm{Na} 2 \mathrm{O}$ & 1.73 & 1.67 & 0.80 & 0.89 & 0.85 & 0.40 & 0.79 & 0.43 & 0.98 & 0.51 & 0.60 & 0.40 & 1.56 & 1.68 \\
\hline $\mathrm{K} 2 \mathrm{O}$ & 0.53 & 0.45 & 0.43 & 0.52 & 0.48 & 0.22 & 0.42 & 0.14 & 0.64 & 0.21 & 0.35 & 0.16 & 1.05 & 0.73 \\
\hline $\mathrm{F}$ & 0.06 & 0.04 & 0.04 & 0.09 & 0.08 & 0.06 & 0.03 & 0.04 & 0.04 & 0.04 & 0.03 & 0.03 & 0.03 & 0.01 \\
\hline $\mathrm{Cl}$ & 0.05 & 0.09 & 0.04 & 0.21 & 0.22 & 0.08 & 0.09 & 0.03 & 0.08 & 0.05 & 0.06 & 0.02 & 0.06 & 0.02 \\
\hline Total & 98.79 & 98.73 & 97.19 & 98.61 & 98.34 & 98.09 & 97.66 & 97.56 & 97.91 & 97.25 & 97.89 & 98.10 & 98.52 & 98.31 \\
\hline $\mathrm{O}=(\mathrm{Cl} . \mathrm{F})$ & 0.04 & 0.04 & 0.03 & 0.09 & 0.08 & 0.04 & 0.03 & 0.02 & 0.04 & 0.03 & 0.03 & 0.02 & 0.03 & 0.01 \\
\hline Total & 98.77 & 98.68 & 97.16 & 98.52 & 98.25 & 98.08 & 97.66 & 97.54 & 97.87 & 97.23 & 97.87 & 98.07 & 98.54 & 12.64 \\
\hline \multicolumn{15}{|c|}{ Structural formulae (according mean Fe3+ values. schumacher. after Gualda \& Vlach. 2005) } \\
\hline $\mathrm{Si}$ & 6.735 & 6.849 & 7.086 & 7.276 & 7.230 & 7.579 & 7.101 & 7.549 & 6.888 & 7.411 & 7.331 & 7.545 & 6.048 & 6.156 \\
\hline ivAl & 1.265 & 1.151 & 0.914 & 0.724 & 0.770 & 0.421 & 0.899 & 0.451 & 1.112 & 0.589 & 0.669 & 0.455 & 1.952 & 1.844 \\
\hline T site & 8.000 & 8.000 & 8.000 & 8.000 & 8.000 & 8.000 & 8.000 & 8.000 & 8.000 & 8.000 & 8.000 & 8.000 & 8.000 & 8.000 \\
\hline viAl & 0.115 & 0.133 & 0.093 & 0.025 & 0.041 & 0.014 & 0.092 & 0.027 & 0.113 & 0.035 & 0.052 & 0.000 & 0.410 & 0.517 \\
\hline $\mathrm{Ti}$ & 0.188 & 0.162 & 0.003 & 0.060 & 0.047 & 0.053 & 0.055 & 0.025 & 0.093 & 0.031 & 0.056 & 0.018 & 0.306 & 0.179 \\
\hline $\mathrm{Cr}$ & 0.000 & 0.000 & 0.000 & 0.000 & 0.000 & 0.000 & 0.000 & 0.000 & 0.000 & 0.000 & 0.000 & 0.000 & 0.000 & 0.000 \\
\hline Felll & 0.544 & 0.517 & 0.647 & 0.321 & 0.454 & 0.205 & 0.609 & 0.331 & 0.630 & 0.442 & 0.439 & 0.275 & 0.647 & 0.583 \\
\hline $\mathrm{Fe}$ & 0.841 & 0.857 & 1.231 & 1.634 & 1.510 & 1.150 & 0.991 & 0.973 & 1.083 & 0.926 & 1.000 & 1.063 & 0.992 & 1.052 \\
\hline $\mathrm{Mn}$ & 0.050 & 0.047 & 0.143 & 0.150 & 0.155 & 0.129 & 0.124 & 0.121 & 0.124 & 0.112 & 0.109 & 0.108 & 0.029 & 0.033 \\
\hline $\mathrm{Mg}$ & 3.412 & 3.434 & 2.938 & 2.970 & 2.904 & 3.631 & 3.218 & 3.648 & 3.044 & 3.571 & 3.450 & 3.711 & 2.771 & 2.734 \\
\hline $\mathrm{Zn}$ & 0.002 & 0.000 & 0.006 & 0.006 & 0.007 & 0.005 & 0.004 & 0.000 & 0.006 & 0.001 & 0.003 & 0.003 & 0.001 & 0.000 \\
\hline C site & 5.153 & 5.149 & 5.062 & 5.166 & 5.118 & 5.188 & 5.093 & 5.125 & 5.093 & 5.119 & 5.110 & 5.178 & 5.155 & 5.097 \\
\hline Excess $C$ & 0.153 & 0.149 & 0.062 & 0.166 & 0.118 & 0.188 & 0.093 & 0.125 & 0.093 & 0.119 & 0.110 & 0.178 & 0.155 & 0.097 \\
\hline $\mathrm{Ca}$ & 1.675 & 1.669 & 1.868 & 1.788 & 1.807 & 1.786 & 1.802 & 1.824 & 1.802 & 1.815 & 1.808 & 1.827 & 1.670 & 1.793 \\
\hline $\mathrm{NaB}$ & 0.172 & 0.182 & 0.070 & 0.046 & 0.075 & 0.027 & 0.105 & 0.051 & 0.105 & 0.066 & 0.082 & -0.005 & 0.175 & 0.110 \\
\hline B site & 2.000 & 2.000 & 2.000 & 2.000 & 2.000 & 2.000 & 2.000 & 2.000 & 2.000 & 2.000 & 2.000 & 2.000 & 2.000 & 2.000 \\
\hline $\mathrm{NaA}$ & 0.305 & 0.279 & 0.158 & 0.206 & 0.167 & 0.084 & 0.115 & 0.067 & 0.170 & 0.077 & 0.083 & 0.115 & 0.263 & 0.362 \\
\hline $\mathrm{K}$ & 0.096 & 0.081 & 0.080 & 0.097 & 0.090 & 0.039 & 0.078 & 0.026 & 0.119 & 0.038 & 0.065 & 0.029 & 0.195 & 0.135 \\
\hline A site & 0.401 & 0.359 & 0.238 & 0.303 & 0.256 & 0.124 & 0.193 & 0.093 & 0.289 & 0.115 & 0.148 & 0.144 & 0.458 & 0.497 \\
\hline Cations & 15.401 & 15.359 & 15.238 & 15.303 & 15.256 & 15.124 & 15.193 & 15.093 & 15.289 & 15.115 & 15.148 & 15.144 & 15.458 & 15.497 \\
\hline $\mathrm{F}$ & 0.027 & 0.020 & 0.019 & 0.041 & 0.035 & 0.027 & 0.013 & 0.017 & 0.020 & 0.017 & 0.015 & 0.013 & 0.014 & 0.005 \\
\hline $\mathrm{Cl}$ & 0.012 & 0.021 & 0.011 & 0.053 & 0.055 & 0.018 & 0.021 & 0.008 & 0.021 & 0.013 & 0.014 & 0.004 & 0.014 & 0.006 \\
\hline $\mathrm{mg}$ & 0.80 & 0.80 & 0.70 & 0.65 & 0.66 & 0.76 & 0.76 & 0.79 & 0.74 & 0.79 & 0.78 & 0.78 & 0.74 & 0.72 \\
\hline \multicolumn{15}{|c|}{ Structural formulae (according max Fe3+ values. schumacher. after Gualda \& Vlach. 2005) } \\
\hline $\mathrm{Si}$ & 6.657 & 6.772 & 7.052 & 7.254 & 7.193 & 7.565 & 7.051 & 7.524 & 6.839 & 7.378 & 7.291 & 7.547 & 5.977 & 6.110 \\
\hline ivAl & 1.343 & 1.228 & 0.948 & 0.746 & 0.807 & 0.435 & 0.949 & 0.476 & 1.161 & 0.622 & 0.709 & 0.453 & 2.023 & 1.890 \\
\hline
\end{tabular}




\begin{tabular}{|c|c|c|c|c|c|c|c|c|c|c|c|c|c|c|}
\hline T site & 8.000 & 8.000 & 8.000 & 8.000 & 8.000 & 8.000 & 8.000 & 8.000 & 8.000 & 8.000 & 8.000 & 8.000 & 8.000 & 8.000 \\
\hline viAl & 0.020 & 0.040 & 0.055 & 0.000 & 0.000 & 0.000 & 0.035 & 0.000 & 0.055 & 0.000 & 0.008 & 0.000 & 0.311 & 0.454 \\
\hline $\mathrm{Ti}$ & 0.186 & 0.160 & 0.003 & 0.060 & 0.047 & 0.052 & 0.055 & 0.025 & 0.092 & 0.031 & 0.056 & 0.018 & 0.302 & 0.177 \\
\hline $\mathrm{Cr}$ & 0.000 & 0.000 & 0.000 & 0.000 & 0.000 & 0.000 & 0.000 & 0.000 & 0.000 & 0.000 & 0.000 & 0.000 & 0.000 & 0.000 \\
\hline Felll & 1.073 & 1.034 & 0.861 & 0.461 & 0.684 & 0.288 & 0.930 & 0.487 & 0.952 & 0.643 & 0.690 & 0.265 & 1.181 & 0.919 \\
\hline $\mathrm{Fe}$ & 0.297 & 0.325 & 1.008 & 1.488 & 1.270 & 1.065 & 0.659 & 0.812 & 0.750 & 0.720 & 0.741 & 1.074 & 0.439 & 0.703 \\
\hline $\mathrm{Mn}$ & 0.049 & 0.046 & 0.142 & 0.149 & 0.154 & 0.129 & 0.123 & 0.121 & 0.123 & 0.112 & 0.109 & 0.108 & 0.029 & 0.033 \\
\hline $\mathrm{Mg}$ & 3.373 & 3.395 & 2.924 & 2.961 & 2.889 & 3.625 & 3.195 & 3.636 & 3.022 & 3.555 & 3.431 & 3.712 & 2.738 & 2.713 \\
\hline $\mathrm{Zn}$ & 0.002 & 0.000 & 0.006 & 0.006 & 0.007 & 0.005 & 0.004 & 0.000 & 0.006 & 0.001 & 0.003 & 0.003 & 0.001 & 0.000 \\
\hline C site & 5.000 & 5.000 & 5.000 & 5.125 & 5.052 & 5.164 & 5.000 & 5.081 & 5.000 & 5.062 & 5.038 & 5.179 & 5.000 & 5.000 \\
\hline Excess C & 0.000 & 0.000 & 0.000 & 0.125 & 0.052 & 0.164 & 0.000 & 0.081 & 0.000 & 0.062 & 0.038 & 0.179 & 0.000 & 0.000 \\
\hline $\mathrm{Ca}$ & 1.655 & 1.650 & 1.859 & 1.783 & 1.798 & 1.782 & 1.789 & 1.817 & 1.789 & 1.807 & 1.798 & 1.828 & 1.651 & 1.779 \\
\hline $\mathrm{NaB}$ & 0.345 & 0.350 & 0.141 & 0.092 & 0.151 & 0.054 & 0.211 & 0.102 & 0.211 & 0.132 & 0.164 & 0.000 & 0.349 & 0.221 \\
\hline B site & 2.000 & 2.000 & 2.000 & 2.000 & 2.000 & 2.000 & 2.000 & 2.000 & 2.000 & 2.000 & 2.000 & 2.007 & 2.000 & 2.000 \\
\hline $\mathrm{NaA}$ & 0.127 & 0.105 & 0.086 & 0.160 & 0.090 & 0.057 & 0.009 & 0.015 & 0.063 & 0.011 & 0.000 & 0.124 & 0.084 & 0.248 \\
\hline $\mathrm{K}$ & 0.095 & 0.080 & 0.080 & 0.097 & 0.089 & 0.039 & 0.077 & 0.026 & 0.118 & 0.037 & 0.064 & 0.029 & 0.192 & 0.134 \\
\hline A site & 0.222 & 0.185 & 0.166 & 0.256 & 0.179 & 0.096 & 0.086 & 0.042 & 0.181 & 0.048 & 0.064 & 0.153 & 0.276 & 0.383 \\
\hline Cations & 15.222 & 15.185 & 15.166 & 15.381 & 15.231 & 15.260 & 15.086 & 15.122 & 15.181 & 15.110 & 15.102 & 15.339 & 15.276 & 15.383 \\
\hline $\mathrm{F}$ & 0.026 & 0.020 & 0.019 & 0.041 & 0.035 & 0.027 & 0.013 & 0.017 & 0.019 & 0.017 & 0.015 & 0.013 & 0.014 & 0.005 \\
\hline $\mathrm{Cl}$ & 0.012 & 0.021 & 0.011 & 0.052 & 0.055 & 0.018 & 0.021 & 0.008 & 0.021 & 0.013 & 0.014 & 0.004 & 0.014 & 0.006 \\
\hline $\mathrm{mg \#}$ & 0.92 & 0.91 & 0.74 & 0.67 & 0.69 & 0.77 & 0.83 & 0.82 & 0.80 & 0.83 & 0.82 & 0.78 & 0.86 & 0.79 \\
\hline $\mathrm{Mg} /\left(\mathrm{Mg}+\mathrm{Fe}^{2+}\right) \mathrm{med}$ & 0.802 & 0.800 & 0.705 & 0.645 & 0.658 & 0.759 & 0.765 & 0.790 & 0.737 & 0.794 & 0.775 & 0.777 & 0.736 & 0.722 \\
\hline $\mathrm{Mg} /\left(\mathrm{Mg}+\mathrm{Fe}^{2+}\right) \max$ & 0.919 & 0.913 & 0.744 & 0.666 & 0.695 & 0.773 & 0.829 & 0.817 & 0.801 & 0.832 & 0.822 & 0.776 & 0.862 & 0.794 \\
\hline $\mathrm{P}$ (kbar) & 2.9 & 2.5 & 1.1 & -0.2 & 0.1 & -1.7 & 1.0 & -1.5 & 2.2 & -0.8 & -0.3 & -1.6 & 7.8 & 7.9 \\
\hline $\mathrm{P}_{\mathrm{HZ}}$ (kbar) & 1.8 & 1.6 & 1.1 & 0.8 & 0.8 & 0.5 & 1.1 & 0.5 & 1.5 & 0.6 & 0.7 & 0.5 & 7.5 & 7.6 \\
\hline $\mathrm{P}_{\mathrm{M}}(\mathrm{kbar})$ & 1.8 & 1.5 & 0.8 & 0.3 & 0.4 & -0.2 & 0.8 & -0.1 & 1.4 & 0.1 & 0.2 & -0.1 & 5.7 & 5.7 \\
\hline $\mathrm{P}_{\mathrm{R}}(\mathrm{kbar})$ & 1.4 & 1.2 & 0.8 & 0.6 & 0.6 & 0.4 & 0.8 & 0.4 & 1.1 & 0.5 & 0.5 & 0.4 & 5.5 & 5.6 \\
\hline $\mathrm{T}\left({ }^{\circ} \mathrm{C}\right)_{\mathrm{R}}$ & 885 & 859 & 764 & 747 & 746 & 712 & 779 & 707 & 825 & 729 & 746 & 713 & 1037 & 1003 \\
\hline $\mathrm{T}\left({ }^{\circ} \mathrm{C}\right)_{\mathrm{HB}}$ & 763 & 759 & 750 & 745 & 748 & 720 & 752 & 725 & 756 & 737 & 742 & 722 & 747 & 735 \\
\hline$\triangle N N O$ & 2.3 & 2.3 & 1.7 & 1.7 & 1.6 & 2.7 & 2.1 & 2.7 & 1.8 & 2.6 & 2.4 & 2.7 & 1.2 & 1.0 \\
\hline $\mathrm{H}_{2}$ Omelt & 4.9 & 4.9 & 5.2 & 2.7 & 3.8 & 2.3 & 5.1 & 3.3 & 5.1 & 3.8 & 3.9 & 2.2 & 7.7 & 8.6 \\
\hline
\end{tabular}


Supplementary Material: Electron microprobe analyses of amphibole from Garzón granites and related rocks, Eastern Cordillera, Colombia.

\begin{tabular}{|c|c|c|c|c|c|c|c|c|c|c|c|c|c|c|}
\hline \multirow{3}{*}{$\begin{array}{l}\text { Mineral } \\
\text { Massif } \\
\text { Sample }\end{array}$} & \multicolumn{14}{|c|}{ Amphibole } \\
\hline & \multicolumn{5}{|c|}{ Altamira } & \multicolumn{9}{|c|}{ Sombrerillo } \\
\hline & GAR-387 & $\begin{array}{l}\text { GAR- } \\
387\end{array}$ & $\begin{array}{l}\text { GAR- } \\
387\end{array}$ & $\begin{array}{l}\text { GAR- } \\
387\end{array}$ & $\begin{array}{l}\text { GAR- } \\
387\end{array}$ & $\begin{array}{l}\text { GAR- } \\
394\end{array}$ & $\begin{array}{l}\text { GAR- } \\
394\end{array}$ & $\begin{array}{l}\text { GAR- } \\
394\end{array}$ & $\begin{array}{l}\text { GAR- } \\
394\end{array}$ & $\begin{array}{l}\text { GAR- } \\
394\end{array}$ & $\begin{array}{l}\text { GAR- } \\
394\end{array}$ & $\begin{array}{l}\text { GAR- } \\
394\end{array}$ & $\begin{array}{l}\text { GAR- } \\
394\end{array}$ & GAR-394 \\
\hline Facies & IM-D & IM-D & IM-D & IM-D & IM-D & MG & MG & MG & MG & MG & MG & MG & MG & MG \\
\hline Grain/Point & anf_07-6 & anf_03-1 & anf_03-2 & anf_03-3 & anf_03-4 & anf_01-4 & anf_01-5 & anf_01-6 & anf_01-7 & $\begin{array}{l}\text { anf_03a- } \\
1\end{array}$ & $\begin{array}{l}\text { anf_03a- } \\
2\end{array}$ & $\begin{array}{l}\text { anf_03a- } \\
3\end{array}$ & $\begin{array}{l}\text { anf_03a- } \\
4\end{array}$ & $\begin{array}{l}\text { anf_03a- } \\
5\end{array}$ \\
\hline $\mathrm{SiO} 2$ & 53.66 & 42.49 & 42.29 & 53.85 & 50.56 & 50.28 & 45.67 & 50.27 & 44.08 & 46.74 & 45.63 & 44.94 & 44.19 & 44.51 \\
\hline $\mathrm{TiO} 2$ & 0.39 & 2.11 & 2.04 & 0.28 & 0.28 & 0.60 & 1.53 & 0.36 & 1.56 & 1.20 & 1.17 & 1.48 & 1.09 & 1.62 \\
\hline $\mathrm{Al} 2 \mathrm{O} 3$ & 3.95 & 13.94 & 13.84 & 3.42 & 6.81 & 3.58 & 7.42 & 3.59 & 8.19 & 6.52 & 7.43 & 8.00 & 8.10 & 7.81 \\
\hline $\mathrm{Cr} 2 \mathrm{O} 3$ & 0.00 & 0.00 & 0.00 & 0.27 & 0.59 & 0.00 & 0.00 & 0.00 & 0.00 & 0.00 & 0.00 & 0.00 & 0.00 & 0.00 \\
\hline $\mathrm{FeO}$ & 9.10 & 13.48 & 13.61 & 8.51 & 10.26 & 16.24 & 19.01 & 18.75 & 19.83 & 18.00 & 18.63 & 19.31 & 19.36 & 20.02 \\
\hline $\mathrm{MnO}$ & 0.30 & 0.25 & 0.26 & 0.30 & 0.26 & 0.52 & 0.45 & 0.44 & 0.47 & 0.48 & 0.48 & 0.44 & 0.47 & 0.47 \\
\hline $\mathrm{MgO}$ & 18.66 & 12.72 & 12.62 & 19.02 & 16.73 & 13.82 & 10.60 & 11.78 & 9.68 & 11.71 & 10.95 & 10.03 & 10.11 & 10.13 \\
\hline $\mathrm{ZnO}$ & 0.01 & 0.07 & 0.00 & 0.02 & 0.00 & 0.02 & 0.02 & 0.03 & 0.00 & 0.05 & 0.05 & 0.07 & 0.03 & 0.04 \\
\hline $\mathrm{CaO}$ & 11.93 & 11.58 & 11.53 & 11.93 & 11.74 & 11.33 & 11.25 & 11.78 & 11.11 & 11.39 & 11.26 & 11.14 & 10.89 & 11.01 \\
\hline $\mathrm{Na} 2 \mathrm{O}$ & 0.53 & 1.80 & 1.79 & 0.45 & 0.90 & 1.07 & 1.71 & 0.71 & 1.76 & 1.43 & 1.65 & 1.73 & 1.80 & 1.72 \\
\hline $\mathrm{K} 2 \mathrm{O}$ & 0.04 & 0.76 & 0.55 & 0.06 & 0.15 & 0.39 & 0.96 & 0.28 & 1.06 & 0.78 & 0.91 & 1.01 & 0.91 & 0.98 \\
\hline $\mathrm{F}$ & 0.02 & 0.02 & 0.03 & 0.00 & 0.01 & 0.15 & 0.14 & 0.12 & 0.10 & 0.19 & 0.17 & 0.14 & 0.15 & 0.12 \\
\hline $\mathrm{Cl}$ & 0.00 & 0.07 & 0.05 & 0.01 & 0.01 & 0.17 & 0.25 & 0.05 & 0.39 & 0.25 & 0.25 & 0.35 & 0.44 & 0.37 \\
\hline Total & 98.58 & 99.30 & 98.61 & 98.10 & 98.31 & 98.17 & 99.01 & 98.16 & 98.23 & 98.74 & 98.57 & 98.64 & 97.53 & 98.81 \\
\hline $\mathrm{O}=(\mathrm{Cl} . \mathrm{F})$ & 0.01 & 0.02 & 0.02 & 0.00 & 0.01 & 0.10 & 0.11 & 0.06 & 0.13 & 0.14 & 0.13 & 0.14 & 0.16 & 0.14 \\
\hline Total & 98.58 & 99.29 & 98.62 & 98.11 & 98.29 & 98.07 & 98.91 & 98.09 & 98.11 & 98.61 & 98.45 & 98.50 & 98.23 & 98.69 \\
\hline \multicolumn{15}{|c|}{ Structural formulae (according mean Fe3+ values. schumacher. after Gualda \& Vlach. 2005) } \\
\hline $\mathrm{Si}$ & 7.482 & 6.116 & 6.118 & 7.532 & 7.125 & 7.398 & 6.815 & 7.428 & 6.684 & 6.930 & 6.819 & 6.757 & 6.716 & 6.690 \\
\hline ivAl & 0.518 & 1.884 & 1.882 & 0.468 & 0.875 & 0.602 & 1.185 & 0.572 & 1.316 & 1.070 & 1.181 & 1.243 & 1.284 & 1.310 \\
\hline T site & 8.000 & 8.000 & 8.000 & 8.000 & 8.000 & 8.000 & 8.000 & 8.000 & 8.000 & 8.000 & 8.000 & 8.000 & 8.000 & 8.000 \\
\hline viAl & 0.131 & 0.481 & 0.478 & 0.096 & 0.256 & 0.018 & 0.120 & 0.053 & 0.147 & 0.070 & 0.128 & 0.174 & 0.167 & 0.073 \\
\hline $\mathrm{Ti}$ & 0.041 & 0.228 & 0.222 & 0.029 & 0.030 & 0.066 & 0.172 & 0.040 & 0.178 & 0.134 & 0.131 & 0.168 & 0.125 & 0.183 \\
\hline $\mathrm{Cr}$ & 0.000 & 0.000 & 0.000 & 0.029 & 0.066 & 0.000 & 0.000 & 0.000 & 0.000 & 0.000 & 0.000 & 0.000 & 0.000 & 0.000 \\
\hline Felll & 0.298 & 0.531 & 0.583 & 0.274 & 0.461 & 0.141 & 0.283 & 0.327 & 0.306 & 0.376 & 0.348 & 0.285 & 0.403 & 0.422 \\
\hline $\mathrm{Fe}$ & 0.763 & 1.091 & 1.064 & 0.722 & 0.748 & 1.857 & 2.089 & 1.990 & 2.209 & 1.856 & 1.980 & 2.143 & 2.058 & 2.095 \\
\hline $\mathrm{Mn}$ & 0.035 & 0.031 & 0.032 & 0.035 & 0.031 & 0.065 & 0.057 & 0.056 & 0.060 & 0.060 & 0.060 & 0.057 & 0.061 & 0.060 \\
\hline $\mathrm{Mg}$ & 3.878 & 2.729 & 2.721 & 3.965 & 3.514 & 3.031 & 2.358 & 2.594 & 2.188 & 2.588 & 2.439 & 2.248 & 2.290 & 2.269 \\
\hline $\mathrm{Zn}$ & 0.001 & 0.008 & 0.000 & 0.002 & 0.000 & 0.002 & 0.002 & 0.003 & 0.000 & 0.005 & 0.005 & 0.007 & 0.003 & 0.004 \\
\hline C site & 5.147 & 5.100 & 5.100 & 5.152 & 5.107 & 5.180 & 5.081 & 5.063 & 5.088 & 5.089 & 5.092 & 5.081 & 5.106 & 5.106 \\
\hline Excess C & 0.147 & 0.100 & 0.100 & 0.152 & 0.107 & 0.180 & 0.081 & 0.063 & 0.088 & 0.089 & 0.092 & 0.081 & 0.106 & 0.106 \\
\hline $\mathrm{Ca}$ & 1.782 & 1.786 & 1.787 & 1.788 & 1.773 & 1.786 & 1.799 & 1.865 & 1.805 & 1.809 & 1.803 & 1.795 & 1.773 & 1.773 \\
\hline $\mathrm{NaB}$ & 0.071 & 0.114 & 0.113 & 0.060 & 0.121 & 0.034 & 0.120 & 0.072 & 0.108 & 0.101 & 0.105 & 0.124 & 0.121 & 0.121 \\
\hline B site & 2.000 & 2.000 & 2.000 & 2.000 & 2.000 & 2.000 & 2.000 & 2.000 & 2.000 & 2.000 & 2.000 & 2.000 & 2.000 & 2.000 \\
\hline $\mathrm{NaA}$ & 0.071 & 0.389 & 0.389 & 0.061 & 0.126 & 0.272 & 0.374 & 0.132 & 0.410 & 0.310 & 0.373 & 0.380 & 0.410 & 0.381 \\
\hline $\mathrm{K}$ & 0.006 & 0.140 & 0.102 & 0.011 & 0.026 & 0.074 & 0.183 & 0.053 & 0.205 & 0.148 & 0.174 & 0.193 & 0.175 & 0.189 \\
\hline A site & 0.078 & 0.528 & 0.491 & 0.072 & 0.152 & 0.345 & 0.558 & 0.184 & 0.615 & 0.457 & 0.547 & 0.573 & 0.585 & 0.569 \\
\hline Cations & 15.078 & 15.528 & 15.491 & 15.072 & 15.152 & 15.345 & 15.558 & 15.184 & 15.615 & 15.457 & 15.547 & 15.573 & 15.585 & 15.569 \\
\hline $\mathrm{F}$ & 0.009 & 0.008 & 0.012 & 0.000 & 0.005 & 0.070 & 0.064 & 0.058 & 0.048 & 0.090 & 0.078 & 0.066 & 0.073 & 0.058 \\
\hline $\mathrm{Cl}$ & 0.000 & 0.017 & 0.012 & 0.002 & 0.002 & 0.042 & 0.064 & 0.011 & 0.099 & 0.062 & 0.065 & 0.090 & 0.113 & 0.095 \\
\hline & 0.84 & 0.71 & 0.72 & 0.85 & 0.82 & 0.62 & 0.53 & 0.57 & 0.50 & 0.58 & 0.55 & 0.51 & 0.53 & 0.52 \\
\hline \multicolumn{15}{|c|}{ Structural formulae (according max Fe3+ values. schumacher. after Gualda \& Vlach. 2005) } \\
\hline $\mathrm{Si}$ & 7.446 & 6.070 & 6.071 & 7.502 & 7.067 & 7.381 & 6.773 & 7.392 & 6.639 & 6.883 & 6.771 & 6.715 & 6.662 & 6.635 \\
\hline ivAl & 0.554 & 1.930 & 1.929 & 0.498 & 0.933 & 0.619 & 1.227 & 0.608 & 1.361 & 1.117 & 1.229 & 1.285 & 1.338 & 1.365 \\
\hline
\end{tabular}




\begin{tabular}{|c|c|c|c|c|c|c|c|c|c|c|c|c|c|c|}
\hline T site & 8.000 & 8.000 & 8.000 & 8.000 & 8.000 & 8.000 & 8.000 & 8.000 & 8.000 & 8.000 & 8.000 & 8.000 & 8.000 & 8.000 \\
\hline viAl & 0.092 & 0.416 & 0.413 & 0.063 & 0.189 & 0.000 & 0.070 & 0.014 & 0.093 & 0.015 & 0.071 & 0.123 & 0.101 & 0.008 \\
\hline $\mathrm{Ti}$ & 0.041 & 0.227 & 0.220 & 0.029 & 0.030 & 0.066 & 0.171 & 0.040 & 0.177 & 0.133 & 0.130 & 0.167 & 0.124 & 0.182 \\
\hline $\mathrm{Cr}$ & 0.000 & 0.000 & 0.000 & 0.029 & 0.066 & 0.000 & 0.000 & 0.000 & 0.000 & 0.000 & 0.000 & 0.000 & 0.000 & 0.000 \\
\hline Felll & 0.514 & 0.879 & 0.928 & 0.458 & 0.831 & 0.246 & 0.566 & 0.547 & 0.611 & 0.687 & 0.670 & 0.569 & 0.772 & 0.791 \\
\hline $\mathrm{Fe}$ & 0.542 & 0.731 & 0.706 & 0.533 & 0.368 & 1.748 & 1.791 & 1.759 & 1.886 & 1.530 & 1.642 & 1.844 & 1.669 & 1.705 \\
\hline $\mathrm{Mn}$ & 0.035 & 0.030 & 0.032 & 0.035 & 0.031 & 0.065 & 0.056 & 0.055 & 0.059 & 0.060 & 0.060 & 0.056 & 0.060 & 0.059 \\
\hline $\mathrm{Mg}$ & 3.860 & 2.708 & 2.701 & 3.949 & 3.485 & 3.024 & 2.343 & 2.582 & 2.173 & 2.570 & 2.422 & 2.234 & 2.272 & 2.251 \\
\hline $\mathrm{Zn}$ & 0.001 & 0.008 & 0.000 & 0.002 & 0.000 & 0.002 & 0.002 & 0.003 & 0.000 & 0.005 & 0.005 & 0.007 & 0.003 & 0.004 \\
\hline C site & 5.085 & 5.000 & 5.000 & 5.099 & 5.000 & 5.150 & 5.000 & 5.000 & 5.000 & 5.000 & 5.000 & 5.000 & 5.000 & 5.000 \\
\hline Excess $\mathrm{C}$ & 0.085 & 0.000 & 0.000 & 0.099 & 0.000 & 0.150 & 0.000 & 0.000 & 0.000 & 0.000 & 0.000 & 0.000 & 0.000 & 0.000 \\
\hline $\mathrm{Ca}$ & 1.774 & 1.772 & 1.774 & 1.781 & 1.758 & 1.782 & 1.788 & 1.856 & 1.793 & 1.797 & 1.790 & 1.783 & 1.759 & 1.759 \\
\hline $\mathrm{NaB}$ & 0.141 & 0.228 & 0.226 & 0.120 & 0.242 & 0.068 & 0.212 & 0.144 & 0.207 & 0.203 & 0.210 & 0.217 & 0.241 & 0.241 \\
\hline B site & 2.000 & 2.000 & 2.000 & 2.000 & 2.000 & 2.000 & 2.000 & 2.000 & 2.000 & 2.000 & 2.000 & 2.000 & 2.000 & 2.000 \\
\hline $\mathrm{NaA}$ & 0.000 & 0.271 & 0.272 & 0.000 & 0.003 & 0.237 & 0.279 & 0.059 & 0.307 & 0.205 & 0.265 & 0.285 & 0.285 & 0.256 \\
\hline $\mathrm{K}$ & 0.006 & 0.139 & 0.101 & 0.011 & 0.026 & 0.074 & 0.182 & 0.053 & 0.204 & 0.147 & 0.172 & 0.192 & 0.174 & 0.187 \\
\hline A site & 0.006 & 0.409 & 0.373 & 0.011 & 0.029 & 0.310 & 0.461 & 0.111 & 0.511 & 0.352 & 0.437 & 0.476 & 0.459 & 0.443 \\
\hline Cations & 15.091 & 15.409 & 15.373 & 15.110 & 15.029 & 15.460 & 15.461 & 15.111 & 15.511 & 15.352 & 15.437 & 15.476 & 15.459 & 15.443 \\
\hline $\mathrm{F}$ & 0.009 & 0.008 & 0.012 & 0.000 & 0.005 & 0.070 & 0.064 & 0.058 & 0.047 & 0.090 & 0.078 & 0.066 & 0.072 & 0.058 \\
\hline $\mathrm{Cl}$ & 0.000 & 0.017 & 0.012 & 0.002 & 0.002 & 0.041 & 0.064 & 0.011 & 0.099 & 0.062 & 0.064 & 0.089 & 0.112 & 0.094 \\
\hline $\mathrm{mg \#}$ & 0.88 & 0.79 & 0.79 & 0.88 & 0.90 & 0.63 & 0.57 & 0.59 & 0.54 & 0.63 & 0.60 & 0.55 & 0.58 & 0.57 \\
\hline $\mathrm{Mg} /\left(\mathrm{Mg}+\mathrm{Fe}^{2+}\right) \mathrm{med}$ & 0.836 & 0.714 & 0.719 & 0.846 & 0.825 & 0.620 & 0.530 & 0.566 & 0.498 & 0.582 & 0.552 & 0.512 & 0.527 & 0.520 \\
\hline $\mathrm{Mg} /\left(\mathrm{Mg}+\mathrm{Fe}^{2+}\right) \max$ & 0.877 & 0.787 & 0.793 & 0.881 & 0.905 & 0.634 & 0.567 & 0.595 & 0.535 & 0.627 & 0.596 & 0.548 & 0.577 & 0.569 \\
\hline $\mathrm{P}$ (kbar) & -0.7 & 7.9 & 7.9 & -1.1 & 1.7 & -0.8 & 2.6 & -0.8 & 3.4 & 1.8 & 2.6 & 3.2 & 3.3 & 3.0 \\
\hline $\mathrm{P}_{\mathrm{HZ}}$ (kbar) & 0.7 & 7.6 & 7.5 & 0.6 & 1.3 & 0.6 & 1.7 & 0.6 & 2.1 & 1.3 & 1.7 & 2.0 & 2.1 & 1.9 \\
\hline $\mathrm{P}_{\mathrm{M}}$ (kbar) & 0.1 & 5.8 & 5.7 & 0.0 & 1.1 & 0.1 & 1.6 & 0.1 & 2.1 & 1.2 & 1.6 & 1.9 & 2.0 & 1.8 \\
\hline$P_{R}(k b a r)$ & 0.5 & 5.6 & 5.6 & 0.4 & 1.0 & 0.5 & 1.2 & 0.5 & 1.6 & 1.0 & 1.2 & 1.5 & 1.5 & 1.4 \\
\hline $\mathrm{T}\left({ }^{\circ} \mathrm{C}\right)_{\mathrm{R}}$ & 735 & 1022 & 1017 & 725 & 788 & 730 & 843 & 692 & 865 & 813 & 834 & 853 & 846 & 858 \\
\hline $\mathrm{T}\left({ }^{\circ} \mathrm{C}\right)_{\mathrm{HB}}$ & 725 & 738 & 738 & 722 & 740 & 737 & 757 & 735 & 758 & 758 & 757 & 754 & 757 & 764 \\
\hline$\triangle N N O$ & 3.0 & 1.0 & 1.0 & 3.1 & 2.4 & 1.7 & 0.7 & 1.3 & 0.4 & 1.1 & 0.8 & 0.5 & 0.6 & 0.6 \\
\hline $\mathrm{H}_{2}$ Omelt & 4.0 & 8.2 & 8.8 & 3.5 & 6.3 & 1.9 & 3.5 & 4.2 & 3.7 & 3.7 & 3.8 & 3.9 & 4.2 & 3.7 \\
\hline
\end{tabular}


Supplementary Material: Electron microprobe analyses of amphibole from Garzón granites and related rocks, Eastern Cordillera, Colombia.

\begin{tabular}{|c|c|c|c|c|c|c|c|c|c|c|c|c|c|c|}
\hline \multirow{3}{*}{$\begin{array}{l}\text { Mineral } \\
\text { Massif } \\
\text { Sample }\end{array}$} & \multicolumn{14}{|c|}{ Amphibole } \\
\hline & \multicolumn{14}{|c|}{ Sombrerillo } \\
\hline & GAR-394 & $\begin{array}{l}\text { GAR- } \\
394\end{array}$ & $\begin{array}{l}\text { GAR- } \\
394\end{array}$ & $\begin{array}{l}\text { GAR- } \\
394\end{array}$ & $\begin{array}{l}\text { GAR- } \\
394\end{array}$ & $\begin{array}{l}\text { GAR- } \\
394\end{array}$ & $\begin{array}{l}\text { GAR- } \\
394\end{array}$ & $\begin{array}{l}\text { GAR- } \\
394\end{array}$ & $\begin{array}{l}\text { GAR- } \\
394\end{array}$ & $\begin{array}{l}\text { GAR- } \\
394\end{array}$ & $\begin{array}{l}\text { GAR- } \\
394\end{array}$ & $\begin{array}{l}\text { GAR- } \\
395\end{array}$ & $\begin{array}{l}\text { GAR- } \\
395\end{array}$ & $\begin{array}{l}\text { GAR- } \\
395\end{array}$ \\
\hline Facies & MG & MG & MG & MG & MG & MG & MG & MG & MG & MG & MG & Dac & Dac & Dac \\
\hline Grain/Point & anf_11a-1 & $\begin{array}{l}\text { anf_11a- } \\
2\end{array}$ & $\begin{array}{l}\text { anf_11a- } \\
3\end{array}$ & $\begin{array}{l}\text { anf_11a- } \\
4\end{array}$ & $\begin{array}{l}\text { anf_11a- } \\
5\end{array}$ & $\begin{array}{l}\text { anf_11a- } \\
6\end{array}$ & $\begin{array}{l}\text { anf_12a- } \\
1\end{array}$ & $\begin{array}{l}\text { anf_12a- } \\
2\end{array}$ & $\begin{array}{l}\text { anf_12a- } \\
3\end{array}$ & $\begin{array}{l}\text { anf_12a- } \\
4\end{array}$ & $\begin{array}{l}\text { anf_12a- } \\
5\end{array}$ & anf_01-1 & anf_01-2 & anf_01-3 \\
\hline $\mathrm{SiO} 2$ & 51.85 & 50.81 & 44.90 & 44.90 & 44.78 & 50.51 & 48.38 & 47.89 & 44.68 & 44.77 & 44.51 & $\overline{4} 4.24$ & $\overline{4} 2.99$ & 46.51 \\
\hline $\mathrm{TiO} 2$ & 0.39 & 0.48 & 1.64 & 1.58 & 1.73 & 0.36 & 0.66 & 0.60 & 1.58 & 1.91 & 1.28 & 1.59 & 1.80 & 1.53 \\
\hline Al2O3 & 2.97 & 3.64 & 8.00 & 7.97 & 7.90 & 3.67 & 5.29 & 5.67 & 8.05 & 8.12 & 8.35 & 10.33 & 11.49 & 8.16 \\
\hline $\mathrm{Cr} 2 \mathrm{O} 3$ & 0.00 & 0.00 & 0.00 & 0.00 & 0.00 & 0.00 & 0.00 & 0.00 & 0.00 & 0.06 & 0.00 & 0.00 & 0.00 & 0.00 \\
\hline $\mathrm{FeO}$ & 15.78 & 16.96 & 19.53 & 19.77 & 19.37 & 16.86 & 18.24 & 18.48 & 19.73 & 19.20 & 19.85 & 14.87 & 15.34 & 14.36 \\
\hline $\mathrm{MnO}$ & 0.45 & 0.46 & 0.51 & 0.51 & 0.47 & 0.46 & 0.42 & 0.40 & 0.51 & 0.49 & 0.45 & 0.50 & 0.51 & 0.51 \\
\hline $\mathrm{MgO}$ & 13.83 & 13.20 & 10.16 & 9.98 & 10.24 & 13.26 & 12.10 & 11.84 & 10.04 & 10.52 & 9.87 & 12.85 & 11.88 & 13.77 \\
\hline $\mathrm{ZnO}$ & 0.02 & 0.00 & 0.05 & 0.04 & 0.06 & 0.03 & 0.04 & 0.03 & 0.00 & 0.01 & 0.02 & 0.01 & 0.00 & 0.03 \\
\hline $\mathrm{CaO}$ & 12.00 & 11.83 & 11.01 & 11.23 & 11.40 & 11.83 & 11.58 & 11.83 & 11.05 & 10.91 & 11.41 & 10.88 & 11.19 & 10.98 \\
\hline $\mathrm{Na} 2 \mathrm{O}$ & 0.83 & 0.90 & 1.75 & 1.68 & 1.65 & 0.80 & 1.20 & 1.31 & 1.72 & 1.87 & 1.68 & 1.42 & 1.74 & 1.39 \\
\hline $\mathrm{K} 2 \mathrm{O}$ & 0.37 & 0.42 & 0.98 & 1.01 & 0.96 & 0.39 & 0.54 & 0.60 & 1.03 & 1.01 & 1.01 & 0.69 & 0.75 & 0.59 \\
\hline $\mathrm{F}$ & 0.15 & 0.14 & 0.13 & 0.12 & 0.13 & 0.13 & 0.18 & 0.16 & 0.13 & 0.13 & 0.15 & 0.05 & 0.02 & 0.03 \\
\hline $\mathrm{Cl}$ & 0.08 & 0.06 & 0.39 & 0.35 & 0.33 & 0.04 & 0.10 & 0.10 & 0.45 & 0.39 & 0.39 & 0.12 & 0.11 & 0.12 \\
\hline Total & 98.72 & 98.90 & 99.06 & 99.14 & 99.02 & 98.35 & 98.72 & 98.91 & 98.97 & 99.38 & 98.97 & 97.55 & 97.82 & 97.99 \\
\hline $\mathrm{O}=(\mathrm{Cl} . \mathrm{F})$ & 0.08 & 0.07 & 0.15 & 0.13 & 0.13 & 0.06 & 0.10 & 0.09 & 0.16 & 0.14 & 0.15 & 0.05 & 0.03 & 0.04 \\
\hline Total & 98.66 & 98.82 & 98.91 & 99.01 & 98.90 & 98.29 & 98.62 & 98.84 & 98.81 & 99.24 & 98.85 & 97.50 & 97.80 & 97.97 \\
\hline \multicolumn{15}{|c|}{ Structural formulae (according mean Fe3+ values. schumacher. after Gualda \& Vlach. 2005) } \\
\hline $\mathrm{Si}$ & 7.533 & 7.410 & 6.722 & 6.729 & 6.709 & 7.396 & 7.129 & 7.068 & 6.708 & 6.670 & 6.689 & 6.484 & 6.342 & 6.768 \\
\hline ivAl & 0.467 & 0.590 & 1.278 & 1.271 & 1.291 & 0.604 & 0.871 & 0.932 & 1.292 & 1.330 & 1.311 & 1.516 & 1.658 & 1.232 \\
\hline T site & 8.000 & 8.000 & 8.000 & 8.000 & 8.000 & 8.000 & 8.000 & 8.000 & 8.000 & 8.000 & 8.000 & 8.000 & 8.000 & 8.000 \\
\hline viAl & 0.042 & 0.036 & 0.133 & 0.136 & 0.104 & 0.029 & 0.048 & 0.055 & 0.133 & 0.095 & 0.167 & 0.269 & 0.340 & 0.167 \\
\hline $\mathrm{Ti}$ & 0.042 & 0.053 & 0.185 & 0.178 & 0.195 & 0.040 & 0.073 & 0.066 & 0.179 & 0.214 & 0.144 & 0.175 & 0.200 & 0.167 \\
\hline $\mathrm{Cr}$ & 0.000 & 0.001 & 0.000 & 0.000 & 0.000 & 0.000 & 0.000 & 0.000 & 0.000 & 0.007 & 0.000 & 0.000 & 0.000 & 0.000 \\
\hline Felll & 0.192 & 0.249 & 0.348 & 0.313 & 0.316 & 0.303 & 0.411 & 0.393 & 0.348 & 0.372 & 0.345 & 0.674 & 0.525 & 0.534 \\
\hline $\mathrm{Fe}$ & 1.725 & 1.819 & 2.097 & 2.165 & 2.111 & 1.761 & 1.837 & 1.888 & 2.129 & 2.020 & 2.149 & 1.149 & 1.367 & 1.213 \\
\hline $\mathrm{Mn}$ & 0.056 & 0.057 & 0.065 & 0.064 & 0.060 & 0.058 & 0.052 & 0.050 & 0.065 & 0.062 & 0.057 & 0.062 & 0.063 & 0.063 \\
\hline $\mathrm{Mg}$ & 2.995 & 2.870 & 2.267 & 2.229 & 2.287 & 2.894 & 2.658 & 2.605 & 2.247 & 2.336 & 2.211 & 2.807 & 2.612 & 2.987 \\
\hline $\mathrm{Zn}$ & 0.002 & 0.000 & 0.005 & 0.004 & 0.007 & 0.003 & 0.004 & 0.003 & 0.000 & 0.001 & 0.002 & 0.001 & 0.001 & 0.004 \\
\hline C site & 5.055 & 5.084 & 5.100 & 5.090 & 5.079 & 5.089 & 5.082 & 5.060 & 5.100 & 5.107 & 5.076 & 5.137 & 5.108 & 5.135 \\
\hline Excess C & 0.055 & 0.084 & 0.100 & 0.090 & 0.079 & 0.089 & 0.082 & 0.060 & 0.100 & 0.107 & 0.076 & 0.137 & 0.108 & 0.135 \\
\hline $\mathrm{Ca}$ & 1.868 & 1.849 & 1.766 & 1.803 & 1.830 & 1.856 & 1.828 & 1.871 & 1.778 & 1.741 & 1.837 & 1.709 & 1.769 & 1.712 \\
\hline $\mathrm{NaB}$ & 0.077 & 0.067 & 0.134 & 0.107 & 0.091 & 0.055 & 0.089 & 0.069 & 0.123 & 0.152 & 0.087 & 0.155 & 0.123 & 0.153 \\
\hline B site & 2.000 & 2.000 & 2.000 & 2.000 & 2.000 & 2.000 & 2.000 & 2.000 & 2.000 & 2.000 & 2.000 & 2.000 & 2.000 & 2.000 \\
\hline $\mathrm{NaA}$ & 0.157 & 0.186 & 0.374 & 0.381 & 0.389 & 0.173 & 0.253 & 0.307 & 0.378 & 0.389 & 0.403 & 0.249 & 0.375 & 0.239 \\
\hline K & 0.068 & 0.079 & 0.188 & 0.194 & 0.183 & 0.072 & 0.102 & 0.113 & 0.198 & 0.191 & 0.194 & 0.129 & 0.142 & 0.110 \\
\hline A site & 0.225 & 0.265 & 0.562 & 0.575 & 0.572 & 0.246 & 0.356 & 0.420 & 0.576 & 0.580 & 0.597 & 0.378 & 0.516 & 0.349 \\
\hline Cations & 15.225 & 15.265 & 15.562 & 15.575 & 15.572 & 15.246 & 15.356 & 15.420 & 15.576 & 15.580 & 15.597 & 15.378 & 15.516 & 15.349 \\
\hline $\mathrm{F}$ & 0.069 & 0.062 & 0.063 & 0.059 & 0.061 & 0.060 & 0.082 & 0.076 & 0.060 & 0.063 & 0.073 & 0.022 & 0.012 & 0.014 \\
\hline $\mathrm{Cl}$ & 0.019 & 0.015 & 0.100 & 0.088 & 0.083 & 0.009 & 0.025 & 0.024 & 0.115 & 0.099 & 0.100 & 0.030 & 0.026 & 0.030 \\
\hline mg\# & 0.63 & 0.61 & 0.52 & 0.51 & 0.52 & 0.62 & 0.59 & 0.58 & 0.51 & 0.54 & 0.51 & 0.71 & 0.66 & 0.71 \\
\hline \multicolumn{15}{|c|}{ Structural formulae (according max Fe3+ values. schumacher. after Gualda \& Vlach. 2005) } \\
\hline $\mathrm{Si}$ & 7.502 & 7.377 & 6.670 & 6.683 & 6.668 & 7.369 & 7.087 & 7.036 & 6.657 & 6.615 & 6.650 & 6.417 & 6.290 & 6.698 \\
\hline ivAl & 0.498 & 0.623 & 1.330 & 1.317 & 1.332 & 0.631 & 0.913 & 0.964 & 1.343 & 1.385 & 1.350 & 1.583 & 1.710 & 1.302 \\
\hline
\end{tabular}




\begin{tabular}{|c|c|c|c|c|c|c|c|c|c|c|c|c|c|c|}
\hline T site & 8.000 & 8.000 & 8.000 & 8.000 & 8.000 & 8.000 & 8.000 & 8.000 & 8.000 & 8.000 & 8.000 & 8.000 & 8.000 & 8.000 \\
\hline viAl & 0.008 & 0.000 & 0.071 & 0.081 & 0.055 & 0.000 & 0.000 & 0.018 & 0.071 & 0.029 & 0.120 & 0.183 & 0.271 & 0.083 \\
\hline $\mathrm{Ti}$ & 0.042 & 0.053 & 0.183 & 0.177 & 0.194 & 0.040 & 0.072 & 0.066 & 0.177 & 0.212 & 0.143 & 0.173 & 0.198 & 0.166 \\
\hline $\mathrm{Cr}$ & 0.000 & 0.001 & 0.000 & 0.000 & 0.000 & 0.000 & 0.000 & 0.000 & 0.000 & 0.007 & 0.000 & 0.000 & 0.000 & 0.000 \\
\hline Felll & 0.384 & 0.455 & 0.696 & 0.625 & 0.593 & 0.471 & 0.684 & 0.604 & 0.697 & 0.745 & 0.611 & 1.146 & 0.901 & 1.003 \\
\hline $\mathrm{Fe}$ & 1.525 & 1.604 & 1.730 & 1.836 & 1.819 & 1.586 & 1.551 & 1.667 & 1.762 & 1.628 & 1.869 & 0.658 & 0.976 & 0.727 \\
\hline $\mathrm{Mn}$ & 0.055 & 0.056 & 0.064 & 0.064 & 0.059 & 0.057 & 0.052 & 0.050 & 0.064 & 0.061 & 0.057 & 0.061 & 0.063 & 0.063 \\
\hline $\mathrm{Mg}$ & 2.982 & 2.857 & 2.250 & 2.214 & 2.273 & 2.883 & 2.642 & 2.593 & 2.230 & 2.317 & 2.198 & 2.778 & 2.591 & 2.956 \\
\hline $\mathrm{Zn}$ & 0.002 & 0.000 & 0.005 & 0.004 & 0.007 & 0.003 & 0.004 & 0.003 & 0.000 & 0.001 & 0.002 & 0.001 & 0.001 & 0.004 \\
\hline C site & 5.000 & 5.025 & 5.000 & 5.000 & 5.000 & 5.041 & 5.004 & 5.000 & 5.000 & 5.000 & 5.000 & 5.000 & 5.000 & 5.000 \\
\hline Excess C & 0.000 & 0.025 & 0.000 & 0.000 & 0.000 & 0.041 & 0.004 & 0.000 & 0.000 & 0.000 & 0.000 & 0.000 & 0.000 & 0.000 \\
\hline $\mathrm{Ca}$ & 1.860 & 1.840 & 1.752 & 1.791 & 1.819 & 1.849 & 1.817 & 1.862 & 1.764 & 1.727 & 1.826 & 1.691 & 1.754 & 1.694 \\
\hline $\mathrm{NaB}$ & 0.140 & 0.134 & 0.248 & 0.209 & 0.181 & 0.110 & 0.179 & 0.138 & 0.236 & 0.273 & 0.174 & 0.309 & 0.246 & 0.306 \\
\hline B site & 2.000 & 2.000 & 2.000 & 2.000 & 2.000 & 2.000 & 2.000 & 2.000 & 2.000 & 2.000 & 2.000 & 2.000 & 2.000 & 2.000 \\
\hline $\mathrm{NaA}$ & 0.094 & 0.118 & 0.257 & 0.276 & 0.295 & 0.118 & 0.162 & 0.236 & 0.261 & 0.263 & 0.313 & 0.090 & 0.248 & 0.082 \\
\hline $\mathrm{K}$ & 0.068 & 0.079 & 0.187 & 0.192 & 0.182 & 0.072 & 0.102 & 0.113 & 0.196 & 0.190 & 0.193 & 0.128 & 0.140 & 0.109 \\
\hline A site & 0.162 & 0.197 & 0.443 & 0.468 & 0.477 & 0.190 & 0.264 & 0.349 & 0.457 & 0.452 & 0.506 & 0.218 & 0.388 & 0.191 \\
\hline Cations & 15.162 & 15.222 & 15.443 & 15.468 & 15.477 & 15.231 & 15.268 & 15.349 & 15.457 & 15.452 & 15.506 & 15.218 & 15.388 & 15.191 \\
\hline $\mathrm{F}$ & 0.069 & 0.062 & 0.063 & 0.059 & 0.060 & 0.060 & 0.082 & 0.076 & 0.059 & 0.062 & 0.072 & 0.022 & 0.012 & 0.014 \\
\hline $\mathrm{Cl}$ & 0.019 & 0.015 & 0.099 & 0.087 & 0.083 & 0.009 & 0.025 & 0.024 & 0.114 & 0.098 & 0.099 & 0.030 & 0.026 & 0.030 \\
\hline mg\# & 0.66 & 0.64 & 0.57 & 0.55 & 0.56 & 0.65 & 0.63 & 0.61 & 0.56 & 0.59 & 0.54 & 0.81 & 0.73 & 0.80 \\
\hline $\mathrm{Mg} /\left(\mathrm{Mg}+\mathrm{Fe}^{2+}\right) \mathrm{med}$ & 0.634 & 0.612 & 0.519 & 0.507 & 0.520 & 0.622 & 0.591 & 0.580 & 0.513 & 0.536 & 0.507 & 0.710 & 0.656 & 0.711 \\
\hline $\mathrm{Mg} /\left(\mathrm{Mg}+\mathrm{Fe}^{2+}\right) \mathrm{max}$ & 0.662 & 0.640 & 0.565 & 0.547 & 0.555 & 0.645 & 0.630 & 0.609 & 0.559 & 0.587 & 0.540 & 0.808 & 0.726 & 0.803 \\
\hline$P(\mathrm{kbar})$ & -1.4 & -0.8 & 3.1 & 3.1 & 3.1 & -0.7 & 0.7 & 1.0 & 3.2 & 3.2 & 3.5 & 5.0 & 6.0 & 3.0 \\
\hline $\mathrm{PHZ}_{\mathrm{Hz}}$ (kbar) & 0.5 & 0.6 & 1.9 & 1.9 & 1.9 & 0.6 & 1.0 & 1.1 & 2.0 & 2.0 & 2.2 & 3.3 & 4.5 & 1.9 \\
\hline $\mathrm{PM}_{\mathrm{M}}(\mathrm{kbar})$ & -0.1 & 0.1 & 1.9 & 1.9 & 1.9 & 0.1 & 0.6 & 0.8 & 2.0 & 2.0 & 2.1 & 3.2 & 4.1 & 1.9 \\
\hline$P_{R}(k b a r)$ & 0.4 & 0.5 & 1.4 & 1.4 & 1.4 & 0.5 & 0.7 & 0.8 & 1.5 & 1.5 & 1.6 & 2.4 & 3.3 & 1.4 \\
\hline $\mathrm{T}\left({ }^{\circ} \mathrm{C}\right)_{\mathrm{R}}$ & 692 & 712 & 858 & 856 & 866 & 712 & 759 & 772 & 858 & 873 & 859 & 916 & 957 & 863 \\
\hline $\mathrm{T}\left({ }^{\circ} \mathrm{C}\right)_{\mathrm{HB}}$ & 726 & 737 & 759 & 758 & 760 & 738 & 753 & 753 & 759 & 763 & 755 & 754 & 748 & 757 \\
\hline$\triangle N N O$ & 1.7 & 1.6 & 0.6 & 0.5 & 0.6 & 1.6 & 1.3 & 1.1 & 0.5 & 0.7 & 0.4 & 1.4 & 0.9 & 1.7 \\
\hline $\mathrm{H}_{2}$ Omelt & 3.1 & 3.2 & 3.9 & 3.8 & 3.8 & 3.3 & 3.8 & 3.7 & 3.8 & 3.6 & 4.1 & 6.7 & 6.9 & 5.4 \\
\hline
\end{tabular}

Notes: Facies abbreviations BQ-M OC = Biotite quartz-monzodiorite with two pyroxenes; L-MG = Leuco monzogranite; BT-MG = Biotite hornblende monzogranite; Rhy = Rhyolite; HB-GD = Hornblende biotite granodiorite; $\mathrm{MG}=$ Monzogranite; $\mathrm{H}-\mathrm{MZ}=$ Hornblende monzodiorite; $\mathrm{E}-\mathrm{MD}=$ Micro-diorite enclave; $\mathrm{IM}-\mathrm{D}=$ Intermediate-mafic dikes; $\mathrm{Dac}=\mathrm{Dacite} ; \mathrm{mg} \#=$ magnesium number. $\mathrm{P}=-3.92+5.03 \mathrm{Al} \mathrm{I}^{\top}$ (Hammarstorm and Zen, 1986); $\mathrm{P}=0.26 \mathrm{e}\left(1.48 \mathrm{Al} \mathrm{T}^{\top} \text { ) (Hammarstrorm \& Zen, 1986); } \mathrm{P}_{\mathrm{M}}=-0.5+0.331(8) \times \mathrm{Al} \mathrm{I}^{\top}+0.995(4) \times(\mathrm{Al})^{\top}\right)^{2}$ from Mutch, et al. $(2016) ; \mathrm{T}\left({ }^{\circ} \mathrm{C}\right)_{\mathrm{R}}=\mathrm{Temperature} \mathrm{from} \mathrm{Ridolfi} \mathrm{et} \mathrm{al.}(2010) ; \mathrm{T}\left({ }^{\circ} \mathrm{C}\right) \mathrm{HB}$ $=\left(\right.$ Holland \& Blundy, 1994); $\triangle N N O=$ oxygen fugacity-amphibole relative to NNO buffer from Ridolfi et al. (2010); $\mathrm{H}_{2}$ Omelt $=$ The water content in the melt from Ridolfi et al. $(2010)$. 
Supplementary Material: Electron microprobe analyses of amphibole from Garzón granites and related rocks, Eastern Cordillera, Colombia.

\begin{tabular}{|c|c|c|c|c|c|c|c|c|c|c|c|c|c|c|}
\hline \multirow{3}{*}{$\begin{array}{l}\text { Mineral } \\
\text { Massif } \\
\text { Sample }\end{array}$} & \multicolumn{14}{|c|}{ Amphibole } \\
\hline & \multicolumn{14}{|c|}{ Sombrerillo } \\
\hline & GAR-395 & $\begin{array}{l}\text { GAR- } \\
395 \\
\end{array}$ & $\begin{array}{l}\text { GAR- } \\
395\end{array}$ & $\begin{array}{l}\text { GAR- } \\
395 \\
\end{array}$ & $\begin{array}{l}\text { GAR- } \\
395\end{array}$ & $\begin{array}{l}\text { GAR- } \\
395\end{array}$ & $\begin{array}{l}\text { GAR- } \\
395 \\
\end{array}$ & $\begin{array}{l}\text { GAR- } \\
395\end{array}$ & $\begin{array}{l}\text { GAR- } \\
395 \\
\end{array}$ & $\begin{array}{l}\text { GAR- } \\
395 \\
\end{array}$ & $\begin{array}{l}\text { GAR- } \\
395 \\
\end{array}$ & $\begin{array}{l}\text { GAR- } \\
395 \\
\end{array}$ & $\begin{array}{l}\text { GAR- } \\
395\end{array}$ & $\begin{array}{l}\text { GAR- } \\
395 \\
\end{array}$ \\
\hline Facies & Dac & Dac & Dac & Dac & Dac & Dac & Dac & Dac & Dac & Dac & Dac & Dac & Dac & Dac \\
\hline Grain/Point & anf_01-5 & anf_01-6 & anf_02-1 & anf_02-2 & anf_02-3 & anf_05-1 & anf_05-2 & anf_05-3 & anf_07-1 & anf_07-2 & anf_07-3 & anf_07-4 & anf_08-1 & anf_08-2 \\
\hline $\mathrm{SiO} 2$ & 47.20 & $\overline{45.46}$ & 49.14 & $\overline{4} 7.41$ & 47.28 & $\overline{4} 7.57$ & $\overline{47.64}$ & $\overline{45.93}$ & 49.40 & 48.98 & $\overline{4} 7.59$ & 47.86 & 47.57 & $\overline{4} 7.37$ \\
\hline TiO2 & 1.33 & 1.52 & 0.81 & 1.44 & 1.33 & 1.51 & 1.13 & 1.49 & 1.20 & 1.33 & 1.52 & 1.10 & 1.40 & 1.51 \\
\hline $\mathrm{Al} 2 \mathrm{O} 3$ & 7.56 & 8.88 & 5.90 & 7.19 & 7.24 & 7.29 & 7.19 & 8.84 & 6.19 & 6.36 & 6.96 & 6.87 & 6.75 & 7.02 \\
\hline $\mathrm{Cr} 2 \mathrm{O} 3$ & 0.00 & 0.00 & 0.00 & 0.00 & 0.00 & 0.00 & 0.00 & 0.00 & 0.00 & 0.00 & 0.00 & 0.00 & 0.00 & 0.00 \\
\hline $\mathrm{FeO}$ & 15.38 & 15.80 & 14.95 & 14.67 & 15.54 & 14.30 & 15.25 & 15.98 & 13.55 & 13.58 & 14.10 & 14.68 & 14.27 & 14.49 \\
\hline $\mathrm{MnO}$ & 0.73 & 0.71 & 0.75 & 0.58 & 0.68 & 0.66 & 0.72 & 0.74 & 0.51 & 0.50 & 0.55 & 0.77 & 0.54 & 0.57 \\
\hline $\mathrm{MgO}$ & 13.57 & 12.45 & 14.41 & 14.06 & 13.42 & 13.80 & 13.80 & 12.28 & 15.39 & 15.08 & 14.67 & 13.91 & 14.52 & 14.33 \\
\hline $\mathrm{ZnO}$ & 0.06 & 0.00 & 0.05 & 0.03 & 0.03 & 0.06 & 0.04 & 0.01 & 0.06 & 0.02 & 0.00 & 0.02 & 0.02 & 0.04 \\
\hline $\mathrm{CaO}$ & 10.75 & 10.63 & 10.48 & 10.82 & 10.86 & 11.14 & 10.75 & 10.84 & 11.04 & 10.88 & 11.00 & 11.20 & 10.87 & 11.02 \\
\hline $\mathrm{Na} 2 \mathrm{O}$ & 1.31 & 1.55 & 1.31 & 1.31 & 1.24 & 1.16 & 1.35 & 1.44 & 1.23 & 1.14 & 1.33 & 1.15 & 1.26 & 1.29 \\
\hline $\mathrm{K} 2 \mathrm{O}$ & 0.48 & 0.59 & 0.32 & 0.50 & 0.44 & 0.63 & 0.48 & 0.63 & 0.46 & 0.48 & 0.57 & 0.45 & 0.52 & 0.51 \\
\hline $\mathrm{F}$ & 0.05 & 0.02 & 0.02 & 0.02 & 0.02 & 0.04 & 0.04 & 0.00 & 0.00 & 0.03 & 0.02 & 0.00 & 0.02 & 0.03 \\
\hline $\mathrm{Cl}$ & 0.11 & 0.19 & 0.07 & 0.11 & 0.13 & 0.16 & 0.17 & 0.14 & 0.12 & 0.09 & 0.19 & 0.11 & 0.15 & 0.17 \\
\hline Total & 98.53 & 97.79 & 98.20 & 98.15 & 98.21 & 98.34 & 98.56 & 98.32 & 99.14 & 98.47 & 98.50 & 98.12 & 97.89 & 98.36 \\
\hline $\mathrm{O}=(\mathrm{Cl} . \mathrm{F})$ & 0.05 & 0.05 & 0.03 & 0.03 & 0.04 & 0.06 & 0.05 & 0.03 & 0.03 & 0.03 & 0.05 & 0.02 & 0.04 & 0.05 \\
\hline Total & 98.48 & 97.75 & 98.16 & 98.11 & 98.18 & 98.28 & 98.53 & 98.32 & 99.12 & 98.43 & 98.44 & 98.09 & 97.86 & 98.33 \\
\hline \multicolumn{15}{|c|}{ Structural formulae (according mean Fe3+ values. schumacher. after Gualda \& Vlach. 2005) } \\
\hline $\mathrm{Si}$ & 6.834 & 6.685 & 7.099 & 6.873 & 6.874 & 6.904 & 6.893 & 6.723 & 7.042 & 7.031 & 6.882 & 6.942 & 6.915 & 6.869 \\
\hline ivAl & 1.166 & 1.315 & 0.901 & 1.127 & 1.126 & 1.096 & 1.107 & 1.277 & 0.958 & 0.969 & 1.118 & 1.058 & 1.085 & 1.131 \\
\hline T site & 8.000 & 8.000 & 8.000 & 8.000 & 8.000 & 8.000 & 8.000 & 8.000 & 8.000 & 8.000 & 8.000 & 8.000 & 8.000 & 8.000 \\
\hline viAl & 0.124 & 0.224 & 0.104 & 0.102 & 0.115 & 0.152 & 0.119 & 0.248 & 0.082 & 0.107 & 0.069 & 0.117 & 0.072 & 0.068 \\
\hline $\mathrm{Ti}$ & 0.145 & 0.168 & 0.087 & 0.157 & 0.146 & 0.165 & 0.123 & 0.164 & 0.129 & 0.144 & 0.166 & 0.120 & 0.153 & 0.165 \\
\hline $\mathrm{Cr}$ & 0.000 & 0.000 & 0.000 & 0.000 & 0.000 & 0.000 & 0.000 & 0.000 & 0.000 & 0.001 & 0.000 & 0.000 & 0.000 & 0.000 \\
\hline Felll & 0.648 & 0.547 & 0.558 & 0.588 & 0.616 & 0.454 & 0.627 & 0.493 & 0.496 & 0.484 & 0.493 & 0.569 & 0.520 & 0.527 \\
\hline $\mathrm{Fe}$ & 1.214 & 1.397 & 1.248 & 1.191 & 1.274 & 1.282 & 1.218 & 1.463 & 1.119 & 1.147 & 1.212 & 1.212 & 1.215 & 1.231 \\
\hline $\mathrm{Mn}$ & 0.089 & 0.088 & 0.091 & 0.072 & 0.084 & 0.081 & 0.089 & 0.092 & 0.062 & 0.061 & 0.068 & 0.095 & 0.066 & 0.069 \\
\hline $\mathrm{Mg}$ & 2.929 & 2.729 & 3.103 & 3.038 & 2.908 & 2.985 & 2.976 & 2.679 & 3.270 & 3.226 & 3.162 & 3.007 & 3.146 & 3.097 \\
\hline $\mathrm{Zn}$ & 0.007 & 0.000 & 0.005 & 0.003 & 0.003 & 0.007 & 0.004 & 0.001 & 0.006 & 0.002 & 0.000 & 0.002 & 0.003 & 0.005 \\
\hline C site & 5.156 & 5.153 & 5.197 & 5.150 & 5.145 & 5.126 & 5.157 & 5.141 & 5.163 & 5.170 & 5.169 & 5.122 & 5.175 & 5.162 \\
\hline Excess $\mathrm{C}$ & 0.156 & 0.153 & 0.197 & 0.150 & 0.145 & 0.126 & 0.157 & 0.141 & 0.163 & 0.170 & 0.169 & 0.122 & 0.175 & 0.162 \\
\hline $\mathrm{Ca}$ & 1.668 & 1.675 & 1.622 & 1.681 & 1.692 & 1.732 & 1.667 & 1.700 & 1.686 & 1.673 & 1.704 & 1.741 & 1.693 & 1.712 \\
\hline $\mathrm{NaB}$ & 0.176 & 0.172 & 0.181 & 0.169 & 0.163 & 0.142 & 0.177 & 0.159 & 0.151 & 0.157 & 0.126 & 0.138 & 0.132 & 0.126 \\
\hline B site & 2.000 & 2.000 & 2.000 & 2.000 & 2.000 & 2.000 & 2.000 & 2.000 & 2.000 & 2.000 & 2.000 & 2.000 & 2.000 & 2.000 \\
\hline $\mathrm{NaA}$ & 0.191 & 0.270 & 0.185 & 0.200 & 0.186 & 0.185 & 0.202 & 0.250 & 0.190 & 0.160 & 0.246 & 0.187 & 0.223 & 0.238 \\
\hline $\mathrm{K}$ & 0.089 & 0.110 & 0.059 & 0.093 & 0.082 & 0.117 & 0.089 & 0.117 & 0.083 & 0.088 & 0.104 & 0.083 & 0.096 & 0.095 \\
\hline A site & 0.279 & 0.380 & 0.244 & 0.293 & 0.267 & 0.302 & 0.291 & 0.367 & 0.273 & 0.248 & 0.351 & 0.270 & 0.319 & 0.333 \\
\hline Cations & 15.279 & 15.380 & 15.244 & 15.293 & 15.267 & 15.302 & 15.291 & 15.367 & 15.273 & 15.248 & 15.351 & 15.270 & 15.319 & 15.333 \\
\hline $\mathrm{F}$ & 0.022 & 0.007 & 0.010 & 0.010 & 0.011 & 0.020 & 0.017 & 0.000 & 0.000 & 0.014 & 0.007 & 0.000 & 0.008 & 0.013 \\
\hline $\mathrm{Cl}$ & 0.027 & 0.047 & 0.018 & 0.026 & 0.032 & 0.040 & 0.042 & 0.034 & 0.029 & 0.021 & 0.046 & 0.026 & 0.037 & 0.042 \\
\hline & 0.71 & 0.66 & 0.71 & 0.72 & 0.70 & 0.70 & 0.71 & 0.65 & 0.74 & 0.74 & 0.72 & 0.71 & 0.72 & 0.72 \\
\hline \multicolumn{15}{|c|}{ Structural formulae (according max Fe3+ values. schumacher. after Gualda \& Vlach. 2005) } \\
\hline $\mathrm{Si}$ & 6.753 & 6.608 & 7.013 & 6.795 & 6.798 & 6.838 & 6.811 & 6.651 & 6.971 & 6.957 & 6.824 & 6.878 & 6.854 & 6.810 \\
\hline ivAl & 1.247 & 1.392 & 0.987 & 1.205 & 1.202 & 1.162 & 1.189 & 1.349 & 1.029 & 1.043 & 1.176 & 1.122 & 1.146 & 1.190 \\
\hline T site & 8.000 & 8.000 & 8.000 & 8.000 & 8.000 & 8.000 & 8.000 & 8.000 & 8.000 & 8.000 & 8.000 & 8.000 & 8.000 & 8.000 \\
\hline
\end{tabular}




\begin{tabular}{|c|c|c|c|c|c|c|c|c|c|c|c|c|c|c|}
\hline viAl & 0.028 & 0.129 & 0.005 & 0.009 & 0.025 & 0.074 & 0.023 & 0.159 & 0.000 & 0.021 & 0.000 & 0.042 & 0.000 & 0.000 \\
\hline $\mathrm{Ti}$ & 0.143 & 0.166 & 0.086 & 0.155 & 0.144 & 0.163 & 0.121 & 0.162 & 0.127 & 0.142 & 0.164 & 0.119 & 0.152 & 0.164 \\
\hline $\mathrm{Cr}$ & 0.000 & 0.000 & 0.000 & 0.000 & 0.000 & 0.000 & 0.000 & 0.000 & 0.000 & 0.001 & 0.000 & 0.000 & 0.000 & 0.000 \\
\hline Felll & 1.187 & 1.075 & 1.113 & 1.106 & 1.116 & 0.889 & 1.168 & 0.981 & 0.957 & 0.964 & 0.880 & 0.990 & 0.924 & 0.912 \\
\hline $\mathrm{Fe}$ & 0.653 & 0.846 & 0.672 & 0.652 & 0.753 & 0.830 & 0.656 & 0.954 & 0.642 & 0.649 & 0.811 & 0.775 & 0.795 & 0.830 \\
\hline $\mathrm{Mn}$ & 0.088 & 0.087 & 0.090 & 0.071 & 0.083 & 0.080 & 0.088 & 0.091 & 0.061 & 0.060 & 0.067 & 0.094 & 0.066 & 0.069 \\
\hline $\mathrm{Mg}$ & 2.894 & 2.697 & 3.065 & 3.003 & 2.876 & 2.957 & 2.941 & 2.650 & 3.237 & 3.192 & 3.135 & 2.980 & 3.118 & 3.071 \\
\hline $\mathrm{Zn}$ & 0.007 & 0.000 & 0.005 & 0.003 & 0.003 & 0.007 & 0.004 & 0.001 & 0.006 & 0.002 & 0.000 & 0.002 & 0.003 & 0.005 \\
\hline C site & 5.000 & 5.000 & 5.036 & 5.000 & 5.000 & 5.000 & 5.000 & 5.000 & 5.030 & 5.031 & 5.057 & 5.000 & 5.058 & 5.050 \\
\hline Excess C & 0.000 & 0.000 & 0.036 & 0.000 & 0.000 & 0.000 & 0.000 & 0.000 & 0.030 & 0.031 & 0.057 & 0.000 & 0.058 & 0.050 \\
\hline $\mathrm{Ca}$ & 1.648 & 1.655 & 1.602 & 1.661 & 1.673 & 1.716 & 1.647 & 1.682 & 1.669 & 1.656 & 1.690 & 1.724 & 1.678 & 1.698 \\
\hline $\mathrm{NaB}$ & 0.352 & 0.345 & 0.362 & 0.339 & 0.327 & 0.284 & 0.353 & 0.318 & 0.301 & 0.313 & 0.253 & 0.276 & 0.264 & 0.252 \\
\hline B site & 2.000 & 2.000 & 2.000 & 2.000 & 2.000 & 2.000 & 2.000 & 2.000 & 2.000 & 2.000 & 2.000 & 2.000 & 2.000 & 2.000 \\
\hline $\mathrm{NaA}$ & 0.010 & 0.092 & 0.000 & 0.027 & 0.019 & 0.040 & 0.021 & 0.086 & 0.036 & 0.000 & 0.117 & 0.046 & 0.088 & 0.109 \\
\hline $\mathrm{K}$ & 0.088 & 0.109 & 0.059 & 0.092 & 0.081 & 0.116 & 0.088 & 0.116 & 0.082 & 0.087 & 0.103 & 0.082 & 0.095 & 0.094 \\
\hline A site & 0.098 & 0.201 & 0.059 & 0.119 & 0.099 & 0.156 & 0.109 & 0.202 & 0.119 & 0.087 & 0.220 & 0.128 & 0.183 & 0.202 \\
\hline Cations & 15.098 & 15.201 & 15.095 & 15.119 & 15.099 & 15.156 & 15.109 & 15.202 & 15.149 & 15.118 & 15.278 & 15.128 & 15.240 & 15.253 \\
\hline $\mathrm{F}$ & 0.022 & 0.007 & 0.010 & 0.010 & 0.011 & 0.020 & 0.017 & 0.000 & 0.000 & 0.014 & 0.007 & 0.000 & 0.008 & 0.013 \\
\hline $\mathrm{Cl}$ & 0.027 & 0.047 & 0.017 & 0.026 & 0.031 & 0.040 & 0.041 & 0.033 & 0.028 & 0.021 & 0.046 & 0.026 & 0.037 & 0.041 \\
\hline mg\# & 0.82 & 0.76 & 0.82 & 0.82 & 0.79 & 0.78 & 0.82 & 0.74 & 0.83 & 0.83 & 0.79 & 0.79 & 0.80 & 0.79 \\
\hline $\mathrm{Mg} /\left(\mathrm{Mg}+\mathrm{Fe}^{2+}\right) \mathrm{med}$ & 0.707 & 0.661 & 0.713 & 0.718 & 0.695 & 0.700 & 0.710 & 0.647 & 0.745 & 0.738 & 0.723 & 0.713 & 0.721 & 0.716 \\
\hline $\mathrm{Mg} /\left(\mathrm{Mg}+\mathrm{Fe}^{2+}\right) \max$ & 0.816 & 0.761 & 0.820 & 0.822 & 0.793 & 0.781 & 0.818 & 0.735 & 0.835 & 0.831 & 0.794 & 0.794 & 0.797 & 0.787 \\
\hline $\mathrm{P}$ (kbar) & 2.5 & 3.7 & 1.1 & 2.2 & 2.3 & 2.3 & 2.2 & 3.7 & 1.3 & 1.4 & 2.0 & 1.9 & 1.8 & 2.1 \\
\hline $\mathrm{P}_{\mathrm{HZ}}$ (kbar) & 1.6 & 2.3 & 1.1 & 1.5 & 1.5 & 1.5 & 1.5 & 2.3 & 1.1 & 1.2 & 1.4 & 1.4 & 1.4 & 1.4 \\
\hline $\mathrm{P}_{\mathrm{M}}(\mathrm{kbar})$ & 1.5 & 2.3 & 0.8 & 1.4 & 1.4 & 1.4 & 1.4 & 2.3 & 0.9 & 1.0 & 1.3 & 1.2 & 1.2 & 1.3 \\
\hline$P_{R}(k b a r)$ & 1.2 & 1.7 & 0.8 & 1.1 & 1.1 & 1.1 & 1.1 & 1.7 & 0.8 & 0.9 & 1.0 & 1.0 & 1.0 & 1.1 \\
\hline $\mathrm{T}\left({ }^{\circ} \mathrm{C}\right)_{\mathrm{R}}$ & 834 & 871 & 775 & 833 & 827 & 838 & 819 & 866 & 805 & 810 & 844 & 816 & 832 & 843 \\
\hline $\mathrm{T}\left({ }^{\circ} \mathrm{C}\right)_{\mathrm{HB}}$ & 760 & 755 & 755 & 761 & 760 & 755 & 759 & 752 & 757 & 756 & 761 & 756 & 760 & 761 \\
\hline$\triangle N N O$ & 1.7 & 1.3 & 2.0 & 1.9 & 1.7 & 1.7 & 1.8 & 1.2 & 2.2 & 2.1 & 2.0 & 1.8 & 2.0 & 1.9 \\
\hline $\mathrm{H}_{2} \mathrm{Omelt}$ & 5.6 & 6.0 & 4.8 & 5.1 & 5.5 & 5.0 & 5.3 & 6.0 & 4.3 & 4.5 & 4.0 & 5.3 & 4.2 & 4.4 \\
\hline
\end{tabular}

Notes: Facies abbreviations BQ-M OC = Biotite quartz-monzodiorite with two pyroxenes; L-MG = Leuco monzogranite; BT-MG = Biotite hornblende monzogranite; Rhy = Rhyolite; HB-GD = Hornblende biotite granodiorite; $M G=$ Monzogranite; $\mathrm{H}-\mathrm{MZ}=$ Hornblende monzodiorite; $\mathrm{E}-\mathrm{MD}=$ Micro-diorite enclave; $\mathrm{IM}-\mathrm{D}=\mathrm{Intermediate-mafic}$ dikes; Dac = Dacite; $\mathrm{mg} \#=$ magnesium number. $\mathrm{P}=-3.92+5.03 \mathrm{~A} \mathrm{~T}^{\top}$ (Hammarstorm and Zen, 1986); $\mathrm{P}=0.26 \mathrm{e}\left(1.48 \mathrm{Al} \mathrm{I}^{\top}\right.$ ) (Hammarstrorm \& Zen, 1986); $\mathrm{P}_{\mathrm{M}}=-0.5+0.331(8) \times \mathrm{Al} \mathrm{I}^{\top}+0.995(4) \times\left(\mathrm{Al} \mathrm{I}^{\top}\right)^{2}$ from Mutch, et al. $(2016) ; \mathrm{T}\left({ }^{\circ} \mathrm{C}\right)_{\mathrm{R}}=\mathrm{Temperature} \mathrm{from} \mathrm{Ridolfi} \mathrm{et} \mathrm{al.}(2010) ; \mathrm{T}\left({ }^{\circ} \mathrm{C}\right) \mathrm{HB}$ $=\left(\right.$ Holland \& Blundy, 1994); $\triangle N N O=$ oxygen fugacity-amphibole relative to NNO buffer from Ridolfi et al. (2010); $\mathrm{H}_{2}$ Omelt $=$ The water content in the melt from Ridolfi et al. $(2010)$. 
Supplementary Material: Electron microprobe analyses of amphibole from Garzón granites and related rocks, Eastern Cordillera, Colombia.

\begin{tabular}{|c|c|c|c|c|c|c|}
\hline \multirow{3}{*}{$\begin{array}{l}\text { Mineral } \\
\text { Massif } \\
\text { Sample }\end{array}$} & \multicolumn{6}{|c|}{ Amphibole } \\
\hline & \multicolumn{6}{|c|}{ Sombrerillo } \\
\hline & GAR-395 & $\begin{array}{l}\text { GAR- } \\
395\end{array}$ & $\begin{array}{l}\text { GAR- } \\
395\end{array}$ & $\begin{array}{l}\text { GAR- } \\
395 \\
\end{array}$ & $\begin{array}{l}\text { GAR- } \\
395\end{array}$ & GAR-395 \\
\hline Facies & Dac & Dac & Dac & Dac & Dac & Dac \\
\hline Grain/Point & anf_09-1 & $\begin{array}{l}\text { anf_09- } \\
2\end{array}$ & $\begin{array}{l}\text { anf_09- } \\
3\end{array}$ & $\begin{array}{l}\text { anf_09- } \\
4\end{array}$ & $\begin{array}{l}\text { anf_09- } \\
5\end{array}$ & anf_09-6 \\
\hline $\mathrm{SiO} 2$ & 48.96 & 44.25 & 46.67 & 44.54 & 45.51 & 47.40 \\
\hline $\mathrm{TiO} 2$ & 0.91 & 1.37 & 1.37 & 1.64 & 1.25 & 1.21 \\
\hline $\mathrm{Al} 2 \mathrm{O} 3$ & 6.26 & 8.16 & 8.00 & 9.82 & 9.19 & 7.55 \\
\hline $\mathrm{Cr} 2 \mathrm{O} 3$ & 0.00 & 0.00 & 0.00 & 0.00 & 0.00 & 0.00 \\
\hline $\mathrm{FeO}$ & 13.81 & 14.43 & 15.03 & 15.91 & 15.98 & 14.93 \\
\hline $\mathrm{MnO}$ & 0.61 & 0.59 & 0.65 & 0.63 & 0.72 & 0.70 \\
\hline $\mathrm{MgO}$ & 15.23 & 13.04 & 13.55 & 12.29 & 12.56 & 13.45 \\
\hline $\mathrm{ZnO}$ & 0.02 & 0.02 & 0.02 & 0.00 & 0.02 & 0.06 \\
\hline $\mathrm{CaO}$ & 10.91 & 13.17 & 10.84 & 10.98 & 10.90 & 11.32 \\
\hline $\mathrm{Na} 2 \mathrm{O}$ & 1.17 & 1.44 & 1.45 & 1.71 & 1.58 & 1.20 \\
\hline $\mathrm{K} 2 \mathrm{O}$ & 0.26 & 0.60 & 0.48 & 0.69 & 0.61 & 0.61 \\
\hline $\mathrm{F}$ & 0.00 & 0.06 & 0.04 & 0.04 & 0.02 & 0.04 \\
\hline $\mathrm{Cl}$ & 0.08 & 0.20 & 0.14 & 0.16 & 0.10 & 0.15 \\
\hline Total & 98.24 & 97.33 & 98.25 & 98.41 & 98.43 & 98.63 \\
\hline $\mathrm{O}=(\mathrm{Cl} . \mathrm{F})$ & 0.02 & 0.07 & 0.05 & 0.05 & 0.03 & 0.05 \\
\hline Total & 98.22 & 97.27 & 98.21 & 98.36 & 98.40 & 98.57 \\
\hline $\begin{array}{l}\text { Structural } \\
\text { 2005) }\end{array}$ & cording mea & $\mathrm{Fe} 3+\mathrm{ve}$ & lues. sch & nacher. a & fter Gualda & \& Vlach. \\
\hline $\mathrm{Si}$ & 7.024 & 6.594 & 6.782 & 6.533 & 6.645 & 6.877 \\
\hline ivAl & 0.976 & 1.406 & 1.218 & 1.467 & 1.355 & 1.123 \\
\hline T site & 8.000 & 8.000 & 8.000 & 8.000 & 8.000 & 8.000 \\
\hline viAl & 0.082 & 0.027 & 0.153 & 0.231 & 0.226 & 0.168 \\
\hline $\mathrm{Ti}$ & 0.098 & 0.154 & 0.150 & 0.181 & 0.137 & 0.132 \\
\hline $\mathrm{Cr}$ & 0.000 & 0.000 & 0.000 & 0.000 & 0.000 & 0.000 \\
\hline Felll & 0.625 & 0.431 & 0.598 & 0.551 & 0.608 & 0.494 \\
\hline $\mathrm{Fe}$ & 1.032 & 1.367 & 1.228 & 1.401 & 1.343 & 1.317 \\
\hline $\mathrm{Mn}$ & 0.075 & 0.074 & 0.080 & 0.078 & 0.089 & 0.086 \\
\hline $\mathrm{Mg}$ & 3.257 & 2.896 & 2.935 & 2.687 & 2.733 & 2.909 \\
\hline $\mathrm{Zn}$ & 0.003 & 0.003 & 0.002 & 0.000 & 0.002 & 0.006 \\
\hline C site & 5.172 & 4.952 & 5.147 & 5.129 & 5.138 & 5.113 \\
\hline Excess C & 0.172 & -0.048 & 0.147 & 0.129 & 0.138 & 0.113 \\
\hline $\mathrm{Ca}$ & 1.677 & 2.103 & 1.688 & 1.726 & 1.705 & 1.760 \\
\hline $\mathrm{NaB}$ & 0.151 & -0.055 & 0.165 & 0.146 & 0.156 & 0.128 \\
\hline B site & 2.000 & 2.000 & 2.000 & 2.000 & 2.000 & 2.000 \\
\hline $\mathrm{NaA}$ & 0.175 & 0.471 & 0.243 & 0.341 & 0.291 & 0.210 \\
\hline $\mathrm{K}$ & 0.048 & 0.113 & 0.089 & 0.128 & 0.113 & 0.114 \\
\hline A site & 0.223 & 0.585 & 0.332 & 0.469 & 0.404 & 0.324 \\
\hline Cations & 15.223 & 15.585 & 15.332 & 15.469 & 15.404 & 15.324 \\
\hline $\mathrm{F}$ & 0.001 & 0.027 & 0.020 & 0.016 & 0.007 & 0.016 \\
\hline $\mathrm{Cl}$ & 0.018 & 0.052 & 0.035 & 0.041 & 0.025 & 0.038 \\
\hline mg\# & 0.76 & 0.68 & 0.70 & 0.66 & 0.67 & 0.69 \\
\hline
\end{tabular}

$\begin{array}{lllllll} & 0.76 & 0.68 & 0.70 & 0.66 & 0.67 & 0.69 \\ \text { Structural formulae (according max } & \text { Fe } 3+ & \text { values. } & \text { schumacher. } & \text { after } & \text { Gualda } \& \text { Vlach. }\end{array}$ 2005) 


\begin{tabular}{|c|c|c|c|c|c|c|}
\hline $\mathrm{Si}$ & 6.952 & 6.618 & 6.707 & 6.469 & 6.575 & 6.818 \\
\hline ivAl & 1.048 & 1.382 & 1.293 & 1.531 & 1.425 & 1.182 \\
\hline T site & 8.000 & 8.000 & 8.000 & 8.000 & 8.000 & 8.000 \\
\hline viAl & 0.000 & 0.057 & 0.062 & 0.150 & 0.139 & 0.098 \\
\hline $\mathrm{Ti}$ & 0.097 & 0.154 & 0.148 & 0.179 & 0.136 & 0.131 \\
\hline $\mathrm{Cr}$ & 0.000 & 0.000 & 0.000 & 0.000 & 0.000 & 0.000 \\
\hline Felll & 1.087 & 0.264 & 1.105 & 0.997 & 1.086 & 0.885 \\
\hline $\mathrm{Fe}$ & 0.553 & 1.541 & 0.702 & 0.936 & 0.844 & 0.911 \\
\hline $\mathrm{Mn}$ & 0.074 & 0.074 & 0.079 & 0.078 & 0.088 & 0.085 \\
\hline $\mathrm{Mg}$ & 3.223 & 2.907 & 2.902 & 2.661 & 2.705 & 2.884 \\
\hline $\mathrm{Zn}$ & 0.003 & 0.003 & 0.002 & 0.000 & 0.002 & 0.006 \\
\hline C site & 5.038 & 5.000 & 5.000 & 5.000 & 5.000 & 5.000 \\
\hline Excess C & 0.038 & 0.000 & 0.000 & 0.000 & 0.000 & 0.000 \\
\hline $\mathrm{Ca}$ & 1.660 & 2.110 & 1.669 & 1.709 & 1.687 & 1.745 \\
\hline $\mathrm{NaB}$ & 0.302 & -0.110 & 0.331 & 0.291 & 0.313 & 0.255 \\
\hline B site & 2.000 & 2.000 & 2.000 & 2.000 & 2.000 & 2.000 \\
\hline $\mathrm{NaA}$ & 0.021 & 0.528 & 0.073 & 0.190 & 0.130 & 0.080 \\
\hline $\mathrm{K}$ & 0.047 & 0.114 & 0.088 & 0.127 & 0.112 & 0.113 \\
\hline A site & 0.068 & 0.642 & 0.161 & 0.317 & 0.241 & 0.192 \\
\hline Cations & 15.106 & 15.642 & 15.161 & 15.317 & 15.241 & 15.192 \\
\hline $\mathrm{F}$ & 0.001 & 0.027 & 0.020 & 0.016 & 0.007 & 0.016 \\
\hline $\mathrm{Cl}$ & 0.018 & 0.052 & 0.035 & 0.040 & 0.024 & 0.037 \\
\hline mg\# & 0.85 & 0.65 & 0.81 & 0.74 & 0.76 & 0.76 \\
\hline $\mathrm{Mg} /\left(\mathrm{Mg}+\mathrm{Fe}^{2+}\right) \mathrm{med}$ & 0.759 & 0.679 & 0.705 & 0.657 & 0.670 & 0.688 \\
\hline $\mathrm{Mg} /\left(\mathrm{Mg}+\mathrm{Fe}^{2+}\right) \mathrm{max}$ & 0.854 & 0.654 & 0.805 & 0.740 & 0.762 & 0.760 \\
\hline $\mathrm{P}$ (kbar) & 1.3 & 3.3 & 2.9 & 4.5 & 4.0 & 2.5 \\
\hline $\mathrm{P}_{\mathrm{HZ}}$ (kbar) & 1.2 & 2.1 & 1.8 & 2.9 & 2.5 & 1.6 \\
\hline $\mathrm{P}_{\mathrm{M}}(\mathrm{kbar})$ & 0.9 & 2.0 & 1.8 & 2.9 & 2.5 & 1.6 \\
\hline$P_{R}(k b a r)$ & 0.9 & 1.5 & 1.3 & 2.2 & 1.8 & 1.2 \\
\hline $\mathrm{T}\left({ }^{\circ} \mathrm{C}\right)_{R}$ & 798 & 914 & 850 & 907 & 873 & 835 \\
\hline $\mathrm{T}\left({ }^{\circ} \mathrm{C}\right)_{\mathrm{HB}}$ & 757 & 761 & 759 & 756 & 755 & 754 \\
\hline$\triangle N N O$ & 2.2 & 1.2 & 1.7 & 1.2 & 1.3 & 1.6 \\
\hline $\mathrm{H}_{2} \mathrm{Omelt}$ & 5.0 & 4.3 & 5.7 & 6.0 & 6.1 & 5. \\
\hline
\end{tabular}

Notes: Facies abbreviations BQ-M OC = Biotite quartz-monzodiorite with two pyroxenes; L-MG = Leuco monzogranite; BT-MG = Biotite hornblende monzogranite; Rhy = Rhyolite; HB-GD = Hornblende biotite granodiorite; $\mathrm{MG}=$ Monzogranite; $\mathrm{H}-\mathrm{MZ}=$ Hornblende monzodiorite; $\mathrm{E}-\mathrm{MD}=$ Micro-diorite enclave; IM-D = Intermediate-mafic dikes; Dac = Dacite; $\mathrm{mg} \#=$ magnesium number. $\mathrm{P}=-3.92+5.03 \mathrm{Al}{ }^{\top}$ (Hammarstorm and Zen, 1986); P= 0.26e (1.48Al $\left.\mathrm{I}^{\top}\right)\left(\right.$ Hammarstrorm \& Zen, 1986); $\mathrm{P}_{\mathrm{M}}=-0.5+0.331(8) \times \mathrm{Al}^{\top}+0.995(4) \times\left(\mathrm{Al}^{\top}\right)^{2}$ from Mutch, et al. $(2016) ; \mathrm{T}\left({ }^{\circ} \mathrm{C}\right) \mathrm{R}=\mathrm{Temperature}$ from Ridolfi et al. $(2010) ; \mathrm{T}\left({ }^{\circ} \mathrm{C}\right) \mathrm{HB}$ $=\left(\right.$ Holland \& Blundy, 1994); $\triangle N N O=$ oxygen fugacity-amphibole relative to NNO buffer from Ridolfi et al. $(2010) ; \mathrm{H}_{2} \mathrm{Omelt}=$ The water content in the melt from Ridolfi et al. $(2010)$. 
Supplementary Material: Electron microprobe analyses of micas from Garzón granites and related rocks, Eastern Cordillera, Colombia.

\begin{tabular}{|c|c|c|c|c|c|c|c|c|c|c|c|c|c|c|c|}
\hline \multirow{3}{*}{$\begin{array}{l}\text { Mineral } \\
\text { Massif } \\
\text { Sample }\end{array}$} & \multicolumn{15}{|c|}{ Micas } \\
\hline & \multicolumn{5}{|c|}{ Sombrerillo } & \multicolumn{7}{|c|}{ Algeciras } & \multirow{3}{*}{$\begin{array}{l}\text { GAR- } \\
356 \\
\text { BH-MG }\end{array}$} & \multirow{3}{*}{$\begin{array}{l}\text { GAR- } \\
356 \\
\text { BH-MG }\end{array}$} & \multirow{3}{*}{$\begin{array}{l}\text { GAR- } \\
356 \\
\text { BH-MG }\end{array}$} \\
\hline & L-102 & L-102 & $\mathrm{L}-102$ & L-102 & L-102 & $\begin{array}{l}\text { GAR- } \\
354\end{array}$ & $\begin{array}{l}\text { GAR- } \\
354\end{array}$ & $\begin{array}{l}\text { GAR- } \\
354\end{array}$ & $\begin{array}{l}\text { GAR- } \\
354\end{array}$ & GAR-354 & $\begin{array}{l}\text { GAR- } \\
354\end{array}$ & $\begin{array}{l}\text { GAR- } \\
354\end{array}$ & & & \\
\hline Facies & $\begin{array}{l}\text { BQ-M- } \\
\text { OC }\end{array}$ & $\begin{array}{l}\text { BQ-M- } \\
\text { OC }\end{array}$ & $\begin{array}{l}\text { BQ-M- } \\
\text { OC }\end{array}$ & $\begin{array}{l}\text { BQ-M- } \\
\text { OC }\end{array}$ & $\begin{array}{l}\text { BQ-M- } \\
\text { OC }\end{array}$ & L-MG & L-MG & L-MG & L-MG & L-MG & L-MG & L-MG & & & \\
\hline Grain/Point & bt_01-1 & $\begin{array}{l}\text { bt_16a- } \\
1\end{array}$ & bt_17a_1 & bt_03a- & bt_02-1 & bt_01-1 & bt_02-1 & 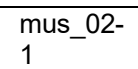 & bt_04-1 & $\begin{array}{l}\text { bt_chl_04- } \\
2\end{array}$ & bt_05-1 & bt_05-1 & bt_01-1 & bt_05-1 & bt_08-1 \\
\hline $\mathrm{SiO} 2$ & 37.73 & 36.02 & 36.05 & 37.19 & 37.22 & 37.61 & 37.42 & 45.50 & 38.05 & 26.81 & 38.04 & 38.04 & 36.28 & 36.77 & 36.62 \\
\hline TiO2 & 4.30 & 4.54 & 4.21 & 4.29 & 4.59 & 1.64 & 1.81 & 0.38 & 1.64 & 0.15 & 1.95 & 1.95 & 3.83 & 3.31 & 3.56 \\
\hline $\mathrm{Al} 2 \mathrm{O} 3$ & 12.98 & 13.25 & 13.50 & 13.51 & 13.86 & 16.99 & 17.29 & 28.69 & 17.66 & 17.73 & 17.72 & 17.72 & 13.63 & 13.76 & 14.13 \\
\hline $\mathrm{FeO}$ & 18.31 & 18.87 & 19.49 & 18.73 & 18.92 & 18.04 & 18.52 & 5.27 & 17.55 & 24.68 & 18.12 & 18.12 & 16.38 & 17.20 & 17.26 \\
\hline $\mathrm{MnO}$ & 0.13 & 0.15 & 0.10 & 0.12 & 0.12 & 1.94 & 1.45 & 0.15 & 0.79 & 0.95 & 0.58 & 0.58 & 0.49 & 0.55 & 0.55 \\
\hline $\mathrm{MgO}$ & 13.40 & 12.71 & 12.81 & 12.86 & 12.97 & 8.94 & 8.78 & 2.50 & 9.58 & 15.00 & 9.26 & 9.26 & 13.78 & 13.95 & 13.23 \\
\hline $\mathrm{ZnO}$ & 0.07 & 0.08 & 0.00 & 0.05 & 0.10 & 0.11 & 0.00 & 0.00 & 0.03 & 0.06 & 0.00 & 0.00 & 0.00 & 0.05 & 0.03 \\
\hline $\mathrm{BaO}$ & 0.23 & 0.00 & 0.09 & 0.15 & 0.00 & 0.00 & 0.00 & 0.00 & 0.00 & 0.04 & 0.00 & 0.00 & 0.37 & 0.44 & 0.43 \\
\hline $\mathrm{CaO}$ & 0.04 & 0.15 & 0.07 & 0.16 & 0.00 & 0.08 & 0.12 & 0.03 & 0.00 & 0.23 & 0.02 & 0.02 & 0.10 & 0.04 & 0.43 \\
\hline $\mathrm{Na} 2 \mathrm{O}$ & 0.20 & 0.17 & 0.21 & 0.20 & 0.13 & 0.13 & 0.12 & 0.35 & 0.12 & 0.04 & 0.18 & 0.18 & 0.12 & 0.08 & 0.06 \\
\hline $\mathrm{K} 2 \mathrm{O}$ & 9.30 & 8.98 & 9.05 & 8.69 & 9.37 & 9.59 & 9.25 & 10.62 & 9.64 & 0.21 & 9.76 & 9.76 & 9.25 & 9.38 & 9.33 \\
\hline $\mathrm{F}$ & 0.16 & 0.13 & 0.10 & 0.14 & 0.14 & 0.43 & 0.43 & 0.14 & 0.43 & 0.05 & 0.46 & 0.46 & 0.36 & 0.42 & 0.37 \\
\hline $\mathrm{Cl}$ & 0.36 & 0.39 & 0.43 & 0.29 & 0.38 & 0.02 & 0.02 & 0.00 & 0.01 & 0.00 & 0.04 & 0.04 & 0.10 & 0.07 & 0.12 \\
\hline $\mathrm{O}=(\mathrm{F} . \mathrm{Cl})$ & 0.15 & 0.14 & 0.14 & 0.12 & 0.14 & 0.19 & 0.19 & 0.06 & 0.18 & 0.02 & 0.20 & 0.20 & 0.17 & 0.19 & 0.18 \\
\hline Total & 97.06 & 95.34 & 95.96 & 96.27 & 97.68 & 95.34 & 95.03 & 93.59 & 95.32 & 85.93 & 95.94 & 95.94 & 94.55 & 95.84 & 95.93 \\
\hline \multicolumn{16}{|c|}{ Cation proportion (on the basis of 230 ) } \\
\hline ivSi & 5.663 & 5.531 & 5.513 & 5.617 & 5.560 & 5.738 & 5.714 & 6.347 & 5.746 & 4.555 & 5.724 & 5.724 & 5.568 & 5.587 & 5.562 \\
\hline ivAl & 2.296 & 2.398 & 2.433 & 2.383 & 2.440 & 2.262 & 2.286 & 1.653 & 2.254 & 3.445 & 2.276 & 2.276 & 2.432 & 2.413 & 2.438 \\
\hline ivTi & 0.041 & 0.070 & 0.054 & 0.000 & 0.000 & 0.000 & 0.000 & 0.000 & 0.000 & 0.000 & 0.000 & 0.000 & 0.000 & 0.000 & 0.000 \\
\hline$\Sigma T$ & 8.000 & 8.000 & 8.000 & 8.000 & 8.000 & 8.000 & 8.000 & 8.000 & 8.000 & 8.000 & 8.000 & 8.000 & 8.000 & 8.000 & 8.000 \\
\hline viAl & 0.000 & 0.000 & 0.000 & 0.022 & 0.000 & 0.793 & 0.825 & 3.064 & 0.888 & 0.106 & 0.866 & 0.866 & 0.033 & 0.050 & 0.091 \\
\hline viTi & 0.485 & 0.524 & 0.484 & 0.487 & 0.516 & 0.188 & 0.208 & 0.040 & 0.186 & 0.020 & 0.221 & 0.221 & 0.442 & 0.378 & 0.407 \\
\hline $\mathrm{Fe}$ & 2.298 & 2.423 & 2.493 & 2.366 & 2.364 & 2.302 & 2.365 & 0.615 & 2.216 & 3.507 & 2.280 & 2.280 & 2.102 & 2.185 & 2.192 \\
\hline $\mathrm{Mn}$ & 0.017 & 0.020 & 0.013 & 0.015 & 0.016 & 0.251 & 0.188 & 0.018 & 0.100 & 0.137 & 0.074 & 0.074 & 0.064 & 0.071 & 0.071 \\
\hline $\mathrm{Mg}$ & 2.998 & 2.909 & 2.920 & 2.895 & 2.888 & 2.033 & 1.998 & 0.520 & 2.156 & 3.799 & 2.077 & 2.077 & 3.152 & 3.159 & 2.995 \\
\hline$\Sigma 0$ & 5.852 & 5.929 & 5.963 & 5.852 & 5.839 & 5.641 & 5.670 & 4.279 & 5.628 & 7.645 & 5.598 & 5.598 & 5.835 & 5.880 & 5.792 \\
\hline $\mathrm{Zn}$ & 0.007 & 0.009 & 0.000 & 0.005 & 0.011 & 0.013 & 0.000 & 0.000 & 0.003 & 0.008 & 0.000 & 0.000 & 0.000 & 0.005 & 0.003 \\
\hline $\mathrm{Ba}$ & 0.014 & 0.000 & 0.005 & 0.009 & 0.000 & 0.000 & 0.000 & 0.000 & 0.000 & 0.003 & 0.000 & 0.000 & 0.023 & 0.026 & 0.025 \\
\hline $\mathrm{Ca}$ & 0.007 & 0.025 & 0.012 & 0.027 & 0.000 & 0.013 & 0.020 & 0.005 & 0.000 & 0.042 & 0.004 & 0.004 & 0.017 & 0.007 & 0.070 \\
\hline $\mathrm{Na}$ & 0.058 & 0.049 & 0.061 & 0.059 & 0.038 & 0.040 & 0.034 & 0.095 & 0.035 & 0.013 & 0.054 & 0.054 & 0.036 & 0.025 & 0.018 \\
\hline $\mathrm{K}$ & 1.781 & 1.759 & 1.765 & 1.674 & 1.785 & 1.866 & 1.802 & 1.890 & 1.857 & 0.045 & 1.873 & $\begin{array}{l}1.873 \\
\end{array}$ & 1.811 & 1.818 & 1.808 \\
\hline$\Sigma A$ & 1.866 & 1.843 & 1.844 & 1.774 & 1.834 & 1.933 & 1.856 & 1.990 & 1.895 & 0.112 & 1.931 & 1.931 & 1.887 & 1.881 & 1.924 \\
\hline \multicolumn{16}{|l|}{ Anions } \\
\hline $\mathrm{F}$ & 0.074 & 0.064 & 0.047 & 0.066 & 0.065 & 0.208 & 0.209 & 0.063 & 0.208 & 0.025 & 0.217 & 0.217 & 0.174 & 0.201 & 0.176 \\
\hline $\mathrm{Cl}$ & 0.092 & 0.100 & 0.111 & 0.075 & 0.097 & 0.005 & 0.005 & 0.000 & 0.002 & 0.000 & 0.010 & 0.010 & 0.025 & 0.017 & 0.032 \\
\hline mg\# & 0.57 & 0.55 & 0.54 & 0.55 & 0.55 & 0.47 & 0.46 & 0.46 & 0.49 & 0.52 & 0.48 & 0.48 & 0.60 & 0.59 & 0.58 \\
\hline
\end{tabular}

Notes: Facies abbreviations BQ-M OC = Biotite quartz-monzodiorite with two pyroxenes; L-MG = Leuco monzogranite; BT-MG = Biotite hornblende monzogranite; Rhy = Rhyolite; HB-GD = Hornblende biotite granodiorite; $\mathrm{MG}=$ Monzogranite; $\mathrm{H}-\mathrm{MZ}=$ Hornblende monzodiorite; $\mathrm{E}-\mathrm{MD}=$ Micro-diorite enclave; Dac = Dacite; $\mathrm{mg} \#=$ magnesium number; $\Sigma \mathrm{T}=$ sum of tetrahedral cations; $\Sigma \mathrm{O}=$ sum of octahedral cations; $\Sigma A=$ sum of interlayer cations. 
Supplementary Material: Electron microprobe analyses of micas from Garzón granites and related rocks, Eastern Cordillera, Colombia.

\begin{tabular}{|c|c|c|c|c|c|c|c|c|c|c|c|c|c|c|c|}
\hline \multirow{3}{*}{$\begin{array}{l}\text { Mineral } \\
\text { Massif } \\
\text { Sample }\end{array}$} & \multicolumn{15}{|c|}{ Micas } \\
\hline & \multicolumn{15}{|c|}{ Algeciras } \\
\hline & $\begin{array}{l}\text { GAR- } \\
356\end{array}$ & $\begin{array}{l}\text { GAR- } \\
356\end{array}$ & $\begin{array}{l}\text { GAR- } \\
357\end{array}$ & $\begin{array}{l}\text { GAR- } \\
357\end{array}$ & $\begin{array}{l}\text { GAR- } \\
357\end{array}$ & $\begin{array}{l}\text { GAR- } \\
357\end{array}$ & $\begin{array}{l}\text { GAR- } \\
357\end{array}$ & $\begin{array}{l}\text { GAR- } \\
357\end{array}$ & $\begin{array}{l}\text { GAR- } \\
358\end{array}$ & $\begin{array}{l}\text { GAR- } \\
361\end{array}$ & $\begin{array}{l}\text { GAR- } \\
372\end{array}$ & $\begin{array}{l}\text { GAR- } \\
372\end{array}$ & $\begin{array}{l}\text { GAR- } \\
372\end{array}$ & $\begin{array}{l}\text { GAR- } \\
372\end{array}$ & $\begin{array}{l}\text { GAR- } \\
372\end{array}$ \\
\hline Facies & BH-MG & BH-MG & BH-MG & BH-MG & BH-MG & BH-MG & BH-MG & BH-MG & IM-D & Dac & BH-MG & BH-MG & BH-MG & E-MD & E-MD \\
\hline Grain/Point & bt $11-1$ & bt $13-1$ & bt $01-1$ & bt_02- & bt_03- & bt_04- & bt_05- & bt_06- & bt_01- & bt $03-1$ & bt_01_R- & $\begin{array}{l}\text { bt_01_R- } \\
2\end{array}$ & bt_01_R- & bt_01_E- & bt_05_E- \\
\hline $\mathrm{SiO} 2$ & 36.69 & 37.44 & 36.13 & 36.98 & 37.05 & 36.26 & 36.67 & 36.59 & 37.61 & 37.40 & 36.81 & 36.32 & 36.49 & 37.25 & 36.75 \\
\hline TiO2 & 3.05 & 2.74 & 3.98 & 3.37 & 3.45 & 3.28 & 3.59 & 3.30 & 3.37 & 4.64 & 4.31 & 4.69 & 4.15 & 4.47 & 4.34 \\
\hline $\mathrm{Al} 2 \mathrm{O} 3$ & 14.01 & 13.25 & 13.60 & 13.74 & 13.71 & 14.01 & 13.56 & 13.53 & 14.21 & 14.58 & 13.46 & 13.48 & 13.47 & 13.83 & 13.94 \\
\hline $\mathrm{FeO}$ & 16.58 & 15.67 & 17.23 & 16.68 & 17.31 & 17.01 & 16.50 & 16.22 & 19.62 & 13.58 & 14.71 & 15.32 & 15.48 & 15.21 & 15.33 \\
\hline $\mathrm{MnO}$ & 0.55 & 0.39 & 0.67 & 0.53 & 0.54 & 0.71 & 0.47 & 0.61 & 0.27 & 0.16 & 0.33 & 0.33 & 0.39 & 0.27 & 0.32 \\
\hline $\mathrm{MgO}$ & 14.09 & 15.29 & 12.83 & 14.04 & 14.00 & 13.92 & 14.12 & 14.34 & 12.04 & 16.09 & 15.26 & 15.07 & 15.28 & 15.09 & 14.91 \\
\hline $\mathrm{ZnO}$ & 0.09 & 0.03 & 0.00 & 0.03 & 0.00 & 0.07 & 0.09 & 0.03 & 0.05 & 0.05 & 0.00 & 0.04 & 0.04 & 0.00 & 0.05 \\
\hline $\mathrm{BaO}$ & 0.38 & 0.05 & 0.62 & 0.40 & 0.35 & 0.57 & 0.29 & 0.61 & 0.30 & 0.97 & 0.94 & 0.92 & 0.57 & 0.72 & 0.92 \\
\hline $\mathrm{CaO}$ & 0.08 & 0.15 & 0.02 & 0.09 & 0.04 & 0.04 & 0.13 & 0.00 & 0.03 & 0.03 & 0.00 & 0.09 & 0.12 & 0.10 & 0.09 \\
\hline $\mathrm{Na} 2 \mathrm{O}$ & 0.09 & 0.11 & 0.09 & 0.09 & 0.10 & 0.12 & 0.06 & 0.09 & 0.08 & 0.55 & 0.15 & 0.26 & 0.16 & 0.14 & 0.15 \\
\hline $\mathrm{K} 2 \mathrm{O}$ & 9.56 & 9.42 & 9.16 & 9.23 & 9.54 & 9.20 & 9.35 & 9.11 & 9.42 & 8.18 & 9.13 & 8.71 & 8.68 & 9.07 & 8.89 \\
\hline $\mathrm{F}$ & 0.31 & 0.38 & 0.22 & 0.27 & 0.30 & 0.28 & 0.25 & 0.24 & 0.05 & 0.14 & 0.24 & 0.21 & 0.23 & 0.24 & 0.19 \\
\hline $\mathrm{Cl}$ & 0.14 & 0.11 & 0.11 & 0.17 & 0.15 & 0.16 & 0.15 & 0.17 & 0.23 & 0.17 & 0.20 & 0.20 & 0.20 & 0.20 & 0.21 \\
\hline $\mathrm{O}=(\mathrm{F} . \mathrm{Cl})$ & 0.16 & 0.18 & 0.12 & 0.15 & 0.16 & 0.15 & 0.14 & 0.14 & 0.07 & 0.10 & 0.14 & 0.13 & 0.14 & 0.14 & 0.13 \\
\hline Total & 95.46 & 94.85 & 94.54 & 95.47 & 96.39 & 95.49 & 95.09 & 94.72 & 97.21 & 96.45 & 95.41 & 95.52 & 95.13 & 96.43 & 95.96 \\
\hline \multicolumn{16}{|c|}{ Cation proportion (on the basis of 230 ) } \\
\hline ivSi & 5.575 & 5.615 & 5.595 & 5.536 & 5.591 & 5.603 & 5.575 & 5.615 & 5.657 & 5.514 & 5.563 & 5.496 & 5.530 & 5.559 & 5.526 \\
\hline ivAl & 2.425 & 2.385 & 2.405 & 2.464 & 2.409 & 2.397 & 2.425 & 2.385 & 2.343 & 2.486 & 2.398 & 2.404 & 2.406 & 2.432 & 2.471 \\
\hline ivTi & 0.000 & 0.000 & 0.000 & 0.000 & 0.000 & 0.000 & 0.000 & 0.000 & 0.000 & 0.000 & 0.039 & 0.099 & 0.064 & 0.009 & 0.003 \\
\hline$\Sigma T$ & 8.000 & 8.000 & 8.000 & 8.000 & 8.000 & 8.000 & 8.000 & 8.000 & 8.000 & 8.000 & 8.000 & 8.000 & 8.000 & 8.000 & 8.000 \\
\hline viAl & 0.049 & 0.074 & 0.035 & 0.056 & 0.028 & 0.044 & 0.049 & 0.074 & 0.176 & 0.047 & 0.000 & 0.000 & 0.000 & 0.000 & 0.000 \\
\hline viTi & 0.462 & 0.385 & 0.392 & 0.377 & 0.412 & 0.380 & 0.462 & 0.385 & 0.381 & 0.514 & 0.490 & 0.534 & 0.473 & 0.502 & 0.491 \\
\hline $\mathrm{Fe}$ & 2.110 & 1.989 & 2.224 & 2.118 & 2.186 & 2.172 & 2.104 & 2.077 & 2.468 & 1.674 & 1.859 & 1.939 & 1.962 & 1.898 & 1.928 \\
\hline $\mathrm{Mn}$ & 0.087 & 0.068 & 0.070 & 0.092 & 0.060 & 0.080 & 0.087 & 0.068 & 0.035 & 0.019 & 0.042 & 0.042 & 0.050 & 0.034 & 0.041 \\
\hline $\mathrm{Mg}$ & 2.951 & 3.177 & 3.151 & 3.168 & 3.209 & 3.273 & 2.951 & 3.177 & 2.699 & 3.536 & 3.438 & 3.399 & 3.452 & 3.356 & 3.342 \\
\hline$\Sigma 0$ & 5.823 & 5.864 & 5.877 & 5.899 & 5.852 & 5.892 & 5.823 & 5.864 & 5.820 & 5.839 & 5.869 & 5.956 & 5.980 & 5.837 & 5.848 \\
\hline $\mathrm{Zn}$ & 0.000 & 0.003 & 0.000 & 0.008 & 0.011 & 0.003 & 0.000 & 0.003 & 0.006 & 0.006 & 0.001 & 0.005 & 0.004 & 0.000 & 0.005 \\
\hline $\mathrm{Ba}$ & 0.037 & 0.024 & 0.020 & 0.034 & 0.017 & 0.037 & 0.037 & 0.024 & 0.018 & 0.056 & 0.056 & 0.055 & 0.034 & 0.042 & 0.054 \\
\hline $\mathrm{Ca}$ & 0.002 & 0.015 & 0.006 & 0.007 & 0.021 & 0.000 & 0.002 & 0.015 & 0.005 & 0.005 & 0.001 & 0.015 & 0.020 & 0.017 & 0.015 \\
\hline $\mathrm{Na}$ & 0.025 & 0.026 & 0.029 & 0.036 & 0.016 & 0.026 & 0.025 & 0.026 & 0.023 & 0.157 & 0.044 & 0.077 & 0.047 & 0.040 & 0.043 \\
\hline $\mathrm{K}$ & 1.803 & 1.788 & 1.838 & 1.792 & 1.819 & 1.779 & 1.803 & 1.788 & 1.807 & 1.538 & 1.760 & 1.681 & 1.678 & 1.727 & 1.705 \\
\hline$\Sigma A$ & 1.868 & 1.856 & 1.893 & 1.876 & 1.884 & 1.845 & 1.868 & 1.856 & 1.859 & 1.762 & 1.861 & 1.833 & 1.783 & 1.826 & 1.823 \\
\hline \multicolumn{16}{|l|}{ Anions } \\
\hline $\mathrm{F}$ & 0.147 & 0.181 & 0.106 & 0.130 & 0.141 & 0.135 & 0.121 & 0.117 & 0.024 & 0.066 & 0.114 & 0.101 & 0.111 & 0.111 & 0.092 \\
\hline $\mathrm{Cl}$ & 0.037 & 0.027 & 0.029 & 0.045 & 0.039 & 0.042 & 0.040 & 0.045 & 0.057 & 0.043 & 0.051 & 0.052 & 0.051 & 0.050 & 0.053 \\
\hline mg\# & 0.60 & 0.63 & 0.57 & 0.60 & 0.59 & 0.59 & 0.60 & 0.61 & 0.52 & 0.68 & 0.65 & 0.64 & 0.64 & 0.64 & 0.63 \\
\hline
\end{tabular}

Notes: Facies abbreviations BQ-M OC = Biotite quartz-monzodiorite with two pyroxenes; L-MG = Leuco monzogranite; BT-MG = Biotite hornblende monzogranite; Rhy = Rhyolite; HB-GD = Hornblende biotite granodiorite; $\mathrm{MG}=$ Monzogranite; $\mathrm{H}-\mathrm{MZ}=$ Hornblende monzodiorite; $\mathrm{E}-\mathrm{MD}=$ Micro-diorite enclave; IM-D = Intermediate-mafic dikes; Dac = Dacite; $\mathrm{mg} \#=$ magnesium number; $\Sigma \mathrm{T}=$ sum of tetrahedral cations; $\Sigma O=$ sum of octahedral cations; $\Sigma A=$ sum of interlayer cations. 
Supplementary Material: Electron microprobe analyses of micas from Garzón granites and related rocks, Eastern Cordillera, Colombia.

\begin{tabular}{|c|c|c|c|c|c|c|c|c|c|c|c|c|c|c|c|}
\hline \multirow{3}{*}{$\begin{array}{l}\text { Mineral } \\
\text { Massif } \\
\text { Sample }\end{array}$} & \multicolumn{15}{|c|}{ Micas } \\
\hline & \multicolumn{4}{|c|}{ Altamira } & \multicolumn{11}{|c|}{ Sombrerillo } \\
\hline & $\begin{array}{l}\text { GAR- } \\
386\end{array}$ & $\begin{array}{c}\text { GAR- } \\
386\end{array}$ & $\begin{array}{c}\text { GAR- } \\
386\end{array}$ & $\begin{array}{l}\text { GAR- } \\
386\end{array}$ & GAR-394 & GAR-394 & GAR-394 & GAR-394 & GAR-394 & $\begin{array}{c}\text { GAR- } \\
395\end{array}$ & $\begin{array}{c}\text { GAR- } \\
395\end{array}$ & $\begin{array}{c}\text { GAR- } \\
395\end{array}$ & $\begin{array}{c}\text { GAR- } \\
395\end{array}$ & $\begin{array}{c}\text { GAR- } \\
395 \\
\end{array}$ & $\begin{array}{c}\text { GAR- } \\
395\end{array}$ \\
\hline Facies & HB-GD & HB-GD & HB-GD & HB-GD & MG & MG & MG & MG & MG & Dac & Dac & Dac & Dac & Dac & Dac \\
\hline Grain/Point & bt_01-1 & bt_02-1 & bt_05-1 & bt_06-1 & bt_01-1 & bt_02-1 & bt_03-1 & bt_05-1 & bt_08-1 & bt_02- & bt_04- & bt_06- & $\begin{array}{c}\text { bt- } \\
\text { mat_07- } \\
\end{array}$ & $\begin{array}{c}\text { bt- } \\
\text { mat_08- } \\
\end{array}$ & $\begin{array}{c}\text { bt- } \\
\text { mat_09- } \\
1\end{array}$ \\
\hline $\mathrm{SiO} 2$ & 36.24 & 36.58 & 36.68 & 36.23 & 36.91 & 36.79 & 36.86 & 37.24 & 36.93 & 35.97 & 35.87 & 35.69 & 40.79 & 36.29 & 34.82 \\
\hline $\mathrm{TiO} 2$ & 3.17 & 3.30 & 3.59 & 3.44 & 3.59 & 3.67 & 3.75 & 3.88 & 3.68 & 2.70 & 3.39 & 3.10 & 2.96 & 2.39 & 2.87 \\
\hline $\mathrm{Al} 2 \mathrm{O} 3$ & 14.29 & 14.51 & 14.42 & 14.53 & 12.97 & 12.50 & 12.64 & 12.65 & 12.90 & 15.33 & 14.79 & 15.18 & 16.04 & 14.98 & 14.41 \\
\hline $\mathrm{FeO}$ & 17.66 & 18.01 & 18.29 & 18.34 & 22.12 & 21.13 & 21.06 & 21.27 & 21.16 & 20.13 & 20.79 & 20.06 & 15.71 & 19.07 & 19.11 \\
\hline $\mathrm{MnO}$ & 0.51 & 0.43 & 0.47 & 0.56 & 0.26 & 0.25 & 0.25 & 0.26 & 0.24 & 0.54 & 0.55 & 0.50 & 0.47 & 0.49 & 0.46 \\
\hline $\mathrm{MgO}$ & 13.13 & 13.20 & 13.31 & 13.07 & 11.07 & 11.65 & 11.59 & 11.64 & 11.64 & 11.55 & 10.78 & 11.24 & 10.39 & 11.75 & 11.70 \\
\hline $\mathrm{ZnO}$ & 0.05 & 0.07 & 0.06 & 0.04 & 0.07 & 0.00 & 0.05 & 0.05 & 0.00 & 0.06 & 0.07 & 0.04 & 0.04 & 0.04 & 0.06 \\
\hline $\mathrm{BaO}$ & 0.32 & 0.65 & 0.19 & 0.50 & 0.00 & 0.04 & 0.00 & 0.10 & 0.05 & 0.66 & 0.70 & 0.69 & 0.06 & 0.12 & 0.00 \\
\hline $\mathrm{CaO}$ & 0.05 & 0.12 & 0.05 & 0.09 & 0.04 & 0.00 & 0.06 & 0.00 & 0.03 & 0.07 & 0.00 & 0.03 & 1.52 & 0.42 & 0.09 \\
\hline $\mathrm{Na} 2 \mathrm{O}$ & 0.17 & 0.14 & 0.18 & 0.13 & 0.07 & 0.15 & 0.16 & 0.10 & 0.15 & 0.14 & 0.11 & 0.11 & 0.06 & 0.09 & 0.13 \\
\hline $\mathrm{K} 2 \mathrm{O}$ & 9.05 & 8.97 & 9.60 & 9.16 & 9.55 & 9.47 & 9.21 & 9.48 & 9.48 & 8.79 & 9.27 & 8.92 & 8.63 & 9.22 & 9.33 \\
\hline $\mathrm{F}$ & 0.10 & 0.07 & 0.08 & 0.06 & 0.27 & 0.27 & 0.27 & 0.29 & 0.30 & 0.08 & 0.03 & 0.04 & 0.04 & 0.04 & 0.08 \\
\hline $\mathrm{Cl}$ & 0.05 & 0.14 & 0.12 & 0.15 & 0.27 & 0.23 & 0.36 & 0.25 & 0.25 & 0.11 & 0.18 & 0.17 & 0.08 & 0.11 & 0.11 \\
\hline $\mathrm{O}=(\mathrm{F} . \mathrm{Cl})$ & 0.06 & 0.06 & 0.06 & 0.06 & 0.17 & 0.16 & 0.20 & 0.18 & 0.18 & 0.06 & 0.05 & 0.05 & 0.03 & 0.04 & 0.06 \\
\hline Total & 94.74 & 96.13 & 96.97 & 96.24 & 97.05 & 96.00 & 96.07 & 97.04 & $\mathbf{9 6 . 6 3}$ & 96.07 & 96.48 & 95.72 & 96.77 & 94.97 & 93.10 \\
\hline \multicolumn{16}{|c|}{ Cation proportion (on the basis of 230 ) } \\
\hline ivSi & 5.559 & 5.544 & 5.518 & 5.500 & 5.654 & 5.674 & 5.674 & 5.679 & 5.654 & 5.506 & 5.509 & 5.492 & 5.956 & 5.582 & 5.493 \\
\hline ivAl & 2.441 & 2.456 & 2.482 & 2.500 & 2.341 & 2.272 & 2.293 & 2.274 & 2.328 & 2.494 & 2.491 & 2.508 & 2.044 & 2.418 & 2.507 \\
\hline ivTi & 0.000 & 0.000 & 0.000 & 0.000 & 0.005 & 0.054 & 0.033 & 0.047 & 0.018 & 0.000 & 0.000 & 0.000 & 0.000 & 0.000 & 0.000 \\
\hline$\Sigma T$ & 8.000 & 8.000 & 8.000 & 8.000 & 8.000 & 8.000 & 8.000 & 8.000 & 8.000 & 8.000 & 8.000 & 8.000 & 8.000 & 8.000 & 8.000 \\
\hline viAl & 0.142 & 0.136 & 0.074 & 0.100 & 0.000 & 0.000 & 0.000 & 0.000 & 0.000 & 0.271 & 0.186 & 0.245 & 0.717 & 0.297 & 0.172 \\
\hline viTi & 0.366 & 0.376 & 0.406 & 0.393 & 0.414 & 0.426 & 0.434 & 0.445 & 0.424 & 0.311 & 0.392 & 0.359 & 0.325 & 0.276 & 0.340 \\
\hline $\mathrm{Fe}$ & 2.265 & 2.283 & 2.301 & 2.329 & 2.834 & 2.725 & 2.711 & 2.713 & 2.709 & 2.577 & 2.670 & 2.582 & 1.918 & 2.453 & 2.521 \\
\hline $\mathrm{Mn}$ & 0.066 & 0.055 & 0.060 & 0.072 & 0.034 & 0.033 & 0.032 & 0.034 & 0.031 & 0.070 & 0.072 & 0.066 & 0.058 & 0.064 & 0.062 \\
\hline $\mathrm{Mg}$ & 3.002 & 2.982 & 2.984 & 2.958 & 2.527 & 2.678 & 2.659 & 2.646 & 2.656 & 2.635 & 2.468 & 2.578 & 2.261 & 2.694 & 2.751 \\
\hline$\Sigma 0$ & 5.886 & 5.880 & 5.875 & 5.895 & 5.859 & 5.908 & 5.881 & 5.891 & 5.868 & 5.918 & 5.842 & 5.883 & 5.371 & 5.833 & 5.881 \\
\hline $\mathrm{Zn}$ & 0.005 & 0.008 & 0.007 & 0.005 & 0.008 & 0.000 & 0.005 & 0.006 & 0.000 & 0.007 & 0.008 & 0.005 & 0.005 & 0.004 & 0.007 \\
\hline $\mathrm{Ba}$ & 0.019 & 0.038 & 0.011 & 0.030 & 0.000 & 0.002 & 0.000 & 0.006 & 0.003 & 0.040 & 0.042 & 0.041 & 0.003 & 0.007 & 0.000 \\
\hline $\mathrm{Ca}$ & 0.008 & 0.020 & 0.008 & 0.015 & 0.007 & 0.000 & 0.009 & 0.000 & 0.005 & 0.011 & 0.000 & 0.005 & 0.238 & 0.070 & 0.016 \\
\hline $\mathrm{Na}$ & 0.051 & 0.040 & 0.052 & 0.038 & 0.022 & 0.046 & 0.048 & 0.028 & 0.044 & 0.042 & 0.032 & 0.034 & 0.018 & 0.028 & 0.040 \\
\hline $\mathrm{K}$ & 1.771 & 1.734 & 1.842 & 1.774 & 1.866 & 1.863 & 1.808 & 1.844 & 1.852 & 1.716 & 1.816 & 1.751 & 1.608 & 1.809 & 1.877 \\
\hline$\Sigma A$ & 1.854 & 1.840 & 1.920 & 1.862 & 1.903 & 1.911 & 1.870 & 1.885 & 1.904 & 1.816 & 1.898 & 1.836 & 1.871 & 1.918 & 1.940 \\
\hline \multicolumn{16}{|l|}{ Anions } \\
\hline $\mathrm{F}$ & 0.051 & 0.034 & 0.038 & 0.028 & 0.130 & 0.130 & 0.132 & 0.139 & 0.148 & 0.037 & 0.017 & 0.020 & 0.019 & 0.017 & 0.037 \\
\hline $\mathrm{Cl}$ & 0.014 & 0.036 & 0.031 & 0.039 & 0.070 & 0.060 & 0.094 & 0.065 & 0.065 & 0.028 & 0.047 & 0.043 & 0.019 & 0.029 & 0.030 \\
\hline mg\# & 0.57 & 0.57 & 0.56 & 0.56 & 0.47 & 0.50 & 0.50 & 0.49 & 0.50 & 0.51 & 0.48 & 0.50 & 0.54 & 0.52 & 0.52 \\
\hline
\end{tabular}

Notes: Facies abbreviations BQ-M OC = Biotite quartz-monzodiorite with two pyroxenes; L-MG = Leuco monzogranite; BT-MG = Biotite hornblende monzogranite; Rhy = Rhyolite; HB-GD = Hornblende biotite granodiorite; $M G=$ Monzogranite; $\mathrm{H}-\mathrm{MZ}=$ Hornblende monzodiorite; $\mathrm{E}-\mathrm{MD}=$ Micro-diorite enclave; IM-D = Intermediate-mafic dikes; Dac = Dacite; $\mathrm{mg} \#=$ = magnesium number; $\Sigma \mathrm{T}=$ sum of tetrahedral cations; $\Sigma O=$ sum of octahedral cations; $\Sigma \mathrm{A}=$ sum of interlayer cations. 
Supplementary Material: Electron microprobe analyses of clinopyroxene from Garzón granites and related rocks, Eastern Cordillera, Colombia.

\begin{tabular}{|c|c|c|c|c|c|c|c|c|c|}
\hline \multirow{2}{*}{$\begin{array}{l}\text { Mineral } \\
\text { Massif }\end{array}$} & \multicolumn{9}{|c|}{ Clinopyroxene } \\
\hline & \multicolumn{9}{|c|}{ Sombrerillo } \\
\hline Sample & $\mathrm{L}-102$ & $\mathrm{~L}-102$ & $\mathrm{~L}-102$ & $\mathrm{~L}-102$ & GAR-394 & GAR-394 & GAR-394 & GAR-394 & GAR-394 \\
\hline Facies & BQ-M-OC & $B Q-M-O C$ & BQ-M-OC & $B Q-M-O C$ & MG & MG & MG & MG & MG \\
\hline Grain/Point & cpx_03-3 & cpx_06-1 & cpx_08-2 & cpx_14-1 & cpx_01-1 & cpx_02-1 & cpx_03-1 & cpx_04-1 & cpx_05-1 \\
\hline $\mathrm{SiO} 2$ & 51.87 & 51.98 & 51.21 & 52.71 & 51.76 & 52.14 & 52.02 & 52.69 & 53.17 \\
\hline TiO2 & 0.39 & 0.52 & 0.84 & 0.26 & 0.31 & 0.12 & 0.45 & 0.05 & 0.29 \\
\hline Al2O3 & 1.17 & 1.53 & 3.85 & 0.79 & 1.21 & 0.45 & 1.44 & 0.25 & 1.50 \\
\hline $\mathrm{Cr} 2 \mathrm{O} 3$ & 0.00 & 0.00 & 0.00 & 0.00 & 0.00 & 0.00 & 0.04 & 0.00 & 0.00 \\
\hline $\mathrm{FeO}$ & 13.11 & 11.70 & 14.71 & 13.95 & 12.22 & 12.05 & 12.07 & 12.41 & 20.51 \\
\hline $\mathrm{MnO}$ & 0.44 & 0.37 & 0.33 & 0.40 & 0.68 & 0.74 & 0.65 & 0.73 & 1.23 \\
\hline $\mathrm{MgO}$ & 13.73 & 13.69 & 15.07 & 15.50 & 12.16 & 11.47 & 12.28 & 11.01 & 17.13 \\
\hline $\mathrm{ZnO}$ & 0.00 & 0.00 & 0.00 & 0.02 & 0.00 & 0.01 & 0.02 & 0.00 & 0.07 \\
\hline $\mathrm{CaO}$ & 19.69 & 20.47 & 11.42 & 16.74 & 20.95 & 22.32 & 21.32 & 23.46 & 3.78 \\
\hline $\mathrm{Na} 2 \mathrm{O}$ & 0.30 & 0.32 & 0.62 & 0.27 & 0.51 & 0.44 & 0.54 & 0.41 & 0.30 \\
\hline $\mathrm{K} 2 \mathrm{O}$ & 0.00 & 0.00 & 0.35 & 0.00 & 0.03 & 0.00 & 0.02 & 0.00 & 0.45 \\
\hline Total & 100.69 & 100.60 & 98.41 & 100.67 & 99.83 & 99.76 & 100.86 & 101.02 & 98.42 \\
\hline \multicolumn{10}{|c|}{ Structural formulae (on the basis of 4 cations and 60 ) } \\
\hline $\mathrm{Si}$ & 1.939 & 1.939 & 1.945 & 1.963 & 1.957 & 1.980 & 1.945 & 1.982 & 2.042 \\
\hline $\mathrm{Al}^{+3}$ & 0.052 & 0.061 & 0.055 & 0.035 & 0.043 & 0.020 & 0.055 & 0.011 & 0.000 \\
\hline T site & 1.991 & 2.000 & 2.000 & 1.998 & 2.000 & 2.000 & 2.000 & 1.993 & 2.042 \\
\hline $\mathrm{Al}^{+3}$ & 0.000 & 0.006 & 0.117 & 0.000 & 0.011 & 0.000 & 0.009 & 0.000 & 0.068 \\
\hline $\mathrm{Ti}$ & 0.011 & 0.015 & 0.024 & 0.007 & 0.009 & 0.003 & 0.013 & 0.001 & 0.008 \\
\hline $\mathrm{Cr}$ & 0.000 & 0.000 & 0.000 & 0.000 & 0.000 & 0.000 & 0.001 & 0.000 & 0.000 \\
\hline \multicolumn{10}{|l|}{$\mathrm{Fe}$} \\
\hline $\mathrm{Mn}$ & 0.014 & 0.012 & 0.011 & 0.013 & 0.022 & 0.024 & 0.021 & 0.023 & 0.040 \\
\hline $\mathrm{Mg}$ & 0.765 & 0.761 & 0.853 & 0.860 & 0.685 & 0.649 & 0.684 & 0.617 & 0.981 \\
\hline $\mathrm{Zn}$ & 0.000 & 0.000 & 0.000 & 0.001 & 0.000 & 0.000 & 0.000 & 0.000 & 0.002 \\
\hline $\mathrm{Ca}$ & 0.789 & 0.818 & 0.465 & 0.668 & 0.849 & 0.908 & 0.854 & 0.945 & 0.156 \\
\hline $\mathrm{Na}$ & 0.022 & 0.023 & 0.046 & 0.020 & 0.037 & 0.033 & 0.039 & 0.030 & 0.022 \\
\hline $\mathrm{K}$ & 0.000 & 0.000 & 0.017 & 0.000 & 0.001 & 0.000 & 0.001 & 0.000 & 0.022 \\
\hline M sites & 2.009 & 2.000 & 2.000 & 2.002 & 2.000 & 2.000 & 2.000 & 2.007 & 1.958 \\
\hline mg\# & 0.69 & 0.71 & 0.65 & 0.69 & 0.67 & 0.66 & 0.68 & 0.65 & 0.60 \\
\hline \multicolumn{10}{|c|}{ Molecular components } \\
\hline wo & 39.88 & 41.83 & 25.88 & 33.81 & 43.70 & 46.24 & 44.10 & 47.84 & 8.48 \\
\hline en & 38.69 & 38.91 & 47.51 & 43.55 & 35.28 & 33.06 & 35.34 & 31.23 & 53.45 \\
\hline fs & 21.43 & 19.26 & 26.61 & 22.64 & 21.02 & 20.70 & 20.55 & 20.93 & 38.08 \\
\hline
\end{tabular}

Notes: Facies abbreviations BQ-M OC = Biotite quartz-monzodiorite with two pyroxenes; L-MG = Leuco monzogranite; BT-MG = Biotite hornblende monzogranite; Rhy = Rhyolite; HB-GD = Hornblende biotite granodiorite; $M G$ = Monzogranite; $\mathrm{H}-\mathrm{MZ}=$ Hornblende monzodiorite; $\mathrm{E}-\mathrm{MD}=$ Micro-diorite enclave; Dac = Dacite; wo = wollastonite; en = enstatite; fs = fosterite; $m g \#=$ magnesium number. 
Supplementary Material: Electron microprobe analyses of orthopyroxene from Garzón granites and related rocks, Eastern Cordillera, Colombia.

\begin{tabular}{|c|c|c|c|c|c|c|c|}
\hline \multirow{2}{*}{$\begin{array}{l}\text { Mineral } \\
\text { Massif }\end{array}$} & \multicolumn{7}{|c|}{ Orthopyroxene } \\
\hline & & & & Sombrerillo & & & \\
\hline Sample & L-102 & L-102 & L-102 & $L-102$ & L-102 & L-102 & L-102 \\
\hline Facies & $\begin{array}{c}\text { BQ-M- } \\
\text { OC }\end{array}$ & BQ-M-OC & BQ-M-OC & BQ-M-OC & BQ-M-OC & BQ-M-OC & BQ-M-OC \\
\hline Grain/Point & opx_03-1 & opx_03-2 & opx_05-1 & opx_08-1 & opx_09-1 & opx_14-2 & opx_17-1 \\
\hline $\mathrm{SiO} 2$ & 51.56 & 51.54 & 51.90 & 51.62 & 51.50 & 51.98 & 51.64 \\
\hline $\mathrm{TiO} 2$ & 0.28 & 0.31 & 0.28 & 0.25 & 0.21 & 0.31 & 0.22 \\
\hline $\mathrm{Al} 2 \mathrm{O} 3$ & 0.52 & 0.41 & 0.54 & 0.47 & 0.50 & 0.53 & 0.38 \\
\hline $\mathrm{Cr} 2 \mathrm{O} 3$ & 0.00 & 0.00 & 0.00 & 0.00 & 0.04 & 0.00 & 0.00 \\
\hline $\mathrm{FeO}$ & 28.71 & 28.82 & 26.49 & 28.36 & 27.27 & 26.86 & 27.36 \\
\hline $\mathrm{MnO}$ & 1.04 & 1.25 & 0.76 & 0.96 & 0.82 & 0.79 & 0.77 \\
\hline $\mathrm{MgO}$ & 18.09 & 17.62 & 19.69 & 18.32 & 18.96 & 19.24 & 19.28 \\
\hline $\mathrm{ZnO}$ & 0.06 & 0.06 & 0.07 & 0.05 & 0.05 & 0.06 & 0.06 \\
\hline $\mathrm{CaO}$ & 1.02 & 1.62 & 0.98 & 1.18 & 1.38 & 1.51 & 0.88 \\
\hline $\mathrm{Na} 2 \mathrm{O}$ & 0.00 & 0.02 & 0.02 & 0.00 & 0.03 & 0.00 & 0.00 \\
\hline $\mathrm{K} 2 \mathrm{O}$ & 0.00 & 0.00 & 0.02 & 0.02 & 0.00 & 0.00 & 0.00 \\
\hline Total & 101.28 & 101.65 & 100.75 & 101.22 & 100.76 & 101.29 & 100.60 \\
\hline
\end{tabular}

Structural formulae (on the basis of 4 cations and 60 )

\begin{tabular}{|c|c|c|c|c|c|c|c|}
\hline $\mathrm{Si}$ & 1.957 & 1.954 & 1.957 & 1.957 & 1.950 & 1.956 & 1.958 \\
\hline ivAl & 0.023 & 0.018 & 0.024 & 0.021 & 0.023 & 0.024 & 0.017 \\
\hline T site & 1.980 & 1.972 & 1.981 & 1.978 & 1.973 & 1.980 & 1.975 \\
\hline viAl & 0.000 & 0.000 & 0.000 & 0.000 & 0.000 & 0.000 & 0.000 \\
\hline $\mathrm{Ti}$ & 0.008 & 0.009 & 0.008 & 0.007 & 0.006 & 0.009 & 0.006 \\
\hline $\mathrm{Cr}$ & 0.000 & 0.000 & 0.000 & 0.000 & 0.001 & 0.000 & 0.000 \\
\hline Felll & 0.046 & 0.057 & 0.048 & 0.052 & 0.066 & 0.047 & 0.055 \\
\hline $\mathrm{Fe}$ & 0.865 & 0.857 & 0.788 & 0.847 & 0.798 & 0.798 & 0.812 \\
\hline $\mathrm{Mn}$ & 0.033 & 0.040 & 0.024 & 0.031 & 0.026 & 0.025 & 0.025 \\
\hline $\mathrm{Mg}$ & 1.024 & 0.996 & 1.107 & 1.035 & 1.070 & 1.079 & 1.089 \\
\hline $\mathrm{Zn}$ & 0.002 & 0.002 & 0.002 & 0.001 & 0.001 & 0.002 & 0.002 \\
\hline $\mathrm{Ca}$ & 0.041 & 0.066 & 0.040 & 0.048 & 0.056 & 0.061 & 0.036 \\
\hline $\mathrm{Na}$ & 0.000 & 0.001 & 0.001 & 0.000 & 0.003 & 0.000 & 0.000 \\
\hline $\mathrm{K}$ & 0.000 & 0.000 & 0.001 & 0.001 & 0.000 & 0.000 & 0.000 \\
\hline M site & 2.020 & 2.028 & 2.019 & 2.022 & 2.027 & 2.020 & 2.025 \\
\hline mg\# & 0.54 & 0.54 & 0.58 & 0.55 & 0.57 & 0.57 & 0.57 \\
\hline
\end{tabular}

Molecular components

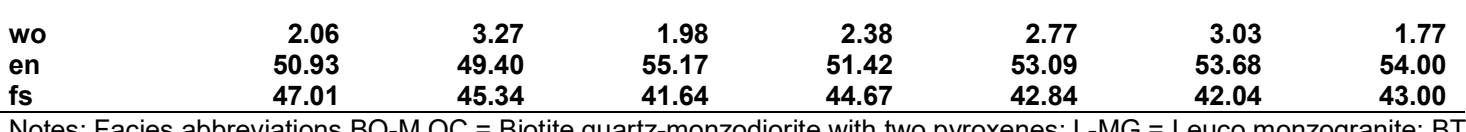

Notes: Facies abbreviations BQ-M OC = Biotite quartz-monzodiorite with two pyroxenes; L-MG = Leuco monzogranite; BT-MG = Biotite hornblende monzogranite; Rhy = Rhyolite; HB-GD = Hornblende biotite granodiorite; $\mathrm{MG}=$ Monzogranite; H-MZ = Hornblende monzodiorite; E-MD = Micro-diorite enclave; IM-D = Intermediate-mafic dikes; Dac = Dacite; wo = wollastonite; en = enstatite; fs = fosterite; $\mathrm{mg \#}=$ magnesium number. 
Supplementary Material: Electron microprobe analyses of magnetite and ilmenite from Garzón granites and related rocks, Eastern Cordillera, Colombia.

\begin{tabular}{|c|c|c|c|c|c|c|c|c|c|c|c|c|}
\hline Mineral & $\mathrm{Mt}$ & $\mathrm{IIm}$ & Mt & $\mathrm{IIm}$ & Mt & $\mathrm{IIm}$ & Mt & $\| \mathrm{m}$ & Mt & $\mathrm{IIm}$ & $\mathrm{Mt}$ & $\mathrm{IIm}$ \\
\hline Massif & \multicolumn{6}{|c|}{ Sombrerillo } & \multicolumn{6}{|c|}{ Algeciras } \\
\hline Sample & \multirow{2}{*}{\multicolumn{2}{|c|}{$\begin{array}{c}\mathrm{L}-102 \\
\mathrm{BQ}-\mathrm{M} \text { OC }\end{array}$}} & \multirow{2}{*}{\multicolumn{2}{|c|}{$\begin{array}{c}L-102 \\
B Q-M ~ O C\end{array}$}} & \multirow{2}{*}{\multicolumn{2}{|c|}{$\begin{array}{c}L-102 \\
B Q-M ~ O C\end{array}$}} & \multirow{2}{*}{\multicolumn{2}{|c|}{$\begin{array}{c}\text { GAR-358 } \\
\text { IM-D }\end{array}$}} & \multirow{2}{*}{\multicolumn{2}{|c|}{$\begin{array}{c}\text { GAR-372 } \\
\text { BH-MG }\end{array}$}} & \multirow{2}{*}{\multicolumn{2}{|c|}{$\begin{array}{c}\text { GAR-372 } \\
\text { BH-MG }\end{array}$}} \\
\hline Facies & & & & & & & & & & & & \\
\hline $\begin{array}{l}\text { Grain/ } \\
\text { Point }\end{array}$ & $\underset{a-1}{\operatorname{mag}_{-1} 13}$ & ilm_13a- & mag_03-1 & ilm_03a-1 & mag_09a $_{-1}$ & ilm_09a- & $\begin{array}{c}\text { mag- } \\
\text { anf_06 } \\
-1\end{array}$ & $\begin{array}{c}\text { ilm- } \\
\text { anf_06 } \\
-1\end{array}$ & $\underset{02-1}{\operatorname{mag} R}$ & $\underset{\mathrm{R}-1}{\mathrm{ilm}-02}$ & $\begin{array}{l}\text { mag } \\
\text { R_03- } \\
1\end{array}$ & $\begin{array}{l}\text { ilm_03 } \\
\text { a_R-1 }\end{array}$ \\
\hline $\mathrm{SiO} 2$ & 0.52 & 0.03 & 0.0652 & 0.03 & 0.04 & 0.00 & 0.08 & 0.06 & 0.05 & 0.02 & 0.0652 & 0.03 \\
\hline $\mathrm{TiO} 2$ & 0.56 & 48.28 & 0.4997 & 50.49 & 0.29 & 49.88 & 1.66 & 48.75 & 0.25 & 45.78 & 0.4997 & 50.49 \\
\hline $\mathrm{Al} 2 \mathrm{O} 3$ & 0.03 & 0.01 & 0.4563 & 0.00 & 0.41 & 0.01 & 0.06 & 0.00 & 0.08 & 0.01 & 0.4563 & 0.00 \\
\hline $\mathrm{Fe} 2 \mathrm{O} 3$ & 74.2 & 7.9 & 74.6 & 5.0 & 75.3 & 6.0 & 73.1 & 8.8 & 75.3 & 11.8 & 74.6 & 5.0 \\
\hline $\mathrm{FeO}$ & 35.1 & 38.8 & 35.3 & 42.2 & 35.1 & 41.0 & 36.1 & 36.6 & 34.5 & 27.4 & 35.3 & 42.2 \\
\hline $\mathrm{MnO}$ & 0.04 & 4.49 & 0.0332 & 3.02 & 0.02 & 3.73 & 0.17 & 6.84 & 0.10 & 12.67 & 0.0332 & 3.02 \\
\hline $\mathrm{MgO}$ & 0.02 & 0.02 & 0 & 0.02 & 0.01 & 0.02 & 0.00 & 0.17 & 0.03 & 0.04 & 0 & 0.02 \\
\hline $\mathrm{CaO}$ & 0.00 & 0.03 & 0.0255 & 0.10 & 0.00 & 0.01 & 0.02 & 0.03 & 0.02 & 0.57 & 0.0255 & 0.10 \\
\hline $\mathrm{Na} 2 \mathrm{O}$ & 0.00 & 0.00 & 0 & 0.00 & 0.01 & 0.00 & 0.00 & 0.00 & 0.04 & 0.00 & 0 & 0.00 \\
\hline $\mathrm{K} 2 \mathrm{O}$ & 0.00 & 0.01 & 0.0165 & 0.01 & 0.01 & 0.01 & 0.00 & 0.01 & 0.00 & 0.00 & 0.0165 & 0.01 \\
\hline \multicolumn{13}{|l|}{$\mathrm{BaO}$} \\
\hline $\mathrm{ZnO}$ & 0.63 & 0.03 & 0.0136 & 0.04 & 0.05 & 0.00 & 0.00 & 0.05 & 0.00 & 0.16 & 0.0136 & 0.04 \\
\hline V2O3 & 0.00 & 0.34 & 0.7879 & 0.38 & 0.78 & 0.37 & 0.28 & 0.33 & 0.24 & 0.29 & 0.7879 & 0.38 \\
\hline $\mathrm{NiO}$ & 0.00 & 0.01 & 0.028 & 0.00 & 0.01 & 0.00 & 0.02 & 0.01 & 0.00 & 0.00 & 0.028 & 0.00 \\
\hline $\mathrm{Nb} 2 \mathrm{O} 3$ & 0.00 & 0.01 & 0.097 & 0.05 & 0.04 & 0.01 & 0.00 & 0.00 & 0.04 & 0.02 & 0.097 & 0.05 \\
\hline Total & 103.854 & 99.2266 & 104.6412 & 100.8926 & 104.71 & 100.55 & 104.26 & 100.80 & 103.14 & 97.60 & 102.71 & 99.35 \\
\hline \multicolumn{13}{|c|}{ Structural formulae on the basis of 2 oxygen, 2 cations for ilmenite and 3 cations for magnetite } \\
\hline $\mathrm{Si}$ & 0.0179 & 0.0008 & 0.0022 & 0.0008 & 0.0012 & 0.0000 & 0.0029 & 0.0015 & 0.0018 & 0.0005 & 0.0013 & 0.0000 \\
\hline $\mathrm{Ti}$ & 0.0145 & 0.9197 & 0.0129 & 0.9475 & 0.0074 & 0.9389 & 0.0430 & 0.9125 & 0.0066 & 0.8825 & 0.0320 & 0.8500 \\
\hline Al & 0.0011 & 0.0004 & 0.0184 & 0.0000 & 0.0167 & 0.0002 & 0.0022 & 0.0000 & 0.0032 & 0.0003 & 0.0061 & 0.0000 \\
\hline $\mathrm{Fe}+3$ & 1.9295 & 0.1498 & 1.9241 & 0.0944 & 1.9399 & 0.1135 & 1.8960 & 0.1649 & 1.9708 & 0.2274 & 1.9191 & 0.2893 \\
\hline $\mathrm{Fe}+2$ & 1.0141 & 0.8221 & 1.0119 & 0.8805 & 1.0058 & 0.8589 & 1.0403 & 0.7619 & 1.0024 & 0.5880 & 1.0289 & 0.6788 \\
\hline $\mathrm{Mn}$ & 0.0011 & 0.0963 & 0.0010 & 0.0638 & 0.0005 & 0.0790 & 0.0048 & 0.1441 & 0.0030 & 0.2750 & 0.0016 & 0.1622 \\
\hline $\mathrm{Mg}$ & 0.0011 & 0.0008 & 0.0000 & 0.0007 & 0.0004 & 0.0006 & 0.0000 & 0.0062 & 0.0015 & 0.0014 & 0.0014 & 0.0023 \\
\hline $\mathrm{Ca}$ & 0.0000 & 0.0008 & 0.0009 & 0.0027 & 0.0001 & 0.0003 & 0.0007 & 0.0008 & 0.0008 & 0.0156 & 0.0008 & 0.0059 \\
\hline $\mathrm{Na}$ & 0.0000 & 0.0000 & 0.0000 & 0.0002 & 0.0009 & 0.0000 & 0.0000 & 0.0000 & 0.0029 & 0.0000 & 0.0000 & 0.0004 \\
\hline $\mathrm{K}$ & 0.0002 & 0.0002 & 0.0007 & 0.0002 & 0.0004 & 0.0002 & 0.0000 & 0.0004 & 0.0000 & 0.0000 & 0.0000 & 0.0001 \\
\hline $\mathrm{Cr}$ & 0.0047 & 0.0015 & 0.0037 & 0.0006 & 0.0039 & 0.0008 & 0.0020 & 0.0002 & 0.0013 & 0.0000 & 0.0015 & 0.0000 \\
\hline $\mathrm{Ba}$ & 0.0000 & 0.0000 & 0.0000 & 0.0000 & 0.0000 & 0.0000 & 0.0000 & 0.0000 & 0.0000 & 0.0000 & 0.0000 & 0.0000 \\
\hline $\mathrm{Zn}$ & 0.0160 & 0.0006 & 0.0003 & 0.0007 & 0.0014 & 0.0000 & 0.0000 & 0.0010 & 0.0001 & 0.0030 & 0.0006 & 0.0008 \\
\hline V & 0.0000 & 0.0069 & 0.0216 & 0.0075 & 0.0213 & 0.0074 & 0.0077 & 0.0066 & 0.0067 & 0.0060 & 0.0067 & 0.0063 \\
\hline $\mathrm{Ni}$ & 0.0000 & 0.0002 & 0.0008 & 0.0000 & 0.0004 & 0.0000 & 0.0006 & 0.0001 & 0.0000 & 0.0000 & 0.0000 & 0.0004 \\
\hline $\mathrm{Nb}$ & 0.0000 & 0.0001 & 0.0017 & 0.0006 & 0.0007 & 0.0002 & 0.0000 & 0.0000 & 0.0008 & 0.0003 & 0.0000 & 0.0039 \\
\hline Total & \multirow{2}{*}{\multicolumn{2}{|c|}{$\begin{array}{ll}3.0001 & 2.0002 \\
595 & \end{array}$}} & 3.0004 & 2.0003 & 3.0008 & 2.0001 & 3.0001 & 2.0003 & 3.0017 & 2.0000 & 3.0000 & 2.0005 \\
\hline $\mathrm{T}\left({ }^{\circ} \mathrm{C}\right)$ & & & \multirow{2}{*}{\multicolumn{2}{|c|}{541}} & \multicolumn{2}{|c|}{533} & \multicolumn{2}{|c|}{653} & \multicolumn{2}{|c|}{587} & \multicolumn{2}{|c|}{683} \\
\hline $\log f \mathrm{O} 2$ & \multirow{2}{*}{\multicolumn{2}{|c|}{$\begin{array}{c}-18 \\
+1.26\end{array}$}} & \multirow{2}{*}{\multicolumn{2}{|c|}{$\begin{array}{c}-21 \\
+0.16\end{array}$}} & \multirow{2}{*}{\multicolumn{2}{|c|}{$\begin{array}{r}-20 \\
+1.46\end{array}$}} & \multirow{2}{*}{\multicolumn{2}{|c|}{$\begin{array}{r}-16 \\
+1.23\end{array}$}} & \multirow{2}{*}{\multicolumn{2}{|c|}{$\begin{array}{c}-16 \\
+3.54\end{array}$}} & \multirow{2}{*}{\multicolumn{2}{|c|}{$\begin{array}{c}-14 \\
+2.64\end{array}$}} \\
\hline$\Delta N N O$ & & & & & & & & & & & & \\
\hline
\end{tabular}

Notes: Facies abbreviations BQ-M OC = Biotite quartz-monzodiorite with two pyroxenes; L-MG = Leuco monzogranite; BT-MG = Biotite hornblende monzogranite; Rhy = Rhyolite; HB-GD = Hornblende biotite granodiorite; $\mathrm{MG}=$ Monzogranite; $\mathrm{H}-\mathrm{MZ}=$ Hornblende monzodiorite; IM-D = Intermediate-mafic dikes; Dac = Dacite. Average temperature $\left[\mathrm{T}\left({ }^{\circ} \mathrm{C}\right)\right] \mathrm{T}$ and oxygen fugacity $($ logfO2) of Carmichael (1967); Anderson (1968); Lindsley \& Spencer (1982); Stormer (1983), and discrimination of FeO and Fe2O3 from Carmichael (1967) calculated using Lepage (2003) program. $\Delta$ NNO = log10fO2 relative to NiNiO buffer. 
Supplementary Material: Electron microprobe analyses of magnetite and ilmenite from Garzón granites and related rocks, Eastern Cordillera, Colombia.

\begin{tabular}{|c|c|c|c|c|c|c|c|c|c|c|}
\hline Mineral & Mt & $\| \mathrm{m}$ & Mt & $\mathrm{IIm}$ & Mt & IIm & Mt & $\mathrm{IIm}$ & Mt & $\mathrm{IIm}$ \\
\hline Massif & \multicolumn{4}{|c|}{ Altamira } & \multicolumn{6}{|c|}{ Sombrerillo } \\
\hline Sample & \multicolumn{2}{|c|}{ GAR-383 } & \multicolumn{2}{|c|}{ GAR-388 } & \multicolumn{2}{|c|}{ GAR-394 } & \multirow{2}{*}{\multicolumn{2}{|c|}{ GAR-394 }} & \multicolumn{2}{|c|}{ GAR-394 } \\
\hline Facies & \multicolumn{2}{|c|}{ Rhy } & \multicolumn{2}{|c|}{ H-MD } & \multicolumn{2}{|c|}{ MG } & & & \multicolumn{2}{|c|}{ MG } \\
\hline $\begin{array}{l}\text { Grain/ } \\
\text { Point }\end{array}$ & mag_02- & ilm_02-1 & mag_01- & $i_{-1}+01$ & mag_01- & ilm_01-1 & $\underset{2-1}{\operatorname{mag}_{2} 0}$ & $\mathrm{ilm}_{-1} 02$ & $\operatorname{mag}_{3-1} 0$ & $\mathrm{ilm}_{1}$ 03- \\
\hline $\mathrm{SiO} 2$ & 0.71 & 0.02 & 0.00 & 0.01 & 0.05 & 0.02 & 0.10 & 0.03 & 0.09 & 0.04 \\
\hline TiO2 & 2.55 & 48.45 & 0.07 & 49.56 & 0.12 & 47.72 & 0.18 & 49.60 & 0.51 & 48.08 \\
\hline $\mathrm{Al} 2 \mathrm{O} 3$ & 0.00 & 0.06 & 0.07 & 0.00 & 0.18 & 0.01 & 0.29 & 0.01 & 0.15 & 0.01 \\
\hline $\mathrm{Fe} 2 \mathrm{O} 3$ & 66.4 & 9.6 & 75.9 & 6.8 & 75.3 & 10.0 & 75.7 & 6.0 & 74.8 & 8.4 \\
\hline $\mathrm{FeO}$ & 35.8 & 36.6 & 34.3 & 23.3 & 34.6 & 39.7 & 35.0 & 40.0 & 35.1 & 38.9 \\
\hline $\mathrm{MnO}$ & 0.17 & 6.38 & 0.07 & 20.82 & 0.01 & 3.10 & 0.04 & 4.47 & 0.01 & 4.32 \\
\hline $\mathrm{MgO}$ & 0.00 & 0.03 & 0.00 & 0.06 & 0.00 & 0.02 & 0.01 & 0.03 & 0.02 & 0.04 \\
\hline $\mathrm{CaO}$ & 0.24 & 0.25 & 0.03 & 0.08 & 0.05 & 0.02 & 0.03 & 0.01 & 0.04 & 0.00 \\
\hline $\mathrm{Na} 2 \mathrm{O}$ & 0.00 & 0.05 & 0.03 & 0.01 & & 0.00 & & 0.02 & & 0.00 \\
\hline $\mathrm{K} 2 \mathrm{O}$ & 0.00 & 0.01 & 0.04 & 0.04 & 0.00 & 0.00 & 0.02 & 0.02 & 0.00 & 0.01 \\
\hline $\mathrm{Cr} 2 \mathrm{O} 3$ & 0.07 & 0.00 & 0.00 & 0.00 & 0.13 & 0.01 & 0.07 & 0.03 & 0.06 & 0.00 \\
\hline $\begin{array}{l}\mathrm{BaO} \\
\mathrm{ZnO}\end{array}$ & 0.02 & 0.23 & 0.00 & 0.00 & 0.00 & 0.04 & 0.00 & 0.05 & 0.00 & 0.00 \\
\hline V2O3 & 0.23 & 0.20 & 0.12 & 0.28 & 0.55 & & 0.59 & 0.40 & 0.55 & 0.34 \\
\hline $\mathrm{NiO}$ & 0.00 & 0.00 & 0.01 & 0.00 & 0.00 & & 0.00 & & 0.00 & \\
\hline $\mathrm{Nb2O3}$ & 0.00 & 0.10 & 0.10 & 0.01 & 0.01 & 0.10 & 0.00 & 0.05 & 0.01 & 0.03 \\
\hline Total & 99.51 & 100.97 & 103.07 & 100.35 & 103.46 & 99.78 & 104.47 & 100.14 & 103.85 & 99.27 \\
\hline \multicolumn{11}{|c|}{ Structural formulae on the basis of 2 oxygen, 2 cations for ilmenite and 3 cations for magnetite } \\
\hline $\mathrm{Si}$ & 0.0256 & 0.0005 & 0.0000 & 0.0004 & 0.0016 & 0.0005 & 0.0035 & 0.0007 & 0.0030 & 0.0010 \\
\hline $\mathrm{Ti}$ & 0.0692 & 0.9060 & 0.0019 & 0.9320 & 0.0032 & 0.9036 & 0.0046 & 0.9374 & 0.0132 & 0.9154 \\
\hline $\mathrm{Al}$ & 0.0000 & 0.0018 & 0.0030 & 0.0001 & 0.0074 & 0.0004 & 0.0118 & 0.0003 & 0.0062 & 0.0003 \\
\hline $\mathrm{Fe}+3$ & 1.8017 & 0.1791 & 1.9872 & 0.1288 & 1.9640 & 0.1900 & 1.9537 & 0.1137 & 1.9443 & 0.1596 \\
\hline $\mathrm{Fe}+2$ & 1.0797 & 0.7605 & 0.9976 & 0.4870 & 1.0028 & 0.8359 & 1.0052 & 0.8405 & 1.0131 & 0.8224 \\
\hline $\mathrm{Mn}$ & 0.0052 & 0.1343 & 0.0019 & 0.4408 & 0.0002 & 0.0661 & 0.0011 & 0.0951 & 0.0002 & 0.0926 \\
\hline $\mathrm{Mg}$ & 0.0002 & 0.0010 & 0.0000 & 0.0023 & 0.0000 & 0.0009 & 0.0004 & 0.0013 & 0.0010 & 0.0013 \\
\hline $\mathrm{Ca}$ & 0.0093 & 0.0066 & 0.0012 & 0.0022 & 0.0017 & 0.0005 & 0.0012 & 0.0002 & 0.0016 & 0.0000 \\
\hline $\mathrm{Na}$ & 0.0000 & 0.0026 & 0.0018 & 0.0004 & 0.0000 & 0.0002 & 0.0000 & 0.0012 & 0.0000 & 0.0000 \\
\hline $\mathrm{K}$ & 0.0000 & 0.0002 & 0.0020 & 0.0011 & 0.0000 & 0.0000 & 0.0007 & 0.0007 & 0.0002 & 0.0003 \\
\hline $\mathrm{Cr}$ & 0.0019 & 0.0000 & 0.0001 & 0.0000 & 0.0036 & 0.0003 & 0.0019 & 0.0006 & 0.0016 & 0.0000 \\
\hline $\mathrm{Ba}$ & 0.0000 & 0.0000 & 0.0000 & 0.0000 & 0.0000 & 0.0000 & 0.0000 & 0.0000 & 0.0000 & 0.0000 \\
\hline $\mathrm{Zn}$ & 0.0005 & 0.0041 & 0.0000 & 0.0001 & 0.0000 & 0.0007 & 0.0000 & 0.0009 & 0.0001 & 0.0000 \\
\hline V & 0.0067 & 0.0040 & 0.0034 & 0.0057 & 0.0152 & 0.0000 & 0.0161 & 0.0081 & 0.0151 & 0.0068 \\
\hline $\mathrm{Ni}$ & 0.0000 & 0.0000 & 0.0002 & 0.0000 & 0.0000 & 0.0000 & 0.0000 & 0.0000 & 0.0001 & 0.0000 \\
\hline $\mathrm{Nb}$ & 0.0000 & 0.0013 & 0.0017 & 0.0002 & 0.0002 & 0.0013 & 0.0000 & 0.0006 & 0.0002 & 0.0004 \\
\hline Total & 3.0000 & 2.0018 & 3.0022 & 2.0011 & 3.0000 & 2.0001 & 3.0004 & 2.0012 & 3.0001 & 2.0002 \\
\hline $\mathrm{T}\left({ }^{\circ} \mathrm{C}\right)$ & \multicolumn{2}{|c|}{$\frac{3.0000^{3}}{688}$} & \multicolumn{2}{|c|}{500} & \multicolumn{2}{|c|}{537} & \multicolumn{2}{|c|}{518} & \multicolumn{2}{|c|}{589} \\
\hline logfO2 & \multirow{2}{*}{\multicolumn{2}{|c|}{$\begin{array}{c}-16 \\
+2.53\end{array}$}} & \multirow{2}{*}{\multicolumn{2}{|c|}{$\begin{array}{c}-18 \\
+4.71\end{array}$}} & \multirow{2}{*}{\multicolumn{2}{|c|}{$\begin{array}{c}-18 \\
+3.25\end{array}$}} & \multirow{2}{*}{\multicolumn{2}{|c|}{$\begin{array}{c}-20 \\
+1.98\end{array}$}} & & \\
\hline$\triangle N N O$ & & & & & & & & & & \\
\hline
\end{tabular}

Notes: Facies abbreviations BQ-M OC = Biotite quartz-monzodiorite with two pyroxenes; L-MG = Leuco monzogranite; BT-MG = Biotite hornblende monzogranite; Rhy = Rhyolite; HB-GD = Hornblende biotite granodiorite; $\mathrm{MG}=$ Monzogranite; $\mathrm{H}-\mathrm{MZ}=$ Hornblende monzodiorite; IM-D = Intermediate-mafic dikes; Dac = Dacite. Average temperature $\left[T\left({ }^{\circ} \mathrm{C}\right)\right] \mathrm{T}$ and oxygen fugacity $($ logfO2) of Carmichael (1967); Anderson (1968); Lindsley \& Spencer (1982); Stormer (1983), and discrimination of FeO and Fe2O3 from Carmichael (1967) calculated using Lepage (2003) program. $\triangle \mathrm{NNO}=$ log10fO2 relative to NiNiO buffer. 
Supplementary Material: Electron microprobe analyses of magnetite and ilmenite from Garzón granites and related rocks, Eastern Cordillera, Colombia.

\begin{tabular}{|c|c|c|c|c|c|c|}
\hline Mineral & Mt & $\mathrm{IIm}$ & Mt & $\mathrm{IIm}$ & $\mathrm{Mt}$ & $\mathrm{IIm}$ \\
\hline Massif & \multicolumn{6}{|c|}{ Sombrerillo } \\
\hline Sample & \multicolumn{2}{|c|}{ GAR-395 } & \multirow{2}{*}{\multicolumn{2}{|c|}{ GAR-395 }} & \multicolumn{2}{|c|}{ GAR-395 } \\
\hline Facies & \multicolumn{2}{|c|}{ Dac } & & & \multicolumn{2}{|c|}{ Dac } \\
\hline $\begin{array}{l}\text { Grain/ } \\
\text { Point }\end{array}$ & mag_02 & ilm_02 & $\underset{-1}{\text { mag_0 }_{-1} 04}$ & ilm_04-1 & mag_05 & ilm_05 \\
\hline $\mathrm{SiO} 2$ & 0.08 & 0.03 & 0.0319 & 0.0047 & 0.05 & 0.00 \\
\hline TiO2 & 0.04 & 48.73 & 0.2777 & 49.1 & 0.16 & 47.14 \\
\hline $\mathrm{Al} 2 \mathrm{O} 3$ & 0.07 & 0.02 & 0.1562 & 0 & 0.08 & 0.01 \\
\hline $\mathrm{Fe} 2 \mathrm{O} 3$ & 76.3 & 8.8 & 76.1 & 7.8 & 76.5 & 11.1 \\
\hline $\mathrm{FeO}$ & 34.7 & 30.8 & 34.9 & 21.7 & 34.7 & 22.4 \\
\hline $\mathrm{MnO}$ & 0.07 & 12.71 & 0.1182 & 21.91 & 0.13 & 19.66 \\
\hline $\mathrm{MgO}$ & 0.00 & 0.01 & 0 & 0 & 0.02 & 0.00 \\
\hline $\mathrm{CaO}$ & 0.08 & 0.16 & 0.031 & 0.1505 & 0.06 & 0.00 \\
\hline $\mathrm{Na} 2 \mathrm{O}$ & 0.00 & 0.01 & 0.0303 & 0 & 0.00 & 0.00 \\
\hline $\mathrm{K} 2 \mathrm{O}$ & 0.01 & 0.00 & 0 & 0 & 0.01 & 0.00 \\
\hline $\mathrm{Cr} 2 \mathrm{O} 3$ & 0.06 & 0.00 & 0.0409 & 0 & 0.00 & 0.01 \\
\hline \multicolumn{7}{|l|}{$\mathrm{BaO}$} \\
\hline $\mathrm{ZnO}$ & 0.00 & 0.01 & 0.0309 & 0.0994 & 0.02 & 0.08 \\
\hline V2O3 & 0.34 & 0.32 & 0.3056 & 0.2394 & 0.25 & 0.23 \\
\hline $\mathrm{NiO}$ & 0.00 & 0.00 & 0.0207 & 0 & 0.02 & 0.00 \\
\hline $\mathrm{Nb} 2 \mathrm{O} 3$ & 0.02 & 0.04 & 0.05 & 0.394 & 0.00 & 1.13 \\
\hline \multirow[t]{2}{*}{ Total } & 104.10 & 100.74 & 104.52 & 100.65 & 104.33 & 100.63 \\
\hline & \multicolumn{6}{|c|}{$\begin{array}{l}\text { Structural formulae on the basis of } 2 \text { oxygen, } 2 \text { cations for ilmenite and } 3 \\
\text { cations for magnetite }\end{array}$} \\
\hline $\mathrm{Si}$ & 0.0027 & 0.0007 & 0.0011 & 0.0001 & 0.0016 & 0.0000 \\
\hline $\mathrm{Ti}$ & 0.0011 & 0.9129 & 0.0072 & 0.9215 & 0.0040 & 0.8863 \\
\hline Al & 0.0029 & 0.0006 & 0.0063 & 0.0000 & 0.0031 & 0.0002 \\
\hline $\mathrm{Fe}+3$ & 1.9781 & 0.1649 & 1.9662 & 0.1470 & 1.9783 & 0.2080 \\
\hline $\mathrm{Fe}+2$ & 0.9986 & 0.6406 & 1.0022 & 0.4528 & 0.9979 & 0.4685 \\
\hline $\mathrm{Mn}$ & 0.0019 & 0.2681 & 0.0034 & 0.4629 & 0.0037 & 0.4161 \\
\hline $\mathrm{Mg}$ & 0.0000 & 0.0005 & 0.0000 & 0.0000 & 0.0009 & 0.0000 \\
\hline $\mathrm{Ca}$ & 0.0030 & 0.0042 & 0.0011 & 0.0040 & 0.0023 & 0.0001 \\
\hline $\mathrm{Na}$ & 0.0000 & 0.0004 & 0.0020 & 0.0000 & 0.0000 & 0.0000 \\
\hline $\mathrm{K}$ & 0.0002 & 0.0000 & 0.0000 & 0.0000 & 0.0003 & 0.0000 \\
\hline $\mathrm{Cr}$ & 0.0017 & 0.0001 & 0.0011 & 0.0000 & 0.0000 & 0.0002 \\
\hline $\mathrm{Ba}$ & 0.0000 & 0.0000 & 0.0000 & 0.0000 & 0.0000 & 0.0000 \\
\hline $\mathrm{Zn}$ & 0.0000 & 0.0003 & 0.0008 & 0.0018 & 0.0006 & 0.0015 \\
\hline $\mathrm{V}$ & 0.0095 & 0.0065 & 0.0084 & 0.0048 & 0.0069 & 0.0047 \\
\hline $\mathrm{Ni}$ & 0.0000 & 0.0000 & 0.0006 & 0.0000 & 0.0007 & 0.0000 \\
\hline $\mathrm{Nb}$ & 0.0004 & 0.0006 & 0.0009 & 0.0051 & 0.0000 & 0.0145 \\
\hline Total & 3.0001 & 2.0003 & 3.0013 & 2.0000 & 3.0004 & 2.0000 \\
\hline $\mathrm{T}\left({ }^{\circ} \mathrm{C}\right)$ & \multicolumn{2}{|c|}{$\begin{array}{l}0.000 \\
479\end{array}$} & \multicolumn{2}{|c|}{574} & \multicolumn{2}{|c|}{566} \\
\hline $\log f \mathrm{O} 2$ & \multirow{2}{*}{\multicolumn{2}{|c|}{$\begin{array}{c}419 \\
-19 \\
+4.58\end{array}$}} & \multirow{2}{*}{\multicolumn{2}{|c|}{$\begin{array}{c}-16 \\
+3.89\end{array}$}} & \multirow{2}{*}{\multicolumn{2}{|c|}{$\begin{array}{c}-16 \\
+4.17\end{array}$}} \\
\hline$\triangle N N O$ & & & & & & \\
\hline
\end{tabular}

Notes: Facies abbreviations BQ-M OC = Biotite quartz-monzodiorite with two pyroxenes; L-MG = Leuco monzogranite; BT-MG = Biotite hornblende monzogranite; Rhy = Rhyolite; HB-GD = Hornblende biotite granodiorite; $\mathrm{MG}=$ Monzogranite; $\mathrm{H}-\mathrm{MZ}=$ Hornblende monzodiorite; IM-D = Intermediate-mafic dikes; Dac = Dacite. Average temperature $\left[\mathrm{T}\left({ }^{\circ} \mathrm{C}\right)\right] \mathrm{T}$ and oxygen fugacity $($ logfO2) of Carmichael (1967); Anderson (1968); Lindsley \& Spencer (1982); Stormer (1983), and discrimination of FeO and Fe2O3 from Carmichael (1967) calculated using Lepage (2003) program. $\triangle$ NNO = log10fO2 relative to NiNiO buffer. 